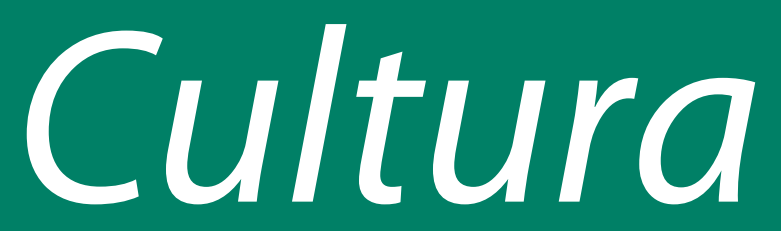

Revista de História e Teoria das Ideias

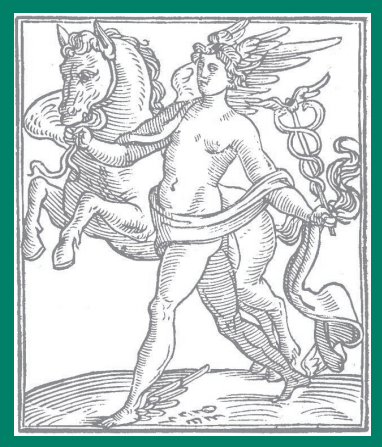

8
8
$\frac{8}{2}$
$\frac{1}{4}$
$\frac{1}{0}$
$\frac{1}{3}$

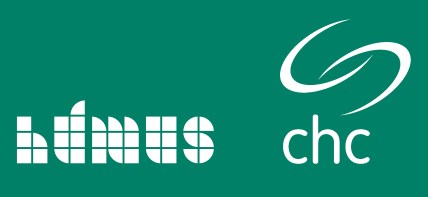




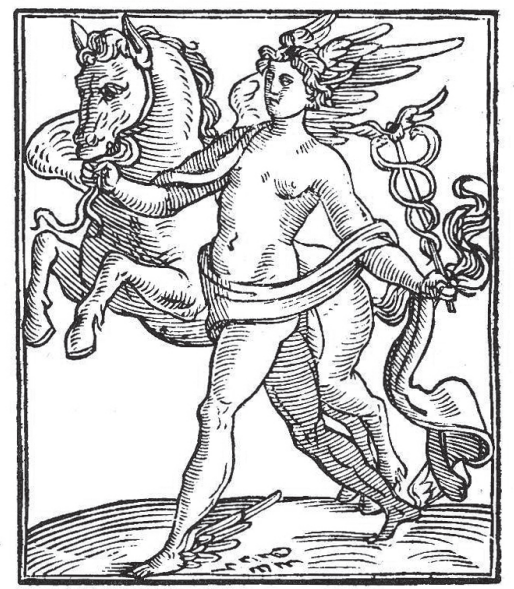

FAMA CHIARA

Nella medaglia d'Antinoo

Uma belíssima figura nua de Mercúrio com as asas talares nos pés e caduceu, significa a clara fama devido à qual os antigos o fizeram mensageiro de Júpiter, e por ele se entende o falar, ou seja, a eficácia da voz e do grito que se expande e difunde por toda a parte. As talares e as asas que tem na cabeça significam as palavras velozes. O cavalo Pégaso entende-se pela clara fama de Antínoo, velozmente transportada e espalhada pelo universo.

Cesare Ripa, Iconologia, ed. Pádua, 1618. 


\section{Cultura}

Revista de História e Teoria das Ideias 


\author{
Cultura - Revista de História e Teoria das Ideias \\ (II Série) vol. 26 - 2009 \\ Publicação semestral do Centro de História da Cultura \\ da Faculdade de Ciências Sociais e Humanas da Universidade Nova de Lisboa
}

Referenciada no catálogo LATINDEX - Sistemas de Informação Internacional de Revistas Científicas e no European Reference Index for the Humanities (ERIH) da European Science Foundation (ESF).

Publicação interdisciplinar em que convergem as perspectivas da história, da filosofia, do pensamento político e dos estudos literários. Trata ideias e práticas políticas, religiosas, científicas, económicas, sociais, estéticas e filosóficas, nas suas formas de expressão e difusão, com destaque para a ligação entre o espaço português e o espaço ibérico, brasileiro e ibero-americano.

Fundador: J.S. da Silva Dias

Director: José Esteves Pereira

Subdirector: Luís Manuel A.V. Bernardo

Coordenador editorial: Adelino Cardoso

Conselho de Redacção: Adelino Cardoso; Ana Maria Martinho; António Camões Gouveia; Cristina Montalvão Sarmento; Isabel Cluny; João Luís Lisboa; José Esteves Pereira; José Henrique Dias; Luís Crespo de Andrade; Luís Manuel A.V. Bernardo; Margarida Isaura Almeida Amoedo; Maria do Rosário Monteiro.

Comissão de acompanhamento científico: Armando Savignano (Univ. Trieste, Itália); Claude Gilbert Dubois (Univ. Bordéus, França); Luís de Oliveira Ramos (Univ. Porto); Norberto Cunha (Univ. Minho); Onésimo Teotónio de Almeida (Brown University, EUA); Roger Chartier (EHESS, Paris e Collège de France, França).

Referees deste número: Clara Rocha (FCSH-UNL); Fernando Catroga (FL-UC); João Freire (ISCTE-IUL); João

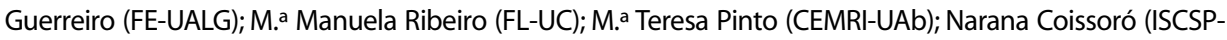
UTL); Norberto Cunha (UM); Paulo Fontes (CEHR-UCP); Paulo Quaresma (ECT-UE); Pedro Calafate (FL-UL) .

Direcção gráfica: Edições Húmus

Editor: Centro de História da Cultura da Faculdade de Ciências Sociais e Humanas da Universidade Nova de Lisboa / Edições Húmus

Depósito legal n. $97341 / 96 \quad$ ISSN:0870-4546

Preço deste número: 16,96 euros Assinatura: 26 euros

Correspondência relativa a colaboração de permutas e oferta de publicações deve ser dirigida a:

Centro de História da Cultura - FCSH da UNL, Av. de Berna, 26 C - 1069-061 LISBOA

Fax:217939228 E-mail:chc@fcsh.unl.pt

Para referência de números anteriores, consultar:www.fcsh.unl.pt/chc

Publicação subsidiada ao abrigo do Financiamento Plurianual da FCT (Fundação para a Ciência e a Tecnologia). 


\section{Cultura}

Revista de História e Teoria das Ideias Vol. 26 - 2009 / II Série

OTempo das Revistas

Coordenação de

Luís Andrade 



\section{ÍNDICE}

O valor das ideias

Luís Andrade

As minhas revistas

Mário Soares

Pensamento e actualidade. As revistas no século XX

Luís Andrade

A luso-brasilidade e o projeto da revista Atlântida

Lucia Maria Paschoal Guimarães

"Uma nova e grande Lusitânia"

Zília Osório de Castro

Uma nova revista de Filosofia?

Adelino Cardoso

Em torno dos periódicos femininos

Teresa Salvador

No rasto da passagem de Ferreira de Castro

pelos suplemento e revista de A Batalha (1919-1927)

Maria João Cabrita

Nação Portuguesa (1914-1916) - Que Integralismo Lusitano?

José Manuel Cordeiro

Da Filosofia Política à Cultura Nacionalista. A segunda série da Nação Portuguesa

(1922-1923)

Paulo Dias Oliveira

Estudos Sociais: percursos temáticos de um ímpeto reformista (1905-1911)

Pedro Silva

Os cavaleiros da espada de pau e os arcanjos da espada dum trovão:

a Renascença Portuguesa e a cultura democrática

Adelaide Maria Muralha Vieira Machado

Índia Nova: nacionalismo e cosmopolitismo num jornal académico 
Edição electrónica e estudo de revistas:

o contributo do Seminário Livre de História das Ideias

Pedro Lisboa

Da língua à cultura científica: a Revista Internacional de Língua Portuguesa

Cristina Montalvão Sarmento

\section{RECENSÕES CRÍTICAS}

Souto, Maria Helena, História do Design em Portugal I

Leonor Ferrão

Guibal, Francis, Le Courage de la raison - La philosophie pratique d'Eric Weil

Luís Manuel A. V. Bernardo

Rosas, João Cardoso (org.), Manual de Filosofia Política

Maria João Cabrita

Mendes, Manuel da Silva, Socialismo Libertário ou Anarchismo

Maria João Cabrita

Autores

Resumos e palavras-chave

Abstracts and keywords 


\title{
O valor das ideias
}

\author{
Luís Andrade*
}

Entre os traços mais salientes da cultura e da política contemporâneas, encontra-se o mérito conferido às novas doutrinas, não só no âmbito da interpretação do mundo e da vida, mas também, e fundamentalmente, nos domínios da transformação das sociedades e do quotidiano.

Acreditava-se que as ideias faziam a história, que o pensamento, ao assomar à condição de consciência efectiva da natureza e da invenção comuns, elucidava os tempos e se metamorfoseava em programa da acção pertinente.

As concepções novas encarregaram-se, assim, de projectar a seu modo o percurso colectivo, desde logo a elevação às novas eras perspectivadas pelas muitas revoluções políticas, estéticas, tecnológicas, que quebraram definitivamente a circularidade ancestral da tradição, transformaram as sociedades segundo um ritmo insuspeito e promoveram o cultivo da modernidade.

Emancipação racional, cultura e política passaram a caminhar a par:a ordem antiga deu lugar a comunidades políticas constituídas de acordo com ideários e contratos sociais originais; as organizações partidárias, resultantes da vida parlamentar, encontraram justificação em representações explícitas do itinerário para a cidade almejada; os imaginários conferiram, nas letras e nas artes, expressão simbólica à luz e ao calor das novas convicções.

Em simultâneo, o número dos que acompanharam e participaram nos acontecimentos políticos e culturais correntes superou, progressivamente, os círculos restritos do poder, ao passar a envolver a generalidade dos membros instruídos das diferentes comunidades, chamados tanto a eleger os seus representantes quanto a seguir a evolução dos acontecimentos nacionais e internacionais.

As novas ágoras em que as sociedades contemporâneas se transformam ficaram a dever-se, no essencial, à imprensa, pois a definição e a instituição do espaço público contemporâneo foram proporcionadas pela mediação expedita e massiva das notí-

\footnotetext{
Seminário Livre de História das ideias, Centro de História da Cultura da Faculdade de Ciências Sociais e Humanas da Universidade Nova de Lisboa.
} 
cias, dos artigos e das controvérsias com que as publicações periódicas ocuparam as suas páginas.

Viveu-se, em consequência, um tempo de palavra impressa: a era em que o hábito de leitura dos periódicos, em casa, nos cafés, nos clubes, nas colectividades, fez nascer a opinião pública e alimentou com desvelo as diferentes constelações de afinidades em que os cidadãos reconheceram filiação, ao mesmo tempo que encontravam, entre si, linhas de fractura e de oposição.

A generalização do debate público democrático, resultado directo da actividade da imprensa periódica e consequência indirecta do papel que a escolarização havia conquistado na vida social, nomeadamente nos meios urbanos, revigorou as expectativas, mais ou menos promissoras, atribuídas às doutrinas e aos imaginários em confronto, ao permitir que a racionalidade categórica que se lhes imputava passasse a surgir associada ao efeito social e político resultante da sua propagação e da sua presença efectiva na comunidade.

Os homens do pensamento, das letras, das artes e das ciências ganharam, em consequência, uma autoridade que superava o domínio próprio da actividade com que cada um tinha alcançado reputação, pois as circunstâncias converteram-nos, genericamente, em figuras de proa da vida colectiva.

A cidade passou a respirar a atmosfera peculiar que a aproximação estreita entre cultura e política lhe proporcionava.

Ao sentirem-se vinculados ao dever que obrigaria os representantes do saber a participar no tecer do destino comum, os homens de cultura viram-se impelidos para a promoção, intramuros, dos avanços civilizacionais; para a divulgação de novas doutrinas regeneradoras, de índole social, política, pedagógica, entre outras; para a definição de causas e de querelas inerentes aos valores que encarnavam; para a crítica metódica de situações tidas por inaceitáveis e para o esclarecimento tempestivo do fluir dos acontecimentos.

A publicação em periódicos passou a prevalecer sobre a edição em livro, pois as constelações de artigos apresentavam-se mais adequadas, quer à formulação e divulgação de um pensamento actuante, quer à constituição e ao sustento metódicos de correntes de opinião, quer, por fim, ao confronto, frequentemente polémico, acerca do significado de teses e de factos.

As revistas revelaram-se, então, uma modalidade de imprensa particularmente adequada à persecução de desígnios compartilhados: as grandes figuras da cultura dirigiram-nas, os títulos multiplicaram-se, as orientações programáticas diversificaram-se, 
os leitores adquiriram o hábito de acompanhar fielmente os semanários, os quinzenários e os mensários da sua simpatia.

A compreensão da história cultural e política contemporânea, ao longo de alguns dos seus períodos mais ricos e intensos, obriga, pois, a atender às condições relativamente particulares em que decorreu, que não resultaram de limitações cerceadoras, mas, pelo contrário, das expectativas sociais elevadas que acompanharam os agentes culturais.

A figura do autor afastou-se então do seu estatuto de simples criador de objectos culturais, ao mesmo tempo que as modalidades de produção e de publicitação se distanciaram dos seus padrões tradicionais.

Foi a percepção de que a peculiaridade da vida cultural no período áureo da imprensa obriga a uma abordagem historiográfica própria, distinta dos procedimentos epistemológicos aplicados a épocas em que os géneros cultivados se confinam às convenções disciplinares, que levou o Seminário Livre de História das Ideias a dirigir os seus trabalhos, num primeiro momento, para a temática da missão cívica dos homens de cultura, com a edição de um conjunto de estudos sobre Dreyfus e a responsabilidade intelectual (Lisboa, Cadernos de Cultura 2, Centro de História da Cultura, 1999); a considerar, de seguida, o percurso dos movimentos cívico-culturais dos decénios iniciais do século XX, com a publicação de Revistas, ideias e doutrinas. Leituras do pensamento contemporâneo (Lisboa, Livros Horizonte, 2003); e a enveredar, por último, pela reedição electrónica - com estudo introdutório, índices e documentação conexa - de alguns dos títulos mais representativos das revistas de ideias e cultura da última centúria, como Alma Nacional, Estudos Sociais, Portugália e O Tempo e o Modo, nas suas duas séries (seguidos, brevemente, por A Águia, Atlântida, Nação Portuguesa, Revista de Educação Geral e Técnica, Estudos, Raiz e Utopia, Suplemento Literário e llustrado A Batalha, cujos trabalhos preparatórios de edição, nomeadamente os analíticos, se encontram concluídos).

Os estudos, e restantes textos, publicados no presente número de Cultura. Revista de História e Teoria das Ideias relevam, igualmente, do trabalho desenvolvido a propósito dos periódicos em que o pensamento e a sensibilidade portugueses recentes conheceram elaboração.

Os artigos seguem três vertentes distintas, embora, entre si, complementares: depoimentos a propósito de revistas, estudos monográficos acerca de títulos salientes, reflexão acerca da natureza e do papel destes periódicos, bem como sobre as questões de âmbito científico colocadas a propósito da sua republicação, em formato electrónico, na actualidade. 
O testemunho do Dr. Mário Soares consiste na transcrição das palavras com que evocou o papel de algumas das revistas principais da história portuguesa recente, bem como a sua condição de articulista, por ocasião da apresentação pública, na Faculdade de Ciências Sociais e Humanas, da reedição de Alma Nacional. Já o depoimento assinado por Adelino Cardoso traça o panorama das revistas filosóficas nas últimas décadas, a partir da recordação do papel activo por si desempenhado na criação e na produção de uma parte importante das publicações que revelaram o incremento que os estudos filosóficos conheceram após a criação dos cursos de especialização.

A maioria dos estudos agora publicados incide, porém, sobre revistas do tempo da I República, não por intuito comemorativo, mas por a nova pátria dos cidadãos ter encontrado nas páginas dos periódicos de ideias um lugar de eleição para a discussão plural e muito intensa entre as diferentes doutrinas do bem comum que a atravessaram. Estas nortearam, supostamente, tanto aqueles que fizeram a "velha" República, quanto os defensores do renascimento nacional ou da nova "grei", bem como todos os que se opuseram ao regime saído do 5 de Outubro, fossem católicos e corporativistas, integralistas e legitimistas, libertários e anarco-sindicalistas.

O projecto de uma comunidade cultural luso-brasileira, com claro significado político, propugnado pela revista Atlântida, editada durante a I Grande Guerra e nos anos que se lhe seguiram, sob a direcção de João do Rio e de João de Barros e com subvenção de governos republicanos portugueses e brasileiros, é objecto de dois estudos, de Lucia Maria Paschoal Guimarães e de Zília Osório de Castro, que, a seu modo, replicam, embora no plano da investigação e na actualidade, o pressuposto da existência de perspectivas e interesses complementares entre aqueles que a história e a cultura uniram.

Os artigos de Maria João Cabrita, José Manuel Cordeiro, Paulo Dias Oliveira, Pedro Silva e Adelaide Vieira Machado - centrados, respectivamente, na colaboração de Ferreira de Castro no Suplemento Literário e Ilustrado de A Batalha, nas edições da primeira série da revista Nação Portuguesa, nos números publicados na segunda série deste título integralista, em Estudos Sociais, editado pelo Centro Académico da Democracia Cristã, em A Águia, publicação associada ao movimento Renascença Portuguesa - constituem estudos desenvolvidos dos periódicos que serviram de órgãos a quatro dos principais movimentos político-culturais da década e meia republicana, além de as suas teses terem prevalecido, nomeadamente no caso da segunda e da terceira publicações referidas, muito para além da vitória da Revolução Nacional, já que os alicerces da cultura política nacionalista e de inspiração católica do Estado Novo lhes são devidos. 
Os estudos de Sandra Ataíde Lobo, acerca de Índia Nova, expressão da elite republicana goesa nos anos incertos da Ditadura Militar, e de Cristina Montalvão Sarmento, sobre a Revista Internacional de Língua Portuguesa, publicada pela Associação das Universidades de Língua Portuguesa, já no final do século XX, dão conta igualmente de duas investigações focadas em títulos emblemáticos, embora de âmbito mais circunscrito.

Já o artigo de Teresa Salvador reveste-se de um alcance geral no domínio das publicações periódicas femininas, ao proceder a análise reflexiva e panorâmica acerca do seu valor, da sua natureza e do seu poder.

As revistas enquanto modalidade editorial de produção e de divulgação do pensamento e da cultura são o objecto de estudo de Luís Andrade, enquanto os pressupostos e as opções que têm presidido à reedição electrónica de revistas, por parte do Seminário Livre de História das Ideias, em colaboração com a Fundação Mário Soares e com a Biblioteca Nacional de Portugal, são apreciados no artigo de que Pedro Lisboa é o autor.

O Projecto Edição de Revistas de Ideias e Cultura do Século XX é financiado pela Fundação para a Ciência e a Tecnologia e pelo Programa Operacional Ciência e Inovação 2010, comparticipado pelo fundo comunitário Feder.

Estamos em crer que o conjunto dos contributos para o conhecimento das revistas de ideias e de cultura portuguesas do século XX agora publicados beneficia quer do afastamento relativamente ao rasto de memória - desde logo, de memória própria e de memória alheia, que muitas destas publicações suscitaram ao longo de décadas, 0 que revela, só por si, a pregnância ideológica que as caracterizou -, quer do desprendimento que guarda relativamente à aproximação da vida cultural a partir do seu viés literário, abordagem inteiramente pertinente e com mérito próprio, mas que, face à complexidade e à diversidade do conjunto das matérias em discussão, se revela muitas vezes parcelar e oblíqua. 



\section{As minhas revistas*}

Mário Soares

Senhor Director da Faculdade, Senhora Professora, Senhores Professores, caro Dr. Alfredo Caldeira, minhas Senhoras e meus Senhores, meus caros Amigos:

Para a Fundação Mário Soares, é realmente um grande gosto, um estímulo e extremamente importante ter uma ligação como esta com a Universidade Nova. Nós temos vindo a colaborar com a Universidade Nova, estamos a fazer cursos de história contemporânea sucessivos - acabámos o último há poucas semanas - e temos vindo a publicar os livros, embora com algum atraso, de cada um destes cursos que constituem uma referência para os estudiosos. É extremamente estimulante para nós, na Fundação, e para os trabalhos que realizamos, ter um contacto assim com uma Universidade com o prestígio da Vossa.

Claro que temos bastantes outros contactos com as Universidades do Minho, do Porto, de Coimbra, de Évora, de Aveiro, dos Açores e do Algarve, bem como com a Universidade Católica de Lisboa e do Porto e, além disso, Universidades estrangeiras. Contudo, com a Universidade Nova de Lisboa, através da realização de cursos anuais, e agora através deste acordo, ficamos a ter uma parceria entre a vossa Universidade, a Biblioteca Nacional e a Fundação. Estamos, assim, a desenvolver e a aprofundar os laços culturais e históricos que nos unem, o que é para nós extremamente gratificante e fecundo.

Portanto, Senhora Professora, que teve a grande gentileza de nos agradecer, e Senhor Director, devo dizer-vos que nós é que agradecemos poder colaborar convosco e ajudar neste projecto, que é extremamente interessante, poder pôr ao alcance dos estudiosos o conteúdo das diferentes revistas de ideias que tiveram uma importância decisiva na história do Portugal do século XX, e que continuam a ter, embora realmente bastante menos do que aquela que têm hoje, por razões diversas, entre elas a importância dos novos meios informáticos.

* Transcrição das palavras do Dr. Mário Soares, Presidente da Fundação Mário Soares, por ocasião da sessão de apresentação da edição electrónica de Alma Nacional, que teve lugar na Faculdade de Ciências Sociais e Humanas da Universidade Nova de Lisboa. 
Como pertenço a outra geração, a informática é, para mim, praticamente chinês. Faço confiança, evidentemente, no director do Arquivo, que está, todo ele, informatizado, desde os pés à cabeça; dotou a Fundação de meios modernos e até, em alguns casos, pioneiros, como disse a Senhora Professora, e agora lançou esta reedição.

Esta edição, para os Senhores, deve ser entusiasmante mas, para mim, é bastante menos, devo confessá-lo. Sou, como sabem, um bibliófilo compulsivo e tenho muitas dessas revistas, em minha casa, que agora estão a ser digitalizadas.

A Alma Nacional é a primeira que se publica e depois vamos publicar A Águia. É a que se segue. Hoje estive a folhear AÁguia, na minha biblioteca, na secção onde tenho as revistas portuguesas. A Águia é uma revista de grande qualidade e teve um papel cultural importantíssimo no início do século XX. A ela estão ligados grandes nomes da nossa Cultura, como Jaime Cortesão, Teixeira de Pascoaes, Leonardo Coimbra e tantos outros.

Pediram-me para falar, aqui, da importância das revistas que mais me marcaram. Devo dizer que, no plano literário, foram o Orpheu, depois a Presença e, mais tarde, o Mundo Literário, uma revista de que se fala muito pouco e que foi dirigida pelo grande poeta Adolfo Casais Monteiro, nos anos do pós-guerra. Teve uma influência bastante grande no Portugal dos anos 50.

Contudo, a revista que mais me marcou no domínio das ideias, da democracia e do pensamento filosófico, crítico e político-ideológico, foi, sem dúvida, a Seara Nova. Considero-me um "seareiro" tardio... Sou, como se sabe, republicano, socialista e laico, como o Prof. António Reis, aqui presente. A Seara Nova foi uma revista republicana, com grande simpatia pelo socialismo em liberdade e cooperativista - sobretudo na sua primeira fase. Demonstrou uma extraordinária criatividade e inteligência crítica. Tinha o melhor que produziu o pensamento português da época, em todos os aspectos. Nasceu em 1921, na fase final da I República, e sobreviveu, graças a Câmara Reys, à Ditadura.

Mais tarde surgiu, em Coimbra, a revista Vértice. Teve, realmente, uma grande influência. Foi uma revista neo-realista fortemente influenciada pelo comunismo, que não disse, no fundo, qual a sua ideologia, porque não podia dizer. Havia então uma censura feroz nesses anos da grande repressão salazarista.

A Vértice foi uma revista do realismo socialista, mas nunca utilizou este título, porque a Censura nunca o permitiria. Chamou-se neo-realista, expressão mais ou menos literária e artística, que teve a vantagem de enganar a Censura. Publicou-se durante muitos anos e teve um papel, sem dúvida nenhuma, muito importante. Fui seu assi- 
nante desde o primeiro número e colaborei nela algumas vezes (poucas), sobretudo no tempo da II Grande Guerra e dos anos que imediatamente se lhe seguiram, em que fui militante comunista.

Iremos publicar também O Diabo - nenhuma confusão com o pasquim do mesmo nome que se publicou depois do 25 de Abril. Antes disso, houve outro O Diabo, nos anos 39, 40, por aí..., dirigido por Campos Lima e Piteira Santos, que teve um papel importante na formação política da geração anterior à minha. E também outra revista que era congénere, que se publicava no Porto, a Sol Nascente, dirigida por Manuel de Azevedo. Foi uma revista breve, mas que teve um papel igualmente crítico da Ditadura, bem interessante.

No final já dos anos 60, houve uma revista que também foi importante: O Tempo e o Modo. Era uma revista católica progressista, assumida como tal e inspirada nos ensinamentos do Concílio Vaticano II. O seu fundador e director foi o escritor Alçada Baptista, meu querido amigo. Nela colaboraram, por pressão de Bénard da Costa, três não-católicos, o que foi altamente inédito e significativo: Salgado Zenha, Jorge Sampaio e eu próprio. Colaborámos no primeiro número de $O$ Tempo e o Modo e ajudámos a lançá-lo, com grande polémica aliás, que nos veio dos nossos correligionários nãocatólicos e antifascistas, que nos perguntavam: "Porque é que vocês estão metidos com esses católicos?"

Os católicos, por seu lado, tinham uma preocupação inversa: "Porque é que vocês, católicos, os aceitaram?" O Bénard da Costa até contou uma vez em público que, no início, estavam em dúvida se nos deviam deixar entrar ou não. Propuseram então ao Alçada Baptista, que aceitou, que, antes de fazerem uma votação secreta sobre se sim ou se não, deviam rezar um padre-nosso, para se inspirarem. Assim foi. Rezaram e depois votaram. Da votação resultou que pudemos entrar. Significava isso, dizíamos nós a brincar, que o Espírito Santo estava connosco...

A revista foi lançada, teve êxito e uma evolução muito curiosa. Já no tempo do Vasco Pulido Valente e de outros, a revista foi assaltada pela extrema-esquerda, praticamente, pelos maoístas, e depois do Maio de 68 transformou-se no inverso daquilo que tinha sido. Não direi o contrário, mas tornou-se muito diferente daquilo que fora na sua fase inicial.

Isto para dizer que as revistas têm todas uma história. Marcaram, realmente, a vida intelectual portuguesa durante o século XX. Não há nenhum livro, por mais interessante que seja - alguns livros do Jaime Cortesão, os livros do António Sérgio, os livros do Raul Proença, que marcaram muito o pensamento político e filosófico do século 
$X X$-, que tenha tido um efeito tão grande como tiveram as revistas que citei, particularmente a Seara Nova. A Seara Nova do tempo dos primeiros números, de Cortesão, de Raul Proença, de Azevedo Gomes, de Câmara Reys e depois de António Sérgio, que foram os grandes motores intelectuais da Seara Nova.

Claro que à direita também houve revistas interessantes, como as que saíram do Integralismo Lusitano. A Nação Portuguesa foi uma revista do Integralismo - também a tenho - onde, pode dizer-se, colaboraram espíritos superiores. Conheci-os quase todos, muito mais tarde. Luiz d'Almeida Braga, Hipólito Raposo, Pequito Rebelo, António Sardinha - que morreu cedo - foram grandes figuras do pensamento, da escrita e da literatura. Mas tinham uma orientação anti-republicana e eram partidários de uma Monarquia mais absoluta ainda do que a de D. Carlos e João Franco. Beberam muito do francês Charles Maurras e deram, indirectamente, um contributo ao salazarismo, de que se arrependeram mais tarde. Raul Proença tem vários textos em que os arrasa e denuncia o Integralismo Lusitano, que se dizia lusitano mas, na verdade, era copiado, em parte, do francês.

Era uma revista de Direita, mas os nomes que citei vieram todos, depois, a arrepender-se do apoio que deram a Salazar. Nos anos finais da vida deles - em que conheci alguns -, todos eram anti-salazaristas. António Sardinha não, porque, como disse, morreu antes.

Portanto, havia revistas de Direita e havia revistas de Esquerda, claramente definidas, que as pessoas liam, compravam, meditavam, discutiam nos cafés, nas tertúlias, por toda a parte, e que tiveram uma importância cultural enorme no meio acanhado de então.

Recolhermos isso tudo, pormos isso ao alcance das novas gerações, é uma empresa extremamente meritória, que deve ser aplaudida porque representa um contributo importante para o esclarecimento do século XX português e, portanto, para o esclarecimento do nosso presente e do nosso futuro próximo. Tudo mudou, é certo, e continua a mudar, aceleradamente. Mas as ideias, como as coisas, têm todas uma raiz, prolongam-se e depois dão os seus frutos em direcção ao futuro.

Para mim e para a Fundação, que aqui represento, é muito importante este acto. Felicito a Universidade Nova e a Faculdade de Ciências Sociais e Humanas, na pessoa do Senhor Director, pela vontade em cooperar connosco e por nos ter aberto a porta para iniciar este trabalho. Muito obrigado. 


\title{
Pensamento e actualidade. As revistas no século XX
}

\author{
Luís Andrade*
}

\section{O século das revistas}

As revistas desempenharam, entre finais do século XIX e o derradeiro quartel do século XX, um papel primordial na vida contemporânea, pois os vigorosos movimentos de pensamento, de sensibilidade e de acção característicos da época singraram, por regra, através deste género de periódicos.

As páginas das revistas deram, então, a conhecer manifestos intransigentes, orientações doutrinárias veementes, gramáticas artísticas e de gosto ousadas, focos de interesses colectivos centrípetos, correntes de opinião marcantes, firmamentos simbólicos inéditos e estilos de vida irreverentes.

A simples consulta de alguns exemplares avulsos dos muitos títulos salientes permite captar o teor dos géneros e dos registos que fizeram com que os seus leitores se tenham visto conduzidos, mesmo nos círculos conservadores, pelo enlevo da consciência e da sensibilidade tidas por contemporâneas, imputável, invariavelmente, à novidade incontestável dos tempos.

Ao mesmo tempo, as revistas rasgaram as janelas que permitiram aos homens e às mulheres comuns franquear, de forma massiva, as circunscrições insulares das culturas tradicionais e aceder, pela imagem e pela palavra, a realidades, efectivas ou imaginárias, surpreendentes.

Em Portugal, como nos outros países desenvolvidos, a actividade dos homens do pensamento, das letras e das artes, bem como a da generalidade dos publicistas, viu-se absorvida pela redacção nos hebdomadários, quinzenários e mensários que fizeram o pulsar, por vezes muito vigoroso, da realidade cultural nacional.

Os autores de relevo, incluindo os mais reputados, não só publicaram regularmente nas revistas originadas nas redes de afinidades pessoais, intelectuais, profissionais e programáticas em que estavam incluídos, como também se destacaram, com muita

\footnotetext{
Seminário Livre de História das ideias, Centro de História da Cultura da Faculdade de Ciências Sociais e Humanas da Universidade Nova de Lisboa.
} 
frequência, como fundadores, directores ou redactores proeminentes de um ou mais títulos destes periódicos.

A publicação regular em revistas por parte daqueles que mais sobressaíram em cada uma das áreas da vida cultural portuguesa contrastou mesmo com a escassa produção de estudos com teor original.

Feita excepção às obras de narrativa romanesca e às escassas monografias destinadas a satisfazer finalidades específicas, verifica-se com facilidade que parte muito significativa dos livros publicados pelos autores mais estimados - para muitos, a quase totalidade das suas obras - consistiu na reunião de textos doutrinários, ensaísticos, literários ou académicos anteriormente dados a conhecer no corpo das publicações periódicas em que haviam colaborado, muitas vezes, durante anos a fio'.

Quem tenha detido a sua atenção no século considerado não terá dificuldade em ilustrar com exemplos próprios, de âmbito geral ou no domínio específico de interesses particulares, o lugar central das revistas na vida da época. As correntes de doutrina política, os movimentos literários, as tendências e as escolas de pensamento - filosófico, pedagógico, filológico, histórico, sociológico, nos seus vários matizes - deram a conhecer as suas teses, os seus programas e as suas referências através dos artigos que as figuras que lhes presidiram publicaram em periódicos de ideias e cultura.

Em todos os domínios da vida cultural, as revistas passaram a constituir fontes não só primordiais como, a seu modo, completas.

Enquanto os leitores das revistas mais representativas do século XX acedem, com facilidade, ao panorama è dinâmica dos movimentos de ideias e da vida cultural portuguesa, de tal modo estes periódicos constituem os repositórios fiéis das orientações e dos registos do intenso fluir cultural da época, todos aqueles que, pelo contrário, descurem estas fontes primordiais não ultrapassarão o limiar da apreciação fragmentária, vulnerável ao anacronismo conceptual e exposta à credulidade envolvente das memórias com que cada movimento de ideias compôs a imagem da identidade própria e as representações daqueles com que, de forma mais ou menos veemente, se confrontou.

\footnotetext{
A propósito do movimento editorial nas três primeiras décadas do século XX, Rui Ramos sublinhou-o: "o mundo dos livros era apenas um anexo do mundo da imprensa, que era quem dava os pés ao império dos escritores" e "muitos dos livros publicados nesta época são simples colecções de textos com que os autores, ocasional ou regularmente, contribuíram para jornais e outras publicações periódicas (...) a ânsia de publicar imediatamente era enorme" (Rui Ramos, História de Portugal, vol. VI, Lisboa, Editorial Estampa, 2001, pp. 54 e 471).
} 
Em suma, as revistas urdiram, durante décadas sucessivas, a vida e o ambiente cultural. Exibiram a cultura portuguesa, na complexidade das suas vozes, dos seus sentidos e das suas dinâmicas, quer ao reunirem a produção reflexiva, literária e mesmo artística das figuras públicas, quer ao promoverem e espelharem a mudança das mentalidades e dos usos.

Os títulos consagrados, a par de outros caídos na penumbra, constituíram o fundamento e o alento de uma era cuja vivacidade ideológica, cultural e cívica deixou sobressair com toda a nitidez o recorte fogoso que a caracterizou, quando confrontada com a atonia ideológica, a debilidade doutrinária, a rasura de sentimentos e a rarefacção cívica das décadas finais do século XX, anunciadas e expostas, aliás, igualmente em páginas de revistas, precisamente naquelas em que o ciclo assinado encontrou o epílogo.

O significado de que as revistas se revestiram, ao longo do período genericamente referido, ganhou uma expressão tão intensa que aconselha a considerar esta modalidade de imprensa, nos traços que determinam a sua peculiaridade, como objecto de investigação e de reflexão autónomo.

Como é sabido, as condições particulares de produção e de circulação das ideias e das representações culturais não constituem um simples dado circunstancial,com significado e alcance instrumentais. No caso das revistas, como de muitas outras modalidades de comunicação colectiva, oral ou escrita, a discursividade e os termos da sua expressão pública caminharam a par, estabelecendo entre si vínculos indeléveis.

Assim sendo, só a consideração das características específicas das revistas como modalidade de imprensa permite revelar o quadro editorial em que a cultura escrita da época considerada se desenvolveu. Esta observação possibilita, desde logo, atender aos géneros jornalísticos, reflexivos e literários mais cultivados - editorial, artigo, crónica, texto de divulgação, poema, conto e novela, entre outros - e recordar as regras a que obedeciam, ou seja, perspectivar a compreensão dos universos de enunciação disponíveis a partir da apreciação dos protocolos relativamente rígidos. Permite, de seguida, consorciar a actividade cultural com as condições da produção editorial, através da apreciação do papel reservado aos diferentes tipos de objectos impressos. Faculta, por fim, a apreensão de disposições gerais respeitantes às modalidades de relacionamento entre publicações e públicos.

\section{A revista como modalidade editorial}

As revistas distinguiram-se, antes de mais, pela sua diversidade. Variaram na motivação que Ihes deu origem, comercial, cívica, ideológica, associativa, entre muitas outras; 
no teor, pois todas as grandes áreas temáticas e da vida social conheceram títulos específicos; na dimensão, do formato de bolso ao volume solene e decorativo; no público, da dona de casa aos cultores do esperanto; na finalidade, recreativa, utilitária, prosélita; na periodicidade, semanal, quinzenal, mensal, trimestral, anual ou, mesmo simplesmente, circunstancial ou irregular.

Sendo a história das revistas parte da história contemporânea, estes periódicos acompanharam as vicissitudes dos tempos, nomeadamente no que respeitou à evolução da parcela da população letrada, aos condicionalismos que afectaram o exercício da liberdade de expressão, aos preços do papel e dos outros aspectos da produção, aos movimentos sociais e à mudança nos hábitos culturais.

Num plano mais restrito, a história das revistas foi inseparável das transformações que marcaram o evoluir da imprensa e da comunicação social do século XX. As revistas beneficiaram, amplamente e ao longo de décadas, dos progressos no registo e na impressão de imagens, ao fazerem valer a ilustração e a fotografia, nomeadamente em reproduções em policromia ${ }^{2}$, nas suas páginas, ao mesmo tempo que viram a relevância relativa de que desfrutaram ao longo de decénios sucessivos ficar diminuída com a preponderância muito acentuada dos meios audiovisuais, no último quartel do século XX, em particular da televisão em emissão a cores e em registo de vídeo, entre os meios de comunicação social.

Porém, a compreensão do carácter destas publicações periódicas, ao longo do ciclo já balizado, não fica comprometida nem pela diversidade das suas expressões, nem pela sucessão de alterações radicais que a evolução da comunicação social conheceu, determinadas, na maioria dos casos, por saltos técnicos bruscos e revolucionários.

É, pelo contrário, possível não só identificar com rigor os traços distintivos das revistas, no quadro das publicações impressas e mesmo dos órgãos de comunicação social, considerados na sua generalidade, como também caracterizar com nitidez o papel ímpar e central que ocuparam, em virtude da natureza que Ihes foi própria, na história das ideias e da cultura contemporânea.

2 Sobre a evolução técnica da impressão, designadamente do apuro na reprodução massiva de imagens, da tricromia em impressão plana, por similigravura (1880), depois, heliogravura (1895) e, por fim, offset (1904), ao impulso inicial da impressão a cores em rotativa (meados da década de 1910), veja-se Daniel Renoult, “Les nouvelles possibilités techniques: le triomphe de la mécanique”, in Roger Chartier e HenriJean Martin (dir.), Histoire de l'édition française. Le livre concurrencé 1900-1950, Paris, Fayard/Cercle de la Librairie, 1991, pp. 28-50. 
O esclarecimento nítido destas duas dimensões beneficia se considerarmos a actividade editorial de revistas das décadas iniciais do século $\mathrm{XX}$, em que a Primeira República portuguesa se inclui, como referência paradigmática da afirmação e do cultivo deste tipo de publicações.

A tentativa de caracterizar as revistas como modalidade específica de imprensa, no quadro da grande diversidade de critérios editoriais que conferiram a cada uma destas publicações uma identidade própria, obriga, por um lado, à identificação de um conjunto de atributos específicos, alguns constantes e outros simplesmente correntes, e, por outro lado, ao confronto com outras modalidades editoriais, designadamente com os jornais, os livros e os boletins, de modo a distinguir, pela confrontação, as linhas de contorno e as tonalidades de cada um destes tipos de publicações.

A consulta singela de uma destas publicações periódicas deixa, por regra, transparecer, nos dizeres impressos no cabeçalho e na ficha técnica, bem como através de folhear ligeiro, quer a identificação própria através da especificação singular dos quesitos peculiares destes periódicos, quer outros atributos fundamentais, nomeadamente de natureza gráfica e física.

A observação imediata permite, só por si, concluir que as revistas se distinguem por ser publicações periódicas, com cadências de publicação predefinidas, mais ou menos compassadas, elaboradas por vários redactores ou colaboradores, compostas por peças editoriais de um ou mais géneros literários e jornalísticos, revestindo-se da forma de brochura com capa e contracapa. Embora se encontrem revistas comemorativas com número único - que assinalam, por regra, essa sua condição anómala - e se registem casos muito invulgares de edições que conheceram, voluntária ou involuntariamente, um só autor, e mesmo números editados com um só artigo, estas excepções relevam inteiramente do recurso a soluções circunstanciais, atípicas e mesmo insólitas, não constituindo qualquer versão particular da modalidade editorial, mas antes um seu simulacro episódico.

Aos atributos comuns apontados, é necessário acrescentar outras particularidades correntes, embora de observância menos estrita. Destaquemos quatro: o artigo como género usual, a orientação editorial desdobrada em conjuntos de peças variadas, a combinação entre texto e imagem, a focagem temática e a correspondente segmentação de destinatários.

$\mathrm{O}$ artigo constituiu o género jornalístico mais saliente nas revistas, pois directores, redactores e colaboradores utilizaram-no, de forma quase invariável, para apresentar programas, expor concepções, defender posições, explanar temas, desenvolver 
opiniões, tecer comentários e formular apontamentos. Com as excepções dos títulos literários, artísticos ou puramente recreativos, as revistas foram obra, em primeiro lugar, de articulistas, designação comum e apropriada para todos aqueles que discorreram, de forma mais ou menos habitual, nas suas páginas.

A plasticidade do artigo condiz, aliás, com a natureza facetada das revistas. Mesmo os periódicos que apresentaram maior rigidez programática não deixaram de ser, número após número, publicações caracterizadas pela adição de vozes, abordagens, interesses, temas, estilos e registos variegados, a tal ponto que cada edição pode ser encarada como um exercício singular na sucessão de compromissos entre a orientação geral e a diversidade das peças publicadas, balizados pela rejeição da uniformidade monótona e pela recusa da dispersão amorfa. Segundo critérios de latitude muito variável e de acordo com composições mais ou menos felizes, foi na declinação de questões, na pluralidade de autorias, no plissado de géneros e de registos que cada novo número insinuou e replicou a tensão essencial da realidade que presumia reflectir e recriar.

Neste domínio, a combinação entre texto e imagem desempenhou, a vários títulos, um papel central na afirmação das revistas, que frequentemente destacaram, em título ou em subtítulo ${ }^{3}$ a condição de publicações ilustradas: em primeiro lugar, pela divulgação de gravuras e de outras produções artísticas, fosse através da publicação de originais, pois foram muitos os artistas plásticos que colaboraram, a diferentes títulos, em revistas ${ }^{4}$, fosse pela reprodução de obras do património artístico nacional e internacional, num caso e no outro segundo técnicas de reprodução e de impres-

3 Dois exemplos muito conhecidos: a llustração Portuguesa, propriedade do jornal O Século, inicialmente dirigida por Carlos Malheiro Dias, que publicou 959 números, entre 1906 e 1930; e A Águia. Revista ilustrada de literatura e crítica, editada no Porto, em cinco séries, entre 1910 e 1932 . Noutros casos, a presença de ilustração, apesar de não surgir no título, era apresentada como argumento de peso. Foi o que se verificou com Contemporânea, cujo anúncio, que antecedeu, em Março de 1915, a publicação dos números espécimen, assim justificava a necessidade da nova revista de "arte, literatura, teatros, sport, modas \& elegâncias, sociedade": "a falta de uma grande llustração, que a nós e aos estrangeiros revele o que dentro de Portugal existe de bello, como creação do espírito, obra d'arte ou encanto da natureza, vem notando-se de há muito, sem que, no entanto, alguém se abalançasse aos sacrifícios e dificuldades de sua realização", pelo que "A CONTEMPORÂNEA Grande Revista llustrada, prestes a sahir a lume, vem preencher pela forma mais completa essa falta lamentável." Na mesma ocasião, a revista prometia, em pequenos folhetos, a publicação próxima de "primorosas folhas de arte a côres" (Daniel Pires et alii, Pacheko, Almada e "Contemporânea", Lisboa, Centro Nacional de Cultura-Bertrand Editora, 1993, pp. 257 e 259).

4 Entre os pintores e desenhadores das primeiras décadas do século XX que sobressaíram como ilustradores, podem recordar-se Rafael Bordalo Pinheiro, Cristiano Cruz, Leal da Câmara, Bernardo Marques, Stuart Carvalhais, Almada Negreiros, Julio, Tom (Thomaz de Mello), Jorge Barradas, António Carneiro, António 
são variadas, frequentemente de grande apuro, como muitos hors-textes publicados deixaram comprovado; em segundo lugar, pelo sortilégio da superação definitiva da sujeição da percepção à experiência directa, uma vez que a reprodução fotográfica passou a permitir tanto testemunhar factos históricos, num registo tido por transparente, quanto captar os segredos da sedução, do ideal, do exótico ou do atroz, numa palavra, a "ver a vida, ver o mundo";"; em terceiro lugar, pelo próprio desenvolvimento do grafismo, que se passou a distinguir pelas suas gramáticas apelativas, associadas à tradução imagética das orientações editoriais, à recriação específica das novas correntes artísticas e decorativas, à exploração surpreendente dos recursos de ilustração e de composição facultados pelo desenvolvimento das técnicas de impressão.

A variedade e o colorido das revistas foram acompanhados pela segmentação dos leitores, reflectida nos títulos - ou, mais frequentemente, nos subtítulos, que por norma os acompanhavam - através de determinativos que explicitavam os desígnios específicos que lhes presidiam. Desde a sua origem remota, a edição de cada título foi concebida como uma composição que interceptava géneros jornalísticos, literários e artísticos com interesses e gostos peculiares ${ }^{6}$. As revistas tenderam, assim, a ser publicações especializadas, fosse por se dedicarem a temáticas precisas (literárias, humorísticas, mundanas, doutrinárias, entre muitas outras), fosse por se dirigirem a públicos bem definidos (jovens, mulheres, homens de letras e crentes de uma confissão religiosa, por exemplo). É de notar que a diferenciação entre títulos se apresentou como característica de tal modo corrente que as próprias revistas de teor geral sentiram a

Pedro, António Soares e Roberto Nobre. É de notar que alguns escritores de destaque, como Jaime Cortesão, José Régio ou José Rodrigues Miguéis, também se aventuraram no domínio da ilustração.

5 A expressão é retirada do célebre artigo, e manifesto, em que a Life - a revista emblemática do fotojornalismo, que chegou a tirar oito milhões de exemplares - se apresentou, a 23 de Novembro de 1936, aos leitores e que merece transcrição por sintetizar o sentido geral da comunicação visual da vida que a reprodução fotográfica tornara possível:"ver a vida; ver o mundo; ser testemunha dos grandes acontecimentos; contemplar o rosto da pobreza e os gestos do orgulho; ver coisas estranhas - máquinas, exércitos, multidões, sombras na selva e na Lua -, ver o trabalho do homem, suas pinturas, torres e achados; ver coisas que ocorrem a milhares de quilómetros de distância, coisas ocultas e descobertas; coisas perigosas que estão para acontecer; as mulheres que amam homens e muitos filhos; ver e tirar partido do que se vê; ver e divertir-se; ver e ser instruído."

6 The Gentleman's Magazine, editado por Edward Cave Junior, em Londres, a partir de Janeiro de 1731 e ao longo de várias décadas, assinala-o no próprio título. Este último foi, aliás, acompanhado por vários subtítulos, como The monthly intelligences e Historical review. Pelo uso da expressão "magazine" para nomear a nova fórmula de periódico, pelo formato reduzido face à restante imprensa, pela periodicidade mensal e pela miscelânea criteriosa de assuntos, Edward Cave criou uma modalidade de imprensa que alcançou de imediato, dentro e fora de Inglaterra, fama e respeito, passando a ser amplamente imitada. 
necessidade de assinalar essa sua condição em subtítulo, ao indicarem a informação como o âmbito que as distinguia 7 .

O confronto com as outras modalidades correntes de edição permite, igualmente, caracterizar o âmbito próprio das revistas, ainda que algumas fronteiras entre géneros de imprensa apresentem zonas híbridas de sobreposição, mais ou menos extensas, e, por regra, fluidas, em conformidade, aliás, com os termos gerais da evolução de cada formato editorial e das sucessivas e profundas transformações que a comunicação social considerada no seu conjunto sofreu ao longo do século XX.

Quando comparadas com os jornais, as revistas podem distinguir-se pela periodicidade, o teor geral e o formato.

A vocação para a cadência diária está registada no próprio radical etimológico, proveniente do francês, do vocábulo "jornal." Destinado a proporcionar informação, o relato jornalístico vive do acontecimento próximo, da novidade, que, pela sua própria natureza, requer despacho e publicitação expeditos, motivo pelo qual os jornais consagrados, ao longo dos tempos e por todo o lado, são quotidianos, matutinos ou vespertinos, capazes de pôr em dia os seus leitores. Ora, a eventual existência de revistas diárias seria um contra-senso, de tal modo é claro que a urgência e a vertigem da informação jornalística contrastam com o escrutínio intencional e avisado, mais ou menos criterioso e reflectido, que as caracteriza.

A diferença de ritmo entre os jornais e as revistas, reflectida na periodicidade mais larga destas últimas, acompanha o teor dominante em cada um dos tipos de periódicos. Embora a informação e a opinião estejam presentes em ambos, a primeira foi, e é, preponderante nos jornais, enquanto a segunda prevaleceu, e prevalece, explícita ou implicitamente, nas revistas. Por outras palavras, as notícias fazem a matéria primeira dos jornais, enquanto, por regra, os artigos perspectivam e estruturam as revistas, preenchidas ainda por outros géneros jornalísticos, literários e artísticos.

É ainda possível reconhecer, por vezes ao primeiro olhar, alguns outros traços distintivos entre estes dois tipos de periódicos. Desde logo, o formato, que nas revistas foi desde sempre muito menor do que o dos jornais, mesmo dos tablóides, que redu-

\footnotetext{
Como aconteceu com a Time, que se apresentou, na sua edição inaugural, a 3 de Março de 1923, em Nova lorque, com o subtítulo Newsmagazine. É de notar que a Time criou um novo tipo de revista, em que os acontecimentos da semana são tratados, em secções fixas, de um modo que se pretende documentado, compreensivo e directo. A sua fórmula foi reproduzida por congéneres um pouco por todo o lado, ainda que, por vezes, com grande diferimento, como aconteceu, entre nós, com a Vida Mundial, criada na década de 1960. O formato das newsmagazines resistiu ao tempo e representa, desde a sua criação até à actualidade, uma parcela muito importante das revistas publicadas na América e na Europa.
} 
ziram a metade as dimensões correntes na imprensa diária. Outras diferenças físicas correntes já foram, implicitamente, sugeridas: a capa, presente nas revistas e ausente nos jornais; o formato de brochura das primeiras e o simples vinco central a unir as folhas dos segundos; o cuidado e a variedade postos na paginação das revistas e a monotonia tradicional da mancha dos quotidianos.

A caracterização das revistas face aos livros apresenta recortes ainda mais nítidos, uma vez que os livros são, em geral, publicações de autor, com arquitectura unitária, discurso uniforme, aspecto completo e definitivo.

Já a distância que separa as revistas dos boletins assenta numa disparidade fundamental: os boletins não são publicações autónomas, mas órgãos vinculados a instituições e, como tal, destinados à satisfação das suas finalidades estatutárias. Além de procederem ao relato da vida interna das organizações em que se integram, dividem-se, por regra, entre um modelo muito próximo do da revista temática e um formato editorial com orientação prática e mesmo com finalidades concretas.

Se, em nota geral, considerarmos as revistas, nomeadamente as das primeiras décadas do século XX, no quadro do conjunto das publicações da época, o aspecto editorial mais saliente é provavelmente o da graciosidade e da diversidade com que atraíram a atenção dos leitores. Este dom natural congénito, capaz de despertar curiosidade, de fomentar interesses e de fidelizar públicos, quer junto dos leitores de outros tipos de publicações, quer entre os que se lhes conservavam arredios, encontrou então condições culturais, técnicas e sociais excepcionais para se fazer sentir.

\section{Revistas e cultura}

No mundo contemporâneo, em que as sociedades passaram a observar-se a si próprias através da mediação da imprensa, o papel constitutivo das representações em que as comunidades vieram a reconhecer-se, e em muitos casos à luz do qual ganharam contorno e definição, foi desempenhado de forma muito relevante, ao longo de décadas sucessivas, por jornais e por revistas. Estas publicações periódicas não foram simples meios de circulação de informação ou de recreio, mais ou menos ilustrados, mas "suportes centrais do espaço público" e "mediadores essenciais das opiniões que se confrontam numa democracia"8, ou seja, actores situados no primeiro plano da vida colectiva, responsáveis tanto pela afirmação e confronto políticos, quanto pela identidade e devir culturais.

\footnotetext{
8 Christophe Charle, Le Siècle de la presse (1830-1939), Paris, Éditions du Seuil, 2004, p. 354.
} 
Dia a dia, os jornais criaram e reflectiram a realidade política?.

À escala pessoal, episódica e ressentida do preterido Brás Cubas, amparado no Humanitismo de Quincas Borba ${ }^{10}$, ou ao nível ambicioso e determinado da putativa representação de grandes desígnios sociais, nacionais e civilizacionais, os jornais, relativamente baratos e com tiragens muitíssimo elevadas ${ }^{11}$, foram a um só tempo arautos, organizadores colectivos, fautores da ordem do dia e instrumentos de combate no quadro de realidades políticas em que a opinião pública - frequentemente cindida, por seu intermédio, em facções opostas - e o sufrágio se haviam tornado decisivos.

Simultaneamente, as revistas reflectiram e criaram a realidade cultural.

Desfrutando de uma relação com o tempo diferente do tropel veloz dos diários, as revistas não se distinguiram por dar a ver, mas evidenciaram-se, antes, por rever, por reapreciar, à luz da fonte de sentido presente na orientação editorial de cada título, as realidades e os eventos do mundo que lhes era coetâneo.

Ao vencerem a prega de tempo necessária à depuração do quotidiano, estes periódicos trouxeram consigo as diferentes expressões e linguagens pelas quais o presente foi adquirindo consciência de si próprio: introduziram conceitos, fixaram temáticas, impuseram linguagens, defenderam teses, estabeleceram referências, instauraram símbolos, criaram mitos, desenharam o movimento das tendências e das modas.

A dimensão compreensiva foi-lhes intrínseca: cada título sintetizou, reformulou e actualizou os instrumentos intelectuais colectivos de que a sociedade, nas suas diferentes instâncias e grupos, dispunha para conferir significado ao evoluir contingente e inaudito do mundo e da vida.

Ora, se a cultura consiste no conjunto de representações colectivas que medeiam a relação dos homens uns com os outros e com o mundo, pelo qual estes conferem sentido à realidade e nela participam, as revistas não só foram poderosas fontes de elabo-

9 Rui Ramos assinalou-o: "a imprensa era o espaço público em que a sociedade e o Estado existiam, e estava para a vida política como a bolsa para a vida económica", pois "o que se dizia na corte, nos ministérios, nos quartéis, nas câmaras municipais, nas oficinas nunca se poderia tornar opinião importante se não fosse publicado nos jornais."Os jornais apareciam tão poderosos que não só "a principal organização dos partidos políticos eram os seus jornais, com a redacção a servir de sede", como também se investiam de finalidades filantrópicas e civilizacionais de monta (Rui Ramos, op. cit., pp. 56-57).

${ }^{10}$ Cf. Machado de Assis, Memórias Póstumas de Brás Cubas, Lisboa, Livros Cotovia, 2005, p. 292 e ss.

11 Em 1906, os onze quotidianos publicados em Lisboa somariam uma tiragem de aproximadamente trezentos mil exemplares diários (Rui Ramos, op. cit., p. 55), enquanto, na cidade-luz e durante a década de 1910, o Petit journal imprimia 1400000 exemplares, ascendendo a tiragem global dos quotidianos parisienses, todos com clara tendência ideológica, a uma cifra superior a 4700000 exemplares (cf. Chistophe Charle, op. cit., p. 156 e ss.). 
ração e de disseminação interpretativas, como também se revelaram particularmente pertinentes e acutilantes, na medida em que ergueram a sua discursividade - numa era em que a autoconsciência era valorizada e a mudança qualitativa tida genericamente por inevitável - a partir da reflexão sobre o fluir vivo dos acontecimentos.

A mediação cultural conheceu, naturalmente, diferentes escalas, em conformidade com os públicos a que cada publicação se dirigia. Porém, a dimensão global de que se revestia não necessitava, à excepção das revistas doutrinárias ou científicas, de garantir sistematicidade ou radicalidade, antes bastava assegurar correspondência entre os tópicos presentes no horizonte de interesses e de referências dos leitores visados e as matérias publicadas.

O protocolo almejado entre a publicação e o seu público seria aquele que fizesse com que os leitores reconhecessem na publicação um símile do seu próprio mundo, ou de uma sua parcela relevante, ao encontrarem nas suas páginas, de forma acessível, amena e variada, como se de um bazar ou depósito ${ }^{12}$ da vida se tratasse, repositórios das matérias e das evocações que julgavam merecer consideração, justificar curiosidade, proporcionar satisfação.

A escolha de perspectivas de abordagem, formatos, temáticas, registos, organização em secções permanentes subordinou-se, pois, ao desígnio de padronizar a relação entre a natureza e a estrutura da publicação e o perfil peculiar dos seus destinatários, de modo não só a facultar o reconhecimento de afinidades relevantes, mas também a conferir-lhes expressão conjunta e facetada. Cada título encerrou, assim, uma visão e uma atitude face ao mundo, uma cosmovisão particular, feita da adição das manchas fragmentadas com que a realidade, ou uma sua parcela significativa, daqueles a quem se dirigia era feita.

Como o relacionamento entre os leitores e os títulos em que cada um revia a sua imagem da realidade ocorreu nas revistas de forma regular e perdurável no tempo, frequentemente ao longo de anos sucessivos, a mediação que estas proporcionaram não se desenvolveu de forma circunstancial e incerta.

Estas publicações não trouxeram à vida a iluminação de um livro tocante, o êxtase de uma récita sublime, a graça de uma representação inesquecível, o deslumbramento

12 O vocábulo "magazine", utilizado em Inglaterra desde meados do século XVIII para designar as primeiras revistas, tem origem na palavra francesa "magasin", a qual provém, por sua vez, do vocábulo árabe "makhazin", plural de"makhzin" (armazém de qualquer tipo). 
de um filme emocionante, mas a trama de uma relação ratificada regularmente, de acordo com a cadência de edição do periódico.

Os títulos da inclinação de cada leitor proporcionam, assim, um envolvimento prolongado, a seu modo folhetinesco, feito tanto de atenção e leitura quanto de simpatia e afecto. A proximidade, originada num primeiro momento pela atracção resultante de afinidades reconhecidas, consolidava-se e estruturava-se depois através de corroboração contínua e regular. Prolongava-se, renovava-se e ampliava-se, em cada nova edição, frequentemente aguardada com expectativa. O cômputo geral superava, então, o somatório fátuo de matérias aparentemente episódicas para se adensar em concepções e quadros de referência estáveis, adoptados muitas vezes como o fundamento de um olhar consolidado e próprio, tido por esclarecido, sobre os homens, os livros e as coisas.

Se cada título, considerado em cada uma das suas edições, invariavelmente datadas, parece (na sua aparência imediata, tanto pela forma física quanto pela variedade e dispersão circunstanciais) uma publicação efémera, já o efeito da sucessão das edições (designadamente se associada ao cultivo continuado de interesses, incluindo os espirituais, que proporcionam aos seus leitores) deixa de o ser, de tal modo a afirmação e a evolução das revistas pressupõem um mínimo de coerência conceptual, temática, valorativa e imagética, mesmo naqueles casos em que foi pela frivolidade e banalidade mundanas que se distinguiram.

O facto de cultura e cultivo caminharem neste caso, como na generalidade das situações, a par, ainda que no âmbito das revistas com ritmo predefinido e preciso, bem como a circunstância de perspectivarem a realidade de forma situada não significa que a sucessão das edições se limite ao desdobramento rígido e sequencial das disposições que lhe serviram de matriz.

O olhar inicial de cada título sobre a realidade que por seu intermédio se deixaria decifrar facilmente passa, com o correr dos anos, da nitidez pertinente e persuasiva à caducidade capciosa, caso não reactualize pressupostos, abordagens e linguagens.

As revistas, ao nomearem e dizerem o mundo, conheceram os diferentes ritmos dos seus ciclos de vida: a erupção oportuna e surpreendente que, pela sua qualidade, alterou o clima cultural dos leitores e, mesmo, do país esclarecido; o trânsito ardente de um período decisivo; a emoção evanescente de uma moda; o acompanhamento marcante e prolongado de situações culturais e históricas estáveis; a afirmação, intermitência e reformulação em diferentes séries; o arco temporal centenário, inerente à 
sedimentação do título junto de um público estável; o declínio prolongado, em consequência da denegação da caducidade ingrata do programa prosseguido.

No seu conjunto, as revistas formaram, assim, um painel panorâmico, sincrónico e diacrónico da cultura viva, decerto o seu registo mais significativo na época considerada, dando a conhecer o sentido das suas expressões e dinâmicas.

Isoladamente, alguns títulos duradouros possibilitam captar os próprios sentidos das transformações culturais, na medida em que as suas edições as integraram e reflectiram, assemelhando-as assim a fotogramas, cada um, por si, estático, mas na sua sucessão claramente cinemáticos, ao revelarem o movimento das diferentes realidades com que preencheram as suas páginas.

O mérito cultural atribuível a cada título minimamente significativo pode ser aferido a partir de dois critérios fundamentais: o da consistência, qualidade e originalidade, ainda que relativa, dos materiais publicados e o da relevância assumida nas transformações da percepção social do mundo e da vida.

A propósito do primeiro destes critérios, é de referir que mesmo títulos apreendidos à boca da tipografia tiveram o merecimento necessário, apesar de não haverem chegado às mãos dos leitores, para passarem a indicar marcos na história das letras e das artes nacionais ${ }^{13}$.

Acreditava-se, em geral, no valor demiúrgico do pensamento, no papel revolucionário das ideias, na verdade definitiva do saber científico, na magnanimidade das letras, na inefabilidade das artes, na necessidade imperativa da modernidade.

Acerca do segundo critério, é de sublinhar que a própria imprensa de natureza comercial se dizia subordinada à missão intelectual e civilizacional de reformar mentalidades e de promover conhecimentos úteis, prolongando e ampliando o espírito oitocentista de "amor da instrução"14.

${ }^{13}$ Como Portugal Futurista (1917) e Cadernos da Juventude (1937), mais tarde reeditados e frequentemente evocados.

${ }^{14}$ Alexandre Herculano deixou-o sublinhado logo na apresentação do número inaugural do célebre O Panorama - Jornal Literário e Instructivo da Sociedade Propagadora dos Conhecimentos Úteis, editado a 6 de Maio de 1837:"neste estado da ilustração e do progresso o que mais importa é o dilatar por todas as nações, e introduzir em todas as classes da sociedade o amor da instrução; porque este é o espírito do nosso tempo, porque esta tendência é generosa e útil" (O Panorama, 1837, p. 1). Patrocinado por Dona Maria Il, o periódico foi dirigido na fase inicial dos seus dezoito anos de publicação, distribuídos por cinco séries, entre 1837 e 1868, pelo autor de O Monge de Cister, romance parcialmente publicado nas suas páginas, tendo obtido, com os quase cinco mil exemplares de tiragem e com a colecção de livros que lhe esteve associada, um êxito significativo, embora muito menor do que o alcançado pela revista inglesa Penny Magazine, com tiragem de trezentos mil exemplares, tomada expressamente por modelo (cf.ibidem, p. 53). 
A obrigação de providenciar a difusão científica, histórica, literária e artística, de difundir informações e conselhos profilácticos, domésticos e técnicos, de colocar a nação a par do mundo civilizado representaria dever comum e indeclinável de toda a imprensa. Esta missão definiria mesmo a grandeza da tarefa histórica e social que reclamava para si e em que gostava de se rever com notória boa consciência.

Instrução e imprensa foram, aliás, realidades próximas e correlativas. A imprensa afirmou-se na medida em que a instrução pública alargou o universo dos leitores, contributo que retribuiu ao chamar a si um papel supletivo de fomento educacional. Os jornais e as revistas dirigiam-se, em primeiro lugar, à classe média, letrada e com posses, fomentada pela diferenciação e pela mobilidade sociais inerentes à escolarização. Em sentido complementar, os homens de imprensa e os restantes publicistas deviam à instrução, escolar ou autodidacta, as competências de redacção e de tradução que os qualificavam, Ihes conferiam estatuto e facultavam modo de vida.

No quadro de um imaginário centrado nas expectativas depositadas na divulgação social das luzes, na redescoberta da autenticidade colectiva, na formação do cidadão esclarecido e empreendedor, escola e imprensa ocupariam papéis complementares e decisivos na edificação das consciências e das almas, no renascimento da nação e no progresso da civilização.

A simpatia e o empenho colocados na promoção da ilustração pública, assente na cultura do escrito e muito distinta da criação da chamada cultura de massas - associada aos imaginários suscitados e suportados por novos meios de comunicação, como a rádio e o cinema, em que as revistas também desempenharam papel de monta -, trouxe consigo uma notável revitalização da vida cultural, na dupla dimensão criativa e de divulgação.

O número de revistas e de outros periódicos literários portugueses, ou com componente literária, criados e publicados ao longo dos três primeiros quartéis do século XX exemplifica-o cabalmente: 275 novos títulos, 25 por ano, em média, nos onze anos compreendidos entre 1900 e 1910; 483 títulos, trinta por ano, em média, nos dezasseis anos que vão de 1911 a 1926; 439 títulos, nove por ano, em média, nos 48 anos do Estado Novo ${ }^{15}$.

${ }^{15}$ Cf. Daniel Pires, Dicionário da Imprensa Literária Portuguesa do Século XX, Lisboa, s. d., vol. I, p. 375 e ss.; vol. II, 2. ${ }^{\circ}$ tomo, p. 635 e ss. Daniel Pires utilizou um critério relativamente abrangente, assente na selecção de revistas e de outros periódicos, a partir da publicação regular e significativa, nas suas páginas, de textos ou de temas literários. Com escrutínio mais restrito, numa "perspectiva selectiva e não sistemática,"no que respeita à relevância literária e cultural das revistas seleccionadas, Clara Rocha analisou número inferior 
As estimativas que se podem fazer para os inventários de revistas de outros domínios temáticos, designadamente a partir da consulta de repertórios e de catálogos, apontam igualmente para números de títulos novos e de publicações em circulação considerados, tanto em termos absolutos quanto relativos, muito relevantes ${ }^{16}$.

É igualmente de recordar quer a circunstância de muitas revistas terem estendido o seu múnus à edição de livros (como aconteceu, por exemplo, com A Águia, que ficou associada à publicação de três centenas de obras), quer as afinidades entre algumas colecções de livros de divulgação (incluindo a célebre "Biblioteca do Povo e das Escolas", distribuída em Portugal e no Brasil) e as temáticas e linguagens presentes na vertente de divulgação de conhecimentos dos periódicos de que nos ocupamos, que, a seu modo, retomavam, desenvolviam e completavam.

Todo este vasto esforço de criação e de divulgação culturais, que teve nas revistas um instrumento privilegiado, foi potenciado e ampliado pela dimensão internacional de que se revestiu.

Esclarecimento racional e subtileza intelectual, expressividade literária e artística, progresso civilizacional e técnico, emancipação humana e social, gosto e moda requintados não representavam valores de extracção vernácula, mas bens irradiados a partir das grandes capitais.

O sentimento de modernidade encontrou nas revistas de vocação internacional os seus mercúrios universais. Por seu intermédio, a vida festiva de Paris, o conservadorismo imperial de Londres, a turbulência de Nova lorque ou o firmamento de Hollywood passaram a ser realidades familiares.

Universalidade, modernidade e cosmopolitismo tornaram-se, então, equivalentes.

de revistas: dezoito novos títulos surgidos entre 1900 e 1910; 45 entre 1911 e 1926; 129 entre 1927 e 1974 (cf. Clara Rocha, Revistas Literárias do Século XX em Portugal, Lisboa, Imprensa Nacional-Casa da Moeda, 1985, p. 635 e ss.). Acerca da edição de novos periódicos durante os anos do Estado Novo, é de sublinhar que as restrições à liberdade editorial eram anteriores à própria possibilidade do exercício da censura, pois os entraves políticos e administrativos colocados aos candidatos a proprietários e a directores de novos títulos foram sempre muitos e variados, a ponto de estes se terem visto, com muita frequência, na necessidade de os contornar através da aquisição ou da tomada de publicações já existentes.

${ }^{16}$ António Nóvoa e Filomena Bandeira incluíram 530 periódicos editados em Portugal, na maioria com o teor próprio das revistas, no Repertório da Imprensa de Educação e de Ensino, dos séculos XIX e XX, ao mesmo tempo que inventariaram, no Catálogo de Imprensa de Educação e Ensino, 2306 publicações. $O$ Repertório resulta da aplicação de um critério de conteúdo, ao reunir as publicações que dedicaram mais de um quarto das suas páginas a temas pedagógicos e educativos, enquanto o Catálogo resulta da aplicação de um critério de contexto, ao abranger as publicações de instituições e grupos associados ao ensino (António Nóvoa, Evidentemente. Histórias da Educação, Porto, Edições ASA, 2005). 
A Revue des deux mondes, uma das publicações internacionais mais antigas, fundada em 1829, muito lida e conceituada na velha Europa e no Novo Mundo ao longo de décadas sucessivas, gravou o intento cosmopolita que lhe presidia no próprio título, evocativo do propósito de aproximar os leitores cultos dos dois continentes tidos por civilizados.

Apesar de a limitação inerente ao obstáculo de os segmentos do público versados em idiomas estrangeiros serem reduzidos, as revistas com vocação internacional conheceram, em muitos casos, grande receptividade, sem equivalência entre outro tipo de publicações, o que permite não só explicar que se encontrem, no decorrer do século XX, muitos magazines com circulação à escala mundial, como justificar a publicação de um mesmo título em várias línguas ${ }^{17}$, por vezes em edições locais e com matéria editorial específica.

O sentimento e o perfume cosmopolitas impregnaram igualmente os títulos nacionais mais vincadamente urbanos, que se queriam arejados e responsavelmente avançados, numa palavra, desejosos de acompanhar o mundo e as suas novidades. Embora muitas revistas tenham conservado os formatos correntes e locais, muitas outras distinguiram-se tanto por se moldarem segundo padrões internacionais, quanto por rasgarem as janelas pelas quais os leitores passaram a vislumbrar a vida mundial. No programa editorial, nos critérios temáticos, nas opções gráficas, no imaginário simbólico, nas traduções, nas referências explícitas, no ardor posto na defesa de convicções e na frivolidade da high life, estes títulos importaram e assimilaram as novidades dos grandes títulos estrangeiros.

Curiosamente, algumas das publicações periódicas que se destacaram na defesa do tradicionalismo não deixaram de se revelar miméticas das suas congéneres europeias, ao reconstituírem os mitos nacionais segundo modelos e práticas alheios.

A dificuldade em captar a pluralidade das dimensões culturais em que as revistas fizeram sentir o papel primordial que ocuparam na circulação de representações, símbolos e valores, ao longo do século considerado, resulta quer da complexidade ínsita em todas as grandes inflexões culturais e das mentalidades (produtos da sobreposição de várias malhas de vínculos independentes, muitas vezes invisíveis e tácitos), quer da difícil consideração da sua articulação com a mudança acelerada e geral da vida e do mundo, presentes, por exemplo, na escala universal da revolução urbana e no progressivo desenvolvimento dos sectores terciários da actividade económica.

17 A Reader's Digest, traduzida em 35 línguas e com distribuição em 120 países, com vendas globais próximas dos trinta milhões de exemplares, através de assinatura, numa parte substancial, constitui provavelmente o exemplo mais eloquente do sucesso, ao longo de muitas décadas, de uma publicação periódica com vocação mundial. 
Embora a objectivação do lugar concreto das revistas na inflexão das mentalidades e no comportamento individual e colectivo se revele muito frequentemente problemática, a aceitação do alcance cultural de que o seu papel se revestiu, bem como dos seus grandes sentidos, parece dificilmente iludível.

\section{Revistas de ideias}

Num contexto mundial em grande convulsão, de que as duas grandes guerras foram os expoentes, atravessado pelos conflitos inerentes à "questão social" (a que a Revolução de Outubro e a política de blocos deram expressões institucionais), marcado pela rápida afirmação de novas capacidades técnicas (como a magia da electricidade, do telefone, do cinema, da telefonia e da televisão exemplificaram) e revolvido pelas mudanças de costumes, linguagens e gostos, que a simples evocação dos anos 20 ou 60 passou a assinalar, o papel desempenhado pelas revistas, como meios de comunicação que simultaneamente reflectiram a mudança e sedimentaram as diferentes expressões da apreensão colectiva da vida e do mundo, não se confinou ao teor específico da esfera jornalística e aos formatos empresariais da imprensa periódica, mas estendeu-se, de forma igualmente muito vincada, aos domínios do conhecimento e da afirmação doutrinária.

Para além da publicação regular dos antigos e dos novos títulos em que o mundo académico, bem como a orla daqueles que lhe eram próximos, dava a conhecer o saber e as novidades disciplinares (cujo interesse, em domínios como a História, a Geografia, a Etnologia, a Filologia, a Filosofia, por exemplo, extravasava o universo da respectiva comunidade especializada), encontramos muitos outros títulos com elaboração cultural exigente e apurada, por regra com natureza claramente doutrinária, subordinados ao desígnio da elaboração e da divulgação da consciência esclarecida do tempo presente, da qual se fazia decorrer, naturalmente, o dever de intervir activamente nas decisões colectivas.

Sendo os homens de letras, do pensamento e das ciências encarados como os símbolos vivos do saber e este concebido como a alma e a matéria do elã libertador contemporâneo, com provas dadas, quer no domínio da edificação voluntária e constitucional da cidade, quer no âmbito da libertação de enleios naturais, o estatuto de que escritores e cientistas desfrutavam e as expectativas que se depositavam na sua ilustração tornaram-se muito elevados.

As figuras da cultura catalíticas desta dimensão emblemática ganharam assim a condição, informal mas corrente, de autoridades tutelares, não só no âmbito espe- 
cífico da actividade em que cada uma tinha revelado o seu mérito, mas também de forma indiscriminada e genérica.

Este prestígio lato, a seu modo olímpico, prolongava, na actualidade, a linhagem extensa dos heróis modernos da cultura, de Galileu a Darwin, de Voltaire a Zola, inscritos numa perspectiva geral do percurso humano em que o esclarecimento racional e a integridade espiritual e altruísta eram concebidos como evoluindo a par.

Pressupunha-se, em consequência, que a condição de homem culto traria consigo uma ética cívica.

Os imperativos que obrigariam as pessoas esclarecidas face aos seus concidadãos dirigir-se-iam em dois sentidos fundamentais.

Acreditava-se, por um lado, que o poder das luzes residia na sua propagação, pois a divulgação universal do saber era condição da constituição da comunidade política, uma vez que a cidadania pressupunha o discernimento individual autónomo, factor de salvaguarda do bem comum (na medida em que facultaria o escrutínio colectivo da vida comunitária) e aspecto determinante do fomento material, pela aplicação industriosa do saber disseminado. As missões civilizadoras atribuídas ao ensino público obrigatório e à imprensa em geral, já referidas, espelhavam esta convicção, que as muitas revistas e outras publicações dedicadas, exclusiva ou parcialmente, à divulgação cultural, científica e de conhecimentos úteis tomaram igualmente como escopo próprio.

Sentia-se, por outro lado, que quem sabia, por estar mais preparado para ver, ouvir ou ler, não podia deixar de intervir na cidade. Abster-se de o fazer representaria conivência culposa e infame.

Investidos na condição de representantes vivos do saber, os autores consagrados estavam em condições de agir em nome dos grandes valores civilizacionais, como a verdade e a justiça, de que seriam os fiéis depositários, desfrutando assim de um ascendente que os elevava à condição de efectiva consciência colectiva, alheia e superior aos jogos retóricos e de poder dos agentes políticos.

Os intelectuais, como realidade colectiva, desempenharam, então, um papel central na formulação, divulgação e debate das ideias e das concepções que atravessaram o conjunto do mundo ocidental.

Poucos anos antes da viragem para o século XX, Eça havia declarado ser Portugal,"na Europa, o único país que não possui uma Revista"18, ao expor o programa da Revista de Portugal, que fundou e dirigiu entre 1889 e 1892. A seu ver, os periódicos deste

${ }^{18}$ Revista de Portugal, Porto, Editores Lugan \& Genelioux, 1889, p. 3. 
tipo, então existentes, não satisfaziam "as curiosidades intelectuais que uma cultura crescente torna felizmente cada dia mais largas e múltiplas"19, sendo o público"prejudicado quando, pela falta de uma Revista onde esses trabalhos [romances, poesia, crítica literária, História, Filosofia, Sociologia, apreciação de actos legislativos, análise dos problemas nacionais, comentários do estado político, entre outros domínios] se produzam, não possa aproveitar do ensino, do conselho e da luz que eles contenham"20. Para os autores seus contemporâneos, a ausência sentida seria igualmente nefasta, pois "tem da falta de uma Revista resultado esta desunião moral e intelectual que nos traz dispersos, como divorciados"21, situação que a publicação do periódico almejado permitiria superar, ao "estabelecer um centro intelectual onde os escritores vivam uns com os outros em mais estreita comunhão"22. Comunhão que Eça queria ampla, já que pretendia congregar, na revista que anunciava, "uma numerosa e ilustre plêiade de espíritos, a mais bem dotada e brilhante que jamais reuniu uma publicação em Portugal", dada a conhecer desde logo na lista de trinta e oito "colaboradores efectivos" do novo título, em que figuravam os autores mais salientes da sua geração e daquela que se lhe seguiu ${ }^{23}$.

Embora Eça tenha afirmado, no folheto programático previamente divulgado, que "a Revista de Portugal, sendo portuguesa, é também implicitamente brasileira - e para a leitura dos dois povos que habitam os dois solos foi ela desde princípio criada"24, a carta-circular distribuída na mesma ocasião, igualmente da sua autoria, faz convergir os diferentes desígnios enunciados para o objectivo de despertar e de exercitar a actividade de produção de ideias nacional, de "'acordar' Portugal, colocando-o ao nível dos restantes países europeus, não pela economia, mas pelas ideias culturais, filosóficas e científicas que podia produzir"25.

A missão histórica e cívica a que os homens de letras se diziam vinculados atravessou, em Portugal como na generalidade do Ocidente, o conjunto da centúria áurea

\footnotetext{
19 Ibidem, p. 4.

${ }_{20}$ Ibidem, pp. 6-7.

${ }^{21}$ Ibidem, p. 7.

22 Ibidem, p. 8.

${ }^{23}$ Basta atender a um terço dos nomes da lista de "colaboradores efectivos" - Antero de Quental, Oliveira Martins, Ramalho Ortigão, João de Deus, Sampaio Bruno, Guerra Junqueiro, Jaime Batalha Reis, Teófilo Braga, Pinheiro Chagas, Conde de Ficalho, Luís de Magalhães, Moniz Barreto e Jaime Moniz - para se verificar que a Revista de Portugal tinha a ambição de ser o órgão da intelligentsia nacional.

24 Ibidem, p. 11.

25 Miguel Real, O Último Eça, Matosinhos, QuidNovi, 2006, p. 145.
} 
das revistas, pois todos aqueles que julgavam trazer à comunidade uma novidade doutrinária emancipadora ou que sentiam, simplesmente, a obrigação de fazer sentir a presença da reflexão avisada, da cultura informada e da vigilância crítica no quotidiano colectivo acabaram por fundar e colaborar em revistas de ideias.

A Seara Nova, revista quinzenal de doutrina e crítica pode ser tomada como exemplo do desiderato persistente que tinha animado, três décadas antes, Eça e os seus antigos e novos companheiros de intervenção pública.

O retrato de grupo dos fundadores da publicação é bem conhecido, ao incluir alguns dos autores mais prestigiados da cultura portuguesa nos domínios da literatura (Raul Brandão e Aquilino Ribeiro), do jornalismo e do pensamento (Raul Proença), da investigação histórica (Jaime Cortesão), da nova pedagogia (Faria de Vasconcelos), a que muitos outros homens do saber se somaram, como, por exemplo, António Sérgio, Ferreira de Macedo, Ezequiel de Campos e o jovem José de Azeredo Perdigão.

A exposição do programa do quinzenário, na sua edição inaugural, publicada em 15 de Outubro de 1921, apresenta-se, logo no parágrafo inicial, inequívoca, quer a respeito das motivações de protesto cívico e das finalidades de reforma social e política esclarecida que lhe presidiam, quer acerca da relevância conferida aos intelectuais na regeneração da República ${ }^{26}$.

Ao invés da breve Revista de Portugal, que desfaleceu no quarto ano de publicação, a Seara Nova distinguiu-se pela tenacidade, pois conheceu 1599 edições, entre 1921 e 1979, por vezes com periodicidade semanal, a que ficou associada, ainda, actividade editorial muito relevante na publicação de livros, bem como numerosos ciclos de conferências e de outras iniciativas variadas de difusão cultural e doutrinária.

A estas duas revistas, somaram-se centenas de outros títulos com fins semelhantes, cobrindo reiteradamente todo o espectro do debate de ideias e da intervenção política, social e cultural que coloriu, segmentou e animou tanto o mundo contemporâneo como a sociedade portuguesa.

Porém, a representação do dever cívico que conduziu à publicação de cada revista não se apresentou uniforme, pois oscilou entre o proselitismo doutrinário de teor polí-

${ }^{26}$ Escreveu Raul Proença, em nome do Grupo Seara Nova: "a Seara Nova representa o esforço de alguns intelectuais, alheados dos partidos políticos mas não da vida política, para que se erga, acima do miserável circo onde se debatem os interesses inconfessáveis das clientelas e das organizações plutocráticas, uma atmosfera mais pura em que se faça ouvir o protesto das mais altivas consciências, e em que se formulem e imponham, por uma propaganda larga e profunda, as reformas necessárias à vida nacional" (Seara Nova, n. ${ }^{\circ} 1,15.10 .1921$, p. 1). 
tico, social, estético, ideológico e confessional e a missão civilizadora da divulgação e da actualização culturais e a intervenção regular, concreta e próxima na vida comum, mais ou menos casuística.

Simultaneamente, o papel representado pelas revistas na constituição dos grupos de intelectuais e no desempenho das missões em que estes se sentiam investidos não conheceu excepções ou variações significativas, de tal modo a publicação periódica de ideias elaborada conjuntamente ocupou, por regra, o lugar central, estruturante e determinante nos movimentos de intelectuais que venceram a condição de fogaréu circunstancial.

Fazer uma revista era, antes de mais, erguer a tribuna que permitia que aqueles que sentissem ter algo de novo ou de relevante a dizer o fizessem, pois foi o meio mais eficaz, ao longo de muitas décadas, para conferir realidade à afirmação pública e continuada de convicções doutrinárias e dos ditames interventivos que lhes estiveram associados.

Eça, nas passagens do Programa da Revista Portugal transcritas, deixou-o sugerido, ao indicar que as revistas são centros intelectuais onde os escritores vivem uns com os outros em estreita comunhão, o que lhes permitiria vencer a desunião moral e intelectual que a sua falta provocaria.

A simples recapitulação mental dos grandes títulos internacionais e nacionais que preencheram a exposição e o debate de ideias públicos, década após década, permite, a quem conheça minimamente o período considerado, imaginar os escaparates de uma boa livraria como dois fora paralelos, um europeu e outro local, em que as grandes correntes doutrinárias se encontravam expostas e os seus principais defensores acantonados, tomando as respectivas revistas por bandeiras e as grandes teses propaladas como dispositivos de afrontamento, simultaneamente mundial e civil, dos espíritos que se queriam esclarecidos, hodiernos e empenhados na defesa de interesses comuns.

Todas as grandes correntes ideológicas, políticas e culturais tiveram as suas revistas, pois a falta de tribuna própria para a produção e divulgação doutrinárias significava ficar excluído do certame colectivo das ideias e concepções, exactamente no momento em que estas eram celebradas como guias indeclináveis da acção individual e colectiva, tão urgente quanto promissora, mesmo deslumbrante.

Quem conheça minimamente o período considerado não pode deixar de identificar, nos domínios da literatura e das artes, os periódicos de realistas, simbolistas, academistas, modernistas (segundo diferentes programas), neo-realistas e surrealistas (de 
outras sensibilidades com poéticas peculiares); no domínio do pensamento político, os títulos monárquicos e constitucionalistas, republicanos, integralistas e legitimistas, nacionalistas, socialistas, libertários, anarco-sindicalistas, democratas-cristãos, corporativistas, cooperativistas, marxistas, liberais e radicais; no domínio confessional, as revistas defensoras da doutrina social da Igreja, neotomistas, conciliares, bem como, em sentido oposto, as de teor anticlerical; a que é necessário acrescentar muitos outros títulos em variados domínios do pensamento e do saber, bem como aqueles cuja idiossincrasia e, por vezes, eclectismo tornam difíceis de qualificar sumariamente, embora a orientação a que obedeceram e o papel que desempenharam no debate de ideias tenham sido claros e relevantes, como aconteceu, por exemplo, com A Águia e a Seara Nova (o que motiva que a primeira surja, por norma, associada ao programa da Renascença Portuguesa e ao "saudosismo", enquanto a segunda esteja na origem do uso corrente do vocábulo "seareiro", não no sentido lato e metafórico de propagador de ideias e doutrinas, mas com o significado específico de autor ou de defensor das concepções expostas na revista que Raul Proença e António Sérgio dirigiram).

Mesmo um relance simples e sumário sobre os títulos agrupados segundo as orientações que Ihes presidiram, como as enunciadas, suscita a necessidade de reflexão sobre o papel desempenhado pelas revistas na constituição dos movimentos de intelectuais e nas modalidades de circulação de ideias e concepções no âmbito do que poderíamos classificar como espaço público doutrinário.

O esboço do esclarecimento destes dois aspectos indissociáveis e centrais na história cultural e política recente pode ser delineado segundo critérios que considerem as revistas de ideias e doutrinas sob cinco linhas de perspectivas principais: como norte e campo magnéticos que polarizam e agregam redactores e colaboradores, conferindo-Ihes uma identidade colectiva; como espaço de auto-revelação e concretização doutrinárias, ao metamorfosearem simpatia programática em pensamento e acção concretos; como conjugação entre a unidade de propósitos e a pluralidade de vozes e registos, em que um conceito de saber próprio encontra a sua expressão; como trajectória do fluir temporal das concepções perfilhadas, patente no fio das inflexões de teor que necessariamente atravessam a sucessão das edições; como empreendimento que procura produzir um efeito social, o que determina que pensamento, pragmática e estratégia surjam, entre si, combinados.

As revistas de ideias foram, pela sua própria natureza, empreendimentos colectivos subordinados a um propósito editorial comum e, como tal, instrumentos particularmente adequados para facultar expressão comum a grupos de intelectuais, os quais 
ultrapassaram, por seu intermédio, o foro da opinião singular para adquirirem voz e autoridade conjunta. Face a outras modalidades de intervenção cívica - petições, provocação de factos simbólicos, constituição de grupos de pressão, actividade associativa, iniciativas institucionais -, estes periódicos apresentaram tanto a vantagem inerente à publicitação regular de uma mesma causa, quanto os inconvenientes resultantes da rigidez do formato e da periodicidade predefinida.

A passagem da intenção à explicitação programática e da orientação e finalidades proclamadas às expressões editoriais concretas que conferiram realidade às revistas não consistiu, por regra, num simples exercício dedutivo, mas antes num conjunto de tarefas desdobradas no tempo, pelas quais os redactores descobriram e revelaram o teor efectivo da sensibilidade, do pensamento e dos propósitos, individuais e colectivos, próprios. Mesmo nos casos em que a dimensão receptiva de um pensamento alheio ou de uma escola cativante prevaleceu sobre qualquer outro aspecto, a formação cultural dos articulistas - as referências idiossincráticas em que se moviam, a sensibilidade aos interesses em jogo, os crivos de critérios próprios - foi determinante para o teor da publicação ficar vinculado à interpretação particular que acompanha qualquer adesão, mesmo quando esta se apresentava com a candura irreal da transparência. As revistas marcantes constituíram o espaço e a oportunidade de redactores e colaboradores unidos por um mesmo propósito, quando tocados pela argúcia e pelo talento, firmarem, singular e conjuntamente, tanto os contornos das diferentes expressões de um pensamento peculiar, quanto a concretização da intervenção efectiva na vida da cidade. Subsumir a identidade de uma revista à letra do programa editorial inicial, embora a relevância do documento fundador se apresente quase sempre patente, é uma redução simplista, a que escapa a matéria efectiva que conferiu identidade, realidade e sentido ao pensamento e à acção próprios.

$\mathrm{Na}$ amplitude da variedade de vozes chamadas a redigir e a colaborar num mesmo título e na paleta dos diferentes registos em que o seu teor se expôs, encontra-se a matéria que permite apreciar, na maioria dos casos, o conceito de saber que lhe deu forma. O esclarecimento deste conceito é relevante: mostra a concepção do mundo e o sistema de valores que fundamentaram o propósito e o teor da publicação, esclarece a natureza do vínculo que uniria esclarecimento e acção e contém, implícita ou explicitamente, o fundamento do mérito social atribuído à cultura e aos seus agentes. Em contexto de conflito de ideias e doutrinas, todo o eclectismo apresentou margens mais ou menos estritas, conformes ao âmbito da representação própria dos limites do saber verdadeiro e pertinente. Uma vez que cada revista foi, pela sua própria natu- 
reza, produto de um propósito editorial que lhe conferiu unidade e simultaneamente expressão da pluralidade das manifestações em que este se desdobrou, a observação de cada publicação a partir da relação que vinculou a unidade programática à diversidade do material publicado torna-se relevante para a compreensão da sua identidade efectiva. É de atender, desde logo, ao tom geral de cada título - doutrinário, de divulgação científica, literário, social, político, confessional -, já que há uma relação solidária e recíproca entre a natureza do saber a propagar e os propósitos pretendidos. Os impulsos para a divulgação humanista, científica ou de ideias resultam de concepções com pressupostos entre si muito distintos, embora sobreponíveis e com relações frequentemente complexas (como, por exemplo, as revistas neo-realistas atestaram, ao servirem de órgãos a um movimento declaradamente literário e artístico e ao distinguirem-se pela publicação muito escassa de produções destes âmbitos). O espectro de géneros e de temáticas publicados regularmente, normalmente distribuídos por diferentes secções estáveis, revela a economia interna da concepção que presidiu à publicação, a importância relativa conferida aos diferentes domínios de que se ocupou, bem como os limites, isto é, a relação de inclusão e de exclusão, a diferentes títulos, próprios.

É igualmente de sublinhar que as revistas de ideias deram a conhecer, a partir das mudanças observáveis na sucessão das edições, o próprio trajecto do pensamento a que conferiram, com plasticidade e rigidez variáveis, da ancilose à metamorfose, realidade. Os títulos mais significativos das diferentes correntes de intelectuais constituem, por regra, registos fiéis dos trilhos culturais e cívicos que estas percorreram. A leitura diacrónica de cada um destes órgãos programáticos torna possível surpreender quer a agregação, dissidência e recomposição do núcleo de autores que atraíram, quer o movimento das ideias e das concepções que caracterizaram o fluir da orientação cultural e cívica a que deram expressão pública. Trata-se, frequentemente, de pequenas deslocações que só revelam todo o seu alcance quando consideradas através do resultado do seu somatório: alterações no destaque relativo das secções em que a publicação se dividia, inflexão nas temáticas abordadas, desuso progressivo de algumas noções e introdução de novas linguagens, revisão do panteão simbólico, adição de novas referências, desdobramento do programa inicial em corolários inéditos, alterações nas tonalidades de gosto e dos sentimentos predominantes. Nas revistas publicadas durante períodos muito longos ou que apresentaram várias séries, as mudanças temáticas, conceptuais e imagéticas ganharam, frequentemente, nitidez explícita, expressa em diferentes ciclos editoriais e distintos episódios de refundação, 
com as consequentes revisões programáticas e editoriais, introduzidas por novos corpos directivos e redactoriais.

Tratando-se de revistas de pensamento e de acção, como se dizia no subtítulo de O Tempo e o Modo, estes periódicos expressavam tanto a orientação geral que lhes presidia quanto o esforço de concretização dos desideratos por que propugnavam. Aos redactores e colaboradores conferiram estímulo e voz, ao mesmo tempo que facultaram aos simpatizantes a possibilidade de reverem considerações e criações próprias em palavra impressa com a sua assinatura. Ao público próximo, procuravam corresponder com envolvência, de modo a tocar, e configurar, os motivos e os gostos diferentes de quem as procurava como alimento espiritual. Em vista estava, por regra, o objectivo de converter um movimento de ideias numa corrente de opinião culta e civicamente interventiva. Pensamento e acção estariam, aliás, muito próximos, de tal modo se conferia à simples afirmação doutrinária mérito histórico e social muito relevante. Os numerosos confrontos polémicos que atravessaram o período considerado e a disposição da vida cultural segundo escolas de pensamento e linhas de sensibilidade bem definidas atestam-no inequivocamente. A divulgação doutrinária e crítica não se circunscrevia ao domínio superlativo das concepções, mas era já acção: acção civilizadora, patriótica, revolucionária, pedagógica, prosélita, épatante ou, simplesmente, heterodoxa, marginal, dialogante. Porém, em qualquer caso, acção: gesto primeiro, condição prévia de todos os outros que na palavra programática recolheriam o sentido. O próprio teor da publicação o expressaria, na dupla vertente de exposição de ideias e das disposições pragmáticas por estas plasmadas, já que a estrutura e o teor da publicação se encontravam tão vinculados à letra enunciada quanto ao cumprimento da missão cultural e colectiva por esta prescrita.

Revistas, intelectuais, ideias emancipadoras e acção imperiosa constituíram, pois, um todo, desdobrado nas sucessivas vagas de sistemas de pensamento e de sínteses da história em que a pretensão ilustrada de captar a natureza e o devir humanos frutificou.

Como facilmente se pode depreender das condições que presidiram à origem dos periódicos de ideias, a elevação e o derrube das doutrinas políticas, sociais ou estéticas obedeceram ao ciclo das gerações, à oposição entre aqueles que tinham menos de trinta anos e os que tinham mais de quarenta, como se pode ler em artigo programático de Sol Nascente ${ }^{27}$. A futuração da vida colectiva, em que o mundo e o

27 Agnelo Mendes e Lúcio Teixeira,"Para elucidação dos de mais de quarenta anos sobre a geração dos de menos de trinta" (Sol Nascente, n. ${ }^{\circ}$ 30, 1.7.1940, p. 5). Este artigo, assinado com pseudónimos irónicos e significativos, vem na sequência de um artigo de Jofre Amaral Nogueira, "O papel duma nova geração” 
tempo encontravam imagem e projecção, apontava mesmo para a convicção de que os novos, pelo simples motivo de o serem, estariam mais perto das fontes de sentido e de ímpeto das coisas humanas.

Ora, uma geração, quando considerada nas suas figuras tutelares, é, como escreveu Eduardo Lourenço, "sempre bem pouca gente" ${ }^{28}$, poucos mais do que os ralos maîtres-à-penser pátrios que ficaram conhecidos como expoentes de cada uma das sucessivas e inovadoras orientações culturais e políticas.

A historiografia da cultura e dos produtos culturais tomou o conceito de geração, decorrente da observação de forte e regular semelhança entre vários homens coetâneos, como apropriado para descrever esta sucessão de vagas de intelectuais, associando-lhe frequentemente as revistas que lhes serviram de órgãos, mais ou menos informais, mesmo quando estas se revelaram tão episódicas quanto fulgurantes, como aconteceu com Orpheu e a sua geração. O mesmo ocorreu nos casos em que autores nascidos num mesmo lustro deram lugar a movimentos culturais cívicos muito distintos entre si, mesmo opostos, como se verificou, nomeadamente, com integralistas e seareiros ${ }^{29}$. A noção de geração - aplicada a conjuntos de novos autores, em oposição polémica às concepções das gerações anteriores, com uma respiração do tempo particular e unidos por uma visão conceptual e programática própria - tornou-se, então, não só um instrumento descritivo sugestivo, como igualmente objecto teórico, discutido na história das letras e das artes, rejeitado por alguns e elevado a questão relevante da epistemologia do saber histórico por outros ${ }^{30}$.

Porém, e independentemente do programa de cada nova vaga de intelectuais, despertar e erguer os portugueses foi desígnio sucessivamente repetido, como se pode depreender das palavras com que Mário Dionísio - volvidos oitenta anos após a carta- circular em que Eça havia anunciado a Revista de Portugal - se referiu retrospectivamente à produção literária dos jovens seus contemporâneos que resultaria do desejo

(Sol Nascente, n. ${ }^{\circ} 28,15.4 .1938$, pp. 6 e 7), e de um inquérito acerca das mesmas questões em curso nas páginas de $O$ Diabo.

${ }^{28}$ Eduardo Lourenço, Sentido e Forma da Poesia Neo-realista, Lisboa, Editora Ulisseia, 1968, p. 38.

29 António Sérgio (1883), Raul Proença (1884), Hipólito Raposo (1885) e António Sardinha (1887) nasceram num lapso de cinco anos.

30 Vide, v. g., Julián Marías, El método histórico de las generaciones, Madrid, Revista de Occidente, 1949, e Benedetto Croce, La storia come pensiero e como azione, Bari, Laterza, 1938. O estudo de Julián Marías vem na sequência da tese de que a história é constituída por gerações, desenvolvida, em diferentes estudos publicados nas décadas de 1930 e 1940, por Ortega y Gasset. 
compartilhado de produzir obras "capazes de acordarem um país inteiro para a sua própria realidade nacional"31.

Na medida em que, ao longo destas oito décadas, a civilização não deixou de chegar da cidade-luz em caixotes transportados no Sud-Express, Eça e Dionísio, como a generalidade dos intelectuais portugueses, filiaram as suas concepções em correntes de pensamento internacionais, por regra com origem ou intermediação francesa.

As manifestações de alguma originalidade conceptual ou doutrinária foram, ao longo deste período, muito escassas e pouco luminosas, o que fez do pensamento sistemático português um campo marcado claramente pela recepção.

Porém, a situação de intermediários por parte dos intelectuais e a afinidade com publicações estrangeiras por parte das revistas em que estes fizeram obra comum não diminuíram nem a aura nem o valor simbólico dos autores e dos seus órgãos, já que ambos representavam e consignavam o progresso civilizacional, a razão vitoriosa, o sangue e a terra, a fidelidade essencial, o rufar do tempo, segundo as diferentes inclinações vigentes na época, ao introduzirem as grandes figuras da cultura e as principais correntes de pensamento internacionais na cultura portuguesa.

O resultado final foi, por regra, idiossincrático e circunstancial, ao combinar a codificação das concepções importadas e inspiradoras - de Michelet e Proudhon a Mounier e Marcuse - com as referências culturais nacionais, segundo o talento e a criatividade, por vezes notórios, de quem representou o escol da sua geração.

Fora do mérito relativo desta condição corrente, ficaram algumas obras literárias - as de Eça de Queirós, Raul Brandão, Fernando Pessoa, Mário de Sá-Carneiro, entre outras mais recentes - que se elevaram à condição do que de melhor os autores da literatura universal do seu tempo escreveram.

\section{Pensar por artigos}

A actividade intensa desenvolvida pelos intelectuais, bem como pela generalidade dos publicistas, nas páginas das revistas, ao longo do período que vimos a considerar, justifica que se atenda à especificidade do artigo como modalidade de expressão da reflexão individual e como meio de produção e de circulação culturais.

$\mathrm{O}$ artigo distingue-se, antes de mais, por unir pensamento e actualidade, ao visar decifrar o sentido de acontecimentos recentes e próximos. O seu domínio apresenta-se como sendo o de esclarecer o que é novo, ou o que surge sob forma renovada,

\footnotetext{
31 Mário Dionísio,"Prefácio”, in Manuel da Fonseca, Obra Poética, 7. a ed., Lisboa, Editorial Caminho, 1884, p. 22.
} 
e assim vencer, através da integração num fio de sentido, a resistência da experiência indeterminada e do dado imediato amórfico.

Embora toda a interpretação se desenvolva segundo quadros analíticos e conceptuais já constituídos e tenha sido corrente pretender submeter o fluir da vida e do pensamento a corpos doutrinários rígidos, que tudo reduziam a algumas certezas invariáveis, a pertinência própria do artigo situa-se na aresta pela qual o presente une o pensado e o inaudito, a retrospectiva e a prospectiva.

$\mathrm{O}$ artigo surge, deste modo, como a consciência do momento. Por seu intermédio, cada circunstância é acompanhada pela indagação acerca do significado que lhe seria próprio, num esforço incessante de esclarecer o fluir e as inflexões dos acontecimentos.

É a proximidade entre a vida e o pensamento que confere ao artigo um interesse peculiar, inerente tanto ao esforço de esclarecimento individual e colectivo do significado das situações, quanto à definição da oportunidade justa para agir.

Neste aspecto, o artigo cristaliza, no plano da argumentação, o sentido de actualidade, sem efemeridade, próprio das melhores revistas, nas quais o pensado e o vivido surgem indelevelmente associados. Muito do encanto da colecção das edições de um título, por parte daqueles que o elegeram como leitura regular, reside no registo fidedigno das certezas e das dúvidas vividas, que encerraram em si as representações segundo as quais as diferentes situações se deram a conhecer, ao mesmo tempo que enriqueciam a formação e moldavam a vida de cada leitor.

Numa época em que se sentia que o presente - inovador, tenso e incerto - reclamava toda a atenção e toda a determinação dos contemporâneos e em que se acreditava, simultaneamente, ser-se chamado a participar em episódios decisivos para o destino das nações e para a própria humanidade, o sentido da actualidade, dos dilemas e dos desafios imediatos que esta colocava tornou-se particularmente agudo.

Quando "o presente é todo o passado e todo o futuro", como Álvaro de Campos vincou na "Ode Triunfal", publicada no número inaugural da revista Orpheu, os tempos não se compadecem com estudos aturados e retiros prolongados, antes requerem a intervenção próxima e contínua. As circunstâncias não reclamam, então, o génio dos tratadistas e a elaboração de sistemas, pois carecem somente de peças esclarecedoras e acessíveis com que os articulistas e os polemistas iluminem as realidades próximas, comprovem a pertinência dos fundamentos das doutrinas que advogam participem activamente na evolução dos acontecimentos.

A sensação de premência interpretativa e de intervenção responsável fez avultar de tal modo o papel desempenhado pelo artigo na vida cultural que se torna fácil verifi- 
car o predomínio, mesmo a quase exclusividade, desta modalidade reflexiva ao longo de períodos extensos da cultura portuguesa contemporânea.

É de registar que este género jornalístico reúne um conjunto de características que Ihe conferem uma grande plasticidade, de que podem beneficiar quer quem o cultiva, quer quem o lê, pois tanto franqueia a sua redacção a qualquer homem letrado, constituindo a porta de ingresso da generalidade dos publicistas, quanto possibilita uma leitura relativamente acessível, desde logo pelo âmbito necessariamente restrito de questões que aborda.

A qualidade de um qualquer artigo pode ser aferida pela pertinência com que combina o horizonte cultural e doutrinário em que se situa com a análise dos elementos próximos cujo significado pretende apreender. Quando se insinua substantivamente no cerne desta relação, o artigo ascende à condição de género reflexivo maior (podendo mesmo representar a literatura mais estimada, aquela que adiciona novos resultados ao estado geral do saber).

Nos artigos de mérito, a abordagem de novos objectos a partir de uma visão estruturada segundo princípios de inteligibilidade estáveis não se apresenta como um processo de pura confirmação, através da redução do novo ao já adquirido, mas como um processo constitutivo de saber inédito e prospectivo, ainda que, por regra, complementar daquele que se dá previamente por adquirido.

A adição da dimensão problemática a horizontes de referência mais ou menos estáveis encontra-se facilitada por alguns dos atributos do próprio formato do género, pois este envolve uma abordagem da realidade parcelar, contingente, sem intuito sistémico, com revisitação, mais ou menos circular, de questões e de temas nodais, no quadro de inquirições de fundo conjectural e em que o recurso à imagem, à metáfora e à analogia é frequente.

Nos seus aspectos mais originais e inerentes à tentativa de captar a especificidade dos objectos singulares sobre os quais reflecte, o artigo, como indagação racional próxima do concreto, da intuição dos seus sinais e do exercício imaginativo das linhas de tensão e de sentidos que o permitem pensar, acabou frequentemente por se aproximar de uma perspectiva ensaística.

Para um lote muito significativo de pensadores, artigo e ensaio tornaram-se então as duas vertentes de um mesmo esforço de esclarecimento simultaneamente crítico, problematizante e cívico. 


\section{Obstáculo e fundamento}

A circunstância de as revistas terem sido, ao longo da centúria considerada, um dos palcos mais significativos da produção e da circulação cultural e de ideias coloca algumas questões peculiares à investigação histórica.

A parte mais visível dos problemas específicos inerentes a estas fontes é relativamente clara: não é fácil encontrar colecções completas dos títulos principais, mesmo nas bibliotecas de referência; alguns dos periódicos reputados conheceram centenas de edições, que ocupam dezenas de milhares de páginas; a recolha dos dispersos de um autor e a reconstituição do seu percurso editorial obrigam à consulta de numerosas edições de muitos títulos diferentes; os textos cuja autoria é difícil de estabelecer, por não se encontrarem assinados ou pelo recurso a pseudónimo, são frequentes; a identificação da orientação editorial de cada título, para além das explicitações programáticas, em manifestos ou editoriais, apresenta-se frequentemente, face à complexidade dos materiais publicados, por vezes ao longo de decénios, problemática e contraditória.

O reconhecimento da importância de que a publicação de revistas de ideias e cultura se revestiu na história recente apresenta-se, pois, proporcional aos obstáculos colocados à investigação por fontes de acesso difícil, muito numerosas, extensas e relativamente uniformes.

Com excepção de alguns estudos parcelares, nomeadamente no âmbito das revistas do campo literário, o conhecimento da história cultural e política portuguesa, tal como se desdobrou nas páginas dos periódicos que lhe deram realidade, tem ficado paralisado pelas dificuldades apontadas.

A superação destes obstáculos epistemológicos pode retirar, actualmente, partido de soluções técnicas de gestão da informação muito favoráveis.

Em termos gerais, um programa adequado à apreensão e interpretação do teor das revistas de ideias e cultura deve ter em consideração a reedição electrónica de lotes de títulos significativos, agrupados, num primeiro momento, segundo as suas afinidades programáticas; a elaboração de bases de dados com os analíticos de todas as peças publicadas, de acordo com as práticas consagradas e adequadas; a possibilidade de consulta das peças constantes nas reedições a partir de índices de autor, de conceitos, de temas, entre outros; o acompanhamento da actividade editorial electrónica com a elaboração de estudos monográficos sobre cada título, incluindo a elaboração de notas acerca dos autores, conceitos, temáticas e recepções mais significativos. 
As condições indispensáveis para o mapeamento de conjuntos cada vez mais amplos de títulos significativos, no plano cultural, ideológico e político, ficariam então asseguradas.

A riqueza, a complexidade, a extensão e a variedade da produção cultural de muitas centenas de autores relevantes, nas páginas dos periódicos de cultura e ideias, deixariam, presumivelmente, de representar um obstáculo ao conhecimento do pensamento e da acção contemporâneos, para se converterem finalmente no seu fundamento. 



\title{
A luso-brasilidade e o projeto da revista Atlântida
}

\author{
Lucia Maria Paschoal Guimarães*
}

Em 1974, o historiador Joaquim Barradas de Carvalho (1920-1980) parecia apreensivo com o futuro político e econômico da nação lusíada, após o advento da Comunidade Econômica Européia. A pátria se encontrava perante uma encruzilhada, no seu ponto de vista. Ou marchava na direção do continente, ou tomava o caminho do oceano. A última alternativa se lhe afigurava mais promissora, a "única condição para que Portugal volte a ser ele próprio"1. Mas a opção, assegurava o historiador,"passava forçosamente pela formação de (...) uma autêntica Comunidade Luso-Brasileira, uma Comunidade Luso-Brasileira que não seja apenas sentimental e ortográfica, (...), nem aquela comunidade que não passou, ainda, de Júlio Dantas para cá, Pedro Calmon para lá..."2

A proposta de Barradas de Carvalho não constituía propriamente uma novidade. Retomava os fios de um antigo projeto, que cingira intelectuais das duas nacionalidades nas primeiras décadas do século passado, voltado para o fortalecimento das relações luso-brasileiras. Seu principal veículo de divulgação foi uma revista cultural, editada em Lisboa entre 1915 e 1920, a Atlântida. Mensário Artístico, Literário e Social para Portugal e Brasil ${ }^{3}$.

Este artigo pretende examinar as motivações que levaram à criação daquele periódico e tecer algumas reflexões sobre o seu conteúdo programático, autores e leitores. A par disso, apresenta os primeiros resultados de uma investigação, que integra empreendimento acadêmico mais amplo, envolvendo professores da Universidade Nova de Lisboa (UNL) e da Universidade do Estado do Rio de Janeiro (UERJ), devendo incorporar-se à Coleção Revistas de Idéias e Cultura, organizada pelo Seminário Livre

\footnotetext{
Universidade do Estado do Rio de Janeiro.

1 Joaquim Barradas de Carvalho. Rumo de Portugal. A Europa ou o Atlântico? (Uma perspectiva histórica). Lisboa: Livros Horizonte, 1974, p. 81 (Coleção Horizonte n. $\left.{ }^{\circ} 26\right)$.

2 Idem, p. 79.

3 Daqui por diante denominada apenas Atlântida.
} 
de História das Idéias (UNL).Projeto, aliás, que à sua maneira também segue as pegadas da Atlântida, pois tem contribuído para estreitar os laços entre o Brasil e Portugal ${ }^{4}$.

Desde o rompimento diplomático de 1894, fruto da acolhida por navios de guerra portugueses a oficiais da marinha brasileira, que se insurgiram contra o governo do presidente Floriano Peixoto ${ }^{5}$, os tradicionais vínculos de amizade que uniam o Itamaraty ao Paço das Necessidades andavam um tanto quanto estremecidos. É bem verdade que houve algumas tentativas para reanimá-los, a exemplo de uma visita do rei D. Carlos ao Rio de Janeiro, programada para junho de 1908, a propósito das comemorações do centenário da abertura dos portos, plano que acabou frustrado pelo assassinato do monarca, em 1 de fevereiro daquele ano ${ }^{6}$.

No entanto, apesar daquele relativo "afrouxamento" no âmbito dos contatos oficiais, informalmente, as relações literárias luso-brasileiras atravessavam uma fase de grande florescimento, estimuladas pelo aparecimento de novos almanaques, jornais e magazines $^{7}$, nos quais participavam intelectuais de ambas as nacionalidades. A distância física que separava os colaboradores não impedia que esses periódicos se tornassem lugares de fermentação intelectual e de relação afetiva, ao mesmo tempo viveiros e espaços de sociabilidade, tal como define François Sirinelli, ao analisar os mecanismos que movimentam as complexas engrenagens dos espaços culturais ${ }^{8}$.

4 Convênio celebrado entre as Universidades Nova de Lisboa e do Estado do Rio de Janeiro, em julho de 2007.

5 A crise fora provocada pela decisão do conde de Paraty de conceder asilo em navios de guerra portugueses aos oficiais da marinha brasileira que se haviam insurgido contra o governo do marechal Floriano Peixoto, na revolta da Armada. Apesar do restabelecimento das relações oficiais em 1895, mediante gestões da Inglaterra, perdurou durante muito tempo no Brasil um sentimento antilusitano, cultivado pelos setores nacionalistas mais acerbados.

6 Diversos eventos já estavam programados, quando a notícia do regicídio chegou ao Brasil, inclusive a convocação de um congresso luso-brasileiro de história, planejado pelo barão do Rio Branco, para ter lugar no Instituto Histórico e Geográfico Brasileiro. Ver Lucia Maria P. Guimarães, Da Escola Palatina ao Silogeu. Instituto Histórico e Geográfico Brasileiro (1889-1938). Rio de Janeiro: Editora do Museu da República, 2007, p. 31.

7 Sobre o surto que propiciou a multiplicação das revistas portuguesas no início do século XX, ver José Augusto Seabra. “Revistas e movimentos culturais no primeiro quarto do século." In: Reis, António et alii, Revistas, Idéias e Doutrinas. Leituras do pensamento contemporâneo. Apresentação de Zília Osório de Castro. Introdução de Luís Crespo de Andrade. Lisboa: Livros Horizonte, 2003, p. 21.

8 François Sirinelli, “Os intelectuais". In: René Rémond (org.), Por uma história política. Rio de Janeiro: Editora UFRJ/Editora FGV, 1996, p. 294. Ver, ainda, a interessante abordagem proposta por Emma Gori,“Um lobby pacifista e elitista: O Grupo de Bloomsbury". In: Domenico Di Masi, A emoção e a regra: os grupos criativos na Europa de 1850 a 1950. Rio de Janeiro: José Olympio, 1997, pp. 131-170. 
Em Portugal, nas páginas d'A Águia, editada na cidade do Porto (1910-1930), publicavam-se contribuições de Ronald de Carvalho, Coelho Neto, Vicente de Carvalho e Lima Barreto, ao lado das de Teixeira de Pascoaes, António Sérgio e Jaime Cortesão. A Atlântida (1915-1920) era dirigida a quatro mãos: em Lisboa, por João de Barros e, no Rio de Janeiro, por Paulo Barreto, o popular João do Rio. O mesmo se observa em relação à revista Orpheu (1915), de duração efêmera, mas muito expressiva, cujo primeiro número foi preparado por Fernando Pessoa e Ronald de Carvalho.

No lado de cá do Atlântico, o panorama se apresentava bem semelhante. Os principais órgãos da imprensa divulgavam com regularidade textos de autores portugueses, como Alberto d'Oliveira, Maria Amália Vaz de Carvalho, Luís da Câmara Reys, Carlos Malheiro Dias e Jaime de Séguier, que assinava, inclusive, uma coluna no Jornal do Commércio. No diário O País, destacavam-se as crônicas de Justino Montalvão, as "Cartas de Lisboa", de José Maria Alpoim, as "Cartas de Paris", de Xavier de Carvalho, bem como os artigos de Santo Tirso ${ }^{10}$.

Entre os temas mais discutidos pelos letrados, distinguia-se o da conveniência de se estabelecer uma comunidade luso-brasileira. A questão fora levantada pela primeira vez por Silvio Romero (1851-1914), um dos fundadores da Academia Brasileira de Letras, na conferência "O elemento português no Brasil", pronunciada no Gabinete Português de Leitura do Rio de Janeiro e publicada em Lisboa em $1902^{11}$. É interessante notar que o acadêmico, alguns anos antes, na sua História da Literatura Brasileira $(1888)^{12}$, se mostrara um censor implacável da matriz cultural lusíada. No entanto, mudou de opinião e passaria a defendê-la vigorosamente, receoso da veracidade de certas notícias veiculadas por jornais europeus:

(...) Berlim. Os pangermanistas estão atualmente ocupados com um projeto de organização mais sólida de um acordo entre os colonos alemães no Brasil. Tem havido em diversas cidades da Alemanha conferências cujo fim é enviar alguns pastores, padres e mestre-escolas ao sul do Brasil. Na cidade de Magdeburgo um dos oradores declarou que parte do sul do Brasil é terra alemã e que deverá mais tarde pertencer ao império germânico. ${ }^{13}$

9 Arnaldo Saraiva, Modernismo brasileiro e modernismo português. Subsídios para o seu estudo e para a história das suas relações. Campinas: Editora UNICAMP, 2004, p. 23.

10 Idem.

11 Cf. Silvio Romero, O elemento português no Brasil (Conferência). Lisboa:Tipografia da Companhia Nacional Editora, 1902.

${ }^{12}$ Cf. Silvio Romero, História da Literatura Brasileira. 7. a ed. Rio de Janeiro; José Olympio; Brasília:INL, 1980, vv.4 e 5.

${ }^{13} \mathrm{Cf}$. Silvio Romero, O elemento português no Brasil (Conferência). Op. cit., p. 35. 
A preocupação externada por Silvio Romero não era infundada. De fato, nos estados meridionais do Brasil existia forte concentração de emigrantes teutões, na sua maioria reunidos em comunidades, onde "a língua portuguesa brilha pela ausência", conforme denunciava Romero. Alarmado, ele argumentava que "a língua, por si só, na era presente serve para individualizar a nacionalidade, é por isso que os alemães consideram a pátria alemã todo e qualquer sítio onde é falada a língua alemã". Antevia que por volta de oitenta ou cem anos, no mais tardar, o núcleo do "Rio Grande do Sul, ao que parece o mais populoso e compacto, tornar-se-á independente e, estendendo a mão ao de Santa Catarina, aliar-se-á com ele, formando ambos a nova nacionalidade"14.

A integridade da Terra de Santa Cruz parecia estar em risco, e Silvio Romero defendia a necessidade de fortalecer os elementos que a constituíam historicamente como nação luso-brasileira, em especial o idioma. Contudo, ele ainda iria mais longe nas suas advertências, sinalizando que a ambição germânica não se limitava ao território brasileiro: “Portugal também faz parte das nações pequenas, mas também pertence ao grupo dos ameaçados, quando não diretamente nas suas plagas européias, de modo inequívoco na África". Para enfrentar o perigo comum, o escritor sugeria que os dois países se unissem e formassem uma federação ${ }^{15}$.

As inquietações que afligiam Silvio Romero por certo também afetavam a intelectualidade lusa. Nos primórdios do século passado, de acordo com Eduardo Lourenço, o Brasil representava para Portugal uma espécie de espaço compensatório - uma dimensão simbólica no imaginário da grandeza da nação, tal como fora a Índia e depois viria a ser a África ${ }^{16}$. Mas a idéia de celebrar uma aliança com a antiga colônia americana só viria a ser expressa publicamente em 1909, por Coelho de Carvalho, na Academia das Ciências de Lisboa.

Por aquela mesma ocasião, a Sociedade de Geografia decidiu lançar um concurso de monografias sobre "o modo mais eficaz de promover a união moral com a mãe pátria" dos portugueses residentes no Brasil e anunciou a intenção de organizar uma expedição ao interior do país. Logo em seguida, o presidente da Sociedade, Zófimo Consiglieri Pedroso, na sessão de 10 de agosto de 1909, apresentaria um plano que ficou conhecido por Acordo Luso-Brasileiro. Propôs a instituição de um grupo de trabaIho permanente, encarregado de estudar medidas para a consecução dos seguintes objetivos: negociar tratados de arbitragem, de cooperação internacional e de comér-

\footnotetext{
${ }^{14}$ Idem.

15 Idem, pp. 3-41.

${ }^{16}$ Eduardo Lourenço. O Labirinto da Saudade. 4. ${ }^{\text {a }}$ edição. Lisboa: Publicações Dom Quixote, 1991, p. 41.
} 
cio; ensejar a criação de entrepostos comerciais e a construção de palácios de exposição em Lisboa e no Rio de Janeiro; promover na medida do possível a unificação da legislação civil e comercial; encorajar a cooperação intelectual - científica, literária e artística -, conferindo equivalência de direitos ou de títulos aos diplomados de um país que decidissem trabalhar no outro; planejar visitas recíprocas de intelectuais, artistas, industriais e comerciantes, bem como fomentar a convocação de congressos científicos e a colaboração entre jornalistas, editores, associações culturais, pedagógicas, artísticas e beneficentes ${ }^{17}$.

O ambicioso programa terminou por permanecer no terreno das intenções, pois seu autor faleceu pouco tempo depois de expô-lo. De mais a mais, havia poucas chances de levá-lo avante, considerando a atmosfera de instabilidade política que marcou o fim da Monarquia e o advento da República portuguesa em 1910.

A idéia de instituir uma comunidade luso-brasileira só voltaria a ser ventilada com intensidade após a deflagração da Primeira Grande Guerra. No Parlamento português, vozes nacionalistas manifestavam suas preocupações diante do avanço do imperialismo germânico. O deputado João Menezes, por exemplo, assinalava que "Brasileiros e portugueses têm de pensar, hoje mais do que nunca, em estreitar suas relações políticas, podendo ir muito além duma aliança"18.

O contexto da guerra também favoreceria a disseminação de culturas políticas nacionalistas no Brasil. Porém, as opiniões sobre aquelas fórmulas se dividiam. Havia quem repudiasse a idéia de uma aliança com Portugal. Herdeiros da vertente mais radical do nacionalismo, admiradores de Floriano Peixoto, a quem veneravam como modelo de civismo, responsabilizavam a colonização lusa pelo atraso cultural, econômico e social do país. Nessa corrente, entre outras figuras, sobressaíam-se o médico e pedagogo Manoel Bonfim, além dos escritores Antonio Torres, Felix Amélio, Jackson de Figueiredo e Álvaro Bomilcar, que disseminavam o antilusitanismo em publicações como O Tempo, Brazilea e Gil Blas, além de incitar a população a participar de campanhas antiportuguesas ${ }^{19}$.

17 Sobre o "Acordo Luso-Brasileiro", ver João do Rio, Portugal d'agora. Lisboa. Porto. Notas de viagem. Impressões. Rio de Janeiro: H. Garnier Livreiro Editor, 1911, pp. 289-292.

18 João Menezes apud Nuno Simões. Actualidade e permanência do Luso-Brasilismo (Conferências e discursos). Lisboa: Edição do autor, 1960, p. 34.

19 Ver Jorge Luís dos Santos Alves. "Duas interpretações da nacionalidade brasileira". Anais da XX Reunião da Sociedade Brasileira de Pesquisa Histórica, Rio de Janeiro, 2005, p. 223. 
Os defensores do congraçamento cultural e político com a antiga metrópole, por seu turno, percebiam no legado lusíada o fator dominante da construção da nacionalidade, baseados na afinidade lingüística, na história e na ocupação do território. A tese desfrutava da acolhida não apenas de destacados membros da colônia portuguesa no Rio de Janeiro, como também de intelectuais da envergadura de Olavo Bilac, de Afrânio Peixoto, de Paulo Barreto e de Graça Aranha, quatro atuantes membros da Academia Brasileira de Letras. Graça Aranha chegou a afirmar que "A união política entre Portugal e Brasil, conseqüência da unidade moral das duas raças, seria a grande expressão internacional da raça portuguesa"20. Já o nome de Paulo Barreto, ou melhor, o seu pseudônimo literário mais famoso, João do Rio, acabaria ligado a um dos esforços mais significativos para estimular o aprofundamento das relações entre os dois países: a criação da revista Atlântida, fruto da sua associação com o poeta, político, publicista e pedagogo português João de Barros (1881-1960),"um incansável apóstolo da aproximação luso-brasileira, como cidadão e governante, como conferencista e escritor", nas palavras de José Carlos Seabra Pereira ${ }^{21}$.

João Paulo Alberto Coelho Barreto nascera no Rio de Janeiro, em 5 de agosto de 1881. Era filho de D. Florência dos Santos Barreto e do educador Alfredo Coelho Barreto, um adepto do positivismo, que batizou o menino na igreja positivista, na esperança de que viesse a abraçar a doutrina de Augusto Comte. Fez os primeiros estudos com o próprio pai e aos dezesseis anos já colaborava nos principais diários fluminenses. Notabilizou-se como o primeiro homem de imprensa a ter o senso do noticiário moderno. Criador da crônica social, um dos mais notáveis escritores da Belle Époque tropical, costumava usar diversos pseudônimos, X, Caran d'ache, Joe, Pall Mall, José Antonio José e João do Rio, o mais conhecido, conforme já se disse. Ingressou na Academia Brasileira de Letras em 1910. Envolveu-se em causas controvertidas e cumpriu uma trajetória acidentada na vida privada, pontuada por ataques dos seus desafetos. Bem-humorado, porém irônico, companheiro de aventuras da sensualíssima Isadora Duncan, apesar de reconhecido como homossexual, possuía personali-

${ }^{20}$ Cf. Graça Aranha apud Bettencourt Rodrigues. Uma Confederação Luso-Brasileira. Prováveis alianças e grupamentos de nações. Fatos, opiniões e alvitres. Lisboa: Livraria Clássica Editora, 1923, p. 8.

${ }^{21}$ Cf. José Carlos de Seabra Pereira apud Arnaldo Saraiva, op .cit., pp. 81-82. 


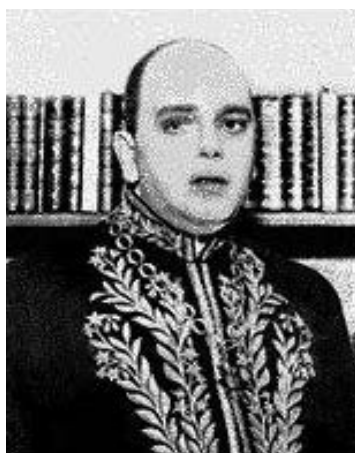

Paulo Barreto com o fardão da Academia

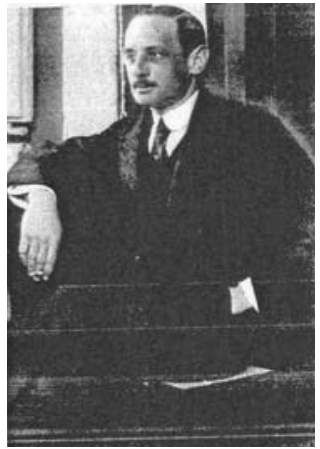

João de Barros

dade contraditória, na opinião do amigo Gilberto Amado:"dentro dele lutavam duas correntes: a do velho Barreto, o 'filósofo', o professor, voltado para o recolhimento, e a de D. Florência, coberta de plumas e tilintante de balangandãs sempre a pular dentro dele"22. Realizou diversas viagens à Europa e consta que guardava grande frustração, porque não conseguira ser nomeado embaixador em Portugal, cargo a que aspirava ardentemente. Faleceu no Rio de Janeiro a 23 de junho de 1921. Seus funerais no cemitério de São João Batista, no bairro de Botafogo, mobilizaram a cidade. $O$ cortejo foi seguido por cerca de cem mil pessoas, na maioria membros da numerosa colônia lusa. Segundo o cronista Antonio Torres, "os motoristas portugueses deram até automóvel de graça a quem quisesse acompanhar o cadáver"23.

Sob o pseudônimo de João do Rio, Paulo Barreto deixou vasta obra, compreendendo diversos gêneros do jornalismo, da literatura e da dramaturgia. Algumas dessas contribuições foram reunidas em livros, a exemplo de Vida Vertiginosa, Portugal d'Agora ${ }^{24}$, No Tempo de Wenceslau..., Fados e Canções de Portugal, As Religiões do Rio, Momento Literário e A Alma Encantadora das Ruas, título que Ihe serviu de proficiência intelectual para a admissão no Instituto Histórico e Geográfico Brasileiro, em 1907. Curiosamente, na biografia do polêmico literato divulgada pela Academia Brasileira de Letras, não há nenhum registro a respeito da sua militância na defesa

22 Gilberto Amado apud Antonio Edmilson Martins Rodrigues. João do Rio. A cidade e o poeta - O olhar de

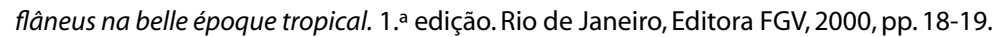

23 Antonio Torres apud Antonio Edmilson Martins Rodrigues. Idem, p. 49.

${ }^{24}$ A obra Portugal d'Agora é dedicada a João de Barros e a Manoel de Sousa Pinto. Ver João do Rio. Portugal d'Agora. Lisboa, Porto, notas de viagem, impressões. Rio de Janeiro: H. Garnier Livreiro-Editor, 1911. 
do luso-brasileirismo, nem tampouco da revista que dirigiu a quatro mãos com João de Barros $^{25}$.

O entrosamento entre os dois Joões, ao que parece, originou-se de uma leitura casual. João de Barros relata que publicara um ensaio, no periódico francês La Revue, a respeito das tendências contemporâneas das letras portuguesas. Pouco depois, para sua surpresa, ao abrir a Gazeta de Notícias do Rio de Janeiro, deparou-se com uma nota sobre o tal ensaio, redigida por alguém que se assinava apenas Joe. A referência servia de mote para lavrar um protesto contra o fato de que as notícias da literatura lusíada só chegavam ao Brasil através da França. Empenhou-se, então, para desvendar a identidade do misterioso autor e concluiu que Joe era um dos pseudônimos de Paulo Barreto, ou de João do Rio, como se queira.

Os futuros parceiros se avistariam pela primeira vez em 1908, durante uma das visitas do escritor carioca a Portugal. O encontro ocorreu na cidade do Porto, promovido pelos irmãos Lello, e marcou o início de uma sólida amizade. João do Rio relembraria o episódio, salientando que durante a conversa descobriram fortes afinidades, a começar pelas idéias políticas, pois ambos eram partidários do regime republicano. Além disso, preocupavam-se com o futuro incerto das relações luso-brasileiras, uma vez que, "se o Brasil se interessava menos por Portugal do que pela França, Portugal não se interessava, ou antes, ignorava tudo do Brasil"26. A solução do problema, por certo, demandava ações oficiais mútuas, contudo eles poderiam somar esforços e, quem sabe, criar uma revista literária para estimular a luso-brasilidade.

O plano ganhou fôlego com a vinda de João de Barros ao Brasil, em 1912. Ele aderiu ao movimento que o seu homônimo já vinha realizando, na imprensa e na Academia Brasileira de Letras. Decidiu apoiá-lo, escrevendo artigos e pronunciando conferências:

É preciso trabalhar muito para que se extinga o desconhecimento que separa as duas nações. O mais urgente, porém, creio que será estabelecer e desenvolver uma sólida aproximação das duas mentalidades, das duas literaturas, das duas artes. Criado esse veículo essencial, mais de metade do trabalho estará feito. E bom seria que - reservadas as diferenças essenciais impostas pelo meio, uma mesma alma palpitasse na vida mental dos dois países.

${ }^{25}$ Cf. Academia Brasileira de Letras. Acadêmicos. Biografia de Paulo Barreto (João do Rio). http://www.academia.org.br/abl/cgi/cgilua.exe/sys/start.htm?infoid=329\&sid=261. Acessado em 23 de novembro de 2007 .

${ }^{26}$ Cf. João do Rio. "O aparecimento de um grande mensário artístico-literário-social para Portugal e Brasil". A Rua, Rio de Janeiro, 5 de novembro de 1915, p. 2. 


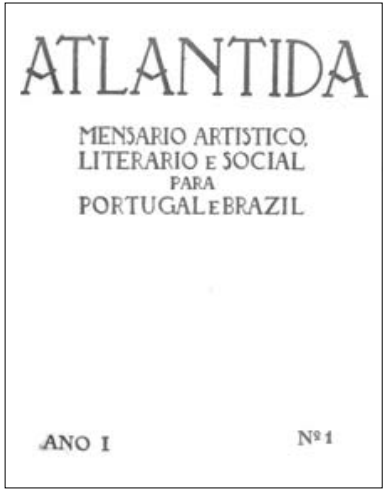

Folha de rosto da Atlântida

Na verdade, é necessário erguer, sobre o vasto Atlântico, um continente moral que nos ligue de vez. ${ }^{27}$

A dupla postulava o fortalecimento dos vínculos entre Brasil e Portugal, fundamentada não apenas nas "simpatias espirituais das tradições do passado, mas também pela conveniência do futuro"28. A este argumento de João de Barros cabe complementar com um outro de João do Rio, isto é, de que "A guerra veio definitivamente forçar a publicação" 29 . Com efeito, o batismo literário da Atlântida. Mensário Artístico, Literário e Social para Portugal e Brasil teve lugar em Lisboa, a 15 de novembro de 1915, data que pretendia homenagear a passagem do vigésimo sexto aniversário da proclamação da República no Brasil. O novo periódico foi recebido com entusiasmo por outros congêneres, a exemplo d'A Águia, que manifestou "fé ardente nos seus altos destinos" 3 .

A denominação Atlântida fora escolhida por João do Rio. Ele se inspirou na lenda do continente perdido, para designar de forma semântica um projeto que buscava (re)estabelecer a ligação entre as duas partes do mundo que as águas do oceano haviam separado ${ }^{31}$. O subtítulo, Mensário Artístico, Literário e Social para Portugal e Brasil, além de indicativo da periodicidade, resumia o seu teor programático e destacava-lhe o caráter binacional.

$\mathrm{Na}$ folha seguinte em posição de destaque, exibia-se a informação de que a revista recebia o "alto patrocínio de S. Ex. as os ministros das Relações Exteriores do Brasil e

${ }^{27}$ Cf. João de Barros. Caminho da Atlântida. Uma campanha luso-brasileira. Lisboa: Livraria Profissional, [1919?], pp.X e XI.

${ }^{28}$ Cf. João de Barros. A aproximação luso-brasileira e a paz. Paris; Lisboa: Livrarias Aillaud e Bertrand, 1919, p. 7.

29 João do Rio, "O aparecimento de um grande mensário artístico-literário-social para Portugal e Brasil". $A$ Rua. Rio de Janeiro, 5 de novembro de 1915, p. 2.

30 A Águia, dezembro de 1915, pp. 252-253. Ver, também, o agradecimento dos diretores da Atlântida. Atlântida. Lisboa, n. ${ }^{\circ}$ 3, 15 de janeiro de 1916, apud Cecília Dias de Carvalho Henriques da Conceição. $A$ revista Atlântida. Documento sócio-cultural e literário de uma época. "Um abraço mental" entre Portugal e o Brasil. Dissertação de mestrado apresentada ao Departamento de Literaturas Românicas na Faculdade de Ciências Sociais e Humanas da Universidade Nova de Lisboa. Lisboa, 1997, p. 18.

31 Inicialmente, por sugestão de Manoel de Oliveira Pinto, a publicação deveria chamar-se Atlântico, em homenagem ao emblemático oceano singrado pelos navegadores portugueses, em cujas margens se situavam as duas nações. Idem. 
dos Estrangeiros e do Fomento de Portugal", acompanhada dos votos de congratulações, formulados por aquelas autoridades, respectivamente, os doutores Lauro Muller, Augusto Soares e Manuel Monteiro. Este último qualificava o empreendimento de "um esteio seguro da indispensável aproximação intelectual e econômica entre as duas Pátrias irmãs". As três mensagens, por sinal, levam a conjeturar se os cumprimentos não passavam de mera retórica ou se constituíam vestígios de um possível envolvimento dos governos no projeto editorial. De qualquer modo, sob a forma de "manifesto"32, os diretores da Atlântida procuravam justificar o empreendimento e explicitar a sua linha programática:

Há muito tempo que a publicação d'uma revista literária que defendesse os interesses comuns do Brasil e de Portugal se impunha e se tornava indispensável. (...) As características especialíssimas criadas pela Guerra européia determinaram um irresistível movimento de solidariedade entre aqueles países e aqueles povos que vivem d'um mesmo ideal, que se alimentam da mesma tradição ou que descendem do mesmo tronco originário. (...) Acontece, porém, que não se conhecem. (...) É precisamente para que Portugal conheça o Brasil e que o Brasil mais se aproxime de Portugal e melhor se conheça, que se vai publicar a Atlântida. (...) É uma obra patriótica esta nossa. E ensinando as duas democracias que o Oceano Atlântico separa, a melhor amar-se e compreender-se a Atlântida tentará substituir, no domínio intelectual e social, aquele lendário continente que dantes ligou a América à Europa...33 [O grifo é nosso.]

O manifesto contém algumas pistas que vale a pena explorar, sobretudo no que diz respeito à associação entre a guerra e o lançamento de uma revista, que se afirmava voltada apenas para os domínios intelectual e social. João de Barros oferece indícios da conexão, em uma conferência pronunciada no Ateneu Comercial do Porto, em 1919, quando fez um comentário sobre as pretensões alemãs na América do Sul ${ }^{34}$. Reportou-se, em particular, à existência de um programa de emigração direcionado para a conquista do Brasil, elaborado por um certo Sr. Lange, e ao projeto do pen-

32 Acreditamos, tal como evidencia Jean-François Sirinelli, que o manifesto de lançamento da Atlântida constitui num excelente sismógrafo para examinar a influência e a amplitude das ações dos intelectuais que estiveram à frente do projeto. Cf. Jean-François Sirinelli. Intellectuels et passions françaises. Manifestes et pétitions au XXe siècle. Paris: Gallimard, 1990, pp. 13-15.

${ }^{33}$ Cf. Atlântida. Lisboa, n. ${ }^{\circ}$, novembro de 1915.

${ }^{34}$ Cf. João de Barros. A aproximação luso-brasileira e a paz. Paris; Lisboa: Livrarias Aillaud e Bertrand, 1919, pp. 16-17. 
sador Otto Richard Tannenberg, sintetizado no livro A Grande Alemanha: a obra do século $X X^{35}$.

Reconhecido como obra paradigmática do pangermanismo ${ }^{36}$, o livro de Tannenberg desqualifica a colonização ibérica no Novo Mundo. A incapacidade da Espanha e de Portugal de governarem suas possessões no ultramar teria provocado a formação de numerosos Estados independentes, onde a raça branca permaneceu minoritária, razão pela qual tais países dificilmente conseguiriam superar a pobreza crônica e o atraso atávico. Contrastando com esse quadro, o pensador alemão aponta a situação privilegiada dos Estados Unidos da América do Norte, nação de ascendência anglo-saxã, cuja prosperidade atribui à preponderância maciça de caucasianos na população yankee.

Otto Tannenberg induz promover o branqueamento demográfico dos Estados de origem ibérica, uma espécie de condição sine qua non para atingirem padrões europeus de civilização. Ele aconselha a partilha da América do Sul entre as três grandes potências imperialistas, a Inglaterra, os Estados Unidos e a Alemanha. A esta última caberia o território situado desde o litoral brasileiro, na altura da cidade do Rio de Janeiro, até o oceano Pacífico, nas proximidades do porto chileno de Antofogasta.

O projeto da Alemanha do Sul realizar-se-ia em longo prazo, devendo estar concluído por volta de 1950, calculava o seu idealizador. No Brasil, é importante frisar, a área aludida abrigava numerosos núcleos de emigrantes teutões, o que conferia forte credibilidade ao plano. Explica-se, assim, por que o chamado "mapa de Tannenberg" hoje em dia ainda continua a ser evocado como documento emblemático de uma pretendida expansão nazista na América Latina.

Mas, para além das elucubrações de Tannenberg sobre o devir dos países ibero-americanos, existia um outro problema contemporâneo mais urgente, e por certo bem conhecido de João de Barros: a cobiça germânica sobre as possessões portuguesas na África austral.

No momento, não vem ao caso discorrer sobre as manobras diplomáticas do kaiser Guilherme II, nem tampouco enumerar as sucessivas incursões do seu exército em Angola e em Moçambique. Todavia, não se pode perder de vista que as investidas ao território angolano, quando articuladas com as ditas aspirações de conquista no continente americano, apontam para uma questão fundamental de geopolítica: a

35 Otto Richard Tannenberg. Le Rêve allemand ! La plus grande Allemagne. L'oeuvre du 20e siècle. Traduit en français de l'ouvrage Gross-Deutschland, publié en 1911. Lausanne: Payot, 1916.

${ }^{36}$ Entende-se como pangermanismo o movimento que apregoava a união dos povos de língua alemã em um único estado. 


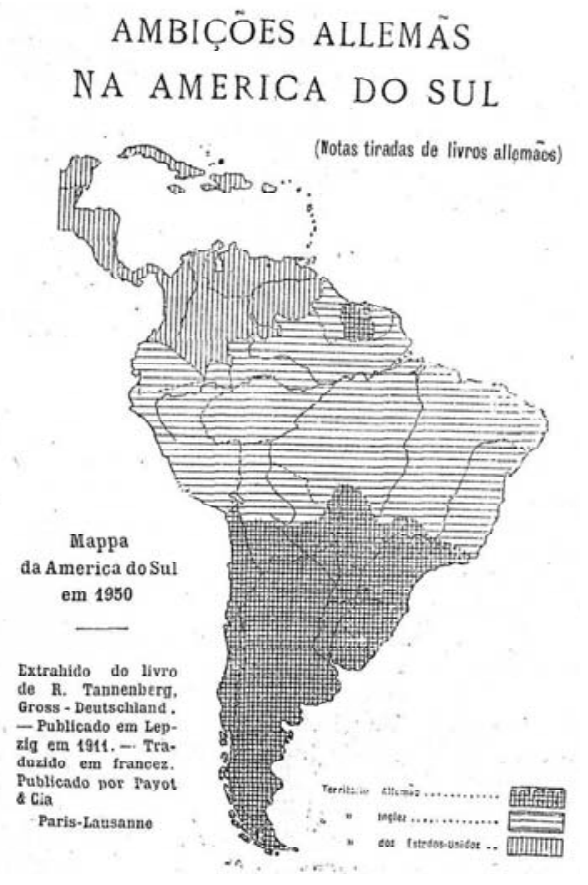

Mapa de Tannenberg

Fonte: Graça Aranha."Prefácio".In: André

Chéradame. O plano pangermanista desmascarado.

Rio de Janeiro: Livraria Garnier, 1917, p. XXXIII.

perspectiva da presença alemã nas duas margens do Atlântico Sul. Sintomaticamente, diversos militares portugueses tangenciariam o problema, pronunciando-se favoráveis à formação de uma comunidade luso-brasileira. $O$ comandante Nunes Ribeiro, por exemplo, inferia, taxativo, que "A garantia do domínio do mar no Atlântico Sul é e será sempre um objetivo comum aos dois países." Seu colega de arma, o capitão-de-mar-e-guerra Henrique Lopes de Mendonça ${ }^{37}$, historiador e autor da letra do hino nacional, A Portuguesa, iria mais longe: batia-se por uma Confederação luso-brasileira. Previa alinhamentos estratégicos no Atlântico, através de novas coligações. No hemisfério norte, reunindo a Inglaterra com os Estados Unidos, e, no sul, Portugal com o Brasil, alianças que "impor-se-iam ao mundo não com intuitos ambiciosos de imperialismo guerreiro, mas como garantia inabalável de paz e de progresso universal"38. Opinião análoga seria emitida pelo general João de Almeida, antigo governador de Angola, aconselhando a federação dos dois países, por meio de uma aliança de natureza mili-

\footnotetext{
37 Henrique Lopes de Mendonça, em 1923, seria eleito sócio correspondente da Academia Brasileira de Letras.
}

38 Nuno Simões, op. cit., pp. 36-37. 
tar, diplomática e econômica ${ }^{39}$. A par dessas manifestações, não se pode esquecer a missão enviada pelo governo de Lisboa ao Rio de Janeiro, em 1918, a pretexto de cumprimentar o presidente Wenceslau Braz, pela decisão de declarar guerra contra o Império alemão e seus aliados ${ }^{40}$. Portanto, diante do cenário aqui exposto em rápidas pinceladas, é possível inferir que, ao lado do objetivo revelado de fortalecer os laços culturais luso-brasileiros, outras motivações também concorreram para precipitar o aparecimento da revista binacional.

Os trabalhos de redação e de impressão da Atlântida se realizavam na cidade de Lisboa $^{41}$, sob a responsabilidade do editor Pedro Bordallo Pinheiro ${ }^{42}$. Nos créditos do periódico não consta a existência de um corpo editorial permanente, nem indicação da quantidade de exemplares que circulava a cada tiragem. Informa-se apenas que, em Portugal, a assinatura anual custava $2 \$ 80$, a semestral $1 \$ 50$, enquanto o número avulso podia ser adquirido por \$25. Já no Brasil, vendiam-se apenas assinaturas anuais e semestrais, aos preços de $12 \$ 50$ e de $7 \$ 00$, respectivamente, quantias razoavelmente acessíveis para a época, considerando o bom padrão gráfico da publicação.

A Atlântida possuía editoração de qualidade. De formato sóbrio, impressa em papel mate, alguns textos eram ilustrados com desenhos e fotografias, outros decorados com caprichadas vinhetas artísticas. A disposição das matérias respeitava uma certa ordem, de maneira a formar dois conjuntos distintos, cujo número de páginas podia variar bastante. O primeiro bloco agregava contribuições literárias, artigos, ensaios e biografias, bem como reproduções de telas de pintores famosos. O segundo era composto por três seções fixas, a saber: "Revista do Mês" - constando da síntese dos principais fatos culturais e políticos ocorridos no período; "Livros" - espaço destinado à divulgação do lançamento de publicações e às resenhas críticas; "Notícias e Comentários” - segmento reservado às cartas de leitores e observações do gênero. Aceitava-se publicidade paga, em geral reclames de empresas, escritórios, lojas, bancos e companhias de seguro, porém não há menção sobre valores cobrados a anunciantes.

39 João de Almeida. Visão do crente. Porto: Companhia Portuguesa, 1918.

40 A missão chefiada pelo ex-ministro Alexandre Braga era integrada por José de Carvalho,Marcelino Mesquita, Augusto Gil, Fausto Guedes Teixeira, além dos militares, capitão-de-fragata Judice Biker e tenente-coronel Antonio Figueiredo Campos. Ver Universidade de Chicago. Brazilian Government, Ministerial Reports, Relações Exteriores 1917-1918, pp. 176-177. http://brazil.crl.edu/bsd/bsd/u1788/000224.html. Acessado em 24 de setembro de 2007.

${ }^{41}$ O escritório da Atlântida funcionava no Largo do Conde Barão, n. ${ }^{\circ} 41$, enquanto a redação se localizava à rua Barata Salgueiro, 41 r/c.

42 Pedro Bordallo Pinheiro (1890-?) era sobrinho-neto do conhecido caricaturista e pintor Rafael Bordallo Pinheiro. 


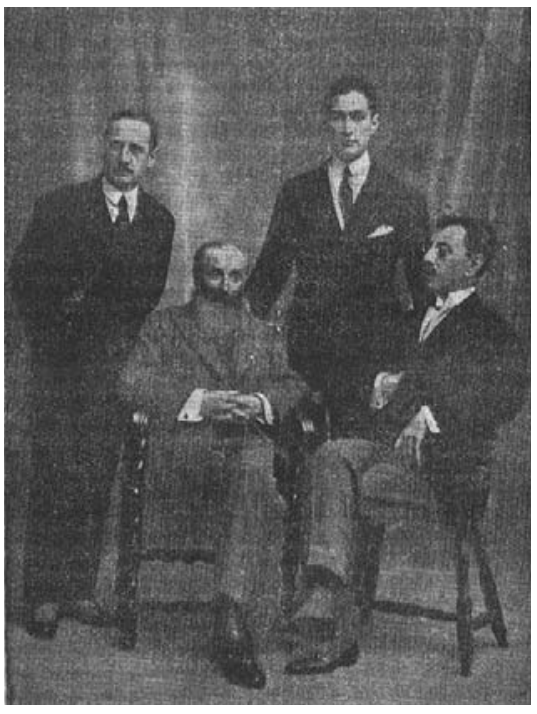

Guerra Junqueiro, Olavo Bilac, Pedro Bordalo Pinheiro e João de Barros

(Última fotografia do grande Poeta, inteiramente inédita, tirada em Lisboa)
Seu conteúdo privilegiava majoritariamente o domínio das letras - poesia e prosa. Os artigos, ensaios e biografias, sempre em menor número, além de contemplar temas ligados à problemática das relações luso-brasileiras, costumavam versar sobre assuntos culturais variados. Os colaboradores não percebiam remuneração e, no que respeita à sua nacionalidade, as fontes levantadas apontam a preeminência dos portugueses. Porém, a constatação não pode ser tomada como sinal de desprestígio do periódico, apesar de a sua proposta não contar com o apoio unânime da intelectualidade brasileira, como já se sublinhou. O predomínio dos conterrâneos de Camões, em larga medida, deve ser atribuído ao estado de guerra, que tornava bem mais difícil a comunicação e o transporte regular entre o Rio de Janeiro e Lisboa ${ }^{43}$.

O inventário dos quatro primeiros números da Atlântida revela a presença de poemas de Olavo Bilac, António Correia d'Oliveira, Júlio Dantas, Augusto Gil, Óscar Lopes, João de Barros e Mário de Alencar; de contos de Afrânio Peixoto, Júlia Lopes de Almeida, Teixeira de Queiroz, Manoel de Sousa Pinto; de crônicas de Aquilino Ribeiro, João do Rio, Aurélio da Costa Ferreira, João Luso e Humberto d'Avelar. Nomes de sólida reputação na esfera literária luso-brasileira, conquanto representem correntes estéticas e teóricas diversas. Aliás, a mélange, quem sabe, possa explicar porque especialistas de história da literatura, apesar de fazerem reiteradas menções à revista e a seus diretores, não aprofundam a análise do seu conteúdo, à exceção do trabalho acadêmico de Cecília Dias de Carvalho Henriques da Conceição, desenvolvido na Universidade Nova de Lisboa ${ }^{44}$.

43 Existem sucessivas notas explicativas da direção da revista, procurando justificar a ausência de colaborações de autores brasileiros previamente anunciadas e que deixaram de ser publicadas, devido aos transtornos provocados pela guerra.

44 Ver Cecília Dias de Carvalho Henriques da Conceição. A revista Atlântida. Documento sócio-cultural e literário de uma época. "Um abraço mental" entre Portugal e o Brasil. Dissertação de mestrado apresentada ao Departamento de Literaturas Românicas na Faculdade de Ciências Sociais e Humanas da Universidade Nova de Lisboa. Lisboa, 1997. 
De qualquer maneira, o ecletismo confirma a intenção anunciada por João de Barros de acolher figuras de todos os quadrantes do mundo letrado, "sem virar a casaca", ou seja, sem abrir mão do republicanismo dos fundadores. Mas a mistura de tendências constituía uma estratégia calculada. Buscava atrair novos simpatizantes para a causa da revista e conquistar um público leitor mais numeroso ${ }^{45}$. A mesma prática se nota na mescla dos autores de artigos, ensaios e biografias. O leque compreendia desde políticos da envergadura do positivista Teófilo Braga e do ministro Manuel Monteiro, até diplomatas como Hélio Lobo, Veloso Rebelo e Alberto d'Oliveira, passando por figuras conhecidas do panorama cultural luso-brasileiro, a exemplo do arquiteto Raul Lino, Luís da Câmara Reys, Bento Carqueja, Moreira Teles, Aureliano Leal e Vítor Vianna, entre outros.

\section{Quadro n.०1}

\section{Atlântida: Classificação e quantificação do material publicado (novembro/1915 a fevereiro/1916)}

\begin{tabular}{|l|c|c|c|c|c|}
\hline Assunto & Nov/1915 & Dez/1915 & Jan/1916 & Fev/1916 & Total \\
\hline Arquitetura & - & - & - & 01 & 01 \\
\hline Belas-Artes & 01 & 01 & 01 & - & 03 \\
\hline Biografias & 02 & 01 & - & - & 03 \\
\hline Diplomacia & - & - & - & 01 & 01 \\
\hline Direito & - & - & - & 01 & 01 \\
\hline Educação & & & 02 & 01 & 03 \\
\hline História & 01 & 01 & 01 & - & 03 \\
\hline Letras (poesia) & 04 & 02 & 04 & 03 & 13 \\
\hline Letras (prosa) & 02 & 02 & 03 & 03 & 10 \\
\hline Política & - & - & - & 01 & 01 \\
\hline Relações Luso-Brasileiras & 03 & 01 & 02 & - & 06 \\
\hline Total & 13 & 08 & 13 & 11 & 45 \\
\hline
\end{tabular}

Fonte: Quadro elaborado com base nos artigos publicados na Atlântida, n.os 1, 2, 3 e 4, relativos, respetivamente, aos meses de novembro de 1915, dezembro de 1915, janeiro de 1916 e fevereiro de 1916.

${ }^{45}$ Ver carta de João de Barros, apud Cecília Dias de Carvalho Henriques da Conceição. Passim. 
A classificação por assunto e a respectiva quantificação demonstram a preponderância do campo das letras - poesia e prosa, privilegiado em mais da metade do total do material publicado. Em seguida, com incidência bem menos expressiva, aparece a temática da luso-brasilidade. As matérias restantes distribuem-se de maneira relativamente equilibrada, entre áreas consideradas representativas do domínio cultural.

Dos seis textos que tratam das relações entre Brasil e Portugal, quatro merecem um rápido comentário, devido às abordagens que desenvolvem. São trabalhos cujos enfoques extrapolam o tradicional argumento da afinidade lingüística, embora nenhum deles explicite uma definição clara do que poderia vir a ser uma "comunidade luso-brasileira".

O artigo "Relações luso-brasileiras", de autoria de Antonio Carlos Moreira Teles ${ }^{46}$, publicado na edição de lançamento da Atlântida, sobressai pelo pragmatismo. Brasileiro, radicado em Lisboa, professor e homem de imprensa, o autor restabelece os fios de continuidade entre o projeto da revista e o plano esboçado por Consiglieri Pedroso, referido como "a iniciativa mais brilhante" para promover o estreitamento das duas nações.

Moreira Teles se detém na análise de dois problemas crônicos, que se arrastavam desde o século XIX e careciam de solução por parte dos altos escalões de ambos os governos: as ausências de um acordo postal e de uma convenção literária. Além disso, discute as causas políticas e econômicas do fracasso de um empreendimento recente, voltado para a criação de uma companhia de navegação de bandeira portuguesa, com linhas regulares para os principais portos brasileiros ${ }^{47}$.

Outro brasileiro, o professor e crítico de arte Vítor Viana ${ }^{48}$, no artigo "Brasil-Portugal", faz uma reflexão sobre o alcance das trocas comerciais e culturais entre os dois países, enfatizando a existência de interesses recíprocos nesse intercâmbio. Para Viana, do

${ }^{46}$ Antonio Carlos Moreira Teles trabalhou na embaixada do Brasil e durante algum tempo dirigiu a Agência Telegráfica Americana. Ver Atlântida. Lisboa, n. ${ }^{\circ} 20$, junho de 1917, p. 704. Estudioso dos problemas luso-brasileiros, publicou, entre outros trabalhos, o livro Brasil e Portugal. Cf. Moreira Teles. Brasil e Portugal - Apontamentos para a história das relações dos dois países. Lisboa: ed. do autor (depositária: Livraria Ventura Abrantes), s.d. (1914).

47 Moreira Teles." "Relações luso-brasileiras." Atlântida. Lisboa, n.o 1, novembro de 1915, pp. 62-67.

${ }^{48}$ Vítor Viana, jornalista, professor, crítico literário e ensaísta, nasceu na cidade do Rio de Janeiro, em 23 de dezembro de 1881. Exerceu diversos cargos públicos. Foi bibliotecário da Escola Nacional de Belas Artes, professor da Escola de Altos Estudos e professor de Geografia Industrial e História das Indústrias na Escola Nacional de Artes e Ofícios Wenceslau Brás. Ingressou na Academia Brasileira de Letras em 11 de abril de 1935. Faleceu no Rio de Janeiro, em 21 de agosto de 1937, e deixou expressiva obra bibliográfica nas áreas da educação e da cultura. 
ponto de vista português, o Brasil continuava a ocupar o posto de melhor mercado intelectual e desaguadouro natural da sua emigração. Posição que também Ihe trazia benefícios, assegura o professor, pois os produtos, os livros e os costumes oriundos da antiga metrópole eram elementos que concorriam para o fortalecimento da nacionalidade, tal como os emigrantes auxiliavam no processo de assimilação de outros estrangeiros introduzidos no país ${ }^{49}$.

No ensaio "Os portugueses no Brasil,", Alberto d'Oliveira oferece um diagnóstico original dos fatores que afetavam o relacionamento luso-brasileiro. Na sua percepção, o principal entrave na aproximação dos dois países não se situava na esfera do comércio, da navegação ou da emigração, mas sim no âmbito do que denomina de "tradicionalismo culto".

Segundo o escritor e diplomata, em virtude do reinado americano de D. João VI, a Terra de Santa Cruz desfrutava de uma situação singular. Fora a única colônia que os portugueses souberam fazer nação. Isto implicava em distinguir "acima da sua americanidade e até da sua latinidade, a sua emancipada e altiva lusitanidade, para manter entre os povos da América a sua verdadeira autonomia, não só territorial, mas moral e histórica" ${ }^{50}$. No entanto, as referências culturais lusas vinham sendo abandonadas no Brasil. Cediam espaço a um cosmopolitismo, que se inspirava tanto em Paris, "a capital intelectual", quanto nos Estados Unidos, "a musa econômica" ${ }^{\text {"1 }}$. A transformação se operava de maneira veloz e urgia revertê-la. Todavia, em Portugal, os assuntos relativos ao Brasil costumavam ser ignorados, até mesmo nas camadas mais cultas. O desconhecimento deixava o campo aberto para a expansão da influência cultural daqueles poderosos rivais. Diga-se de passagem, consoante essa argumentação, que Alberto d'Oliveira sugeriu à Academia das Ciências de Lisboa recomendar ao governo a criação de uma cadeira de história, geografia e literatura brasileiras nas Faculdades de Letras $^{52}$.

O ex-cônsul no Rio de Janeiro e sócio correspondente da Academia Brasileira de Letras assinala ainda um outro obstáculo a vencer: o desdém da sociedade lusíada pelos chamados "brasileiros" - os conterrâneos que se dirigiam para o Novo Mundo,

\footnotetext{
49 Ver Vítor Viana,"Brasil-Portugal,"Atlântida. Lisboa, n. 3, janeiro de 1916, pp. 195-204.

${ }^{50}$ Ver Alberto d'Oliveira,"Os portugueses no Brasil", Atlântida. Lisboa, n. 3, janeiro de 1916, pp. 195-204.

51 Idem.

52 Cf. Atlântida. Lisboa, n. ${ }^{\circ}$ 2, dezembro de 1915, p. 189. . indicativo foi abraçado pela Faculdade de Letras de Lisboa com a introdução da disciplina Estudos Brasileiros nos currículos dos cursos de humanidades, a partir de 1916. A implantação da cadeira, todavia, devido a uma série de contratempos, só veio a se concretizar em 1923, com um ciclo de conferências do historiador e diplomata Oliveira Lima.
} 
faziam fortuna e voltavam para matar as saudades da pátria, tipos como os retratados por Eça de Queiroz nas Farpas, alvos de caricaturas na imprensa e de anedotas mordazes. Preconceito que à sua maneira também traduzia o mal-estar das elites em relação à dependência econômica da antiga colônia e ao desagrado para com a emigração, que roubava a sua melhor força de trabalho ${ }^{53}$.

Talvez a contribuição mais instigante do conjunto aqui selecionado seja o artigo "Solidariedade ethnico-econômica", escrito por Bento Carqueja, da Universidade do Porto ${ }^{54}$. Não pela originalidade do enfoque, mas sim pela permanência da velha mentalidade colonial, ainda que camuflada por doutrinas científicas contemporâneas. Dizendo-se adepto da antropogeografia de Ratzel e inspirado em livro recente, a Storia della colonizzacione europea al Brazile, de um certo Vincenzo Grossi ${ }^{55}$, o autor lança mão das "afinidades étnicas" para sugerir a (re)introdução de certas práticas no intercâmbio comercial entre os dois países.

Carqueja afiança que Portugal possuía a localização geográfica perfeita para se tornar o entreposto mais favorável à colocação de mercadorias brasileiras no Velho Mundo. Recorda, inclusive, que a reexportação de bens oriundos da República sul-americana, no exercício de 1913, alcançara a soma de 102 contos, quantia nada desprezível! Com base neste dado, propõe realizar um levantamento de campo minucioso em todas as regiões do país, de maneira a identificar matérias-primas e artigos em geral, de interesse do mercado europeu. Os resultados da pesquisa serviriam de fundamento para a negociação de futuros tratados de comércio, consoante uma política que se assentava na "solidariedade étnica". Mas em que consistiria essa política? A resposta parecia simples. O Brasil concederia tratamento preferencial à "mãe pátria" no seu sistema de comércio exterior. Reduziria os impostos cobrados sobre a exportação de mercadorias para a velha metrópole, que as revenderia por preços mais altos para outras praças, auferindo assim boa margem de lucro.

O professor se mostrava tão convencido da viabilidade do plano, a ponto de argumentar:"a nossa situação de nação colonial veda-nos, é certo, larga aceitação a determinados produtos brasileiros, mas não são esses produtos que mais possam afetar

53 Ver Arnaldo Saraiva, op. cit., p. 71.

54 Cf. Bento Carqueja, "Solidariedade ethnico-econômica”, Atlântida. Lisboa, n. 3 3, janeiro de 1915, pp. $210-214$.

55 Segundo Bento Carqueja, Vincenzo Grossi empreendera uma viagem ao Brasil para "buscar novas luzes para guiar emigrantes italianos e comerciantes na conquista de novos mercados de trabalho e de comércio". O material coletado fora reunido no livro Storia della colonizzazione europea al Brazile. Esta obra, no entanto, parece ser desconhecida no Brasil. 
o comércio das colônias portuguesas"56. Até o momento, não há nenhuma pista da repercussão da proposta de Bento Carqueja no Brasil. Entretanto, dá para imaginar o alvoroço que certamente teria despertado nos setores nacionalistas mais radicais. Basta lembrar que o seu plano se assemelhava a certas medidas recolonizadoras, apresentadas nas Cortes de Lisboa de 1820, cuja defesa intransigente desaguou nos sucessos da proclamação da independência.

Revistas de idéias e de cultura costumam ter vida efêmera, na maior parte das vezes abreviada pela escassez de recursos. A Atlântida foi uma exceção. Circulou com periodicidade bem regular entre 1915 e 1920, o que reforça a nossa suspeita de que se tratava de uma publicação patrocinada pelos governos das duas Repúblicas. Até o n. ${ }^{\circ}$ 36, de março de 1919, o periódico manteve uma linha editorial coerente com objetivos traçados por seus fundadores e expressos no Manifesto de lançamento ${ }^{57}$. Assim, ao lado da permanente reflexão doutrinária acerca da conveniência da criação da aproximação luso-brasileira, ocupava-se de questões literárias, históricas e artísticas coetâneas, o que lhe proporcionava uma dimensão política e ao mesmo tempo cultural ${ }^{58}$.

Porém, tudo leva a crer que, com o fim da guerra e cessado o perigo alemão, os fundadores da Atlântida tencionavam alterar o foco da publicação e alçar vôos mais ambiciosos. A partir do n. ${ }^{\circ}$ 37, que provavelmente corresponde a abril de 1919, a revista deixou de ostentar o subtítulo "Mensário artístico, literário e social para Portugal e Brasil," para se converter em "Órgão do pensamento latino no Brasil e em Portugal". Na mesma ocasião, passou a ser gerida por três diretores, com a inclusão do brasileiro Graça Aranha, que ficava sediado em Paris.

Até o encerramento das suas atividades, em 1920, as páginas da Atlântida veicularam contribuições da nata da intelectualidade que se movimentava no eixo Lisboa-Rio de Janeiro. Testemunhos de uma época, os textos desses autores merecem reabilitação. Se por um lado suas concepções conquistaram muito mais adeptos nos meios letrados do que no âmbito político-institucional, por outro despertaram memoráveis polêmicas. Pelo menos no cenário brasileiro dos anos 1910-1920, marcado pelo acirramento do nacionalismo intransigente e por campanhas de xenofobia antilusitanas, que identificavam aquelas propostas como manifestações de

${ }^{56}$ Ver Bento Carqueja, ibidem, p. 213.

${ }^{57}$ Cf. Jean-François Sirinelli, Intellectuels et passions françaises. Manifestes et pétitions au XXe siècle. Paris: Gallimard, 1990, pp. 132-139.

${ }^{58}$ Ver a esse respeito Luís Crespo de Andrade,"Introdução,"in Antonio Reis et alii, Revistas, idéias e doutrinas. Op. cit., pp. 11-16. 
colonialismo cultural, defendidas por traidores da pátria em conluio com emigrantes portugueses ${ }^{59}$.

Seja como for, o desaparecimento da revista não implicaria no fim do projeto que seus idealizadores abraçavam. Se João do Rio faleceu subitamente meses após a extinção da Atlântida, João de Barros e a rede de intelectuais que se formara ao seu redor sobreviveram-na, continuaram a disseminar suas propostas, influenciando novas gerações ${ }^{60}$. Não por acaso, depois de passado meio século, o historiador Barradas de Carvalho voltaria a aventar a conveniência da formação de uma comunidade luso-brasileira. De maneira bem mais pragmática do que as aspirações culturais acalentadas pelos dois Joões, convém acrescentar.

59 Não é demais lembrar que João do Rio tornou-se o principal alvo daqueles movimentos, atacado quase que diariamente pela imprensa, a exemplo da celeuma criada em torno da "questão dos poveiros". episódio envolveu emigrantes naturais da Póvoa de Varzim, os quais não se quiseram naturalizar brasileiros e se repatriaram. Estabelecidos no Rio de Janeiro e especializados na pesca de alto mar, não se misturavam com os brasileiros, nem com seus próprios patrícios de outras localidades. Segundo o escritor Lima Barreto, os "poveiros" formariam uma colônia dentro da própria colônia lusitana no Rio.

60 Cf. Lucia Maria P. Guimarães, À sombra das chancelarias. O lado oculto do Congresso Luso-Brasileiro de História. Inédito, submetido para publicação à Revista do IHGB, em maio de 2007. 


\title{
“Uma nova e grande Lusitânia"
}

\author{
Zília Osório de Castro*
}

Esta expressão transcrita pela pena de Jaime Magalhães Lima ${ }^{1}$ não traduz apenas o pensamento de quem a escreveu. As suas raízes, multiformes, iam beber a seiva que as alimentava aos tempos remotos da aventura do encontro com o desconhecido e dos laços que, a partir daí, se foram estreitando e fortalecendo nas terras de aquém e de além-mar. Crescendo a par com as vicissitudes dos tempos e das circunstâncias culturais, fortalecidas com as diferenças aceites ou sofridas, viu-se desde o início marcada pelo hibridismo que de aglutinador passou a consciencializador. Assim se desenvolveu uma identidade complexa que foi acolhendo outros impactes, sem esquecer os que haviam estado na sua origem, desde logo assinalada pelo encontro entre os que tinham chegado do mar e os que tinham nascido na terra. Encontro marcado, aliás, pela sucessiva dinâmica que os tempos da História vieram consolidar com a construção de um "novo" mundo, com tudo o que isso implicaria na globalidade da vivência humana.

Neste modo de pensar, as palavras ultrapassam os limites do seu significado literal. Expressam o sentido de uma realidade que se pretendia perene, sem passado e sem futuro, manifestando-se no presente pela acidental idade dos seus reflexos. Ao mesmo tempo, dupla e una. Dupla porque constituída por duas nações - Portugal e Brasil. Una porque com uma mesma cultura, uma mesma língua, uma mesma tradição, uma mesma raça. Assim o entendiam tanto João do Rio como João de Barros, os grandes entusiastas, juntamente com Olavo Bilac, do ressurgimento da união luso-brasileira. À sua iniciativa se ficou a dever o acto criador e impulsionador da revista Atlântida, enquanto Mensário Artístico, Literário e Social para Portugal e Brazil. Dirigindo-se aos políticos e aos intelectuais, o escritor brasileiro afirmou:

Faculdade de Ciências Sociais e Humanas da Universidade Nova de Lisboa.

Jaime Magalhães Lima, "Carta ao Dr. Bettencourt Rodrigues," Atlântida. Mensário Artístico, Literário e Social para Portugal e Brazil, n. ${ }^{\circ} 22,15$ de Agosto de 1917, p. 847. Esta revista, daqui em diante, será mencionada apenas como Atlântida. 
O vosso dever é trabalhar para defender connosco a herança comum da língua e para manter esse espírito de nacionalidade que não criastes na decadência da Índia, mas que realizaram os nossos comuns maiores estupendamente na obra viva do Brasil. Cada um de vós deste lado do Atlântico, como cada um do outro lado deve ter como princípio, como convicção, de que Portugal é dos mais gloriosos povos da terra (...) Vós deveis ter essa convicção porque ela é a palpável verdade. E nós outros brasileiros, filhos da mesma raça, falando a mesma língua, continuando a mesma arte, com os mesmos sentimentos de triunfo e resistência, nós somos o grande Portugal do outro lado, com essa convicção. ${ }^{2}$

Por seu lado, o poeta lusitano não Ihe ficou atrás ao falar "na existência de tradições comuns, na fraternidade de sangue, nos costumes idênticos, na uniformidade do idioma". E ao lembrar que, "na sua quase totalidade, os formadores do Brasil foram os autênticos lusitanos da epopeia marítima, os nobres da mais alta fidalguia de Portugal e os homens honrados que, à procura do pão, encontravam ali um maior e mais opulento campo de acção para o seu espírito de iniciativa e para o seu trabalho honesto e perseverante"3. Daqui a indiscutível identidade entre portugueses e brasileiros, já que, se nestes termos fora "o sangue lusitano que fizera o Brasil", fora igualmente o mesmo sangue que o consolidara 4 .

Aos emigrantes se ficara a dever a permanência da lusitanidade no Brasil. Ofuscado o mito da "árvore das patacas", com o abandono das autoridades, nascente a implantação de várias colónias estrangeiras, diluiu-se a vitória final, e o Brasil tornou-se num verdadeiro campo de luta, no qual o triunfo, se bem que compensador, tinha os rostos do esforço e da perseverança. Criaram-se, assim, laços de solidariedade que, com a memória do passado e a esperança no futuro, deram origem no português emigrante e no brasileiro residente a uma consciência comum de que o Brasil e Portugal partiIhavam um mesmo destino, no qual o Atlântico tinha um papel fulcral. Esquecer ou ignorar esta realidade seria pôr em causa a identidade de ambas as nações.

Tanto para João do Rio como para João de Barros, esta era uma realidade que não se discutia, por ser incontornável. Era verdade que tinha havido aqui e além correntes de opinião que, por razões diversas, a haviam posto em causa. Sem dúvida que Portugal e os portugueses haviam sido "rudemente maltratados"por "vagos movimentos nati-

\footnotetext{
João do Rio, Adiante!, Paris /Lisboa, Livraria Aillaud e Bertrand, 1919, pp. 232-234.

João de Barros,"Sentido do Atlântico", Presença do Brasil, Lisboa/Rio de Janeiro, 1946, pp. 105-106.

Cf. idem, ibidem, pp. 106-107.
} 
vistas de desconfiança"5. Mas, segundo João de Barros, sem beliscar o essencial de uma relação secular.Tratara-se, antes, de simples "arrufos" cuja duração bem contada não teria ultrapassado os seis meses ${ }^{6}$, sem nunca ter criado sérias tensões entre os dois povos.

Um desses "arrufos" havia-se tornado evidente com a proclamação da independência brasileira. A ida de D. João VI, da Família Real e da Corte para o Brasil em finais de 1807 e a chegada em 1808 marcaram de forma indelével os dois territórios, ao tempo, o português europeu e o português americano, assim como as suas gentes ${ }^{7}$. Relembre-se que o Brasil se tornou, então, a sede da Monarquia portuguesa. Depois, ele próprio foi elevado à categoria de Reino, mediante a Carta Régia de 16 de Dezembro de 1815, que criou o Reino Unido de Portugal e do Brasil, sob o poder de um único monarca - D. João VI, então ainda Príncipe Regente - e identificado nos símbolos de uma mesma bandeira ${ }^{8}$. A queda do Antigo Regime e o início da monarquia liberal constitucional reflectiram-se profundamente num todo até então indivisível. Por incapacidade ou inabilidade das Cortes vintistas em ultrapassarem o diferendo entre a unidade ou a união entre os dois reinos, o Brasil declarou a independência em 1822. As consequências deste acto reflectiram-se, de imediato, aquém e além-Atlântico, com aspectos negativos para ambos os países. Só o Rei conseguiu, afinal, deixar uma porta entreaberta para um futuro prestígio monárquico e imperial da Casa de Bragança, que a morte do soberano não deixaria concretizar e que a abdicação de D. Pedro tornaria impraticável ${ }^{9}$.

No entanto, as cláusulas do Tratado de Paz e Aliança assinado pelo Rei de Portugal e pelo Imperador do Brasil a 29 de Agosto de 1825, que consagrou sob o ponto de vista legal a independência brasileira, não se limitou a regular os seus termos relativamente às duas nações e seus respectivos direitos. $\mathrm{O}$ art. $3^{\circ}{ }^{\circ}$, que impedia o Brasil de anexar territórios angolanos, respeitando ali a soberania portuguesa, consagrava Portugal como parte no domínio do Atlântico Sul ${ }^{10}$. O plano geopolítico então apenas

\footnotetext{
João de Barros, "A Aproximação Luso-Brasileira e a Paz de Versailles,",Presença do Brasil, cit., p. 82.

Idem, ibidem.

7 Cf. Idem, ibidem, pp. 81-82.

8 Veja-se, sobre este assunto, Maria de Lourdes Viana Lyra, A Utopia do Poderoso Império. Portugal e o Brasil. Bastidores da Política, Rio de Janeiro, Sete Letras, 1994.

9 Veja-se, por todos, Zília Osório de Castro, Portugal e Brasil. Debates Parlamentares. 1821-1826, Lisboa, Assembleia da República, 2002, nomeadamente a Introdução.

10 Veja-se, a este respeito, Idem, "A 'Varanda da Europa' e o 'Cais do lado de lá',', Tratados do Atlântico Sul. Portugal-Brasil, 1825-2000, Lisboa, Ministério dos Negócios Estrangeiros. Instituto Diplomático, 2006, pp. 23-48, e respectiva bibliografia.
} 
esboçado adquiriu um outro impacte pela pena de João de Barros. Explicitamente falava na formação de um triângulo que, tendo como vértices Lisboa, Rio de Janeiro e Luanda, reconhecia uma hipotética supremacia nesta área do oceano e ao Brasil as vantagens que daí lhe poderiam advir em termos de relações internacionais, nomeadamente face à Inglaterra e aos Estados Unidos da América. Poder-se-ia dizer que o Atlântico ficava dividido em duas áreas de influência cultural e política: uma anglo-saxónica, ao norte; outra latina, ao sul.

Apesar de os contextos nacionais e internacionais serem diferentes, a continuidade de um projecto comum de domínio do Atlântico Sul unia de novo Portugal e o Brasil, nos inícios do século XX. E mais. Servia-Ihe para reforçar a proposta política de aproximação luso-brasileira, tal como o autor citado a apresentava, interpretando um pensamento que não seria apenas seu. “Ambição,',note-se, não só de domínio político dos mares do Sul, mas também de relações comerciais entre Portugal, Brasil e Angola, "naturalmente" unidos pelo mesmo sentido de Atlântico.

Ontem o Brasil, amanhã Angola. E através de crises, desalentos e derrotas, sempre um domínio certo para a coragem portuguesa: - o domínio do mar (...) Levámos connosco para o Brasil essa fé invencível, esse sentido do Atlântico, que ali floresce na mesma coragem aventurosa. Um dia, não muito longe, compreender-se-á como ele corresponde a uma realidade histórica segura: - será quando entre Portugal, o Brasil e Angola se estabelecerem as relações comerciais que inevitavelmente, naturalmente, se estabelecerão entre os dois países e a nossa colónia. ${ }^{11}$

Se a independência do Brasil constituiu um marco indelével nas relações luso-brasileiras, talvez até pelo modo por que se processou e pelas repercussões que se fizeram sentir, despoletou ao longo do século XIX e princípios do século XX reacções contraditórias. Por um lado, as tensões ou "arrufos", como acima foram mencionados, fragilizaram o relacionamento entre as duas potências iguais, porque igualmente soberanas. Por outro, no entender das duas personalidades que se têm vindo a citar - João do Rio e João de Barros - e que decerto expressavam sentimentos consentâneos de brasileiros e portugueses, existiam naturais laços de amizade entre Portugal e o Brasil, por serem nações "irmãs" ${ }^{2}$. Partilhando o mesmo modo de pensar e de sentir, lembravam que o "Brasil surgiu de Portugal no seu momento de ouro", que os dois povos eram

\footnotetext{
11 João de Barros, Sentido do Atlântico, Lisboa, Livraria Aillaud e Bertrand, 1921, p. 38.

12 Cf. João do Rio cit. por João de Barros, A Aproximação Luso-Brasileira e a Paz de Versailles, cit., pp. 94-95.
} 
"ramos do mesmo tronco", que se deviam o "mesmo amor igual"13. Por isso ao constatarem, com apreensão, o enfraquecimento desses laços, manifestaram o empenho em os reforçar de novo, não sem apontarem os principais responsáveis pela situação. No seu entender, fora obra dos políticos e dos intelectuais.

Entre estes últimos, João do Rio mencionava o grupo dos chamados "vencidos da vida". O seu assumido decadentismo penetrara na alma portuguesa e na alma brasileira, semeando o desânimo e a apatia ${ }^{14}$. "Qual o país capaz de resistir quando a fina-flor da sua mentalidade resolve considerar-se o grupo dos vencidos da vida? - perguntava. Ninguém anima um homem, dizendo-Ihe 'Você nada adianta'.O diabo foi o seu pai ser independente"15. E acusava Oliveira Martins, Ramalho Ortigão e Eça de Queiroz de serem falhos de ideal político e social, pelo que a sua acção fora tão destruidora como um bombardeiro de artilharia pesada, como concluía de forma impressiva ${ }^{16}$. Daqui que o "não valer a pena" se tornasse o lema comum, tanto em Portugal como no Brasil. Destruídos deste modo os laços identitários que ligavam as duas nações, destruída também estava a possibilidade de uma política comum. "O sagrado problema da aproximação dos dois povos, a certeza do que adviria em grandeza, riqueza e prestígio para os dois países, a simples ideia dos resultados de uma liga de interesses que fizessem o domínio de uma raça em dois continentes e em todo o mar que os separa, o ideal de tornar pela união de sessenta milhões de criaturas uma língua indestrutível"17, tudo isto, portugueses e brasileiros haviam menosprezado, uns pela falácia do estrangeirismo, outros pelo credo nativista.

Nesta perspectiva, nos últimos tempos praticara-se uma má política, não só por parte do Governo, mas também pela população ${ }^{18}$, influenciada por todos os que, de

13 Idem, ibidem.

${ }^{14}$ Cf. idem, "Aproximação luso-brasileira", Adiante!, cit., pp. 209-210.

15 Idem, pp. 207-208.

${ }^{16} \mathrm{Cf}$. idem, ibidem. Contra essa literatura, manifestara-se igualmente Olavo Bilac: “Dissipou-se o pesadelo. Varreu-se de nós a lembrança dessa literatura que morreu sem ter vivido. A nossa literatura aqui no Brasil é nacionalista e será nacionalista" (Discurso de ... no banquete que lhe foi oferecido em Lisboa no dia 31 de Março de 1916 pela revista "Atlântida", Lisboa, Edição de João de Barros, 1940, p. 12).

17 Idem, ibidem, p. 210.

18 "Ponhamos que as classes mentais e os expoentes máximos da cultura portuguesa tivessem o direito de não dar a menor importância ao Brasil e de desprezar o estado geral das coisas no próprio Portugal. 0 que não lhes era permitido, porém, era continuar a dirigir este povo sem uma ideia activa para lhes trazer remédio, era praticar o snobismo no governo (...). Governar (...) é sempre a responsabilidade colectiva dos que pensam melhor, sabem mais, têm mais inteligência e por consequência podem mais" (Idem, ibidem, p. 212). Em sentido idêntico se exprimia o escritor português, ao apontar o afastamento das "clas- 
um modo ou de outro, contribuíam para a formação da opinião pública. Ao ignorar as suas raízes culturais, tinham deixado de partilhar ideais indispensáveis a um futuro comum de progresso e de prosperidade. Na ordem interna, o Brasil quase deixara instalar o domínio germânico nas províncias do Sul, onde os alemães haviam até tentado implantar a supremacia da própria língua. Em Portugal, a apatia e a indiferença, quando não a incapacidade governativa, geravam e acentuavam uma crise que parecia não ter remédio. No plano internacional, um e outro mais pareciam ter esquecido que eram países atlânticos e que o domínio do Atlântico Sul efectivava a sua presença como potência na comunidade das nações ${ }^{19}$.

Se a governos decadentistas e dandistas se atribuía o resfriamento das relações entre o Brasil e Portugal, relembre-se que o poder político de ambos os países procurava dinamizar uma nova aproximação. Neste plano, inseriam-se a gorada viagem de D. Carlos ao Brasil, em 1908, e a visita a Portugal, em 1919, do Presidente brasileiro Epitácio Pessoa. Contudo, nenhum dos autores citados as valorizou nas páginas da Atlântida. Para ambos, republicanos convictos, teria sido a implantação da República no Brasil, em 1889, e em Portugal, em 1910, a criar um novo espírito, potencial gerador de uma nova política. Atitudes como o reconhecimento pelo Governo brasileiro da República portuguesa ou a nomeação do Dr. Bernardino Machado para a Legação Portuguesa no Rio de Janeiro e a pressão para que a referida Legação fosse elevada a Embaixada ${ }^{20}$ expressavam-no de forma inequívoca. Aliás, contrariando um pouco o excessivo "partidarismo" da afirmação acima referida, recorde-se, e eles próprios assim o fizeram, que já antes, em 1807, portanto nos finais da monarquia constitucional, Consiglieri Pedroso apresentara à Sociedade de Geografia de Lisboa, com data de 10 de Novembro de 1909, uma "Proposta" para a criação de uma comissão que promovesse a aproximação das duas nações. Aproximação moral, entenda-se, "respeitando-se escrupulosamente a independência de cada uma delas" ${ }^{\prime 21}$. Seria potencializada mediante a implementação de várias medidas: realização de congressos periódicos luso-brasileiros, tratado de arbitragem, tratado de comércio, criação de uma linha de navegação, fundação de um entreposto comercial em Lisboa e outro no Rio de

ses dirigentes" do "instinto popular"quanto às vantagens e conveniências da aproximação luso-brasileira (João de Barros, A Aproximação Luso-Brasileira, cit., pp. 15-16).

${ }_{19}$ Cf. Idem, ibidem, pp. 14-15.

20 Sobre a importância que se dava a este quadro do pensamento que se vem analisando, veja-se João de Barros, "A criação da Embaixada Portuguesa no Brasil", Caminhos da Atlântida. Uma Campanha Luso-Brasileira, Lisboa, Atlântida, 1918, pp. 69-79.

${ }^{21}$ Consiglieri Pedroso,"Proposta", O Acordo Luso-Brasileiro, Lisboa, Antiga Casa Bertrand, 1909-1910, p. 20. 
Janeiro, além de outras tantas que visavam a aproximação intelectual, tais como a equivalência dos cursos ministrados em cada um dos lados da Atlântico, e a criação de uma revista que fosse "o órgão para servir de intérprete permanente a este movimento de aproximação luso-brasileira", além de outras iniciativas ${ }^{22}$.

Curiosamente, a guerra - a I Grande Guerra - viria servir de catalisador a ideias e sentimentos, e a palavra "Atlântida" adquiriu novo protagonismo. Face a um germanismo nascente e a um futuro pangermanismo, o mundo latino renasceu, defendendo os seus valores e a sua vitalidade. $\mathrm{O}$ afundamento do Paraná terá sido para muitos o sinal de alerta. E a privação de muitas coisas, um incentivo. Trabalhar tornou-se a palavra de ordem. Implementaram-se a agricultura e a indústria. Nasceu a coesão nacional. A mocidade formou-se e afirmou-se, o pensamento renovou-se, despontou o desejo colectivo de riqueza ${ }^{23}$. Olavo Bilac dizia:"Estamos assistindo nas capitais e nas grandes cidades do país a um formoso e vidente fervor de alto patriotismo." 24

Segundo este modo de pensar, se a guerra tinha sido um bem para o Brasil, não o fora menos para Portugal. A guerra integrara-o no mundo, na vida universal com as qualidades que sempre haviam sido as suas: o heroísmo, o amor ao trabalho, a luta pelo ideal de realizar e aproveitar todas as riquezas. Com a guerra, Portugal recuperara a sua identidade de "povo vivo, um povo com o mesmo sangue juvenil de outrora, capaz de ideal, delirante de entusiasmo"25. Esquecera as velhas querelas políticas e nascera para um novo patriotismo - o patriotismo luso-brasileiro. Este discurso de um idealismo e de um nacionalismo extremos ligava Portugal e o Brasil, para além dos laços políticos, efémeros e transitórios, à perenidade de uma mesma raça, cujas raízes assentavam numa mesma cultura, com valores idênticos que se haviam consolidado ao longo dos séculos ${ }^{26}$. Apresentava-se como um discurso formal e conceptualmente fora do tempo, e ideologicamente fora dos ideais republicanos, tais como têm sido comummente veiculados, e que seriam, consequentemente, ideais perdedores, já que não se podia pôr em causa a filiação política de quem os defendia. Espantam o seu conservadorismo, o ideal de raça inúmeras vezes invocado, a lembrança de uma identidade consciencializada no tempo, a simpatia pela tradição. Note-se, porém, que era

22 Idem, ibidem, p. 21.Veja-se a globalidade da proposta em Idem, ibidem, pp.17-22. Veja-se ainda sobre o mesmo assunto João de Barros, “Civilização Atlântica”, Presença do Brasil, Lisboa/Rio de Janeiro, Edições Dois Mundos, pp. 134-135.

23 João do Rio, "Simples explicações", Adiante!, cit., pp. 142-148.

24 Olavo Bilac, cit. por Idem,"Discursos e acção", Adiante!, cit., p. 149.

25 João do Rio, "Aproximação Luso-Brasileira", Adiante!, cit., p. 215.

${ }^{26}$ Cf. João do Rio, Idem, ibidem, pp. 236-237. 
um conservadorismo que não se identificava com o tradicionalismo, já que a esperança no futuro a construir perpassava de forma igualmente continuada em ambos os autores, identificando-os ideologicamente pelo repúdio dos excessos e da exclusividade da tradição.

Nestes termos, a aproximação luso-brasileira, para além de uma questão política, era uma questão cultural, porque só esta dava sentido a um modo de ser e de estar em que aquela se inseria. Compreende-se deste modo a crítica de ambos os autores aos políticos e aos intelectuais do tempo. No seu entender, uns e outros haviam esquecido não só a construção do futuro, mas também a certeza de que este se realizava a partir do passado identitário. Significativas são as palavras de João de Barros, evocando a sua experiência pessoal quando, nos inícios da República, procurara despertar o entusiasmo pela aproximação com o Brasil:

Quando, em 1912, voltei do Brasil, e falei na campanha de João do Rio pela aproximação entre os dois países, e aqui tentei continuá-la (...) encontrei em redor do meu entusiasmo, nos chamados intelectuais, nos dirigentes, um cepticismo que me gelava, um cepticismo que, mais tarde, vim encontrar quando se deu a nossa participação na guerra europeia (...) as blagues caíam sobre os pobres ingénuos que defendiam o estreitamento das relações luso-brasileiras, não só em nome das nossas simpatias espirituais, das nossas tradições, do nosso passado, mas também pela conveniência do nosso futuro. ${ }^{27}$

Procurar no passado o sentido do futuro... Ao passado pertencia o contributo do "sangue lusitano" 28 para a emergência do Brasil, ao passado pertencia a vocação marítima, a vocação atlântica dos dois países ${ }^{29}$, ao passado pertenciam "as mesmas tradições, a mesma língua, a mesma crença" ${ }^{\prime 30}$. Ao futuro cabia o projecto comum de domínio do Atlântico Sul, assim como a aproximação dos dois países que lhe estava associada. Perfilhado por portugueses e brasileiros, sob o comum "sentido do Atlântico", "substituindo essa lendária Atlântida, que se dizia ligar o velho ao novo mundo, um 'continente moral' existirá sobre o oceano que nos liga ao Brasil. Um continente de almas irmãs, de corações gémeos, gémeos de aspirações, de ideal e de patriotismo (...) almas atlânticas (...) almas de fé indomada no destino das duas nações" ${ }^{\prime \prime 1}$.

27 João de Barros, " A aproximação luso-brasileira e a paz de Versailles," Presença do Brasil, cit., p. 79.

28 Idem,"Sentido do Atlântico,",Presença do Brasil, cit., p. 106.

29 Idem, ibidem, p. 113.

30 Idem, ibidem.

31 Idem, "Civilização atlântica", Presença do Brasil, cit,.p. 142. 
O pendor moral deste projecto, se bem que necessariamente acompanhado de um sentido político, "a política do Atlântico Sul", nas palavras de Consiglieri Pedroso ${ }^{32}$, encontrava na promoção da emigração portuguesa um dos vectores. Perante o crescente afluxo germânico de consequências funestas para a pretendida identidade, nos dois lados do oceano, importava proteger os portugueses que demandassem terras brasileiras. Eram eles os sedimentadores de uma cultura comum, de um patriotismo comum, de uma nação comum. Entendidos estes como "elementos que ficariam predominando na formação do povo brasileiro"33, seriam nacionalizadores, identificadores de uma mesma cultura, expoentes de uma nova civilização greco-latina. O Brasil integrava-se, assim, no mundo ocidental, e Portugal expandia para o Brasil séculos de conquista nesse mesmo mundo ${ }^{34}$. Enfim, se a aproximação luso-brasileira contribuía para a lusitanidade, contribuiria de igual modo para a latinidade, desafiando deste modo o imperialismo germânico não só aquém mas além-Atlântico, e este oceano constituiria uma barreira intransponível ao domínio alemão. O sonho de Tannenberg e do pangermanismo europeu não passaria de uma ilusão.

Em suma, os objectivos da união de Portugal e do Brasil saldavam-se pela afirmação da identidade "genética"das duas nações, pelo domínio do Atlântico Sul em conjugação com Angola e pelo nascimento de uma potência europeia de cariz latino. Daí que o incentivo para se reafirmarem e reforçarem os laços entre as duas nações fosse ganhando forma e desse origem a uma verdadeira campanha que envolveu não só intelectuais, mas também políticos. Neste contexto, que se foi precisando, emergiu a ideia de uma revista que expressasse e divulgasse aquele triplo objectivo, aliás já uma vez enunciado por Consiglieri Pedroso na sua já referida "Proposta". Assim nasceu a Atlântida. Publicada com o patrocínio do ministro das Relações Exteriores do Brasil e do ministro dos Estrangeiros e Fomento de Portugal, contou como colaboradores, durante os 48 números da sua existência, com nomes consagrados nas artes, nas letras, na política de ambos os países. O primeiro número, publicado com a data de 15 de Novembro de 1915, ostentava, como acima se referiu, um subtítulo bem elucidativo que traduzia todo o projecto editorial:Mensário Artístico, Literário e Social para Portugal e Brazil. O último, com que se encerrou a publicação, saiu do prelo quando corria o quinto ano do seu lançamento.

\footnotetext{
32 Consiglieri Pedroso cit. por João de Barros, Ibidem, p. 174.

33 João de Barros, "Sentido do Atlântico," Presença do Brasil, cit., p. 110.

34 Veja-se Idem, A Aproximação Luso-Brasileira e a Paz, p. 21 ss.
} 
Ao longo deste período sofreu algumas alterações, embora sem nunca se afastar do rumo traçado. Contou, desde o início até aos penúltimos números (n. $\left.{ }^{\text {ss }} 46-47\right)$, com a direcção de João de Barros e de João do Rio. A estes juntaram-se no duplo 33-34, como director técnico, Pedro Bordalo Pinheiro, que logo se afastou da função, e no n. ${ }^{\circ}$ 37, como director literário, Graça Aranha, acompanhado de Nuno Simões, como director-gerente, que iriam permanecer até ao último número. De salientar, o "abandono" de um dos mais tenazes impulsionadores da revista desde a primeira hora - João de Barros. O seu nome já não aparece no n. ${ }^{\circ} 48$. Razões profissionais teriam estado na base da decisão de se afastar da direcção do órgão que ajudara a criar para defender os "interesses luso-brasileiros" e "as relações intelectuais e artísticas dos povos latinos"35. Imprescindíveis a sua presença e o seu entusiasmo? Eventualmente... O certo é que a Atlântida não sobreviveu ao afastamento do seu fundador.

Apontam-se como igualmente significativas certas alterações que formalmente ou não se foram notando na revista e que traduziriam a abertura da lusitanidade à latinidade, como referido. Assim, no n. ${ }^{\circ} 25$, todos os artigos se publicaram acompanhados da sua tradução em francês. No seguinte, desapareceu a menção do alto patrocínio das entidades políticas de um e outro países; no n. 37 , um outro subtítulo acompanhou o sentido da mudança ao nomear a Atlântida como Órgão do pensamento latino em Portugal e no Brasil, menção que, a partir daí, passou a ser utilizada. Nesse mesmo número, conjugando-se com a nova orientação, Graça Aranha juntou-se aos anteriores directores, como se sabe. Em palavras lapidares dirigidas "Aos nossos leitores", a revista (talvez pela pena de João de Barros) explicou o significado do novo epíteto:

Com o presente número a Atlântida passa a intitular-se, legitimamente, ÓRGÃO DO PENSAMENTO LATINO EM PORTUGAL E NO BRASIL. Com efeito, a aproximação luso-brasileira, para cuja defesa ela se fundou e por cuja realização tem combatido, só encontrará a sua completa efectivação quando baseada no mesmo e ardente amor pela alma latina que vive e palpita nas duas Pátrias irmãs, filhas de uma só raça, aventurosa, leal e progressiva. ${ }^{36}$

E explicou igualmente a recente colaboração de Graça Aranha e o porquê de lhe ter sido confiada uma função específica:

\footnotetext{
35 "Notas e comentários", Atlântida, n. ${ }^{\text {ss }} 46-47$, p. 286.

36 "Aos nossos leitores", Idem, n. 37, p. 3.
} 
Pela amável aquiescência do grande escritor que é o eminente Graça Aranha, tão querido e estimado nos meios intelectuais parisienses, a Atlântida confiou-lhe a sua direcção literária em França. Espírito superior, alma idealista, inteligência de entusiasmo sempre vibrante, Graça Aranha traça nas primeiras páginas do nosso número de hoje a síntese do nosso programa, e dos resultados que pretendemos colher. França-Brasil-Portugal, amando-se na mais estreita comunhão de aspirações e de interesses espirituais - eis toda a ambição dos que trabalham na Atlântida. ${ }^{37}$

Por seu lado, as primeiras palavras de Graça Aranha como director mostravam bem a sua adesão ao projecto traçado. Falava de um nacionalismo temperado de individualismo, dos benefícios identitários trazidos pela guerra a Portugal e ao Brasil, da vitalidade que trouxe aos portugueses empenhados de novo no seu papel na História, da consciência de que a mesma raça unia os dois povos, da luta comum contra o domínio alemão, do significado do ideal luso-brasileiro ${ }^{38}$. Referindo-se explicitamente às raízes culturais da união luso-brasileira e à sua originalidade, afirmou:

Sendo português, o Brasil não deixará de ser uma nação americana. A originalidade do Brasil é de ser o continuador de Portugal, o herdeiro da espiritualidade latina no mundo americano. O privilégio do Brasil é o de fundir duas forças: a que vem do passado no sangue português e a que recebe do ardente meio físico em que se desenvolve esta transplantação da alma latina. Estas duas forças não se excluem e, enquanto a sua fusão se realiza suavemente e que a impulsão americana move sem violência as ideias e a sensibilidade portuguesa, uma vida ardente inflama o imenso país. ${ }^{39}$

Depois destas palavras fica a certeza de que o alargamento da lusitanidade à latinidade em nada afectava as raízes fundantes do projecto. E que a internacionalização, coroando a nacionalização, colocava no Atlântico a barreira política antigermanista e em França a barreira cultural. Se bem que nominalmente a Atlântida se apresentasse como uma revista de cultura, o nome escolhido descobria uma conotação política. A Atlântida, qualquer que fosse o lugar em que sucessivamente foi situada, desde que Platão a oferecera ao imaginário ocidental ${ }^{40}$, mais do que uma simples ilha, encarnava uma potência política. Internamente bem organizada, constituía uma unidade que

\footnotetext{
37 Idem, ibidem, p. 3.

38 Cf. Graça Aranha, "A Nação", Atlântida, n. 37, pp. 7-12.

39 Idem, ibidem, p. 11.

40 Veja-se, por todos, Pierre Vidal Naquet, A Atlântida, Lisboa, Teorema, 2007.
} 
era afinal a sua força, face a quem desafiasse a sua hegemonia. Se só um cataclismo a fizera soçobrar, não deixou de permanecer imorredoura na memória da humanidade. Ou, como dizia João do Rio:"Para os poetas, expressões das raças, e para as raças, sonhadores colectivos, existiu sempre porém, e existe, e existirá.É o ideal, a hipnose da coragem, é a glória, é o triunfo, é o desejo que cada um tem de realizar-se, realizando (...) A Atlântida é o grande abraço mental entre a Europa e a América (...) Atlântida, grilhão que liga o querer unido das raças novas, em marcha para o futuro, para a felicidade, para a perfeição."41

Daqui que a Atlântida correspondesse a um objectivo e se confundisse com ele. Representava uma esperança e ao mesmo tempo uma realidade. Esperança de ser possível a aproximação"intelectual e moral"entre portugueses e brasileiros. Realidade de ser o "órgão comum de aspirações e interesses" que respondia às exigências do público de Portugal e do Brasil ${ }^{42}$. Mas a Atlântida queria ir mais longe. Queria realizar a esperança e responder às exigências. Pretendia ser a expressão viva da unidade de uma política que correspondesse a um mesmo ideal identitário, com raízes no passado e projecção das identidades singulares no futuro, mediante o contributo para um processo de aproximação que formasse uma real comunidade luso-brasileira. Fora nesse sentido, como se referiu, que Magalhães Lima apelidara de "uma nova e grande Lusitânia" essa comunidade ligada pelo Mare Nostrum que seria então para os portugueses e para os brasileiros o Atlântico.

O mesmo espírito conservador já assinalado a respeito de João de Barros e de João do Rio transparece das páginas da revista. Saliente-se que a questão das relações entre os dois países ultrapassava o quase exclusivismo dos aspectos económicos e políticos com que, na opinião dos seus colaboradores, havia sido tratada até então, para se situar no plano do pensamento, do "tradicionalismo culto". Por isso, precisava de ser equacionada por uma elite cultural que, sem os ignorar, repensasse todo o problema em termos de cultura, até mesmo de "lusitanidade"43. Ou seja, a ideologia característica da Atlântida e dos seus directores presidia, na prática, a um duplo plano em que a vertente cultural e a vertente político-económica se interligavam numa unidade geradora de identidade, porque ambas eram filhas de um mesmo espírito.

Significativas eram as referências explícitas à língua, enquanto "prova actual, flagrante de vitalidade da nossa raça", como afirmava Alberto d'Oliveira, relembrando "a

\footnotetext{
41 João do Rio, "O Sonho da Atlântida", Atlântida, n. 1, p. 15.

42 "Atlântida", Atlântida, n. ${ }^{\circ} 13$, p. 3.

${ }^{43}$ Veja-se, entre outros, Alberto d'Oliveira,"Os Portuguezes no Brazil,"Atlântida, n. ${ }^{\circ}$ 3, pp. 195-204.
} 
parte que cabe a Camões na restauração e na conservação da independência portuguesa" e reafirmando o lugar que ela ainda poderia ocupar na realização das "esperanças e ambições" de Portugal e do Brasil ${ }^{44}$. Por seu lado, língua e cultura estavam especialmente presentes nos inúmeros textos em prosa e em verso publicados nos capítulos referentes ao Ano Artístico e Literário, na Revista do Mês, que habitualmente acompanhavam cada número da revista. A formação cultural de portugueses e brasileiros passava por aqui e aliava-se a questões de educação e de costumes, essenciais para fundamentar e desenvolver uma política económica de interesses comuns, que passava pela implementação do comércio e das carreiras de navegação. Indispensáveis ao progresso interno dos dois países, fortalecia igualmente a presença identitária de ambos na cena internacional.

Chegou o momento de afirmação a Portugal e a todos os da sua raça, tanto os que reivindicam protecção à soberania da mãe pátria como aqueles em quem as razões de estado e de nacionalidade não valem mais do que os vínculos de origem. Os milhões de homens dispersos pelo mundo que falam a língua portuguesa hão-de agora mais do que nunca sentir que precisam uns dos outros, para se não perderem as virtudes que trazem em si, vindas de muitos séculos atrás. À voz que diga além dos mares:“Portugal”, é preciso que responda aqui uma voz de saudade. ${ }^{45}$

A mítica Atlântida renascia sob o signo irmanado de Portugal e do Brasil.Um ideal de império? Diríamos que não. Mas a construção de uma potência atlântica que pudesse ser ouvida na cena internacional, decerto. E que contrapusesse a cultura latinizada ao germanismo nascente e ao saxonismo corrente, sem dúvida. No entender dos directores e colaboradores, só com o contributo da imigração o projecto teria sucesso ${ }^{46}$. Por isso, propunha-se que não só se promovesse uma imigração de qualidade, como se evitasse que os emigrantes perdessem a nacionalidade ${ }^{47}$. Neste sentido apelava-se ao apoio, à educação, à divulgação da literatura, à promoção dos estudos brasileiros em Portugal, ao patriotismo, à consciência nacional. De igual modo, a elevação do consulado do Rio de Janeiro a embaixada, a eventualidade de uma confederação luso-brasileira e a hipótese de assinatura de um tratado de navegação foram assuntos

44 Idem, ibidem, p. 196.

45 Nuno Simões, "Portugal-Brasil.Um depoimento," Atlântida,"n. ${ }^{.5}$ 35-36, p. 980.

${ }^{46}$ Cf., por exemplo, Manuel Gaspar de Lemos, "Brasil-Portugal. Um Projecto de Lei", Atlântida, n.os 42-43, p. 792.

${ }^{47}$ Cf. Mário Carvalho,"Navegação entre Portugal e o Brasil," Atlântida, n.o 1, p. 83. 
focados nas páginas da Atlântida como imprescindíveis ao desejado estreitamento de relações. Por último, e não seriam de menor importância, enumeravam-se os aspectos económicos. E enumeravam-se em último lugar porque seria o culminar, na prática, da política cultural inicialmente enunciada. A criação do porto franco de Lisboa, a intensificação de relações comerciais, nomeadamente no respeitante ao cacau, questões económico-financeiras, as culturas cerealíferas, etc., etc., eram tópicos enunciados sem cessar.

Estes temas, a que se poderiam juntar outros de significado idêntico, traduzem o modo de pensar de uma elite intelectual, imbuída do que se podia considerar um forte pendor nacionalista, e não apenas da sensibilidade de quem os escrevia. No entanto, não poderá talvez ser avaliada como expressão de ideias e sentimentos coesos que formassem uma corrente de opinião que nos seus princípios fundantes se opusesse com êxito à dos utilitaristas e à dos germanistas. A sua vocação atlântica alargava-Ihe os horizontes marcados pela latinidade. Este sentido recusava a exclusividade identitária de uns e os sonhos imperialistas de outros. Fosse como fosse, o projecto da Atlântida não foi perfilhado apenas por um grupo de intelectuais isolados, sob o alto patrocínio de entidades políticas das duas nações. Quando a revista estava já nos derradeiros números da sua existência, o senador Manuel Gaspar de Lemos elaborou um projecto de lei de pendor nacionalista, não para demonstrar a já tão ventilada conveniência da aproximação de Portugal e do Brasili ${ }^{48}$, mas, segundo as suas palavras, para se "sair do campo abstracto das simples aspirações e entrar no das realizações concretas" ${ }^{\prime 49}$. Temia a perda da identidade cultural do Brasil e, igualmente, a sua identidade política.

Apresentou, por isso, o seu projecto ao Senado, a 19 de Junho de 1919. Apontava ali seis pontos para serem submetidos à apreciação dos senadores. No seu entender, a missão histórica de Portugal não terminara ainda, nem relativamente às suas colónias, nem a respeito do Brasil. E era urgente retomá-la, dadas as condicionantes do tempo. Dizia:

A grande crise universal, desencadeada pela guerra, ameaça como que aluir todas as existências nacionais nos seus mais sólidos fundamentos e os povos sentem a imperiosa necessidade de se afirmarem etnicamente para garantirem o seu futuro. ${ }^{50}$

\footnotetext{
${ }^{48}$ Cf. Manuel Gaspar de Lemos, op. cit., ibidem, pp. 791-796.

49 Idem, ibidem, p. 791.

50 Idem, ibidem, p. 791.
} 
Entre os referidos seis pontos, importa salientar a emigração, a língua, a administração recíproca nas autarquias locais, a equiparação dos cursos superiores, a navegação comercial e o porto franco. Este plano, com as incidências particulares que iria suscitar, seria entregue a duas comissões, uma em Portugal e outra no Brasil.Em cada país teria o nome de "Comissão de estudo para o estreitamento das relações entre Portugal e o Brasil". Seria presidida honorificamente pelos respectivos Presidentes da República e, efectivamente, pelos ministros dos Negócios Estrangeiros de cada país. Levado ao Senado, o documento recebeu a aprovação com louvor de cada ponto, com observações elogiosas. Note-se, porém, que era um texto eminentemente político, veiculado por uma instituição política. Poder-se-á perguntar se não facilitaria uma demasiada intervenção na vida interna recíproca de dois países e se, como tal, não teria um cariz "colonialista". Publicado no que viria a ser o último número da revista, sem ocasião para qualquer referência aos ecos que teria provocado no Brasil, desde já nada se pode adiantar a esse respeito.

A nosso ver, dois únicos pontos poderão levantar a suspeita de que nem tudo terá corrido bem. Um consiste numa declaração de princípios nada usual, na qual chamava a atenção o "negrito" da grafia, e que rezava:"A direcção da ATLÂNTIDA não toma a responsabilidade - porque não tem que tomar... - das doutrinas e opiniões expressas ou defendidas nos artigos assinados pelos seus ilustres colaboradores". O outro resulta da imediata suspensão da revista, apesar de estar anunciado um próximo número, que seria duplo, e com o qual se iniciaria o quinto ano de existência da publicação. Sofria, assim, um destino igual ao do mito que lhe dera o nome. Deste modo desaparecia o ideal de "uma nova e grande Lusitânia", uma vez sonhado. 



\title{
Uma nova revista de Filosofia?
}

\author{
Adelino Cardoso*
}

O título, sem dúvida extemporâneo, desta reflexão tem ecos de uma outra fase da vida filosófica nacional, em que predominava o entusiasmo pelo muito que havia a fazer, mas não é porventura descabido num momento em que o desencanto afecta franjas significativas da sociedade portuguesa, incluindo instituições filosóficas. De facto, o panorama das revistas de Filosofia em Portugal é um espelho do estado da investigação e do ambiente sociocultural. Depois de um período de efervescência e vitalidade, caiu-se numa situação de algum entorpecimento, apesar do esforço bem-sucedido de alguns.

Ao longo das últimas décadas, acompanhei o lançamento de um número razoável de novas revistas de Filosofia e participei activamente na génese e vida interna de algumas com enorme convicção e, inclusive, militância. A reflexão que proponho não pode ser alheada desse envolvimento.

Enquanto estudante universitário (1969-1975), só esporadicamente consultei aquela que era, de facto, a Revista Portuguesa de Filosofia (RPF), criada em 1945' , e que fez um percurso solitário ao longo de quase três décadas, depois de gorado o empreendimento da Revista Filosófica lançada por Joaquim de Carvalho (1951-1954)². Apesar do

\footnotetext{
Centro de História da Cultura da Faculdade de Ciências Sociais e Humanas da Universidade Nova de Lisboa.

1 A Revista Portuguesa de Filosofia, publicação trimestral, lançada no início de 1945 (Janeiro-Março), como "Secção trimestral de ciências filosóficas da Brotéria sob o patrocínio do Instituto de Filosofia de M. Miguel Carvalho, de Braga", tendo como direcção o director da Brotéria e três professores do IMC.

A apresentação da nova revista, sob o título "Porquê e programa da Revista Portuguesa de Filosofia" (pp. 5-8), justifica o seu aparecimento e delineia as linhas orientadoras de um projecto renovador, que visa dar um novo fôlego à reflexão e especulação no meio cultural português, que tão avesso tem sido à produção filosófica:"A actividade filosófica em Portugal, nos últimos séculos, foi a bem dizer nula. Incapacidade especulativa, adversidade do ambiente, deficiência da cultura, preconceitos de formação escolar? De tudo um pouco, tomando as coisas na generalidade. (...) As coisas vão-se modificando, agora, e ainda bem. A renovação concorrerá, assim, para formar uma mentalidade nova" (pp. 5-6). O horizonte é escolástico, mas apelando a um exercício autónomo da razão, tomando como exemplo "Pedro Hispano, Francisco Sanches, Gomes Pereira, Leão Hebreu" (p. 6).

2 A Revista Filosófica, publicada pela Atlântida (Coimbra), e da qual foram publicados doze números, representa o esforço basicamente conseguido de uma revista apta a acompanhar o movimento geral das
} 
esforço renovador e do impacte que os seus fundadores projectaram, a verdade é que a RPF se manteve numa posição relativamente apagada, fruto porventura de um meio académico pouco exigente e de horizontes muito limitados. A regularidade da sua publicação, a qualidade geral dos artigos publicados e o esforço de renovação que actualmente desenvolve fazem dela um caso único no panorama filosófico nacional. O programa "ambicioso" dos seus mentores mantém-se ainda em larga medida válido: "ajudar Portugal a pôr-se em contacto com o mundo filosófico estrangeiro (...), mas de forma não puramente receptiva, antes crítica"3.

O 25 de Abril alargou o espaço de intervenção cultural, estimulou a crítica e a produção intelectual, mas, no que respeita à filosofia, por diversas razões, a que não será alheio o sentimento da urgência da acção política, a reflexão filosófica não recebeu especial impulso no período revolucionário.

A pedrada no charco foi dada pela revista Filosofia e Epistemologia, que teve uma recepção invulgar e um impacte significativo na Filosofia e áreas próximas (mas também na área científica). Daí adveio um novo prestígio à Filosofia. Dadas as características da Filosofia e Epistemologia e a mobilidade da equipa, aliada ao sempre delicado segmento das relações humanas, a revista durou o tempo suficiente para, com os cinco ou seis números publicados, deixar uma marca, afirmar um estilo. E foi muito.

ideias, onde a matriz, sendo filosófica, inclui igualmente o contributo regular de cientistas, e onde está sistematicamente presente a colaboração estrangeira. No editorial do $n .{ }^{\circ} 1$, significativamente intitulado "Posição," J. de Carvalho faz um diagnóstico da situação da filosofia no seu tempo e das exigências que se Ihe colocam, afirmando nomeadamente:"A situação cultural que vivemos não é, porém, superável pela ressurreição ou pela importação de qualquer sistematização doutrinal, a qual poderia apresentar-se com justificação política, mas nunca seria uma solução à altura dos tempos e das responsabilidades de um Povo que deve reconhecer-se livre e digno na ordem do pensamento como se reconhece livre e digno na ordem da sensibilidade e da acção" (Revista Filosófica, n. ${ }^{\circ}$, Março de 1951, p. 7).

Coincidindo com a extinção da Revista Filosófica, surge a revista Filosofia, lançada em 1954 pelo Centro de Estudos Escolásticos. Dirigida por António Alberto de Andrade e Manuela Saraiva, não obstante o seu inegável interesse, não teve impacte e não se constituiu como um desafio estimulante para a RPF, principalmente pelo facto de adoptar o mesmo tipo de postura intelectual e de se firmar no mesmo campo teórico. Como é expressamente afirmado na "Abertura" do primeiro número:"Mas esse facto de a Filosofia tradicionalmente ensinada nas nossas Escolas ser a Escolástica, é inegável que contribuiu para a sua escolha."

Por seu lado, Philosophica Conimbricensia. Revista de Filosofia e Cultura Portuguesa, lançada por Silva Dias, pese embora o esforço incansável do autor, é um objecto insólito e de certo modo desgarrado: inclui um único e extenso artigo de 94 páginas [uma conferência proferida pelo autor no ano de 1966, em Braga] do próprio Silva Dias, intitulado "Braga e a Cultura Portuguesa do Renascimento."'De resto, nem editorial, nada que marque a intenção da revista e o espaço em que se inscreve.

3 "Porquê e Programa da Revista Portuguesa de Filosofia", p. 7. 
A revista era o resultado do trabalho de uma equipa de investigação com vínculos internacionais sólidos.

Criada no ano lectivo de 1977-78 pelo Grupo de Investigação de Filosofia e Epistemologia (GIFE), Filosofia e Epistemologia não se assume expressamente como uma revista. Por conseguinte, não tem director, órgãos redactoriais e/ou consultivos. O que se propõe ao leitor é uma colecção de filosofia que dê voz pública ao trabalho a desenvolver pelo GIFE.

O texto de apresentação é um manifesto e um diagnóstico muito lúcido do estado da filosofia em Portugal, porventura a única área universitária onde não havia institucionalmente investigação. Vale a pena transcrever o essencial desse texto de apresentação para medirmos o caminho percorrido e também registarmos o tom enérgico e o diagnóstico lúcido e crítico de uma situação escandalosa e insustentável. No sentido genuíno do termo, eu diria que o lançamento de Filosofia e Epistemologia corresponde ao momento crítico em que uma mudança súbita permite vencer o estado de letargia. A força é a de uma equipa com horizontes bem definidos e uma estratégia adequada. A proverbial falta de meios, tão habilmente explorada para justificar quase tudo o que se deixa por fazer, não inibiu os membros do GIFE de lançarem um projecto ambicioso, que não foi cumprido da maneira como foi concebido pelos seus mentores, mas se desdobrou em múltiplas linhas fecundas, seguindo aquilo que, em boa linguagem leibniziana, se chama "um curso composto", diversificado e multilinear. O carácter pioneiro da iniciativa é bem expressamente marcado: “Em Junho de 1977 reuniu-se pela primeira vez um grupo de licenciados em Filosofia que de comum tinham talvez apenas o desejo de fazerem filosofia e de evitarem aquilo que, entre nós, a vida post-universitária, e em particular o ensino, tão sugestivamente propiciam: o abandono de qualquer trabalho de investigação, a resignação à banalidade, a cedência aos manuais, a derrapagem autista e a consolação magistral" (p. 9). E um pouco mais abaixo:"O grupo (a que entretanto se ligaram, de modos diversos, pessoas vindas de outros quadrantes) funcionou sempre sem qualquer tipo de apoio exterior, dado que não há a nível universitário quaisquer iniciativas que procurem estimular a prática da Filosofia para os já licenciados, nem há, a nível institucional, qualquer modalidade de apoio à investigação filosófica e epistemológica. É preciso que se diga e repita claramente o seguinte: não há nenhum centro de investigação de filosofia ou de epistemologia no nosso país, o que não deve acontecer com mais nenhuma actividade que tenha existência universitária. $\mathrm{E}$, enquanto esta situação se não alterar, enquanto não se criarem condições de amplo e efectivo apoio à investigação filosófica e epistemológica 
em Portugal, nada se alterará" (pp. 9-10). Em tom de manifesto, acrescenta-se que "a ausência quase total de actividade filosófica [na tradição cultural portuguesa] não deve impedir-nos, hoje, de proclamarmos a sua urgência". Do ponto de vista estratégico, o grupo afasta-se da "filosofia portuguesa", de horizontes estreitos, e da "filosofia universitária", anquilosada e amarrada a rotinas empobrecedoras.

O grupo funciona autonomamente, por sua conta, sem apoios. De referir ainda que, decorrido um ano desde o início da sua actividade, o grupo fez um percurso imenso: de um projecto vago passou a interesses definidos em áreas específicas. Não há muito mais maneiras de avançar na investigação.

O texto de apresentação marca ainda o elevado nível de exigência:"o trabalho do grupo, apesar das dificuldades e das deficiências do seu funcionamento (porventura insuperáveis no quadro desapoiado em que nos movemos), apesar das limitações daí decorrentes, e mesmo da falta de orientação estimulante, vai continuar, e vai continuar atento à actualidade filosófica e científica sem ceder às facilidades da mera divulgação, exigente na sua raiz filosófica sem cair em hermetismos de curta duração e duvidoso alcance, comprometido nas suas intenções estratégicas sem qualquer cedência aos dogmatismos" (pp. 10-11).

No terceiro número (1981), ainda do GIFE, faz a transição para uma revista de Filosofia, que passará a ser dirigida (n. ${ }^{4}$, agora do Seminário Permanente de Filosofia do Conhecimento da FCSH) por Manuel Maria Carrilho e Fernando Gil.

O êxito e a aura de Filosofia e Epistemologia vão ser muito estimulantes para a gestação de novos projectos. Dada a vida efémera de Estudos Filosóficos (1982), com um único número publicado, pode dizer-se que a Análise (1984-2006) foi a mais directa herdeira da experiência constituída por Filosofia e Epistemologia.

A revista Filosofia Actual (1982-1984) é um caso especial na medida em que resulta da iniciativa de finalistas do curso de Filosofia da Faculdade de Letras de Lisboa, entre os quais se destacam Carlos Fontes, Aníbal Lamy e Luís Pedro de Morais, que respondem à exigência de prosseguir a formação depois de concluída a licenciatura e ao intento de fazer da Filosofia um espaço de diálogo e de intervenção públicos. A sua breve existência deveu-se a divergências internas, aquando do esforço de alargamento e consolidação da equipa redactorial, que se traduziram numa cisão, da qual nasceu um novo projecto, a revista Logos (1984-1988).

O contexto em que a Logos surge, que coincide, aliás, com o lançamento da Análise, é já muito diferente daquele em que Filosofia e Epistemologia se afirmou.E isso a vários níveis: a filosofia goza de um prestígio assinalável junto do público culto; vários cursos 
de mestrado funcionam regularmente; o Ministério da Educação assume a formação contínua como um trabalho a realizar sistematicamente, reforçando a ligação entre Secundário e Superior; existe a percepção de que, a par da Epistemologia, existem outras áreas da Filosofia a requerer atenção e trabalho articulado.

No intuito de enquadrar a Logos e alargar o seu campo de intervenção, o núcleo fundador (Carlos Fontes, Luís Pedro Morais e eu próprio) criou uma associação: Filosofia Aberta - Centro de Estudos e Divulgação. O nome, Filosofia Aberta, sugeria o intento de estabelecer pontes, em especial entre filosofia e cultura, arte e educação. A organização dos sete números publicados, o último dos quais duplo, é elucidativa a esse respeito: depois de um primeiro número algo ecléctico, seguem-se números temáticos, reservando sempre espaço para artigos avulsos, sobre as artes (números 2 e 6), literatura (número 4), guerra e paz (número 3), progresso (número 5) e Europa (número 7-8).

Além do número 1, que é sempre especial, agradou-me o número 4, que intentou fazer a ponte entre filosofia e literatura, com diferentes tipos de textos: ensaios, poemas. $\mathrm{O}$ artigo que mais prazer me deu foi justamente o que publiquei nesse número, "Ramos Rosa, poeta da autenticidade", que me deu a oportunidade de contactar com o poeta, de quem sou leitor e admirador. Conservo boa memória das suas palavras de carinho e encorajamento do poema que então me dedicou. À distância de vinte anos, direi que há na poesia de Ramos Rosa um estado de indeterminação e uma atmosfera exaltante, muito afim daquilo que é a pulsação dos possíveis no sistema leibniziano.

Logos fez o seu percurso, alcançou o essencial dos seus objectivos: foi um espaço de convívio, de encontro, de estímulo a jovens investigadores. $O$ acolhimento público foi muito favorável: Logos tinha muitos leitores ${ }^{4}$, um núcleo de amigos e próximos que acompanhavam e estimulavam a sua elaboração. $O$ tom despretensioso da revista era certamente um argumento a seu favor.

A morte algo intempestiva da Logos deveu-se a fragilidades internas: incapacidade de evoluir e profissionalizar-se. Viveu principalmente do meu entusiasmo, mas sucumbiu ao amadorismo, à falta de estruturas. A decisão de cessar a publicação de $\operatorname{Logos}^{5}$, amadurecida no Verão de 1988, foi assumida no dia 29 de Setembro desse ano, no termo de uma viagem a pé entre a Faculdade de Letras de Lisboa e a Casa do

4 Em média, com uma distribuição amadora, Logos vendeu 950 exemplares, de uma tiragem de 1500: os números 1 e 4 venderam mais de mil, mas o número 6 ficou aquém dos setecentos.

5 O anúncio da morte constitui a primeira frase do editorial do último número: "Com a publicação do número 7-8 cessa a publicação de Logos" (Logos, Filosofia Aberta - Centro de Estudos e Divulgação, n. 8, $^{\circ}$ Dezembro de 1988). 
Alentejo, em resultado da minha convicção de que não era viável dar um salto qualitativo e garantir, ao nível gráfico e redactorial, uma base estável. A pergunta expectável "Como vai a nossa Logos?", que o Professor Gama Caeiro me fez no jantar desse 29 de Setembro, tinha duas respostas possíveis:"está bem; o próximo número vai ser sobre pensamento português" ou "vai acabar, por dificuldades logísticas". A resposta que dei, com algum pesar, foi a segunda. A conversa prosseguiu, com o meu amável interlocutor a tentar descortinar se não haveria razões mais prosaicas, como a falta de dinheiro para prosseguir o intento. Percebeu que não, e a conversa derivou para outros assuntos. O número que poderia ter sido o de um novo fôlego da Logos veio a ser, com os devidos reajustamentos e a uma escala mais vasta, o número 13 da Análise, que eu coordenei. Da Logos, ficou a saudade de um projecto feliz, a que faleceu a arte da metamorfose e do aperfeiçoamento.

Entretanto, participei na génese da revista Filosofia, da Sociedade Portuguesa de Filosofia, e fui membro da redacção, desde a sua fundação, em 1985, até ao volume II, n. ${ }^{\circ} 1-2$ (1988), um número duplo sobre o ensino da Filosofia. O meu afastamento voluntário deveu-se a divergências sobre aspectos internos de funcionamento da revista. Enquanto manteve a regularidade da sua publicação (1985-1992), Filosofia reflectiu o dinamismo e abrangência da SPF, respondendo à intenção expressa no editorial do n. ${ }^{1}$ :

O que determina a publicação de Filosofia é, pois, a intenção de potenciar as virtualidades de trabalho comum próprias de uma associação como é a S. P. F., pondo-as ao alcance de todos os que se encontrem seriamente comprometidos com a investigação, com a aprendizagem ou com o ensino das disciplinas filosóficas. ${ }^{6}$

Extinta a Logos, passei de imediato para a Análise. Numa fase de alguma incerteza na vida interna desta, F.Gil, no final de um Seminário na FCSH, convidou-me para integrar a redacção da Análise. Aceitei de bom grado o honroso convite, que foi o ponto de partida para uma colaboração de mais de dez anos, durante os quais fui a maior parte do tempo secretário de redacção, e F. Gil o director. Foi uma experiência de grande intensidade e uma oportunidade de trabalhar numa escola de excelência, com um estilo muito próprio: o Gabinete de Filosofia do Conhecimento (GFC), fundado em 1984 por Fernando Gil, José Gil, José Mariano Gago, Manuel Villaverde Cabral, António 
Marques, Diogo Pires Aurélio, entre outros. O GFC deu um contributo assinalável à investigação e ao alargamento de um espaço público de debate e comunicação.

O estilo que a Análise cultivou é aquele que se encontra expresso no editorial do número 1 - rigor da análise, atenção ao outro, lealdade aos problemas, pensar por si:"Há muitas moradas na casa de Deus, mas a análise é o único método em filosofia. Por isso, tantas revistas têm este nome, sinal de um compromisso a que pretendemos também vincular-nos. Será o único. ANÁLISE não privilegiará moradas dentro do conhecimento. Está aberta - é um convite - à reflexão metafísica, à filosofia das artes e das ciências, do direito e das ciências humanas e quereria ser ocasião de confluências e lugar de acolhimento para o risco de pensar por conta própria."7

Análise foi um caso exemplar de uma revista articulada com um programa de investigação coerente e pluridisciplinar e um núcleo de colaboradores nacionais e internacionais altamente qualificados. Concomitantemente, havia uma atenção especial aos novos investigadores. Ao contrário do que tantas vezes acontece, em sede de redacção da Análise, a constatação de que se tratava de um primeiro artigo de um autor jogava a favor da sua publicação. Fernando Gil tinha um empenho especial nessa descoberta de novos talentos.

No final dos anos noventa, o ambiente interno e a atmosfera ambiente da Análise sofrem alguma degradação. Internamente, diminuem a participação, o entusiasmo, a capacidade de protagonizar novos projectos de investigação; externamente, diminuem o impacte e a capacidade de atracção que Análise já tivera. As razões serão múltiplas e não estou em condições de um olhar suficientemente isento para as examinar. Ainda assim, julgo que a fórmula amargurada de Fernando Gil,“A Análise está cada vez mais uma revista como as outras", exprime bem o sentimento de uma crise de identidade, exigindo um esforço suplementar de afirmação e renovação. Maria Luísa Couto Soares e André Barata intentaram responder a esse desafio. Como parte do problema, entendo guardar silêncio sobre a extinção da Análise, que poderia eventualmente responder à necessidade de uma revista que acompanhe e reforce a constituição de uma comunidade filosófica nacional. Efectivamente, a Análise teve uma função agregadora no meio filosófico e um forte impacte junto da comunidade científica e de um vasto número de leitores, donde resultou a capacidade de se fazer ouvir para lá do círculo de amigos e colaboradores. 
O panorama actual das revistas de Filosofia caracteriza-se pela proliferação de um número talvez excessivo de títulos, cuja lógica é a da departamentalização dos mesmos ${ }^{8}$, acompanhada de uma diminuição do público leitor. Isso reflecte a capacidade financeira dos Institutos/Departamentos de Filosofia, resultante do investimento público na investigação, mas corresponde também a algum enclausuramento. Porventura aquela que tem feito um maior esforço de renovação e abrangência é a Revista Portuguesa de Filosofia, que poderá ter um papel importante numa fase ainda incipiente da comunidade filosófica portuguesa, mas em que o intercâmbio, o diálogo e o debate de ideias se inscrevem progressivamente no ethos de quantos, entre nós, exercem a filosofia de um modo produtivo e inovador. Por outro lado e numa perspectiva optimista, a intensificação das relações entre unidades de investigação, a coordenação de estratégias e a tendência para a fusão que se vislumbra no horizonte permitem augurar a possibilidade, num futuro não muito distante, da criação de uma revista de filosofia que seja ponto de encontro e factor de comunidade filosófica.

8 Exceptuam-se as revistas Disputatio e Phainomenon, que correspondem às duas correntes filosóficas mais influentes hoje e que, por isso mesmo, têm um lugar próprio. 


\title{
Em torno dos periódicos femininos
}

\author{
Teresa Salvador
}

\section{Primeira questão: valorizar}

As revistas femininas ${ }^{1}$ não são o género menor de uma espécie. Para o reconhecer, basta atender à crítica situacional e às propostas reformistas de certos artigos, entre os quais os dedicados ao sufragismo, ao divórcio, à educação e à formação profissional $^{2}$, artigos de provocação e resistência, que mobilizaram o público para o debate de ideias e que constituem, no seu todo, um legado de posições em confronto, com múltiplas variações. As revistas femininas são, como quaisquer revistas, plataformas de fixação de ideias e, por conseguinte, suportes incontornáveis para a história das mentalidades e dinâmicas sociais, de modo que esta não se sistematiza inteiramente sem as incluir e tomar como fonte de estudo.

A constatação de tal condição de imprescindibilidade contrasta com a situação de geral desconsideração a que têm estado sujeitas. Esta situação foi confirmada e exposta por Vitorino Magalhães Godinho durante um seminário por ele orientado na Universidade Nova de Lisboa, em 1979, tendo então sugerido a inventariação dos periódicos femininos. Ivone Leal, que informa sobre o caso, acolheu a sugestão e procedeu ao arrolamento de periódicos ${ }^{3}$, resultando o livro Um Século de Periódicos Femininos: Arrolamento de periódicos entre 1807 e 1926. No livro colocam-se duas questões que de modo algum são despiciendas: uma, qual a datação a ter em conta para o fecho do arrolamento?; outra, qual o critério de selecção dos periódicos? Atenda-se a cada uma delas.

\footnotetext{
Universidade de Évora.

1 Ao usar-se o termo "revista" está-se a ceder, tão-só momentaneamente, à designação comum, que não é adequada nem sequer vantajosa, como se mostrará mais tarde.

2 As mais antigas temáticas substantivas são o direito eleitoral e a instrução. Para o primeiro caso, verifique-se a colaboração de Virginia Wood em A Voz Feminina. Jornal semanal, científico, literário e noticioso exclusivamente colaborado por senhoras: dedicado às ilustres senhoras [5 Jan. 1868-27 Jun. 1869]. Trata-se de uma mulher conhecedora do que se passava lá fora (cf. a série de artigos "O que se faz lá fora" que publicou em O Progresso [4 jul. 1869-26 Dez. 1869]).

3 O seminário foi dedicado ao século XIX português. Cf. Leal, Ivone, Um Século de Periódicos Femininos. Arrolamento de periódicos entre 1807 e 1926, Lisboa, CIDM, 1992, p. 10.
} 
O ano de 1807 corresponde naturalmente ao lançamento de Correio das Modas, considerado pela autora como "o primeiro periódico conhecido", ao passo que, fosse qual fosse a data a fixar no final do século XIX ou no início do século XX para o fecho do levantamento a efectuar, ela não deixaria de ser artificialmente imposta. Neste período não se registaram rupturas no paradigma editorial nacional ou acontecimentos políticos com impacte nas concepções e práticas editoriais. Assim, desobrigada de assumir datas, Ivone Leal resolveu lucidamente a questão com a indicação do ano de introdução da censura em Portugal - 1926 -, por sinalizar uma descontinuidade na liberdade de expressão. Esta delimitação temporal permitiu obter uma primeira periodização, tomada como referência para efeitos de organização e estudo. Quanto à questão do critério de selecção, a autora optou por excluir, sem ser demasiado segregadora, os periódicos que não se dedicavam expressamente às mulheres ou se limitavam à "publicação de figurinos, desenhos, moldes ou músicas"4. O recurso a tal critério visou criar um corpus autónomo mediante o reconhecimento da especificidade das matérias abordadas. Deste modo, coube a Ivone Leal demarcar um sector da imprensa periódica como campo de estudo, na continuidade da linha avançada por Clara Rocha ${ }^{5}$ para as revistas literárias do século XX e depois seguida por António Nóvoa e Justino Magalhães ${ }^{6}$ para a imprensa escolar dos séculos XIX e XX, entre outros de outras áreas do saber ${ }^{7}$.

O critério de selecção estabelecido por Ivone Leal afigura-se pertinente, não pela evidente perspicácia intrínseca nem pela notória capacidade resolutiva, antes por

4 Idem, p. 12. Correio das Modas, de 1807 [Lisboa], é tido pela autora como "o primeiro periódico conhecido" (Idem, p. 13). Em Espanha, o periódico mais antigo, tanto quanto se sabe, é La Pensadora Gaditana, publicado em Madrid e em Cádis ao longo do ano de 1768. Era assinado por Beatriz Cienfuegos, supostamente o pseudónimo de um frade (cf.Leston, Xosé V.F., A prensa de mulleres en Galicia (1841-1994), Lisboa, Edições Universitárias Lusófonas, 1996, p. 21). O periódico mais antigo em Inglaterra é The Female Spectator, de Elizabeth Haywood, fundado em 1744. Note-se que a influência da imprensa estrangeira na criação dos periódicos portugueses, na opção temática e na abordagem dos conteúdos está por estudar.

5 O livro em causa é: Rocha, Clara, Revistas Literárias do Século XX em Portugal, Lisboa, Imprensa Nacional-Casa da Moeda, 1985.

6 De António Nóvoa, indicam-se dois títulos: Nóvoa, António, A Imprensa de Educação e Ensino. Repertório analítico (séculos XIX-XX), Lisboa, Instituto de Inovação Educacional, 1993; Nóvoa, António, "A imprensa de educação e ensino: Concepção e organização do Repertório português", in Catani, Denice B. \& Bastos, Maria Helena C. (orgs.), Educação em Revista - A imprensa periódica e a história da educação, S. Paulo, Escrituras, 1997, pp. 11-31. De Justino Pereira de Magalhães, remete-se para o artigo: Magalhães, Justino, "A imprensa de educação e ensino, repertório analítico (séculos XIX-XX)", Educação, Sociedade e Culturas, 3, 1995, pp. 216-219.

7 Um exemplo: Nunes, Fátima, Imprensa Periódica Científica (1772-1852). As leituras de "sciencia agrícola" em Portugal, Lisboa, Estar, 2001. 
remeter para o problema da vulnerabilidade deste tipo de publicação, associando-o a dois preconceitos, precisamente a frivolidade e a futilidade. Um e outro configuram acusações recorrentes: frivolidade pelo tratamento escrupuloso dado a assuntos irrelevantes ou, pelo contrário, pelo tratamento indiferente dado a matérias importantes; futilidade pela falta de sentido dos discursos, o que ridicularizava ou conferia indignidade a quem os assinava. Daí impor-se tantas vezes o cuidado em obscurecer a revelação do nome, sendo frequente o uso, quase lúdico, de pseudónimos, anagramas, acrósticos ou conjuntos de iniciais, cuja eficácia dependia da resistência à decifração.

O problema da vulnerabilidade, decorrente do predomínio de ideologias sexistas enraizadas, transversalizadas e internalizadas, tanto afectava os artigos dedicados à moda, quanto os artigos de conteúdo político: os primeiros, por serem considerados próprios das mulheres ou conformes à sua natureza; os segundos, por lhes serem impróprios ou estarem desajustados do papel social convencionado, naturalmente politicofóbico. Tal mentalidade contribuiu para inferiorizar a imprensa feminina perante a imprensa em geral que ganhara, por razões várias, uma forte consciência do valor de si mesma. Todavia, nem sempre os ataques depreciativos vinham do exterior. Muitas vezes constituíam-se e assumiam-se no interior do núcleo editorial, independentemente de os responsáveis serem homens ou mulheres. llustrativo é o texto de apresentação de Vida Feminina. Revista semanal da mulher e para a mulher, supostamente escrito por uma das secretárias de redacção ${ }^{8}$, onde se esclarece o público leitor sobre a natureza da revista: espaço "onde a mulher se sente mulher e onde a futilidade feminina, que é afinal a Vida, é tratada com algum carinho e sem política nenhuma"'.

Ao contrário do que acima se possa ter feito supor, a inferiorização não era participada por todos e nem toda a imprensa feminina se apresentava acomodada à imagem idealizada do "belo sexo", compreendida entre o próprio e o impróprio. Também se apresentou extrovertida, combativa e decidida a permanecer no espaço informativo, equacionando os problemas da mulher e da sociedade, juntando a vida privada com a pública e harmonizando valores. Dois efémeros periódicos exemplificam a diversidade

8 As secretárias de redacção eram Albertina Paraíso e Virgínia Quaresma. Para o conhecimento da actividade feminista de uma e outra, consulte-se a seguinte obra: Castro, Z. O. de, Esteves, J., Dicionário no Feminino (Séculos XIX-XX), Lisboa, Livros Horizonte, 2005.

9 Cf. Vida Feminina. Revista Semanal da Mulher e para a Mulher, p. 1. Procedeu-se sempre à actualização ortográfica das citações, por não se ver qualquer vantagem na fiel transcrição do português da época. 
de posicionamentos, ambos publicados em Lisboa no ano de 1822: um, O Toucador. Periódico sem política dedicado às senhoras ${ }^{10}$, dirigido e redigido por Almeida Garrett e Luís Francisco Midosi; outro, Gazeta das Damas ${ }^{11}$, propriedade de Caetano António de Lemos e redigido principalmente por três colaboradoras anónimas.

$\mathrm{Na}$ Introdução de O Toucador, declara-se que ficam intencionalmente de fora "as tarefas de politicar e despoliticar"12. E os títulos dos artigos - "Bailes,, "Jogo", "Modas", "Namoro", "Passeios" e "Teatro" - confirmam a mundaneidade da folha garrettiana, motivada e regulada por uma ideologia conservadora e vaporosamente coquette. É notório e óbvio o distanciamento de Almeida Garrett em relação às intelectuais suas contemporâneas. Numa linha editorial diferente, a Gazeta das Damas revela uma intenção formativa, edificante e interventiva, declarando-se uma folha "com política" para instrução das "tão benévolas leitoras dos negócios políticos"13. A invocação da necessidade nacional de aproximação das mulheres à política, pelo menos na qualidade de observadoras e comentadoras, coexiste, no mesmo espaço, com o apelo ao cultivo da domesticidade angélica, como se fosse insignificante e invisível o desacerto das duas mundividências. De facto, se alguns artigos não fazem contenção no uso do tom crítico, irónico e exaltado, outros postulam um ideal de mulher do tipo "companheira doméstica". Cita-se exemplificativamente: "Dama de um espírito cultivado, e de um coração bem formado, e virtuoso. Eis aqui a companheira, e não a escrava de seu condigno Esposo: Ela satisfaz os seus desejos, e alivia-lhe igualmente as suas penas; recompensa-lhe os seus cuidados, e suaviza a sua sorte por efusões de ternura: a gravidade, a ino-

10 Trata-se do segundo periódico feminino publicado em Lisboa, de 22 de Fevereiro a 7 de Março de 1822. Era exclusivamente redigido por Almeida Garrett e Luís Francisco Midosi. Conhecem-se sete números (1-7), cada um com dezasseis páginas, de formato rectangular $(a=17,8 / \mathrm{I}=11,5)$, produzidos na tipografia Imprensa Liberal.

11 Considera-se ser o terceiro periódico feminino: semanário publicado em Lisboa, de 29 de Novembro a 6 de Dezembro de 1822. Conhecem-se três números (1-3), cada um com quatro páginas, de formato rectangular ( $a=25,2 / \mathrm{I}=15,7)$, produzidos na tipografia J. F. M. de Campos e Régia Tip. Silvana. As três colaboradoras principais assinavam por: Uma Senhora Portuguesa; Semiramis; Uma Outra Anónima. As restantes escondiam a identidade.

12 Cf. s.a.,"Introdução," O Toucador, Lisboa, 1993, p. 27. Excluídas a política e as altas ciências, todo o interesse está nas notícias "da sociedade, do tom, da moda, etc." (Idem, p. 27).

${ }^{13}$ Cf. s.a.,"s.t.", Gazeta das Damas, 1 (Nov.) 1922, s. p. A mesma intencionalidade está subjacente no plano de trabalho que consistia "na sólida instrução de todas as classes do Belo-Sexo sobre os princípios da pura moral. No amor, em que pretendemos inflamar esta maioria da Nação pelas suas novas instituições, para que ela o inspire desde o berço à geração futura" (cf.ldem, s. p.). A instrução e a educação dominavam nos assuntos tratados, fosse para mobilizar os políticos ("As pensionistas do Estado"), fosse para reivindicar ("Educação") ou para reformar comportamentos ("Dever das mães"). 
cência e a modéstia mostrar-se-ão em seu rosto."14 A dificuldade em considerar, no momento da publicação, a possibilidade de existência de contradição ideológica entre o conteúdo dos artigos e o projecto editorial tipifica bem a imprensa feminina. Além do mais, admita-se, ser "boa filha, boa esposa e boa mãe" era um programa socialmente irrenunciável e politicamente estimável, por colaborar na promoção dos valores civilizacionais acantonados à volta da ideia de Progresso e vinculados ao reformismo liberal. Logo, o programa encaixava bem no modus vivendi familiar, ao mesmo tempo que seguia o espírito moderno, defensor da instrução e intervenção política das mulheres. Poucos foram os periódicos consistentes com a intransigência inerente à legitimidade da cidadania inclusiva e à aplicação de uma "ética mínima"15 baseada na justiça social, proporcionadora de bem-estar comum. A Gazeta das Damas não foi caso de excepção, não obstante a sua presença disruptiva na Lisboa de Oitocentos.

Para desconstruir preconceitos sobre as revistas femininas e apreciar entre elas as diferenças qualitativas, importa que à inventariação sucedam quer a selecção e análise de temáticas dominantes, quer a contextualização e comparação com outros discursos de época, nacionais e internacionais ${ }^{16}$. Ivone Leal deixou apenas subentendida esta orientação, posto que o objectivo imediato lhe condicionou o desenvolvimento.

14 Idem, s.p.

${ }^{15}$ A expressão "ética mínima" corresponde exactamente ao título de um livro de Adela Cortina [Ética Mínima. Introducción a la filosofía práctica, Madrid, Tecnos, 1986] e designa o referencial de exigência ética que garante o ideal da dignidade humana como absolutamente valioso e fim incondicionado.

${ }^{16}$ No livro de Xosé V. F. Leston, A prensa de mulleres en Galicia (1841-1994), encontra-se a seguinte observação à imprensa de mulheres em Portugal:"Malia a cantidade total de publicacións, case comparable a de España, debemos salientar que practicamente ningunha destas revistas pon en cuestión o modelo dominante acerca do papel social da muller. Neste aspecto esta prensa está mais próxima de galega que de española" (p.58).

Não cabe neste trabalho, de abordagem incoativa e circunscrita a Portugal, a remissão para situações internacionais. Mas foi proveitosa a leitura do livro de Alison Adburgham (Women in Print. Writing Women and Women's Magazines from the Restoration to the Accession of Queen Victoria, London, Allen \& Unwin, 1972) e de Laurel Brake (Subjugated Knowledges, Journalism, Gender and Literature in the Nineteenth Century, London, Macmillan, 1994), onde merecem destaque quer a análise feita às revistas de mulheres publicadas entre 1880 e 1890, quer os debates da imprensa, quer a relação estabelecida entre mulheres escritoras e jornalistas. Pela razão supra-indicada, resistiu-se à tentação de sumariar o caso brasileiro exposto por Kátia de Carvalho ("As imagens femininas no Rio de Janeiro, anos 20:Um sistema de informação cultural", Ciência de Informação, vol. 20, 1, 1995), disponível na net, e Nelly Novaes Coelho ("A emancipação da mulher e a imprensa feminina.Século XIX-século X",Cosmo on line,1/12/2001). Registe-se a impossibilidade de consultar a dissertação de Maria Fernanda Baptista Bicalho, também brasileira (Bicalho, Maria Fernanda Baptista, O Belo Sexo: A imprensa, identidade feminina no Rio de Janeiro em fins do século XIX e inícios do século XX, Rio de Janeiro, Museu Nacional, 1988, 268 pp. [Dissertação]). Note-se que, apesar de não ter sido consultada, considerou-se que omitir a sua referência invisibilizava injustamente a obra. 
A investigação nesta linha foi assegurada por Ana Maria Costa Lopes, subordinando-a ao tema"a imagem da mulher"e limitando-a ao século XIX.Trata-se de um período significativo pelos antagonismos e contradições que modelavam e organizavam a vida das mulheres: por um lado, uma compulsiva fixação no círculo doméstico por contaminação de ideais do Romantismo sofisticado, do naturalismo exagerado e de certo modelo burguês emergente; por outro, uma ostensiva vontade de auto-afirmação pública e de denúncia da desigualdade cívica. Os periódicos, de grande popularidade e variedade em Oitocentos, contaminados por esses antagonismos e contradições, constituem uma fonte para a recuperação de imagens da mulher: reivindicativas ou subordinadas; frívolas e fúteis ou reflexivas e activas; instrumentalizadas ou desprezadas. Da investigação de Ana Maria Costa Lopes resultou o livro Imagens da Mulher na Imprensa Feminina de Oitocentos. Percursos de modernidade ${ }^{17}$, imprescindível leitura para compreender a configuração de estereótipos e correlacionar essas interpretações tópicas com as mundividências da época.

Ivone Leal e Ana Costa Lopes ${ }^{18}$ comprovaram que os periódicos femininos não são um género menor, quer como produto de imprensa, quer como fonte de investigação. Existe substância de pesquisa resultante dos posicionamentos pluralistas e críticos tomados com a participação nos debates da época.

\section{Segunda questão: classificar}

A leitura dos livros das duas autoras e a consulta de alguns periódicos femininos colocaram uma questão de ordem prática: no conjunto dos periódicos, como diferenciar revistas e jornais? A questão surge quando Ana Maria Costa Lopes refere, sem qualquer explicação, A Voz Feminina, O Progresso e A llustração Feminina como revis-

17 Cf. Lopes, Ana Maria Costa, Imagens da Mulher na Imprensa Feminina de Oitocentos. Percursos de modernidade, Lisboa, Quimera Editores, 2005.

18 Não são as únicas detentoras de elementos comprovativos, mas para o presente estudo elas são as autoras mais adequadas para o estudo do feminismo português. Em função deste critério, e sem diminuir o mérito de ninguém, não se tomou em consideração a dissertação de licenciatura de Rosemarie Wank-Nolasco Lamas, intitulada O Feminismo Português através da Leitura de Alma Feminina e de Portugal Feminino [Lisboa, Universidade Católica de Lisboa, 1993]. Também se não considerou o livro A Mulher em Textos e Contextos. Um recenseamento bibliográfico tematicamente indexado sobre publicações periódicas portuguesas (1974-1988), de Luís Esteves de Melo Campos [Lisboa, Comissão da Condição Feminina, 1989], pela mesma razão. A justificação serve ainda para o artigo de Liliana da Silva Araújo Simões, “A publicidade nas revistas femininas" [Boletim da Comissão da Condição Feminina, Ano X, n. ${ }^{\circ}$ 3-4 (Jul./Dez.) 1981, Lisboa, CCF, pp. 107-112]. 
tas ${ }^{19}$. Ora, as duas primeiras apresentam-se no subtítulo como jornais: A Voz Feminina. Jornal semanal, científico, literário e noticioso exclusivamente colaborado por senhoras: dedicado a ilustração das senhoras ${ }^{20} ;$ O Progresso. Jornal semanal político, literário e noticioso ${ }^{21}$. $O$ terceiro periódico assume-se apenas como semanário: $A$ llustração Feminina. Semanário d'instrução e recreio dedicado ao sexo feminino e redigido por várias senhoras e cavalheiros ${ }^{22}$. Da consulta de sessenta e uma publicações do século XIX (ver Anexo: Lista de periódicos femininos), verificaram-se duas situações: grande variabilidade na designação subtitulada, desde jornal, revista, semanário, periódico, publicação e incluindo folha; omissão da referência à categoria. A designação "revista" apenas se regista em Jornal das Damas. Revista de literatura e moda, de 1865-1879, A Mulher. Revista de família, de 1883-1885, e em A Jóia. Revista quinzenal literária, de 1887. O primeiro caso é deveras curioso por se reconhecer com dupla identidade, mas, comparando os três entre si e estes com os restantes periódicos de tipo jornal, não se detectam traços distintivos específicos e identificadores suficientes para extrair critérios de decisão.

O jornalista Silva Pereira, que em 1883 analisou vários periódicos femininos em cinco artigos publicados na revista $A$ Mulher, classificou-os a todos como jornal. Afirma: "Entre os jornais portugueses que em diversas épocas têm sido dedicados e oferecidos à mulher encontram-se alguns que tiveram vida efémera, outros que passaram por não poucas modificações e vicissitudes sem contudo se lhes alterar a índole, outros finalmente que foram bafejados pelas auras da estima pública, dando-se perfeitamente no santuário da família, sendo os enlevos da mamã e lidos com

19 Cf. Lopes, Ana Maria Costa, Imagens da Mulher na Imprensa Feminina de Oitocentos. Percursos de modernidade, Lisboa, Quimera Editores, 2005, p. 361.

${ }^{20}$ A Voz Feminina. Jornal semanal, científico, literário e noticioso exclusivamente colaborado por senhoras: dedicado a ilustração das senhoras foi publicado entre 5 de Janeiro de 1868 e 27 de Junho de 1869 . Conhecem-se 76 números (1-50: 1868;51-76:1869), cada um com quatro páginas, de formato rectangular $(a=42,5 ; \mid=31,5)$, de periodicidade semanal e produzido na tipografia Voz Feminina, Tip. Luso-Britânica. A Redacção era constituída por Francisca Martins Wood, Guilherme Wood, Guiomar Torrezão e Pinho Almeida.

21 O Progresso. Jornal semanal político, literário e noticioso, continuação de $A$ Voz Feminina. Foi publicado entre 4 de Julho de 1869 e 26 de Dezembro de 1869. Conhecem-se 25 números, cada um com quatro páginas, de formato rectangular $(a=43 ; \mid=31)$, de periodicidade semanal e produzido na tipografia Luso-Britânica. A Redacção era constituída por Francisca Martins Wood e Guilherme Wood.

${ }^{22}$ A Ilustração Feminina. Semanário d'Instrução e recreio dedicado ao sexo feminino e redigido por várias senhoras e cavalheiros foi publicado entre 17 de Agosto de 1868 e 1 de Novembro de 1868. Conhecem-se doze números, cada um com quatro páginas, de formato rectangular $(a=43 ; \mathrm{I}=31)$, de periodicidade semanal e produzidos na Tipografia Lisbonense. 
avidez pelas filhas ${ }^{\prime \prime 23}$. Sendo Silva Pereira um estudioso do jornalismo, a uniformidade tipológica atribuída aos periódicos femininos corresponde ao modo usual de então os classificar - jornal -, tanto mais que já se havia estabelecido alguma distinção entre jornal e revista, segundo José Tengarrinha. $\mathrm{O}$ autor de História da Imprensa Periódica Portuguesa informa: “(...) foi o grande desenvolvimento da imprensa periodista em Portugal no $2 .^{\circ}$ quartel do século XIX que tornou possível e necessária a separação entre o jornal e a revista, não especialmente diferenciados pela periodicidade, mas pelas matérias que os constituíam e pela maneira de as desenvolver"24. Consultando os periódicos femininos, reconhece-se formato comum, paginação aproximada, arranjo gráfico similar e conteúdo afim, preenchido por notícias e artigos. A transferi-los da categoria "jornal" para a de "revista", ter-se-á de decidir, pelos critérios de Tengarrinha, se as matérias e o seu desenvolvimento, independentemente da novidade veiculada, da polémica suscitada ou mantida e da qualidade reflexiva incorporada, resultam ou não de processos de investigação com referenciais teóricos explícitos, quer sobre questões pertinentes, quer sobre problemas teóricos ou práticos. Esta grelha de malha apertada aplica-se bem para distinguir artigos académicos de artigos jornalísticos, ou seja, peças de construção discursiva reactiva, mais ou menos imediata, e com procedimentos argumentativos de impacte público moderado ou arrasador. Ora, o que se encontra nos periódicos femininos configura o artigo jornalístico e não o outro. A verdade, poder-se-á argumentar, é que nem todas as revistas são académicas, por conseguinte, os artigos também não, e Tengarrinha refere-se a eles. Nesse caso, mantendo a mesma linha de raciocínio, replicar-se-á que certos artigos jornalísticos são tão elaborados e ponderosos quanto os das revistas não-académicas. Logo, a diferença não é significativa, como Tengarrinha considerou. Ainda assim, como encontrar justificação para a adopção da designação "revista" para as três publicações mencionadas por Ana Costa Lopes?

Tome-se uma outra via para elucidação. Clara Rocha, que investigou a fundo as revistas literárias portuguesas do século XX, classificou-as em duas secções: uma que atende ao aspecto material e à periodicidade; outra que aprecia a matéria temática. Ao justificar a primeira secção, compara o jornal e a revista, considerando que aquele é mais efémero, tem maior frequência, dispensa capa, apresenta um formato maior e está obrigado à datação "porque se quer justamente em cima do acontecimento", seja

${ }^{23}$ Cf. Silva Pereira, "Jornais para as damas, Semanal das Musas, Jornal dos Amores ou as Calovriadas de Coimbra", A Mulher, (8) 1883, p. 63.

${ }^{24}$ Cf. José Tengarrinha, História da Imprensa Periódica Portuguesa, Lisboa, Portugália Editora, 1965, p. 134. 
ele qual for ${ }^{25}$. Tais características, válidas para as revistas em geral, confirmam, pelas razões acima aduzidas, que os periódicos femininos do século XIX correspondem maioritariamente ao tipo jornal.Todavia, no século XX o apuramento inclina-se a favor da revista. A simples existência de capa, a par de outros elementos menos ostensivos, já ajuda a decidir.

Na segunda secção, Clara Rocha reparte as revistas por grupos em função da matéria: de entretenimento e informação; culturais; marginais; políticas ou de opinião; artes e letras. A repartição aplica-se legitimamente aos jornais. Seguindo a classificação proposta, pode-se dizer que os jornais femininos do século XIX e inícios do século XX são sobretudo de convivência e informação utilitária (saúde, tarefas domésticas, educação, etc.), apresentando secções pequenas e variadas (notícias, rubricas de opinião, textos literários, moda, charadas), favorecendo a assimilação de dados com função prestativa no quotidiano doméstico e na criação de ambiente familiar, ou seja, promovendo a inserção da mulher no lar. A dimensão política ou cultural coexiste variavelmente em muitos.

A partir de 1926 e até 1974, preferiu-se a modelação do periódico em revista e boletim, neste caso se figurasse como órgão de uma associação com vínculo ao Estado Novo. O suplemento e a exclusividade da carga ideológica fizeram dos periódicos os mediadores entre a produção da informação consentida e o consumo da informação disponibilizada. Nada obsta a incluir alguns no grupo "política e opinião".

Em suma, para o século XIX é difícil argumentar a favor da troca de designação (jornal para revista) e nem se vê qualquer vantagem nisso. De modo algum os artigos ficam diminuídos em pregnância na afirmação da identidade pública das mulheres ou perdem pragmatismo na intenção de dar a conhecer abertamente tal identidade. Porque não designá-los por jornal, o termo que geralmente ostentam, ou simplesmente por periódico?

\section{Terceira questão: poderes e limites}

Quer o livro de Ana Costa Lopes, quer o de Ivone Leal induzem a considerar a importância da escrita jornalística na revelação da realidade que se é, se conhece e se constrói. Encontram-se muitos artigos em que a escrita se assume como instrumento de poder, permitindo dizer em público o que se quer dizer, e como instrumento do poder, obstaculizando dizer em público o que se gostaria de dizer ou dizendo tão-só o que o poder quer

${ }^{25}$ Cf. Clara Rocha, Revistas Literárias do Século XX em Portugal, Lisboa, Imprensa Nacional-Casa da Moeda, 1985 , p. 25. 
que seja dito. Ambas as autoras advertem para a multiplicidade de vozes femininas, umas afinadas, outras desafinadas com os vários discursos epocais, mas que no seu conjunto serviram o intuito, como refere Helena Konig, de "quebrar com os actos monológicos da razão masculina" (p. 209). Uma questão desponta aqui: como é que se foi legitimando a escrita do sujeito feminino, sexualmente diferenciado? Sem desprezar as determinantes históricas, sociais e económicas, sem dúvida que a escrita periódica se legitimou na medida em que o conceito de feminismo, um conceito de identidade, ganhou expressão e multiplicou as suas expressões. Em termos gerais, o feminismo corresponde a "la primera forma de identidad pública que las mujeres, ante una aguerrida minoría y, posteriormente, en grupos cada vez más extensos, se han otorgado desde el fin del siglo XVII"26. A identidade dá-se a conhecer pela voz e é mediante a escrita que as mulheres têm voz pessoal e pública. Ter voz significa conceber a vida agregada à coisa pública e, de certa maneira, bordejar o poder. Quatro ideias se configuram aqui em articulação:

- primeira, o feminismo é correlato do processo de autoconsciencialização da condição da mulher;

- segunda, a escrita, como registo da voz identitária, tem importante papel ilocutório cívico;

- terceira, a tipicidade do feminismo está na sua vinculação à "coisa pública", não obstante a variedade de manifestações e filiações;

- quarta, o repúdio do feminismo tem consequências emancipatórias negativas pela retracção política provocada.

Não é, pois, inconsequente optar-se por ser feminista, posição de vanguarda, ou por ser feminina, posicionamento mais conservador. Quando no século XIX e até meados do XX se repudiava o termo "feminista", numa compreensível demarcação da sua expressão violenta ${ }^{27}$ e num deliberado afastamento das correntes políticas que a ele se

${ }^{26}$ Trata-se de uma definição abrangente tomada para efeitos de trabalho, cuja referência filosófico-jurídica é a declaração de Olympe de Gouges, correctora da Declaração dos Direitos do Homem e do Cidadão, de 1789 (cf. Giulio de Martino e Marina Bruzzese, Las Filósofas. Las Mujeres Protagonistas en la Historia del Pensamiento, Valência, Ediciones Cátedra, 1996, p. 291). A não-univocidade do feminismo permite usar o termo no plural - feminismos. Assim se contempla um espectro de posicionamentos que vão do liberalismo moderado ao radicalismo defendido, por exemplo, por Betty Friedan (cf.Betty Friedan, The Feminine Mystique, Harmondsworth, Penguin, 1983).

27 Noticiosas eram as manifestações sufragistas promovidas pela inglesa Emmerline Pankhurst (1858-1938), fundadora da Women's Social and Political Union, em 1903, que terminavam, incontidamente, com violência, incêndios e destruições. 
associavam, e quando se tomava reactivamente a designação "feminina" ${ }^{\text {, }}$, a dimensão cívica perdia força reivindicativa no espaço público e provocava retracção política. Ora o esvaziamento da dimensão cívica gerava uma situação artificial e errática, dado que o horizonte ético onde pontuavam a igualdade entre os sexos e a emancipação jurídica e económica da mulher se desgarrava da acção reivindicativa cujo principal objectivo visava, em última instância, a participação e influência nas decisões governativas.

A dificuldade em optar por um ou outro conceito também se prende com o facto de o feminismo demorar a consolidar-se epistemologicamente, o que permitiria eliminar confusões conceptuais e vigiar eventuais contradições. Os periódicos do século XIX e de quase todo o século XX podem mostrar a relação entre a confusão dos posicionamentos e a inconsistência conceptual. Em A Assembleia Literária. Jornal d'instrução ${ }^{29}$, primeiro periódico fundado, pertencente e dirigido por uma mulher Antónia Pusich -, a infirmeza conceptual é evidente. Como escreve uma das colaboradoras em tom assertivo, trata-se de um "jornal redigido pelo espírito feminil" que investe na luta "pela nossa liberdade e pelos sagrados direitos que a sociedade nos tolhe" ${ }^{130}$. O suplemento de carga reivindicativa permite afirmar que o termo "feminil"é correlato de feminista. Porém, em Alma Feminina, boletim oficial do Conselho Nacional das Mulheres Portuguesas publicado entre 1917 e 1946 - "jornal de mulheres e feito por mulheres"-, declara-se no editorial que o feminismo "não quer roubar a mulher à família mas reivindica para ela direitos sociais mais extensos e complexos" ${ }^{\prime \prime 1}$.E, por não

28 O termo "feminina" tem uma conotação negativa por corresponder à internalização do ideal feminino, um constructo próprio do paradigma patriarcal que ideologicamente combina, tal como Simone de Beauvoir denunciou em O Segundo Sexo, a estrutura subjectiva da mulher e o comportamento social que dela é expectável. Ser feminina neste sentido corresponde à afirmação ou imposição da feminilidade. Feminina pode, ou não, ser solidário ou sinónimo de antifeminismo.

${ }^{29}$ A Assembleia Literária. Jornal d'instrução foi publicado em Lisboa entre 4 de Agosto de 1849 e 15 de Abril de 1851, inicialmente em regime semanal e depois quinzenal. Conhecem-se quarenta números (mais dezassete da 2. a série: 1951), cada um com oito páginas, de formato rectangular ( $a=25 / \mathrm{h}=18$ ), produzidos na Tipografia G. M. Martins, J. B. Morando, Tip. Gratidão, Imp. e Tip. de Alexandrina Amélia de Sales, Tipogafia de Silva, de Lisboa. Ivone Leal assinala o carácter inovador do jornal:“(...) na imprensa do século XIX a expressão'periódico feminino' queria dizer jornal destinado por homens a público feminino e contendo matérias que esses homens entendiam ser as que interessavam ou deviam interessar às mulheres. A partir da publicação de 'A Assembleia Literária' aquela expressão amplia-se e altera o seu significado, na exacta medida em que o conteúdo do jornal se torna diferente" (cf. Ivone Leal, Um Século de Periódicos Femininos. Arrolamento de periódicos entre 1807 e 1926, Lisboa, CIDM, 1992, p. 56).

${ }^{30}$ Cf. Antónia Luísa Pontes Cabral, 4 de Agosto de 1849, p. 1.

${ }^{31}$ Órgão do Conselho Nacional das Mulheres Portuguesas, Alma Feminina. Jornal de Instrução foi publicado em Lisboa entre Janeiro de 1917 e 15 de Maio de 1946, com regularidade mensal. 
querer ser exclusivamente feminista, integra actividades domésticas mais sofisticadas em secções como a moda e a ménagère, a literatura, a ciência, a vida social, a arte. Os motivos concretos, a vida real e os factos estão na base de uma doutrinação aparentemente neutra:"calmamente, sem intentos de revolução, sem impulsos e sem necessidade de nos encostarmos a qualquer doutrina político-religiosa"32. O programa editorial não vai além da razoabilidade moderada, sem determinação para recusar qualquer ordem de restrição interventiva e para defender a decisão pela própria vida.

Notável na crítica à homogeneidade e ao simbolismo do paradigma estruturante da humanidade é $A$ Voz Feminina. $O$ título exprime a estratégia adoptada: dar voz às mulheres através da escrita e deste modo mantê-las presentes no espaço público. $A$ expectativa potenciada pela dimensão política é imensa. Vale a pena transcrever esta significativa passagem:"Porque não poderão as senhoras escrever tão bem ou tão mal como os homens? Estamos a meados do século XIX e ainda não Ihes parece isso possível? As tolas e os tolos; as ignorantes e os ignorantes ou não escrevem ou escrevendo descrevem-se; ambos dizem tolices, ambos ostentam a sua falta de saber: as sensatas e os sensatos, as instruídas e os instruídos reproduzam-se como tais nos seus escritos. O sexo não influi nisso, mas sim o grau de talento com que nos achamos dotados e a cultura das nossas faculdades intelectuais. Acostumem-se, meus senhores e senhoras que duvidam, a crer que a instrução e as ideias que se adquirem estudando em diferentes países, as diferentes fases da família humana equiparam a mulher ao homem"33. $\mathrm{A}$ Voz Feminina, considerado por Ivone Leal como "o primeiro jornal feminista surgido na Europa" ${ }^{\prime \prime}$, apostou na constituição de ideais de cidadania inclusiva e tomou um sentido de eficácia e de serviço cívico exemplar no jornalismo nacional. O jornal criou imensa expectativa, potenciada pela dimensão política e novidade. Incomodou e foi extinto.

A falta de apoio, ou o apoio retirado ao jornal, prende-se com as diferentes concepções de ser feminista, quer dizer, de ter consciência da condição da mulher: uma, conservadora, interpreta o feminismo como uma manifestação com vista a reivindicar e assumir os direitos e deveres inerentes ao papel de esposa e mãe: outra, radical, interpreta-o como acção reivindicativa de direitos e deveres iguais entre os seres

32 Idem, p. 1.

${ }^{33}$ Cf. Francisca Wood, “Declaração”, A Voz Feminina, 35 (Set.) 1868, p. 1.

${ }^{34} \mathrm{Cf}$. Ivone Leal, Um Século de Periódicos Femininos. Arrolamento de periódicos entre 1807 e 1926, Lisboa, CIDM, 1992, p. 71. Francisca Wood também estava convencida disso mesmo: “Um jornal redactado por senhoras é hoje uma novidade na Europa, de cuja iniciativa deveríamo-nos, as portuguesas, ufanar-nos. Mas, segundo todas as aparências, não nos ufanamos" (cf. Francisca Wood, "Editorial", A Voz Feminina, n. ${ }^{\circ}$ 13,1868 , s.p.). 
humanos. O jornal de Francisca Wood provocou a reacção das mulheres vinculadas ao feminismo conservador, entre elas Maria Amália Vaz de Carvalho. Criticou-lhe o despropósito de ter voz pública, desafiante, esgrimista e invasora do espaço de influência e exercício do masculino poder político:"(...) o jornal, enfim, deve ser masculino, exclusivamente masculino, porque só os homens têm o espírito positivo que este género demanda" ${ }^{\prime 35}$. Quer uma quer outra, pela reacção e contra-reacção, foram legitimando a escrita do sujeito feminino como forma de sustento, e ambas sabiam que a escrita jornalística criava a oportunidade para a voz das mulheres se instalar publicamente. Maria Amália Vaz de Carvalho, que "rejeitou os ideais de emancipação igualitária das mulheres, atacou o divórcio e negou a legitimidade do outorgamento do direito de voto às mulheres" ${ }^{\prime 36}$, só poderia, por coerência, condenar; Francisca Wood só poderia fazer o que fez.

Os periódicos femininos foram (e são) mediadores das vozes das mulheres e dos modos de participação na vida pública ${ }^{37}$.

\section{Parágrafo conclusivo}

Que importa explorar e sistematizar temas, imagens e ideias disseminadas pela escrita jornalística da autoria de mulheres em periódicos femininos, é um dado adquirido. A abordagem que se realizou, embora preocupada em dilucidar questões prévias, afirma o potencial investigativo dos periódicos femininos, aliás confirmado pelas três dissertações académicas realizadas no espaço luso-brasileiro. Dois pontos a reforçar, para terminar: os periódicos têm legitimidade como objecto de estudo e deixam em aberto a possibilidade de uma leitura intertextual que faça emergir as diversas vontades de afirmação de um colectivo desdobrado em muitas gerações.

${ }^{35}$ Cf. Amália Vaz de Carvalho, "Correspondência”, A Voz Feminina, 25 (Set.) 1868, s.p. Resposta de Francisca Wood:"Se assim é, já não falta tudo, tendo uns dito que a redactora desta folha é um homem com bigodes retorcidos, outras que se quer fazer homem" (Idem, s.p.).

${ }^{36}$ Cf. Virgínia Dias, "Maria Amália Vaz de Carvalho", in Zília Osório de Castro e João Esteves, Dicionário no Feminino (Séculos XIX-XX), Lisboa, Livros Horizonte, 2005, p. 581.

37 Quarenta e seis anos mais tarde, escrevia-se em Alma Feminina, Boletim Oficial da Comissão Nacional das Mulheres Portuguesas:"On peut dire de la façon la plus absolue que le manque frappant d'équilibre moral, qu'on remarque dans les sociétés modernes, est la conséquence inévitable de l'absence de l'action consciente de la femme. Et voilà, pourquoi le féminisme, ayant pour but d'élever et de libérer la plus grande partie du genre humain, s'impose efficacement à tous les esprits illustrés. L'isolement auquel la femme a été condamnée et son éloignement de la vie publique a constitué toujours, et constitue, encore, un fort embarras au progrès" (cf. Alma Feminina, Ano 1, n. ${ }^{\circ}$ 1, 1915, pp. 1-2). 


\section{Anexo}

A Imprensa Feminista (1807-1974)

Lista de periódicos inventariados

\begin{tabular}{|c|c|c|c|}
\hline N.o & Anos & Periódicos & Localidade \\
\hline 1 & 1807 & Correio das Modas & Lisboa \\
\hline 2 & 1822 & Gazeta das Damas & Lisboa \\
\hline 3 & 1822 & $\begin{array}{l}\text { OToucador } \\
\text { Jornal sem política destinado às senhoras portuguesas }\end{array}$ & Lisboa \\
\hline 4 & 1823 & $\begin{array}{l}\text { Diálogo de Duas Velhas } \\
\text { As mulheres que são da antiguidade ao modernismo falam } \\
\text { verdade }\end{array}$ & Lisboa \\
\hline 5 & 1823 & $\begin{array}{l}\text { Eugénia } \\
\text { Dedicado às damas }\end{array}$ & Lisboa \\
\hline 6 & 1823-1824 & $\begin{array}{l}\text { Periódico das Damas } \\
\text { Semanal }\end{array}$ & Lisboa \\
\hline 7 & $\begin{array}{c}1836 \\
1840-1843 \\
1844-1853\end{array}$ & L'Abeille & Lisboa \\
\hline 8 & 1836 & $\begin{array}{l}\text { Colecção de Novas Modinhas } \\
\text { Para honesto recreio das madamas e apaixonadas do } \\
\text { harmonioso canto }\end{array}$ & Lisboa \\
\hline 9 & 1836 & $\begin{array}{l}\text { Semanal das Musas } \\
\text { Poesias feitas ou coleccionadas por M. C. A. e Silva }\end{array}$ & Lisboa \\
\hline 10 & 1836 & Tardes de Verão ou o Divertimento das Damas & Lisboa \\
\hline 11 & $\begin{array}{l}1836-1846 \\
1849-1852\end{array}$ & $\begin{array}{l}\text { O Correio das Damas } \\
\text { Ed.de modas. Semanal }\end{array}$ & Lisboa \\
\hline 12 & 1837 & Jornal dos Amores ou as Calovriadas de Coimbra & Lisboa \\
\hline 13 & $\begin{array}{l}1838-1839 \\
1842\end{array}$ & $\begin{array}{l}\text { O Beija-Flor } \\
\text { Semanário de instrução dedicado ao belo sexo }\end{array}$ & Lisboa \\
\hline 14 & 1839 & $\begin{array}{l}\text { Recreio Teatral } \\
\text { Dedicado ao belo sexo }\end{array}$ & Lisboa \\
\hline
\end{tabular}




\begin{tabular}{|c|c|c|c|}
\hline 15 & 1839 & $\begin{array}{l}\text { O Romancista } \\
\text { Jornal de recreio. Dedicado em especial ao belo sexo }\end{array}$ & Lisboa \\
\hline 16 & 1839 & $\begin{array}{l}\text { Pax Julia } \\
\text { Dedicado à Comissão de Senhoras que promove o bazar em } \\
\text { benefício da Soc. Teat. Bejense. Número único }\end{array}$ & Beja \\
\hline 17 & 1840 & A Rosa Oferecida às Belas & Lisboa \\
\hline 18 & 1842 & $\begin{array}{l}\text { O Toucador das Damas } \\
\text { Hebdomário literário }\end{array}$ & Lisboa \\
\hline 19 & 1845 & $\begin{array}{l}\text { O Jardim das Damas } \\
\text { O Jornal do Tom }\end{array}$ & Lisboa \\
\hline 20 & 1849 & $\begin{array}{l}\text { OMundo às Avessas } \\
\text { Semanário do belo sexo }\end{array}$ & Lisboa \\
\hline 21 & $1849-1851$ & $\begin{array}{l}\text { A Assembleia Literária } \\
\text { Jornal d'instrução }\end{array}$ & Lisboa \\
\hline 22 & $1850-1851$ & $\begin{array}{l}\text { O Judeu Errante } \\
\text { Jornal de modas e de literatura amena dedicado às } \\
\text { senhoras; Jornal de modas dedicado às senhoras }\end{array}$ & Lisboa \\
\hline 23 & 1851 & $\begin{array}{l}\text { A Açucena } \\
\text { Jornal de modas e literatura }\end{array}$ & Lisboa \\
\hline 24 & 1851 & $\begin{array}{l}\text { A Quinzena } \\
\text { Literatura, modas e teatros }\end{array}$ & Lisboa \\
\hline 25 & $1852-1855$ & $\begin{array}{l}\text { A Beneficência } \\
\text { Jornal dedicado à Associação Consoladora dos Aflitos }\end{array}$ & Lisboa \\
\hline 26 & $1853-1862$ & $\begin{array}{l}\text { OMensageiro das Damas } \\
\text { Jornal de modas }\end{array}$ & Lisboa \\
\hline 27 & 1856 & $\begin{array}{l}\text { O Interessante } \\
\text { Jornal de segredos }\end{array}$ & Braga \\
\hline 28 & 1856 & $\begin{array}{l}\text { Almanaque das Damas para o Ano de } 1856 \text { (Bissexto). } \\
\text { Dedicado às assinantes do Mensageiro das Damas }\end{array}$ & Lisboa \\
\hline 29 & $1858-1859$ & $\begin{array}{l}\text { A Cruzada } \\
\text { Jornal religioso e literário }\end{array}$ & Lisboa \\
\hline 30 & $1858-1860$ & $\begin{array}{l}\text { Mundo Elegante } \\
\text { Periódico das modas, literatura, teatros, belas-artes, etc.* } \\
\text { *A 2. a série de Mundo Elegante intitula-se O Mundo Elegante, Vila } \\
\text { Nova, } 1960 .\end{array}$ & Porto \\
\hline
\end{tabular}




\begin{tabular}{|c|c|c|c|}
\hline 31 & 1860 & A Moda Portuguesa & Porto \\
\hline 32 & 1862 & Emancipação da Mulher & Porto \\
\hline 33 & $1862-1863$ & Hinos e Flores & Coimbra \\
\hline 34 & 1862 & $\begin{array}{l}\text { Mensageiro das Damas } \\
\text { Jornal de literatura e modas }\end{array}$ & Lisboa \\
\hline 35 & 1863 & $\begin{array}{l}\text { Recreio das Damas } \\
\text { Oferecido às damas portuguesas de toda a Índia }\end{array}$ & Nova Goa \\
\hline 36 & $1863-1865$ & $\begin{array}{l}\text { Boudoir } \\
\text { Crítica, teatros, música, modas, notícias, caricaturas }\end{array}$ & Lisboa \\
\hline 37 & 1865 & $\begin{array}{l}\text { A Esperança } \\
\text { Semanário de recreio literário dedicado às damas }\end{array}$ & Porto \\
\hline 38 & $1867-1879$ & $\begin{array}{l}\text { Jornal das Damas } \\
\text { Revista de leitura e modas }\end{array}$ & Lisboa \\
\hline 39 & 1867 & $\begin{array}{l}\text { Flor Literária } \\
\text { Periódico científico, instrutivo, literário e de modas }\end{array}$ & Lisboa \\
\hline 40 & 1868 & $\begin{array}{l}\text { A llustração Feminina } \\
\text { Semanário de instrução e recreio dedicado ao sexo feminino }\end{array}$ & Lisboa \\
\hline 41 & $1868-1869$ & $\begin{array}{l}\text { A Voz Feminina } \\
\text { Jornal seminal científico, literário e noticioso. } \\
\text { Exclusivamente colaborado por senhoras }\end{array}$ & Lisboa \\
\hline 42 & 1869 & $\begin{array}{l}\text { O Progresso } \\
\text { Jornal político, literário e noticioso }\end{array}$ & Lisboa \\
\hline 43 & $\begin{array}{l}1870-1890 \\
1928\end{array}$ & Almanaque das Senhoras & Lisboa \\
\hline 44 & 1875 & Bouquet Literário & Porto \\
\hline 45 & 1876 & $\begin{array}{l}\text { Teatro e Modas } \\
\text { Publicação hebdomadária }\end{array}$ & Porto \\
\hline 46 & $1876-1877$ & $\begin{array}{l}\text { A Borboleta } \\
\text { Hebdomadário dedicado às damas bracarenses }\end{array}$ & Braga \\
\hline 47 & 1877 & $\begin{array}{l}\text { Gazeta das Salas } \\
\text { Jornal para as damas }\end{array}$ & Lisboa \\
\hline 48 & 1877 & $\begin{array}{l}\text { Jornal das Senhoras } \\
\text { Publicação diária }\end{array}$ & Porto \\
\hline
\end{tabular}




\begin{tabular}{|c|c|c|c|}
\hline 49 & 1879 & $\begin{array}{l}\text { O Pirilampo } \\
\text { Folha quinzenal literária e filosófica, dedicada às damas } \\
\text { bracarenses }\end{array}$ & Braga \\
\hline 50 & 1882 & $\begin{array}{l}\text { As Damas Portuguesas } \\
\text { Jornal literário }\end{array}$ & Porto \\
\hline 51 & 1883 & $\begin{array}{l}\text { O Elegante } \\
\text { Jornal de modas para homens, senhoras e crianças. } \\
\text { Dedicado particularmente aos alfaiates e costureiras }\end{array}$ & Lisboa \\
\hline 52 & 1883 & OBouquet & Porto \\
\hline 53 & 1883 & $\begin{array}{l}\text { A Mulher } \\
\text { Jornal de modas }\end{array}$ & Funchal \\
\hline 54 & 1883-1885 & $\begin{array}{l}\text { A Mulher } \\
\text { Revista ilustrada da família }\end{array}$ & Lisboa \\
\hline 55 & 1884-1885 & $\begin{array}{l}\text { As Crianças } \\
\text { Jornal de educação dedicado às mães }\end{array}$ & Lisboa \\
\hline 56 & $1884-1886$ & Gazeta Musical & Lisboa \\
\hline 57 & 1885-1888 & Almanaque das Senhoras Portuenses & Porto \\
\hline 58 & 1885 & $\begin{array}{l}\text { O Cartão de Visita } \\
\text { Semanário das elegantes }\end{array}$ & Coimbra \\
\hline 59 & 1885 & $\begin{array}{l}\text { Beja-Creche } \\
\text { Número único. Publicado pela comissão da creche e } \\
\text { dedicado às senhoras que a têm coadjuvado }\end{array}$ & $\begin{array}{c}\text { Beja } \\
\left(2 .^{\text {a ed. }}\right. \\
\text { Coimbra })\end{array}$ \\
\hline 60 & 1886 & OBouquet & Porto \\
\hline 61 & 1886 & $\begin{array}{l}\text { A Mocidade } \\
\text { Semanário de instrução e de recreio dedicado às damas } \\
\text { portuguesas }\end{array}$ & Porto \\
\hline 62 & 1886 & $\begin{array}{l}\text { O Sinapsismo } \\
\text { Jornal em prosa e verso }\end{array}$ & $\begin{array}{c}\text { Ponta } \\
\text { Delgada }\end{array}$ \\
\hline 63 & 1886 & $\begin{array}{l}\text { A Pátria } \\
\text { Periódico destinado às costureiras }\end{array}$ & Porto \\
\hline 64 & $1886-1887$ & $\begin{array}{l}\text { Lisboa Elegante } \\
\text { Contos, versos, teatros e bailes }\end{array}$ & Lisboa \\
\hline 65 & 1887 & $\begin{array}{l}\text { A Arte } \\
\text { Semanário literário dedicado às damas reguenses }\end{array}$ & Régua \\
\hline
\end{tabular}




\begin{tabular}{|c|c|c|c|}
\hline 66 & 1887 & $\begin{array}{l}\text { O Bocage } \\
\text { Semanário literário, científico e noticioso }\end{array}$ & Lisboa \\
\hline 67 & 1887 & $\begin{array}{l}\text { O Cisne } \\
\text { Semanário literário, noticioso e charadístico dedicado às } \\
\text { damas lamacenses }\end{array}$ & Lamego \\
\hline 68 & 1887 & $\begin{array}{l}\text { A Corbeille } \\
\text { Semanário literário d'instrução e recreio, dedicado às damas } \\
\text { portuenses }\end{array}$ & Porto \\
\hline 69 & 1887 & $\begin{array}{l}\text { O Escalpelo } \\
\text { Semanário literário e de crítica imparcial }\end{array}$ & Lisboa \\
\hline 70 & 1887 & $\begin{array}{l}\text { A Grinalda } \\
\text { Semanário literário, científico, noticioso e charadístico. } \\
\text { Dedicado às Exmas. damas desta cidade }\end{array}$ & Elvas \\
\hline 71 & 1887 & $\begin{array}{l}\text { A Jóia } \\
\text { Revista quinzenal de literatura dedicado às damas } \\
\text { vimaranenses }\end{array}$ & Guimarães \\
\hline 72 & 1887 & $\begin{array}{l}\text { O Mundo Elegante } \\
\text { Mensageiro semanal de modas e bom tom. Dedicado às } \\
\text { senhoras portuguesas e brasileiras }\end{array}$ & Paris \\
\hline 73 & 1887 & $\begin{array}{l}\text { A Rosa } \\
\text { Publicação quinzenal literária. Dedicada às damas } \\
\text { portuguesas }\end{array}$ & Porto \\
\hline 74 & 1888 & $\begin{array}{l}\text { O Dedal } \\
\text { Quinzenário noticioso e literário dedicado às costureiras }\end{array}$ & Porto \\
\hline 75 & 1889 & $\begin{array}{l}\text { O Agulheiro } \\
\text { Destinado às costureiras }\end{array}$ & Porto \\
\hline 76 & 1889 & $\begin{array}{l}\text { O Alfinete } \\
\text { Semanário humorístico destinado às costureiras }\end{array}$ & Porto \\
\hline 77 & 1890 & $\begin{array}{l}\text { Gazeta das Salas } \\
\text { Periódico literário dedicado às damas portuguesas e } \\
\text { brasileiras }\end{array}$ & Lisboa \\
\hline 78 & 1890 & $\begin{array}{l}\text { A Pérola } \\
\text { Semanário literário destinado às Exmas. damas desta } \\
\text { cidade }\end{array}$ & Elvas \\
\hline 79 & 1890 & $\begin{array}{l}\text { A Religião da Mulher } \\
\text { Jornal noticioso e auxiliador do professorado }\end{array}$ & $\begin{array}{l}\text { Albergaria- } \\
\text {-a-Velha }\end{array}$ \\
\hline
\end{tabular}




\begin{tabular}{|c|c|c|c|}
\hline 80 & 1893 & $\begin{array}{l}\text { A Tesoura } \\
\text { Semanário humorístico. Órgão das costureiras }\end{array}$ & Porto \\
\hline 81 & 1893 & $\begin{array}{l}\text { OMundo Musical } \\
\text { Jorna das damas portuguesas e brasileiras. Anunciador da } \\
\text { moda }\end{array}$ & Lisboa \\
\hline 82 & 1894 & $\begin{array}{l}\text { O Boletim da Moda } \\
\text { Revista dos Armazéns Grandela }\end{array}$ & Lisboa \\
\hline 83 & 1894 & O Jornal das Damas & Porto \\
\hline 84 & 1894-1985 & $\begin{array}{l}\text { A Estação de Paris } \\
\text { Revista de modas, literatura, elegância e bom tom }\end{array}$ & Lisboa \\
\hline 85 & 1895 & $\begin{array}{l}\text { A Utilidade } \\
\text { Revista de interesse da economia doméstica }\end{array}$ & Lisboa \\
\hline 86 & 1896 & $\begin{array}{l}\text { A Crónica } \\
\text { Suplemento à Estação de Paris }\end{array}$ & Lisboa \\
\hline 87 & 1896 & $\begin{array}{l}\text { Jornal das Senhoras } \\
\text { Semanário ilustrado colaborado por damas }\end{array}$ & Lisboa \\
\hline 88 & 1897 & A Moda Elegante & $\begin{array}{l}\text { Paris e } \\
\text { Lisboa }\end{array}$ \\
\hline 89 & $1899-1900$ & Ave Azul & Viseu \\
\hline 90 & 1902 & $\begin{array}{l}\text { Jornal das Senhoras } \\
\text { Publicação trissemanal ilustrada }\end{array}$ & Lisboa \\
\hline 91 & 1902-1904 & $\begin{array}{l}\text { A Sociedade Futura } \\
\text { Publicação quinzenal de literatura, ciência e arte }\end{array}$ & Lisboa \\
\hline 92 & 1904 & Os Serões das Senhoras & - \\
\hline 93 & 1904-1905 & $\begin{array}{l}\text { Jornal das Senhoras } \\
\text { Retratos, biografias, romances, letras e contos, teatro e } \\
\text { salões. modas, contos e charadas }\end{array}$ & Lisboa \\
\hline 94 & 1906-1910 & $\begin{array}{l}\text { Jornal da Mulher } \\
\text { (Secção de OMundo) }\end{array}$ & Lisboa \\
\hline 95 & 1907-1908 & Alma Feminina & Lisboa \\
\hline 96 & 1909-1911 & $\begin{array}{l}\text { A Mulher e a Criança } \\
\text { Revista quinzenal ilustrada }\end{array}$ & Lisboa \\
\hline 97 & 1910 & $\begin{array}{l}\text { A Violeta } \\
\text { Dedicada às senhoras e meninas de Castelo de Vide }\end{array}$ & $\begin{array}{l}\text { Castelo } \\
\text { de Vide }\end{array}$ \\
\hline
\end{tabular}




\begin{tabular}{|c|c|c|c|}
\hline 98 & 1910 & $\begin{array}{l}\text { O Jornal da Mulher } \\
\text { Revista quinzenal ilustrada }\end{array}$ & Lisboa \\
\hline 99 & 1910 & Mosaico Feminino & Coimbra \\
\hline 100 & 1911-1918 & $\begin{array}{l}\text { A Madrugada } \\
\text { Propriedade da Liga Republicana das Mulheres Portuguesas }\end{array}$ & Lisboa \\
\hline 101 & 1912 & $\begin{array}{l}\text { Em Homenagem a Ana Pereira } \\
\text { Número único }\end{array}$ & Lisboa \\
\hline 102 & 1912 & $\begin{array}{l}\text { A Mulher Livre } \\
\text { Centro da Mocidade Republicana Intransigente } \\
\text { Número único }\end{array}$ & Braga \\
\hline 103 & 1912 & $\begin{array}{l}\text { A Mulher Livre } \\
\text { Revista mensal educativa. Órgão da Associação de } \\
\text { Propaganda Feminista }\end{array}$ & Lisboa \\
\hline 104 & $1912-1913$ & $\begin{array}{l}\text { A Mulher Portuguesa. } \\
\text { Revista mensal educativa } \\
\text { Associação de Propaganda Feminista }\end{array}$ & Lisboa \\
\hline 105 & 1913 & $\begin{array}{l}\text { Educação Feminista } \\
\text { Quinzenário literário, científico e artístico }\end{array}$ & Lisboa \\
\hline 106 & 1914 & A Guerra & Lisboa \\
\hline 107 & $\begin{array}{l}1914 \\
1915\end{array}$ & $\begin{array}{l}\text { Parisiana } \\
\text { Revista llustrada de elite e literatura, arte e música }\end{array}$ & Porto \\
\hline 108 & 1914-1917 & $\begin{array}{l}\text { Boletim Oficial do Conselho Nacional das Mulheres } \\
\text { Portuguesas }\end{array}$ & Lisboa \\
\hline 109 & 1915 & A Vida Elegante & - \\
\hline 110 & 1915-1918 & $\begin{array}{l}\text { A Semeadora } \\
\text { Associação de Propaganda Feminista }\end{array}$ & Lisboa \\
\hline 111 & 1917 & $\begin{array}{l}\text { Moda Elegante } \\
\text { Enciclopédia da mulher }\end{array}$ & Lisboa \\
\hline 112 & 1917-1946 & $\begin{array}{l}\text { Alma Feminina } \\
\text { Boletim oficial do Conselho Nacional das Mulheres } \\
\text { Portuguesas }\end{array}$ & Lisboa \\
\hline 113 & 1921 & $\begin{array}{l}\text { A Mulher Médica na Família } \\
\text { Revista quinzenal ilustrada }\end{array}$ & Lisboa \\
\hline 114 & 1922 & $\begin{array}{l}\text { A Rainha da Moda } \\
\text { Figurino Português da Grande Moda de Paris }\end{array}$ & - \\
\hline
\end{tabular}




\begin{tabular}{|c|c|c|c|}
\hline 115 & 1925 & $\begin{array}{l}\text { Estrela } \\
\text { Órgão do Comité Nacional das UCMF }\end{array}$ & Porto \\
\hline 116 & 1925 & $\begin{array}{l}\text { Eva Magazine } \\
\text { Jornal da mulher e do lar }\end{array}$ & Lisboa \\
\hline 117 & 1925 & $\begin{array}{l}\text { A Moda } \\
\text { Jornal para senhoras }\end{array}$ & Lisboa \\
\hline 118 & 1925 & $\begin{array}{l}\text { Vida Feminina } \\
\text { Revista mensal da mulher para a mulher }\end{array}$ & Lisboa \\
\hline 119 & 1925-1927 & $\begin{array}{l}\text { Mulheres do Norte } \\
\text { Mensário de arte e literatura }\end{array}$ & Porto \\
\hline 120 & 1926 & $\begin{array}{l}\text { Femina } \\
\text { Literatura, arte e moda }\end{array}$ & Lisboa \\
\hline 121 & 1930 & Portugal Feminino & Lisboa \\
\hline 122 & 1931 & $\begin{array}{l}\text { Fémina } \\
\text { Arte e moda }\end{array}$ & Lisboa \\
\hline 123 & 1932 & $\begin{array}{l}\text { Feminismo } \\
\text { Órgão do Instituto de Higiene Física }\end{array}$ & Lisboa \\
\hline 124 & 1946-1947 & $\begin{array}{l}\text { A Mulher } \\
\text { Órgão do Conselho Nacional das Mulheres Portuguesas }\end{array}$ & Lisboa \\
\hline 125 & $\begin{array}{l}1942-1958 \\
1964\end{array}$ & $\begin{array}{l}\text { Os Nossos Filhos } \\
\text { Mensário de puericultura, enfermagem, psicologia, } \\
\text { educação, vida escolar, literatura, moda infantil, etc. }\end{array}$ & Lisboa \\
\hline 126 & 1944-1952 & Boletim da Associação Feminina Portuguesa para a Paz & Lisboa \\
\hline 137 & 1955 & $\begin{array}{l}\text { Cinderela. } \\
\text { Revista para mulheres }\end{array}$ & Lisboa \\
\hline 128 & 1956 & Crónica Feminina & Lisboa \\
\hline 129 & 1957 & Ela & Lisboa \\
\hline 130 & 1957 & Jornal Feminino & Porto \\
\hline 131 & 1959 & Almanaque de Crónica Feminina & Lisboa \\
\hline
\end{tabular}




\section{Observação}

A lista apresentada resulta da consulta de dois livros (Ivone Leal, Um Século de Periódicos Femininos. Arrolamento de periódicos entre 1807 e 1926, e Ana Maria Costa Lopes, Imagens da Mulher na Imprensa Feminina de Oitocentos. Percursos de modernidade), de dois dicionários (Dicionário no Feminino. Séculos XIX-XX e Dicionário da Imprensa Periódica Literária Portuguesa do Século XX.1941-1974) ${ }^{38}$ e ainda de dois livros de Silva Pereira (Os Jornais Portugueses e Jornalismo Português) ${ }^{39}$.

Da lista, excluíram-se Moda llustrada (Lisboa, 1875), A Moda llustrada (Lisboa, 1879) e A Moda (Porto, 1882), pois esgotam-se nesse campo temático.

Incluíram-se periódicos escritos por homens, por homens e mulheres e só por mulheres, de vários tipos e destinados a vários sectores, como, por exemplo, as costureiras, o único grupo profissional com reconhecimento (cf. A Pátria, O Dedal, O Agulheiro, $O$ Alfinete, A Tesoura).

Excluiu-se O Idealista, quinzenário dirigido e editado por Áurea Paes Falcão ( $A$ Andorinha), publicado em Odemira entre 15 de Março de 1931 e 19 de Julho desse ano, num total de dez números. A razão é uma só: dirige-se ao público em geral com os objectivos de "Sobretudo Educar", de evitar questões políticas, religiosas e sobre a igualdade, e de regionalizar ("Do nosso programa consta também um pouco de regionalismo" $)^{40}$.

Incluíram-se gazetas e almanaques, seguindo o critério de Silva Pereira.

No Relatório das Publicações Periódicas Portuguesas de 1964 (Lisboa, Biblioteca Nacional) e no Suplemento referente ao ano de 1962, encontrou-se na Secção Economia Doméstica (pp. 237-238) uma lista de periódicos dirigidos ao concreto das mulheres esposas e mães, na linha, por exemplo, de $A$ Mulher (1883), As Crianças (1884) e $A$ Utilidade (1895). Dela não se consideraram: Modas e Bordados. Vida Feminina (Lisboa, 1912); O Enxoval da Noiva (Lisboa, 1951); A Mulher no Lar (Lisboa, 1957); Bordados à Máquina (Lisboa, 1958); O Bastidor e... a Máquina (Lisboa, 1959); Mãos de Fadas. Revista mensal de lavores (Lisboa, 1961). Trata-se de revistas técnicas ou limitadas a um só campo.

${ }^{38}$ Cf. Pires, Daniel, Dicionário da Imprensa Periódica Literária Portuguesa do Século XX (1941-1974), 2 vols., Lisboa, Grifo Limitada, 1999.

${ }^{39}$ Cf. Silva Pereira, Jornalismo Português, Lisboa, Typ. Tavares, 1895; Os Jornais Portugueses, Lisboa, Imp. Libanio da Silva, 1898.

40 Vale a pena transcrever a justificação dada por Áurea Paes Falcão no editorial do primeiro número do jornal:"Nunca sonhámos ser outra coisa que não fosse esposa e mãe, mas foi justamente esse mister sublime superior a todos os misteres que Deus, nos seus insondáveis propósitos, não quis conceder-nos...." 
Após alguma hesitação, decidiu-se excluir Mãos Dadas, Fagulha e Menina e Moça, da Mocidade Portuguesa Feminina, precisamente por se dirigirem à juventude. A incluí-las, deveriam ter-se em consideração outras que surgiram, por exemplo, no âmbito dos Centros Escolares e de certas escolas, como as de enfermagem.

Excluíram-se os periódicos publicados depois do 25 de Abril de 1974, por requererem uma pesquisa, de momento impossível de realizar. Tal significou não considerar Faces de Eva. Estudos sobre a mulher, revista académica, nem Ex æquo, revista da Associação Portuguesa de Estudos sobre as Mulheres, ambas lançadas em 1999 e ambas referenciadoras.

A lista, que não se considera estar completa, pois é expectável a descoberta de outros periódicos, optou por dar prioridade ao ano de publicação, seguido do nome e subtítulo do periódico e do local de publicação. Deste modo, pretendia-se obter leituras passíveis de responder imediatamente às seguintes questões: Quantas revistas foram publicadas por ano, em cada século e no total dos dois séculos? Quais os periódicos que se assumiam como revista? Onde eram publicados? Sumariamente, verifica-se que, dos 131 títulos, 71 foram publicados em Lisboa, 25 no Porto, um simultaneamente em Lisboa e Paris, outro apenas em Paris e os restantes 32 pontuaram de norte a sul em localidades de distinta dimensão. Constata-se que em 1878 foram publicados nove periódicos em locais diversos, estando outros em publicação. Numa análise temática geral, os conteúdos integram-se mais ou menos nos mesmos campos: Higiene e medicina, Crítica e reivindicação, Vida social, Conhecimentos úteis, Receitas culinárias, Moda, Relatos históricos, Costumes, Curiosidades, Literatura, Charadismo e Anedotas. 



\title{
No rasto da passagem de Ferreira de Castro pelos suplemento e revista de A Batalha (1919-1927)
}

Maria João Cabrita*

\begin{abstract}
Eu escrevo em muitos jornais - e em todos eles com independência. Mas há um apenas em que eu me sinto verdadeiramente livre, um apenas em que julgo não serem efémeras as minhas ideias, os meus períodos, as minhas palavras - é neste. É n'A Batalha. Minha pena encontra novas expressões, novas arremetidas, novos entusiasmos. É n'A Batalha onde se pode ter a noção das duas grandes coisas que eu amo na vida, depois de me ter desiludido de muitas outras - o Futuro e a Liberdade. ${ }^{1}$
\end{abstract}

Durante duas décadas, a actividade de jornalista proporcionou a José Maria Ferreira de Castro (1898-1974) a liberdade económica necessária à escrita de seus livros, ao seu sonho de romancista. Filho de uma família humilde de Ossela, em Oliveira de Azeméis, e desde cedo órfão de pai, Ferreira de Castro emigrou para o Brasil com apenas doze anos. Passou parte da sua adolescência a trabalhar em regime de "semi-escravatura" no Seringal Paraíso, no interior da Amazónia, onde redigiu os primeiros contos e a novela Criminoso por Ambição (1916), e posteriormente em Belém do Pará, onde começou a colaborar com alguns jornais locais - Jornal dos Novos e A Cruzada. As dificuldades desta fase da sua existência são, de resto, transpostas para as páginas de $A$ Selva $(1930)^{2}$ - exercício catártico, onde procurou libertar-se da vertigem do seu passado.

Ferreira de Castro desembarcou em Lisboa em 1919, ano em que a central dos sindicatos portugueses, a União Operária Nacional, pouco depois Confederação Geral do Trabalho (CGT), trouxe à luz o seu órgão de imprensa, o diário $A$ Batalha. Este veículo

Centro de Estudos Humanísticos da Universidade do Minho.

1 Castro, Ferreira de, A Batalha, 23 de Fevereiro de 1926, apud Baptista, Jacinto, Surgindo Vem ao Longe a Nova Aurora, Lisboa, Livraria Bertrand, 1977, p. 10.

2 Remetemos para Alves, Ricardo António, Anarquismo e Neo-Realismo, Lisboa, Âncora Editora, 2002, pp. 22-23. 
de ideias anarco-sindicalistas ${ }^{3}$, enraizadas, sobretudo, no "comunismo anarquista" de Kropotkine ${ }^{4}$, abriu de imediato as portas ao jovem recém-chegado, que já contava com alguma experiência nesse universo contíguo à literatura - em especial, destaca-se a sua passagem por todas as secções do semanário Portugal, destinado à comunidade lusa de Belém do Pará, que fundou em 1917 e co-dirigiu.Tanto mais que a sua escrita espelhava naturalmente as ideias libertárias, ideias relevantes do seu modo de ser e estar no mundo, a que permaneceu fiel mesmo nas horas em que a sobrevivência poderia ter ditado o rompimento. Trata-se, como sublinha Ricardo António Alves:

[da] afirmaação da liberdade individual, postura refractária à autoridade, internacionalismo, anti-militarismo, tolerância que excluía conciliação em face de valores essenciais, feminismo e, inclusive, o respeito e comunhão com a natureza, atitude que hoje designaríamos genericamente como ecologista. ${ }^{5}$

Em 1927, o escritor integrou os quadros de O Século, como responsável pela área internacional. Em 1934, cansado da permanente acção da censura sobre os seus artigos e em discórdia com o rumo que João Pereira da Rosa dava ao jornal, pediu uma licença sem vencimento e dedicou-se única e exclusivamente à arte do romance conquanto a sua curta passagem, no ano seguinte, pela direcção do semanário cultural oposicionista O Diabo. Já então a sua fama como escritor lhe permitia viver dos direitos de autor - notoriedade alcançada com a publicação de Emigrantes (1928), biografia de personagens que não têm lugar no mundo, e sobretudo com a Selva (1930), a obra lusófona até à data mais traduzida. A personalidade humanista que perpassa a sua obra - cujos pontos centrais substanciam uma tentativa de compreender o mundo, a consciência da complexidade e contrariedade da natureza humana, e o inconformismo ante a injustiça social - constitui, igualmente, uma referência cívica e moral na luta contra o regime ditatorial e em prol dos direitos humanos.

Dele podemos dizer:foi visceralmente libertário. A sua inclinação natural para os ideais libertários foi alentada primeiramente por leituras desorganizadas e, depois, pelo

3 Sobre o impacte do anarco-sindicalismo na sociedade portuguesa do início do século XX, veja-se Fonseca, Carlos da, Para uma Análise do Movimento Libertário e a Sua História, Lisboa, Antígona, 1988. Sobre o contexto específico de emergência de $A$ Batalha, remetemos para Freire, João, "Revistas anarquistas portuguesas: Entre a política e a cultura", in Revistas Ideias e Doutrinas, Lisboa, Livros Horizonte, 2003, pp. 153-180.

4 Remetemos para Préposiet, Jean, Histoire de l'anarchisme, Paris, Éditions Tallandier, 1993, pp. 262-287.

5 Alves, Ricardo António, Anarquismo e Neo-Realismo, Lisboa, Âncora Editora, 2002, p. 118. 
estudo de algumas obras de sociologia que, como confessaria em 1953, constituíram para si "uma explicação dum mundo que eu sofria, mas não sabia julgar"6. Acabaria por ir ao encontro de Proudhon, Malatesta, mas principalmente de Kropotkine - tendo por preocupação maior o bem-estar da humanidade, as misérias de qualquer e todo o povo do mundo, o seu legado dá-nos disso testemunho. Escritor do proletariado, como sublinhou Jorge Amado, foi um libertário idealista e idílico, um defensor do comunismo sem governo, da síntese entre as liberdades económica e política. Um verdadeiro "Prometeu de si", porque apenas agrilhoado à liberdade - nas palavras de Ricardo António Alves, "foi, no fundo, autor de si próprio"7. E isso reflectem as suas palavras:

(...) levo como único estandarte vitorioso o orgulho da minha independência; o orgulho supremo de não me curvar perante os homens ou mitos, esse orgulho que só possuem e compreendem as almas verdadeiramente livres, sem nenhum estigma de escravidão. ${ }^{8}$

Conquanto alérgico ao encantamento do poder político, que inebria os homens de acção, não deixou de lutar pela causa comum da liberdade sempre que a sua consciência ditou que o fizesse - o seu envolvimento quer no Movimento da Unidade Democrática, durante as Presidenciais de 49, quer na constituição da Sociedade Portuguesa de Escritores, em 1954, foi disso paradigmático. Mais do que apolítico, definiu-se como antipolítico e, enquanto tal, desaprovou a excessiva interferência dos libertários nas organizações dos trabalhadores, escrevendo:

Aos libertários cabe exercer a sua acção ou nos organismos específicos ou nos respectivos sindicatos, mas como simples componente deles e não como mentores. ${ }^{9}$

Individualismo e antibolchevismo completam, com o apoliticismo, o perfil do seu pensamento libertário. Na perspectiva do escritor, a identidade e a prática revolucionárias revelam a consciência individual, a liberdade de escolha. Trata-se, porém, de um individualismo distinto do egoísmo e do alheamento - tanto mais que solidário

6 "Carta de Ferreira de Castro a Winifred L. Chappell - 30 de Outubro de 1953",Idem, p. 195.

7 Idem, p. 162.

8 "Ecos da Semana - A arte, a vida e a sociedade", in A Batalha - Suplemento Semanal e llustrado, Ano II - 9 de Março de $1925-$, n. ${ }^{\circ} 67$, p. 4.

9 "7 de Maio de 1946", apud Pedroso, Alberto e Ventura, António, Alexandre Vieira - 30 Anos de sindicalismo, Lisboa, Edições 1 de Outubro, 1985, p. 137. 
com a sorte dos outros e ciente de que a grande obra do futuro é uma obra colectiva. Afastando-se, assim, do individualismo puro de Max Stirner, acaba por se aproximar do individualismo mutualista proudhoniano.

Diferentemente de outros libertários, Ferreira de Castro compreendeu a hostilidade proudhoniana à emancipação das classes trabalhadoras pela via política, tal como defendido por Karl Marx, e opondo-se ao comunitarismo autoritário, vitorioso na Revolução Russa, reviu-se no antibolchevismo de Kropotkine. A sua crítica ao poder soviético alcança o ápice em "O ódio da proscrita", o conto que encerra $A$ Casa dos Móveis Dourados (1927), onde cognomina Lenine de "novo ditador" e sublinha:"Agora os proscritos da Rússia já não são os aristocratas, mas sim os revolucionários que discordam dos actuais dirigentes... Todos eles têm sido postos na fronteira"10.

Para o escritor, negar a autoridade significou afirmar a liberdade e, por isso mesmo, se reviu como "libertário", e não como "anarquista". Como esclareceria Campos Lima, em A Teoria Libertária ou o Anarquismo (1926), enquanto o termo "anarquista" assume um sentido negativo, dado traduzir "o que não é," o termo "libertário" incorpora igualmente "o que é" - negar a autoridade não significa que se negue qualquer espécie de organização.

\section{De que modo os pilares do pensamento libertário de Ferreira de Castro se revelam na sua passagem pelos suplemento e revista de $A$ Batalha?}

No seu quarto ano de existência, a 23 de Dezembro de 1923, A Batalha trouxe a público um suplemento semanal, inicialmente intitulado $A$ Batalha - Suplemento Literário e llustrado e posteriormente, a partir do número catorze, A Batalha Suplemento Semanal Ilustrado. Suplemento de oito páginas, contendo artigos de divulgação cultural e de intuito educativo - como denotam as secções "O que todos devem saber" e "Zico \& Zeca", esta última dirigida às crianças, que preenchiam as duas últimas páginas -, foi publicado à segunda-feira, até 31 de Janeiro de 1927, perfazendo 166 números. No artigo de abertura, revelava o seu desígnio nos termos seguintes:

Órgão de exposição doutrinária e elemento de educação e de aperfeiçoamento moral e intelectual, ele destina-se a ser o companheiro espiritual do operário e a contribuir para a formação da sua consciência revolucionária, ao mesmo tempo que deseja despertar o raciocínio, para as ideias renovadoras que defendemos, dessas outras classes chamadas,

${ }^{10}$ Castro, Ferreira de, A Casa dos Móveis Dourados, Lisboa, Edições Spartacus,1927, p. 182. 
quer pela sua situação de exploradoras quer pela função útil que desempenham, a colaborar na obra de transformação social que empreendemos. ${ }^{11}$

Em 1925, a CGT alargou o seu meio de difusão do ideário libertário, da ideia de que "só o estudo cria uma ideologia consciente e coerente, capaz de fazer raiar de vez a Verdade e a Justiça"12, através da publicação de uma revista quinzenal de arte, literatura e actualidades, de "novos horizontes sociais", a Renovação - cuja existência, de 2 de Julho de 1925 a 15 de Junho de 1926, não ultrapassaria os 24 números. A emergência desta nova publicação revelou, como sublinha Jacinto Baptista, a falta de unanimidade, no seio quer da cúpula da Confederação, quer da própria redacção de $A$ Batalha, sobre o alcance do suplemento face às necessidades de propaganda.

O autor de $A$ Selva colaborou assiduamente nestas duas publicações, onde assinou 134 artigos sobre uma variedade de temas: sociais, literários, políticos, ideológicos, etc. - quer sob forma de crónica, quer sob a de conto. Integrando, assim, um grupo de colaboradores que contou, para além de militantes operários, com a "elite" do anarquismo, do sindicalismo e da intelectualidade portuguesa: Pinto Quartim, Emílio Costa, Eduardo Frias, Campos Lima, Adolfo Lima, César Porto, Adelaide Cabette, Arnaldo Brasão, Cristiano Lima, Bento Faria, Jaime Brasil, Julião Quintinha, Nogueira de Brito e Mário Domingues, entre outros.

Para além de artigos dispersos pelas páginas do suplemento literário de $A$ Batalha, do número 5 ao 152, assinou as secções "Nota de arte"; "A arte e a vida"; "Motivos para águas-fortes"; "Ecos da Semana - A arte, a vida e a sociedade"; e "A Epopeia do trabalho" - os textos desta secção estiveram na origem da publicação de um livro com o mesmo título, em 1926. Na revista dirigida por Santos Arranha, assinou dezasseis crónicas - sobre a arte e o seu papel educativo, o trabalho, a injustiça social, os intelectuais e a ditadura, o escritor revolucionário Alberto Ghiraldo, a natureza, a morte dos apóstolos, a ideia evolutiva da justiça, etc. -, para além de dois artigos intitulados "Ideologia". Por si só, a colecção de artigos assinados pelo escritor no suplemento e na revista do órgão da CGT reflecte a energia fecundante das ideias libertárias que impregnou toda a sua obra, a sua revolta por viver numa sociedade que despertava não mais que desdém e indignação nas gerações futuras.

\footnotetext{
11 "Saber para poder. Saber o que se pode fazer", in A Batalha - Suplemento Literário e llustrado, Ano I - 3 de Dezembro de $1923-$, n. ${ }^{\circ}$, p. 1.

12 Idem, ibidem, p. 1.
} 
A arte social constituiu um dos temas de fundo abordados por Ferreira de Castro ao longo desta colaboração. Na perspectiva do escritor, Émile Zola foi o grande fomentador de toda a arte social - "abriu novos horizontes moraes, novos firmamentos espirituais, na noite tenebrosa em que vem vivendo a Humanidade, sob o poderio do Ouro, sob o domínio da Força"13 -, promovendo, assim, a ideia emancipadora que revelou o segredo da libertação ao escravo. Mas não se deve confundir a arte com a vida, tal como tendem a fazer o realismo ou o naturalismo. Como sublinha o escritor:

Pintar, com o sangue do coração lacerado, a Dor, a Miséria, a Opressão - esse é o papel da Arte Social. Desentranhar a Verdade, destruir os bonzos do Preconceito, despedaçar as griIhetas dos Dogmas, incinerar as múmias do Passado - essa é a missão do artista revoltado.

Mas tudo isso, como processo artístico, é ainda fixar aspectos da Vida e da não Vida em si, - não é consorciar totalmente a Vida como Arte - é, pelo contrário, engrandecer a Vida, envolvendo-a em ideal e elevando-a até à Arte. ${ }^{14}$

Na perspectiva de Ferreira de Castro, a arte social e a arte moderna são indissociáveis - mas a arte social não se limita a tratar dos estatutos sociológicos, nem deve ser compactada em fórmulas, como a entendiam alguns artistas do século XIX, dado que deve ser livre. Repudiando o classicismo e os seus sacerdotes, porque inimigos da liberdade, alerta:"criemos uma beleza nova, que corresponda à vida, à sensibilidade e à mentalidade contemporâneas"15. Tanto mais que a genialidade do artista dimana dos caminhos que trilha, do que traz de novo, e não da facilidade com que se coloca na via percorrida pelos outros - como viria a sublinhar em "Arte Moderna"16. Novidade incompreendida pela crítica, que só por isso suscita uma apreciação negativa:

Crítica... Trabalho de traças, fundindo-se vorazmente, ingloriamente na obra-alheia; broca em tarefa destruidora, já que lhe está vedada toda a ideia-creadora: - lápis negro anotando à margem critérios que levam a si o condão de fazer sorrir aos lábios austeros da Posteridade... ${ }^{17}$

13 "O imortal Zola", in A Batalha - Suplemento Semanal e llustrado, Ano I - 9 de Março de 1925 - n. ${ }^{\circ} 30$, p. 5.

14 "A arte e a vida" - "A verdade na literatura", Idem, ibidem - Ano I - 22 de Setembro de 1924 - n. ${ }^{\circ} 43$, p. 3.

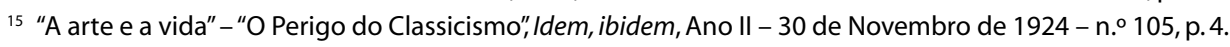

16 Renovação, Ano I - 1 de Março de 1926 - n. ' 17, pp. 6-7.

17 "A missão da crítica", in A Batalha - Suplemento Literário e llustrado, Ano I - 14 de Janeiro de 1924 - n. 7 , p. 5 . 
O que se revela fecundo numa personalidade criativa é destrutivo na crítica, fruto de um trabalho de negação, de um critério individual. Por isso, as obras imortais têm sido repudiadas pela crítica: "Nenhum génio jámais satisfez à critica do seu tempo, acostumada a lisonjear a mediocridade" (p. 5) - tendo por função amarrar a arte ao poste do passado, dado crescer sobre a impressão do que já foi feito, mesmo que não visto e, pior, do que já foi dito. Ferreira de Castro mostra o abismo entre a tradição crítica francesa e a portuguesa: enquanto aquela tem hábitos de probidade, esta não os tem - não passa do culto da mediocridade, elevado por "espermatozóides da nulidade"18. Obedecendo a ideias feitas, a clichés literários, os críticos portugueses analisam a obra alheia conforme os seus padrões estéticos, morais, artísticos e sociais - uma obra é boa, quando em sua conformidade ${ }^{19}$.

Do mesmo modo que os críticos, o academismo exalta o passado:

(...) as academias não são mais do que um edifício mui vetusto, a procura de quem o desmorone definitivamente ou de quem o restaure - actualisando-o.

As academias podiam ter alguma utilidade, se nelas não imperasse o espírito da senilidade - o espírito do Passado. ${ }^{20}$

As academias são negação de talento e de evocação, o sepulcro dos horizontes modernos e um "jazigo de vaidades"21. Não indicam, nem revelam o futuro; diferentemente dos intelectuais - bússola da humanidade, das novas aspirações e novos anelos da liberdade. Por isso mesmo, nenhum intelectual livre se encontra à vontade no seio de uma academia. Sob a égide do Futuro e como ministro da ideia, todo o intelectual deve ser guardião da sua época. Disso nos dá conta em "A campanha de Marrocos"22, ao defender que todo o intelectual ibérico deve protestar contra a barbaridade que os espanhóis infligem aos mouros, e em "Os Intelectuais e as Ditaduras"23, entre muitos outros artigos.

\footnotetext{
18 Idem, ibidem, p. 6.

19 Remetemos para "Quem fomenta a 'publicidade exagerada' e quem edita os 'maus livros', prejudicando a cultura popular",Idem, ibidem, Ano II - 23 de Novembro de 1924 - n. ${ }^{\circ}$ 104, pp. 5-6.

20 "Os falsos templos da ciência e da arte", in A Batalha - Suplemento Semanal e Ilustrado, Ano II - 1 de Dezembro de $1924-$ n. ${ }^{\circ}$ 53, p. 1.

21 Idem,ibidem, p. 2.

22 A Batalha - Suplemento Semanal e llustrado, Ano I- 15 de Setembro de 1924 - n. ${ }^{\circ}$ 42, pp. 1-2.

23 Renovação, Ano I - 15 de Março de 1926 - n. ${ }^{\circ}$ 18, pp. 1-2.
} 
A consideração da ditadura como uma salvação constitui, na perspectiva do escritor, o último cartucho gasto pelos reaccionários, dado os moldes do mundo coevo serem distintos dos de um passado recente ${ }^{24}$. Em "Os intelectuais e as ditaduras", confere aos intelectuais a missão de desfazerem "o ninho onde a víbora reaccionária vai distendendo os seus aneis" 25 - em nome do espírito moderno, da civilização e da inteligência devem combater o eclipsar da liberdade que configuram as ditaduras. E alerta para a crise da intelectualidade portuguesa:

Confesso com tristeza, com desolação, que não creio muito na acção combativa dos nossos intelectuais contra uma possível, embora efémera ditadura. E não creio, porque nós sofremos uma crise de intelectualidade, que é a pior de todas as crises - porque é a crise-mãe, a que fecunda e cria todas as outras. Não temos intelectuais dignos dêste nome - é dizer, intelectuais criadores. ${ }^{26}$

É evidente o seu combate contra a imprensa burguesa, sobretudo contra a falta de criatividade e rebeldia dos jovens publicistas que aí escrevem e se auto-intitulam de "intelectuais". Mas nem por isso perde a esperança em ver hasteada a bandeira da inteligência, ou seja, da liberdade - inquieto e sofrido, o povo acabará por içá-la.

Esta ideia de crise da intelectualidade já perpassara, de resto, a crítica do escritor à proposta de boicote à literatura alemã, feita por alguns intelectuais no Congresso da Imprensa Latina, em 192427. Questionou:"Que intelectuais são esses que pedem a decapitação duma espiritualidade e duma celebração que têm direito a ser internacionais?"28. Em vez de criar fronteiras à arte e ao pensamento, como o faz a ideologia subjacente a esta proposta, a ideologia do escravo, os intelectuais devem eliminá-las.

Sob o estigma da arte social, Ferreira de Castro escreve, na secção "A Arte e a Vida" do suplemento, uma série de cinco artigos sobre a literatura branca - "O culto da literatura branca"29;"O sexo na literatura e a sua evolução desde os incestos das tragé-

\footnotetext{
24 Veja-se "Está queimado o último cartucho da burguesia", in A Batalha - Suplemento Semanal e llustrado, Ano III - 21 de Junho de 1926 - n. 134 (III Ano), p. 1.

25 Renovação, Ano I - 15 de Março de 1926 - n. ${ }^{\circ}$ 18, p. 1.

26 Idem, ibidem, p. 1.

27 Veja-se "Os Intelectuais Alemães", in A Batalha - Suplemento Semanal e Ilustrado, Ano I - 10 de Março de 1924 - n. 15 , pp. 4-6.

28 Idem, ibidem, p. 4.

${ }^{29}$ A Batalha-Suplemento Semanal e llustrado, Ano III - 12 de Abril de 1926 - n. 124 , p. 1.
} 
dias clássicas à novela contemporânea" ${ }^{\prime \prime 0}$; As características da literatura branca"131;“O teatro mercenário e a literatura branca"32; $\mathrm{e}$ "Os perigos da literatura branca" ${ }^{13}$ - assim como artigos sobre a crise do livro e do teatro. A literatura branca - literatura sem intenções ou véus, apregoada pelos editores e directores sob intuito mercantilista resulta, naturalmente, do ambiente reaccionário coevo. Como sublinha o escritor, no artigo de abertura da série subordinada ao tema,"não se necessita agora de escritores, necessitam-se de eunucos, cujas palavras tenham a mesma inútil neutralidade da sua virilidade perdida..." ${ }^{\prime \prime 4}$.

Em contraposição à "literatura vermelha" - que reivindica, em nome da liberdade, da literatura e da verdade da vida -, caracteriza a "literatura branca" de "prosa burguesa, industrial, sem ideias, sem revelação de almas, sem nada de nobre, de elevado, a justificar o papel que gastou para ser impresso" ${ }^{\prime \prime 35}$. E todo o escritor que bajula a burguesia, como inimigo da verdade, é cúmplice dos seus defeitos, dos seus vícios e da sua religião, como um falso moralista despido de qualquer anseio renovador. Branqueamento que enfraquece mais a literatura novelesca que a dramaturgia. Sobre as "peças brancas",escreve:"o teatro que não ofende preconceitos e lisongeia a burguesia está mais livre, mais audacioso, do que a pálida literatura que aqui ando a combater ${ }^{136}$. Mais convencional do que o teatro - o que em si constitui um paradoxo, dado que este se dirige a um auditório composto pelo mais variado público -, a"literatura branca" embarga a renovação literária e ideológica, constituindo, deste modo, um perigo para a mentalidade moderna.

No artigo de encerramento desta série temática, o escritor demora-se na análise dos perigos decorrentes desta feição literária e, curiosamente, alerta para o facto de constituir uma ameaça para a legião de mulheres que constituem um exemplo de emancipação - conquanto sejam os homens, e não as mulheres, os potenciais compradores dos livros fúteis escritos por Júlio Dantas, os seus discípulos nacionais e mestres estrangeiros. $O$ escritor vê neste tipo de literatura a espada sabiamente manejada pela burguesia e pela Igreja contra toda a rebeldia e insubmissão, e alerta:

\footnotetext{
30 Idem, Ano III - 19 de Abril de 1926 - n. ${ }^{\circ} 125$, p. 4.

31 Idem, Ano III - 26 de Abril de 1926 - n. ${ }^{\circ} 126$, pp. 4-5.

32 Idem, Ano III - 3 de Maio de 1926 - n. ${ }^{\circ} 127$, p. 4.

33 Idem, Ano III - 10 de Maio de 1926 - n. ${ }^{\circ} 128$ (III Ano), p. 5.

34 "O culto da literatura branca", in A Batalha - Suplemento Semanal e Ilustrado, Ano III - 12 de Abril de 1926 - n. 124, p. 1.

35 "O sexo na literatura e a sua evolução desde os incestos das tragédias clássicas à novela contemporânea", Idem, Ano III - 19 de Abril de 1926 - n. 125, p. 4.

36 "O teatro mercenário e a literatura branca", Idem, Ano III - 3 de Maio de 1926 - n. ${ }^{\circ}$ 127, p. 4.
} 
Combatê-la é o nosso dever. Em nome do espírito moderno. Em prol da verdadeira literatura. Contra a reacção dominante. Contra o espírito retrógrado, jesuíta, de que essas novelas brancas são folhas dispersas, mas perigosas. ${ }^{37}$

Com a mesma sapiência, manifestara a sua indignação ante as afirmações feitas por alguns livreiros de Lisboa sobre a crise do livro ${ }^{38}$. Estes atribuíam-na a dois factores: ao exagero de publicidade a obras más e parcialidade da critica jornalística; e à abundância editorial do mau livro resultante da publicação de autor. Sobre o primeiro, Ferreira de Castro lembrou o seu combate ao modo amistoso, parcial e inútil com que se faz crítica em Portugal - como atrás referido. Neste sentido, ser-se bom escritor depende da amizade que se tem com algum crítico e do lugar que ocupa na sociedade. Qualquer escritor que extravase as fronteiras do universo de valores do crítico é tido por "modernista" ou "subversivo" - mas só estes acompanham a evolução literária. E na verdade, segundo o escritor, esse exagero e essa parcialidade ficam-se a dever aos próprios editores, dada a relação que incrementam com os jornalistas e jornais com o intuito de aumentarem as vendas. Por outro lado, boicotar a entrada de novos escritores no mundo literário pode trazer, por consequência, a ruína de trilhos futuros. Os editores, através das suas políticas editoriais, viradas para o lucro e não para a revelação de novos talentos, boicotam a evolução do gosto do grande público.

Educar o público constitui, igualmente, uma preocupação de Ferreira de Castro no âmbito do teatro - manifesta-se solidário com a ideia de Eduardo Frias, de "criar um público para o bom teatro, um público que possa dar com a sua presença, aplaudindo ou reprovando, uma orientação à escolha dos futuros repertórios"39. O escritor considera o teatro (industrial) como a arte mais inferior, comum e mesquinha que existe em Portugal; e disso nos dá conta em "O mercantilismo e a miséria artística do teatro português":

Não há uma idea a presidir, a engrandecer, a justificar a existência do teatro. Só há apetites; ambições, industrialismos, subserviências, interesses comerciais - sede de dinheiro, ânsia de imerecida glória! ${ }^{40}$

37 "Os perigos da literatura branca", Idem, Ano III - 10 de Maio de 1926 - n. ${ }^{\circ} 128$ (III Ano), p. 5.

${ }^{38}$ Remetemos para "Quem fomenta a 'publicidade exagerada' e quem edita os 'maus livros', prejudicando a cultura popular", Idem, Ano II - 23 de Novembro de 1924 - n. ${ }^{\circ} 104$, pp. 5-6.

39 "Ecos da Semana - A arte, a vida e a sociedade", Idem, Ano II - 30 de Novembro de 1924 - n. ${ }^{\circ}$ 105, p. 4.

40 Idem, Ano III - 28 de Junho de $1926-$ n. ${ }^{\circ} 135$, p. 2. 
Mesmo o Teatro Nacional, que deveria estimular e facultar as revelações, demitiu-se deste papel, limitando-se, tal como os outros, a disputar as simpatias do grande público ${ }^{41}$. A preponderância dos interesses materiais atrofia, amesquinha e industrializa a arte. A arte livre exige uma sociedade nova, também ela livre. Proclamar a liberdade de ambas equivale a anunciar a morte dos seus estatutos ${ }^{42}$.

Também no âmbito educativo, o autor considera que a literatura infantil não cumpre a sua missão ${ }^{43}$. Os escritores que se dedicam a este tipo de literatura não se apercebem da sua responsabilidade social - as crianças de hoje são os adolescentes de amanhã e os adultos do depois de amanhã - e acabam por envenenar o espírito infantil,com a fábula, o sobrenatural e o dogma. Na perspectiva do escritor, o homem deve conhecer desde a sua infância os signos da Verdade; do mesmo modo que a sociedade, dando ouvidos à psicologia, antropologia e pedagogia modernas, deve proteger a criança das misérias da vida ${ }^{44}$.

Ainda no capítulo da arte, Ferreira de Castro assina recensões de livros, crónicas sobre a máquina na arte contemporânea que, na sua perspectiva, constitui uma afronta ao reaccionarismo burguês ${ }^{45}$, e o cinema. Sobre este último, assinala o seu papel artístico e educador no seio da colectividade ${ }^{46}$. Tal como na literatura e no teatro, sob orientação mercantilista, o cinema contemporâneo - em especial os filmes americanos envenena os espíritos, mantém as multidões nas trevas, demitindo-se da sua função educativa. No âmbito artístico, constitui um privilégio europeu, sobretudo francês e alemão. Arte nova, para além do teatro e do romance, o cinema tem "um grande papel renovador, pela sua sugestão estética, sentimental e ideológica"47, proporcionando à humanidade novas e valiosas conquistas.

${ }^{41}$ Veja-se "Ecos da Semana - A arte, a vida e a sociedade", Idem, Ano II - 6 de Abril de 1925 - n. ${ }^{\circ}$ 71, p. 2. O autor tece neste artigo uma crítica à estreia da peça Abade Constantino no Teatro Nacional - uma peça obsoleta que, na sua perspectiva, não deveria sair dos arquivos. Considera que o Teatro Nacional cumpre mal a sua função ao ressuscitar peças obsoletas em detrimento da divulgação da dramaturgia moderna, de novos ideais.

42 "A Arte e a Vida - Os intuitos sociais da actual literatura italiana", Idem, Ano III - 28 de Dezembro de 1925 - n. ${ }^{\circ} 109$, p. 4.

43 Remetemos para "O que se escreve e o que é necessário escrever para a educação da criança", Idem, Ano II - 6 de Janeiro de 1925 - n. ${ }^{\circ} 58$, p. 2

44 Veja-se "A Sociedade e o Problema Infantil,"Idem, Ano II - 25 de Maio de 1925 - n. 78, pp.4-5. Este número foi dedicado à semana da criança.

45 Vejam-se "A Arte e a Vida - A máquina na arte contemporânea", Idem, Ano III - 7 de Dezembro de 1925 n. ${ }^{\circ}$ 106, p. 4; e "A Arte e a Vida - O espírito perante a máquina", Idem, Ano III - 14 de Dezembro de 1925, n. ${ }^{\circ}$ 107, pp. 5-6.

46 “O cinema moderno e o seu papel artístico e educador",in Renovação, Ano I - 15 de Maio de 1926 - n. ${ }^{\circ} 22$, pp. 10-11.

47 Idem, ibidem, pp. 10-11. 
A injustiça social constitui, igualmente, horizonte de investida da escrita de Ferreira de Castro nas duas publicações de $A$ Batalha, quer através das suas abordagens sobre a epopeia do trabalho e inserção da mulher nesse mundo, quer sobre a deportação, o colonialismo e a farsa da justiça, quer sobre a censura.

Na secção “A Epopeia do Trabalho", publicada no suplemento entre os números 75 e 95 , escreveu crónicas sobre os mais diversos ramos da actividade humana - os pescadores, os ferreiros, os mineiros, os cavadores, os sábios, os lenhadores, os tipógrafos, os carregadores, os escritores, os escultores, os ceifeiros, os construtores, as costureiras, as dactilógrafas e os fogueiros -, mostrando o que cada uma delas tem de sublime e de desespero. Sobre o propósito destas crónicas, escreve:

Só o trabalho é hoje verdadeiramente epopeico (...).

E o homem vai marcando sob a égide desse trabalho assombroso, que é feito de dor e de alegria, mas sempre triunfante e construtivo, extraordinárias horas de epopeia.

Hoje Homero teria de recrutar as suas legiões heróicas entre os que trabalham.

Os operários são os verdadeiros heróis contemporâneos. ${ }^{48}$

Ilustradas por Roberto Nobre - seu companheiro de ideias e de vida, tal como Jaime Brasil -, estas crónicas constituem, no seu conjunto, uma moldura humana e social da época, ilustrativa dos sacrifícios a que se submete a maior parte dos trabalhadores, de uma miséria epidérmica. É na alma destes mártires sociais que vive a revolta emancipadora; porque entre eles soa a voz de revolta contra as péssimas condições em que desenvolvem as suas actividades, muitas delas imprescindíveis ao bem-estar da minoria detentora do poder económico. $\mathrm{O}$ eco da voz de quem não vive, mas unicamente sobrevive, consumido até à exaustão. A título de exemplo, retenhamos o olhar sobre o fado dos "detentores de todas as chaves do Alfabeto", os tipógrafos:

E trabalham e trabalham, na penumbra das oficinas e ali são como sacerdotes do Génio Humano até que a morte lhes apague a última energia ou até que a tuberculose, que é o númen de fatalidade da nobre profissão, lhes torne cor de marfim a parte das mãos que os tipos não enegreceram. ${ }^{49}$

48 "A Epopeia do Trabalho", in A Batalha - Suplemento Semanal e llustrado, Ano III - 22 de Novembro de 1926 - n. ${ }^{\circ} 156$, p. 5.

49 "A Epopeia do Trabalho - Os Tipografos", Idem, Ano II - 30 de Junho de 1925 - n. 83 , p. 5. 
Constituem os quadros destas crónicas o mais profundo manifesto da indignação de Ferreira de Castro face a uma sociedade de antíteses, de ouro e sangue, de capitalistas e esfomeados, manifesto que se alastra por alguns artigos da Renovação:"As profissões humildes - A alma nómada dos amoladores de tesouras e navalhas" ${ }^{0}$; "Natal sem pão e sem liberdade" ${ }^{\prime \prime}$; $\mathrm{e}$ "O inverno e os pescadores" alertou, entre outras coisas, para a necessidade de os trabalhadores conquistarem férias pagas, pois, contrariamente à opinião dos exploradores, não se trata de um luxo, mas de uma exigência do físico, exausto por um labor diário ${ }^{53}$. Constitui essa conquista um bem tanto para o indivíduo como para a colectividade em que se empenha, reconhecido, então, por uma grande parte da comunidade internacional.

Quero argumentar com o Brazil, em cuja capital os empregados do comercio conseguiram já as ferias anuaes, sem redução dos seus salários. Quero argumentar com a Alemanha, a Austria, a Holanda, a Dinamarca, a Noruega e a Suécia, cujo patronato, em maioria, reconheceu a necessidade desse descanço anual, e em minoria, isoladamente - oh! triste falta de solidariedade nos gestos nobres! - já o tem concedido. Porque não se iniciar, então em Portugal, esse mesmo movimento, esse movimento humanitário, de profundo interesse social, que em França vem sendo defendido por nomes ilustres na Sciencia e nas Letras? ${ }^{54}$

A par desta reivindicação, escreve sobre a incursão da mulher no mundo do trabaIho. A emancipação da mulher constitui um dos temas mais caros ao ideário libertário que perpassa as publicações de $A$ Batalha - o inquérito sobre a integração da mulher na vida sindical levado a cabo pelo suplemento, a partir do número 39, é disso paradigmático. A anteceder este gesto fomentado pela CGT, Ferreira de Castro escreveu, em "O esforço da mulher na vida moderna"

Quebrados evidentemente os elos de preconceitos vetustos, a mulher desfruta hoje de uma maior liberdade - mas logo esta conquista foi aproveitada pela burguesia, logo com os destroços dos grilhões despedaçados os burgueses fundiram novas algemas. ${ }^{56}$

\footnotetext{
50 Renovação, Ano I - 15 de Outubro de 1925 - n. ${ }^{\circ}$ 8, p. 11.

51 Idem, Ano I - 1 de Janeiro de 1926 - n. 13 , pp. 4-5.

52 Idem, Ano I - 15 de Fevereiro de 1926 - n. 16 , pp. 6-7.

53 Veja-se "Ante os Pórticos do Estio - Lutemos pelas férias dos que trabalham!", in Renovação, Ano I - 2 de Julho de 1925 - n. 1 , pp. 10-11; e "E enquanto os opulentos senhores se divertem", in A Batalha Suplemento Semanal e llustrado, Ano III - 13 de Julho de 1926 - n. ${ }^{\circ} 137$, p. 4.

54 "Ante os Pórticos do Estio - Lutemos pelas férias dos que trabalham!", p. 11.

55 A Batalha - Suplemento Semanal e llustrado, Ano I - 9 de Junho de 1924 - n. ${ }^{\circ} 28$, pp. 4-5.

56 Idem, ibidem, p. 4.
} 
Em conformidade com a opinião dominante no seio do movimento sindical, considerou a remuneração miserável da mulher como um pretexto para a burguesia explorar também o trabalho dos homens; ou seja, a sua entrada no mundo do trabalho sob o intuito quer de se emancipar, quer de contribuir para a economia familiar acabou por criar "um problema grave a que os exploradores do trabalho alheio dificultam a solução" ${ }^{\prime 57}$. Combatente da sociedade que mantém a mulher na dependência económica do homem, alertou para o facto de a sua emancipação dever ser conquistada sem sacrifício do virtuosismo que lhe é característico, sem desvios da senda da sua vida; reconhecendo a maldição que recai sobre este esforço: "uma sentença iníqua, lançada postumamente sobre a cabeça da Eva"58.

O degredo constitui um outro tema de demora da passagem de Ferreira de Castro na imprensa anarquista, tanto mais que a sua experiência de emigrante desprotegido fez crescer em si uma ternura pelos exilados. De um ponto de vista lógico, a deportação constitui um contra-senso, pois querer desterrar todos os perturbadores da "paz" burguesa corresponde a deportar o país inteiro. Trata-se de um acto que afronta os direitos dos homens, direitos conquistados com tantos sacrifícios. Revoltado ante esta injúria, o escritor denuncia a traição e o tráfico da liberdade por parte dos políticos, questionando:

Que Ihes importa que a Liga dos Direitos do Homem, as personalidades venerandas da república e as classes operárias protestem, se eles sabem que uns não sairão do campo ideológico e que para os outros têm as cabinas e os sabres da guarda republicana? ${ }^{59}$

Na sua perspectiva, os políticos não têm qualquer autoridade moral para ordenar deportações e acabam, por imposição da força, por violar a justiça burguesa - a ideia de que a prisão deve constituir um meio de reeducação e não um castigo - e humilhar a mentalidade contemporânea. Os barcos que partem para África repletos de exilados são comparáveis aos que dela vieram com os porões cheios de escravos ${ }^{60} .0$ termo "degredo" oculta um destino inexorável, traz à presença um quadro "de côres sinistras (...) onde os personagens soluçam, gritam e se contorcem; mães, filhos, irmãos, pais velhinhos e

57 Idem, ibidem, p. 5.

58 Idem, ibidem, p. 5

59 "As deportações como afronta à nossa época e à nossa mentalidade", in A Batalha - Suplemento Semanal e llustrado, Ano III - 4 de Janeiro de 1926 - n. ${ }^{\circ} 110$, p. 1.

60 "A caminho do degredo - e as responsabilidades da sociedade", in Renovação, Ano I - 15 de Novembro de $1925-$ n. ${ }^{\circ} 10$, p. 6. 
tropegos" ${ }^{\prime \prime 1}$; uma tela descrita pelo escritor na hora da realização de mais uma deportação em massa decretada pela justiça; e que assinala a urgência em se romper com o silêncio que envolve esta tragédia. Mais do que noticiar o degredo, a imprensa tem a obrigação de revelar a dor dos que partem e dos que ficam a chorar a sua partida.

Esses, que são obrigados a abandonar a sua família - quando a têm - e a sua terra, não passam, frequentemente, de homens em demanda da sobrevivência, de trabaIho, de tecto e de comer, numa sociedade que teima em explorá-los e em mantê-los na mais profunda ignorância, distantes do sol sadio - "esse sol da razão que aviva as células de todos os sentimentos bons" ${ }^{\prime \prime 2}$. Na perspectiva de Ferreira de Castro, a redução dos crimes que levam ao degredo resultará, tão-somente, de uma profunda transformação social - enquanto a sociedade, em nome do egoísmo burguês, extorquir a carne dos sacrificados, de pouco valerá a palavra dos sábios da criminologia. Urge deslocar-se a ênfase, da punição para a preservação.

A completar a abordagem deste tema, em "O deportado" ${ }^{63} \mathrm{o}$ escritor debruça-se sobre o sentimento que vai na alma de quem vive essa experiência sufocante, sob um céu de cor de chumbo, e que acaba por descobrir que a verdadeira crueldade e tirania reinam na terra de onde vem, da civilização que o transformou numa fera, e não para onde vai - aí só paira a sua sombra. Terra em que a justiça constitui uma farsa, pois de outro modo seria a mesma para todos, e não é, como de resto veio a mostrar a absolvição dos implicados na tentativa de golpe militar de 18 de Abril de 1925. Um perdão que simboliza, nas palavras do escritor:

o triunfo duma casta sobre tôdas as regalias, sobre todas as liberdades, conquistadas com o sangue de muitas gerações, demonstrando também a necessidade de defesa que os homens livres devem tomar, para que o cérebro não seja esmagado pelos pés. ${ }^{64}$

Da mesma forma que critica a exploração da mão-de-obra na sociedade coeva, repugna o colonialismo e a sua política de pilhagem. Ao comentar a campanha dos espanhóis em Marrocos ${ }^{65}$, escreve:

61 Idem, ibidem, p. 6.

62 Idem, ibidem, p. 6.

63 Renovação, Ano I - 15 de Dezembro de 1925 - n. 12, p. 8.

64 "As Metamorfoses da Justiça: O significado do julgamento", in A Batalha - Suplemento Semanal e llustrado, Ano II - 5 de Outubro de 1925 - n. 97, p. 1.

65 Veja-se "A campanha de Marrocos", Idem, Ano I - 15 de Setembro de 1924 - n. ${ }^{\circ}$ 42, pp. 1-2. 
A missão de Espanha e de Portugal, a missão da península através dos últimos séculos, não foi a de civilizar, como se diz na História, foi a de pilhar e a de escravizar. ${ }^{66}$

Consequentemente, é incompreensível que se cognomine de "heróicos" feitos que, à data, não podem ser compreendidos senão como "actos de pirataria" - Vasco da Gama constitui um desses heróis que o escritor reconhece como salteador ${ }^{67}$. Diferentemente, aplaude o gesto de todos os revoltados contra a escravatura, da que os ingleses impõem na Índia, os espanhóis em Marrocos, e os portugueses na costa de África ${ }^{68}$. Mas o nascimento do homem livre pressupõe a morte dos apóstolos - se na Europa é já um facto, nos países colonizados é algo que está por vir -, sejam estes religiosos ou ateus. Descrença que constitui a vitória da humanidade:

Pois só é verdadeiramente emancipado aquele que não é discípulo, aquele que não é fiel, aquele que não é mestre nem sacerdote. As ideias só são verdadeiramente emancipadoras quando estão no espírito dos homens e não quando para se comungar nelas se tem de adorar a um só homem. A grande obra do futuro tem de ser uma obra colectiva. ${ }^{69}$

Da mesma forma que cresce para além do universo de crenças, seitas e dogmas, o homem livre deve derrubar as muralhas que separam as raças. A liberdade, diferentemente da religião, permite a união entre elas ${ }^{70}$. Ser-se um homem livre significa estar-se liberto das grilhetas morais da religião, seja esta qual for, viver-se com os olhos postos no futuro, e não no passado, tanto mais que a evolução das ideias assim o exige.

Presença constante do suplemento, interrompida apenas com a sua estadia em Madrid, entre meados de Dezembro de 1925 e princípios de Abril do ano seguinte, de onde trouxera a promessa de colaboração de alguns escritores rebeldes espanhóis ${ }^{71}$, Ferreira de Castro acabaria por embater de frente no edifício da censura, instalado

66 Idem, ibidem, p. 1.

67 Veja-se "Ecos da Semana - A arte, a vida e a sociedade", in A Batalha - Suplemento Semanal e llustrado, Ano I - 20 de Abril de 1925 - n. ${ }^{\circ} 73$, p. 6.

68 Remetemos para "Gandhi, o revolucionário indiano", Idem, Ano I - 3 de Março de 1924 - n. ${ }^{\circ} 14$ pp. 4-5.

69 "A morte dos apóstolos", in Renovação, Ano I - 15 de Maio de 1926 - n. 1, p. 2.

70 Veja-se "O Ouro de Israel e a Situação da Raça Proscrita", in A Batalha - Suplemento Semanal e llustrado, Ano II - 23 de Março de 1925 - n. ${ }^{\circ}$ 69, p. 4.

71 Veja-se "A Obra de Ferreira de Castro - O seu subjectivismo e objectivismo estudados por um escritor espanhol",Idem, Ano III - 19 de Abril 1926 - n. ${ }^{\circ} 125$, p. 7. 
após o golpe militar de 28 de Maio de 1926, que esteve na origem do Estado Novo. A 22 de Junho, $A$ Batalha recebeu, como de resto todos os jornais da capital, um ofício que estabelecia a censura à Imprensa, obrigando a saída das publicações à entrega de quatro exemplares no Comando-Geral da GNR. Instituiu-se, assim, um mecanismo oficial de controlo e repressão que se manteria, sob diversas formas e intensidades, até à Revolução de 25 de Abril de 1974. Como Ferreira de Castro suspeitava, a burguesia, com o apoio militar, havia lançado a sua bóia de salvação.

O número do suplemento que se seguiu à instauração da repressão abriu com um artigo do escritor contra esse estado de coisas, o profundo golpe infringido pelo militarismo triunfante, vestido nos tons do fascismo, à liberdade do pensamento - intitulado "Perante o lápis dos censores"72, acentua a afronta da censura à mentalidade contemporânea. Nele escreve:

quando tudo parece anunciar festivamente a alvorada da liberdade, quando as mais fortes mentalidades da nossa época anunciam um novo mundo, não com a falsa razão de uma profecia, mas sim com o rigor scientifico, filho do estudo, dos conhecimentos da evolução e do confronto de todas as épocas, ressuscitam antigos censores, para cercear a liberdade mais consagrada, mais defendida, essa liberdade que até os tiranos contemporâneos empalidecem ao ultrajá-la - a do pensamento. ${ }^{73}$

Na esteira das experiências espanhola e italiana, e como já havia mostrado na conferência que proferiu no Sindicato dos Profissionais de Imprensa, logo após a sua chegada de Madrid, o autor evidenciou a inutilidade deste veto. Tanto que, mais cedo ou mais tarde, as palavras publicadas pelos exilados no estrangeiro acabarão por desacreditar a ditadura - o sistema será minado de fora para dentro. Na sua perspectiva, não se deve compreender a liberdade de pensamento de um ponto de vista utilitário, como uma espada ao serviço de certos ideais; e, tanto quanto é injustificável a opressão à imprensa anarquista, é injustificável a opressão à burguesia - mesmo sendo esta um "catavento de paixões ao serviço de quem detém o poder político"74. A sua depuração exige uma outra sociedade, uma outra ideologia, assente nas cinzas do conservadorismo dos que a submetem à censura.

\footnotetext{
72 Idem, Ano III - 5 de Julho de 1926 - n. 136 , pp. 1-2.

73 Idem, ibidem, p. 1.

${ }^{74}$ Idem, ibidem, p. 2.
} 
Ferreira de Castro interrompe a colaboração no suplemento após a publicação deste manifesto; retoma-a passados dois meses, a pedido dos seus camaradas, por solidariedade profissional e ideológica. Jacinto Baptista refere esta ausência como fruto de "um incidente desagradável" e o seu retorno, no seguimento da passagem da direcção de $A$ Batalha de Santos Arranha para Joaquim de Sousa, como um esforço para recuperar colaboradores estimados pelo público operário ${ }^{75}$.

Sobre este facto, o escritor sublinha:

Eu regresso... Mas regresso triste, por ver que esta tribuna, que se ergueu para ser livre, que para ser livre vive, não pode, contudo, viver agora livremente. Os mais nobres protestos serão sufocados pelo lápis implacável do censor...

É esta certeza no futuro que, no momento em que regresso a estas colunas amigas, enche de sol a minha alma. ${ }^{76}$

Num tom provocatório, assinala a impossibilidade de escrever sobre coisas sérias ${ }^{77}$. Porém, num último fôlego, acabaria por fazê-lo, utilizando-se da ironia peculiar ao pensamento libertário. Num acto de coragem, tão nobre quanto o que o levara a levantar a voz contra a censura, Ferreira de Castro encerra este capítulo da sua vida, a sua longa viagem pelas páginas do suplemento de $A$ Batalha, a versar sobre a covardia. Resignados pelas necessidades da vida, os covardes surgem em todos os sectores da sociedade coeva, e a excepção será a vítima:

Será esse jovem impulsivo e idealista, que ainda não pensou em instalar-se na vida, que ignora ainda o prazer burguês da comodidade. Só esse esmagará a lesma viscosa da covardia. Só esse dará a sua nobre fronte aos golpes da clava que manejam todos os outros - os que se adaptaram, os que transigiram, os que defendem as tristes lentilhas. ${ }^{78}$

Na sua perspectiva, a condescendência e a covardia do homem crescem com a civilização - daí o jornalismo sul-americano ser mais audaz que o europeu ${ }^{79}$. O escritor

75 Baptista, Jacinto, Surgindo Vem ao Longe a Nova Aurora, Lisboa, Livraria Bertrand, 1977, p. 146.

76 "De regresso... o culto do eufemismo perante uma situação que exige palavras concretas", in A Batalha Suplemento Semanal e llustrado, Ano III - 6 de Setembro de 1926 - n. ${ }^{\circ} 145$, p. 1.

77 Veja-se "O escritor Rubén Darío: o triste aspecto moral de um homem que trouxe à Europa o génio sul-americano", Idem, Ano III - 27 de Setembro de 1926 - n. 148, p. 2.

78 "Imagens de água profunda", Idem, Ano III - 26 de Outubro de 1926 - n. ${ }^{\circ} 152$, p. 1.

79 "Imagens de água profunda",Idem, Ano III - 29 de Novembro de 1926 - n. ${ }^{\circ} 157$, p. 5. 
anunciava tratar, ainda, da "morte da covardia". Porém, o artigo não veio a lume. Terá sido censurado? Provavelmente. Mas resta saber por quem. O suplemento não resistiu muito mais tempo, publicando o último número a 31 de Janeiro de 1927. A Batalha sucumbiria poucos meses depois, a 27 de Maio de 1927.

Profundo conhecedor da natureza humana, como de resto revela a sua obra literária, Ferreira de Castro compreendeu, como poucos, que todo e qualquer homem se debate com um conflito interno: a escolha entre ser fiel às convicções e o instinto de sobrevivência. No seu caso, podemos concluir que se manteve fiel ao seu amor pela humanidade, não por uma classe em particular, não por um povo em particular.

\section{Bibliografia}

ALVES, Ricardo António, Anarquismo e Neo-Realismo, Lisboa, Âncora Editora, 2002.

BAPTISTA, Jacinto, Surgindo Vem ao Longe a Nova Aurora, Lisboa, Livraria Bertrand, 1977.

CASTRO, Ferreira de, A Casa dos Móveis Dourados, Lisboa, Edições Spartacus, 1927.

FONSECA, Carlos da, Para uma Análise do Movimento Libertário e a Sua História, Lisboa, Antígona, 1988.

FREIRE, João, “Revistas anarquistas portuguesas: Entre a política e a cultura”, in Revistas - Ideias e Doutrinas, Lisboa, Livros Horizonte, 2003, pp. 153-180.

PEDROSO, Alberto e VENTURA, António, Alexandre Vieira - 30 Anos de sindicalismo, Lisboa, Edições 1 de Outubro, 1985.

PRÉPOSIET, Jean, Histoire de l'anarchisme, Paris, Éditions Tallandier, 1993.

A Batalha: Suplemento Literário e llustrado, Lisboa, Órgão da CGT, 166 números, 1923-27.

Renovação: Revista Quinzenal de Arte, Literatura e Actualidades, Lisboa, Secção Editorial de "A Batalha",24 números, 1925-26. 



\section{Nação Portuguesa (1914-1916) \\ - Que Integralismo Lusitano?}

José Manuel Cordeiro*

1. O maior problema que se depara a quem queira produzir qualquer trabalho científico sobre a Nação Portuguesa, Revista de Cultura Nacionalista, e na sua primeira demão Revista de Filosofia Política, é a sua desmesurada extensão que abarca onze séries, prolongando-se pelo período temporal que decorre de 1914 a $1938^{1}$.

Partindo desta premissa, apenas um caminho parece ficar disponível, se não queremos transvestir o artigo, numa lauta obra que é delimitar um espaço que possa ser, ao mesmo tempo, justificável, harmónico e suficientemente sistemático. Nesta ordem de ideias, os anos em que o pensador de Monforte teve parte mais activa no periódico, isto é, entre os anos de 1914-1916, datas entre as quais foi publicada a primeira série, e 1922-1924, datas entre as quais foi o director da Nação Portuguesa, parecem-nos ser susceptíveis de caber em artigos científicos.

Sobre estas séries em estudo, convém salientar alguns quesitos que podem diferenciar a primeira série, de carácter mais teórico e doutrinal, das restantes séries, de índole mais prática. Em primeiro lugar, a tentativa de maior divulgação do periódico experimentando a conquista duma maior franja de audiência - este esforço é visível na opção de dividir a Nação Portuguesa em duas partes distintas:"na primeira, inserimos os estudos de momentânea curiosidade, feitos de crónicas, transcrições, referências à revista, etc.; na segunda, os ensaios de crítica, filosofia, história e ciência, em que os altos problemas do espírito vão sendo discutidos e formam propriamente a contribuição original que dispensamos ao ressurgimento mental em que nos empenhamos"2; seguidamente, o aparecimento de publicidade, embora com carácter elitista e dirigida a uma camada de população restrita (mas que outra gente lhes podia interessar?), e de permutas com revistas coevas reputadas de importantes; finalmente, o recurso à

Seminário Livre de História das Ideias, Centro de História da Cultura da Faculdade de Ciências Sociais e Humanas da Univerisdade Nova de Lisboa.

1 A catalogação integral dessas onze séries está a ser paulatinamente preparada; esta encontra-se, pratica-

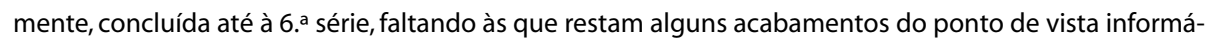
tico e de revisão final.

2 "Expediente. Aos Leitores," Nação Portuguesa, 3.a Série, n. 1, p. VIII. 
memória, à tradição e à identidade nacional expressas em rubricas como, por exemplo, “Os Nossos Mestres",“Cipo,"“Memento” e, principalmente, na coluna que passou a ser frequente em todos os números posteriores à 1. a série, "Das Ideias, das Almas \& dos Factos", secção que teve sempre uma vertente mais prática e de intervenção na vida política nacional, comentando, salientando, maldizendo, interrogando, conforme se adequava melhor à circunstância do próprio movimento do Integralismo Lusitano.

Vejamos então, por ora, um dos modos possíveis de encarar a primeira série da Nação Portuguesa ${ }^{3}$.

2.Se, do ponto de vista da descendência ideológica, os "moços" da Nação Portuguesa, são filhos de Ramirez", então a Nação Portuguesa dos "moços" é a herdeira da brevíssima Alma Portugueza publicada em Lovaina.

É na Alma Portugueza - Órgão do "Integralismo Lusitano" - Revista de philosophia, litteratura e arte, sociologia, educação, instrucção e actualidades ${ }^{5}$, que só deu à luz dois números em 1913, que encontramos o que virá a entender-se, grosso modo, por Integralismo Lusitano, quais os seus propósitos, os seus fundamentos e a sua inspiração ideológica. É nestes planos que se espelharão o movimento integralista lusitano no decorrer da sua longa existência publicista no formato revista (1913-1938) e o diário A Monarquia (1917-1925) no formato jornal.

Que podemos colher na Alma Portugueza como chave interpretativa para compreender os intuitos da Nação Portuguesa? Sabendo que, hoje, a Nação Portuguesa tem um vulto que obnubila as noventa e sete páginas da Alma Portugueza, entendemos, também, que não será por acaso. A Nação Portuguesa contém nela a real herança da Alma; acrescentou-lhe algo de novo - novos e importantes correligionários - e passou a publicar-se em terras lusas, isto é, no seu espaço geográfico natural.Da Alma, transita

3 No que se refere aos assuntos tratados na revista Nação Portuguesa [N.P.], este artigo será desenvolvido unicamente com o recurso à base de dados que será disponibilizada oportunamente, tentando-se, para o efeito, demonstrar como, partindo dessa mesma base de dados, se poderão configurar tematicamente as suas potencialidades, nomeadamente na selecção dos artigos de que se busque informação tida como necessária.

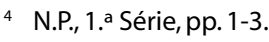

5 Alma Portuguesa (Maio e Setembro de 1913, Louvain). Colaboradores: Domingos de Gusmão Araújo (Director), Ramos Ribeiro (Director Artístico), Rolão Preto (Secretário de Redacção), D. António Alvares Pereira (Cadaval - Administrador), Ascenso Siqueira, Alberto de Monsaraz, Luis de Almeida Braga, Henrique de Paiva Couceiro, Alberto Pinheiro Torres, Ayres d'Ornellas e Alexandre Corrêa. 
para a Nação Alberto de Monsaraz, que será o seu director, bem como transitam o director daquela - Domingos de Gusmão Araújo - e os colaboradores Luiz d'Almeida Braga e Rolão Preto, sendo que este ressurgirá apenas na segunda série.

Inultrapassável é o facto de a revista integralista, agora publicada em terras lusas, se assumir como a revista do tradicionalismo e por isso na continuidade do que já era defendido na Alma, pois aí, no artigo da responsabilidade da redacção ${ }^{6}$, assume-se que o movimento iniciado com a Alma pretende ser um órgão de união de todos os patriotas na alma e consciência portuguesas, fundados no tradicionalismo progressista e no cristianismo com "a sombra protectora de Nun'Alvares, herói e santo, a mais pura consubstanciação da alma nacional"."

Por motivos à altura anunciados como imprevistos, o verdadeiro manifesto ideológico só viu a luz do dia no número dois da revista com o título "O Integralismo Lusitano"8 e com a menção de que iria continuar; porém, tal não ocorreu nem com este artigo de Luís d'Almeida Braga, nem com outros dois, também de alguma profundidade ideológica, nomeadamente os artigos de Domingos de Gusmão Araújo ("Idealismo e acção") e de Alexandre Corrêa ("Da origem do poder").

O artigo "Integralismo Lusitano" publicado na Alma aponta-nos como orientação político-ideológica um retorno ao religioso e ao artístico, como contraponto e em vez do que diziam estar a ser a sociedade coetânea, regida e orientada por valores materialistas e cientistas. A regeneração do país, dizia-se, só poderia efectuar-se "pelo culto à tradição e pelo amor à pátria", e nesta via de apelo à tradição defendia-se que

Foi porque rompia violentamente com o passado, esperando tudo do individualismo democrático e republicano, julgando assim que a renascença do seu paiz estava ligada a essa condição imaginária, que o Risorgimento italiano e o Tugen Bund alemão tiveram vida estéril e ephemera duma onda perdida no alto mar, fallencia que é bom lembrar agora, quando um movimento análogo tenta afirmar-se entre nós. ${ }^{10}$

6 À altura, Alberto de Monsaraz ainda não era anunciado como Conde de Monsaraz, facto que só viria a ocorrer no número dois, e último, da revista (pp. 1-9).

7 Cf. Alma Portuguesa, p. 9.

8 Alma Portuguesa, pp. 53-57.

9 Alma Portuguesa, pp. 53-57.

${ }^{10} \mathrm{Cf}$. Alma Portuguesa, p. 57. 
3. No artigo de abertura da Nação Portuguesa, intitulado "Anunciação", o seu autor ${ }^{11}$ deixa claro o apelo ao regresso da tradição ao utilizar a personagem de Lúcio Castanheiro de $A$ llustre Casa de Ramires para a anunciar. Este apelo exigiu a crítica ao constitucionalismo, por um lado, e o elogio à monarquia orgânica por oposição ao republicanismo "cartista", que radicou as suas fundações na Revolução Francesa e nos enciclopedistas, por outro. As críticas estenderam-se também ao sufrágio universal e ao poder pessoal. É neste artigo que o movimento integralista se apresenta desde logo como anticontratualista (contrário à soberania popular, encarando a história política como garantia da verdade de tais princípios) e aponta o desiderato de que a Nação Portuguesa será a tribuna da defesa de tais princípios para "bem de Portugal"12. O regresso à tradição será o tópico mais frequente da revista, assim como a decisão do seu continuado ancoramento na história de Portugal.

Ora, a Nação Portuguesa vai tentar desenvolver todo o seu programa nesta primeira série durante doze números, que se publicarão pelo período compreendido entre 1914 e Novembro de 1916. Também não deixa de ser significativo que, dos articulistas anunciados, nem todos escreveram para a revista, nomeadamente o Padre Amadeu de Vasconcelos (pseudónimo Mariotte); apesar disso e dos anúncios repetidos de ser colaborador, nunca foi dada qualquer justificação para o facto de nada ter escrito em prol deste movimento e de não ter qualquer acção nesta particular revista. Encontramos, apenas no último número desta primeira série, indícios de uma presumível justificação para tal facto e logo pela pena do seu director, Alberto de Monsaraz:"... João do Amaral, Mariotte e Alfredo Pimenta afirmaram valorosamente os seus ideais de força, de ordem e de disciplina sociais... Destes três publicistas ilustres, João do Amaral é sem dúvida o único integralista. ${ }^{13}$ Aliás, este artigo é demonstrativo das características do movimento integralista lusitano e das suas fundações ideológicas, apresentando-se como o balanço da actividade desenvolvida pelo integralismo contra-revolucionário e é também a passagem de testemunho para o "moço" António Sardinha. Também não colaboraram com artigos nesta série Ayres d'Ornellas ${ }^{14}$, D. Luís de Castro, Francisco de Sousa Gomes Veloso, João da Rocha Páris, José de Azevedo Castelo Branco e Simião Pinto de Mesquita.

11 O artigo, não estando assinado, assumimo-lo aqui da responsabilidade do director.

12 N.P., pp. 1-3.

13 Cf. N.P., p. 357.

14 Apesar de não ter artigos em seu nome, surge tratado na revista em breves análises das suas publicações tal como a recensão da obra Um Ano de Guerra, havendo vários extractos de diversos capítulos onde se

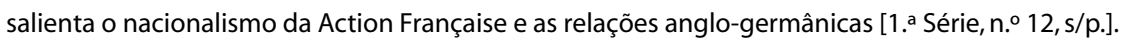


Na lista de colaboradores fundadores, ou seja, aqueles que são anunciados no decorrer dos doze números da revista e que apresentam artigos assinados, encontramos ${ }^{15}$ Adriano Xavier Cordeiro, Alfredo Pimenta, António Sardinha (António de Monforte), Domingos de Gusmão Araújo, Francisco L.Vieira d'Almeida, Garcia Pulido, Gustavo Ferreira Borges, Hipólito Raposo, João do Amaral, José A. Pequito Rebelo, Luiz d'Almeida Braga, Luís Cabral de Moncada e o seu director, Alberto de Monsaraz.

Assumindo-se, desde já, a herança da Alma Portuguesa, importa realçar que nos encontramos perante uma revista de um outro vulto, em que os artigos que dão jus ao seu expressivo subtítulo são abundantes e de variados autores.

Os artigos que se nos apresentam como fundacionais e fundamentais para se entender aquilo que ainda poderemos designar, nesta primeira série, como o integralismo "moço" perpassam por todos os doze números, onde se vão notando aqui e ali algumas contrariedades e algum proselitismo; do mesmo modo, perpassa por muitos artigos uma constante procura de gizar um rumo e cativar novos correligionários ${ }^{16}$. Recordamos, a título de exemplo, a extensa passagem de esclarecimento da redacção por se publicar um artigo de Alfredo Pimenta intitulado "Parlamentarismo". Neste esclarecimento fica claro que há a necessidade de acentuar que, apesar de Alfredo Pimenta ainda se mostrar republicano, é, ainda assim e apesar disso, aceite pelos integralistas, e é-o porque têm a opinião de que as doutrinas que Pimenta professa lhes estão próximas, sendo levados os integralistas da redacção a assumir que "até perdoamos ao seu alto espírito o curioso paradoxo de ainda se declarar republicano..."17.

$O$ regresso à tradição, como escopo fundante do movimento integralista, impõe o regresso à monarquia, mas não a constitucional. A monarquia tradicional será a monarquia orgânica, e será por ela que o movimento integralista, tal como se expressa na Nação, se irá digladiar com o(s) movimento(s) republicano(s), por um lado, e, por outro, com os monárquicos de cariz constitucionalista e parlamentar.

Na sua postura inconformada com a situação política, qualquer justificação servia para afrontarem a República e para dela se demarcarem; a título de exemplo, no artigo, aparentemente inócuo e da responsabilidade da redacção, intitulado "A Nossa

${ }^{15}$ N.P., 1. a Série, n. 1 e n. ${ }^{\circ} 12$, em números intermédios; curiosamente, o número da lista de colaboradores ia variando.

${ }^{16}$ A título de exemplo, veja-se o artigo "Movimento Integralista" em que se apresentam as adesões ao Integralismo Lusitano de José Alves Monteiro e Garcia Pulido. N.P., 1. a Série, n. ${ }^{\circ}$ 7, contracapa.

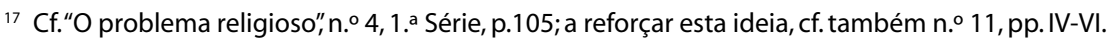


Ortografia"18, pretendia-se responder a pretensas críticas que a redacção da revista entretanto tinha recebido, nomeadamente sobre a falta de uniformização da ortografia; disseram os autores do artigo que respeitavam e respeitariam a ortografia dos colaboradores, mas, caso tal uniformização viesse a ocorrer, não seguiriam a da "República" mas a dos maiores da Dinastia de Avis, bem como a dos metodistas (Verney e Moraes). Aproveitava-se, portanto, qualquer motivo para criticar a República, fosse pela reforma ortográfica que então se pretendia operar, fosse pelo que fosse. “Da República nada queremos", diziam-no a viva voz ${ }^{19}$.

Encaramos, portanto, que a importância atribuída a esta primeira série da Nação Portuguesa se deve muito ao facto de abarcar um grande número de artigos relacionados directamente com a marca ideológica do que entendiam ser o "Integralismo Lusitano." Um qualquer excurso nesta temática deverá necessariamente passar, também, pelos temas conexos ao Integralismo Lusitano, nomeadamente o tradicionalismo, a monarquia, o nacionalismo, a democracia e o municipalismo. Por isto mesmo, assumida a existência de um Integralismo Lusitano e assumida a ideia de monarquia integral, ou integralista na perspectiva de Hipólito Raposo, retira-se do seu artigo "Natureza da Representação" a defesa de que o tipo de monarquia considerada e a considerar pelo Integralismo será aquela que passar da representatividade política para a delegação das classes e dos interesses e de que, nas diversas funções dos seus diversos órgãos do Estado, deve dar-se especial incidência às funções municipais ${ }^{20}$.

Retira-se da leitura e análise desta primeira série da Nação Portuguesa que o tema "Integralismo" poderá ser encarado em múltiplas vertentes, seja a sua ligação ao que se entende ser o nacionalismo, seja a sua ligação aos seus fundamentos histórico-ideológicos, bem como a vertente daquilo que se entende ser a ideia de governo descentralizado que se propõe instaurar ou, dito de outro modo, que se pretende restaurar.

No artigo "O que nós queremos - Monarquia orgânica tradicionalista e anti-parlamentar", da responsabilidade da redacção, nunca será demais recordar que nele surge a apresentação programática do Integralismo Lusitano e que nele poderemos dilucidar as linhas de acção daquilo que pretendem os integralistas acerca da organização político-administrativa da Nação nas suas diversas vertentes. Quanto à Chefia do Estado (Rei), assumir-se-á a crítica ao absolutismo, propondo-se a monarquia orgânica como a verdadeira monarquia; D. Manuel II seria o legítimo herdeiro da coroa da

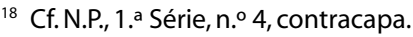

19 N.P., 1 a Série, n. $^{\circ} 4$, contracapa.

20 N.P., $1 .^{\text {a Série, n. }}{ }^{\circ}$ 5, pp. 133-137.
} 
nação portuguesa, uma vez que viam nele o legítimo intérprete desta concepção ${ }^{21}$. Apontam também as linhas directrizes para o modo de Governação, a constituição das Corporações, o papel da família, assim como as formas descentralizadoras municipalistas. Não olvidam o modo de organização da Justiça, da Instrução/Educação, nem o papel da Ciência e da Religião e a importância da Nação espiritual22.

Pela pena de José Pequito Rebelo, no artigo intitulado“Pela Dedução à Monarquia”23, nota-se o empenho na demonstração dedutiva da inevitabilidade da monarquia orgânica como regime político. Nesta sua caminhada dedutiva, o autor recorre ao conhecimento da história pátria para tal demonstração e justificação. A história pátria é apresentada como o campo empírico da ciência política, e a este campo empírico aplica-se a lei dos três estados propostos por Comte, esclarecendo-se o processo a três tempos de evolução do pátrio regime: tradicionalismo empírico, metafísica revolucionária e, finalmente, tradicionalismo positivo. Rebelo apresenta-nos neste processo dedutivo o papel das elites e aponta-as como a minoria equilibrante da sociedade; a monarquia orgânica nascerá da aliança que se estabelecer entre o Rei e a elite (intelectual), e será, dada a sua natureza apresentada por demonstração, de cariz reaccionário em relação às políticas revolucionárias. $\mathrm{O}$ autor acrescenta ainda a todo este périplo demonstrativo a ideia de "Integração" buscada, na sua formulação biológica e aplicada analogicamente à sociedade humana. Este artigo é, na nossa modesta perspectiva, um incontornável marco para a compreensão do que viria a ser o Integralismo Lusitano, não só porque aponta os pontos cardeais do movimento, mas também porque traça o destino da sua acção político-ideológica.

Outra questão incontornável para o estudo do Integralismo prende-se com a sua pretensa e presumida ligação à Action Française. Aliás, aquando do aparecimento da Nação Portuguesa, começaram a surgir as primeiras reacções na imprensa e as primeiras insinuações sobre tal ligação. Alberto de Monsaraz, aproveitando o ensejo para agradecer os apoios que na sociedade portuguesa iam surgindo ao movimento integralista e tradicionalista, tenta, ao mesmo tempo que responde às críticas de vária ordem, uma descolagem em relação aos movimentos da Action Française.

As mais cerradas críticas também se relacionavam com a tentativa de colagem do movimento integralista lusitano ao maurrasianismo da Action, pelo que, durante a publicação da primeira série, vão ser bastantes os artigos para tentar demonstrar que

\footnotetext{
21 Cf. N.P., pp. 67-69.

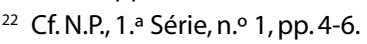

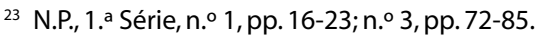


assim não é. Lembremo-nos, como mero exemplo entre tantos outros que poderiam ser invocados, do artigo "A Magna Carta - Lei de 4 de Junho de 1824 - João $\mathrm{VI}^{\prime 24} \mathrm{em}$ que tal documento régio se apresenta e transcreve como o documento nobre do Integralismo Lusitano, pretendendo-se ao mesmo tempo afastar quaisquer semelhanças do Integralismo Lusitano com as concepções políticas defendidas por Maurras. Ayres d'Ornellas vê também neste artigo os fundamentos do tradicionalismo e entende-o como o modo de arrepiar caminho do constitucionalismo importado. Contudo, tal posição assim assumida do tradicionalismo não era do agrado do "moço" de Monforte, uma vez que através do seu artigo "Poder Pessoal e Poder Absoluto"25, onde também tentou uma resposta a tais críticas de colagem do movimento Integralista Lusitano ao maurrasianismo da Action, criticou as posições assumidas por Ayres d'Ornellas, nomeadamente o facto de este ter entendido que o texto "A Magna Carta - Lei de 4 de Junho de 1824 - João VI" seria o verdadeiro documento do tradicionalismo. Ora, a assunção de tal texto e de tais posições sobre o tradicionalismo teria como consequência a aceitação dos Três Estados e das Cortes Gerais e por isso mesmo da monarquia constitucionalista. Inaceitável! E isto tanto para Sardinha como para um grande punhado de integralistas.

O modo de Sardinha escapar a tais críticas e não aceitar a posição de Ayres d'Ornellas é fazer a demonstração de que a origem do Integralismo Lusitano se insere num movimento mais amplo na história de Portugal e que aí, sim, se deverá ancorar o verdadeiro movimento tradicionalista ${ }^{26}$. A corroborar tal posição, encontra-se Garcia Pulido, nomeadamente na defesa da monarquia municipalista, posição que defende na polémica que encetou com Raul Brandão e que ficou documentada nas páginas da Nação Portuguesa ${ }^{27}$.

A verdade é que, apesar de tais tentativas de afastamento do maurrasianismo, não foi possível, de todo, convencer nem os de dentro do movimento integralista, nem

${ }^{24}$ Nação Portuguesa - Revista de Filosofia Política, 1. a Série, n. ${ }^{\circ}$, pp. 224-227.

${ }_{25}$ Nação Portuguesa - Coimbra, Julho 1914. 1. a Série, n. ${ }^{\circ}$ 4, pp. 106-120.

${ }^{26}$ Cf. N.P., Série I, n. ${ }^{4}$, pp. 106-120. Também a este propósito se deverá consultar o artigo de Garcia Pulido "Carneiro com batatas" (N.P., 1. a Série, pp. 306-315), onde o autor critica o sistema representativo (parlamentar) e o sistema eleitoral (partidarista). Procura demonstrar que as causas da anarquia em que se vivia eram da responsabilidade do constitucionalismo e da soberania popular. O parlamentarismo, dizia, era responsável por proteger interesses particulares e não os interesses nacionais; pelo mesmo diapasão afirma que os partidos políticos pugnam por interesses particulares e de grupos e dentro do próprio partido se defendem apenas interesses individuais, diluindo-se deste modo o interesse nacional.

${ }^{27}$ Cf. N.P., pp. 337-340. 
os críticos e opositores externos ao movimento que entretanto iam surgindo não só em número, mas também em qualidade. Pois, curiosamente, enquanto uns tentavam afastar-se do maurrasianismo, outros, por seu turno, queriam um Maurras português, abriam, por isso, as portas à crítica ao mesmo tempo que outros afanosamente as tentavam fechar.O artigo "Carta ao Sr. Moreira de Almeida"28, assinado por "Um português tão desiludido do 4 como do 5 de Outubro" [sic], apresenta-se como uma exortação para que o jornalista Moreira de Almeida ocupe em Portugal o papel que Maurras ocupou em França, dando-lhe inclusivamente a receita, que é a de elaborar uma reflexão sobre o passado distante, longe dos liberalismos e dos republicanismos, aquele passado distante da criação natural do país - a distância exige-se, uma vez que se aponta a "Geração de 89", e tudo o que ela representa, como a causa da ruína moral e material da Nação' 29 .

Outra vertente importante deste movimento é a sua acção política, pelo que também é digno de nota que no decorrer desta série o movimento do Integralismo Lusitano comece activamente à procura de intervenção política, não se coibindo da polémica, nem de intervenções mais "musculadas". Anunciam-se, no decurso desta primeira série, as Conferências da Liga Naval sobre a Questão Ibérica e a criação do Centro Integralista de Lisboa. É com a criação deste Centro que surgirá um diário de propaganda, ou seja, o já aludido diário Monarquia ${ }^{30}$. Despontará também o importante Centro Integralista em Coimbra, impulsionando-se a todo o vapor a profusão das ideias e ideais integralistas pelo país fora. Testemunhas deste facto são as revistas de cariz integralista e nacionalista que por todo o país vão surgindo e que a Nação Portuguesa continuadamente anuncia com garbo.

A leitura de toda a série leva-nos de facto a constatar que há acção política activa destes "moços". É, no entanto, Alberto de Monsaraz quem nos fará um auto-retrato do Integralismo Lusitano no fim dos doze números da 1. a Série da Nação Portuguesa no seu artigo "Caminho Andado".

O fim da publicação, em Novembro de 1916, que o autor não esconde dizendo-o frontalmente, deve-se a "dificuldades de toda a ordem, umas directamente relacionadas com a guerra... outras devidas ao facto dos colaboradores se encontrarem dispersos e a tipografia em terra diversa da administração" (nesta altura, a tipografia era em Famalicão, e a administração em Coimbra). Apesar da noção das dificuldades

\footnotetext{
${ }^{28}$ Cf. N.P., 1. a Série, n. ${ }^{\circ}$ 2, pp. 53-54.

29 Cf. N.P., 1. a Série, n. ${ }^{\circ}$ 1, pp. 24, 25.

${ }^{30}$ Cf. N.P., 1. ${ }^{a}$ Série, n. ${ }^{\circ} 8$, contracapa.
} 
ocorridas com a publicação da Nação Portuguesa, a verdade é que Monsaraz afirma que não foi com isso prejudicada a propaganda do movimento integralista. Afirma, também:

A Nação Portuguesa foi a primeira publicação do nosso grupo; destinava-se apenas a criar entre nós, nas esferas superiores da sociedade, uma elite intelectual que compreendesse o alcance das ideias e princípios que defendemos e fizesse justiça ao esforço, à tenacidade, ao patriotismo da nossa campanha partidária. ${ }^{31}$

Podemos perguntar-nos se vemos Alberto de Monsaraz a encerrar com satisfação esta aventura com a primeira série e se entendeu que tinha sido cumprida a sua missão. A resposta por ele dada é lacónica - o "resultado alcançou-se e alcançou-se rapidamente" - e termina o artigo dizendo que "os progressos da ideia contra-revolucionária em Portugal têm sido verdadeiramente formidáveis". Era este o espírito de missão cumprida do primeiro núcleo dos "moços" do Integralismo Lusitano.

A carta de Ramalho Ortigão a João do Amaral [Carta de um velho a um novo] também lhes outorga a missão de continuar a obra daquele que será assumido como um dos mestres. Tal documento não é visto senão como o testemunho da "geração avô" à "geração neto" no que concerne à transmissão dos valores políticos da tradição, que se consubstancia no exemplo pessoal do "avô" que não abandona a luta mas que assume que a fará de cabelos já ruços. Aliás, esta assunção do Mestre é reassumida na oração fúnebre a Ramalho Ortigão ${ }^{32}$. Nesta "Oração fúnebre", João do Amaral (a corporizar o sentimento da Nação Portuguesa) salienta que da sua actividade política, nomeadamente a carta que lhe é dirigida [Carta de um velho a um novo], se revaloriza Ramalho como um Mestre dos Moços do Integralismo Lusitano.

No último número, Alberto de Monsaraz não só faz o balanço da actividade dos integralistas enquanto movimento da elite intelectual, das diversas revistas publicadas pelo país fora e das obras publicadas que defendem o ideário integralista, como ainda vaticina o futuro próximo do movimento. Neste artigo de balanço informa que “Um periódico, semanário ou diário, que brevemente há-de aparecer em Lisboa, virá centralizar o movimento, dar-lhe mais unidade e vigor, fazendo-o sair pouco a pouco da fase de preparação em que até hoje se tem desenvolvido".

\footnotetext{
31 Cf. N.P., 1. ${ }^{\text {a Série, n. }}{ }^{\circ} 12$, p. 357.

32 Cf. N.P., 1. ${ }^{\text {a Série, n. }}{ }^{\circ}$ 9, contracapa.
} 
Aponta-nos Alberto de Monsaraz o modo e o momento da entrada na segunda fase do movimento integralista ${ }^{33}$.

4. Atendendo ao trabalho realizado de indexação da Nação Portuguesa, permita-se-nos fazer um brevíssimo excurso, entre tantos possíveis, por um dos temas expendidos pelas páginas da revista e que nos permitirá apontar para a elaboração de um conhecimento mais alargado do modo como os assuntos eram entendidos por diversos colaboradores. Seleccionando, a título de exemplo, artigos tidos como essenciais para entender o modo como os integralistas da Nação Portuguesa, 1. a Série, assumiam a ideia de tradicionalismo ${ }^{34}$, deparamo-nos com o facto de que são incontornáveis os seguintes artigos para o estudo de tal postura pelos autores da nossa revista integralista ${ }^{35}$ :

"Pela Dedução à Monarquia", José Pequito Rebelo; "Segunda Carta ao Sr. Moreira de Almeida", Um Portuguez tão desiludido do 4 como do 5 de Outubro; “Senhor Rei, Salvae-nos..., Alberto de Monsaraz; "Pela Imprensa”, Alberto de Monsaraz; “As velhas liberdades e a nova Liberdade", A. Xavier Cordeiro; "Poder pessoal e poder absoluto", António Sardinha; “O 'Liberalismo' de Alexandre Herculano", M. M;"A Política histórica: O NOVO PRÍNCIPE", Gama e Castro;"A Fórmula Política", Vieira de Almeida;"O TERROR", Garcia Pulido (excerto do "Canapé da Europa"); "A Magna Carta - Lei de 4 de Junho de 1824", D. João Vl; “Movimento Integralista”, Redacção;"Os povos e os governos que

33 O movimento faseado do Integralismo Lusitano está bem escalpelizado por Manuel Braga da Cruz, in "Integralismo Lusitano" - Análise Social n. ${ }^{\circ}$ 70, pp. 137-182. Entendemos, também, que esta primeira fase foi um período de "laboratório" onde se alinharam e perfilaram diferentes concepções político-filosóficas, bem como diferentes compreensões de organização do movimento do Integralismo luso. Tais posturas serão verificadas com os movimentos cisionistas de que as séries subsequentes nos darão nota, a começar exactamente pela segunda, que se tratará também nas páginas deste número da revista.

${ }^{34}$ Outros artigos poderiam também ser citados; apesar de o seu conteúdo tratar também de assuntos relacionados com o tradicionalismo, não pretendemos com esta lista ser exaustivos, queremos apenas demonstrar as potencialidades de dispor de tal informação. Lembramo-nos, a título de exemplo, de dois artigos da autoria de António Sardinha, "Teófilo mestre da contra-revolução" e "Apologia da Guerra,"onde se colhem também importantes achegas para o assunto; mas outros há e de outros autores também.

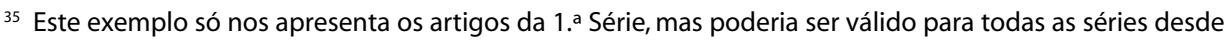
que estivessem já disponibilizadas pela Biblioteca Nacional de Lisboa. A inserção desta lista neste texto pretende demonstrar a grandiosidade desta revista e a grande dificuldade em isolar os seus conceitos fundamentais devido à sua enorme dispersão. Se tivéssemos que anexar os artigos das subsequentes séries, então o rol seria ainda mais fastidioso. No entanto, o investigador só deverá animar-se quando tanto material está à sua disposição. 
merecem," Luís Cabral de Moncada; "A Comezaina", Garcia Pulido (excerto da obra O Canapé da Europa); "O Rei do Trabalho: As Cartas de El-Rei. A Monarquia Operária - A incapacidade das democracias para resolver a questão obreira. Exemplos e opiniões", António Sardinha; “Depois da Guerra”, Anónimo; "Ramalho Ortigão: A Carta,' Ramalho Ortigão (citado por Alberto de Monsaraz); "Os nossos primeiros estadistas," Ramalho Ortigão (citado por Alberto de Monsaraz); “Conceito Nacional de Soberania,, Hipólito Raposo; "O Espírito da Democracia”, Luiz d'Almeida Braga; "A desnacionalização do nosso Direito: Introdução à conferência pronunciada na Liga Naval, na noite de 11 de Maio de 1914, subordinada ao título 'A Questão Ibérica - O Direito e as Instituições',' A. Xavier Cordeiro;"Carneiro com batatas!',Garcia Pulido (excerto de O Canapé da Europa); "Tradição e Nacionalidade", Luiz d'Almeida Braga (excerto do livro A Questão Ibérica); "Política Interna", João do Amaral; "A solução monárquica, comentários, por Alfredo Pimenta,"Redacção;"O Cerco do Porto,"Garcia Pulido;"Mudança d'Ares,"pelo Dr. Samuel Maia, Redacção;"Um ano de guerra,"por Ayres d'Ornellas, Redacção;“Caminho Andado," A. M. (Alberto Monsaraz); "A Teoria da Nobreza”, António Sardinha;"Pensamento político de Eça de Queiroz", Hipólito Raposo; “O depoimento anti-parlamentar dos nossos economistas", P. R. [Pequito Rebelo]; "Da renascença do tradicionalismo na arte e na política", Luiz d'Almeida Braga.

A escolha de alguns dos artigos transcritos permitirá perceber que a informação a que o trabalho de indexação levou disponibiliza o acesso a diversos itens e conteúdos. Como mero exemplo, transcrevemos para o presente texto o que se pode obter imediatamente sem a leitura integral dos artigos de António Sardinha ("A teoria da nobreza") (6 $^{36}$ e de Luiz d'Almeida Braga ("Da renascença do tradicionalismo na arte e na política") ${ }^{37}$.

Acompanha a indicação do artigo de Sardinha, e de todos os outros artigos, uma breve apresentação do seu conteúdo. No caso concreto, ficamos a saber que, com este artigo, o autor

pretende demonstrar de que só com o regresso às bases da Monarquia Tradicional (Família, Município, Província e Estado) se pode salvar a Nação do estado em que se encontrava. Esclarece-nos sobre as características de tal monarquia e o modo de retorno à sua antiga nobreza, que características esta deve apresentar e como é que alguém a ela pode ascender. Esta análise, Sardinha, diz que pode e deve ser elaborada de acordo com a "lei da capilariedade social" do antropo-sociólogo Vacher de Lapouge. De tal análise conclui que

\footnotetext{
36 N.P., pp. 359-376.

37 N.P., pp. 391-395.
} 
a nobreza é uma característica inerente à natureza humana e estará sempre associada ao conceito de "honra".

A bibliografia citada no artigo é diversificada e vem também expressa na indexação, permitindo-nos, entre outras coisas, uma melhor compreensão dos autores que influenciavam, positiva ou negativamente, o movimento integralista lusitano e, neste caso concreto, um dos seus coriféus - António Sardinha ${ }^{38}$. Permita-se-nos transcrever aquela bibliografia que maior significado tem no contexto do artigo "A teoria da nobreza", bem como enumerar os autores lá citados como recurso e apoio das posições despendidas: Bourget, Paul: L'Étape; Brito, Manuel da Costa Juzarte de: Livro Genealógico das Famílias Desta Cidade de Portalegre e Livro do Armeiro-Mór do Reyno; Chailley-Bert: Enquête sur I'enseignement secondaire; Jouvenel, Robert de: La République des camarades; Lapouge, Vacher de: Race et milieu social; Machado, José de Sousa: Brasões Inéditos; Niceforo, Alfredo: Les Classes pauvres; Renan: Souvenirs d'enfance et de jeunesse; Ribeiro, João Pinto: Uzurpação, Retenção e Restauração de Portugal; Sampaio, Alberto: As Villas do Norte de Portugal; Stendhal: Rouge et noir; Taine: Notes sur l'Angleterre; Vera, Álvaro Ferreira de: Origens da Nobreza Política. $O$ autor socorre-se, ainda, no seu artigo de autores como Le Play, La Tour du Pin, Duque de Ávila e Bolama (1806-1881),Tácito, Augusto Comte, Alexis de Tocqueville, Georges Clemenceau, Georges de Avenel, Pierre-Joseph Proudhon, Louis de Bonald, Émile Faguet, Joseph Grasset, Alexandre Herculano, Oliveira Martins, George Monk, Blanc de Saint-Bonnet, Bento Marciel Parente, Haussonville, não descurando a importância, para o tema, de autores como Frei Manuel do Cenáculo Vilas Boas.

Seguindo agora o mesmo padrão anterior, vejamos o que ocorre em relação ao artigo de Luiz d'Almeida Braga “Da renascença do tradicionalismo na arte e na política". Com este artigo, o autor faz um

Apelo ao retorno da religião no trabalho artístico, criticando o trabalho coetâneo por se basear, diz, em meros dados experimentais, concepção oriunda do Positivismo. A arte e a Fé devem caminhar pelo mesmo trilho, aponta o autor. A decadência portuguesa é causada pela ausência de ideal e por um "materialismo violento" que advém dos Descobrimentos, pelo que a regeneração deve passar pelo enfraquecimento do Estado central e pelo retorno ao municipalismo.

${ }^{38}$ Também será, portanto, possível enumerar todas as obras e autores citados por um qualquer articulista da Nação Portuguesa, dando-nos um enorme potencial de informação e elementos de trabalho sistematizados à partida. 
A bibliografia citada no artigo é parca, restringindo-se a Balzac: A Comédia Humana; Luís d'Almeida Braga:O Culto da Tradição; Homero: llíada e Odisseia; Rousseau:O Contrato Social; e as autoridades de que se socorre são também de interessante análise e vão de Afonso I, Rei de Portugal, passando por Afonso de Albuquerque, Maurice Barrès, Paul Bourget, Carlyle, Augusto Comte, Conde de Chambord, S. João da Cruz, Dante, Vasco da Gama, Goethe, Ernest Hello, Henrique V, Rei de França, D. José I, Rei de Portugal, Le Play, D. Miguel, Rei de Portugal, Bartolomé Murillo (pintor), Friedrich Nietzsche, Pedro Guilherme Frederico (economista), Nuno Álvares Pereira, Rivarol, Ruskin, Mouzinho da Silveira, Taine, Santa Teresa de Ávila, Alexis de Tocqueville, Leão Tolstoi, Paul Verlaine, terminando a nossa listagem com Leonardo da Vinci.

5. Um tema interessante que se poderá observar nesta primeira série da Nação Portuguesa é a determinação daquilo que os seus colaboradores denominaram de "Monarquia Integral" e que, tratado assim, só ocorre em dois artigos: um de José Pequito Rebelo, "Monarquia Integral e República Democrática"39, e outro de Luís d'Almeida Braga, "O Espírito da Democracia" ${ }^{\prime \prime 0}$.

No primeiro artigo, propõe-se um estudo comparativo entre duas formas de regime político governativo: Monarquia Integral e República Democrática, no que concerne aos fins do Estado, à Soberania, à Descentralização, às Eleições e à Representação, ao Parlamento, ao Poder Central, às políticas económico-financeiras, religiosas, sociais e de defesa diplomático-militar. Escalpeliza-se cada um dos regimes, chegando-se à conclusão de que só o regime monárquico-integral pode continuar a obra histórica da Nação. Também neste texto se apresenta a Nação como eterna e múltipla, contrariando a opção da representatividade só do povo.

No segundo texto, de Luís d'Almeida Braga, tenta-se demonstrar que a constituição da nação e dos seus regimes políticos se encontra condicionada por factores históricos, geográficos e religiosos. O autor salienta a ideia de que após a destruição da família, cuja origem fez radicar no individualismo cartesiano com o seu apogeu em Rousseau, a Nação só pode ser reconstituída e restaurada pelo regresso à monarquia tradicional. Defende-se, por isso, o regresso à monarquia tradicional, uma vez que a monarquia constitucional se baseia nos mesmos princípios individualistas, que não

\footnotetext{
39 N.P., pp. $179-186$.

40 N.P., pp. $279-285$.
} 
são outra coisa senão o ideário dos revolucionários e do republicanismo. Portanto, o autor conclui que só a Monarquia Integral "coloca a Pátria acima de tudo", ao invés dos interesses particulares e individualistas.

Com o trabalho produzido no âmbito desta indexação, torna-se-nos mais fácil e célere averiguar se o movimento autodenominado de Integralista Lusitano apresenta, de facto, um corpus coerente e característico de princípios político-filosóficos que nos permita afirmar, também, se tem um corpus doutrinalmente coerente e assente em princípios tais que permita caracterizá-lo e diferenciá-lo de outras correntes doutrinárias internacionalmente similares, trabalho que, por ora, nos coibiremos de executar para não alongarmos demasiadamente este artigo.

Também nos parece evidente que, durante todo o decurso de publicação desta primeira série, começa a ser nítido que as mais importantes posições políticas são antíteses das posições dominantes no movimento republicano e parlamentarista. Assim, o Integralismo Lusitano começa por se afirmar assumindo-se "anti" e opositor a outros movimentos seus coetâneos e mesmo predecessores. Uma análise de mediação assente nos estudos das fontes doutrinais, e da sua inclusão nos textos produzidos de ideais filosófico-políticos, permitirá, também com base na indexação realizada, justificar, ou não, se este movimento é na verdade e essencialmente um movimento oposicionista ao Partidarismo, ao Parlamentarismo, ao Eleitoralismo, ao Republicanismo e ao Liberalismo. Sabendo-se que tal postura antitética também o fora em França com três alvos preferenciais - Anti-Parlamentarismo, Anti-Semitismo e Anti-Protestantismo -, verifica-se que em Portugal o movimento integralista lusitano não tem os mesmos alvos preferenciais de crítica social e de antagonismos.

$\mathrm{Na}$ verdade, entendemos que, com a primeira série da Nação Portuguesa, poderemos perceber que, com as diversas posições lá assumidas, qualquer deriva para uma determinada concepção doutrinal ou doutrinária não colheria o apoio de todos os colaboradores. Foi o que de facto aconteceu. Também podemos verificar que o"nacionalismo" não foi o tema central da primeira série da Nação Portuguesa. Contudo, sê-lo-á da segunda e das subsequentes, independentemente das cisões que se conheceram no seio do movimento dos moços tornados homens. Aliás, a segunda série passará a ter como subtítulo Revista de Cultura Nacionalista e não Revista de Filosofia Política como na primeira. É significativo.

Com este bosquejo sobre a primeira série da Nação Portuguesa, pretendemos demonstrar que a ideia de um Integralismo Lusitano coerente e doutrinal pode e deve ser buscado no interior da sua mais importante expressão que é toda a 
Nação Portuguesa em todas as suas séries, bem como o diário Monarquia e a revista Integralismo Lusitano.

Há um enorme trabalho de depuração, que permitirá tornar o Integralismo Lusitano no corpus doutrinário que ele, de facto, aparenta ter. Para que tal depuração possa ocorrer, é necessário ter em consideração que é preciso descortinar os seus temas conceptuais e doutrinais fulcrais e a sua importância no período de vida do Integralismo Lusitano. Entendemos que ainda falta estabilizar os conceitos de tradicionalismo, monarquia, nacionalismo, democracia, municipalismo, revolução/contra-revolução e que só depois se poderá propor um corpo doutrinário para o que foi ou pretendeu ser o Integralismo Lusitano.

Com este esboço pretendemos demonstrar que a questão introduzida no título deste artigo ainda não a encontramos satisfatoriamente respondida para o período em apreço, se é que algum dia o será. Não nos conformando com a ideia de que sobre o Integralismo Lusitano esteja tudo dito e tudo feito, pretendemos, com o trabalho de indexação e estudo realizado sobre a revista Nação Portuguesa, abrir um novo sulco no campo de estudo de tão importante movimento filosófico-político português, que terminará com um estudo similar sobre a revista Integralismo Lusitano e sobre o diário A Monarquia. 


\title{
Da Filosofia Política à Cultura Nacionalista. A segunda série da Nação Portuguesa (1922-1923)
}

\author{
Paulo Dias Oliveira*
}

Decorrido o interregno de Novembro de 1916 - data do número doze da primeira série - a Julho de 1922 - data do primeiro número da segunda série -, período durante o qual se publicou, com extracção diária, o periódico A Monarquia, cujo primeiro número viu a luz a 12 de Fevereiro de 1917, e o derradeiro, ano VII, n. ${ }^{\circ} 1198$, a a 10 de Fevereiro de 1925, o Integralismo Lusitano volta a ter uma revista de grande divulgação para propagandear o seu ideário.

São essas preocupações propagandísticas, como seria natural, que enformam o artigo de abertura desta segunda série. Esta peça intitulada "Porque voltámos"1 , cuja autoria se remete para a Direcção, embora, segundo tudo nos leva a crer, não havendo porém provas palpáveis, o "escrevinhador" não possa deixar de ser António Maria de Sousa Sardinha.

O citado artigo, verdadeiramente programático, traça as linhas mestras em que se vai mover o Integralismo Lusitano no período pós-Pacto de Paris. Mas talvez seja este o momento apropriado para esboçar, embora brevemente, algumas linhas concernentes a esse assunto; para essa tarefa usaremos, em nosso auxílio, a obra de Leão Ramos Ascensão, O Integralismo Lusitano.

A 17 de Abril de 1922 era assinado, em Paris, o Pacto conluiado entre os dois ramos da Casa de Bragança, onde se reconhecia a realeza de D. Manuel II, sem que se acautelasse a sua sucessão, na pessoa de D. Duarte Nuno, pois o rei não tinha descendentes $^{2}$. A Junta Central do Integralismo viu-se perante um facto consumado, ao qual era

\footnotetext{
Universidade do Algarve.

1 Nação Portuguesa, Revista de Cultura Nacionalista, 2. Série, n. ${ }^{0}$ 1, Julho de 1922, pp. 1 a 5.

2 Para melhor elucidação daquilo que se decretou, optámos por transcrever o Pacto de Paris: “Os abaixo assinados, analisada detidamente a situação política do País e cônscios de que interpretam o sentir da grande maioria dos monárquicos portugueses que são a maioria do País, desejando sincera e lealmente ver terminadas as dissensões entre a Família Monárquica, que só aproveitam aos partidos da República, com grave prejuízo da nossa Causa e do nosso País; Ouvidos os seus Augustos Mandantes e por Eles devidamente autorizados, declaram: O primeiro signatário: a) que o seu Augusto Mandante, na falta de herdeiro directo, aceitará o Sucessor indicado pelas Cortes Gerais da Nação Portuguesa. b) Igualmente aceitará as resoluções das mesmas Cortes, quanto à Constituição Política da Monarquia Restaurada.c) Que de
} 
impossível obedecer e, para que não fosse uma força de bloqueio à união monárquica, "a Junta Central resolveu suspender a sua actividade, bem como a publicação do jornal A Monarquia"'.

Com a suspensão da actividade política convém, neste momento, fazer um ponto da situação no que se refere à Junta Central do Integralismo Lusitano. O primeiro a abandonar esse órgão foi Rui Enes Ulrich, mas em 1919 mais dois membros não se encontravam já no seu seio: Xavier Cordeiro, por ter falecido, e João do Amaral, por ter emigrado. Por outro lado, os enviados a Paris pela Junta Central, Alberto Monsaraz e Luís d'Almeida Braga, que tinham sido pressionados pela Infanta Aldegundes a aderir ao chamado Pacto de Paris, foram também afastados. Ficou a Junta Central do Integralismo constituída por António Sardinha, Hipólito Raposo, Pequito Rebelo, Rolão Preto e Afonso Lucas; são estes mesmos filiados que vamos encontrar com um papel primordial na série da Nação Portuguesa que ora é objecto das nossas preocupações.

acordo com a Santa Sé será resolvida a questão religiosa, mediante diploma a ser submetido às Cortes. Pelo segundo signatário foi dito: que perante as declarações anteriores o seu Augusto Mandante pedia e recomendava a todos os seus partidários que acatem como Rei de Portugal o Senhor Dom Manuel II e que se unam lealmente sob a mesma bandeira que abriga todos os Monárquicos, que é a bandeira da Pátria e a Bandeira que há-de salvar Portugal. Feito em Paris, aos 17 de Abril de 1922. (a) Ayres d'Ornellas; (b) Conde d'Almada e Avranches, Leão Ramos Ascensão, Integralismo Lusitano, Porto, Edições Gama, 1943, pp. 191 a 192.

3 Idem, Ibidem, pp. 80-81. Pelos mesmos motivos atrás aludidos, trasladamos, igualmente, o comunicado da Junta Central do Integralismo Lusitano perante o conluio do qual resultou o Pacto de Paris:"INTEGRALISMO LUSITANO - Tendo tomado conhecimento do texto do acordo dinástico firmado pelo senhor Conde d'Almada e Avranches como representante de Sua Alteza a Senhora Infanta D. Maria de Aldegundes de Bragança, tutora do Príncipe Real Senhor Dom Duarte Nuno, e pelo Senhor Conselheiro Ayres d'Ornellas, como representante do Senhor Dom Manuel II - a Junta Central do Integralismo Lusitano, coerente com as suas anteriores declarações e procedimentos, torna públicas as resoluções seguintes: $1 .^{\text {a }}$ - Verificando que no referido acordo não foram salvaguardados os princípios da Monarquia Portuguesa, reconhece com mágoa a impossibilidade moral e política de promover a sua execução, retomando desde hoje a sua independência. 2. - Para que não possa atribuir-se ao Integralismo Lusitano a responsabilidade de retardar ou prejudicar o advento da Monarquia, suspende imediatamente a sua actividade de organização política, até que as circunstâncias demonstrem que só os processos e doutrinas do Nacionalismo podem assegurar a certeza da restauração. 3. ${ }^{\mathrm{a}}$ - Afirma o seu propósito de continuar o combate à república, pela defesa e propaganda doutrinária dos princípios do Integralismo Lusitano, enquanto não lhe for dado lutar de novo no campo da acção política pela proclamação da Monarquia dos Municípios e das Corporações cujas Cortes Gerais aclamarão por direito o Rei Legítimo, reconhecendo-o na Pessoa de Sua Alteza Real, o Senhor Dom Duarte Nuno de Bragança.4. ${ }^{\text {- }}$ Dando conta desta atitude às Juntas Provinciais e Municipais, aos Núcleos Paroquiais, às Juntas Escolares e a todos os seus filiados, protesta-lhes o justo louvor pela lealdade com que, através dos maiores perigos, perseguições e sacrifícios, souberam honrar os seus compromissos e testemunha-lhes o mais profundo reconhecimento pelas demonstrações de apreço que lhes ficou devendo. Lisboa, 4 de Maio de 1922", idem, ibidem, pp. 193 a 195. 
Depois deste breve excurso, voltemos a essa peça editorial, onde, após se cimentar a ideia de que a Nação Portuguesa é a forma de "acordar entre nós a preocupação das questões contemporâneas", se desenha a traço grosso o quadro da decadência da sociedade portuguesa, nas suas vertentes mentais e morais, declínio esse que não é mais do que a herança do romantismo liberal. Para fundamentar esta posição, Sardinha socorre-se de alguns excertos da primeira obra impressa de Eça de Queiroz, O Crime do Padre Amaro, o que lhe faculta a conclusão de que a "morte de Portugal" se deve à perda das raízes que prendem a nação à alma eterna da história.

Num momento seguinte, do ponto de vista positivo ou de reconstrução, é necessário ter em conta a missão de "Reaportuguesar Portugal", na expressão de Afonso Lopes Vieira ${ }^{4}$. Embora não se encontre devidamente explicitada a tarefa de "reaportuguesamento", esta deveria pressupor várias etapas que, sem preocupações metodológicas, consistiriam nas que se seguem: defesa de um nacionalismo tradicionalista; apologia da monarquia social; combate contra o individualismo económico e a plutocracia contemporânea; criação de uma Ordem Nova. Parece-nos que, neste momento, o mais indicado é a concretização de cada uma destas condicionantes.

No que se refere ao primeiro item, temos que ter em conta que este nacionalismo tradicionalista deve assentar na assunção das razões fundamentais da pátria, com todas as leis aduzidas da raça e do meio, tendo como ideal a criação de um projecto superior de civilização cristã, isto é, católica. Neste nacionalismo tradicionalista terão que estar sempre pressupostas as raízes lusas com os seus concomitantes usos e costumes.

A segunda etapa desta linha doutrinal passa pela constituição daquilo que os Integralistas denominam Monarquia Social. Este tipo de monarquia subentende um regresso ao passado e à tradição anterior aos regimes monárquicos absolutistas (D. João I e a Casa dos Vinte e Quatro são muitas vezes a bandeira arvorada por Sardinha), na qual se dá a congregação dos interesses e das profissões como superior

4 Além do aludido retorno às raízes e à alma da nação, seja o que isso for, nunca conseguimos alcançar de modo significativo o sentido da expressão "Reaportuguesar Portugal". Esta expressão terá que ir sempre no sentido de fuga às influências estrangeiras, liberais sem dúvida, e, nos dias de hoje, de fuga à globalização. Por outro lado, Camilo Castelo Branco, que nunca sofreu da maleita revolucionária, confessando mesmo que tinha sido miguelista e havia pugnado nas fileiras de R. Mac-Donnell (cf. Discurso Proemial da "Maria da Fonte", Obras Completas, Vol. XVI, Porto, Lello \& Irmão, 1993, p. 866), asseverava de um modo suavemente premonitório que "não é anatomizando o cadáver das velhas tradições de um povo que na ponta do escalpelo se descobre o gérmen da fortuna desse povo", Princípios para uma consequência, "Delitos de Mocidade", Obras Completas, Vol.XV, p. 1215. 
garantia da liberdade dos povos. Porém, esta liberdade não é aquela que o individualismo liberal quis oferecer aos povos, porque este tipo de liberdade, confessam os amantes da monarquia integral, é geradora do liberalismo económico que, por seu turno, engendra a plutocracia contemporânea, uma das razões da decadência da sociedade europeia, senão a principal; é antes uma liberdade orgânica émula da autoridade, da competência e da hierarquia.

Toda esta linha argumentativa aporta à ideia da necessidade imperiosa de constituição duma nova ordem política, social e económica ${ }^{5}$, ordem essa que se estruture como o baluarte da resistência contra o individualismo económico liberal e afronte a mentira plutocrática e revolucionária ${ }^{6}$. Ora bem, esse é, precisamente, o tema central do segundo e seguinte artigo desta série.

Para a consolidação duma Ordem Nova, é tarefa prioritária a crítica àquela que muitos pressupõem ser uma nova ordem, isto é, o novo regime político, social e económico estabelecido na Rússia desde 1917, escassos cinco anos antes do aparecimento da série da Nação Portuguesa de que nos ocupamos neste momento. Para esse efeito, António Sardinha vai servir-se de dois textos de autores próximos do regime comunista soviético, a saber, o texto de Fernando de los Ríos, Mi viaje a la Rusia sovietista, de 1921, e o Memorando de Lev Davidovich Bronstein, mais conhecido nos palcos políticos pelo pseudónimo de Trotsky, apresentado ao IX Congresso do Partido Comunista da União Soviética, reunião que decorreu entre 29 de Março e 1 de Abril de 1920.

Munido destas duas "armas", dispara, então, o pensador de Monforte a conclusão de que no Estado leninista, ou "ditadura leninista" como lhe prefere chamar, se deu "o eclipse dos direitos do homem", isto porque o ser humano é encarado como simples produtor, isto é, como "homo economicus." $\mathrm{E}$, mais adiante, remata que este estado de coisas é função do facto de o Estado comunista bolchevista ser, também ele, uma "excrescência" do individualismo próprio da democracia liberal e da filosofia das luzes.

5 Pode-se perguntar até que ponto vão as analogias entre esta Ordem Nova e o futuro conceito de construção do Estado Novo.

6 Sobre esta questão, veja-se o violento e um pouco obscuro artigo de Domingos de Gusmão Araújo,"Hora do Quadrante", n. ${ }^{\circ}$ 2, pp. 49-51, onde o autor atesta:"a plutocracia judaica amolece, afrouxa e desarticula as virtudes austeras. A maçonaria traz punhais na sombra. $O$ protestantismo, religião das raças materiais e menos idealistas, por conseguinte, menos requintadas e anti-romanas, cultiva o individualismo e desnacionaliza; a teosofia inverte e desnatura o sobrenatural."Araújo propõe ainda nesta peça a criação dum Instituto Nacionalista que tivesse como missão a seriação, sistematização e coordenação dos "valores visíveis da Pátria e nos desse o equivalente das chamadas virtudes cívicas da democracia". 
Nessa ordem de ideias, vem à luz que o regime dos sovietes não é uma nova ordem, mas sim o desenvolvimento da velha ordem liberal num sentido muito específico.

Partindo da ideia, agora consolidada, de que todas as organizações sociais ocidentais são filhas do regime liberal, vai o mestre integralista esquematizar a sua nova concepção de organização estadual. Esta tem como pedra basilar não o indivíduo, o ser isolado, mas a família. Por sua vez, do ponto de vista profissional, os indivíduos inserem-se em grémios ou corporações que são as células básicas dos municípios, e a reunião destes, no mesmo sentido, forma as províncias que, como não poderia deixar de ser, da sua conglomeração dão origem à Pátria ou à Nação ${ }^{7}$, unidade irredutível a que tudo se encontra sujeito, inclusive, como veremos, o Estado e o seu primeiro magistrado, ou seja, o Rei, fazendo jus à sua divisa do pelicano: pola lei e pola grei ${ }^{8}$. Este é o "grande caminho da Tradição", diz à puridade António de Sousa Sardinha.

Ainda na perspectiva do autor alentejano, este novo sistema social vai encontrando o seu terreno de difusão através da Europa. Citando os casos de França, através de Maurras, Suíça, Espanha, Portugal, por meio do seu Integralismo, e Itália, pela mão de Mussolini, afirma que tudo isto não é mais do que a rampa de lançamento da luta contra a plutocracia ocidental ${ }^{9}$. Termina toda esta congeminação com a "pérola" de que Portugal terá o destino glorioso de ser o inaugurador dessa Ordem Nova, "para prestígio da Cristandade e aumento da civilização, na sua missão renovada de 'povo conquistador e descobridor'".

Para terminar a análise desta peça doutrinal acerca da tentativa de esboçar a construção duma ordem nova do ponto de vista político, social e económico - que, bem vistas as coisas, apenas constitui um regresso ao passado e à tradição lusa, ou a enten-

7 Existem claras linhas de analogia entre esta concepção da sociedade e a protagonizada por Krause e expendida no Ideal de la Humanidad para la vida, Barcelona, Ediciones Orbis, 1985 (vejam-se, por exemplo, pp. $73,74,78,140$ e ss. e passim). A despeito de tudo isso, Sardinha, de modo equívoco, vai fazer radicar a filosofia krausiana, à semelhança da filosofia kantiana, no individualismo; a esse propósito, consulte-se, do pensador de Monforte,"A Crise do Estado,"Nação Portuguesa, 3.a série, n. 1, p. 36, col. 1 e 2.

8 Sobre a questão da unidade da Nação Portuguesa, vejam-se os artigos de Sardinha,"O Sul contra o Norte I e II", n. ${ }^{\circ}$ 2, pp. 73-81 e n. ${ }^{\circ}$ 3, pp. 125-133, onde o pensador de Monforte refuta a tese do antagonismo entre o Sul, arabizado e mercantilista, e o Norte, célula autóctone da Pátria. Seguindo ainda a sua argumentação, existe uma identidade linguística nacional que traduz, em última instância, quer a identidade da raça, quer a unidade da fé. Por outro lado, acerca da questão da ordem nova, veja-se, de César A. de Oliveira,"Novus nascitur ordo", n. ${ }^{\circ}$ 3, pp. 120-124, e Félix Correia,"Ante a Catástrofe. Na derrocada inevitável desta sociedade, ficarão de pé os sindicatos. Os alicerces da Cidade-Nova", n. ${ }^{\circ}$ 6, pp. 278 a 281.

9 Sobre a situação na Europa e em particular em Itália, vejam-se os artigos de Rolão Preto intitulados “Crónica Social", n. ${ }^{\circ}$ 1, pp. 33-36, n. ${ }^{\circ}$ 4, pp. 171-173 e n. ${ }^{\circ}$ 6, pp. 273-276. 
dida pelos integralistas como tal, isto é, um passado idealizado que seria visto como a "época de ouro" da nação -, não podemos deixar de fazer referência à visão profética messiânica que enforma a parte final do artigo. Este messianismo vai tornar-se um dos traços distintivos, fundamentalmente através da pena de Sardinha, da doutrina do Integralismo Lusitano e, num momento posterior, lançará raízes numa visão hispânica que desemboca num movimento de carácter holístico: a união hispano-americana, que não é mais do que o protótipo da congregação de todas os países de língua portuguesa e castelhana pelos quatro cantos do mundo ${ }^{10}$.

A análise dos artigos doutrinais do periódico não poderia deixar de fazer referência a um outro conjunto de peças, todas produzidas pelo labor do pensador de Monforte, que complementam esta tentativa de construção duma nova ordem social. Estão, neste caso, os textos referentes à "Teoria do Município. Exposição do problema", n. ${ }^{7}$, pp. 301 a 310, e à “Teoria do Município Il. Do valor do localismo”, n. 8 , pp. 356 a 375;“O significado do Amadis I", n. ${ }^{\circ}$ 9, pp. 400 a 409, e “O significado do Amadis II", n. 10 , pp. 455 a 468, e, embora num registo completamente diferente, "A religião da Beleza l," n. ${ }^{\circ}$ 12, pp. 601 a $613^{11}$. Termina esta segunda "dose de pratos" integralistas o texto "Mais longe ainda!", n. ${ }^{\circ}$ 12, pp. 561 a 567, peça que encerra esta renovada série da revista. Sentemo-nos e recostemo-nos para saborear, a pouco e pouco, esta nova sequência da exposição do ideário do Integralismo Lusitano.

10 Sobre o espírito que anima esta última iniciativa, vejam-se, de Sardinha, "O Génio Peninsular", n. ${ }^{\circ} 4$, pp. 150 a 158; Direcção, "A Marcha do Hispanismo" e "Glória ao Brasil,"n. 2, pp. 91-92 e n. 3, pp. 97-99; Afonso Lopes Vieira, "Palavras em louvor da Festa da Raça”, n. ${ }^{4}$, pp. 145-146; Antonio Ballesteros Beretta, "La Fiesta de la Raza," n. * 4, pp. 147 a 149; Angélica Palma, "Hispanismo e Nacionalismo," n. 5, pp. 193 a 194 ; António Sardinha, "Hispanismo e Espanholismo - Ainda a entrevista a Miramar", n. 5, pp. 211 a 214 ; Direcção, "Portugal e Brasil", n.o 9, pp. 415 a 423, e todo o n.o 11 dedicado à gloriosa Nação Brasileira e que contém o que se segue: Afonso Lopes Vieira, "Saudação ao Brasil," pp. 489 a 490; Direcção, “Definindo intenções,'pp. 491 a 493; J. Lúcio de Azevedo, “Da história da colonização do Brasil referida às missões religiosas,"pp. 494 a 501;Manuel Múrias, "A língua portuguesa no Brasil,'pp. 502 a 506; Bettencourt Rodrigues, "Portugal-Brasil e a diplomacia inglesa (trecho duma conferência sobre "Confederação luso-brasileira e bloco luso-hispano-americano" feita a pedido da "Federação Paulista de Estudantes" no Clube Português de S. Paulo, a 6 de Dezembro de 1922)", pp. 507 a 512; Carlos Malheiro Dias, "A génese da colonização do Brasil (excerto inédito da "introdução" ao 3. volume da História da Colonização Portuguesa no Brasil)", pp. 513 a 520; Direcção, "Oliveira Lima”, pp. 521 a 523; Gilberto Freyre, “O Sr. Oliveira Lima em Portugal”, pp. 523 a 525; Luiz d'Almeida Braga, “Das belas letras brasileiras," pp. 526 a 533; José Augusto Vaz Pinto, “O futuro político do Brasil,"pp. 534 a 541; Direcção, "A retirada para o Brasil,"pp. 542 a 544; António Sardinha,"A lição do Brasil. A Jackson de Figueiredo," pp. 545 a 556; Direcção, “D. Luís da Cunha e o Brasil”, pp. 557 a 560.

11 Este artigo, a despeito de ser numerado com I, conforme pode ser constatado pelo título acima, nunca chegou a ser continuado, pois não encontrámos em número nenhum da Nação Portuguesa o seu prosseguimento. 
O primeiro dos textos mencionados vai aprofundar aquilo que já tinha sido posto em relevo a propósito da questão da ordenação da sociedade numa nova ordem. O município, como tinha sido alvitrado, forma uma das peças nucleares desta nova disposição social, política e económica, conjuntamente com a família, o grémio ou a corporação, que o antecedem, e a província, que se encontra imediatamente a seguir e antes da verdadeira unidade irredutível: a Nação. Não é facto digno de espanto que o autor integralista comece a sua análise por uma citação de Alexandre Herculano extraída da História de Portugal e que consiste em atestar que "o estudo do Município, nas origens dele, nas suas modificações, na sua significação como elemento político, deve ter para a geração actual subido valor histórico, quando a experiência tiver demonstrado a necessidade de restaurar esse esquecido mas indispensável elemento de toda a boa organização social"12.

Serve, então, este texto de mote para encetar uma crítica às doutrinas do século XIX que levaram à dissolução dos vínculos sociais e à consequente anarquia com que o Estado se depara, sendo o município o agrupamento natural que mais sofreu com esse "progresso"13. Como não podia deixar de ser, vai Sardinha tentar perceber "o que seja de facto o Município". Para esse efeito, socorre-se das definições de Savigny, Tocqueville, Ahrens (que aparece, erradamente, grafado Arhens), H. de Tausey, Sismondi, Royer-Collard, Castadot, Rowe, municipalista americano, Laveleye, Cánovas del Castillo, Maura e, mais à frente, do Visconde de Almeida Garrett.Toda esta armação teórica permite-lhe concluir que o município é a criação espontânea ou natural de circunstâncias históricas, mesológicas, geográficas e demográficas.

Em seguida, socorrendo-se de Adolfo Posada, catedrático de Direito Municipal Comparado na Universidade de Madrid, põe o problema do município como o verdadeiro problema do Estado. É aqui que é necessário fazer uma pequena reflexão que nos ajude a esclarecer a verdadeira importância deste texto, pois o município

12 António Sardinha,"Teoria do Município. Exposição do problema,"n. ${ }^{\circ}$ 7, p. 301, col. 1.

${ }^{13}$ Atesta-nos o autor alentejano: "atingiram as consequências extremas as doutrinas do século passado sobre a constituição do Estado e a natureza do poder. Baseadas no indivíduo, como célula fundamental da sociedade, fizeram tábua rasa dos agrupamentos naturais, de que o ser colectivo se tecia e que, sendo, na sua formação, organismos anteriores à vida e aparecimento do Estado, representam forças essenciais, para cuja coordenação e guarda o Estado existe como lógico agente ponderador (...) os princípios saídos da Revolução Francesa e tornados por Napoleão em corpo legal, suprimiram assim todas as fecundas actividades locais - ou Comunas, encaradas político-administrativamente, ou Corporações, se as encararmos profissionalmente - abrindo caminho desta forma à dissolução dos vínculos sociais e à consequente anarquia em que o Estado moderno se desmantela e oscila", idem, ibidem, p. 301, col. 1-2. 
e a sua dilucidação encerram o verdadeiro problema do Estado. Quer isto significar que é o município, então, a verdadeira célula nuclear da nova ordem social, é ele o problema real e absoluto da sua constituição, o seu primeiro tijolo, e é sobre ele que toda a organização política, económica e social deve assentar. Nessa ordem de ideias, o município aparece como o Estado elaborador e realizador das energias colectivas; é ele, em conexão com os grémios ou corporações, que prende os indivíduos ao património ancestral comum. Esta linha de raciocínio vai levar o autor a distinguir a cidade, entendida como aglomeração de indivíduos, e o município, encarado como a concreção de famílias.

Para terminar toda a sua argumentação, faltava apenas demonstrar que este renascimento dos concelhos era incompatível com o espírito republicano, liberal e democrático. Por conseguinte, em momento complementar, o autor vai dedicar-se a essa tarefa com afinco, tentando deixar claro que a revolução, a República e todas as suas posteriores evoluções são as responsáveis pelo estado deplorável das coisas no país e, por extensão, em toda a Europa, preconizando um regresso às fórmulas económicas da Idade Média com o acentuar da organização familiar, gremial e municipal, sendo que só nesta última e não no Estado é que se realiza o verdadeiro ideal democrático.

Noutra ordem de ideias, mas sempre com o mesmo propósito, surge o conjunto de dois artigos realizados sob a epígrafe de "O significado de Amadis", que pretendem caracterizar o génio nacional através deste romance de cavalaria, peça onde a moralidade se constitui como o seu conteúdo mais profundo. Aliás, garante-nos o pensador do além-Tejo, o pecado do romantismo é a sobreposição da ordem sentimental à ordem ética da vida, e esse foi mais um factor, inspirado directamente dos livros de cavalaria que não o Amadis, que conduziu à decadência e anarquia da civilização ocidental.

Desse modo, vai Sardinha tentar estabelecer a autoria da obra baseando-se em argumentos raciais, etnográficos, jurídicos, literários e sociais. Para esta tarefa, conta com o apoio de Menéndez Pelayo, que assevera que a obra terá sido escrita por portugueses ou galegos, culminando na tese de que a obra se deve a João ou Vasco de Lobeira. Encerra o texto a tese de que a Europa é devedora a Portugal não só da mudança do eixo civilizacional do Mediterrâneo para o Atlântico como, ainda, da anterioridade da lírica galaico-portuguesa, cujo paradigma é o Amadis, em relação à poesia provençal, italiana e alemã, tese que deixamos à discrição do eventual leitor.

Por último, no artigo dedicado à estética, Sardinha tenta estabelecer um laço entre a arte e a beleza, por um lado, e a espiritualidade, isto é, o conteúdo ético-moral sub- 
jacente à existência, por outro lado. Nesse sentido, esta peça é o seguimento lógico daquilo que já se afirmou sobre o carácter do Amadis, ou seja, sobre a personalidade específica dos lusitanos. Devido a tudo isso, não será motivo de espanto que o pensador vá enraizar a verdadeira essência do belo e da estética na Idade Média, alvitrando que o verdadeiro defeito do Renascimento, além da acentuação do individualismo, foi arraigar a arte ao prazer singelo dos sentidos, olvidando-a como meio de evolução para estados de espiritualidade cada vez mais elevados.

Termina esta segunda série, como já foi posto em destaque, com um artigo significativamente intitulado "Mais longe ainda!," texto que, ainda que assacado à redacção, nós, à falta de melhor alvitre, adjudicaremos ao pensador nascido em Monforte, como já fizemos a propósito de "Porque voltámos". A peça inicia-se com a condenação dos princípios implícitos no Pacto de Paris, apelidado de "vergonha política e moral",e consequentemente com a afirmação, implícita, da verdade dos ideais do Integralismo Lusitano, que se constitui como "uma doutrina completa da reacção." Desta forma, o Integralismo Lusitano, rejeitando essa convenção, segue, orgulhoso, o seu caminho específico.

O autor empreende, de seguida, um breve olhar sobre a realidade política europeia, detendo-se, por instantes, na situação política da Itália de Mussolini e da Espanha de Primo de Rivera, regimes onde encontra o embrião dessa nova ordem por que tanto pugna. Continuando, atesta-nos que o que lhes faz falta é um fundo doutrinal, base essa que, como resulta evidente, embora de forma tácita no texto, só o Integralismo Lusitano poderia fornecer. Tudo aquilo que se acaba de expor conduz, inevitavelmente, à seguinte conclusão: aqueles homens, o nosso credo! Não termina Sardinha esta análise do caminho percorrido sem antes fazer uma referência à França e à Action Française, bem como à putativa instauração duma nova ordem neste cantinho ocidental. Reafirma, por último, que a denominação do artigo se constitui como um enorme brado:"mais longe, muito mais longe ainda!".

Encerrada a visão deste ângulo mais teórico e político do periódico, que agora é sede de nossos cuidados, restar-nos-á referir outros aspectos que, no nosso entender, surgem como complemento das inquietações sociais e políticas. Estão neste caso os textos que se debruçam sobre temáticas económicas. Destes artigos, temos que destacar os que se seguem: "Teoria do Imposto," n. 1, pp. 13 a 16, "Uma doutrina de economia agrária (Crítica do livro recente do sr. Ezequiel de Campos - 'Lázaro!...' I', n. ${ }^{\circ}$ 5, pp. 215 a 221, e "Uma doutrina de economia agrária (Crítica do livro recente do sr. Ezequiel de Campos - 'Lázaro!...'III',n. 7, pp. 289 a 295 - todas estas peças são devedo- 
ras da capacidade de escrita de José Pequito Rebelo.É precisamente este conjunto de textos que iremos tratar já na continuação desta nossa análise.

No artigo dedicado à Teoria do Imposto, depois de algumas considerações sobre os malefícios que o "morbus democrático" provocou na Teoria do Estado, História da Instituições e nas Ciências Económicas, ensaia o pensador do Gavião a articulação de alguns quesitos sobre a reforma urgente da Ciência das Finanças, em particular no "problema primacial do imposto".

Para alcançar os seus desígnios, começa por delinear a história do imposto até à contemporaneidade ${ }^{14}$, onde, ainda segundo o seu alvitre, o imposto tem as seguintes características: é um peso tirânico sobre a economia pública, o que conduzirá, inevitavelmente, à sua ruína; explora uns em favor de outros, o que o torna, de forma evidente, iníquo; tende a ser a fonte exclusiva das receitas públicas; conduz a um aumento exponencial das despesas ${ }^{15}$.

Por outro lado, a política monárquica pressupõe, após o equilíbrio das finanças públicas, o desaparecimento progressivo do imposto; este apenas protagonizará um caso de excepção, através de três vias principais: em primeiro lugar, pela via da descentralização, esta solução terá como consequência a diminuição das despesas públicas; seguidamente, pela instituição da monarquia, esta opção levará a que haja um decréscimo das clientelas políticas e extinguirá órgãos de governo obsoletos; finalmente, pela constituição da propriedade e indústria do Estado, este requisito fornecerá os meios de que necessita para a sua subsistência. Este património do Estado deverá, necessariamente, advir das "novas conquistas do fomento metropolitano e colonial"16.

Merece aqui, ainda, algumas palavras a recensão crítica da obra de Ezequiel de Campos, igualmente da pena do pensador do Gavião, intitulada "Uma doutrina de economia agrária - Crítica do livro recente do Sr. Ezequiel de Campos. Lázaro.....Este artigo é encetado com alguns encómios ao trabalho de Campos, o que lhe permite atingir o seguinte corolário: se se abstraísse de tudo o que na obra se encontra de ideologia democrática, isto é, de "metafísica revolucionária", não haveria qualquer crítica

14 Esclarece-nos Rebelo que é com o Renascimento que o imposto se torna o instrumento do Estado, o polvo tentacular sobre todas as formas de riqueza, concepção que se complexifica com a democracia moderna.

15 Sobre a política de aumento exponencial da despesa pública, cf. o artigo de Afonso Lucas, "Na varanda de Pilatos (Empréstimos \& moeda falsa)", n. 7 , pp. 322 a 329, onde se analisa a política financeira da República.

${ }^{16}$ Acerca da questão do fomento colonial, veja-se o artigo de José Augusto Vaz Pinto, “Da administração das colónias em Monarquia Orgânica",n. • 9, pp. 396 a 399, onde se analisa a situação colonial do ponto de vista administrativo, social e político. 
a empreender. Porém, ao analisar o plano de reforma agrária de Ezequiel de Campos, não se coíbe de tecer alguns considerandos: por exemplo, a expropriação de terras no Sul pelo valor da matriz, que para Rebelo equivale às reformas adoptadas pelo regime soviético, é considerada um verdadeiro atentado à propriedade privada (ainda para mais para ele próprio, se tivermos em linha de conta que era possuidor de considerável latifúndio); por outro lado, vai amparar a enfiteuse, duramente criticada por Campos. As objecções ao projecto agrário não terminam por aqui, todavia, delas não atentaremos em pormenor para não estendermos em profusão a análise do artigo em causa. Para quem for portador de maior curiosidade, a leitura integral do texto será o melhor remédio para a maleita indiciada.

Também revelam algum interesse, mais que não seja do ponto de vista da sociedade europeia, ou de parte dela, durante "os loucos anos 20", as peças da responsabilidade de Francisco Rolão Preto, apelidadas de "Crónica Social" e patenteadas no n. ${ }^{\circ} 1$, pp. 33 a 36, no n. ${ }^{\circ}$, pp. 171 a 173, e no n. ${ }^{\circ} 6$, pp. 273 a 276.

Os citados artigos têm como objectivo dar a conhecer os traços gerais que auxiliem a compreensão das lutas sociais que se desenrolam na Europa contemporânea. Nesse âmbito, o autor realça, fundamentalmente, os conflitos entre fascistas e comunistas italianos que, na sua perspectiva, considera "um dos factos mais interessantes da história social dos últimos dias".

Abstraindo dos casos particulares que são enumerados pelo autor beirão - acontecimentos em Roma, Bolonha, Val Tonnazza, etc. -, o que nos parece relevante é o facto de se ter em linha de conta a identificação entre o Integralismo Lusitano e o fascismo da Idea Nazionale, processo em que o autor esgaravata até às próprias origens do "fascio" em Itália. Nessa ordem de ideias, considera Preto a Itália, em geral, e Mussolini, em particular, como os verdadeiros receptáculos da "Ordem Nova”.Contudo, em todas estas considerações é necessário tomar em linha de cálculo o alvitre do pensador de Monforte que, no caso do fascismo, tal como em relação à Espanha e a Primo de Rivera, admitia que a todos eles escasseava um fundo teórico e ideológico que os pudesse escorar.

A despeito de anunciar que se vai ocupar do fenómeno da subida ao poder de Mussolini, em crónica de 31 de Outubro de 1922, tal intento nunca vai chegar a ser concretizado. Na sua última crónica, que vem à luz, como já se explicitou, no n. ${ }^{\circ} 6$, apenas encontramos um motivo de interesse: a definição da monarquia social. Seguindo o pensamento de Rolão Preto, a monarquia social é o tipo de governo em que existe uma representação nacional na qual o interesse profissional tem a sua salvaguarda 
técnica na capacidade de cada indivíduo e em que a harmonia social se garante no interesse nacional, isto é, na solidariedade. Seja como for, o autor chega à seguinte conclusão: todo esse processo se encontra abarcado pelas virtudes orgânicas do nosso sindicalismo. Por último, anuncia o escritor beirão o projecto de redigir uma obra intitulada Monarquia Social, propósito que, segundo conseguimos apurar, nunca passou de mera intenção.

Em relação aos vários artigos publicados sob a epígrafe "Crónica Política", apenas um nos parece merecer atenção mais prolongada: a obra da pena de Afonso Lucas, subintitulada "A Nova Babel", que apareceu no n.0 1, pp. 37 a $42^{17}$.

O ponto de partida do autor é o qualificativo de política de extrema-direita, empregue por um jornal que não é identificado no texto, aposto ao movimento do Integralismo Lusitano. Nessa ordem de ideias, esclarece Lucas que o movimento do Integralismo Lusitano é Nacionalista, Reaccionário e Renovador. Passando a esclarecer as suas asserções, vai definir o que entende pelo termo "nacionalista", porquanto considera a nação definida no espaço, tal evento significa "independência"; porque considera a nação na sua diversidade multicultural que resulta das circunstâncias naturais, tal ocorrência significa "liberdade"; pois considera a nação na diferenciação e especialização funcional dos seus órgãos naturais e legítimos, ao mesmo tempo autónomos (escala de interesses parciais) e solidários (interesse geral dominando e coordenando), tal circunstância significa "competência" e "dignidade." Por tudo aquilo que ficou exposto, o movimento do Integralismo Lusitano afirma-se como tradicionalista (a palavra "tradição", esclarece Lucas, significa transmissão), regionalista e defensor do sindicalismo orgânico.

Continuando a exposição do seu ideário, acrescenta: reaccionários, porque anti-iluministas, antiliberais e anti-românticos ${ }^{18}$; revolucionários, por dever e necessidade

17 Os outros artigos publicados sob a mesma inscrição, por ordem de publicação, são: do mesmo autor, presente no n. ${ }^{\circ}$, subintitulado “Os Vendilhões do Templo", pp. 174 a 178; de Nuno de Montemor (pseudónimo do Padre Joaquim Augusto Álvares de Almeida), com o subtítulo de "Notre politique, à nous", n. ${ }^{\circ}$ 6, pp. 267 a 272; de Augusto da Costa, denominado “A Crise Portuguesa e a crise geral do Estado", n. 9 9, pp. 410 a 415. Veja-se também, embora com título diverso na "Revista de Política Externa", o artigo de Garcia Moreno no n. ${ }^{\circ}$, pp. 137 a 144, onde se analisa o Tratado de Versalhes e o movimento reaccionário a nível europeu.

18 Sobre o uso do prefixo anti- no movimento do Integralismo Lusitano, veja-se a revista, em doze fascículos, dirigida por Albano Magalhães e Marcelo Caetano, Ordem Nova, cujo subtítulo é Revista Anti-Moderna, Anti-Liberal, Anti-Democrática, Anti-Burguesa e Anti-Bolchevista; Contra-Revolucionária; Reaccionária, Católica, Apostólica e Romana; Monárquica; Intolerante e Intransigente; Insolidária com Escritores, Jornalistas e quaisquer Profissionais das Letras, das Artes e da Imprensa, Lisboa, J. Fernandes Júnior, 
transitória, pois sem uma revolução nacional é impossível "endireitar a nação"; autoritários por natureza, porquanto esta engloba a disciplina, a hierarquia e a integração. Ainda não satisfeito, acrescenta renovadores pois pretendem voltar às "instituições naturais em que Portugal se criou" e, tendo isso em atenção, monárquicos por convicção porque "a Monarquia é a forma da Nação; a Nação, a essência da Monarquia".

Tudo isto lhe permite chegar ao seguinte corolário: o movimento do Integralismo Lusitano não se posiciona em lugar político nenhum, isto porque todos (partidos políticos, movimentos políticos) aceitam o jogo político republicano, e o Integralismo Lusitano recusa-se a aceitá-lo. $\mathrm{O}$ autor remata, ainda, de forma paradoxal, que, a posicionar-se em algum sítio, esse seria na extrema-esquerda ${ }^{19}$.

São também motivo de detença, na nossa parca opinião, as crónicas de Francisco Veloso apelidadas de "Política Religiosa", que vêem a luz no n. ${ }^{\circ} 2$, pp. 82 a 88, n. 4, pp. 183 a 190 e n. ${ }^{\circ}$, pp. 314 a 321, mais que não seja pelo facto de a Religião, em geral, e o catolicismo, em particular, ocuparem um lugar de destaque no quadro teórico do movimento do Integralismo Lusitano.

Nesse sentido, cumpre-nos fornecer, neste momento, as linhas fundamentais com que se cosem as citadas peças do periódico. $O$ primeiro desses documentos esboça, desde logo, o seu objectivo geral, as relações entre a Igreja e o Estado, definindo, à partida, a fórmula geral que deve presidir a estas relações:"a Igreja soberana no foro espiritual, livre de exercer plenamente a sua acção, em relações de cooperação nacional e de boa vizinhança com o Estado livre e soberano".

Seguidamente, urge defender os privilégios naturais da Igreja no que respeita ao direito de associação, ensino e outras liberdades complementares, reconhecendo-lhe o seu papel primacial para a Nação, pois esta é "a depositária da tradição religiosa da Raça e Mestra da verdadeira fé".

O ponto de partida do artigo seguinte é o opúsculo em que Salazar determina os objectivos e meios de acção do Centro Católico. Porém, a questão mais candente na imprensa católica reside no facto de se determinar se os membros do Centro Católico podem ou não ter acção política. No caso vertente, o autor defende que os membros do Centro Católico não só podem mas devem ter acção política, pois o objectivo ou alvo do Centro é a "união no terreno religioso e a acção no terreno constitucional." Por

1926-1927. Como se pode constatar, só o católico, apostólico, romano e monárquico se não podem transformar com o prefixo anti-, e mesmo alguns desses, vendo bem, são passíveis de se tornar "antis", como, por exemplo, antiprotestante e anti-republicano.

19 Para sopesar os seus argumentos, cf. art. cit., p. 42, col. 1 e 2 . 
outro lado, tendo como propósito a restauração das liberdades da Igreja e o aspirar ao bem comum da pátria, isso acarreta que o Centro Católico deva ter como tarefa, necessariamente, a crítica ao liberalismo e às instituições liberais, pois são estas "que o Centro deve considerar como seu inimigo".

O derradeiro artigo apenas concretiza e explicita os objectivos, já aludidos anteriormente, do Centro Católico, a saber: liberdade da Igreja, cristianização das leis e dos costumes, equilíbrio das forças partidárias em colisão e atenção aos interesses económicos da Nação. Reitera, por último, que os interesses partidários nunca, em caso algum, se podem sobrepor aos aspectos doutrinais da religião.

Não podem deixar ainda de nos merecer uns momentos de ponderação, embora de uma forma mais breve e concisa, os artigos que se preocupam com a "rescrita da história", isto é, a tentativa de fornecer um contrapeso à história romântica e liberal, que depois de 1820 tinha quase monopolizado a chamada "história científica"20. Estão neste âmbito os artigos de António Rodrigues Cavalheiro, “À margem dum processo (A questão Gomes Freire),"n. 2, pp.61 a 72, e n. 5, pp. 222 a 229, "Questões de História” e "1640" de António Sardinha publicados, respectivamente, no n. 5 , pp. 230 a 240, e n. ${ }^{\circ} 6$, pp. 241 a $251^{21}$.

O primeiro dos artigos citados cumpre uma função muito específica: lançar uma nova luz, ou seja, uma diferente perspectiva sobre os chamados "heróis liberais", dos quais Gomes Freire de Andrade não será dos mais despiciendos. Como é do domínio público, com o declinar do século XIX multiplicaram-se as tentativas de criação de cultos cívicos e de heróis cívicos que tinham como propósito a substituição dos cultos e santos de carácter religioso 22 .É precisamente a essa tentativa de positivistas,

20 Sobre a mesma questão, veja-se, por exemplo, de António Ventura,"António Sardinha: Mitologia integralista e Revisão da História de Portugal", Estudos sobre História e Cultura Contemporâneas de Portugal,Lisboa, Caleidoscópio, 2004, em particular pp. 219 a 221. Ventura refere uma série de personalidades históricas malqueridas aos liberais que o labor de Sardinha tenta reabilitar, ou denegrir, caso sejam bem-queridas. Não tivemos oportunidade de confirmar todas as referências do autor, mas de uma delas, Gomes Freire de Andrade, referido na p.221, temos a certeza, como se pode constatar infra, de que o artigo original não foi da responsabilidade de Sardinha mas sim de António Rodrigues Cavalheiro.

${ }^{21}$ Ainda de algum interesse é o artigo de César A. de Oliveira, "Sobre as Águas do Dilúvio," 2.a série,"I - A margem da História," n. ${ }^{9}$ 9, pp. 385 a 395, e“Il - Dois séculos de penitência,"n. ${ }^{\circ} 12$, pp. 588 a 597, 3.a série, n. ${ }^{\circ}$ 9-10, pp. 427 a 434, e n. 11 , pp. 464 a 470. A despeito de se ortografar no último artigo (a seguir), o que é verdade é que não nos foi possível deparar com a sua continuação em nenhum dos números seguintes da Nação Portuguesa.

22 Sobre essa questão, veja-se, por exemplo, o artigo de Fernando Catroga, “O Culto Cívico de D. Pedro IV e a construção da memória liberal', separata da Revista de História das Ideias, Volume 12, Coimbra, Faculdade de Letras, 1990, pp. 445 a 470. 
republicanos, socialistas e anarquistas que Cavalheiro quer opor um dique. O método utilizado pelo autor, que é amplamente discutível, consiste em denegrir a imagem do general postulando a sua ligação a interesses estrangeiros, liberais e/ou franceses ${ }^{23}$; por esse motivo, conclui que "nunca soube servir a pátria", ou ao filosofismo iluminista e enciclopédico. Por outro lado, analisando a sua participação nas campanhas do Roussillon e da Catalunha (1793-1794), qualifica-o de mercenário e descreve aquilo que assevera como vergonhoso comportamento militar ${ }^{24}$.

Mais importante do ponto de vista teórico, como o próprio nome elucida, é o artigo do pensador de Monforte intitulado "Questões de História". Essas questões têm como catalisador a edição do primeiro volume da História de Portugal de Fortunato de Almeida, que, desde logo, é catalogada de incompleta e deficientíssima, porquanto omite fontes nacionais de elevada relevância. Esta crítica abre vereda, então, para que o autor discorra acerca dos defeitos da história romântica, que conduziu ao abuso "abominável da imaginação dentro dos domínios da história",e verbere a história positivista do documento e da experimentação.

Em "1640" encontramos, em moldes completamente diferentes, a visão messiânica corporizada na "crença nacional na vinda do Desejado" 25 do Brasil "como a grande razão ultramarina de Portugal". Todo este corrupio de argumentos pressupõe um encómio largo do nosso século XVII, "os nossos avós de 600", elaborado de tal forma que sentimos a mesma sensação que Eça de Queiroz terá experimentado acerca da visão da história de Pinheiro Chagas, a qual não nos coibimos de citar:"outro qualquer ter-se-ia contentado em folhear um livro de história, para colher, aqui e além, datas ou nomes de batalhas. Você, não. Você encerrou-se dentro da História, como Carlos Magno, revolvendo o pó dos antepassados, procurando penetrar-se da nobre fé que os fez grandiosos, dormindo com as façanhas do Condestável Nun'Álvares debaixo do travesseiro, para surpreender e poder imitar as palpitações daquele puro coração de herói. In-fólios, códices, manuscritos, memórias, forais, crónicas - tudo você absorveu. Mil vezes você passou e repassou, como diz Michelet, o sombrio rio dos Mortos. Dia a dia, reviveu todo o passado épico. E enfim uma hora chegou em que você decerto se

${ }^{23}$ Para se aquilatar a sua argumentação, tenha-se em conta que o autor chega a certificar que todas as influências lhe provêm do lado materno, da parte de sua mãe, a Condessa de Schafftgotsche (provavelmente austríaca, pois o local de nascimento de Gomes Freire de Andrade é Viena).

24 Se houver curiosidade em ponderar as suas razões, ver art. cit., n. ${ }^{\circ}$ 5, pp. 222 a 226.

25 Ainda sobre a mesma temática, assegura Sardinha no mesmo artigo: "tocar no valor do Sebastianismo, como fonte de energia, mas de energia positiva, na dinâmica da alma nacional." $\mathrm{E}$, em outro lugar, assevera, a "crença sebástica (...) [como] o fundamento mais sólido do génio da Grei". 
considerou digno de ter recebido em Sagres, nalguma véspera de partida de caravelas, as confidências sublimes do infante D. Henrique" ${ }^{\prime 26}$.

Para encerrar esta nossa análise concernente à segunda demão da Nação Portuguesa, Revista de Cultura Nacionalista, apenas gostaríamos de fazer menção, o mais breve que nos for possível, aos dois artigos assinados pelo Padre Avelino Soares sob o mote "Estudos de Filosofia": no n. ${ }^{\circ}$ 5, com o subtítulo de "Duas palavras de introdução," pp. 203 a 205 , e no n. ${ }^{\circ} 12$, denominado "As grandes linhas da filosofia tradicional", pp. 568 a $576^{27}$.

O primeiro dos artigos de Soares inicia-se pela tentativa de explicação do porquê das temáticas filosóficas numa revista, fundamentalmente, de acção política e de carácter prático e nacionalista. $O$ texto, para não destoar, empreende uma crítica cerrada ao filosofismo ${ }^{28}$, romantismo, agnosticismo, epicurismo, materialismo e positivismo e chega a bom porto no projecto de esboçar, embora em grandes linhas temáticas, os quadros elementares da filosofia tradicional, como não podia deixar de ser, na sua vertente sociológica, política e pedagógica.

A peça seguinte inicia-se, nessa ordem de ideias, com a definição da filosofia tradicional, de raiz aristotélico-tomista, enquanto metafísica e antipositivista, embora utilize os elementos provenientes das ciências ditas positivas, almejando investigar não só o modo, mas também a justificação e a utilidade dos fenómenos do mundo. Por fim, conecta a filosofia com a autoridade, que, por sua vez, faz emanar da natureza, isto é, de Deus, com a propriedade e com o trabalho, realçando o valor da família, da educação e da pedagogia, tentando alcançar o modelo duma filosofia cristã de raiz humanista.

Terminamos, deste modo, os artigos que reputamos mais significativos da segunda série desta revista de filosofia política e cultura nacionalista. Para quem tiver mais

${ }^{26}$ Eça de Queiroz, Brasil e Portugal, in "Notas Contemporâneas", Obras de Eça de Queiroz, Vol. II, Porto, Lello \& Irmão, s/d, p. 1397. Não posso deixar de salientar, no texto de Eça, a alusão a Nuno Álvares Pereira, uma das figuras históricas mais gradas ao movimento do Integralismo Lusitano.

${ }^{27}$ Um outro artigo pareceria, à partida, tratar da mesma problemática, neste caso escrito por Domingos de Gusmão Araújo e intitulado "Leonardo Coimbra (Esbocetos de crítica),", n. ${ }^{\circ}$ 4, pp. 167 a 170; no entanto, queda-se pela análise da poema "Adoração" e resume no final, de forma um pouco apressada de mais quer-nos parecer, o pensamento filosófico do autor mencionado.

${ }^{28}$ É de estranhar que nem Sardinha, por maioria de razão, nem qualquer outro integralista tenham a preocupação de salientar e elogiar ou, pelo menos, referenciar o conjunto de autores que combateu, com razão ou sem ela (embora isso pouco importasse aos integralistas), os filósofos do século XVIII, entre eles Palissot (1730-1814), autor de Cercle (1755) e Philosophes (1760) onde ataca os enciclopedistas; Henry Poinsinet (1735-1769), que escreveu Le Petit philosophe (1760); Fréron (1719-1776) e o Abade Trublet (1697-1770), que mantiveram inúmeras pendências com Voltaire. 
curiosidade acerca destes escritos integralistas, é sempre possível a consulta, a disponibilizar pela Biblioteca Nacional de Portugal, da base de dados com a fichagem completa das onze séries desta importante revista de pensamento nacionalista integral.

Em relação às características físicas da publicação, há que salientar a sua periodicidade mensal entre o número um, Julho de 1922, e o número dez, Abril de 1923. Tal acontecimento pode denotar uma de duas coisas ou, atendendo bem, ambas: a disponibilidade financeira e o elevado compromisso de todos os seus redactores. A última pode ainda indicar um período de "combate cerrado" das hostes integralistas, elemento que terá sempre que ser tido em conta por quem historiar o movimento.

Não podemos, do mesmo modo, deixar de realçar o excessivo decurso de tempo entre o número dez, Abril de 1923, como já foi posto em saliência, e os números onze e doze, respectivamente de Outubro ou Novembro (nesta publicação aparece um artigo de Afonso Lopes Vieira datado de Outubro de 1923) e de Novembro ou Dezembro (figura uma referência ao declinar do ano de 1923 no artigo "Mais longe ainda", número doze, p. 566). Esta disparidade pode ser entendida de modos diferentes: como o número é temático, dedicado à gloriosa nação brasileira, a falta de artigos sobre o tema pode ser uma explicação; também plausível é a falta de meios financeiros (vejam-se, por exemplo, as tentativas de angariação de fundos); problemas com a impressão podem ser também uma hipótese; o número doze, como já tinha acontecido com o nove, foi impresso em Santo Tirso, como se pode constatar já de seguida.

Todos os números desta série tiveram como director António de Sousa Sardinha, sendo Domingos de Gusmão Araújo o secretário, e J. Fernandes Júnior, o editor. No que se refere ao património, o número um não tem qualquer alusão, do número dois até ao quatro a propriedade é atribuída à Empresa da "Nação Portuguesa", e à Sociedade Integralista Editora, Limitada os números restantes.

Quanto aos lugares de composição e impressão da Nação Portuguesa, eles são os que se seguem: o número um é composto na Rua Serpa Pinto, 38 - 3.․ Lisboa e impresso no Largo do Calhariz, 29, na mesma cidade; para os números dois e três, o Largo do Directório, 8 - 3. em Lisboa é o lugar da composição, mantendo-se a impressão no mesmo sítio; para os números do quatro ao oito, dez e onze, ocorre manifestar-se o ponto da Redacção e Administração que coincide com o da composição (Largo do Directório, 8 - 3.), mantendo-se inalterável o local da impressão; por fim, para os números nove e doze, a Redacção e a Administração passam a ocupar em exclusividade o Largo do Directório, 8 - 3. ${ }^{\circ}$, e a composição e a impressão transitam para a Tipografia Tirsense, em Santo Tirso. 



\title{
Estudos Sociais: percursos temáticos de um ímpeto reformista (1905-1911)
}

\author{
Pedro Silva*
}

\section{A urgência da "cristianização social" e o papel dos "católicos de acção"}

Consolidar a prática do catolicismo social e difundir as ideias da democracia cristã constituiu a dupla finalidade dos Estudos Sociais, enunciada no editorial de apresentação da revista, em Janeiro de $1905^{1}$, e repetida até ao fim da sua publicação, em Março de 1911. "O campo social em que o cristianismo, desde a segunda metade do século XIX, tem exercido as suas energias restauradoras é o que nós escolhemos para o contributo do nosso trabalho."2 A apresentação da proposta cristã e católica para a resolução da questão social constituía a prioridade desta publicação coimbrã que, também e desde sempre, manifestou vontade em afirmar-se como interveniente no debate/ /confronto travado entre a Igreja Católica e a cultura moderna. A concepção cristã do mundo, composta pelas denominadas "unidades sobrenaturais do Cristianismo que abrangem o homem, unidade de progenitura, unidade de redenção e unidade de fim", deveria saber confrontar-se com os movimentos racionalista e materialista usando da palavra e da argumentação, uma vez que "o espírito moderno é resistente aos actos

\footnotetext{
Seminário Livre de História das Ideias, Centro de História da Cultura da Faculdade de Ciências Sociais e Humanas da Universidade Nova de Lisboa.

1 Redacção,"Apresentando-nos,"in Estudos Sociais, v. 1, n. 1 (Jan. 1905), pp. 1-2.Todos os números da revista se encontram disponíveis para consulta em: http://purl.pt/736/1/. Nas notas de rodapé que se seguem, utilizar-se-á a abreviatura E.S. para referências aos Estudos Sociais. Também as notas relativas aos artigos da revista aparecem com indicação do nome do articulista, título do artigo, volume, número e páginas. A indicação do ano aparecerá quando não estiver referida no corpo do texto ou quando se entender pertinente.

2 Idem, p.2. Uma reunião do CADC, em 30 de Outubro de 1904, decidiu criar uma revista que actualizasse o pensamento social da Igreja. O principal impulsionador foi Artur Leite Amorim, que nunca permitiu que a publicação fosse apresentada como o órgão do Centro. Os objectivos e as pessoas foram, no entanto, comuns e sempre se publicaram nos E.S. notícias sobre a vida do Centro. Muitos artigos foram, também, a transcrição de conferências realizadas no Centro. Ver: Alberto Diniz da Fonseca, “Elementos para a História do C.A.D.C.", in Estudos, n. ${ }^{\text {ss }} 40-41$ e n. ${ }^{\text {s }}$ 47-48, 1926, e Joaquim Pinharanda Gomes, O Servo de Jesus. Alberto Diniz da Fonseca (1884-1962), Guarda, Liga dos Servos de Jesus, 1988.
} 


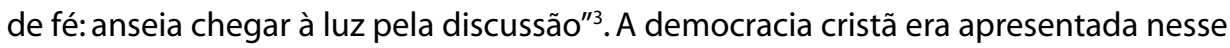
primeiro editorial como uma actualização "da grande obra da cristianização social"4 $\mathrm{e}$ acreditava-se que, graças à sua implantação, se iria assistir, ao longo do século XX, ao restabelecimento do princípio vital do Cristianismo, abafado desde a reforma protestante:"restaurar tudo em Cristo" 5 . Procurava-se, assim, efectivar o magistério de Leão $\mathrm{XIII}$ que, tendo refutado os erros do liberalismo económico e do socialismo irreligioso e tendo reabilitado a classe operária, dera início a uma nova fase na história da Igreja Católica ${ }^{6}$. Esta nova era já tinha sido assinalada pelo próprio Leão XIII. De facto, na encíclica Graves de Communi Re, o Papa afirmava que, após a Rerum Novarum, se estabelecera uma nova "nova comunidade de acção", no campo social, dinamizada por iniciativas como os secretariados do povo, as associações operárias ou os seguros de doença. Desta forma, o catolicismo social constituiu, a partir da segunda metade do século XIX, uma área em que a Igreja depositou grandes esperanças na sua relação e resposta ao mundo moderno ${ }^{7}$.

Também em Portugal, numa época caracterizada pelo avanço de uma corrente de sectarismo intolerante que procurava arrancar da alma portuguesa a religião, a realização de um congresso nacional de democracia cristã assinalaria a regeneração moral e social do povo português ${ }^{8}$. A democracia era considerada uma força de acção "neste país de declamação e platonismos. Não se pode ser católico só de princípios, para não falarmos dos católicos por tradição, por educação e por dever de ofício; nos tempos tristíssimos que vamos atravessando é preciso sobretudo ser católico de

3 Redaç̧ão, idem, p. 2.

4 Idem, p. 2.

5 Idem, p. 2.

6 Redacção,"Um aniversário 15 de Maio de 1891-15 de Maio de 1905,"vol. 1, n. o 5, pp. 209-210.

7 Para além de se dar à ordem social cristã um conteúdo de acordo com os dados concretos da evolução social, nesta nova fase procurar-se-ia igualmente fazer face à sociedade moderna através da restauração do tomismo, imposto a todas as escolas católicas, e através do estabelecimento de normas nas relações entre a Igreja e o Estado. Ver Pierre Thibault, Savoir et pouvoir (Philosophie thomiste et politique cléricale au XIXe siècle, Québec, Les Presses de I'Université Laval, 1972.

8 Severo, “Congresso nacional de democracia cristã”, v. 1, n. 11 (Nov. 1905), pp. 498-499. O I Congresso das Agremiações Populares Católicas realizou-se em Lisboa, entre 16 e 18 de Junho de 1906, e o II Congresso no Porto, entre 7 e 9 de Junho de 1907. Se o primeiro encontro tinha tido como principal preocupação a organização do movimento social cristão, o segundo teve como principal objectivo a unidade programática desse movimento. Ver Manuel Braga da Cruz, As Origens da Democracia Cristã e o Salazarismo, Lisboa, Editorial Presença, 1978. Os E.S. sempre se mostraram empenhados na realização e organização destes congressos, publicando, por exemplo, regulamentos, propostas, conclusões ou diversas reflexões em torno dos resultados obtidos. 
acção" ${ }^{\prime \prime}$. A religião estava longe de ser reduzida à esfera privada, defendendo-se, pelo contrário, a intervenção dos católicos na vida política através da democracia cristã. Esta era a melhor forma de responder ao anticlericalismo e, também por esse motivo, deveria ser ensinada e exercida nas comunidades rurais, nos sindicatos, no Governo e nas instituições locais. O retrato que se fazia da vida política portuguesa era bastante crítico e, logo em 1905, um artigo intitulado “Factos sociais e lições emergentes. O que muitos sentem e poucos dizem"10 procedia a uma crítica quer da evolução política da Europa, quer da situação política em Portugal. A divinização do Estado era apontada como a principal característica da evolução política da Europa. Em Portugal, "a doutrina pagã da divindade do Estado tem (...) perfeita realização. O Estado é tudo"11: controla o ensino, as obras de caridade social e até as consciências. Também o facto de a lei ser considerada a "norma suprema da moralidade", passando a ser expressão da vontade popular e não o reflexo da vontade divina, constituía outra crítica dirigida contra o ideário político europeu. “Ao absolutismo dum único sucedeu o despotismo das massas."12 Considerava-se que o sistema representativo possuía uma noção de direito volátil, e o povo continuava a ser explorado por novos tiranos como os partidos. A soberania deveria voltar a residir no povo e não nos deputados ${ }^{13}$.

Os objectivos de 1905 perduraram ao longo do ano seguinte. O editorial do primeiro número de $1906^{14}$ reafirmava o empenho na consolidação da democracia cristã e do movimento católico social em Portugal, e, no final desse mesmo ano, num artigo que constituía simultaneamente um balanço e um programa ${ }^{15}$, a redacção renovava o empenho em continuar a fazer da revista um espaço editorial onde não só se publicassem os trabalhos, com interesse religioso, produzidos em Coimbra e em todo o país, como se apresentassem também soluções para os problemas actuais. As áreas temáticas privilegiadas continuavam a ser o papel da Igreja Católica na história (em especial a sua contribuição para a abolição da escravatura e para a reabilitação do papel da mulher), a questão social e a ciência.

9 Severo, Idem, p. 498.

10 Theodorico, v. 1, n. 3 (Mar. 1905), pp. 115-119. O artigo resultou duma reflexão em torno das eleições realizadas no dia 12 de Fevereiro para a Câmara dos Deputados, classificadas, desde logo, como uma comédia.

11 Idem, p. 116.

12 Idem, p. 118.

13 Um outro artigo de Maio de 1905 criticava o funcionamento da política portuguesa, afirmando que não era o povo quem elegia os seus representantes, mas sim os dois grandes partidos. Propunha, como solução, a mudança da lei eleitoral. Heraclito, “Correspondência”, v. 1, n. o 5, p. 249.

14 "Apresentando-nos", v. 2, n. ${ }^{\circ}$ 1, p. 1.

15 “Estudos Sociais", v. 2, n.o 12, pp. 491-492. 
No início de 1907, num artigo intitulado"Para a luta"16, a redacção dos Estudos Sociais renovava os objectivos fundadores da revista: contribuição para a formação/educação religiosa dos estudantes universitários ${ }^{17}$ e para a implantação do movimento católico-social, considerado uma nova modalidade de apostolado eclesial. Neste editorial reafirmava-se que a democracia se baseava no Evangelho, que constituía a base do"futuro triunfo do Catolicismo"18, e enunciava-se "uma ordem social cristã em contraposição ao socialismo utópico e revolucionário"19. $\mathrm{O}$ artigo aproveitava não só para responder às acusações de heterodoxia, assegurando que a revista nunca se tinha desviado da doutrina católica e que a autoridade eclesiástica nunca tinha colocado entraves à sua publicação, como aproveitava para insistir que os católicos deveriam ser ousados e empreendedores."O conservantismo, convém dizê-lo bem alto, é o nome especioso da apatia." ${ }^{20}$ Neste artigo acentuava-se, igualmente, o papel a desempenhar pela imprensa católica, uma vez que "a revolução social só poderá fazer-se pela corrente possante das ideias, pela sugestão da verdade, que fere o espírito ou o sentimento"21. A imprensa católica, terreno ingrato em Portugal, era considerada o apostolado mais eficaz em Portugal, pois um bom jornal vale "o melhor templo"22. Os católicos deveriam ser ousados e empreendedores, fazendo da "arena da imprensa" um espaço que educasse para o aperfeiçoamento moral e que servisse não apenas para reflectir, mas também para transformar o mundo. Entre as várias reflexões que se publicaram na revista sobre esta temática, destaca-se um longo artigo de Elpis, "O jornal católico do século XX", onde se apresentavam as características que deveria possuir um jornal: popular, intelectual, noticioso e moderno. Além disto, defendia-se a intervenção política, sempre que fossem travadas polémicas com publicações não-católicas ou anticlericais ${ }^{23}$.

16 “Para a luta”, v. 3, n..$^{1, \text { pp. 1-5. }}$

17 Esta preocupação irá estar presente em inúmeros artigos publicados na revista. Desde breves notas sobre o papel do CADC de Coimbra no acolhimento aos estudantes que chegavam à cidade, passando por artigos sobre os perigos de correntes intelectuais anticatólicas, muitos foram os temas relativos à formação dos jovens católicos. Destacam-se, assim e por exemplo, um artigo intitulado "Cartas a um caloiro" (v. 6, n. 5 e 6, pp. 214-221); outro denominado "A crise religiosa entre os jovens", do Pe. Mandonnet (v. 6, n. 11 e 12, pp. 446-462) ou um outro artigo intitulado “Continência, higiene e celibato", de José Garcez (v. 4, n. ${ }^{\circ}$, pp. 179-194; v. 6, n. ${ }^{\circ}$ 1, pp. 3-8, e n. ${ }^{\circ}$ 2, pp. 41-46), onde se reflectia acerca da educação sexual dos jovens e da relação entre castidade e doenças infecciosas.

18 "Para a luta", p. 4.

19 Idem, p. 4.

20 Idem, p. 2.

21 Idem, p. 2.

22 Idem, p. 2.

${ }^{23}$ V. 1 , n. ${ }^{\circ} 12$, pp. $508-517$, v. 2, n. ${ }^{\circ} 8,9$ e 10, pp. 343-353 e v. 3, n. ${ }^{\circ} 4$, pp. 138-147. 
No editorial do número correspondente ao mês de Janeiro de 1908, ano em que os Estudos Sociais passaram a ter uma nova direcção ${ }^{24}$, objectivos idênticos aos delineados em anos anteriores foram aí enunciados ${ }^{25}$. Reafirmava-se o propósito em continuar a editar uma revista que abordasse temas relativos à questão social, sempre de acordo com a doutrina católica, sendo a encíclica Pascendi definida como estrela e escudo da revista. Nesse mesmo número, criticavam-se abertamente aqueles leitores da imprensa católica que não se preocupavam nem com o anticatolicismo que grassava por toda a Europa, nem com a problemática da questão social ${ }^{26}$.

Difundir as doutrinas sociais cristãs, melhorar as condições de vida dos operários e contrariar a crise civilizacional e moral da sociedade contemporânea constituíam as finalidades da revista, traçadas pela redacção no editorial do mês de Janeiro de $1909^{27}$."Para sermos pois católicos, precisamos de ser sociais." ${ }^{\text {"28 }}$ Relembrava-se o passado da revista de forma apaziguadora: os agravos e a desconfiança iniciais deveriam ser esquecidos, uma vez que os Estudos Sociais contribuíram para que existissem, em Portugal, núcleos de operários cristãos, padres animados pelas doutrinas sociais, seminários onde se ensinava a sociologia, congressos sociais e leigos empenhados. Faltava, apenas, coordenar estas realidades dispersas. $\mathrm{O}$ editorial retomava a crítica dirigida aos políticos portugueses, afirmando que eles não se concentravam nas verdadeiras questões, ao preferirem satisfazer clientelas. "Os inimigos do regime (...) preocupam-se mais em fomentar arruaças e revoluções do que em melhorar o estado moral, intelectual e material do povo." ${ }^{129}$ Considerava-se que só os católicos estavam a defender os interesses dos mais desfavorecidos, lutando contra a tentativa de destruição da família e fazendo dos municípios um "conjunto de interesses

24 Entre Janeiro de 1905 e Abril de 1907, Artur Leite de Amorim ocupou o cargo de administrador.Entre Abril e Dezembro de 1907, o Pe. Francisco Cotrim da Silva Garcez é o proprietário, editor e director, cabendo essas funções, entre Janeiro e Dezembro de 1908, ao Pe. António Rodrigues de Oliveira e, entre Janeiro de 1909 e Março de 1911, ao Pe. Elias de Aguiar.

${ }^{25}$ A nova direcção, depois de ter prestado uma homenagem ao seu antigo director, o Pe. Francisco Garcez, referia a possibilidade de tornar a revista quinzenal e mais acessível a todos, variando os assuntos e apresentando artigos menos longos: “Explicação prévia”, v. 4, n.o 1 (Jan. 1908), pp. 1-4. Também em Fevereiro do mesmo ano, alertava para a urgência em reestruturar a organização do CADC."Notas do mês", v. 4, n. ${ }^{\circ}$ 2, pp. 84-85.

26 "Bons conselhos e correcção fraterna", v. 4, n. 1, pp. 16-20, e n. 4, pp. 139-141.

27 "O nosso quinto ano,"v. 5, n. 1 , pp. 1-6.

${ }^{28}$ Idem, p. 4.

29 Idem, p.4. 
regionais, uma comunidade de ideias ao mesmo tempo que uma comunidade de indivíduos" ${ }^{\prime 30}$.

Em 1910, comunicava-se aos leitores dos Estudos Sociais que a revista se tinha tornado o órgão oficial da Unidade da Mocidade Católica Portuguesa ${ }^{31}$. Com esta transformação, acreditava-se que a publicação teria mais colaboradores, o que aumentaria a sua qualidade. A divisa da revista continuava a ser:"restaurar tudo em Cristo". Nesse mesmo ano, emergiu entre as preocupações dos Estudos Sociais a necessidade em tornar a escola um espaço de propaganda católica."A escola está sendo o vasto e magnífico campo de operações em que os adversários de Deus e da Pátria trabalham sem desfalecimentos." ${ }^{\prime 2}$ Alertava-se, assim, para o facto de o livre-pensamento e a maçonaria actuarem na escola através da imprensa e apelava-se à luta contra o "maçonismo cosmopolita. À cruzada a favor da boa-imprensa temos de associar, sem hesitações, a cruzada da boa-escola. Pela Escola e pela Imprensa"33.

Entre os meses de Abril e Setembro de 1910, os Estudos Sociais abordaram a temática da conciliação entre democracia e cristianismo."Todo o nosso programa se resume nessas duas palavras que constituem o enunciado completo das nossas doutrinas: Democracia Cristã." ${ }^{\prime 34}$ Procurava-se pôr termo à ideia de que à Igreja apenas interessava o mundo transcendental, apresentando-se o catolicismo social como prova do contrário $^{35}$. Afirmava-se que a democracia cristã era a verdadeira democracia, uma vez

30 Idem, p. 4.

31 “Continuando", v. 6, n. 3 (Abril 1910), pp. 1-2. O principal responsável por esta alteração foi Álvaro Diniz da Fonseca (1888-1918). Logo em 1905, os E.S. publicaram um artigo de A. Girão em que se defendia a criação de uma estrutura nacional que agregasse todos os centros universitários católicos. Dessa forma, coordenar-se-ia a difusão da democracia cristã nas universidades de forma a fazer frente ao socialismo e à corrente anarquista, “União da Juventude Católica”, v. 1, pp. 230-236. Também no início de 1908, num artigo intitulado "Acção social católica. O CADC e os estudantes católicos de Portugal", apelava-se à união das juventudes católicas universitárias de todo o país, cabendo ao Centro de Coimbra a liderança desse movimento, V. 4, n. 3, pp. 111-115, n. 4, pp. 133-138, e n. 5, pp. 195-202. De acordo com Pinharanda Gomes, a nova geração do CADC (Cerejeira, Salazar, Pacheco de Amorim, Mário de Figueiredo, Lopes de Melo e Joaquim Diniz da Fonseca) queria receber a revista, em 1911, livre de encargos, mas Álvaro D. da Fonseca negou-se, reservando para si a propriedade do título (talvez para utilizar para a União), Gomes, op. cit.

32 Zuzarte Mendonça,"Repetindo e insistindo,"v. 6, n. 1 (Abril 1910), p. 9.

33 Idem, p. 10.

34 In D.,"O que é que vocês querem,"v.6, n. ${ }^{\circ} 4$ (Jul. 1910),pp. 121-125. D. era um dos pseudónimos de Alberto Diniz da Fonseca.Primeiro-secretário da redacção dos E.S., advogado, político e jornalista.Viveu entre 1884 e 1962. Ver: Gomes, op. cit. Também Hermínio Correia, num artigo intitulado "A Igreja inimiga da democracia" (v. 6, n..$^{1}$, pp. 11-16), afirmava:"Mas como explicar esta antinomia entre a pretensa Democracia revolucionária e socialista dos nossos dias e o Evangelho?!"

35 Idem, p. 14. 
que as principais obras sociais tenham sido, desde sempre, realizadas por cristãos, e a democracia ateia era animada pelo ódio às classes mais ricas ${ }^{36}$ e procurava "confundir com uma determinada forma de governo o que não passa de uma forma de governar"37. Significava isto que o movimento socialista procurava difundir a ideia de que a instauração do regime democrático só seria possível através da aplicação das ideias correspondentes à sua ideologia. Os Estudos Sociais consideravam esta ideia perigosa, particularmente num país como Portugal, onde o povo era apático e indiferente. Estabelecer os fundamentos da democracia em Portugal só seria possível, não através de nova legislação, mas da criação de uma elite que reformasse a sociedade. Tal elite deveria ser constituída por cristãos, uma vez que o Cristianismo era considerado a força moral da democracia ${ }^{38}$.

No número 5 de 1910, correspondente aos meses de Agosto e Setembro, a Direcção do Centro Académico de Democracia Cristã de Coimbra publicou nos Estudos Sociais uma declaração onde afirmava que o Centro era democrático, não sendo, colectivamente, nem monárquico nem republicano. O catolicismo social era o seu programa que, através da reorganização corporativa da sociedade, procurava levar sustento, independência e ensino ao povo ${ }^{39}$. O ideal democrático do CADC não estava conotado com nenhum regime político e encontrava a sua raiz apenas no Cristianismo.“Este conduz ao progresso, em todas as situações sociais, desde o quietismo das monarquias absolutas até à vitalidade exuberante das repúblicas livres." ${ }^{40} \mathrm{Na}$ opinião da Direcção do Centro coimbrão, o Liberalismo tinha destruído a antiga organização social corporativa, deixando os operários à mercê da competitividade - situação de sujeição económica e moral, marcada pelo desprezo. Se se apoiava a ascensão das classes operárias, através do trabalho, às propostas de nivelamento social, da autoria de correntes da democracia revolucionária, contrapunha-se a reactivação das corporações a nível local.

${ }^{36}$ A este propósito, ver Zé Franco,“Democratas de nome e democratas a valer",v.6, n. ${ }^{\circ} 2$ (Mai. 1910), pp.64-68. Esta ideia estava presente na Graves de Communi Re, quando Leão XIII referia as paixões dos homens turbulentos como uma das principais causas da discórdia entre ricos e proletários e das calamidades para os Estados. Ver: http://www.vatican.va.

37 D., idem, p. 121.

38 D., idem, p. 125. Definia-se democracia como o estado social em que as camadas populares procurariam exercer os seus direitos, lutar pelo progresso material e moral, participar na realização de reformas legislativas e cooperar entre si.

39 "Enquanto vivia a Monarquia, O C.A.D.C. não foi nem podia ser colectivamente monárquico; hoje, que vive a República, o C.A.D.C. não é nem pode ser colectivamente republicano", in "Protesto do Centro Académico de Democracia Cristã", v. 6, n. os 5 e 6 (Ago. e Set. 1910), p. 226.

40 Idem, p. 226. 
“Pelo regime corporativo, adaptado às necessidades de cada região e concretizado em institutos de previdência e socorro mútuos, teremos conseguido a melhoria económica das populações rurais." ${ }^{41}$ A solução apontada pelo CADC para resolver a questão social consistia, assim, no cruzamento de duas realidades:reorganização corporativa da sociedade e reactivação das instituições de política local. Esta rejeição da estruturação social e económica e dos excessos de centralismo estatal resultantes do liberalismo conduziu à revalorização dos corpos intermédios, o que redescobriu o pensamento tomista ${ }^{42}$. Isto só seria possível através de uma educação eficaz do povo e da aplicação da doutrina social cristã, donde "flui a justiça e a moralidade que é também um facto de economia"43. A questão social não era, assim, concebida como uma questão exclusivamente política, mas era perspectivada enquanto questão teológica, moral ou religiosa, de caridade/solidariedade e de justiça social. Esta constituía uma das ideias centrais da encíclica Graves de Communi Re: a base da resposta à problemática social era a lei da caridade mútua, a ciência da caridade que, para além da esmola, criava uma infinidade de instituições permanentes que contribuíam para o bem comum. Defendia-se com mais facilidade constituir a Igreja a estrutura que resolveria mais os problemas sociais, através da sua organização paroquial e diocesana, do que o Estado.

\section{Democracia cristã e catolicismo social: a resposta à questão social}

Na certeza de que a doutrina católica continha a resposta mais adequada à questão social, foram publicados nos Estudos Sociais vários artigos de reflexão em torno da natureza da democracia cristã e do catolicismo social. A publicação destes artigos assumia um carácter de urgência para a redacção da revista, dada a instabilidade político-social vivida em Portugal, a perda de influência da Igreja junto do poder político e da sociedade em geral e a descristianização das classes populares ${ }^{44}$. Os Estudos Sociais integraram-se, assim, no amplo movimento do catolicismo social e procuraram formar os seus leitores através da publicação de artigos sobre a natureza, a evolução e as respostas

41 Idem, p. 229.

42 Ver: François-George Dreyfus, Histoire de la démocratie chrétienne en France, Paris, Éditions Albin Michel, 1988, pp. 58-59.

43 "Protesto", p. 228.

44 De acordo com Braga da Cruz, podem estabelecer-se três fases no crescimento da democracia cristã em Portugal: a primeira correspondeu ao associativismo católico antiliberal (1843-1894), a segunda ao sindicalismo católico anti-socialista (1898-1910) e a terceira a uma fase de intervenção e expressão política marcada pela acção do Centro Católico (1910-1917). 
possíveis à questão social e sobre o pensamento e a obra de figuras marcantes do catolicismo internacional. Entre estas, contavam-se Frédéric Ozanam ${ }^{45}$ e a Sociedade de S.Vicente Paulo, fundada em 1833; o bispo alemão Ketteler e a sua obra de 1848, Os Fundamentos de uma Concepção Cristã do Estado, cujas ideias sempre foram consideradas seminais para o catolicismo social ${ }^{46}$; Windthorst e a formação do Partido do Centro Alemão, em 187047; Albert de Mun e La Tour du Pin, fundadores dos Círculos Católicos de Operários ${ }^{48}$, em 1871; o italiano Giuseppe Toniolo ${ }^{49}$ e Léon Harmel que criaram os Círculos de Estudo, em $1891^{50}$. Também a Obra dos Congressos, instituída em Itália, no ano de $1874^{51}$, a União de Friburgo, criada na Suíça em $1884^{52}$, e as Semanas Sociais, criadas em França em 1904, foram referidas inúmeras vezes nos Estudos Sociais.

Destaque mereceu, desde logo, a publicação integral da carta encíclica de Pio X, II fermo proposito, de 11 de Junho de 1905, dirigida aos bispos de Itália ${ }^{53}$. Nessa carta, o Papa apresentava o duplo e vasto campo da acção católica, individual e colectivo,

45 Viveu entre 1813 e 1853. Historiador, doutor em Direito e professor de Literatura Estrangeira na Sorbonne. A sua acção simboliza a caridade paternalista católica que se manterá na mentalidade católica durante muitos anos.

${ }^{46}$ Wilhelm Emmanuel Freiherr von Ketteler. Bispo de Mongúcia, teólogo e político alemão que viveu entre 1811 e 1877.

47 O Partido do Centro Alemão foi fundado em 1870 e procurava defender os valores do catolicismo. Foi várias vezes apontado como modelo nos E.S., assim como o seu líder, Ludwig Windthorst. Este foi advogado e político, viveu ente 1812 e 1891 e fundou, em 1890, a Wolksverein fur das Katolische Deutchland (União do Povo por uma Alemanha Católica), também várias vezes mencionada na revista.

48 "Círculos Católicos de Operários,"v. 1, n. ${ }^{\circ}$ 10, pp.421-425, e n. ${ }^{\circ} 11$, pp.472-475. Neste artigo apresentava-se a vida do fundador dos círculos, Maurice Maignen (director do Círculo de Jovens Operários de Paris; viveu entre 1822 e 1890), e descrevia-se o crescimento desse movimento, desde o círculo de Montparnasse até aos círculos espalhados por toda a França, salientando-se o contributo do capitão La Tour du Pin (René Charles Humbert Chambly de la Charce La Tour du Pin viveu entre 1834 e 1924, foi oficial militar francês, autor de obras históricas, sociais e científicas, e marquês) e de Alberto de Mun (político e deputado que viveu entre 1841 e 1914; para além de estar ligado aos Círculos, foi o promotor da Associação Católica da Juventude Francesa; foi citado inúmeras vezes nos E.S.).

49 Viveu entre 1845 e 1918. Economista e sociólogo, fundou na Universidade de Pisa a Unione Cattolica per gli Studi Sociali in Italia, lançando por toda a Itália vários círculos de estudos sociais. É várias vezes citado nos E.S. enquanto um dos representantes mais relevantes do pensamento social católico internacional.

${ }^{50}$ Viveu entre 1829 e 1915. Industrial próximo de Leão XIII, o objectivo dos círculos era o de formar os operários através do denominado método ascendente, em que a liderança pertencia aos operários e não aos aristocratas ou clérigos.

${ }^{51}$ Organização católica que procurava defender os direitos da Igreja, promover obras caritativas e organizar o movimento associativo italiano.

${ }^{52}$ União Católica de Estudos Sociais, presidida entre 1884 e 1891 pelo cardeal Mermillod e conhecida pelo nome de União de Friburgo; os estudos desta União irão estar na base da redacção da Rerum Novarum, em 1891.

${ }^{53}$ V. 1, n. ${ }^{\circ}$ 7, pp. 325-328, n. ${ }^{\circ}$, pp. 362-365, n. ${ }^{\circ}$ 9, pp. 401-403, e n. ${ }^{\circ} 10$, pp. 434-437. 
e as condições para que ela fosse eficaz. Com esta carta, o Papa abria, igualmente, a possibilidade de uma participação política activa dos católicos. "A constituição actual dos Estados oferece indistintamente a todos a faculdade de influir nos negócios públicos, e os católicos (...) podem em boa consciência aproveitar-se daquela faculdade para provar que são capazes, tanto ou melhor que os outros, de cooperar no bem-estar material e civil do povo (...). Estes direitos civis são vários e vão até ao de intervir directamente na vida política do país, representando o povo nas câmaras legislativas." ${ }^{54}$ Como afirmou Braga da Cruz, devido à perda da influência da Igreja sobre a sociedade e à crescente organização do socialismo, no final do século XIX, a necessidade da formação de um partido político e de uma resposta aos problemas sociais agudizou-se $\mathrm{e}^{55}$.

A relação dos Estudos Sociais com o Partido Nacionalista foi marcada pelo distanciamento, registando-se, no entanto, variações entre as posições assumidas pelo primeiro corpo redactorial da revista e o segundo. Recorde-se que a segunda denominação do CADC de Coimbra foi a de "Centro Nacional Académico",em 1902. A escolha desta denominação visava apoiar o movimento nacionalista e fazer frente à acção de Bernardino Machado em Coimbra, que procurava divulgar e recrutar estudantes para o movimento republicano ${ }^{56}$. Em 1907, publicou-se na revista o programa do Partido Nacionalista ${ }^{57}$ que aliava a defesa dos direitos da Igreja à questão social e agrícola e à renovação moral. As principais ideias deste programa político eram muito semelhantes às características fundamentais daquilo que Mayeur denominou de catolicismo intransigente: exaltação da tradição, elogio do repouso e do mundo rural, anticapitalismo, sociedade orgânica, exaltação da monarquia cristã e nostalgia da Europa cristã face à Europa das Nações ${ }^{58}$. Se a transformação do Centro Católico no Partido Nacionalista, em 1903, não merecera o apoio de Sousa Gomes e de outras figuras do movimento católico social, a partir de 1908 a nova redacção dos Estudos Sociais manifestou uma simpatia

${ }^{54}$ O Papa punha igualmente fim ao Non expedit que proibia a participação política dos católicos italianos. "Razões muito graves (...) nos levam a desviar-nos da regra outrora traçada (...) Segundo esta regra era geralmente proibido aos católicos italianos a intervenção no poder legislativo,", p. 402.

${ }_{55}$ Cruz, op. cit., Cap. 1, ponto 4.1.

${ }^{56}$ A primeira denominação do centro foi a de Centro Académico de Propaganda Católica ou Centro Académico Per crucem ad lucem, em 1901. Ver M. Trindade, O Padre Luís Lopes de Melo e a sua época (1885-1951), Coimbra, Casa do Castelo - Editora, 1958.

57 "3. ${ }^{\circ}$ congresso nacionalista realizado em Braga nos dias 27, 28 e 29 do corrente", v. 3, n. ${ }^{\circ}$ 10, pp. 406-412.

58 Jean-Marie Mayeur, "Catholicisme intransigeant, catholicisme social, démocratie chrétienne", in Annales, 1972. 
e um apoio mais claros a tal partido ${ }^{59}$. Foi num artigo intitulado "Política Nacionalista" que se incentivou o movimento ideológico do nacionalismo a crescer, afirmando-se que, no seu seio, iria nascer o Partido Católico Português ${ }^{60}$. Apesar de os ditos partidos rotativos terem acabado com qualquer entusiasmo político, "é inegável que a Ideia Nacionalista vai lavrando com firmeza e segurança". A propaganda do partido e o seu recente acordo com o Governo asseguravam "a viabilidade do Partido Católico Português militante". Referia-se, igualmente, que o lançamento da ideia nacionalista por um punhado de católicos nunca despertara tanto interesse como agora, mostrando os "rapazes dos seminários" muito entusiasmo por essas movimentações. $O$ Partido Nacionalista deveria acolher esse apoio que lhe poderia ser muito útil no futuro. "Se dirigíssemos ou mesmo se pertencêssemos a qualquer partido político militante, não olharíamos este movimento com a indiferença que eles afectam. Se tivéssemos influência na direcção do Partido Nacionalista, não deixaríamos também de aconselhá-la a que animasse com interesse os entusiásticos rapazes." Na campanha eleitoral de 1908, a maioria dos candidatos do Partido Nacionalista publicaram artigos nos Estudos Sociais. Foi o caso de Gomes dos Santos, Abúndio da Silva, Alberto Pinheiro Torres ou Alberto Diniz da Fonseca ${ }^{61}$.

59 Recorde-se, a este propósito, a polémica mantida entre a Voz de Santo António, democrata-cristã e franciscana, e o Mensageiro do Coração de Jesus, que terminará com o encerramento da primeira revista por ordem do Papa em 14 de Abril de 1910. Ver Braga da Cruz, op. cit., cap. III, 4.

60 J.C.,"Política Nacionalista”, v. 4. n. 1 (Jan. 1908), p. 39. Sobre a questão do nacionalismo católico (sua ligação ao Ultimato e ao Ralliement de Leão XIII), ver Ferreira, António Matos, "Repercussões do Ultimatum

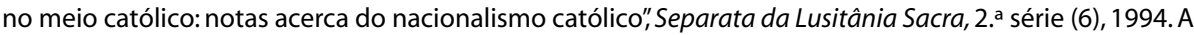
partir deste ano, os congressos do Partido Nacionalista passaram a merecer cobertura noticiosa nos E.S., anunciando-se a sua realização ou publicando-se as suas conclusões (casos dos congressos realizados na Covilhã e em Viseu; ver v. 4, n. 10 e 11, pp.459-461).

${ }^{61}$ Ver Gomes, op. cit. Um desses candidatos, Abúndio da Silva, irá expor detalhadamente, na sua obra Cartas a um Abade. Sobre alguns aspectos da questão político-religiosa em Portugal, de 1913, a sua opinião e vivência relativamente ao Partido Nacionalista e à polémica da obrigatoriedade, ou não, do voto católico nesse partido. Partindo da certeza de que os católicos deviam aceitar o regime republicano, cumprindo as directrizes de Leão XIII definidas desde 1892 e difundidas em Portugal por Domenico Jacobini, Bastos Pina e Quirino de Jesus, Abúndio da Silva criticava o facto de o Centro Nacional se ter transformado em Partido Nacionalista, sob influência dos Jesuítas. Confessava que, depois de ter aderido ao partido, se retirara, pois considerara ter sido um grave erro a imposição a todos os católicos de votarem no partido. Em relação à proibição da Voz de Santo António, considerava que os Franciscanos tinham sido vítimas de um complô dos Jesuítas. $\mathrm{O}$ catolicismo acabou reduzido ao nacionalismo, e este à monarquia. Após o regicídio, os nacionalistas atacaram republicanos e liberais monárquicos, ficando isolados. Abúndio da Silva defendia a formação de uma união pelos católicos, e não de um partido, que lutasse pela realização de obras sociais, pela Pátria e não por um regime político particular.Ver António Matos Ferreira, Um Católico Militante diante da Crise Nacional, Lisboa, UCP, 2007. 
Desta forma, foi vasta a amplidão das temáticas publicadas acerca do catolicismo social e da democracia cristã. Para além dos artigos referidos, sobre os pensadores católicos e a realidade portuguesa, foram criadas duas secções, "Movimento social" e "Vulgarização social", que procediam à divulgação de soluções práticas para problemáticas sociais várias como a habitação social ou o alcoolismo. Também artigos sobre temas históricos foram apresentados na revista. Foi o caso de um longo artigo sobre o contributo do Cristianismo para a abolição da escravatura ${ }^{62}$. Este artigo ocupou muitas páginas da revista, durante os seus dois primeiros anos de vida, e possuía como ideia central o facto de o Cristianismo ter reabilitado as virtudes do trabalho manual, ao contrário da civilização greco-romana. A importância dada a este artigo era óbvia:transpor para a situação vivida pelo operariado no século XIX a condição libertadora da religião cristã vivida na Antiguidade. Merecedora de particular destaque foi a secção "Crónica social do estrangeiro". Esta rubrica foi publicada em praticamente todos os números da revista e aí encontramos uma grande variedade de temas: a prática e a repercussão política do catolicismo social em países como a Áustria, Bélgica, Espanha ou Alemanha (aumento da influência política da Igreja); a forma como a questão social e o socialismo evoluíram nos países estrangeiros (o impacte das greves); a situação russa; a situação da Igreja Católica e da religião no mundo (a descristianização da Itália, a Igreja na América Latina, o anticlericalismo, a expansão da catolicismo nos Estados Unidos da América); a acção de Pio X (com destaque para a condenação dos democratas cristãos italianos), a evolução política da Europa ou a participação dos católicos na vida política.

Esta diversidade de temas era comum às revistas sociais e católicas da época, como é possível verificar através da leitura de algumas revistas de origem francesa como Le Mouvement social (Revue catholique internationale) ${ }^{63}$, La Démocratie chrétienne (Revue sociale) ${ }^{64}, L^{\prime}$ Association catholique. Revue des questions sociales et ouvrières ${ }^{65}$, Chronique des Comités du Sud-est. Revue mensuelle d'action catholique destinée aux Comités de la

62 Diógenes, “Escravidão e Cristianismo. Ensaio apologético," v.1, n. 1 (Jan. 1905), pp. 10-17; n. 2, pp. 68-78; n. ${ }^{\circ}$, pp. 166-174, e n. ${ }^{\circ}$, pp. 307-318; v. 2, n. ${ }^{\circ} 2$, pp. 71-81, n. ${ }^{\circ}$ 3, pp. $114-120$ e n. ${ }^{\circ} 4$, pp. 155-161 v. 2, n. ${ }^{\circ}$ 11 (Nov. 1906), pp. 457-464. Diógenes é um pseudónimo de Artur Bívar, jornalista e escritor católico que viveu entre 1881 e 1946. Nasceu em Vila Viçosa e colaborou com as mais diversas publicações católicas. Usava, também, o pseudónimo de Spiritus Asper. Ver Coelho, Armindo Lopes e Neves, Moreira das, Artur Bívar, esse grande esquecido, Arcos de Valdevez, 1983.

${ }^{63}$ Reims, 1909-1914.

${ }^{64}$ Lille, 1894-1908. Passará a ser, em 1909 e até 1958, La Chronique sociale de France.Revue d'étude et d'action. Organe des Semaines sociales de France.

${ }^{65}$ Paris, 1876-1908 e 1911-1914. 
"Croix", aux groupes de propagande catholique, aux oeuvres d'éducation populaire et $d^{\prime}$ 'organisation sociale ${ }^{66}$. Partindo da análise de alguns números e artigos destas revistas, dos respectivos índices e das suas secções dedicadas à análise de imprensa nacional e estrangeira da época (outras revistas francesas e publicações italianas, espanholas, norte-americanas, mexicanas, inglesas, alemãs ou belgas), conclui-se que os temas abordados eram idênticos aos presentes nos Estudos Sociais: doenças profissionais, salário, socialismo e religião, sindicalismo, caixas rurais, desemprego, crédito agrícola, criminalidade, agricultura, mutualidades, cooperação, educação popular, habitação, educação feminina, greves, direito à vida, escola primária, higiene sexual, Igreja primitiva e questões sociais, ensino profissional, natalidade, acção social do clero, alcoolismo, direito familiar ou educação da juventude ${ }^{67}$. As principais áreas editoriais também eram semelhantes. A revista francesa L'Association catholique. Revue des questions sociales et ouvrières apresentava, relativamente ao ano de 1904, uma linha editorial semelhante e secções idênticas:"'documentos e factos sociais','"crónica bibliográfica,','crónica do estrangeiro,','movimento social e movimento católico,"'união de estudos dos católicos sociais" ${ }^{\prime \prime}$.

\subsection{O abade Gayraud e a defesa da verdadeira democracia}

A publicação nos Estudos Sociais de artigos que reflectissem sobre as ideias sociais e democráticas católicas iniciou-se com a tradução de um texto do abade Gayraud intitulado "As doutrinas da democracia cristã" ${ }^{\circ}$. A expressão "democracia cristã" tinha sido utilizada, em 1891, pelo bispo de Lyon, Lamourette, num discurso na Assembleia Nacional em que procurava realçar a diferença entre a Igreja Democrática e Popular (de acordo com a revolução) e a Igreja Aristotélica e Elitista do Antigo Regime.O abade francês Hyppolyte Gayraud viveu entre 1856 e 1911 e, para além de teólogo, foi também político e deputado. Ao longo da sua vida combateu o modernismo e defendeu

66 Lyon, 1892-1908.

67 Le Mouvement social, XXXVle Année, Tomo LXXI, 1. emestre, 1911.

68 Os E.S. recebiam inúmeras revistas portuguesas e estrangeiras: Revue de deux mondes, La Démocratie chrétienne, Études, L'Association catholique, Le Sillon, Eco Franciscano, Ecos de Roma, La Semana Catholica, O Novo Mensageiro do Coração de Jesus, O Progresso Católico, Razón y Fé, Revista Católica de las Cuestiones Sociales, Revista Social, Voz de Santo António, O Amigo da Religião, A Democracia Cristã, O Grito do Povo, O Petardo e Revista Católica. A revista possuiu mesmo duas secções que davam conta das revistas que se recebiam: a "Revista das revistas" e a "Revistas e jornais". Recorde-se ainda, a este propósito, que, em 1906, foram dadas instruções ao núncio apostólico em Lisboa para que impulsionasse a melhoria da imprensa católica no nosso país.

69 Gayraud,"As doutrinas da democracia cristã," v. 1, n.o 1 (Jan. 1905), pp. 3-9, e n. 2 (Fev. 1905), pp. $78-82$. 
a criação de um partido democrata-cristão que não seria estritamente confessional. Pertenceu ao grupo a que se convencionou chamar de "abades democratas", responsável por uma assinalável acção de divulgação da democracia cristã ${ }^{70}$. Os abades democratas são considerados a segunda geração com ligação ao Catolicismo social, tendo sido a primeira geração dos aristocratas (Mun e Pin), e a terceira a dos jovens educados na Rerum Novarum e no Ralliement (Sillon, Action Française, entre outros grupos) ${ }^{71}$. Outra periodização relativa ao movimento da democracia cristã/catolicismo social em França foi a delineada por Dreyfus. Para este historiador, ao período compreendido entre 1815 e 1848 correspondeu o começo do catolicismo político francês que terminou com a Revolução de 1848 e com o fracasso do primeiro partido católico. Entre 1848 e 1891, emergiu o catolicismo intransigente e social que também terminou com o insucesso do segundo partido católico formado por Albert de Mun, em 1885. Até 1914 , as duas tentativas de formação de partidos democratas-cristãos protagonizadas pelos abades democratas e pelo Sillon também fracassaram, constituindo a democracia cristã, em vésperas da I Guerra Mundial, uma corrente de pensamento e uma virtualidade política ${ }^{72}$.

Tendo sido editado nos dois primeiros números da revista, a intenção da publicação do texto de Gayraud era clara: formar os leitores nos conteúdos da democracia cristã. Recomendava o abade democrata que os cristãos/católicos soubessem viver no seio de um regime democrático, uma vez que ele se estabelecera de forma irreversível, quer enquanto facto político, quer enquanto facto social, e apelidava de absurda a possibilidade da restauração da monarquia absoluta. O sufrágio universal, apesar de poder funcionar de formas distintas, deveria ser aceite, e a tentativa de melhorar a condição do operariado era considerada uma das principais características da democracia enquanto facto social, classificando-se o socialismo como a corrente mais agressiva na efectivação dessa tendência. $O$ abade Gayraud defendia, porém, que a verdadeira democracia emergira graças à evolução moral do Cristianismo. “A democracia é, para nós, um facto, um progresso, um resultado do Evangelho." ${ }^{173}$ Ela não tinha sido o resultado da igualdade natural entre os homens, mas da evolução social do cris-

\footnotetext{
70 Outros abades democratas foram Garnier, Naudet, Fesch, Lemire, Pierre Dabry, Dehon, tendo sido todos eles, várias vezes, referidos em artigos dos E.S.

71 Catholicisme hier, aujourd'hui, demain, encyclopédie publiée sous la direction de G. Jacquemet, Paris, Letouzey et Ané, 1947, Tomo II, pp. 703-722.

72 François-George Dreyfus, op. cit.

${ }^{73}$ Idem, p. 8. O Evangelho, no entanto, não defende nenhum tipo de regime político.
} 
tianismo que conduzira o povo à idade adulta, tirando-o da menoridade e do paternalismo com que era tratado nas aristocracias e nas monarquias, e lhe dera a capacidade de se governar a si mesmo. Se o conceito essencial da democracia era o da igualdade dos cidadãos perante o poder e a lei, a base dessa igualdade era o Cristianismo ao afirmar a igualdade de todos os homens perante Deus. $O$ pensador francês considerava que os excessos revolucionários, o (falso) dogma da soberania do número ou os graves defeitos do parlamentarismo não caracterizavam a democracia na sua essência e apelava à sua organização, evitando, assim, a anarquia. Em 1904, Gayraud afirmava, num artigo intitulado "Un catholique peut-il être socialiste?": "O horizonte do catolicismo social é tão vasto quanto o do reformismo socialista. ${ }^{174}$

\subsection{Salgueiro e a oposição entre "democracia revoltada" e democracia cristã}

De teor mais apologético que didáctico, o artigo intitulado "O catolicismo social" foi publicado em dois números e teve como subtítulos "A democracia revolucionária e as suas relações com a democracia cristã" e "As conclusões da falsa e da verdadeira democracia"75. Este artigo constituía, para além de uma reflexão, uma apologia do movimento social católico. “O catolicismo social é o cristianismo lógico. No seu fundo encontramos a ideia da Igreja, isto é, a ideia dum laço permanente entre todos os homens ou a ideia duma sociedade terrestre precedendo e preparando uma outra mais elevada. $\mathrm{O}$ catolicismo social é, pois, a sequência natural e inevitável destas duas ideias. O valor apologético deste conceito é evidente, e não admira que os pensadores católicos tenham procurado apresentá-lo em toda a sua luz." ${ }^{176}$ De acordo com a enciclopédia Catholicisme hier, aujourd'hui, demain, o conceito de "catolicismo social" não correspondeu a um sistema claro e articulado, à semelhança do marxismo, mas constituiu uma resposta original e dispersa ao laicismo estatal e ao desaparecimento do Cristianismo da economia. De facto, existiam ideias específicas do catolicismo social que não se encontravam na origem das tradições liberal e socialista. Tais ideias foram, por exemplo, o aperfeiçoamento moral do Homem e da Sociedade, a ligação entre Direito Natural e Direito Positivo através das instituições, as noções correlativas de pessoa e de comunidade, a família, as relações entre corpos intermédios e Estado, as

\footnotetext{
74 Revue du Clergé Français, 1904, Tome XXXIX, p. 647. Esta revista foi editada em Paris entre 1894 e 1904.

75 Ver v. 1, n.o 5 (Maio 1905), pp. 227-230; n. 6 (Jun.1905), pp. 262-266; e n.o 8 (Agosto 1905), pp. $352-354$.

76 Salgueiro, idem, p. 229.
} 
organizações profissionais sob controlo do Estado e a noção de economia orientada e coordenada ${ }^{77}$. Também Mayeur afirmou, em 1986, que no fim do século XIX eram usados, indiferentemente, os termos "cristianismo social","catolicismo social" e "socialismo católico", tendo sido três os factores que contribuíram para a afirmação do termo "catolicismo social": os livros de Georges Goyau, Autour du Catholicisme social, de 1897-1912, e de Max Turmann ${ }^{78}$, Le Développement du catholicisme social depuis l'encyclique "Rerum Novarum", de 1900, e a encíclica Graves de Communi Re que, ao condicionar fortemente o termo "democracia cristã", favorecera o estabelecimento do termo "catolicismo social." Mayeur considerava que o termo não se referia apenas a uma doutrina, mas também a um projecto que procurava resolver a questão social e que não se devia confundir a história do catolicismo social com a da assistência social ou com a doutrina social da Igreja.

Para Salgueiro, então, a resposta natural do Cristianismo à questão social passava pela prática do catolicismo social. A mensagem cristã seria, dessa forma, actualizada e contribuiria para a construção de uma comunidade terrestre mais justa. De facto, o Evangelho era considerado um código social válido para este mundo e para todas as épocas, que fazia do cristianismo uma religião democrática e social e que já continha, antes da Revolução Francesa, os ideais de igualdade, de fraternidade e de solidariedade. Se a essência da democracia era a melhoria das condições de vida do povo, então a Igreja Católica sempre estivera na vanguarda da organização da sociedade humana, defendendo, inclusive, a possibilidade da revolta popular. Mais do que a monarquia, era a democracia o regime político preferido pela Igreja Católica."A Igreja vive sob todas as formas de governo. Ratificadas pelo povo, elas são todas legítimas, mas o governo que, mais que qualquer outro, é o governo do povo pelo povo e para o povo é aquele sob o qual a Igreja do povo, a Igreja Católica respira o ar que melhor se coaduna com seus princípios e com o seu coração. Bela doutrina! Quem não a perfilha

77 J. Folliet, “Catholicisme social”, tomo II, pp. 703-722. Importante para a formulação do conceito de "catolicismo social" foi também a mudança de título operada numa obra de Paul Lapeyre. De facto, em 1894 editava-se o livro Le Socialisme catholique ou Christianisme intégral. Tome premier, Les vérités mâles, tendo o título mudado, em 1896, aquando da edição do segundo volume, para Le Catholicisme social. Les remèdes amères. Lapeyre foi várias vezes referido nos E.S., nomeadamente a propósito de um artigo redigido por si na revista francesa La Démocratie chrétienne, sobre a imprensa católica.V. 1, n. ${ }^{\circ}$ 3, p. 159.

78 Sobre o pensamento de Max Turmann, sociólogo nascido em 1866, ver:"L'oeuvre des catholiques sociaux de France depuis l'Encyclique "Rerum Novarum", in L'Association catholique. Revue des questions sociales et ouvrières, Tomo LVII, n. ${ }^{\circ}$ 3, 15 de Março de 1904, pp. 193-211. Turmann é várias vezes referido nos E.S., nomeadamente a propósito de um artigo publicado na revista francesa L'Association catholique sobre sociedades de socorros mútuos. V. 1, n. ${ }^{\circ}$ 3, pp. 159-160. 
entusiasticamente, como sendo a manifestação sublime do génio liberal e acentuadamente democrático da Igreja Católica?"79. A democracia cristã era o regime político que mais favorecia a implantação das práticas sociais do catolicismo social. Face a esta evidência, o articulista manifesta a sua estranheza perante o aparecimento de uma democracia que não a cristã, a que apelida de revoltada ou revolucionária. A luta pela implantação de modelos de democracia contrários ao defendido pela democracia cristã só fará com que o progresso se suspenda. "As exigências do espírito contemporâneo têm no seu fundo um acentuado princípio de revolta, originado por causas múltiplas, que certamente retardará a marcha regular e ordeira para um novo estado de coisas." ${ }^{80}$ De acordo com Poulat, nos seus inícios, a democracia cristã assumia-se como alternativa e antítese à democracia criada em 1789, da qual só esperava erros e

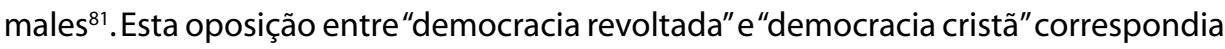
à oposição entre democracia cristã e social presente na encíclica Graves de Communi Re. O argumento de que a democracia revoltada apenas pensava nos bens terrenos e na felicidade temporal encontrava-se também presente na encíclica.

\subsection{Análise e planos de Julio Monzó para o movimento católico social em Portugal}

Ilustrativos das ideias partilhadas pela maioria dos articulistas que escreviam para os Estudos Sociais, foram dois artigos da autoria de Julio Monzó ${ }^{82}$. Estes artigos constituíram uma das mais completas reflexões publicadas na revista acerca do papel desempenhado pelo Cristianismo/Igreja Católica na resposta à questão social. O primeiro, intitulado "A missão dos círculos católicos de operários em Portugal"83, descrevia o contributo da Igreja Católica para a resolução dos problemas sociais ao longo dos

79 Idem, pp. 353-354.

80 Idem, p. 263.

81 Émile Poulat, Église contre bourgeoisie, Tournai, Casterman, 1977.

82 Professor, escritor e jornalista espanhol (1882-1943).

83 Julio Monzó, "A missão dos círculos católicos de operários em Portugal. Discurso pronunciado no dia 11 de Dezembro de 1905 ante os sócios da Associação de Socorros Mútuos 'A democracia cristã' nas salas da Venerável Ordem Terceira de S. Francisco, em Lisboa.Dedicado ao Reverendo Padre Benevenuto de Sousa." v. 1, n. ${ }^{\circ} 2$ (Dez. 1905), pp. 517-537; v. 2, n. 1 (Jan. 1906), pp. 20-31, e n. ${ }^{\circ} 2$ (Fev. 1906), pp. 63-70. Muitos foram os artigos e notícias publicados nos E.S. cujo conteúdo versava sobre a acção dos CCO portugueses. Logo no primeiro número, foi publicada na secção "Notas do Mês" uma notícia sobre a acção dos círculos de Viseu e da Covilhã.Ver v. 1, n. ${ }^{\circ}$ 1, p. 54. Também se publicaram as listas de homenagem a Manuel Fructuoso da Fonseca (jornalista católico que viveu entre 1862 e 1908 e que fundou, em 9 de Julho de 1898, o Círculo do Porto) de forma a contribuir para a construção de uma nova sede do Círculo do Porto. Ver v. 4, n. ${ }^{\circ}$ 10, 
séculos. Traçar a evolução da questão social implicava para Monzó fazer referência aos seguintes acontecimentos polarizadores: o cristianismo primitivo contribuiu decisivamente para a melhoria da situação dos escravos; na Idade Média, os mosteiros e as confrarias foram as instituições que mais apoios prestaram aos desfavorecidos; "durante o absolutismo o Clero acolheu-se junto do rei, esquecendo o povo seu natural aliado (...) isto foi o suficiente para que entre o povo e o clero se estabelecesse um divórcio, o que, em muito, iria favorecer a futura emergência das correntes socialistas" ${ }^{\prime \prime 4}$; o liberalismo prolongou o absolutismo, ao permitir que os partidos monopolizassem a vida política da sociedade; o socialismo, se num momento inicial foi "a primeira solução dada ao que se havia de chamar questão social"85, acabou por se revelar uma utopia sem fundamento moral, e o seu futuro será a dissolução em lutas internas; o triunfo do capitalismo não foi mais do que o triunfo da lei da concorrência que esmagou o operário e destruiu a organização corporativa da sociedade. "Assim vieram e neste estado nos encontraram as lutas entre o capital e o trabalho que tanto caracterizam a nossa época; e o operário, vendo-se só, começou a não contar senão consigo, jurando guerra e guerra de extermínio ao padre, ao burguês e ao rei." ${ }^{\prime \prime 6}$ Para Julio Monzó, só a implantação de um modelo sociopolítico de inspiração cristã poderia repor a justiça social. A Rerum Novarum constituíra a grande reacção ao radicalismo socialista e marcara o início do movimento do catolicismo social por toda a Europa e, também, nas nações ibéricas. O segundo artigo de Julio Monzó, intitulado “Fins, organização e unificação do movimento católico popular português" ${ }^{\prime 87}$, considerava que a questão social radicava na disseminação de uma concepção optimista da existência humana distinta da visão pessimista enunciada pelo Cristianismo. Anterior à questão social, existia um falso conceito metafísico, o optimismo, que era ilimitado e que tinha estado na origem de uma nova organização da sociedade que considerava a desigualdade social uma injustiça. O catolicismo devia opor-se ao "individualismo britânico, ao darwinismo aplicado à vida" e contrariar o optimismo no bem-estar material ${ }^{88}$.

11 e 12, e v. 5, n. ${ }^{\circ}$. Em Fevereiro de 1908, a redacção comunicava que era impossível publicar todas as notícias sobre a vida dos $\mathrm{CCO}$ devido à falta de espaço editorial na revista. V.4, n. ${ }^{\circ}$ 2, p. 85.

${ }^{84}$ Idem, p. 21.

${ }^{85}$ Idem, p. 24.

${ }^{86}$ Idem, p. 21.

87 Julio Monzó, “Fins, organização e unificação do movimento católico popular português. Relatório apresentado ao $1 .{ }^{\circ}$ congresso das agremiações populares de Portugal, reunido em Lisboa em Junho de 1906", v. 3, n. 3 (Mar. 1907) pp. 99-119.

${ }^{88}$ Idem, p.110. 
Ambos os artigos de Julio Monzó analisavam, igualmente, o estado da questão social em Portugal. As tradições democráticas portuguesas, anteriores ao parlamentarismo inglês e à Revolução Francesa ${ }^{89}$, foram corrompidas pela influência galicana que conduzira ao absolutismo. No século XIX, devido à artificialidade e à corrupção da organização partidária da sociedade e do poder, os mais desfavorecidos afastaram-se do poder político, o que provocou a expansão do movimento socialista ${ }^{90}$. Comum aos dois artigos era a preocupação de Julio Monzó em contribuir para a estruturação do movimento católico social em Portugal. O magistério de Leão XIII, porém, viera recordar aos católicos que bastava eles observarem a sua tradição para responder à questão social ou a qualquer outra crise moderna que se apresentasse. Os operários deveriam, assim, recuperar os antigos grémios populares, substituídos pela concorrência liberal desenfreada, e unir-se não em partidos mas em classes - desta forma, teriam grande influência na vida económica e social de uma nação. A acção de todos os Círculos Católicos de Operários deveria ser mais bem articulada quer na luta contra o socialismo, quer na sua vida interna. No que respeita a este último aspecto, a acção religiosa deveria constituir a primeira prioridade para os círculos, uma vez que era isso que os distinguia dos socialistas e dos excessos revolucionários (as revoluções bloqueavam o progresso e impediam o desenvolvimento de uma confiança na evolução política persistente). Para tal, todos os círculos deveriam ter um director espiritual e deveriam ser realizados anualmente exercícios espirituais. Para além de uma acção religiosa, os Círculos Católicos deveriam desenvolver ainda uma acção social e política, colocando membros quer na política local, quer no Parlamento. De acordo com Policarpo, os Círculos Católicos de Operários sempre reduziram a questão social a uma questão religiosa e moral, e a desigualdade, inerente à condição natural do homem, fazia com que o operário tivesse que receber uma educação apropriada para ocupar o seu lugar natural. O enfoque dos círculos fora sempre na educação espiritual e religiosa dos operários e não na melhoria da sua condição socioeconómica. Os Círculos estavam ao serviço da regeneração e da moralização dos operários ${ }^{91}$. O discurso de Monzó termi-

89 De acordo com Monzó, Oliveira Martins realçou este facto através do conceito de civilização ibérica.

90 Essa expansão também se deveu à acção de algumas personalidades carismáticas. "Arrastados em Portugal pelo doutrinarismo de acção de Fontana ou pelas divagações especulativas-sentimentais de Antero de Quental, muitíssimos operários e muitos intelectuais enfileiraram decididos no nascente partido socialista que, graças a eles, poude gozar (...) de uma força e de um prestígio poucas vezes igualado nos tempos modernos por nenhuma outra agrupação de homens." Idem, p. 24.

91 João Policarpo, O Pensamento Social do Grupo Católico de "A Palavra" (1872-1913), Lisboa, INIC/Centro de História da Cultura da Universidade Nova de Lisboa, 1992, Parte II, cap. I. 
nava com uma série de propostas concretas para a organização do movimento dos Círculos Católicos de Operários, referindo, no que à imprensa católica dizia respeito, a necessidade de criar dois jornais, em Lisboa o Associação Operária e, no Porto, O Grito do Povo,"sendo a excelente revista Estudos Sociais, sob a sua forma especulativa, como a voz de todo este movimento, destinada a defender os seus interesses ante o público culto e no campo das ideias" ${ }^{\prime \prime 2}$.

\subsection{0 contributo de Gomes dos Santos:}

\section{intervencionismo estatal e sindicalismo católico}

Também o jornalista católico Gomes dos Santos ${ }^{93}$ prestou um contributo imprescindível para os Estudos Sociais. Se os dois artigos de Julio Monzó procuravam analisar todas as dimensões da questão social (histórica, teórica e moral) e traçar um plano de acção para a sua solução, a secção "Movimento Social", da responsabilidade de Gomes dos Santos, desempenhou um papel fundamental na divulgação de temáticas sociais como a Previdência Operária, o teatro social, o descanso dominical, o problema da mendicidade, a acção do Instituto Social de Barcelona, o apostolado popular desenvolvido pelos denominados "Capelães do Trabalho" na Bélgica, a acção das Semanas Sociais Católicas, o trabalho ao domicílio ou os círculos de estudos. Para além desta rubrica, destacam-se, ainda, dois artigos de cariz mais reflexivo redigidos por Gomes dos Santos. O primeiro desses artigos foi publicado em Junho de 1908 e aí se desenvolviam reflexões críticas em torno da democracia ${ }^{94}$. Resultado da leitura do livro de Adolphe Prins ${ }^{95} L^{\prime}$ Esprit du gouvernement, o texto defendia que o denominado princípio igualitário e das maiorias (com o consequente perigo da denominada "tirania do número"), assim como a ideia de sufrágio universal (responsável pela substituição das corporações por divisões administrativas baseadas no número), eram a base de uma concepção falsa de democracia. Outro dos motivos que conduzira Gomes dos Santos à redacção do artigo fora o facto de se encontrar difundida em Portugal a ideia de que a democracia e a república eram a solução para tudo. Desta forma, esqueciam-se os

92 Monzó, "A missão...," p. 69. A própria revista publicou, logo em Fevereiro de 1905, um artigo intitulado "Opiniões da Imprensa" em que comunicava aos leitores os elogios que os E.S. tinham recebido das outras revistas católicas de Portugal.Ver v. 1, n. ${ }^{\circ} 2$, extratexto.

93 Gomes dos Santos foi jornalista, escritor e editor. Viveu entre 1881 e 1918. Editor da colecção "Ciência e Religião".

94 Gomes dos Santos, "A democracia e a política", v. 4, n. 6 (Jun. 1908), pp. 226-232.

95 Adolphe Prins, 1845-1919, era um jurista belga. 
outros actores sociais, para além do povo, e no Parlamento usava-se o termo "democracia" sem se conhecer o seu verdadeiro significado."Recomenda-se a república para tudo e a propósito de tudo (...) é, ao mesmo tempo, um sistema completo, político, económico, religioso, moral e até terapêutico" ${ }^{\prime \prime 6}$. Por fim, Gomes dos Santos desenvolvia algumas considerações em torno da importância da política local enquanto escola de democracia e afirmava que a actividade política deveria ser igual à actividade científica: aos melhores deveria caber o exercício do poder (o sufrágio universal conduzia à supremacia da política sobre a técnica, ao favorecer a quantidade em detrimento da qualidade).

O segundo artigo intitulava-se"A associação operária"; aí se enunciava a ideia de que o corporativismo operário era a principal estratégia para resolver a questão social ${ }^{97}$."O direito de associação, tão levianamente condenado por alguns mal inspirados conservadores, nem sequer é discutível. Ninguém pode impedir esse impulso da natureza"98 que origina uma comunidade de interesses, por parte de quem partilha as mesmas condições de vida, formando como que uma "alma colectiva, a que podemos chamar a alma profissional"99. Para Gomes dos Santos, o associativismo encontrava a sua fundamentação no "próprio direito natural"100. Se existiram corporações profissionais no mundo antigo, "o espírito corporativo só se estabelece definitivamente na sociedade cristã"101. As antigas corporações medievais tinham dado origem aos actuais municípios e, a nível económico, impediram o monopólio e a exploração. Gomes dos Santos considerava, assim, que a questão social era consequência da Revolução Francesa, que abolira as corporações antigas ao conceber o trabalho como uma mercadoria, e referia que Leão XIII propusera como solução que as associações operárias seguissem o exemplo das antigas corporações. Gomes dos Santos terminava apelando para que as colectividades de operários católicos existentes em Portugal se transformassem em associações profissionais, à semelhança do que ocorrera na Bélgica, onde o sindicalismo católico bloqueara o sindicalismo socialista ${ }^{102}$.

\footnotetext{
96 Gomes dos Santos constatava que nunca em nenhum país se tinha implantado uma democracia absoluta. Idem, p. 226. Era a apresentação da República como um “messianismo social”.Ver Catroga, op. cit., p. 45.

97 Gomes dos Santos, “A associação operária”, v. 5, n. 3 (Mar. 1909), pp. 98-108.

98 Idem, p. 99.

99 Idem, p. 100.

100 Idem, p. 146.

101 Idem, p. 101.

102 Também Alberto Pinheiro Torres irá debruçar-se sobre a questão do associativismo/mutualismo num artigo intitulado "Associações mutualistas" e publicado em três números. Defendia que a democracia
} 


\section{A Igreja face ao mundo: reforma e conciliação}

As importantes temáticas da conciliação entre catolicismo e mundo moderno e do apostolado da Igreja Católica foram abordadas em muitos artigos dos Estudos Sociais. Ao acompanhar o evoluir da situação política nacional e internacional, a revista estava atenta aos perigos inerentes ao inevitável avanço do laicismo. Questões como o divórcio, o ensino, o feminismo ou as consequências da adopção da Lei de Separação em França ocuparam muitas páginas dos Estudos Sociais. Neste âmbito, posições de pendor mais crítico assumidas por alguns articulistas tiveram como consequência a acusação de modernismo. A redacção dos Estudos Sociais, porém, sempre mostrou ter consciência do perigo e da polémica que a apresentação e a discussão de determinadas ideias poderiam gerar entre os seus leitores. Assim, o editorial publicado em Março de 1905, intitulado "Elucidação", assegurava que os Estudos Sociais e o CADC contavam com o apoio do bispo de Coimbra, apesar de o primeiro número da revista ter sido publicado sem o respectivo "imprimatur eclesiástico"103. Simultaneamente a este esclarecimento, a revista alertava para a necessidade de se pôr fim a um certo tipo de conservadorismo católico que poderia impedir os avanços resultantes de uma eventual aplicação das doutrinas da democracia cristã.

Foram três os articulistas que abordaram, com sensibilidades distintas, a necessidade de uma reforma do corpo eclesiástico e da conciliação do pensamento católico com o mundo moderno: Carlos Martel e o Padre Sena de Freitas, nos primeiros anos

cristã era a vanguarda político-social, e não o socialismo, uma vez que a revolução social só se efectivaria se precedida por uma revolução moral. Acreditava-se que o mutualismo daria origem a uma nova fase da vida económica, na condição de se abandonar o falso individualismo moderno. "Associações mutualistas. Relatório apresentado ao Primeiro Congresso de Democracia Cristã em 18 de Junho de 1906", v. 2, n. 6 (Jun. 1906), pp. 241-247; n. 7 (Jul. 1906), pp. 289-296, e n. 8 e 9 (Ago. e Set. 1906), pp. 336-347. Pinheiro Torres viveu entre 1876 e 1962, foi eleito deputado em 1908 e em 1910 pelo Partido Nacionalista. Participou no I Congresso da Democracia Cristã em Lisboa, em 1906, e foi director de várias publicações católicas (O Grito do Povo, Democracia Cristã, entre outras). Ver Dicionário Biográfico Parlamentar (1834-1910), Lisboa, Imprensa de Ciências Sociais/Assembleia da República, 2004.

${ }^{103}$ V.1, n. ${ }^{3}$ 3, pp. 105-107. A redacção apresentava ainda, como garantia da ortodoxia da revista, a publicação da carta de Pio X, onde se condenava a actuação daqueles democratas-cristãos italianos que tinham desobedecido aos seus bispos. A figura de Manuel Correia de Bastos Pina (1830-1913), bispo-conde entre 1872 e 1913, foi decisiva na resposta do catolicismo ao mundo moderno em Coimbra e em Portugal. Amigo do $2 .^{\circ}$ conde de Samodães (Francisco de Teixeira de Aguilar e Azeredo, 1828-1918) e de Sousa Gomes, foi acusado pelos sectores católicos mais conservadores de liberal. Grande admirador de Leão XIII, ao longo do seu bispado desenvolveu várias acções de cariz social e procurou difundir o neotomismo em Portugal. Ver A. Jesus Ramos, O Bispo de Coimbra, Coimbra, Gráfica de Coimbra, 1995. 
de publicação da revista, e Gonçalves Cerejeira, no âmbito da segunda direcção dos Estudos Sociais. Na verdade, se Carlos Martel era mais radical e assumia alguns riscos no jogo entre ortodoxia e heterodoxia, o Pe. Sena de Freitas, através de artigos da sua autoria e da tradução de um discurso do famoso bispo norte-americano John Ireland, colocava a ênfase na conciliação e adaptação da Igreja ao mundo de então. Cerejeira enfatizava a verdade que a Igreja possuía no seu património, preferindo, assim, redigir um artigo em que expusesse todos os benefícios que a lgreja trouxera à história humana. Tal como refere Manuel Clemente, não existiu verdadeiramente um movimento modernista em Portugal, e a segunda redacção dos Estudos Sociais abrandou a abertura ao século verificada nos primeiros anos de publicação da revista ${ }^{104}$.

\subsection{O reformismo de Martel:}

\section{a adaptação do Clero à ciência e à democracia}

Os artigos de Carlos Martel sobre a reforma do Clero foram publicados em 1905 e 1906 e intitulavam-se"Estudos do Clero" e"O Clero e a política"105. Distribuídos por sete números, os dois artigos começavam por apresentar a situação da civilização ocidental, marcada pela crise de valores e pela decadência moral, analisavam de seguida a crise vivida pelo corpo eclesial, face às exigências do apostolado moderno, e terminavam com uma reflexão acerca do enquadramento e das linhas orientadoras da acção política do Clero. Se o Cristianismo já não constituía o fundamento da sociedade, a ciência era a nova divindade moderna. Não existiam, porém, cientistas cristãos, e as grandes reformas do pensamento, ocorridas nos últimos três séculos, tinham-se realizado não só sem a participação de representantes da religião, como também com um sentimento de hostilidade para com a Igreja. A concepção moderna de ciência moderna subvertia toda a ordem moral, civil e religiosa ao considerar que apenas as ciências físicas e naturais, por serem úteis, mereciam ser estudadas.

Para Correia Guedes, também a situação do Clero se poderia incluir nesta crise civilizacional, uma vez que o corpo eclesial demonstrava uma enorme desorientação relativamente ao entendimento da sua função no seio da sociedade. Era necessário que o

\footnotetext{
${ }^{104}$ Ver"Modernismo",in Dicionário de História Religiosa de Portugal, v. 3, 2000, e Seabra, Jorge, António Amaro, Nunes, João, O CADC de Coimbra, a democracia cristã e os inícios do Estado Novo (1905-1934), Coimbra, Edições Colibri/Faculdade de Letras da Universidade de Coimbra, 2000.

${ }^{105}$ Carlos Martel, “Estudos do Clero”, in E.S., v. 1, n. 1 (Jan. 1905), pp. 21-32; n. 4, pp. 174-183, e n. ${ }^{\circ}$ 5, pp. 218 -227. Idem, “O Clero e a política", in E.S., v. 1, n. ${ }^{\circ} 7$ (Julho 1905), pp. 297-306, n. ${ }^{\circ} 11$, pp. 464-472, e v. 2, n. 2, pp. 56-63, e n. 8 e 9, pp. 329-336. Carlos Martel era o pseudónimo de Correia Guedes. Ver Estudos, 1926.
} 
Clero acabasse com a sua "abstenção científica e social" ${ }^{106}$ e se misturasse com o resto da sociedade de forma a não"estar em oposição integral com o mundo moderno"107. A Igreja Católica devia adaptar-se à sociedade moderna e, se era uma sociedade divina, também era uma sociedade humana sujeita à mudança dos tempos, sendo "necessário ter fé na sociedade moderna" ${ }^{108}$."E porque época alguma contém o Cristianismo integral realizado no seu modo de pensar, de sentir, de querer e de operar"109, ele sempre se adaptou a tudo. No início do século $X X$, passaram a existir novas exigências que se colocaram ao apostolado da Igreja."A ciência e a democracia são hoje as duas forças incomparáveis que tudo dominam"110, sendo urgente tornar cristã a democracia e revitalizar a missão científica do Clero. Um movimento social de inspiração cristã contribuiria para a felicidade temporal do homem, anteciparia e substituir-se-ia às reformas defendidas pelo socialismo e colocaria a Igreja no caminho do progresso, logo, no centro da vida pública, o que, dando-lhe uma influência política renovada, permitiria ter real eficácia na vida interior dos cidadãos. Este movimento ia contra o plano usado pelo Clero nos últimos séculos que consistia em salvar a sociedade por meio do indivíduo e não por meio da própria sociedade.“O cristianismo individual é impotente onde não existe o cristianismo social."111

Central ao pensamento de Carlos Martel era a defesa da intervenção do Clero na vida política. Para Martel, a tradição da Igreja sempre se ocupara, de forma benéfica, da política, e o sacramento do sacerdócio não retirava à pessoa os seus direitos de cidadão. Ao contrário da Bélgica e da Alemanha, onde a acção política dos católicos era considerada um modelo ${ }^{112}$, em Portugal o Clero tinha sido escravizado pelo regalismo

${ }^{106}$ Idem, “O Clero e a Política”, p. 298. Fundamental era a renovação da formação ministrada nos seminários. A este propósito, três dos pensadores católicos que mais se dedicaram a este assunto colaboraram nos E.S.:Gomes dos Santos, Abúndio da Silva e Sena de Freitas.Ver Manuel Clemente,"Seminários,"in Dicionário de História Religiosa de Portugal, v. 4, 2001. Inúmeros foram os artigos onde a necessidade de reforma dos seminários portugueses foi referida. Nesses artigos, abordavam-se assuntos como a formação teológica, a necessidade da formação na questão social ou as reformas em curso em Espanha e na Itália. Em 1909, foram publicados dois artigos, intitulados "Em volta de um livro" $\mathrm{e}$ "Em volta dos seminários", onde se defendia que a formação dos futuros padres deveria incluir matérias relativas ao catolicismo social.Ver v.5, n. 8 , pp. 332-338, e n. ${ }^{\circ} 10$ e 11, pp. 391-398.

${ }^{107}$ Idem, p. 298

${ }^{108} / \mathrm{dem}$, p. 304. Carlos Martel acrescenta que era preciso conservar do passado o que ele tinha de bom.

${ }^{109} / \mathrm{dem}$, p. 305.

${ }^{110}$ Idem, p. 465.

111 Idem, p.466

${ }^{112} \mathrm{Na}$ Bélgica, os católicos organizaram-se, sempre sob a orientação da hierarquia, sendo que a maioria dos governantes deste país eram católicos. Também os católicos alemães mantiveram os seus direitos graças à sua acção política. 
e pelo liberalismo."Hoje entre nós, sob as aparências do liberalismo, vigora uma política antipopular e antinacional por excelência, porque, para educar o povo à liberdade e à democracia, não há força como a do Clero."113 Portugal era, assim, governado por capitalistas, por proprietários de terras retiradas à Igreja e por uma burguesia liberal moderna que cultivava o espírito de revolta e de servilismo e que desfrutava dos bens da nação, só pensando no mercado. O Clero podia contribuir para a criação de uma nova pátria, desde que abandonasse atitudes clericalistas - o "clericalismo não é o catolicismo"114 - e reconquistasse a sua liberdade e autonomia, recusando qualquer tipo de "favoritismo oficial ou de protecção leiga."15 A defesa da separação não se confundia com o ataque aos dogmas, como explicava Martel em nota de rodapé. “Devo observar que não sustento aqui tese alguma, coloco-me apenas na hipótese de todas as contingências actuais. Quando me saem da pena as palavras direito e necessidade, não quero significar mais nada do que direitos relativos e necessidades relativas aos tempos em que vivemos. Trato estas questões em ordem à vida prática, não na ordem da verdade absoluta. Não comprometo pois nem a fé, nem a doutrina da Igreja; exponho opiniões ou o que considero como opiniões pessoais sem pretensão alguma dogmática." ${ }^{116}$ Carlos Martel terminava com um apelo à prática da liberdade e da acção social por parte dos católicos:"A liberdade não é um princípio ideal que devemos venerar apenas em teoria, mas é o nosso poder de operar em conformidade com a nossa constituição moral, religiosa e intelectual. O Clero cometeu no último século a falta irreparável de não amar nem a liberdade política, nem a liberdade democrática, nem a liberdade científica e filosófica"117. A propósito da condenação do liberalismo pelo Papa no célebre Syllabus, Carlos Martel dizia: "pois fiquem sabendo que, a par de muito boa gente, mesmo de muito bons teólogos, não considero o Syllabus como um documento autêntico. Em todo o caso, aquelas célebres proposições não podem ser interpretadas fora do contexto donde foram extraídas, nem ao sabor do primeiro escrevinhador que se lembre de inventar heresias"118.

\footnotetext{
${ }^{113} /$ dem, p. 62.

${ }^{114}$ Idem, p. 330.

${ }^{115}$ Idem, pp. 331-332.

${ }^{116} / d e m$, p. 332 - em nota de rodapé com o número 1.

${ }^{117}$ Idem, pp. 334-335.

${ }^{118}$ Idem, p. 335. O Syllabus complectens praecipius nostrae aetatis errores e a encíclica de Pio IX Quanto cura datam de 8 de Dezembro de 1864, e o primeiro documento foi publicado pela primeira vez, em Portugal, no jornal $A$ Nação em 10 de Janeiro de 1865.
} 


\section{2. A conciliação de Sena de Freitas}

Mais conciliadora e menos crítica foi a posição do Pe. Sena de Freitas, expressa num conjunto de artigos publicados entre Setembro de 1905 e Janeiro de 1906 e intitulados "Católicos e catolicismo"119,"A intolerância católica e as suas raias"120,"Da tolerância católica"121 e "Optimismo ou pessimismo"122. Criticava o conhecido jornalista católico ${ }^{123}$, não só os historiadores que, por má-fé ou ignorância, confundiam católicos com catolicismo e papas com pontificado, como também certos apologistas católicos que branqueavam o passado da Igreja, não percebendo que essa posição só deteriorava a fé."Fique dito por uma só vez: os Papas não são o pontificado, assim como os católicos não são o catolicismo." ${ }^{124}$ Nos dois artigos sobre a tolerância/intolerância católica, afirmava Sena de Freitas que "toda a religião é intolerante no que para ela é dogma fundamental"125. A intolerância, porém, se era fruto da ignorância e do fanatismo religioso (ou anti-religioso), poderia constituir um desastre para a História, sendo necessário estabelecer os seus limites. Os católicos deveriam, assim, ser tolerantes para com quem defendia ideias diferentes ou contrárias às suas, sendo esta uma atitude inteligente, fruto da leitura, do estudo e da sabedoria que só a idade proporcionava, e constituindo igualmente o reflexo da infiltração do espírito cristão na maneira de pensar e de sentir dos homens. Num último artigo, defendia Sena de Freitas que, se o mundo actual se encontrava marcado pelo progresso técnico e científico e pelo retrocesso moral, o movimento social cristão aproximaria a lgreja da sua vocação original e permitiria uma atitude optimista face ao futuro. A Igreja possuía a capacidade de se reformar e de se adaptar ao ambiente humanitário da época, o qual era fruto da fermentação do Evangelho. Para este renascimento, Sena de Freitas considerava positivo o fim da relação de dependência entre o Estado e a Igreja. "A Igreja livre no Estado

\footnotetext{
${ }^{119}$ V. 1, n. ${ }^{\circ}$ 9, pp. 381-386.

${ }^{120}$ V. 1, n. 10 , pp. 461-464.

${ }^{121}$ V. 1, n. ${ }^{\circ} 12$, pp. $501-507$.

122 V.2, n. ${ }^{\circ}$, pp. 2-10.

${ }^{123} \mathrm{O}$ Pe. José Joaquim de Sena de Freitas foi jornalista, escritor e cónego da Sé de Lisboa. Viveu entre 1840 e 1913. Foi considerado "um consagrado" por Alberto Diniz da Fonseca quando iniciou a sua colaboração com a revista coimbrã.

${ }^{124}$ Padre Sena de Freitas, “Católicos e catolicismo”, p. 385, Set. 1905. Já na obra Autópsia da Velhice do Padre Eterno, de 1888, Sena de Freitas acusara Guerra Junqueiro de igual confusão.Também em 1905, os Estudos Sociais transcreveram uma conversa mantida entre os dois onde se debatera, ente outros assuntos, a história da Igreja Católica.Ver “Numa livraria de Lisboa. Diálogo com Guerra Junqueiro," v. 1, n.o 7 (Jul. 1905), pp.319-324.

${ }^{125}$ Idem, "A intolerância católica e as suas raias", p. 462.
} 
livre é, não em tese, mas com certeza na hipótese e na síntese, a melhor das situações para a grande Instituição fundada por Jesus, se a experiência e a história servem para alguma coisa." ${ }^{126}$ Esta defesa da separação não punha em causa o papel fundamental da Igreja Católica. Em 1875, Sena de Freitas assinava uma obra, Os Lazaristas, em que criticava a peça de teatro de António Enes por querer "descatolizar"a sociedade portuguesa, atacando injustamente a referida congregação religiosa, fundada por Vicente de Paulo e completamente distinta da Companhia de Jesus. Afirmava ele que não era verdade que a sociedade impedisse casamentos com vista à condução de raparigas para a vida monástica, concluindo que a crítica tecida contra os padres e os sacramentos reduzia a religião ao "Evangelho puro" sem qualquer tipo de mediação eclesial127. A obra de Enes era considerada uma apoteose do liberalismo maçónico.

A contribuição do Pe. Sena de Freitas para os Estudos Sociais inclui também a tradução de um discurso do célebre bispo norte-americano John Ireland. Intitulado "A Igreja e o século", o artigo foi publicado em três números entre Março e Maio de 1905 e foi apresentado aos leitores da revista como um "admirável programa das relações actuais da Igreja com o século"128. Reflectindo sobre as relações entre Revelação e ciência e entre Igreja e democracia, Ireland sublinhava que os princípios que movem o século XIX - justiça social, bem-estar generalizado e direito à criação pelo trabalho do necessário à vida - estavam contidos no pensamento cristão. Dessa forma, cabia aos católicos serem modelos de patriotismo e de virtude cívica, aderirem aos governos legítimos e trabalharem com energia. A Igreja tinha sido morosa na resposta aos avanços do século e tinha esquecido a sua capacidade de adaptação, que resultava da sua própria catolicidade. A nova cruzada consistia em estabelecer um contacto íntimo entre a lgreja e o século. Se o século era ambicioso de saber, então a lgreja devia estimular essa ânsia, pois não existia qualquer tipo de oposição entre Revelação e ciência.

${ }^{126}$ Idem,"Optimismo ou pessimismo," p. 8.

${ }^{127}$ A publicação de Os Lazaristas de António Enes gerou uma polémica com Sena de Freitas e muitos outros pensadores acerca da questão da influência do catolicismo sobre as consciências individuais. Esta polémica constituiu um exemplo daquilo que Matos Ferreira denomina de anticlericalismo estético-literário (ver Matos Ferreira,"Anticlericalismo", in op. cit.).

${ }^{128}$ John Ireland, "A Igreja e o século. Discurso pronunciado pelo grande Bispo de S. Paulo no Minnesota (Estados Unidos) Mgr.Ireland e acuradamente traduzido pelo cónego Sena de Freitas",v. 1, n. 3 (Mar.1905), p. 108-114; n. ${ }^{\circ} 4$, pp. 161-166, e n. ${ }^{\circ}$ 5, pp. 211-218. Ireland foi bispo de S. Paulo do Minnesota entre 1884 e 1918. Um outro artigo da sua autoria também foi publicado nos E.S.:"O papado e a reunião da cristandade", v. 4, n. 8 e 9, 1908. Para além deste, outros três bispos são frequentemente citados nos E.S. como modelos de acção ou de pensamento: James Gibbons, Henry Edward Manning e Wilhelm Emanuel von Ketteler. 
Se o século XIX era um século de liberdade, o século da democracia, a lgreja sabia viver no âmbito de qualquer tipo de regime político. Para Ireland, o regime político mais adequado à Igreja Católica era a democracia, uma vez que ela constituía o desenvolvimento lógico da igualdade, liberdade e fraternidade cristãs.

\subsection{A ortodoxia de Gonçalves Cerejeira}

A posição de Manuel Gonçalves Cerejeira, exposta numa conferência proferida no CADC de Coimbra, em Outubro de 1909, mais do que procurar conciliar o Catolicismo com as mudanças trazidas pelo "século", consistiu em realçar o papel da Igreja na história da humanidade. O percurso da Europa coincidia, em sua opinião, com o da Igreja Católica, uma vez que esta instituição tinha sido, e continuava a ser, a principal "alavanca civilizadora"129. Fora a Igreja, por exemplo, a grande responsável pela dignificação da mulher e pelo fim da escravatura ${ }^{130}$. A Revolução Francesa acabara, porém, com o ideal de justiça e de amor, sustentado na Idade Média pelo "enorme poder papal". Este tinha constituído uma obra social grandiosa ao ser o responsável pela garantia da liberdade dos povos e ao defender os mais fracos. $O$ impulso reformista da Revolução Francesa, se inicialmente positivo, acabou desvirtuado por uma tendência revolucionária e descristianizadora, geradora de consequências desastrosas, como a ocorrência de inúmeras mortes e o início do culto ao Deus-Estado. Se a igualdade perante a lei era de louvar, a igualdade absoluta de direitos já era duvidosa ${ }^{131}$. No entanto, "não é J.J. Rousseau que confessa que a Europa deve ao Cristianismo a menor frequência das revoluções e a maior doçura dos nossos costumes políticos? (...) Tirem o sentimento religioso ao miserável que tem fome" e ele será um revoltado e um revolucionário ${ }^{132}$. Também a infalibilidade não escravizara a razão humana, pelo contrário,

\footnotetext{
${ }^{129}$ Manuel Gonçalves Cerejeira, "A Igreja e os críticos. Conferência realizada no CADC de Coimbra em 30-10-09", v. 5, n.o 10 e 11, pp. 399-408. Quando redigiu este artigo, Cerejeira (1888-1977) ainda não tinha sido ordenado sacerdote. Vindo do Seminário de Braga, matriculara-se na Faculdade de Teologia em 1909. Foi ordenado sacerdote em 1 de Abril de 1911. Em 1912, matriculou-se na Faculdade de Letras. A sua experiência jornalística começou em 1909, na Palavra, a convite de Sousa Gomes; colaborou depois nos E.S. e desenvolveu-se plenamente com $O$ Imparcial, onde assumiu funções de director.

${ }^{130}$ Onde o Cristianismo não imperara, a Mulher encontrava-se num estado de exploração. Uma das glórias da Igreja foi a "reabilitação da fraqueza e da formusura", idem, p. 400. A Igreja procedeu a uma revolução moral com a luta pela dignificação do escravo. Essa luta tivera como protagonista, entre outros, o Pe. António Vieira.

131 "... eu e o meu pai, Richelieu e um camponês não têm os mesmo direitos." Idem, p. 401.

${ }^{132}$ Idem, pp. 404-405.
} 
libertara-a porque Ihe mostrara a verdade."Trabalhe a ciência e siga livremente o seu método. Além do seu, fica um outro campo mais vasto transcendente, onde só pode librar-se a razão iluminada pela fé." ${ }^{133}$ A Bíblia não fora feita para ensinar a ciência, mas a virtude ${ }^{134}$. A certeza da compatibilidade entre ciência e fé será, em 1922, uma das principais temáticas do seu livro A Igreja e o Pensamento Contemporâneo. Nessa obra, Cerejeira procurará demonstrar a falsidade do positivismo, materialismo, cientismo, diletantismo, pessimismo e realismo, correntes de pensamento surgidas no "estúpido século XIX" e que defendiam a incompatibilidade da religião com a ciência e o fim das religiões de autoridade pelo progresso intelectual. Através da exposição dos limites da ciência experimental (esterilidade do ateísmo cientifico, impossibilidade de fundamentar a moral na ciência e de negar as suas bases metafísicas) e do reajustamento da ciência no conjunto dos saberes humanos (ciência, filosofia e teologia coordenam-se enquanto três tipos diferentes de conhecimento), Cerejeira concluía que ciência e fé partilhavam uma concepção de verdade semelhante: objectiva, cognoscível, impessoal, fonte de autoridade e imutável. Terminava com uma nota de esperança: se o sentimento religioso se estava a atrofiar nas nações latinas, e mesmo assim, em Portugal o CADC de Coimbra era a prova do oposto, em países como a Bélgica, a Holanda, a Alemanha, a Inglaterra ou os EUA ele triunfava.

A certeza da perfeita adequabilidade da Igreja Católica ao mundo moderno permaneceu o principal objectivo de um outro artigo de Gonçalves Cerejeira, intitulado "Renascença cristã"135. Esta longa reflexão procurava demonstrar a verdade do Catolicismo através das conversões de Ferdinand Brunetière ${ }^{136}$, Paul Bourget ${ }^{137}$, Joris-Karl Huysmans ${ }^{138}$, François Coppée ${ }^{139}$ e Adolphe Retté ${ }^{140}$. “O acontecimento mais

133 Idem, p. 406.

134 "A bíblia parece a firmar a intervenção divina na primeira aparição da vida sobre a terra? Mas isso é hoje um postulado científico", in Idem, p. 407.

${ }^{135}$ V. 6, n. ${ }^{\circ}$ 7, 8 e 9 (Out., Nov. e Dez. 1910), pp. 246-253, n. ${ }^{\circ} 10$ (Jan. 1911), pp. 345-358, e n. ${ }^{\circ} 11$ e 12 (Fev. e Abr. 1911), pp. 423-445.

${ }^{136}$ Viveu entre 1849 e 1906 e foi um conhecido crítico literário e académico. Foi também director da revista Revue des deux mondes. Gomes dos Santos assinou, nos E.S., um artigo intitulado "Fernando Brunetière" onde descrevia a sua vida e a sua acção enquanto crítico literário e onde analisava o seu pensamento, sobretudo no que respeitava à ideia da "bancarrota da ciência”,'à distinção entre religião e ciência e entre moral e catolicismo.V. 2, n. 12 (Dez. 1906), pp.493-501.

${ }^{137}$ Escritor que viveu entre 1852 e 1935.

${ }^{138}$ Viveu entre 1848 e 1907. Para além de escritor, foi também crítico de arte.

${ }^{139}$ Escritor francês que viveu entre 1842 e 1908.

${ }^{140}$ Poeta simbolista e escritor anarquista que viveu entre 1863 e 1930. 
notável dos últimos anos do século XIX, e princípios do século $\mathrm{XX}$, um sendo das luzes, o outro porventura o da recristianização social, é essa consoladora afirmação de fé dos supremos representantes do pensamento contemporâneo."141 Para o "pessimismo moderno", existia um remédio eficaz:"a oxigenação cristã do ambiente literário e social". Se o desespero tinha "roubado" o genial Antero de Quental a Deus, o mesmo não ocorrera com Oliveira Martins. Graças à dedicação e à fé de uma esposa, de uma filha ou de um amigo, "a incredulidade abriu bancarrota." O retorno à "fé da infância" constituía para Cerejeira uma tendência do espírito da época. O Evangelho era considerado o melhor auxiliar do instinto social, e a organização científica da humanidade era uma fraude, assim como a vigência de uma moral sem Deus. Explicando a conversão de Brunetière, conhecido pelo seu livre-pensamento, Cerejeira afirmava que ele fora conduzido pelo seu rigoroso método científico à verdade católica. A fé cristã fora, para o conhecido jornalista francês, o culminar da evolução da lógica do espírito, sendo que as ciências físicas, a antropologia, a etnografia e a linguística não explicavam o sentido da vida humana. Cerejeira citava ainda Brunetière, para quem o verdadeiro sentido da divisa republicana "Liberdade, igualdade e fraternidade" só era possível alcançar no âmbito do Cristianismo ${ }^{142}$."O progresso da democracia é o facto mais notável da história, e o mais constante, e foi sempre paralela a ascensão do povo e a da Igreja. Procure-se a liberdade no maometismo, no budismo ou no paganismo: ela só cresceu e só vive aquentada ao calor da ideia cristã." ${ }^{143} \mathrm{O}$ futuro cardeal de Lisboa terminava afirmando que Brunetière escolhera a Igreja Católica porque ela constituía um governo, uma doutrina, uma tradição e uma sociologia. Após a descrição da vida e da conversão de Coppée e Retté, Cerejeira apresentava o caso de Paul Bourget, "um fervoroso católico [que] pretende (o que é mais) sê-lo cientificamente..." ${ }^{144}$. Bourget fora poeta e psicólogo e analisara os males da sensibilidade moderna, formada por autores como Baudelaire, Renan, Flaubert ou Stendhal. Revoltara-se contra o pessimismo reinante, e o estudo profundo de certos estados de alma conduzira-o à "verificação experimental da verdade da solução cristã"145. Com os seus romances, em especial Le Disciple, "inaugurava finalmente aquilo que ele chamou com felicidade "apologética experimental", a qual consiste em estabelecer (...) que, sendo dada uma

\footnotetext{
${ }^{141}$ Cerejeira, "A Renascença Cristã", 1910, p. 246.

${ }^{142} \mathrm{~A}$ fórmula científica "determinismo, selecção e luta pela vida" era completamente errada.

${ }^{143}$ Idem, pp. 252-253.

${ }^{144}$ Idem, p. 425.

${ }^{145}$ Idem, p. 430.
} 
série de observações sobre a vida humana, tudo nessas observações se passou como se o Cristianismo fosse a verdade"146. Relativamente a Huysmans, Cerejeira afirmava que "readquiriu a fé por uma experiência íntima, por provas internas, que relevavam da arte e da mística"147. A conversão dos cincos escritores citados constituía um sintoma da forte corrente espiritual que penetrava na literatura, na filosofia e na arte, reconciliando-as com o Cristianismo. De acordo com Gugelot, o movimento das conversões em França verificara-se sobretudo entre escritores e artistas, e a conversão correspondia a um momento de irrupção do sagrado num mundo descristianizado. $O$ intelectual católico assumia uma importância superior à do teólogo ${ }^{148}$. Também este será um tema fundamental da obra A Igreja e o Pensamento Contemporâneo. Cerejeira afirmará, nesses textos, que o ideal religioso fazia parte da natureza individual de cada homem e que a crise civilizacional compreendia uma crise da certeza e uma crise da moral. Os grandes intelectuais "desesperavam da razão" e depois de uma longa procura acabariam por encontrar na Igreja Católica todos os elementos que a razão postulava: doutrina esclarecedora, moral e culto. A questão das conversões foi, também, abordada em outros artigos dos Estudos Sociais. Assim, em 1907, Gomes dos Santos, num artigo intitulado “Roads to Rome", apresentava uma obra que compilava 65 conversões ao catolicismo e narrava a conversão de dois anglicanos ao catolicismo ${ }^{149}$; em 1910, comunicava-se a conversão do poeta Gomes Leal.

\subsection{As acusações de modernismo}

Face às posições mais críticas e ousadas de Carlos Martel, foram inevitáveis as acusações de modernismo dirigidas aos Estudos Sociais. Logo em Outubro de 1906, a redacção da revista respondeu a um artigo da Revista Católica ${ }^{150}$, reafirmando total obediência à autoridade e ao dogma católicos. De facto, a publicação de Viseu tinha publicado um artigo intitulado "Os Estudos Sociais desmascarando-se" onde colocava em causa a ortodoxia da revista coimbrã. De acordo com Pinharanda Gomes, apesar de o cónego Miguel Ferreira de Almeida ser uma voz autorizada (tinha, por exemplo, traduzido o Curso de Filosofia do Cardeal Mercier), a acusação de modernismo dirigida aos Estudos Sociais era precipitada, uma vez que a encíclica Pascendi só seria

\footnotetext{
${ }^{146}$ Idem, pp. 431-432.

${ }^{147}$ Idem, p. 436.

${ }^{148}$ Frédéric Gugelot, La Conversion des intellectuels au catholicisme en France, Paris, CNRS Éditions, 1998.

${ }^{149}$ V. 3, n. ${ }^{\circ} 10$, pp. 385-394.

${ }^{150}$ Redacção,"Nota da redacção em réplica à 'Revista Católica' de Viseu”, v. 2, n.o 10, pp. 393-395.
} 
publicada em 9 de Setembro de $1907^{151}$. Também no mesmo número, Carlos Martel assinou um artigo intitulado "Liberalismo e Syllabo" em que respondia às referidas acusações ${ }^{152}$. Afirmava ele que os católicos deviam saber distinguir entre o que há de relativo e de absoluto no catolicismo e defendia a existência de um liberalismo católico, preconizado por Leão XIII e pelos católicos belgas, alemães, ingleses, irlandeses e americanos. Relativamente ao Syllabus, Martel defendia que não podia ser atribuído ao Papa, pois não correspondia a um dogma decretado "ex cathedra"153. O texto não possuía assinatura, data, selo, destinatário, autor, ordem ou autorização do Papa ${ }^{154}$."É um documento anónimo. Falta nele a ligação do contexto que dê um significado positivo a qualquer das 80 proposições." 155

Devido a esta polémica, a redacção criou em Novembro de 1906 uma nova secção onde poderiam ser publicados artigos com ideias divergentes da linha editorial da revista. Esta secção iniciou-se com a edição de um artigo do Pe. Benevenuto, intitulado "O Liberalismo de Carlos Martel"156, onde se defendia que, à liberdade ilimitada, se contrapunha a liberdade vigiada pela autoridade eclesiástica e pelo Estado. A ideia de liberdade de Carlos Martel era contestada, pois não se podiam admitir na comunidade social todas as ideias e doutrinas, o que poria em causa a paz social. Leão XIII não podia ser considerado um liberal, e o liberalismo tinha sido várias vezes condenado pelos papas. A redacção afirmava que Carlos Martel nunca tinha defendido a liberdade ilimitada de que falava o Padre Benevenuto ${ }^{157}$.

${ }^{151}$ Gomes, op. cit. e A Tradução Portuguesa do "Curso de Filosofia" do Cardeal Mercier, Editora Pax.

${ }^{152}$ Carlos Martel, “Liberalismo e Syllabo", v. 2, Out. 1906, pp. 395-407.

153 “Prezo-me de ser inteiramente submisso nos ensinamentos da Igreja, mas nem por isso me julgo obrigado a reconhecer o Syllabo como um documento dogmático e infalível, como um documento oficial do Sumo Pontífice; e era isto que eu queria dizer na nota incriminada", Idem, p. 402.

154 “'A carta de remessa do Cardeal Antonelli não pode autenticar o documento porque: $1 .^{\circ}$ não é um documento infalível; o Papa não pode delegar a infalibilidade em ninguém; $2 .^{\circ}$ porque diz somente que o Papa quis que se fizesse um Syllabo e que fosse mandado aos bispos mas não diz quando, nem como, nem onde, nem por quem este Syllabo foi composto", idem, p. 402.

${ }^{155}$ Idem, pp.402-403. Algumas destas suspeitas relativamente ao Syllabus também se encontram num artigo publicado na Revue du clergé français. Aí afirma-se: "... este progresso, este liberalismo, esta civilização que Pio IX condena (...) não são todo o progresso, todo o liberalismo, toda a civilização moderna...,' A. Boudinhon, 1905, Tome XLII, p. 421.

${ }^{156}$ Pe. Benevenuto, “O Liberalismo de Carlos Martel”,'v. 2, pp. 480-484. Nesta nova secção não se publicariam debates exclusivamente pessoais pois preferia-se a "elevação dos conceitos".

${ }^{157}$ Também em 17 de Novembro de 1906, o Pe. José Lopes de Faria criticou Carlos Martel na publicação A Restauração, de Guimarães. Dizia ele que Martel não reconhecia a doutrina do Syllabus, onde se defendia não serem possíveis acordos entre partidos católicos e acatólicos. Ver Gomes, op. cit. 
Em Dezembro de 1907, o Pe. Francisco Garcez referia-se de novo às ideias de Carlos Martel ao criticar uma obra de um colaborador da revista $A$ Voz de Braga ${ }^{158}$. Reafirmava ele a ortodoxia das ideias do articulista da revista coimbrã, referindo o exemplo de pensadores estrangeiros que defendiam as mesmas ideias e que faziam um apelo à mudança dos costumes da Igreja Católica e não da sua doutrina. "Pondo de parte a debatida questão da autenticidade do Syllabus, porque nos basta, para o acatarmos, saber que as doutrinas, por ele condenadas, o foram em documentos autênticos da Santa Sé - e, enquanto o foram, têm o nosso incondicional acatamento; e a outra questão sempre antiga e sempre nova - a do liberalismo - porque sabemos que há liberalismo-pecado e liberalismo-virtude (...) afastando estes pontos, fica-nos o trabalho de Carlos Martel reduzido a considerações várias, sob diferentes epígrafes, em torno desta afirmação: a influência da religião revelada sobre a vida civil das nações já há muito se tornou ténue, estéril e quase nula. (...) O que ele quer é a reforma dos costumes e não do dogma." ${ }^{159} \mathrm{O}$ verdadeiro perigo era, assim, o facto de a perda de influência política e social da Igreja junto do poder conduzir a uma descristianização generalizada da população.

Finalmente, o novo corpo redactorial dos Estudos Sociais, que iniciara funções em Janeiro de 1908, manifestou uma posição que não ilibava, de forma clara, a anterior redacção da acusação de modernismo. De facto, em Fevereiro de 1908 foi publicado na secção "Notas do mês" um artigo intitulado "Nós e a 'Revista Católica', onde se respondia à acusação de modernismo, transcrevendo-se extractos do artigo onde tal acusação era feita ${ }^{160}$. A revista de Viseu acusava a revista coimbrã de nunca se ter retractado das suas simpatias modernistas, apresentando como prova o facto de, apesar de ter anunciado a publicação da encíclica Pascendi, nunca o ter feito. Os Estudos Sociais representavam um perigo para os futuros padres, uma vez que circulava nos seminários. A resposta consistiu em afirmar que o cónego Miguel Ferreira de Almeida inventava modernistas onde não os havia e que os Estudos Sociais sempre tiveram o apoio do bispo-conde ${ }^{161}$. O cónego deveria também ter visto que o corpo redactorial da revista mudara. “De resto os erros a que a Revista se refere nada temos com eles, visto não serem da nossa responsabilidade."162 Para além destes factos, o número de

\footnotetext{
${ }^{158}$ Pe. F. Garcez, “Estudos do Clero. Resposta a Carlos Martel, colaborador dos 'Estudos Sociais' de Coimbra, por um colaborador da 'Voz de Braga'", v. 3, Dez. 1907, pp. 566-567.

159 Idem, p. 567.

${ }^{160}$ J.C., v. 4, Fev. 1908, pp. 80-82.

161 “Ou pretenderá a Revista católica que também S. Ex. ${ }^{a}$ Revma, como nós, é modernista?", idem, p. 82.

${ }^{162}$ Idem, p. 82.
} 
Dezembro de 1907 fora apenas publicado em Fevereiro de 1908 devido ao elevado número de páginas que a publicação da encíclica Pascendi exigia. Foi precisamente nesse número, correspondente ao mês de Dezembro de 1907, mas só publicado em Março de 1908, que a redacção antiga, num artigo assinado por S. G. (Sousa Gomes), respondia a esta acusação, feita em Fevereiro de 1908, voltando a reafirmar que os Estudos Sociais sempre foram contra o modernismo e que sempre foram ortodoxos na doutrina exposta ${ }^{163}$.

\subsection{A condenação do modernismo}

O número dos Estudos Sociais correspondente ao mês de Dezembro de 1907 foi dedicado, na totalidade, à análise e condenação das ideias modernistas. No entanto, já em Agosto do mesmo ano, na secção "Documentos e factos sociais", tinha sido publicado o decreto Lamentabili sine exitu, onde se condenavam 65 proposições extraídas, maioritariamente, das obras de Alfred Loisy ${ }^{164}$. Este decreto ficou conhecido pelo nome de "Syllabus de Pio X" e nele se condenava uma série de postulados acerca do dogma e da sua evolução, dos Evangelhos, da Revelação, da Ciência e dos Sacramentos. Com data de 3 de Julho, foi publicado na revista coimbrã logo no mês seguinte. De acordo com a Revue du Clergé Français, o novo Syllabus não era idêntico ao de 1864, pois não continha nenhuma proposição obscura, nem era um decreto "ex-cathedra" e não teria, seguramente, o mesmo impacte do documento anterior, uma vez que dizia respeito à evolução intelectual do pensamento católico e não à sociedade civil ou à sociedade moderna no seu todo ${ }^{165}$.

O número de Dezembro começava com um artigo do Pe. Francisco Garcez, onde se afirmava que a finalidade do modernismo era a transformação da Igreja através da negação da sua doutrina ${ }^{166}$. No entender do Pe. Garcez, muitos fiéis viviam o catoli-

\footnotetext{
${ }^{163}$ S.G., "Apêndice. A propósito da nota do mês 'Nós e a Revista Católica' editada nos Estudos Sociais no n. 2 de 1908", v. 3 (Dez. 1907), pp. 576-589. Este foi o único artigo assinado por Francisco de Sousa Gomes nos E.S.

164 “Decreto da Santa Inquisição Romana e Universal”, v. 3, pp. 322-331. O decreto foi publicado em latim em português, dividindo-se as páginas em duas colunas. Alfred Loisy viveu entre 1857 e 1940 . A sua obra L'Évangile et l'Église, onde se defendia a evolução radical dos dogmas e a liberdade total na crítica bíblica, foi publicada em 1902 e, no ano seguinte, o boletim da Arquidiocese de Paris proibiu a leitura de todos os seus livros. Em 1908 foi excomungado, um ano depois da excomunhão de Georges Tyrrel (jesuíta irlandês que viveu entre 1861 e 1909 e que foi uma figura cimeira no seio da controvérsia modernista).

165 J. Bricout, “Le nouveau 'Syllabus',' in R.C.F., 1907, Tomo LI, pp. 225-232.

${ }^{166}$ Pe. Francisco Garcez,"O Modernismo,"v. 3, pp. 474-477.
} 
cismo apenas nos aspectos do seu agrado, não aderindo de forma integral à doutrina estabelecida. Viviam num "comodismo egoísta. Este comodismo prático devia procurar na heresia a sua justificação (...). Vieram então os chamados modernistas trazer, no comodismo teórico, a justificação desejada para o comodismo prático que, por seu lado, era terreno profícuo à implantação e difusão do primeiro"167. As críticas modernistas à doutrina e ao funcionamento da Igreja Católica visavam destruí-la. Publicava-se de seguida a encíclica Pascendi Dominici ${ }^{168}$. Este documento pontifício, composto pela análise das doutrinas modernistas (classificadas de agnósticas, imanentes e deformadoras da história religiosa, da concepção dos dogmas, da tradição, da relação entre ciência e fé, dos sacramentos, das relações entre Estado e Igreja e dos livros sagrados), pela exposição das suas causas (curiosidade, orgulho e ignorância da filosofia escolástica) e respectivos remédios (reposição do estudo da escolástica nos seminários e nas universidades católicas e exercício de uma vigilância eficaz sobre a produção livresca dos pensadores católicos), terminava afirmando que o modernismo reunia todas as heresias alguma vez existentes. A encíclica foi considerada notável pela Revue du clergé français que afirmava constituir ela a prova de que Pio $\mathrm{X}$ não era inimigo do progresso. No entanto, no número seguinte, um artigo intitulado "Ce qui n'est pas du modernisme" afirmava que, se a adesão era absoluta, era necessário que o pensamento de Pio $\mathrm{X}$ fosse compreendido de forma correcta e sem exageros ou medo. Os estudiosos deveriam apresentar as suas conclusões de forma clara, caminhar na via da verdade e do bem, mas não deixar de cultivar a filosofia, a teologia especulativa e positiva através do método histórico e do espírito crítico ${ }^{169}$. Ainda da autoria de Pio $X$, foi também publicado nos Estudos Sociais um documento onde se anunciava a excomunhão de todos aqueles que incorriam nos erros modernistas e onde se alertava para a necessidade de se vigiar os estudos de exegese bíblica e a actuação dos professores e formadores dos seminários e das universidades católicas ${ }^{170}$. Também publicada no número de

\footnotetext{
${ }^{167}$ Idem, p. 474.

${ }^{168}$ Pio X, "Pascendi Dominici”, vol. 3, n. ${ }^{\circ}$ 12, pp. 478-553. Esta encíclica foi publicada nos E.S. em latim e em português, dividindo-se cada página em duas colunas. Já em 1905, aquando do segundo aniversário do seu pontificado, se tinha publicado um elogio à acção de Pio $X$ no que dizia respeito à sua acção social e ao ensino da doutrina cristã em todo o mundo. Ver:v. 1, n. ${ }^{\circ} 8$, pp. 376-378, R.C.F., 1907, Tomo LII, pp. 5-17 e pp. 129-146.

${ }^{169}$ R.C.F., 1907, Tomo LII, pp. 5-17 e pp. 129-146.

${ }^{170}$ Pio X, "Motu proprio do Nosso Santo Padre Pio X pela divina Providência sobre as sentenças do conselho pontifício encarregado dos Estudos bíblicos e sobre as censuras e penalidades em que incorrem os que não acatam os decretos contra os erros modernistas", v. 3, pp. 554-558.
} 
Dezembro de 1907, foi a tradução de um artigo da revista francesa L'Univers, onde se comentava a resposta dos modernistas à encíclica de Pio X, Pascendi ${ }^{171}$. Tal resposta encontrava-se dividida em duas partes: a primeira consistia na defesa das posições modernistas face às falsas acusações da encíclica; a segunda parte, considerada "mais ofensiva", pretendia demonstrar que algumas ideias modernistas, consideradas erróneas pela encíclica, estavam de acordo com a tradição da lgreja. Era o caso da relação entre fé e ciência. A principal acusação dos modernistas à encíclica consistia no facto de o documento pontifício apresentar e conceber o modernismo como um sistema filosófico completo, quando tal não se tinha verificado. Na realidade, da aplicação da crítica a várias áreas do conhecimento, surgiram conclusões filosóficas dispersas ${ }^{172} .0$ comentário a esta resposta dos modernistas reafirmava, então, o carácter herético do modernismo devido, entre outras causas, à subordinação completa da fé à ciência, a uma deformada exegese bíblica e a uma visão hermética de Cristo. Outra crítica que se fazia a esta análise modernista da encíclica Pascendi prendia-se com o valor comparativo das religiões. Se para os modernistas era incorrecta a acusação a eles dirigida de que todas as religiões possuíam o mesmo valor, pois, no seu entender, as religiões correspondiam a estádios diferentes do evoluir humano e sempre "provocam uma experiência útil e salutar"173, a verdade é que o Pe. Tyrrel, ao defender que todas as religiões tinham o mesmo valor, tornava válida a acusação presente na encíclica.

A temática do modernismo foi também abordada em dois artigos de Gaspard Decurtins. O primeiro foi publicado entre Agosto e Novembro de 1907 e procedia a uma análise da distinção entre "reforma social-cristã" e "reformismo católico"174. Decurtins apresentava uma síntese histórica onde eram abordadas questões como o papel fundador de Ketteler, a filiação do reformismo católico no neokantismo e a resposta de Leão XIII a esse reformismo através da fundamentação da sua doutrina na filosofia tomista, considerada compatível com a ciência actual.

${ }^{171}$ L.G., "A anti-encíclica”, v. 3, pp. 559-566. O artigo era antecedido da seguinte nota:"a anti-encíclica é uma brochura de 230 páginas que não apresenta os nomes dos autores e é editada pela Società internazionale scientifico-religiosa editrice-Roma".

${ }^{172}$ Esta constitui uma das principais conclusões do estudo de Pierre Colin, L'Audace et le soupçon, Paris, Desclée de Brouwer, 1997.

${ }^{173}$ Idem, p. 562.

174 “'Carta a um amigo. Sobre a reforma social cristã e o'reformismo católico'”, v. 3, n.o 8 (Ago. 1907), pp. 310-316, n. 9 , pp. 357-365, e n. ${ }^{\circ} 11$, pp. 446-454. Gaspard Decurtins viveu entre 1855 e 1916. A sua carreira política esteve ligada ao partido católico conservador suíço. Deixou a carreira política em 1905, passando a ser professor de sociologia na Universidade de Friburgo. Fez parte da União de Friburgo, união social católica de estudos económicos e sociais. Contribuiu para os primeiros esboços da encíclica Rerum Novarum. 
Em Março e Abril de 1909, foi publicado um artigo de G. Decurtins em que se analisava o impacte da encíclica Pascendi ${ }^{175}$. Afirmava ele que a história comparada procurava, por todos os meios, encontrar semelhanças entre as religiões, de forma a proclamar a sua igualdade e a poder afirmar que "na sucessão das formas da ideia religiosa a religião é um elo, simples sim, mas indispensável"176. Para o teólogo suíço, o que era idêntico era apenas "o mesmo sentimento do pecado e a mesma necessidade de expiação"177. A pretensão de se explicar a origem do Cristianismo através do evolucionismo religioso partia de uma concepção panteísta de Deus, quando o facto mais importante da História fora a encarnação. Só um Deus pessoal poderia evitar a anarquia moral. Decurtins terminava o artigo afirmando que Pio $X$ tinha visto com clareza as tendências destruidoras do modernismo e o perigo que ele representava para a civilização cristã.

Um longo artigo, publicado em onze números e intitulado "Imutabilidade e evolução da doutrina católica", procurava responder às questões levantadas pelo modernismo e assegurar definitivamente as posições ortodoxas dos Estudos Sociais ${ }^{178}$. Da autoria do novo director da revista, o Pe. António Rodrigues de Oliveira, esta longa reflexão procurava responder a duas acusações frequentes: a de que o dogma era imóvel e a de que a doutrina evoluía de acordo com o progresso cultural e científico. Só o Espírito Santo esclarecia a doutrina católica ao longo dos tempos e aí radicava a única possibilidade de progresso do dogma católico. Criticava-se o racionalismo, que punha em causa a verdade contida na Revelação ao equipará-lo a um sistema filosófico e defendia-se que o depósito da Revelação não tinha que ser verificado pela ciência, mas pelo trabalho exegético da Igreja Católica. A doutrina da Igreja podia progredir através de três formas: extensão, clareza ou certeza. Exemplos disso eram os dogmas da Imaculada Conceição e da Infalibilidade Pontifícia que sempre estiveram contidos na fé implícita da Igreja, tornando-se, depois, explícitos. Sempre que se fixava um dogma, isso constituía um progresso. Sendo um ponto assente "a perfeita raciona-

\footnotetext{
${ }^{175}$ G. Decurtins, “A propósito da encíclica", in Idem, v. 5, n. 3 (Mar. 1909), pp. 81-85; n. ㄴ, pp. 161-166.

${ }^{176}$ Idem, p. 161.

177 Idem, p. 162.

${ }^{178}$ A.R.O., "Imutabilidade e evolução da doutrina católica. A evolução da doutrina e do dogma católicos não se processa da mesma forma que a evolução científica. A Revelação divina operou-se ao longo dos séculos. Se está toda contida nas palavras do Criador ao primeiro Homem, também é verdade que se foi revelando através da acção dos profetas, de Jesus Cristo e do Espírito Santo.,"v. 4, n. ${ }^{2}$ (Fev. 1908), pp. 42-47; n. ${ }^{\circ} 6$, pp. 217-225; n. ${ }^{\circ} 12$, pp. 465-472; v. 5, n. ${ }^{\circ} 1$, pp. 7-11; n. ${ }^{\circ} 4$, pp. 130-136; n. ${ }^{\circ} 6$, pp. 205-211; n. ${ }^{\circ}$ 7), pp. 249-253; n. 10 e 11, pp. 361-365; n. ${ }^{\circ}$, pp. 81-86; n. ${ }^{\circ}$ e 6 , pp. 161-164; n. ${ }^{\circ}$, 8 e 9, pp. $233-238$.
} 
lidade e necessidade do desenvolvimento da doutrina da Igreja em um vasto sistema teológico"179, a filosofia sempre fora essencial à teologia."Foi à custa da filosofia que se elaborou e fixou uma tecnologia teológica, e por meio desta que se aplanaram e resolveram enormes dificuldades e se dirimiram inúmeras e formidáveis controvérsias." ${ }^{180}$

Finalmente, entre Agosto e Dezembro de 1910, foi publicado um artigo intitulado"O Papa e o Sillon" cujo conteúdo consistia na carta que Pio X dirigira aos membros dessa associação francesa e onde eles eram advertidos quanto às suas ideias modernistas ${ }^{181}$. Nessa carta fazia-se uma breve história do Sillon e da sua postura desobediente em relação à autoridade eclesiástica, criticando-se as suas concepções de igualdade, de fraternidade e de dignidade e o espírito e os métodos adoptados. Constatava-se que a verdade católica estava acima de todas as outras, devendo o Sillon obedecer à doutrina católica na sua totalidade. A oscilação do pensamento deste grupo, entre ideologia política e interpretação da doutrina e civilização cristã, terminou na sua proibição ${ }^{182}$. Mais do que o seu pensamento, a meio caminho entre socialismo e liberalismo, ou da origem social dos seus membros, foi a personalidade de Sangnier que se destacou. Em Outubro do mesmo ano, publicava-se o artigo "Carta de M Marc Sangnier a S.S. Pio X"183 em que o fundador do Sillon reafirmava a sua obediência à doutrina católica e onde se retractava do seu projecto de criar uma religião mais universal do que a professada pela Igreja Católica.

\section{Notas finais}

Em 1908, num artigo sobre o III Congresso das Agremiações Populares, apelava-se à difusão do catolicismo social entre os operários, para que estes recristianizassem a sociedade e se tornassem "operários-agente", deixando de ser unicamente "operários-

\footnotetext{
${ }^{179}$ Idem, p. 249.

180 Idem, p. 164.

${ }^{181}$ V.6, n. ${ }^{\circ}$ 5, 6, pp. 200-213, e n. ${ }^{\circ}$ 7,8 e 9, pp.300-311. A actividade e o pensamento do Sillon e de Marc Sangnier foram várias vezes referidos nos E.S. Assim, na secção "Revista das revistas" fazia-se referência a um artigo de Le Sillon onde se abordavam questões como o amor à pátria e a Cristo e a duração do capitalismo. Ver v. 1, n. 3, p. 160. Em Junho do mesmo ano, referia-se um congresso do Sillon onde se discutia a importância dos círculos católicos de estudo. Ver v. 1, n. 6, pp. 285-291. Também em Março de 1908, referia-se Marc Sangnier a propósito da necessidade de criar uma Internacional de estudantes católicos. Ver "A acção social católica", v. 3, n. ${ }^{\circ}$ 3, pp. 111-115, e n. 4, pp. 133-138, e n. 5, pp. 195-202. Sangnier volta a ser referido a propósito da apresentação da ideia da criação de uma Associação Nacional da Juventude Católica Portuguesa, no congresso da Covilhã das Agremiações Católicas. Ver v.4, n. 10 e 11, pp. 393-104.

${ }^{182}$ Ver Jeanne Caron, Le Sillon et la démocratie chrétienne, Paris, Éditions Plon, 1967.

${ }^{183}$ V. 6, n. ${ }^{\circ} 7,8$ e 9 , pp. 312-314.
} 
-elemento"184. Às categorias de "operário religioso, instruído, virtuoso e laborioso"185, juntava-se a noção de "operário-apóstolo". Os Estudos Sociais procuraram, desde o primeiro número, contribuir para a constituição de uma estrutura de apoio às classes trabalhadoras que permitisse à Igreja Católica actualizar a sua tarefa de evangelização junto dos mais desfavorecidos, responder ao crescimento do movimento socialista, readquirir peso político e proceder a uma renovação interna.Para além deste facto, foi sempre claro para a revista que, se "o problema do homem surge todas as vezes que se põe o problema económico", o catolicismo continha a resposta à questão social, uma vez que defendia a fraternidade e a igualdade entre os homens e possuía a verdadeira noção de economia, aquela que se centra no Homem e não nos bens materiais ${ }^{186}$. Os Estudos Sociais depositaram uma confiança total nas potencialidades do catolicismo social, fazendo deste a sua principal bandeira, de acordo com as ideias de Leão XIII, o iniciador de uma nova etapa na história da Igreja. Estruturas como os Círculos Católicos de Operários, os Círculos de Estudo, as Juventudes Católicas ou, de uma forma mais lata, a defesa da reorganização corporativa da sociedade, tudo poderia contribuir para a resolução da questão social. Esta certeza da verdade e das potencialidades práticas do Catolicismo encontrava-se na origem da ambição da Igreja Católica em desempenhar um papel, no mínimo, tão relevante quanto o do Estado na resolução da questão social.De acordo com Misner, apenas com a Rerum Novarum a Igreja passou a justificar a intervenção governamental, sendo que, até aí, a visão paternalista sobre a resolução dos problemas sociais dispensara a intervenção estatal. Para este autor, a autonomia das organizações operárias católicas fora sempre limitada ou pela hierarquia ou pelos patrões, e a tensão entre autonomia e paternalismo na organização e pensamento do movimento católico social só seria verdadeiramente resolvida com o Concílio Vaticano ${ }^{1187}$.

O entendimento da noção de democracia cristã ao longo dos cinco anos em que os Estudos Sociais foram publicados apresentou variações, o que se enquadra nas difi-

\footnotetext{
${ }^{184}$ J.C.," "Acção social", v. 4, n. ${ }^{\circ}$ 8, pp. 343-346.

${ }^{185}$ Ver Policarpo, op. cit., Parte II, Capítulo II.

${ }^{186}$ Charles Calippe, “Doutrinas católicas sociais”, v. 5, n. 10 e 11, pp. 380-390. O artigo consistia numa análise da obra de Henri Lorin, Études sur les principes du Catholicisme social. Lorin era presidente das Semanas Sociais em França, e, segundo Calippe, a obra, apesar de não apresentar ideias novas, compilava todo o pensamento social católico do século XIX. Procurava, ainda, analisar o valor social dos dogmas fundamentais da criação, do pecado original e da redenção. Charles Calippe viveu entre 1869 e 1942, foi doutor em teologia, professor de Escritura no seminário de Amiens e membro do Comité das Ligas Sociais de Compradores e da Comissão das Semanas Sociais.

${ }^{187}$ Paul Misner, Social Catholicism in Europe, New York, Crossroad, 1991.
} 
culdades sentidas pela Igreja Católica, nacional e internacional, quanto ao modelo político a seguir. De facto, o movimento social católico acabou por não saber revestir-se de soluções políticas credíveis, e a democracia cristã constituiu uma noção em constante reformulação. Se num primeiro momento foi apresentada na sua vertente política, com o tempo foi sendo abordada na sua vertente social, isto é, enquanto resolução da questão social. A democracia era uma "forma de governar" e não uma "forma de governo". Era portanto uma praxis que devia ser conduzida pela moral católica e que devia servir de base a uma "organização corporativa da sociedade", concretizada nas instituições políticas locais e regionais. Se, por um lado, se reduzia a democracia à "melhoria das condições do povo", retirando-lhe toda a dimensão política e considerando que a discussão da organização do poder era uma discussão distinta da "questão social", por outro lado, em vários artigos dos Estudos Sociais discutiu-se a fundamentação da democracia (resultado do Evangelho e não da igualdade natural dos homens) e da igualdade perante a lei (assente na igualdade dos homens perante Deus), o monopólio da vida política pelos partidos, verificado no século XIX, a destruição da natureza corporativa da sociedade pelo capitalismo e o sufrágio universal ( a "tirania do número" enquanto oposição à organização corporativa da sociedade e enquanto limitação ao governo exercido por uma elite). Leão XIII, com a sua política do Ralliement e a dificuldade em encontrar uma posição face à evolução política, acabou por propor soluções sociais e não políticas para a resolução da crise social. Interessava ao Papa, não a definição política do regime democrático, mas a educação moral da democracia, tema da encíclica de Leão XIII, Longinqua, dirigida aos bispos norte-americanos e datada de 6 de Janeiro de 1895. Se não havia uma clara noção quanto ao regime político a adoptar pelos católicos, existia uma estratégia para retomar o poder: o movimento social católico.

Ao longo dos cinco anos em que os Estudos Sociais foram publicados, o debate intelectual foi esmorecendo em favor da apologia da doutrina e posições da Igreja e da formação dos estudantes católicos da Universidade de Coimbra e do público em geral. O debate intelectual deu lugar ao didactismo do leitor, em especial nas matérias relativas ao movimento social católico ${ }^{188}$. De facto, os Estudos Sociais procuraram res-

\footnotetext{
${ }^{188}$ Exemplo deste esforço de "doutrinação" do leitor foi a publicação das lições de Joseph Biederlack na Universidade de Innsbruck. A publicação deste artigo, traduzido por Artur Bívar, suscitou críticas devido ao facto de não se ter optado por um texto original de origem nacional. Ver Gomes, op. cit. Biederlack foi professor e jesuíta e viveu entre 1845 e 1930."Natureza da Questão Social. Causas da questão social. Causas e génese da questão social. As causas da questão social. Teoria liberal económica. A questão
} 
ponder aos desafios intelectuais da época, uma vez que o recrudescimento religioso, verificado no final do século XIX, ocorrera sobretudo ao nível do povo e não tivera expressão nas esferas mais intelectuais e ligadas ao poder ${ }^{189}$. Neste âmbito, foram publicados alguns artigos de carácter filosófico, tendo sido criada, embora por um breve período de tempo, uma secção denominada "Estudos filosóficos". Nesta secção, foram editados dois artigos, assinados por E.A.: um sobre a alma ${ }^{190}$ e outro sobre os conceitos de liberdade, determinismo e livre-arbítrio ${ }^{191}$. Também em 1910, o Pe. Luís Lopes de Melo assinou um artigo intitulado "A natureza da alma humana. No círculo de estudos do CADC de Coimbra", onde reflectia sobre os excessos do materialismo e do cartesianismo, a verdade e o rigor da escolástica, a relação entre psicologia e alma e a imortalidade da alma enquanto garante da moral ${ }^{192}$. Embora de cariz mais teológico, também o artigo denominado "À volta de Jesus. Síntese histórica" procurava "actualizar" a temática face às correntes intelectuais da época ${ }^{193}$. A questão da responsabilidade do individualismo moderno para a eclosão da questão social foi também abordada por Abúndio da Silva num artigo de reflexão sociológica intitulado“Organicismo sociológico e os católicos"194. O artigo procurava desfazer duas objecções colocadas ao critério organicista da sociologia: a primeira era a de que o organicismo destruiria a liberdade individual, e a segunda era a de que o organicismo justificaria a supremacia do Estado sobre a Igreja. A concepção da sociedade como um organismo constituía uma hipótese científica e era possível conciliar lei com liberdade individual. A questão da necessidade de modernização da Igreja e dos seus membros (clero e laicado) foi perdendo espaço editorial em favor da condenação do modernismo. $O$ debate/con-

social. Princípios fundamentais do Liberalismo. Crítica do liberalismo económico. O socialismo. I. Noção e divisão do socialismo. O socialismo de Estado,"in E.S., v. 1, n. 3 (Mar. 1905), pp. 130-141, n. ${ }^{\circ}$ 6, pp. 257-262, e n. ${ }^{8}$, pp. 349-351, v. 1, n. ${ }^{9}$ 9, pp. 396-401; n. ${ }^{\circ}$ 1, pp. 476-480; v. 2, n. ${ }^{\circ}$ 5, pp. 202-206; n. ${ }^{\circ} 6$, pp. 259-267; n. ${ }^{\circ}$, pp. 301-306, e n. ${ }^{\circ} 8$ e 9, pp. 361-365, v. 2, n. ${ }^{\circ} 10$, pp. 434-440; n. ${ }^{\circ} 11$, pp. 472-479, n. ${ }^{\circ} 12$, pp. 520-523; v.3, n. ${ }^{\circ}$ 2, pp. 61-66;n. ${ }^{6}$, pp. 225-232, e n. 7 (Jul. 1907), pp. 272-277.

${ }^{189}$ Ver António Matos Ferreira, “Anticlericalismo,"in Dicionário de História Religiosa de Portugal, Lisboa, Círculo de Leitores, 2000, v. 1.

190 "A psico-física e a doutrina espiritualista", v. 4, n. ${ }^{0}$ 1, pp. 5-10.

191 “Liberdade e determinismo," v. 4, n. ${ }^{\circ}$ 4, pp. 169-174.

${ }^{192}$ V. 6, n. 7 e 8, pp. 266-280.

${ }^{193}$ Partindo de estudos sobre a existência de Jesus Cristo, refutavam-se as teorias que defendiam quer a inexistência humana de Cristo, quer a ideia de que Ele era um mito construído pelos desejos religiosos do homem. G.A.P.S., v., 6, n. ${ }^{0} 11$ e 12, pp. 411-422.

${ }^{194}$ V. 3, n. ${ }^{3}$ 3, pp. 119-126, e n. ${ }^{4}$, pp. 147-152. Manuel Isaías Abúndio da Silva foi um célebre advogado e jornalista que viveu entre 1874 e 1914 e que, para além do artigo referido, viu várias obras suas serem publicitadas nos E.S. (Tratado de Direito Eclesiástico, O Dever Presente, O Capital-Salários). 
fronto com as ideias do mundo laico foi-se esbatendo, e mesmo a questão da ciência amplamente abordada na revista através da rubrica "Crónica científica", da autoria de Amadeu de Vasconcelos ${ }^{195}$, não se debruçou sobre as interrogações levantadas pela ciência à religião ou à Igreja, optando por perspectivar a ciência como uma prova da doutrina católica.

195 Jornalista, polemista e divulgador científico. Viveu entre 1879 e 1952. 


\title{
Os cavaleiros da espada de pau \\ e os arcanjos da espada dum trovão: \\ a Renascença Portuguesa e a cultura democrática
}

\author{
Adelaide Maria Muralha Vieira Machado*
}

Quando procuramos ecos precursores em Portugal para o movimento da Renascença Portuguesa, pelo menos três nomes, entre outros, são de destacar: Guerra Junqueiro, Sampaio Bruno e Basílio Teles. Enquadrados num posicionamento político militante e alternativo à monarquia (só após o Ultimato inglês no caso de Junqueiro, mas questionando as correntes materialista e positivista), eram activistas e publicistas mas também pensadores e filósofos que procuravam dar sentido a uma nova identidade portuguesa. Em termos culturais, situavam-se na charneira ou comungavam do simbolismo decadentista e nefelibata, e do naturalismo mais ou menos romântico, sob a influência de Victor Hugo e Tolstoi, mas também de Proudhon ou Jaurès. Todos participaram nas lutas pela implantação da República e todos se desiludiram com o seu andamento político.

A busca de justiça social dentro do ideal libertário que acompanhou estas três figuras reflectida em obra publicada e nas tertúlias que animaram à sua volta, assim como os seus temas favoritos (a pátria enquanto princípio espiritual de coesão e harmonia, o sebastianismo como busca e solução para o ser português, bem como os problemas que transcendiam as categorias racionais tais como o mal, o nascimento, a morte, a identidade), encontraram seguimento na Renascença Portuguesa e inspiraram os seus fundadores. Seguindo o órgão divulgador do movimento, A Águia, damos conta desta influência, também baseada na admiração de condutas pessoais e políticas, insuspeitas.

Leonardo Coimbra, a propósito do trabalho de Basílio Teles sobre o Livro de Job, em torno da problemática do mal, identificando-se com o autor ao identificá-lo com o criacionismo bergsoniano, escreveu:

Religião e Ciência são impotentes perante um Bem e um Mal para elas irredutíveis e absolutos. Um criacionismo moral verá na dualidade Espírito-Natureza o motivo da sua acção e o valor da sua realidade. Na continuidade vivida do esforço moral encontrará Deus, o inces-

Seminário Livre de História das Ideias, Centro de História da Cultura da Faculdade de Ciências Sociais e Humanas da Universidade Nova de Lisboa. 
sante acréscimo dos domínios espirituais (...). O homem tem a responsabilidade, livremente tomada de moralizar a natureza, isto é, as paixões, a inteligência, os instintos, a cegueira. ${ }^{1}$

Reverenciando a postura de Basílio Teles, como o exemplo da pessoa e do político que se procurava, e que a revista pretendia ajudar a perfilar, terminava o artigo apelando à juventude para que se revisse naquela figura² .

Guerra Junqueiro e Sampaio Bruno foram também, postumamente, homenageados pela revista com números a eles especialmente dedicados, participados pelos principais colaboradores e representantes das letras portuguesas.

No número dedicado a Junqueiro, Leonardo Coimbra dedicou várias páginas à análise crítica da obra do poeta, filósofo e pensador. Distanciando-se do naturalismo do qual Junqueiro, segundo ele, nunca se libertara, elogiava sobretudo o poeta de A Pátria, como o momento de libertação interior e visionária.

Deixamos de lado o que classificamos de parte polémica ou combativa para nos demorarmos gostosamente na alegria espiritual da parte de enternecimento e lírica contemplação e na parte do espiritualismo reconstrutivo. (...) Há mesmo na Pátria... visões proféticas, messiânicas, dum formidável volume de humanas realidades metafísicas (..... ${ }^{3}$

Quanto ao pensador, Coimbra lembrava o motivo por que só na criação poética aquele autor conseguia por vezes a liberdade total, fora do determinismo intelectualista e formal, e que o colocava a par de Cervantes, Shakespeare, Dante ou Camões. O idealismo evolucionista de Junqueiro contrastava com a ideia de ausência de princípio e fim, progresso ou decadência, interligação primordial de Espírito-Matéria, que presidiam à filosofia de Leonardo e dimensionavam a sua ideia de liberdade.

Movimento contínuo, élan vital eram passíveis de recomeço, renovação ou queda a cada instante no tempo concreto ou psicológico, isto é, a espiral como percurso necessário da humanidade em tempo abstracto perdia a validade perante a força do momento vital, que tornava cada um possuidor do conhecimento da liberdade absoluta, no plano espiritual.

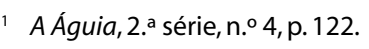

2 "É como se perdidos num jardim, cheio de monstros requintados, de repente os nossos olhos vissem o sólido raizame de algum carvalho, ou como se, num quente salão perfumado, entrasse de repente a rajada da Montanha. Abençoado o austero homem, que é um grande exemplo à nossa mocidade."; A Águia, 2. ${ }^{\text {a }}$ série, n. ${ }^{\circ}$, p. 123.

3 A Águia, 3.a série, n. ${ }^{\circ s} 13-14$ a 17-18, p. 18. 
Nesse sentido, com Sampaio Bruno o encontro de ideias era maior, e a sua influência foi clara quer no poeta da Renascença, Teixeira de Pascoaes, quer no seu filósofo de serviço, Leonardo. Também em artigo de homenagem póstuma, depois de gabar o brilhante combate de Bruno contra o positivismo, em Brasil Mental, apresentava-o como precursor de Bergson de Matéria e Memória, no esforço de entender e dar sentido ao universo e ao homem, a Deus e à existência do mal. A questão de a unidade cósmica das pluralidades humanas só ser possível no absoluto divino era partilhada por estes pensadores.

A queda de Deus pelo encontro com o mal como mistério divino, correspondente a uma ruptura nas consciências humanas, era também teorizada por Pascoaes; digamos que, desta forma, toda a redenção humana seria sempre um contributo para a redenção divina ${ }^{4}$.

Acompanhando o filósofo e pedagogo francês, na necessária interacção entre os planos substanciais, na dualidade espírito e matéria, que enformavam a acção e o real concreto, descortinava: "O absoluto é o alimento de nossas almas, e se ao termo do nosso cogitar sempre encontramos o relativo, é, felizmente, porque sempre a realidade é actividade socialista - o eu cooperando com o vós." ${ }^{5}$

Através destas homenagens feitas na revista, para além de permitir descodificar a importância e os limites das influências recebidas, levantava-se um pouco o véu da episteme do movimento da Renascença Portuguesa.

Continuando nesse caminho, passamos agora ao trio fundador: Teixeira de Pascoaes, Leonardo Coimbra e Jaime Cortesão. Em 1906, encontravam-se os três no Porto, Pascoaes já como advogado e com 29 anos, Coimbra com 23 e a frequentar a Academia Politécnica, e Cortesão com 22 anos, a estudar na Escola Médico-Cirúrgica. Nesse ano, Leonardo e Pascoaes conhecem-se e têm uma longa conversa. Segundo este último, em carta a Sant'Anna Dionísio, a amizade que os uniu para o resto da vida começou nesse encontro, o único, aliás, antes do processo que deu início ao movimento da Renascença.

Um ano depois, Jaime Cortesão, Leonardo Coimbra e Álvaro Pinto ${ }^{6}$ fundaram uma revista de curta duração mas que funcionou como a primeira experiência, um ensaio

4 Em plena sintonia de pensamento, o poeta pergunta: "O tempo cai, degrada-se no espaço, o íntimo desenvolve-se em episódio, o centro alastra à circunferência. A concentração temporal seguida do abandono, queda espacial, não é bem uma visão bergsonista?", A Águia, 2.a série, n. ${ }^{\circ} 48$, p. 181.

5 A Águia, 2. a série, n. ${ }^{4}$ 48, p. 181.

6 Convém ressalvar aqui que Álvaro Pinto foi a alma organizativa do movimento e do seu órgão divulgador. 
do grupo para o trabalho de maior fôlego que se seguiu. A Nova Silva adoptou como lema Libertas?.

Seguindo um texto fundador aí publicado por Leonardo Coimbra, encontramos algumas pontes com o pensamento do movimento da Renascença, do qual ele próprio viria a ser considerado o principal filósofo.

Eu vi a Vida gloriosa erguer-se no horizonte da minha alma oculta. Por um recolhimento contemplativo e extático tinha esquecido o homem e quase acendia a estrela do meu destino cósmico. Nesse momento criador vi a essência, a unidade original e eterna, através a acidentalidade humana sensível. Eu era envolto em sonho e em luar. O meu corpo conhece a lua, lembrava-se e a alma era cheia de saudades. Em mim um clamor ardente de vida, em minha carne um gesto criador, de balbuciante mistério. Senti então o poder da carne reveladora. ${ }^{8}$

Através desta prosa poética, revelavam-se os contornos do que viria a ser a sua base filosófica: o criacionismo espiritualista e personalista. $O$ seu universo era uma sociedade livre, de consciências, e a consciência feita pessoa, traduzida em actividade livre e criadora. Sob a influência de Renouvier ${ }^{9}$, e na esteira de Henri Bergson, considerava o acto criador como sendo a libertação da consciência que percorria a matéria, e se, por um lado, o conhecimento do mundo sensível era a inserção da alma na mortalidade da matéria, seria também, por outro, na fluência da matéria que se revelava a serena iluminação do espírito. A partir de um determinado plano, a diferença fugia à natureza das coisas para se centrar, enquanto actividade uniformizadora, na dualidade de sentido.

O vitalismo personalista desta filosofia revelava-se, ainda, considerando que o amor, a morte, Deus, o universo não eram puras ideias, mas vivências, formas de existência, desafios em que o homem singular se projectava com tudo aquilo de que era feito e o caracterizava. Contrariando o que considerava o raciocínio especulativo da filosofia pós-kantiana, considerava o principal trabalho do filósofo procurar, sob os artifícios

7 "Libertas. Sem servilismos de programas, de escolas, de dogmas - absolutamente livres de preconceito obedeceremos tão-somente aos impulsos da razão incoercível e indomada! Libertas! Na luta das paixões, que convulsionam a Humanidade, será essa palavra fecunda o estímulo da nossa actividade. A directriz do nosso esforço. Libertas! Sim, liberdade e com ela o supremo Bem, a suprema Justiça.,"Nova Silva, n. ${ }^{1}$, p. 1.

8 Nova Silva, n. ${ }^{\circ}$ 2, p. 10.

9 «La connaissance de la personne en tant que conscience et volonté est le fondement de toutes les connaissances humaines», Charles Renouvier, Le Personnalisme, Félix Alcan Éditeurs, Paris, 1903, p. 1. 
deformadores da representação, os dados imediatos da consciência. As intuições racionalizadas davam a conhecer a realidade do pensamento sob a forma de noções. Sendo que nada era em si e por si, a realidade era o máximo racional de sistematização de noções ${ }^{10}$.

Essência, existência e vivência comungavam em diferentes graus ou planos da integralidade da pessoa, do mundo e do cosmos. O instante, se vivido a partir da vida íntima do ser em comunhão com os vários planos, seria um momento de integral realidade.

Esta ligação entre a ordem pessoal, planetária e cósmica prendia-se directamente com conceitos de imaginário que davam os primeiros passos na psicologia e na psicanálise. Bergson, em sintonia, desenvolvia na sua ideia da "Durée" esta noção de algo que permanecia e transportava as leis universais, nos níveis da consciência de cada um, reveladas pela experiência; como uma tensão entre o que estava determinado e os mecanismos da acção livre, elas funcionavam como alavancas motoras da vida, o élan vital ${ }^{11}$.

Neste sentido, também para Leonardo Coimbra, as formas de objectividade que o plano cósmico ia organizando, uma vez que a consciência reflectida era uma das suas criações, iam desde a actividade mecânica, enquanto esquema de agir social, pela herança e memória biológica, até à clara consciência que um ser toma de si e do seu Universo.

Sentir e imaginar comungando da mesma natureza revalorizavam assim a razão na sua apreensão reflectida da realidade. Logo, o pensamento era criacionista, não porque criasse a realidade, mas porque a sua adaptação à vida social era obra da sua liberdade efectiva, isto é, da sua acção solidária, tornando-se, por tal, numa permanente criação.

Exterioridade e interioridade estavam em comunicação como rios que misturam as águas no campo das consciências: "Quando digo que existe é o universo inteiro que pela minha boca vem falar dizendo: Consinto. Se digo 'eu', é o infinito que fala um 'nós'

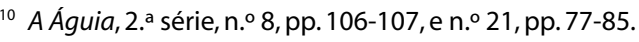

11 «À cette question spéciale nous avons répondu jadis en définissant l'être vivant par une certaine puissance d'agir en quantité et en qualité : c'est cette action virtuelle qui extrait de la matière nos perceptions réelles, information dont elle a besoin pour se guider, condensations, dans un instant de notre durée, de milliers, de trillions d'évènements s'accomplissant dans la durée énormément moins tendue dans les choses; cette différence de tension mesure précisément l'intervalle entre le déterminisme physique et la liberté humaine, en même temps qu'elle explique leur dualité et leur coexistence.», Henri Bergson, La Pensée et le mouvant: essais et conférences, Presses Universitaires de France, 1950, p. 61.
} 
que os meus ouvidos não escutam, mas que o corpo obediente às ligações gravíticas respeita e conhece."12

Recorrendo a Bergson, podemos reforçar esta ideia:

Sans doute enfin l'univers matériel défini comme la totalité des images est une espèce de conscience, une conscience où tout se compense et se neutralise, une conscience dont toutes les parties éventuelles, s'équilibrant les unes les autres par des réactions toujours égales aux actions, s'empêchant réciproquement de faire saillie. ${ }^{13}$

Esta memória consciente e genésica estava presente nos contornos atribuídos à Saudade, como teoria de conhecimento de si próprio e dos homens:"Conhecer é sempre anunciar na transitividade dos mundos a estabilidade da ideia (...) o conhecimento é pois fundamentalmente uma obra de saudade (...) saber não será recordar; mas é, pelo menos, inserir no fluxo sensível a firmeza de um juízo que o domina." ${ }^{14}$

Utilizando um tempo psicológico de retorno, Bergson ${ }^{15}$ veria a memória como a ligação entre um passado que não era mais um presente, mas sim um futuro que o aguarda.

O filósofo português daria desta ideia de memória/saudade uma imagem dramatizada. “O amor perfeito é Deus, perfeita identidade do inteligível com o intelecto; o amor humano seria, fora da beatitude, a coincidência da ideia com o objecto, seja na vida social o acordo de todas as ideias sobre o objecto social, que é a própria vida da sociedade humana. ${ }^{116} \mathrm{E}$ desse combate consigo próprio e que envolvia o todo surgiria, pela via da concretização do amor como a via possível, a unidade original e eterna ${ }^{17}$.

12 A Águia, 2. ${ }^{\text {a série, n. }}{ }^{\circ}$ 14, p. 67.

13 Henri Bergson, Matière et mémoire, Libraire Félix Alcan, Paris, 1928, pp. 262-263.

${ }^{14}$ A Águia, 3. ${ }^{\text {a }}$ série, n. ${ }^{\text {os }} 7-12$, p. 163.

15 «Mais pour toucher la réalité de l'esprit, il faut se placer au point où une conscience individuelle, prolongeant et conservant le passé dans un présent qui s'enrichit, se soustrait ainsi à la loi lui-même de la nécessité, qui veut que le passé se succède sans cesse à lui-même dans un présent qui le répète simplement sous une autre forme, et que tout s'écoule toujours. En passant de la perception pure à la mémoire, nous quittions définitivement la matière pour l'esprit.», Idem, ibidem, p. 263.

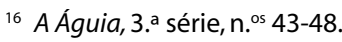

17 "Já viram essa terra seca e mirrada que um estio voraz queimou com beijos de fogo? Aquela desolação inquieta não lembra uma face severa que sente e inutilmente procura falar uma alma inundada de enternecimento. Eis o que é uma virgem amorosa. Terra estéril e mísera e que impetuosa torrente de vida não referve e tumultua a dentro do cárcere de um mentiroso poder! Assim era então junta a mim a mais próxima irmã do meu destino. Os seus flancos vibráteis, o seu ventre misterioso, os seus peitos húmidos, 
Sendo a filosofia de Leonardo uma filosofia de liberdade e sendo esta relativa na ordem humana, pela remoção dos seus limites, aparecia agora como força espiritual ou amor, produto da experiência humana, logo cooperante e libertadora. A impossibilidade de uma consciência solitária ser criadora baseava o processo psicológico da construção da personalidade como obra de conhecimento e liberdade ${ }^{18}$.

Esta liberdade conduzia à percepção consciente que, segundo Bergson, caminhava em direcção à matéria, ao mesmo tempo, ou na medida em que nos desembaraçássemos daquilo que se pode designar como juízos prévios da acção. No entanto, todo o acto ou pensamento libertador comungava com os vários planos ou ordens numa contribuição automática, mas também desejada.

Para melhor explicar o movimento de ascensão espiritual experimentado pelo jovem Leonardo na Nova Silva, vamos mais uma vez recorrer a Henri Bergson, que Leonardo Coimbra, bem como toda a sua geração, tanto estudou e admirou.

Non seulement, par sa mémoire des expériences déjà ancienne, cette conscience retient de mieux en mieux le passé pour l'organiser avec le présent dans une décision plus riche et plus neuve, mais vivant d'une vie plus intense, contractant, par sa mémoire de l'expérience immédiate, un nombre croissant de moments extérieurs dans sa durée présente, elle devient plus capable de créer des actes dont l'indétermination interne, devant se répartir sur une multiplicité aussi grande qu'on voudra des moments de la matière, passera d'autant plus facilement à travers les mailles de la nécessité. Ainsi, qu'on l'envisage dans le temps ou dans l'espace, la liberté parait toujours pousser dans la nécessité des racines profondes et s'organiser intimement avec elle. L'esprit emprunte à la matière les perceptions d'où il tire sa nourriture, et les lui rend sous forme de mouvement, où il a imprimé sa liberté. ${ }^{19}$

Para o filósofo português, esse impulso vital conduzia a Deus, e foi essa visão panteísta que a entrega integral ao êxtase sensual do amor lhe proporcionou ${ }^{20}$.

os seus olhos de fogo, as suas húmidas pálpebras diziam o mais eloquente pedido, erravam, na órbita fatal da matéria, para os meus braços trémulos e magnéticos!,"Nova Silva, n. ${ }^{\circ}$ 2, p. 10.

${ }^{18}$ A Águia, 2.a série, n. ${ }^{\circ}$ 8, pp. 106-107, e 3. a série, n. ${ }^{\circ 5} 9-10$, pp. 81-89.

19 Henri Bergson, idem, ibidem, pp. 278-279.

20 "E eis o que ouvi ao seu corpo sonoro e luminoso: Na eternidade copularam as estrelas e geraram-me em sonho. Sou o sonho. Falo luz, são astros os meus gestos. Das entranhas da terra subi em luar, na terra fiquei em sonho e sou o luar das almas. Numa noite tempestuosa, cheia de clamor das formas rezando a imperfeição, fulgurei nos olhos de um tigre. Oh! que pavor e assombro havia na minha prece! lluminei um dia uma serpente e subi aos céus nas asas duma ave. Criei uma alma, indaguei a vida e fui homem. Como tem sido dolorosa e bela a minha peregrinação humana! Esqueceu-me o passado, ignoro a vida, 
Duma queda de Deus ${ }^{21}$ resultara a criação, na qual o Bem e o Mal lutavam. Numa perspectiva de economia do mal, o homem devia associar-se a esta luta e com o seu esforço colaborar na redenção de si mesmo, do cosmos e do próprio Deus. Nesse sentido, Criador e criatura estavam indissoluvelmente ligados por leis universais, mas o ponto de ligação construía-se transcendentalmente a partir da vivência para a essência e evoluiria quer por abstracção do particular, esvaziando-o de conteúdo, quer em sentido contrário, adicionando particularidades ao máximo generalizante. $O$ ser puro encontrar-se-ia como princípio de toda a realidade, excedendo-se no todo a soma das partes, como bem absoluto.

Os cinco números publicados da Nova Silva representavam a tendência anarquista e anticlerical do grupo originário da Renascença Portuguesa, então dominante no meio estudantil. $\mathrm{O}$ anarquismo desta geração tinha uma finalidade personalista e solidária, opondo-se, no entanto, a qualquer tipo de colectivismo político. Com Proudhon atribuíam à justiça, cuja dimensão em abrangência conceptual assinalavam através da maiúscula, uma acção regeneradora. Com Tolstoi adoptavam uma atitude pacífica na aceitação do amor na sociedade, para alguns também o anseio de retomar por essa via a pureza do cristianismo primitivo. E com Kropoktine encontravam na origem de uma consciência moral generosa o auxílio mútuo e solidário.

A revista anunciava ainda os preparativos para a formação de uma escola livre que não chegou a concretizar-se, mas que prenunciava os projectos de educação alternativa, tão caros à Renascença. Divulgava-se também na Nova Silva a constituição de um grupo com sede no Porto chamado Amigos do $A B C$, à semelhança do grupo francês (Les Amis de L'Abaissé) de Os Miseráveis de Victor Hugo. Este grupo satisfez a necessidade de intervenção social suprapartidária sentida pelos jovens publicistas. Entretanto, a agudização da situação política veio a dispersar este núcleo, no qual só Campos Lima e Cristiano Carvalho continuaram, mas desta feita em ligação com o anarco-sindicalismo. A maioria dos outros jovens fora ganha para a militância republicana, sobretudo a partir das greves estudantis de 1907.

\footnotetext{
não compreendo o Universo e, no entanto, há em mim, insofrida e insaciável, uma imensa ânsia de luz, de verdade, de comunhão. Criei a alma e fui sua vítima. Como as há estreitas, tenebrosas e mirradas! Aspiro, soluço, sofro e não posso revelar-me, o cárcere é opaco, não posso revelar-me. Há almas ligeiras, simples, etéreas, puras e luminosas. Aí floresço as flores eternas do ideal. Sou a nuvem que leva o povo de Moisés à terra da promissão. Sou o sorriso da criança e a suavidade de Cristo, a timidez da virgem e a humildade do mendigo, a quimera do poeta e a loucura do herói. Incendeio as almas e ergo-as na plenitude da sua beleza, aproximo-as na nudez da sua absoluta verdade. Por mim se conhecem as almas, num olhar possuem-se no mais completo contacto", Nova Silva, n. ${ }^{\circ}$ 2, pp. 10-11.

${ }^{21}$ Renouvier, na obra sobre o personalismo, dedica um capítulo ao problema da Queda de Deus.
} 
Leonardo Coimbra (que só se filiará no Partido Republicano em 1914) e Jaime Cortesão aderem à República, com a esperança de que o exercício da liberdade e dos direitos democráticos contribuísse, na linha defendida por Sampaio Bruno, para uma evolução consciente de cada um no sentido da autonomia individual, e consequente maturidade política e intelectual. Leonardo Coimbra, anos mais tarde, em 1925, na revista A Águia, em polémica com o Integralismo Lusitano, reforçava esta atitude expectante na raiz da adesão ao Partido Republicano:

Sem obstáculos, teríamos a sociedade ideal, anarquista, do trabalho colectivo em acordo de liberdades subindo (...) é um ideal.Tentemo-lo por tendência e aspiração: dará a democracia benévola, atenta, fazendo da compreensão, da expressiva inteligência, a alma do seu esforço. E não se diga que esta Democracia está em crise, ela é até a alma dos outros movimentos sociais que julgam contrariá-la. ${ }^{22}$

Pouco depois de implantada a República, publicava-se o primeiro número da primeira série de A Águia, no dia 1 de Dezembro de 1910, fundada e dirigida por Álvaro Pinto, regressado da Madeira e entusiasmado com a vitória republicana. Nela participou todo o núcleo principal da futura Renascença Portuguesa: Jaime Cortesão, Leonardo Coimbra, Augusto Casimiro, Mário Beirão, Afonso Lopes Vieira, Raul Proença, António Sérgio, mas também Guerra Junqueiro, José Teixeira Rego, Sampaio Bruno, Manuel Laranjeira, Miguel de Unamuno, Raul e Júlio Brandão.

Tolstoi, Victor Hugo e António Nobre tiveram homenagem destacada nesta série que constou de dez números. Pascoaes, na direcção cultural da revista, anunciou o seu movimento poético-filosófico, com expressão original da saudade na essência do Espírito Lusitano, contendo em si o renascimento da Raça. Dá-se nesta série um encontro poético entre Jaime Cortesão e Teixeira de Pascoaes, no poema "A humanização da natureza", e aquele aderiu à concepção original e transcendente do ser lusitano.

Terminados os dez números que Álvaro Pinto se tinha proposto, a série acaba, e Jaime Cortesão escreve a Álvaro Pinto, informando-o do quanto era lamentado, nomeadamente em Lisboa, o fim da revista. Perante este facto, teve a ideia da criação de um movimento cultural que congregasse os intelectuais que andavam dispersos e que de alguma forma contribuísse positivamente para a situação do país,"com uma 
acção social orientadora e educativa"23. Nesse sentido, escreveu também uma carta a Raul Proença, convidando-o a elaborar um programa-manifesto que desse corpo à sua ideia. A associação que lhe propunha deveria ter três sedes, em Lisboa, Porto e Coimbra, para que juntasse os intelectuais e artistas de todo o país ${ }^{24}$.

Contactado Teixeira de Pascoaes, este propôs que a primeira reunião se realizasse em Coimbra. Assim foi, mas de Lisboa ninguém compareceu, e o poeta ficou encarregue da redacção do manifesto de apresentação. Cortesão resumirá mais tarde as conclusões da reunião de Coimbra:

Aí se lançaram as bases da nova organização que se propunha dois fins essenciais: restituir Portugal à consciência dos seus valores espirituais próprios; e promover em todo o país, por meio de uma revista, que fosse o órgão do movimento, de edições de livros, Universidades Populares, conferências, exposições e concertos, uma profunda acção cultural, junto de todas as camadas sociais. ${ }^{25}$

Na reunião seguinte em Lisboa, sem a presença de Teixeira de Pascoaes, foi lido o seu manifesto, que não obteve o apoio dos lisboetas. Raul Proença e António Sérgio protagonizavam o desacordo que, resumidamente, se baseava na crítica de que onde se lia lusitanismo deveria ler-se europeísmo.

Apesar de Proença ter chegado a escrever um manifesto alternativo, nenhum dos dois seria publicado ou assumido como programático para o movimento da Renascença Portuguesa. Só mais tarde foram divulgados na Vida Portuguesa, revista que se publicou entre 1915 e 1921, sob a direcção de Jaime Cortesão e destinada a analisar, promover e publicitar as actividades educativas e culturais do movimento.

A Águia inicia a 2. a série em Janeiro de 1912 e, até à 5. a série ou ano XX em 1932, será

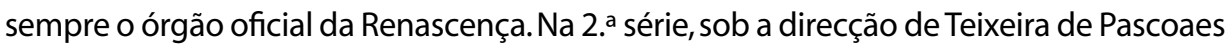
até 1917, Álvaro Pinto desde essa data até 1921, e na 3. a série sob a direcção de Leonardo Coimbra de 1922 a 1927, a revista conheceu o momento de maior divulgação literária e doutrinária, durante o qual se procurou, sem nele se esgotar, credibilizar e dar consistência ao Saudosismo, como meio para o renascimento da "Pátria Portuguesa":

23 Jaime Cortesão, in Alfredo Ribeiro dos Santos, A Renascença Portuguesa, Fundação Eng. António de Almeida, 1990, p. 80. Para a história do movimento, ver também Paulo Samuel, $A$ Renascença Portuguesa, Fundação Eng. António de Almeida, 1990.

24 "Ora o que há a fazer é essa obra titânica de orientar esta gente, de criar um público consciente e ilustrado e de impor artistas e intelectuais. Este é o fim principal, que a meu ver a Associação deve ter...", Jaime Cortesão, idem, ibidem, p. 78.

${ }^{25}$ Jaime Cortesão, idem, ibidem, p. 82. 
A Saudade é o próprio sangue espiritual da Raça; o seu estigma divino, o seu perfil eterno. Claro que é a saudade no seu sentido profundo, verdadeiro, essencial, isto é, o sentimento-ideia, a emoção reflectida, onde tudo o que existe, corpo e alma, dor e alegria, amor e desejo, terra e céu, atinge a sua unidade divina. Eis a Saudade vista na sua essência religiosa, e não no seu aspecto superficial e anedótico de simples gosto amargo de infelizes. É na Saudade revelada que existe e razão da nossa Renascença original e criadora. ${ }^{26}$

Assim, se a Renascença Portuguesa não era um movimento político, foi de facto um movimento politizado e politizante, isto é, a alternativa proposta à sociedade portuguesa passava necessariamente por uma organização diferente, porque se corporizava num novo tipo de político ${ }^{27}$.

Esta visão integrada do homem e da sociedade permitiu-lhes entender a importância da educação, do ensino e de novas formas de pedagogia, o que era, de resto, uma agenda comum à intelectualidade dispersa que pretendiam congregar; melhor dizendo, a ideia de uma elite preparada que assumisse a missão de mudar um país, dar-lhe uma identidade renascida e um caminho de conhecimento moral e filosófico foi o pilar do movimento Renascença Portuguesa e a vocação do seu órgão divulgá-los.

Leonardo Coimbra e Teixeira de Pascoaes, o primeiro através da filosofia, o segundo, da poesia, intentaram uma explicação totalizadora para o desvendar de um horizonte futuro, a reconhecer como tendo sido sempre o dos portugueses.

Estabelecendo pontes com a política que se pretendia, Leonardo Coimbra veria na democracia a expressão da sua filosofia de liberdade, demonstrando o seu valor e a eficácia do seu espaço, na relação inteligente que permitia estabelecer entre liberdade e autoridade ${ }^{28}$. Demarcando-se do autoritarismo, apresentava a ideia de autoridade como acordo construído pela experiência vivida em comum, que equivalia, no

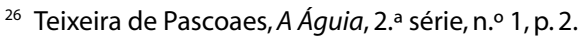

27 "Associação mais para actuar a distância pelo pensamento e pelo sentimento, a Renascença Portuguesa, revista mais de ideias e sentimentos, $A$ Águia, não deixará todavia aquela Associação, como não deixará esta revista, de olhar para as necessidades do momento e será, quanto possa, um órgão de crítica e reconstrução imediata da vida social e política e da nação. Tendo como destino supremo a contribuição para a nova consciência intelectual, do homem e do cidadão, não pode, no entanto, esquecer os males imediatos e terríveis que oprimem a pátria e, para que o remédio apareça, dará o que no seu esforço e saber possa existir", Leonardo Coimbra, A Águia, 3. a série, n. ${ }^{\circ}$ 1, p. 7.

28 "A república que quase todos nós fundadores da Renascença, sonhamos bela e pura, cheia de feridas (...) teremos de servir a república com a consciência de democratas que sabem o valor e o significado da democracia e não querem uma república de formalismo político, sem conteúdo social de melhor justiça, mais heróica fraternidade, mais lúcida compreensão e esforço de progresso no bem," A Águia, 3. ${ }^{a}$ série, n. ${ }^{\circ}$ 1, p. 6. 
espaço da democracia, o único possível para a existência da autoridade consentida porque processo de construção permanente e colectivo, à ideia de justiça ${ }^{29}$.

Como revista cultural, celebraram a vida ao reverem-se no vitalismo criacionista e, sobretudo, na Matéria e Memória de Henri Bergson, na saudade genésica como característica impressa na alma portuguesa alcançável através de um percurso de autoconhecimento pessoal e colectivo, e atingível de imediato pela expressão poética porque, segundo Pascoaes, o saudosismo era revelado ao poeta ou à alma poética. Daqui a importância e o inegável peso da poesia na revista.

Assumindo-se como espaço de debate e reflexão, as páginas da revista foram muitas vezes palco de polémicas que não raro opunham colaboradores e membros do Movimento.Se Fernando Pessoa, após a publicação na revista de uma série de artigos, fundamentando o surgimento do que considerava ser a nova literatura portuguesa ${ }^{30}$, se afastou do movimento para abraçar um projecto futurista corporizado na revista Orpheu, outros exemplos houve em que os desacordos não motivaram afastamento.

Neste sentido, António Sérgio foi um caso paradigmático de alguém que participou activamente ao longo de toda a publicação, que editou parte importante da sua obra pedagógica e ensaística através da editora da Renascença e que no entanto sempre se demarcou do saudosismo ${ }^{31}$ e da visão transcendental de ser português. Acreditava no poder/dever das elites intelectuais e na missão que tinham a cumprir em Portugal como em qualquer outro país, mas de forma coordenada e solidária.

Em consonância, defendeu uma nova maneira de fazer História. Distanciando-se da historiografia que procurava edificar através de um passado heróico ou exemplar, cruzava os factores geográficos e económicos em termos globais para através da análise comparativa teorizar, interpretando à luz do conhecimento presente, sobre os erros e as virtudes a emendar e a preservar, respectivamente, no futuro ${ }^{32}$.

Foi ainda a única voz que se ergueu contra a participação portuguesa na Grande Guerra, desmistificando os laços de raça ou consanguinidade latina versus germânica,

29 "De maneira que os dois modos de fazer o acordo da Autoridade com a Liberdade são duas tendências ideais: uma que apresenta o facto da Autoridade como força social impondo-se às liberdades, outra que vê no tempo a génese dessa Autoridade por actos anteriores de inteligência e acordo", $A$ Águia, 3. a série, n. ${ }^{\text {os }} 37-48$, p. 37.

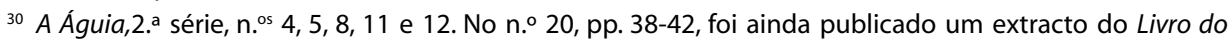
Desassossego.

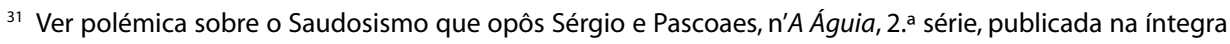
em Paulo Samuel, $A$ Renascença Portuguesa, 1990.

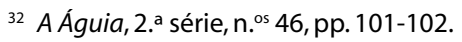


sobrepondo-lhes a moral e o direito, e a consequente fraternidade, como únicas formas de validação legítima de povos e nações ${ }^{33}$, que era, como se pode ver, e como António Sérgio também viu, um problema que, para além de político, era cultural. Uma ideia de cultura como algo vivo e em permanente construção levou-o a defender um renascimento da cultura portuguesa ${ }^{34}$ através de uma educação que não se limitasse à transmissão de um amontoado de conhecimentos, mas que desempenhasse um papel libertador no sentido da autonomia e do encontro entre o indivíduo e uma moral cívica ${ }^{35}$.

Colocando a reforma da educação como base para qualquer outro tipo de reforma que se quisesse efectuar em Portugal ${ }^{36}$, acreditava que o desenvolvimento e o progresso das ciências deveriam ter em conta ou por medida o bem comunitário, isto é, que nem sempre aos progressos científicos correspondiam os progressos da razão humana ${ }^{37}$, no que se compaginava com o espírito da revista e do seu núcleo fundador.

António Sérgio começou a sua colaboração em AÁguia em 1911, estreando-se como poeta $^{38}$, pelo meio e em tempo de exílio sidonista no Brasil. Em conjunto com Álvaro Pinto, iniciou o movimento equivalente à Renascença Portuguesa no Rio de Janeiro, - Anuário do Brasil, sendo a partir dessa cidade que A Águia era editada ${ }^{39}$. Mais tarde, quando a revista Pela Grei, fundada com Ezequiel de Campos, teve problemas de publicação, a revista da Renascença abriu uma secção destinada à continuação da publicação Pela Grei nas suas páginas ${ }^{40}$. António Sérgio terminou a sua colaboração em 1932 com um apelo à democracia como ideal de partilha, de participação e representação e defendendo a consequente adequação das instituições públicas, educacionais e políticas a esse ideal."Regime democrático da sociedade, por isso mesmo, é que uma viva moral, espiritual e não uma matéria que se conserve por si, pela força da inércia, tem de ser instaurado, continuadamente, pela propaganda e pelo jornal diário, pelo livro de doutrina e pela escola pública, num esforço contínuo de criação social."41

Retirando o balanço das cinco séries, facilmente constatamos a importância desta revista pelo cumprimento e, em muitos casos, o ultrapassar dos objectivos a que se

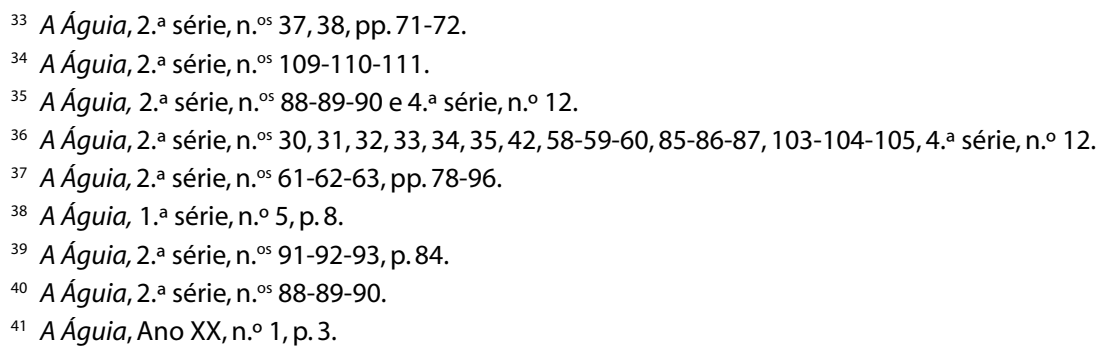


tinha proposto. Toda a vanguarda intelectual das mais diversas áreas da arte à ciência encontrou espaço para expor os seus estudos, teorias e críticas, já que, muito embora Sérgio fosse o paradigma de um apoio polémico à publicação, muitos outros debates animaram as páginas de $A$ Águia nas mais diversas áreas, desde a literatura, a filosofia, a história, as artes e a economia às novas ciências sociais e humanas como a antropologia, a psicanálise, a filologia e linguística, a pedagogia.

Em defesa de um novo enquadramento político e social, não será demais ressaltar que o que à primeira vista parecia uma enumeração de saberes compartimentados e antigos adquiriu na revista um sabor de novidade transdisciplinar, isto é, traduziu-se na procura de novas formas de conhecer, pela compreensão e interpretação do todo, como instrumento ou ferramenta de aplicação e interligação inteligente dos saberes particulares, ao que não foram alheios o conhecimento dos passos dados pela física, a matemática, a psicologia ou a psicanálise coevas.

A divulgação de temas e teorias de vanguarda desembocava não raras vezes na crítica como forma autónoma de apreciação e validação da obra intelectual, que foi outro dos aspectos importantes desenvolvidos pela revista, desde a recensão à divulgação crítica de acontecimentos culturais, editoriais ou pedagógicos dentro e fora do movimento da Renascença Portuguesa, ou do país, com especial destaque para o Brasil. Estes aspectos permitiram alargar qualitativamente o horizonte de intervenção da publicação.

Por outro lado, a promoção e a publicitação de revistas de especialidade ou generalistas oriundas de todo o mundo, em especial do continente americano, que tal como A Águia procuravam manter-se no acompanhamento e divulgação de trabalhos de vanguarda, completavam o papel que pretendiam em correlação com os objectivos anunciados de acordo com a filosofia defendida. $O$ conjunto de autorias e temáticas foi assim completado por uma geografia de produção intelectual que muito contribuiu para o sucesso e a perenidade da revista.

A partir destes pressupostos, a mensagem cultural e política que convém reter fundamentava-se numa ideia de liberdade e na forma do seu aperfeiçoamento, o espaço da democracia. A missão desinteressada de uma elite intelectual que era preciso mobilizar, e a cujos saberes urgia dar sentido, através do exemplo da acção concreta e da partilha alargada, implicava uma nova definição, quer de intelectual, quer de político. Foi por essa via que o Movimento e a Revista entraram, e foi nesse contexto que, apesar das diferenças, se conseguiram alianças.

Com Leonardo Coimbra, claramente, a liberdade era uma descoberta interior provocada e alimentada pela exterioridade de todas as vivências, enquanto para António 
Sérgio era uma construção intelectual, conquista de uma maturidade autónoma e racional, educativamente assistida.

O personalismo do filósofo do Porto colocava a jusante, isto é, como primordial ou necessária a ligação entre o plano pessoal e universal, numa organicidade genética e espiritual que a memória traduzia em identidade e em liberdade; quer dizer, entre o determinismo físico e a liberdade humana existiam diferenças de qualidade e duração que projectavam o primeiro na finitude e a segunda no infinito idealizado. O vitalismo completava a compreensão do aqui e do agora nos vários graus e planos, fundamentando a liberdade com a autoridade cooperante, porque vinda de um cada vez maior número de experiências reais, ou vividas, no encontro das inteligências com o seu objecto. O pluralismo que presidia a esta filosofia, relativo e progressista, partia da imutabilidade do seu processo de desenvolvimento, um espaço-tempo desigual mas combinado, que equacionava a partir da experiência todas as dimensões do ser e do dever ser, como formas inseparáveis de construção da verdade humana e base da vida social.

António Sérgio idealizava a democracia como fim, como possibilidade de sucesso para a sociedade humana, numa espécie de revolução permanente de actualizações políticas e institucionais em consonância com o aperfeiçoamento moral e espiritual dos cidadãos, criando automaticamente condições para o desenvolvimento do princípio da liberdade e da igualdade de condições externas. Educar, dever da elite intelectual, era sobretudo preparar para a participação cívica, logo cooperativa, para o espírito de iniciativa e trabalho, tendo como produto mentalidades críticas e experimentais. Esta era a medida, o homem livre e racional, que não se compadecia ou vergava perante consanguinidades rácicas, ou fronteiras estabelecidas pela história. $\mathrm{A}$ identidade construída, não como particularidade transcendente, mas como projecto consciente e harmónico entre pensamento e acção, no espaço da universalidade humana, conduzia a um cosmopolitismo que não negava a nacionalidade, mas que a via antes de mais como um processo de conquista de adesões político-culturais no sentido lato.

Partindo do homem universal, ou negando-o a priori para o encontrar em cada particularidade, era no plano da existência e na validação da experiência que os caminhos se encontravam, não fora Kant afinal a figura tutelar. Assim, para além do importante debate intelectual, em torno das questões filosóficas que fundamentavam a liberdade ou a democracia, distinguia-se como prova de credibilidade sine qua non uma postura moral daí decorrente. 
Do conturbado período da I República, o senso comum não reteve o real valor do debate em torno do pensamento e acção democráticos, que davam os primeiros passos. Julgamos não arriscar erro se, ao pegar neste movimento, na sua revista e nas que se seguiram animadas por estes pensadores e, caminhando por aí, chegarmos a encontrar um fio condutor até ao 25 de Abril 1974. Não será demais terminar, ressalvando a importância de um estudo desse tipo para uma maior compreensão e participação positiva nos desafios da actualidade. 


\title{
Índia Nova: nacionalismo e cosmopolitismo num jornal académico*
}

\author{
Sandra Ataíde Lobo**
}

\begin{abstract}
Crescemos na mesma rua, em Margão, que houve um tempo em que se chamou dos Prazeres, para passar a adoptar o nome, que até hoje conserva, de Abade Faria - ele na casa dos avós maternos, eu na dos paternos, que é ainda casa minha. Tal como ele vinte e quatro anos antes o fizera, também eu, um dia, parti - um e outro aos dezoito anos de idade, deixando para trás, não indiferentes, as lembranças da infância e os fervores da adolescência, mas acompanhados pela sombra iluminada de um ideal. Um ideal em que, ao desassossego de aspirações artísticas juvenis, que quem julgou inocente e inofensivo se enganou, se juntava o desassossego de uma inquietante, contraditória consciência nacionalista emergente - um sentimento descentrado, situado entre dois pólos civilizacionais, espaço em que as culturas ora se avizinham, ora se hostilizam num sistema planetário de múltiplas constelações.

(...) chegou à Coimbra do imaginário de tantos estudantes goeses ansiosos por se tornarem bacharéis com uma bagagem de sonho e de generosidade e também o pressentimento de uma ameaça à sua identidade. ${ }^{1}$
\end{abstract}

Referia-se o escritor Orlando da Costa (Margão, 1929-Lisboa, 2006) a Júlio Francisco António Adeodato Barreto (Margão, 1905-Lisboa, 1937)², que, pelo percurso e pela obra, cedo se tornaria uma referência intelectual de sucessivas gerações goesas. A sua família, culta mas de modestos recursos, com esforço enviara Adeodato Barreto para prosseguir na Metrópole os estudos superiores, seguindo o caminho habitual de mui-

* Dedico este artigo ao meu pai, Jorge Ataíde Lobo (1920-2004), que sempre se sentiu, cultural e afectivamente, duplamente indiano e português. Agradeço a Kalidás Barreto o generoso acesso ao espólio de seu pai, Adeodato Barreto.

** Bolseira de Doutoramento da FCT.

1 Costa, Orlando da, "Indianidade, solidariedade, liberdade", in Barreto, Adeodato, Civilização Hindu seguido de O Livro da Vida (Cânticos Indianos), Lisboa, Hugin, 2000, pp. 7-8.

2 Cf. Costa, Aleixo Manuel da, Dicionário de Literatura Goesa, Lisboa: Instituto Cultural de Macau: Fundação Oriente, [s.d.]; Miranda, Lúcio de, Adeodato Barreto (ensaio biográfico e crítico), Bastorá:Tip. Rangel, 1940, p. 7; Barreto, Adeodato, op. cit., pp. 7-56. 
tos dos jovens do seu meio. Em Coimbra, onde chegou em 1923, completou os cursos de Direito (1928), de Histórico-Filosóficas (1929) e da Escola Normal Superior (1930) e iniciou uma actividade intelectual indissociável dum constante exercício de cidadania que prosseguiria até ao fim da vida.

Integrava Adeodato Barreto uma nova geração da elite cristã goesa criada sob os auspícios da República, a qual viera dar outras oportunidades de consciencialização e intervenção aos naturais das colónias, ao alargar os seus direitos e ao promover alguma autonomia político-administrativa. À dinâmica gerada pelo ambiente político e cultural da República acrescia o sopro das ideias e dos acontecimentos do século, nos quais se inscrevia o despontar do nacionalismo em diversos territórios coloniais, com destaque para a Índia britânica, que particularmente contagiava a juventude das elites locais.

Faltam-nos elementos sobre o pensamento do jovem Adeodato Barreto ao partir de Goa. O que sabemos é que, uma vez em Coimbra, cedo evidencia o convívio com a intelectualidade republicana que o levaria, já sob a ditadura militar, a ingressar no Centro Republicano Académico de Coimbra, sendo pouco depois eleito seu presidente (1928); a envolver-se na dinamização da Universidade Livre de Coimbra, criada em 1925 por Joaquim de Carvalho e Tomás da Fonseca, entre outros; e a dispersar artigos por jornais e revistas republicanos, entre eles a Seara Nova, da qual se tornaria um colaborador assíduo. A adesão aos ideais republicanos conjugou-se com o interesse pelas novas correntes do pensamento indiano e pelos seus mentores, interesse que se espelhou na tradução que efectuou, logo em 1925, da obra de Romain Rolland dedicada a Gandhi ${ }^{3}$ A sua formação intelectual, no que respeitava ao conhecimento

O manuscrito incompleto dessa tradução, que ficou inédita, encontra-se entre os papéis na posse do filho Kalidás Barreto. $O$ jovem universitário conseguiria a autorização de Rolland para publicar a obra, tendo o Prémio Nobel respondido prescindir dos direitos de autor:"Vous avez toute ma sympathie pour la mission que vous avez assumée, vous et vos camarades indiens, d'éclairer vôtre peuple, privé de l'esplendide lumière de vos frères de race, héroïques, de Tagore, de Gandhi, de Aurobindo Ghose, de Jagadish Chandra Bose... cette pléiade de génies dont s'enorgueillit non seulement une race mais tout l'humanité." (cit. in Miranda, Lúcio de, op. cit., p. 7). A obra de Romain Rolland fora editada em 1924, o que por si é revelador do seu impacte em Adeodato Barreto. Uma anotação do intelectual francês no seu diário, a 25 de Abril de 1925, estende esse impacte ao seu grupo de Coimbra: "The same request [de tradução] has been made for Portuguese by a group of young Indians from the University of Coimbra (signed by Francisco Adeodato Barreto). They say how sad and indignant they are that in their own country, Portuguese India (Goa), they are left completely in ignorance of the great Indian fatherland - all the glories of the past and present, Tilak, Gandhi,Tagore; - it was through my book that they discovered them!" (Romain Rolland and Gandhi Correspondance. New Delhi: Publications Division, Ministry of Information and Broadcasting, Govt. of India, 1976, p. 45). 
deste movimento, certamente passou pelo convívio com o grupo de conterrâneos que frequentava a Universidade de Coimbra ${ }^{4}$.

Anos mais tarde, Mário Miranda, seu biógrafo e companheiro universitário, daria um testemunho da paixão com que se entregava ao debate de ideias e descrevia o sonho que o animava, no qual os ideais nacionalistas se conjugavam com as aspirações universalistas 5 .

Carácter motivado para a acção, desde essa altura trabalhou intensamente para transformar esse sonho no programa da sua geração, e fê-lo envolvendo os conterrâneos na dinamização de dois projectos que, apesar da existência efémera, marcaram os percursos da juventude goesa para além da sua geração e representaram uma das poucas iniciativas colectivas goesas, de âmbito cultural e de ressonâncias políticas, na Metrópole.

\section{Instituto Indiano}

A criação dum Instituto Indiano na Faculdade de Letras da Universidade de Coimbra constituía o primeiro destes projectos, pelo qual travou uma batalha a partir do início de 1926. Para tal conseguiu motivar um grupo de colegas goeses e cativar o director da Faculdade, Mendes dos Remédios, bem como os professores Providência da Costa e Joaquim de Carvalho. A dificuldade em reunir condições materiais para a concretização do programa do Instituto levou-o a escrever na Seara Nova, em 1927, num número dedicado ao Oriente organizado por Cordato de Noronha ${ }^{6}$, para apelar ao auxílio dos privados e à protecção dos poderes públicos.

4 Tem sido estudado o lugar da sociabilidade intelectual no cadinho cultural e político metropolitano, para o despertar identitário das elites coloniais e na construção dos ideais que enformariam os programas de ressurgimento cultural e de acção anticolonialista. Cf. Anderson, Benedict, Imagined Communities: Reflexions on the Origin and Spread of Nationalism. Rev. ed. London: New York, 2006, pp. 113-140; Boehmer, Elleke, Empire, the National and the Postcolonial, 1890-1920: resistance in interaction. Oxford: New York, Oxford University Press, 2002; Said, Edward, Culture and Imperialism, London, Vintage, 1994, p. 292 e ss.

5 "Quando o conheci, tinha V. vinte anos de idade e um grande sonho a realizar. Lembra-se? Foi em Coimbra, numa tarde de Outono, à beira do Mondego. Recordo-me perfeitamente de que falámos da pátria longínqua, do seu passado de glória, do seu presente de incertezas, do seu futuro de esperança... E V., com um entusiasmo louco, traçou as linhas gerais de um programa magnífico em prol da terra, de Goa e da Índia-Mater. Tratava-se de rejuvenescer a raça, revigorar-lhe as virtudes, purificá-las dos efeitos da escravidão e, finalmente, pugnar pela expansão do espiritualismo indiano através do mundo europeu para temperar a bruteza de uma civilização grosseiramente materialista” (Miranda, Lúcio de, op. cit.,"Carta Prefácio").

6 Cordato de Noronha (1900-?), médico goês que em 1927 fez exame de estado em Lisboa e prosseguiu a carreira em Moçambique, após especializar-se em oftalmologia em Paris (cf. Costa, Aleixo Manuel da, op. cit., v. 2, pp. 359-361). 
Nesse artigo, Adeodato Barreto fazia o balanço da História do Império Português na Índia como uma hipótese civilizacional falhada, contrapondo o conceito de cooperação entre os povos que via ensaiado na política de Afonso de Albuquerque ${ }^{7}$ ao de assimilação que seguira o seu consulado ${ }^{8}$. 0 primeiro poderia ter conduzido à criação duma civilização luso-indiana, o segundo, ao concretizar-se à sombra da desvalorização e perseguição da cultura nativa, conduzira à alienação goesa das suas raízes. $\mathrm{O}$ Instituto Indiano apresentava-se como um projecto de carácter académico que desafiava a Universidade portuguesa a criar uma tradição indialogista que impulsionasse o conhecimento da cultura indiana, cumprindo Portugal finalmente a sua obrigação enquanto país colonizador ${ }^{9}$.

A argumentação usada em defesa da existência do Instituto construía-se como contradiscurso da ideologia colonial, ao subverter o núcleo da fundamentação do domínio dos povos não-europeus. A responsabilidade civilizacional do colonizador afigura-se não como missão civilizadora, como veiculava o discurso colonial corrente, mas como responsabilidade de fomentar a aproximação dos povos pela promoção do conhecimento, da cooperação e do diálogo civilizacional. Descartava-se deste modo o carácter unilateral do relacionamento entre povos que tinha a sua expressão na política de assimilação e decorria da aspiração universalizante - porque apresentada como modelar e possibilitada pelas relações de domínio - da civilização europeia, a qual constituía o pilar da construção da sua hegemonia cultural ${ }^{10}$.

7 "Foi no tempo de Albuquerque que pela primeira e última vez se tentou e realizou uma cooperação luso-indiana. Conquanto não fosse no terreno artístico e cultural, pois os tempos não eram propícios para isso, era, apesar de tudo, uma cooperação." (Barreto, Adeodato,"O Instituto indiano da F. de Letras de Coimbra", in Seara Nova, n. 99 (12 de Maio de 1927), pp. 54-55).

8 "O próprio povo, teve-o o grande Marquês [de Pombal] de o declarar português, porque já nem indiano era. A famigerada política de 'assimilação' roubara-lhe tudo quanto de mais precioso um povo pode ter: as características próprias, o conhecimento das luzes da sua própria civilização. A infiltração de ideais estranhos à sua raça e às suas tendências amofinou-o. A consequência? Uma pavorosa improdutividade que ainda hoje se ressente e que será dificílimo debelar..." (idem, p. 55).

9 "A mina indiana cedo se esgotou ou foi desviada a sua corrente. A única mina inesgotável e perene, a mina da cultura intelectual, da arte e do sentimento que Portugal não buscara, essa manteve-se para sempre fechada e inacessível para o explorador português. E, contudo, procurá-la e explorá-la era para ele um direito e um dever, direito de que nunca se compenetrou, dever para com a civilização que jamais soube cumprir. (...) Da velha Índia que tanto o entreteve no passado, ele apenas conserva hoje a recordação fumarenta e vaga dum despertar de orgia tumultuosa" (idem, p. 55).

10 "Orientalism is never far from what Denys Hay as called the idea of Europe, a collective notion identifying 'us' Europeans as against all 'those' non-Europeans, and indeed it can be argued that the major component in European culture is precisely what made that culture hegemonic both in and outside Europe: the idea of European identity as a superior one in comparison with all non-European peoples and cultures. 
De acordo com esta concepção, cujo desenvolvimento acarretaria necessárias consequências para a legitimação, senão legitimidade, do domínio colonial, a iniciativa de criação do Instituto Indiano correspondia à ambição dos estudantes goeses de verem reconhecida e divulgada a relevância civilizacional indiana, mas assumia-se sobretudo como provocação para uma nova postura de Portugal enquanto potência colonial.

Se o projecto do Instituto se apresentava primordialmente como um repto aos poderes intelectual e político portugueses, representados respectivamente pela Universidade e pelo Governo, o grupo de estudantes acalentava um outro projecto no qual assumia a responsabilidade de intervir na realidade goesa, promovendo o ressurgimento do seu povo. Tratava-se da criação dum periódico que em torno deste programa congregasse os estudantes indianos nas Universidades portuguesas e contasse com a colaboração de intelectuais goeses e portugueses.

Apesar de este periódico não ser um órgão do Instituto ${ }^{11}$, a visibilidade que deu à receptividade que aquela iniciativa teve permite-nos apreender o papel do Instituto na consolidação da formação intelectual do grupo e a relevância político-cultural reconhecida a estas instituições nos meios académicos e intelectuais coevos. Para além das referências elogiosas na imprensa nacional, esta receptividade revelou-se na oferta de bibliografia para a Biblioteca do Instituto, em cartas de incentivo de intelectuais da dimensão de Sylvain Levi e de Rabindranath Tagore ${ }^{12}$ e num extenso artigo que a sua criação suscitou a um intelectual goês.

No que respeita a bibliografia, verificamos que os dadores foram organizações e instituições académicas e culturais que ofereciam edições próprias, autores e alguns particulares. Entre as primeiras contavam-se organismos com ideologias e vocações tão diversas como a London School of Oriental Studies, instituição orientalista criada em 1916 para preparar os administradores do Império Britânico, a Oxford Majlis Society, sociedade nacionalista indiana fundada em 1898, e a Greater Indian Society, sociedade histórica nacionalista fundada nos anos 20 por um grupo de intelectuais de Calcutá. Entre os autores que ofereciam os seus próprios trabalhos, abundavam intelectuais e académicos goeses radicados na Metrópole ou vivendo em Goa, autores portugueses

There is in addition the hegemony of European ideas about the Orient, themselves reiterating European superiority over Oriental backwardness, usually overriding the possibility that a more independent, or more sceptical, thinker might have had different views on the matter" (Said, Edward, Orientalism, reimpr. with a new Preface, London, Penguin Books, 2003, p. 7).

11 India Nova, n. 5 (31 de Outubro de 1928), p. 1.

12 Tagore comparava o espírito que animava os seus promotores ao que presidia à Universidade de Visvabharati (idem, n. ${ }^{\circ} 1$ (7 de Maio de 1928), p. 3). 
como Leite de Vasconcelos, mas igualmente nomes como o do historiador indiano Surendra Nath Sen e do teósofo irlandês James Cousins, envolvido na divulgação da cultura e do nacionalismo indianos. Finalmente, dos beneméritos particulares sobressai Custódio Adriano de Sousa, um goês radicado em Moçambique. No conjunto abundavam obras de carácter histórico, muitas delas de intelectuais nacionalistas indianos como Prabodh Chandra Bagchi, Kalidas Nag, Baman Das Basu, Jadunath Sarkar e Vinayak Damodar Savarkar. Destacavam-se igualmente diversos indialogistas ocidentais e alguns agentes do movimento nacionalista indiano como Samuel Evans Stokes. Deparamos ainda com um significativo conjunto de obras de carácter histórico, linguístico, literário e de análise da realidade goesa por autores goeses, entre eles o historiador Cristóvão Aires, o intelectual e jornalista Luís Menezes de Bragança, a ensaísta Maria Ermelinda de Stuarts Gomes, o polígrafo Santana Rodrigues e o concanista cónego José de Santa Rita de Sousa.

Sabemos, através duma listagem existente no espólio de Adeodato Barreto, que este núcleo era enriquecido por obras emprestadas pelos dinamizadores do Instituto, sendo de assinalar a existência de diversos títulos de Rabindranath Tagore e de Ananda Coomaraswamy, destacados promotores da civilização indiana no Ocidente, bem como de influentes periódicos nacionalistas indianos como a revista Modern Review (Madras) e o jornal Young India (Nova Deli), para além de jornais goeses ${ }^{13}$.

Encontramo-nos perante a formação duma pequena biblioteca que permitia uma segura iniciação à cultura e pensamento político indianos produzidos coevamente, sendo marcante a presença de autores que, em contacto com destacadas figuras da intelectualidade europeia, vinham defendendo o diálogo civilizacional e promovendo o nascimento duma nova ordem internacional que substituísse as relações de conflito e de domínio pelas relações de paz e de cooperação, as quais pressupunham o respeito do direito à autodeterminação dos povos ainda sujeitos ao domínio europeu.

O Índia Nova publicaria o extracto dum artigo ${ }^{14}$, suscitado pela criação do Instituto, que destacava o espírito deste movimento. $\mathrm{O}$ artigo era redigido por Luís Menezes de Bragança (1878-1938) ${ }^{15}$, um destacado intelectual goês que se tinha envolvido activamente na promoção da autonomia goesa sob os auspícios da República e que vinha

${ }^{13}$ Lista manuscrita de "Livros que o I.I. possui".

${ }_{14}$ Publicado no Boletim do Instituto Vasco da Gama (Pangim) e posteriormente editado em separata com o título À margem duma ideia. A passagem publicada pelo Índia Nova abriria o n. 3 do jornal, sob o título Pensamento Moderno.

${ }^{15}$ Cf. Costa, Aleixo Manuel da, op. cit., v. 2, pp. 293-295. 
mostrando fortes reservas à ditadura portuguesa. Nesta passagem, Menezes de Bragança contrastava duas correntes do pensamento europeu que se confrontavam na Europa do pós-guerra. Uma, de cariz reaccionário, tinha um dos seus representantes em Henri Massis, o qual associava a decadência da civilização europeia ao perigo oriental, acusando o papel das universidades europeias e dos seus intelectuais na formação dum conjunto de intelectuais asiáticos que sob a capa da aproximação civilizacional trabalhavam para a destruição da Europa ${ }^{16}$. A outra, representando o espírito europeu moderno ${ }^{17}$, promovia a aproximação entre o Oriente e o Ocidente "pela compreensão das civilizações"18.

O artigo transcrito terminava unindo nos mesmos princípios e destino os povos, pela afirmação do perigo que a primeira corrente representava para a liberdade e direitos por todo o mundo: "São os princípios de liberdade, de emancipação dos povos. É o ideal da democracia, destruidor dos imperialismos absorventes, das ditaduras assassinas das reivindicações populares, mormente nas colónias, onde buscam restaurar o regímen de sujeição e de subalternismo."19

16 “O Oriente, eis o inimigo.'Les Tagore, les Okakura, les Coomaraswamy, Gandhi lui-même, tous ont été les élèves des universités européennes, ils citent sans cesse nos poètes, nos philosophes et ce sont nos propres idées - entendez nos pires folies - qu'ils nous restituent: c'est avec elles qu'ils travaillent, soit pour nous mieux séduire ou se mieux faire entendre et trouver les voies d'accès favorables à leur propagande politique qui vise notre anéantissement. D'où vient que sous le pretexte de rechercher l'accord, la fusion des esprits d'Orient et d'Occident, leur pensée consonne, par une sort d'harmonie prétablie, avec ce qu'il y a de plus destructeur dans les doctrines européennes ?'" (Bragança, Luís Menezes de, "Pensamento moderno", in Índia Nova, n. 3 (3 de Julho de 1928), p. 2). Esta citação de Henri Massis por Menezes de Bragança é retirada do artigo "Mises au point" inserido no primeiro dos dois volumes que os Cahiers du mois dedicaram em 1925 a um inquérito a diversos intelectuais franceses sob o título "Les appels de I'Orient". No folheto À margem duma ideia, Menezes de Bragança inseria a nota de Massis à passagem que acentua a ideia: "Gandhi invoque Tolstoi; Tagore les lyriques anglais; Ananda Coomaraswamy cite Kant, Boehme, Nietzsche, rapproche Walt Whitman de Tchouang-Tseu et, à la suite d'André Gide, exalte William Blake qu'il considere comme le prophète de l'union de l'Orient et de l'Occident." (Bragança, Luís Menezes de, À Margem duma ideia, Nova Goa, Tip. Bragança \& C. a 1927, p. 33).

17 'Emprego a palavra 'europeu' na acepção que Ihe assinala Paul Valéry, acepção funcional e não meramente geográfica ou histórica, porquanto hoje a mentalidade europeia comporta 'em todos os espíritos cultos a livre coexistência das ideias mais dissemelhantes, dos mais opostos princípios de vida e de conhecimento', não se confinando no quadro estreito das civilizações particularistas” (Bragança, Luís Menezes de, art., cit., ibidem).

18 "Romain Rolland, Henri Barbusse, Brimschveig, Wells, Herman Hesse, Keyserling, Eliseev, para apenas citar alguns, são os homens mais representativos desta corrente" (idem, ibidem).

${ }^{19}$ Idem, p. 2. No folheto, a passagem continua do seguinte modo:"Não posso deixar de chamar para este aspecto do medievalismo a atenção dos inúmeros devotos que essa doutrina conta nesta terra e os quais, numa inconsciência de pasmar, se fizeram seus divulgadores, mal cuidando que estão a fundir as cadeias de escravidão.'Mais tiranos, dizia Tácito, fazem os escravos voluntários do que os escravos forçados que fazem os tiranos'"' (Bragança, Luís Menezes de, op. cit., p. 14). 
As implicações desta afirmação para o momento vivido em Portugal são evidentes, sendo no folheto explícita a denúncia do domínio do pensamento reaccionário no meio político e intelectual da Metrópole ${ }^{20}$, com ecos preocupantes no território goês. Num momento em que se falava da restauração do "Império ultramarino como unidade política distinta e subalterna da Metrópole"21, Menezes de Bragança aconselhava este grupo de jovens a ligarem os objectivos culturais ao esclarecimento político, de modo a criar uma corrente de opinião que contrariasse o rumo da política colonial portuguesa e ajudasse a despertar as consciências goesas ${ }^{22}$. Em larga medida, a resposta a este repto encontra-se no periódico que temos vindo a citar.

\section{Índia Nova: jornal de expansão da cultura indiana}

A 7 de Maio de 1928, poucos dias após a nomeação de Oliveira Salazar para o Ministério das Finanças, fora publicado o primeiro número do jornal Índia Nova, tendo saído cinco números até 31 de Outubro de 1928 e um sexto número, comemorativo do centenário de Francisco Luís Gomes, a 31 de Maio de 1929. Ao longo do tempo, os estudantes sustentaram-no com publicidade angariada junto de empresários em Coimbra e em Goa, mas as dificuldades financeiras acabariam por ditar o seu fim. Para além de Adeodato Barreto, os seus directores foram Telo de Mascarenhas (1899-1969), seu colega em Direito ${ }^{23}$, e José Teles, com quem cursava Ciências Filosóficas ${ }^{24}$. Espelhando a intenção de abarcar os estudantes goeses espalhados pelas universida-

20 "Exumar o passado, pôr de pé fórmulas caducas, evocar símbolos representativos duma mentalidade e duma acção, de que nos separam séculos, - tal tem sido a preocupação capital, para não dizer exclusiva, das classes dirigentes, em Portugal. E quando digo dirigentes, não penso unicamente nos homens de governo. Compreendo neste qualificativo os variados elementos que se propõem orientar a mentalidade portuguesa. Ela prevalece nas escolas, nas academias e, mormente, na imprensa. As excepções contam-se a dedo. Que eu saiba, vejo apenas o núcleo da Seara Nova empenhado em libertar os cérebros dessa tara cultural" (Idem, p. 24).

${ }^{21}$ Idem, p. 26.

22 Idem, pp. 29-30.

${ }^{23}$ Cf.Costa, Aleixo Manuel da, op.cit., v.2, pp. 252-253. Mascarenhas, Telo de, When the Mangotrees Blossomed: Quasi memoirs. Bombay, Orient Longman, 1976. Telo de Mascarenhas, com outros intelectuais goeses como António de Noronha e Fernando da Costa, fundaria em 1926, em Lisboa, um Centro ou Partido Nacionalista Indiano/Hindu que teria no jornal goês Bharat o seu veículo de comunicação com o território ultramarino; os membros destes movimentos adoptaram nomes hindus nos artigos que enviavam para este jornal (cf. Bharat (Quepém), a partir de 1 de Abril de 1926).

${ }^{24}$ Cf.Teles, José," “Adeodato Barreto: conferência do Dr. José Teles realizada no Cine-Teatro Nacional em Agosto de 1941", in CURSO LICEAL DE ADEODATO BARRETO. Anuário: 1941-1942, Nova Goa, Tip. Sadananda, [s.d.], pp. 5-12. 
des portuguesas, tinha como redactores correspondentes o estudante de Direito José António Ismael Gracias (1903-1993) ${ }^{25}$, em Lisboa, e Luiz Couto, que se formaria em Medicina e Farmácia, no Porto ${ }^{26}$.

O título escolhido ao evocar o influente semanário Young India, publicado por Gandhi entre 1919 e 1932, denunciava a simpatia pelo movimento nacionalista que vinha abalando o edifício do Império Britânico na Índia. Tal como o seu inspirador, os jovens estudantes optaram pelo formato de jornal, o que se poderá explicar por implicar menos custos que a produção de uma revista, que aparentemente melhor serviria a vocação do periódico, mas também poderá decorrer do propósito evidente nas suas páginas de, a par dos artigos de reflexão que as atravessam, dar visibilidade através do comentário noticioso a aspectos da actualidade local e internacional, normalmente despercebidos dos jornais portugueses.

O subtítulo "jornal de expansão da cultura indiana" anunciava o âmbito em que se moveria, sendo no editorial de apresentação estabelecido o entendimento abrangente do conceito de cultura, abarcando o campo político-cultural ${ }^{27}$. Tal esforço de divulgação inscrevia-se numa estratégia de resistência cultural ${ }^{28}$ visando a restauração da identidade goesa, considerando-se que a sua reinscrição na civilização indiana permitiria a devolução do sentimento de comunidade e a sua união em torno dum projecto de futuro ${ }^{29}$.

Este projecto decorria da tese do desenraizamento cultural do povo goês, que já víramos aflorada por Adeodato Barreto no artigo da Seara Nova. Ainda no primeiro

${ }^{25}$ Cf. Teixeira, Maria Isabel Gracias da Fontoura de Sousa, e Dias, Paulo Colaço, “José António Ismael Gracias (1857-1919)", in SuperGoa. Link:www.supergoa.com/pt/read/news_cronica.asp?c_news=693.

26 Índia Nova, n. 4 (15 de Setembro de 1928), p. 8. Luís do Couto, entretanto formado, seria substituído no n. 5 por Luís Timóteo de Sousa.

27 "Pretendemos por meio deste jornal, a cuja fundação presidiram intuitos eminentemente culturais, estabelecer contacto entre os nossos leitores e as grandes correntes literárias, artísticas e científicas, sociais e políticas da Grande Índia [designação que evoca o épico indiano 'Mahabharata], de que tão alheado anda o público de Portugal e de Goa" ("Palavras Prévias", in Índia Nova, n. 1 (7 de Maio de 1928), p. 1).

28 Cf. Said, Edward, "Resistance and Opposition", in Culture and Imperialism, London, Vintage, 1994, p. 252 e ss.

29 "E, divulgando a história do nosso País; estudando as suas seculares e sábias instituições que ainda hoje, sendo aplicadas, podem fazer a felicidade dos povos; tomando para as nossas produções literárias e artísticas motivos indianos; propugnando pelo ressurgimento das nossas mais belas tradições e pela renovação moral e intelectual do povo goês, procuraremos despertar no leitor o amor pela civilização indiana, e servir o nosso País que é a nossa preocupação de hoje e d'ontem, de todas as horas, de todos os momentos. Procuraremos (...) realizar a aproximação das nossas crenças (...) para vivermos todos irmanados no mesmo ideal e na tradição comum" ("Palavras Prévias", ibidem). 
número, Santana Rodrigues (Goa, 1887-Lisboa, 1966) ${ }^{30}$ em O Primeiro Dever retomá-la-ia para nela radicar a inexistência dum ideal que unisse os goeses e os soltasse da letargia em que tinham submergido. Considerando um dever de todos os homens e povos a defesa da autonomia e dos direitos que a consolidam ${ }^{31}$, a reapropriação da identidade olvidada era apresentada como essencial à recuperação da auto-estima colectiva e duma virilidade que, estimulada por um reencontrado amor pela liberdade, predispusesse o povo goês a lutar pelos seus direitos ${ }^{32}$.

A identidade cultural ${ }^{33}$ era vista como basilar na estruturação psicológica e moral dum povo e para a afirmação do seu lugar no xadrez da comunidade humana. Identidade histórica, processual, supunha a existência dum povo assumindo-se como agente da sua história, constituindo-se na cadeia do tempo no enlaçar do pensamento e da acção. Identidade sujeita a desestruturação precisamente pela supressão desse agenciamento, através da qual se interrompia a cadeia histórica da sua constituição. Tal era o caso dum povo quando caído na sujeição de outro povo; via desrespeitados e desvalorizados os seus costumes, ideias e crenças, substituídos os modos de organização tradicionais e destituídos dos meios de assegurar o progresso material, iniciando um processo de alienação que no tempo se consolidava pela perda da memória dos traços distintivos da sua identidade.

Tal era o caso dos goeses sujeitos ao secular domínio português. Tal tinha sido o caso dos indianos sujeitos ao domínio britânico. A uni-los, tinham uma civilização comummente construída e tinham a experiência de ruptura com a história provocada

${ }^{30}$ Médico goês que nos anos 20 esteve particularmente envolvido no levantamento dos problemas que afectavam Goa e na divulgação do movimento nacionalista indiano, tendo publicado diversos artigos e obras sobre estas matérias. Cf. Costa, Aleixo Manuel da, op. cit., v. 3, pp. 148-151.

${ }^{31}$ Santana Rodrigues abria o artigo com uma citação de Theodore Roosevelt afirmando esse dever:"Chacun de nous a besoin de se lever pour ses propres droits, tous les hommes et tous les groupes d'hommes sont tenus de conserver le respect d'eux-mêmes; ce respect, ils doivent le réclamer aussi d'autrui en veillant à que qu'il ne leur soit fait aucun tort et à ce qu'il leur soit assurée la plus grande liberté de pensée et d'action" (Rodrigues, Santana, “O primeiro dever,'in Índia Nova, n. 1 (7 de Maio de 1928), p. 5). Esta postura individual e colectiva era considerada essencial para a criação de "uma nova ordem de Justiça e respeito recíprocos, que possa entrelaçar a humanidade" (idem, ibidem).

32 "Não bastam os limites convencionais do território nem a existência prolongada em agregado, para garantir o respeito pelos seus direitos e conter nos cobiçosos os impulsos da ambição. É preciso que uma alma viril, soldada por uma íntima solidariedade e insuflada por uma tradição e um interesse comuns o esteja animando sem cessar, para assinalar por actos e feitos o seu lugar na progressão da humanidade" (idem, ibidem).

${ }^{33}$ Conceito que usamos anacronicamente, mas que consideramos traduzir o sentido que conferiam ao conceito de cultura. 
pelo domínio europeu, a separá-los tinham a emergência coeva do nacionalismo na Índia Britânica, liderado pelas elites nativas.

Concordante com esta linha de pensamento, o Índia Nova propunha-se "investigar e fazer reviver" a História da Índia, demonstrando a excelência da civilização indiana ${ }^{34}$. Não disputando o conceito de progresso e, portanto, uma possível hierarquização dos povos à luz desse conceito, o jornal desafiava a ideia de que o modelo civilizacional europeu traduzia o seu apogeu. Simultaneamente, o jornal dispunha-se a expor como o "elo da cadeia interrompida" vinha sendo modernamente refeito pelos protagonistas do nacionalismo indiano ${ }^{35}$. Evidenciando sempre a preocupação de estabelecer as ligações entre o local e o global, os ideais nacionais e humanistas, encontramos uma particular atenção aos outros movimentos nacionalistas asiáticos e à análise das relações internacionais no mundo do pós-guerra, para elucidar a encruzilhada em que se encontrava a humanidade e expor os princípios que defendiam para o progresso civilizacional.

Através destes diversos níveis de análise e reflexão, no encontro entre a história e a actualidade, o Índia Nova expunha uma mundividência que esperava vir a provocar os goeses para a acção. No que respeita à situação goesa, o discurso respeitante à centralidade da questão da língua e correlativo problema educativo no desenraizamento cultural goês, em particular da sua população católica por nela ter incidido a política de assimilação, concentrava o essencial da crítica às práticas do domínio português, destacava a responsabilidade da elite intelectual na liderança de uma política possível de resistência cultural e reflectia as contradições que marcavam as elites nativas.

\section{A situação goesa na perspectiva da língua e do ensino}

O problema da língua, destacado desde o editorial de apresentação do Índia Nova a ponto de ser eleito o ponto principal do programa do jornal ${ }^{36}$, é um tema recorrente do discurso nacionalista dos povos colonizados, sendo ainda actualmente uma ques-

\footnotetext{
34 “Prosseguindo", in Índia Nova, n. 2 (12 de Junho de 1928), p. 2.

35 Idem,ibidem.

36 “E o ponto mais importante do nosso programa é a questão das línguas maternas. (...) propomos cumprir escrupulosamente o valioso testamento que nos legou o erudito e grande amigo da Índia que foi Cunha Rivara, no seu Ensaio Histórico da Língua Concani, e que reza desta sorte: - 'É pois tempo de reparar os erros passados. É tempo de restaurar a língua materna. A vós, Mocidade Goana, está reservada esta grande obra, elemento essencial da regeneração intelectual e social dos vossos compatriotas (...)'" ("Palavras prévias", in Índia Nova, n.o 1 (7 de Maio de 1928), p. 1).
} 
tão fulcral na reflexão pós-colonial. No contexto colonial surgia às elites que o colocaram, e que principalmente o sentiram, como o sinal mais evidente e preocupante da sua alienação cultural, da sua inescapável condição estrangeira. Enquanto líderes "naturais" da sua sociedade e construtores dum discurso político-cultural nativista, sentiam o paradoxo de serem dotados duma voz por força da educação moldada no ambiente cultural e na língua do dominador.

O problema das línguas maternas não era o do seu uso coloquial salvaguardado pela utilização corrente pelo "povo", mas sim o do seu manuseamento pelas elites, em particular do manuseamento escrito, da capacidade ou mesmo possibilidade de as usarem como veículos de comunicação literária, académica ou doutrinária. Nos casos em que não existia uma tradição de escrita pré-colonial ou em que essa tradição se perdera pela marginalização ou perseguição das línguas e literaturas nativas, essa capacidade achava-se mesmo condicionada a um trabalho linguístico prévio com vista à fixação da língua. Em qualquer caso, a língua do dominador era para essas elites a língua "natural" de criação e comunicação intelectual, sendo um instrumento fundamental na formatação da sua utensilagem mental. A luta pela recuperação da escrita nas línguas maternas surgia, assim, como um passo essencial do movimento de renacionalização das elites e da sua produção intelectual. Concretizando os diversos níveis em que a questão das línguas maternas podia ser equacionada, o Índia Nova publicaria um pequeno conjunto de artigos dedicados ao tema.

José Teles, no segundo número do jornal, analisando o caso indiano, confessava ser possível a um povo, por meio das suas elites, expressar fulgor intelectual numa língua estranha, "a língua que os dominadores lhe impuseram" ${ }^{37}$. A prová-lo estava o escol de pensadores, académicos e políticos que vinham retomando e renovando o fio da tradição cultural indiana ${ }^{38}$. Neste sentido, o caso indiano contrariava a sua própria opinião de que a língua era "o índice mais fiel e duradouro, senão eterno, do valor e do

${ }^{37}$ Teles, José,“Defesa da língua materna,"in Índia Nova, n. 2 (12 de Junho de 1928), p. 4.

38 José Teles citaria uma passagem da obra de Santana Rodrigues, A Índia Contemporânea (1926), para demonstrar essa efervescência:"A Índia do século XX se embelece e se exorna pelo exercício de rútilas virtudes para restaurar o fio maravilhoso da tradição, o sutra interrompido do sincronismo histórico. Um escol de patriotas e de pensadores vibra e afervora a alma nacional. É Ram Mohum Roy, humanista profundo e precursor da emancipação religiosa, é Swami Vivekananda, o exegeta audaz da soberania da razão; é Mahatma Gandhi, como Mazzini, o apóstolo místico da unificação nacional, é Chandra Bose, o Newton da gravitação biológica; é Lokamanya Tilak, como o vigoroso autor do “Essai sur les moeurs", o standard-man da revolução; é Benoy Sarkar, como o sábio crítico do Esprit des Lois, o intérprete sagaz do direito constitucional hindu; é Rabindranath Tagore, o mecenas carinhoso das letras e artes pátrias - é toda uma plêiade de estatuários, a polir, a cinzelar, a alçar a abóbada triunfal dos Estados Unidos da Índia" (idem, ibidem). 


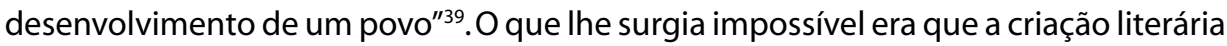
pudesse ter verdadeira qualidade ou atingir o "âmago" da alma dum povo quando expressa numa língua "enxertada". Na sua opinião, esta tese confirmava-se tanto na fraca qualidade da criação literária hindu contemporânea em língua inglesa, como na genialidade universalmente reconhecida da obra literária de Rabindranath Tagore, toda redigida "na língua que sua Mãe Ihe ensinou", o bengali.

A produção literária em língua materna tinha a dupla virtude de melhor expressar as capacidades criativas dum povo e de mais eficazmente nele despertar os sentimentos de amor à terra. Num país multilingue como a Índia, o "movimento romântico" de renascimento literário das diversas línguas maternas espelhava a forma como os intelectuais locais assumiam uma responsabilidade que lhes cabia a eles e não aos políticos, a responsabilidade de sedimentar o nacionalismo no sentimento dos povos.

Reflectindo sobre o caso goês, o cónego José de Santa Rita de Sousa (1863-1940) ${ }^{40}$, professor de concani na Escola Superior das Colónias de Lisboa, num artigo sobre a língua natal de Goa, forneceria elementos sobre a sua história anterior e, particularmente, posterior ao início do domínio português. A história exposta era um vasto repositório de perseguição, a ponto de ainda em meados do século XIX ter sido proibido o uso privado do concani aos seminaristas de Rachol. A desvalorização da língua materna teria tido um efeito perverso sobretudo junto daqueles que poderiam ter preservado a sua utilização literária, os membros das elites nativas assimiladas, os quais, assumindo para si os padrões culturais do dominador com a correspondente hierarquia civilizacional, activamente colaboravam na rejeição da língua nativa ${ }^{41}$. Em consequência, a escrita do concani chegara a uma situação caótica, abundando entre os praticantes o desconhecimento da estrutura gramatical e não estando fixada a sua ortografia ou sequer atingido um consenso sobre o alfabeto para a expressar ${ }^{42}$.

39 Idem, ibidem.

${ }^{40}$ Cf. Costa, Aleixo Manuel da, op. cit., v. 3, pp. 288-289.

41 "Envergonhavam-se de a falar e ajudavam a destruição da literatura. Foi a camada inculta do povo que, sofrendo as prisões do Santo Ofício e outros vexames, salvou a língua" (Sousa, José de Santa Rita de, "A língua concani", in Índia Nova, n. 1 (6 de Junho de 1928), p.4).

42 Sousa, José de Santa Rita de, "A ortografia conkani e a necessidade da sua reforma", in Índia Nova, n. 4 (15 de Setembro de 1928), p.4. A este propósito, o Índia Nova inseriria um rasgado elogio a uma revista concani editada em Bombaim, Gullistan, pelos seus propósitos nacionalistas, mas criticaria a falta de rigor ortográfico nas suas páginas:"Como não usa o nosso alfabeto próprio que é o Devanagari, nem ao menos a sua transliteração mais racional que é, segundo o consenso universal, a jonesiana, é-nos por vezes dificílima a sua leitura, pois cada articulista se exprime segundo a sua pronúncia local, em Goa, e por uma combinação de letras e fonemas que nem sempre é possível interpretar" (Índia Nova, n. 5 (31 de Outubro de 1928), p. 2). 
Havia, pois, um longo caminho a percorrer para atingir o objectivo do jornal de promover uma literatura em concani, juntando-se ao movimento cultural que descrevia no resto da Índia. Tendo planeado a existência duma secção concani e apelado à colaboração literária e linguística que a sustentasse, os promotores do programa acabaram por ver frustrada a sua intenção por falta de material que a alimentasse. Tal significa que provavelmente os próprios membros do corpo redactorial, alguns deles com capacidades literárias provadas, não possuíam um domínio da língua que thes permitisse colmatar a falta de colaboração externa ${ }^{43}$.

Sem uma iniciação ao concani nos currículos escolares, embaladas num ambiente familiar e social em que o português era privilegiado, a relação destas elites com a língua nativa carecia da espontaneidade que só o convívio assíduo poderia conferir e muito menos atingia o refinamento esperado do cultivo duma língua em meios letrados. Neste contexto e no que Ihes dizia respeito, referir a língua nativa como a língua materna e declarar a impossibilidade de atingir o núcleo da sentimentalidade identitária na língua que dominavam, mas que era o símbolo da sua subjugação cultural, traduzia sobretudo o voluntarismo inerente ao projecto de reconstrução duma identidade cultural sobre o qual se propunham fundar um movimento nacionalista goês. Enquanto esse projecto não se concretizasse, estavam "condenados" a comunicar numa língua que recusavam chamar sua ${ }^{44}$ os princípios e os sentimentos que animavam a busca dessa identidade perdida.

Cientes de que uma mudança da situação beneficiaria da introdução das línguas maternas no sistema de ensino, defenderiam esse projecto, recorrendo mesmo às

43 O único texto literário que chegariam a publicar em concani seria uma tradução do Stabat Mater.

${ }^{44}$ No seu primeiro número, o jornal traria o seguinte comentário:"A propósito da 'Protecção à nossa língua' (portuguesa), um jornal de Goa junta a sua voz ao coro de justos louvores que recebeu a proposta do brasileiro dr. Octávio Mangabeira. Não nos revoltamos contra o direito de cada um escolher, para sua, a língua que mais lhe apeteça. Mas como o possessivo está no plural e o artigo é escrito por um goês, não resistimos à tentação de transcrever, muito a propósito, um trecho do 'Ensaio histórico do concany' (p. 77) do grande Cunha Rivara:'Para que se conheça a que ponto tem chegado em Goa a ignorância da língua materna, referimos um facto, há poucos meses acontecido, na Imprensa Nacional da mesma cidade. Um curioso empreendeu publicar um pequeno caderno de Orações na língua de Goa. Suscitou-se na Imprensa questão sobre o preço da composição tipográfica, e exigiam os compositores mais a quarta parte do preço ordinário, alegando que o Regulamento que diz que, quando a obra for em idioma estrangeiro, assim se levará. Facto este que julgamos único no género em toda a historia das línguas antigas e modernas: mas não causará grande estranheza, se soubermos que o próprio editor, indígena, que agora impugnava a exigência da Imprensa, havia em outro tempo, durante as primícias dos seus estudos, chamado sua à língua portuguesa (...)'"(Índia Nova, n.o 1 (7 de Maio de 1928), p. 4). 
teses da moderna doutrina colonialista sobre a matéria ${ }^{45}$. $\mathrm{O}$ artigo em que esta proposta foi expressa respeitava ao ensino não do concani mas do marati, uma das línguas principais da Índia, dominante no estado que confina com Goa e por motivos históricos e económicos largamente usada pelos hindus goeses; neste caso, os argumentos culturais fundiam-se com os económico-sociais.

A Emigração Goesa e o Ensino do Marathy ${ }^{46}$ reflectia sobre o crescente fenómeno migratório goês para o resto da Índia, em particular para o Maharashtra, motivado por uma arrastada crise económica no território. Problema de contornos estruturais, era apresentado como consequência directa duma administração colonial que, pela estreiteza de visão e arbitrariedade das práticas, constituía um entrave constante à iniciativa privada. Desta situação decorria a mentalidade da população cujas aspirações se resumiam a aninhar-se na segurança dum emprego oficial, desprezando a actividade produtiva. Os excluídos da "fortuna" viam na emigração uma saída natural para um futuro sem perspectivas na terra natal.

Este quadro crítico servia de pano de fundo da tese principal do artigo, sendo esta a defesa de que a possibilidade de desenvolvimento de Goa passava pelo estreitamento dos laços com o resto da Índia e de que, em conformidade, o Estado português devia assumir o papel que lhe cabia de criar condições a esse aprofundamento. Em causa estava, não só o problema do fenómeno migratório, mas também a evidência de que a Índia constituía o parceiro comercial natural de Goa, situação que já era real no momento. Tal significava que a lógica de uma política de reaproximação cultural à Índia tinha fundamento em poderosas motivações de ordem económica e social. O caso da prosperidade dos hindus que tinham escapado à política de assimilação, em contraste com a população cristã, demonstrava flagrantemente a tese:"A superioridade comercial dos hindus não é devida senão à cultura que os primeiros possuem da língua marata." ${ }^{\prime 4}$ O ensino em língua nativa já bastante desenvolvido no resto da Índia, com tendência a

45 “Não há ninguém no mundo culto capaz de esquadrinhar inconvenientes no ensino da língua materna, e os próprios colonialistas, como Jules Harmand por exemplo, são os primeiros a aconselhá-lo. (...) Mesmo em Portugal, há muito que, em teoria, se reconheceram os mesmos princípios. O sr. Ernesto de Vasconcelos, no Congresso Colonial de Lisboa de 1900, e o sr. Santa Rita, no de1924, defenderam a tese pela qual todo o ensino nas colónias se deveria fazer em vernáculo. Esta tese ambas as vezes foi aprovada por unanimidade." (Pandit Porbu, "A emigração goesa e o ensino do marathy,"in Índia Nova, n. ${ }^{\circ} 4$ (15 de Setembro de 1928), p.7).

${ }^{46}$ Assinado por um Pandit (sábio) Porbu (apelido comum entre os hindus de Goa), pensamos tratar-se dum pseudónimo.

${ }^{47}$ Idem, p. 5 . 
universalizar-se, levaria a que o inglês perdesse o seu lugar de língua franca, aumentando a desvantagem mesmo dos cristãos goeses educados em colégios ingleses, em relação aos hindus.

O ensino oficial do marati podia assim representar um importante motor do desenvolvimento local, coadunando-se com a ideia de que "a organização do ensino, a fim de produzir resultados úteis e profícuos, necessita atender e considerar as tendências económicas do povo"48. Para além do aspecto económico e social, a convivência dos goeses com esta língua permitir-lhes-ia acederem às manifestações da vida cultural marata e, por esta via, actualizarem-se algumas das facetas mais relevantes do renascimento cultural indiano.

A crítica à política colonial portuguesa no que respeitava ao ensino das línguas maternas inseria-se numa censura geral à sua política educativa no território. Esta censura dirigia-se a um sistema educativo visando a política de assimilação, donde os seus currículos assentavam nas referências culturais metropolitanas sem atenção ao património cultural nativo ou às realidades locais. Por esta razão era apresentado como o responsável principal da alienação e atrofia goesa, em vez de constituir-se como veículo do desenvolvimento intelectual local.

A solução deste problema encontrava-se, na opinião do jornal, em "procurar um campo de expansão mais próximo (...) E esse campo só pode ser a cultura indiana que, à vastidão da sua área, alia a qualidade de ser a que mais naturalmente nos indicam razões étnicas e geográficas, quando não bastem as de pura ordem sentimental"49. Desiludido de qualquer pretensão a que o Estado colonial colaborasse nessa obra, o jornal considerava que a tarefa cabia à iniciativa dos intelectuais ${ }^{50}$, sendo esse o contributo que o Índia Nova buscava dar à causa goesa.

48 Idem, ibidem.

49 "Mons. Excelso de Almeida", in Índia Nova, n. 4 (15 de Setembro de 1928), p. 6.

50 "É que o Estado, sob o ponto de vista da função educativa, há muito que vai falindo, especialmente quando procura adaptar um povo ao génio d'outro cujo standard of life é diferente e por vezes antagónico" (Coelho, Mário, "A criação de um Colégio Universitário em Goa", in Índia Nova, n. 5 (31 de Outubro de 1928), p. 2). Neste artigo, Mário Coelho defendia a criação de um Colégio Universitário em Goa, nitidamente inspirado na experiência de Tagore em Santiniketan, mas com aspirações mais modestas de acordo com as realidades locais. Tal colégio teria, segundo a sua proposta, a vantagem de chamar à terra os intelectuais da diáspora goesa na Índia, na Europa, na América, o que em si constituiria um renovamento do ambiente cultural local. 


\section{A civilização e a modernidade indianas}

Chamando a si a tarefa de espelhar o núcleo da indianidade, o jornal usaria recursos diversos para o aflorar. A necessidade de acrescentar inteligibilidade aos artigos levaria a direcção a criar uma espécie de elucidário, através de pequenos apontamentos em quase todas as páginas sobre figuras do panteão indiano e sobre termos associados ao quotidiano, às religiões hindu e budista, a instituições antigas e modernas, a lendas, a rituais, à botânica, enfim, a um conjunto diversificado de referências que serviam de introdução ao imaginário indiano. Por outro lado, esse mesmo imaginário, cumprindo um dos aspectos do programa, alimentava os abundantes textos literários dos seus colaboradores, oferecendo-se como exemplo para a reinscrição da literatura goesa na memória dos sentidos e da cultura indianos.

A história de carácter exemplar ${ }^{51}$ e largamente centrada em figuras e momentos simbólicos marcaria a sua presença, em tom de referência, em parte significativa dos artigos do jornal, estabelecendo a ponte entre passado e presente na construção da civilização indiana. Esta abordagem, reflectindo uma ordem de prioridades ditadas

51 "Um legado histórico precioso, cheio de grandes exemplos e irradiando glória e virtude, é a base mais sólida e duradoura em que se pode assentar uma nacionalidade" (Barreto, Adeodato, "Shivaji", in Índia Nova, n. ${ }^{3}$ (3 de Julho de 1928), p. 3). Recentemente, Vinay Lal expôs a existência de duas visões coevas sobre o papel da história da Índia numa política de resistência ao poder inglês. A dominante teve um dos primeiros representantes em Bankimcandra Chatterji e apostava numa reapropriação "masculinizada" da narrativa histórica que fundamentasse a moderna resistência do povo indiano:"His historical novels [de Bankim] set out to establish that the various invadors of India, far from being allowed to enter and pillage the country without contest, were given battle at every turn. But Indians, when at all they had any knowledge of the past, gained that understanding from the accounts of Europeans, for whom non-resistance and cowardice characterized the response of Indians to alien invasions, indeed to the mere threat of violence".'A outra defendida por Gandhi, praticamente isolado na sua posição, secundarizava a exemplaridade histórica: "Gandhi, on the other hand, displayed a rather more complex and ambivalent attitude to the question of whether violence had constituted a part of the peoples response to oppression and injustice, whether inflicted by invaders or indigenous rulers. (...) In his treatise of 1909, Hind Swaraj (...) When asked by the imaginary reader whether there was 'any historical evidence as to the success of... soul-force or truth-force', Gandhi replied that if history meant 'the doings of kings and emperors', then 'no evidence of soul-force or passive resistance was [to be found] in such history'.If history, he added, had the meaning - 'it so happened' - given to the word in Gujarati (and other Indian languages), then 'copious evidence' could be supplied. (...) Whatever may have been the forms of resistance in the past, Gandhi knew only too well that his attempt to apply non-violence on a mass scale in India's fight for freedom and thereby induce the social transformation of Indian society was altogether unprecedented. (...) Gandhi rejected the notion, widespread even today, that there are 'lessons' to be learned from history. Perhaps the only lesson was that history itself had to be unlearned" (Lal, Vinay, The History of History: Politics and Scholarship in Modern India. Pbk, 2.a impr., New Delhi, Oxford University Press, 2006, pp. 61-62). 
pela urgência da luta na actualidade, torna, em parte, menos excêntrica a escassez de artigos estritamente históricos, quando seria de esperar pelo seu programa ${ }^{52}$ que a História da Civilização Indiana merecesse lugar de destaque nas páginas do Índia Nova. Os raros artigos versando a história da Índia apresentavam-se como um contributo, entre outros, para a construção duma imagem da indianidade, fortemente apoiada na ideia da civilização indiana como civilização hindu.

Tal é o espírito do artigo sobre Shivaji, fundador do império marata no século XVII, apresentado por Adeodato Barreto como figura titular do nacionalismo hindu pelo seu ideal de construção do "grande Hindu Pad-padashahi" (Império de todos os hindus) ${ }^{53}$. A figura de Shivaji, na sua campanha de libertação do jugo mogol, encarnava as virtudes guerreiras do povo indiano ao serviço do ideal de liberdade, e neste contexto era um exemplo da possibilidade de desconstruir dois estereótipos sobre a Índia no Ocidente, particularmente sofisticados na ideologia colonial: o do desconhecimento do valor da liberdade pelos povos orientais e o da passividade do povo indiano motivada pelo seu pendor contemplativo ${ }^{54}$. Em Shivaji, a luta contra a opressão tinha ainda a virtude de se conjugar com o despontar dum princípio de identidade indiana, tendo por referencial o hinduísmo.

Desta visão da identidade indiana não decorria uma simpatia pelo fundamentalismo hindu, que se alimentava, então como agora, da oposição à comunidade muçulmana ${ }^{55}$. As referências negativas à presença muçulmana na Índia eram remetidas para um passado de domínio em que o proselitismo ditara políticas de intolerância e uma justificada reacção nacionalista hindu; mas mesmo nesse passado surgia o contraponto de Akbar, o imperador mogol do século XVI cujo reinado fora marcado pelo espírito ecuménico e pelo ideal de unidade entre as comunidades. A multiculturalidade não era posta em causa, e a possibilidade de interpenetração das comunidades marcada pelo espírito de tolerância seria mesmo patenteada.

52 "Procuraremos pois investigar e fazer reviver o passado da Índia por todos os meios ao nosso alcance" ("Prosseguindo", in Índia Nova, n. ${ }^{\circ} 2$ (12 de Junho de 1928), p. 2).

53 Barreto, Adeodato,"Shivaji", in Índia Nova, n. 3 (3 de Julho de 1928), p. 3.

${ }^{54}$ Este último estereótipo seria tratado por José Teles num artigo em que defendia que o lugar comum era contrariado pelos momentos áureos da história da Índia, gerados no contexto de grandes impérios nos quais o desenvolvimento intelectual tinha emparelhado com o progresso material (Teles, José, "A lenda da barbárie", in Índia Nova, n. 3 (3 de Julho de 1928), p. 5).

55 Que na época tinha um dos seus teóricos em Vinayak Damodar Savarkar e que os jovens conheciam precisamente através da sua obra Hindu Pad-padashahi dedicada ao império marata. 
Esta posição surge particularmente evidente num texto do hindu Radha Krishna Saksena dedicado a Miyan-Tansen ${ }^{56}$, reconhecido como um dos maiores músicos indianos de sempre, um hindu convertido ao islamismo que fazia parte da corte de Akbar. Neste artigo, Saksena sublinhava como a memória de Miyan-Fansen marcava a cultura indiana, a ponto de se tornar a figura tutelar dum festival musical anual em Gwalior, o qual se distinguia precisamente por juntar na mesma iniciativa artistas hindus e muçulmanos comungando duma herança cultural comum. Por seu turno, Telo de Mascarenhas, num artigo dedicado a Sarojini Naidu (1878-1949), hindu por nascimento mas educada no ambiente muçulmano de Hyderabad, destacaria a visão da poetisa e activista sobre a Índia, afirmando que a sua completude passava pela aliança dos elementos hindu e muçulmano ${ }^{57}$.

A imagem, que apesar de tudo sobrevive, duma inquestionada identificação da indianidade com o hinduísmo afirmava-se no jornal por via duma vislumbrada especificidade civilizacional indiana conferida pela espiritualidade e pelo pensamento filosófico hindu ${ }^{58}$. A característica espiritualista da civilização hindu espelhar-se-ia e alimentar-se-ia do carácter do povo indiano, tanto distinguindo a sua criatividade e expressão intelectual, como moldando uma radical capacidade de resistência ${ }^{59}$. Espiritualismo que não fraccionava o homem, mas antes assumia as suas diversas facetas, ditando uma harmonia entre espírito e matéria. Seria ele que modernamente formataria o renascimento cultural indiano e o movimento político nacionalista, conferindo-Ihes um carácter modelar.

Esta leitura da modernidade indiana seria criteriosamente oferecida tanto pelos artigos de fundo, como pelos comentários à actividade literária, científica e política

56 Saksena, Radha Krishna, “Miyan-Tansen", in Índia Nova, n. 5 (31 de Outubro de 1928), pp.4-5.

57 "Fazendo alusão à liberdade italiana, escrevia a poetisa - diz-se que Mazzini em si não era mais do que um sonhador, que Garibaldi não passava de um soldado, e que cada um deles, separadamente, não teria podido edificar a Itália livre. Na evolução da nossa história nacional os Hindus são Mazzini e os Muçulmanos Garibaldi. Uma união do visionário e do sonhador, do homem de Estado e do Soldado, eis do que nós temos necessidade na nossa grande Índia..." (Mascarenhas, Telo de, "Sarojini Naidu", in Índia Nova, n. 5 (31 de Outubro de 1928), p. 3).

58 "Esta tarefa árdua nos dará margem a que demonstremos como a civilização que teve por berço a Índia (...) ao lado do progresso material que não despreza procura realizar o desenvolvimento incessante do espírito" ("Prosseguindo", in Índia Nova, n. ${ }^{\circ} 2$ (12 de Junho de 1928), p. 2).

59 Tomás da Fonseca marcaria a sua colaboração com o jornal contando a lenda dum filósofo hindu que, aquando da entrada de Alexandre na Índia, se teria atirado a uma pira, demonstrando na prática o que teria afirmado ao imperador: a impossibilidade de este cercear a sua liberdade (Fonseca, Tomás da, "Aspectos da mentalidade hindu", in Índia Nova, n. ${ }^{\circ} 2$ (12 de Junho de 1928, p. 5). 
da Índia contemporânea. Um traço de união ligava o entusiasmo por Rabindranath Tagore ${ }^{60}$, pela prestação de cientistas indianos num Congresso da "New Education Fellowship" ${ }^{\prime 61}$, pelo movimento satyagraha que na época tinha uma expressão mais dramática na pequena região de Bardoli62 ou mesmo pelo movimento swadeshi (nacionalismo industrial) cujos progressos seriam largamente ilustrados pelo jornal. A harmonização entre misticismo e sensualismo na poesia de Rabindranath Tagore, as investigações de Jagadis C. Bose para evitar as experiências em animais sem travar o progresso científico, a radicação da liberdade no domínio do espírito defendida por M. B. Thaker ou a adesão do povo indiano aos métodos de resistência preconizados por Gandhi, fazendo do sofrimento e do sacrifício poderosos veículos de combate, eram exemplos, entre outros, que evidenciavam como aos mais diversos níveis a espiritualidade peculiar à civilização hindu inspirava os percursos dos protagonistas da modernidade indiana. E eram abordagens que alimentavam o orgulho pela partilha dessa identidade comum evidenciado pelos promotores do projecto do Índia Nova.

O idealismo que movia os jovens estudantes goeses ultrapassava os ideais nacionalistas para abarcar o futuro da humanidade e o contributo que a civilização indiana poderia dar à sua causa. Na sua opinião, o caminho para a construção desse futuro auspicioso vinha sendo apontado pelos intelectuais que a Oriente e a Ocidente preco-

60 "E se Mahatma Gandhi, o apóstolo máximo, é a força espiritual e redendora da Índia: Tagore, o Poeta-Santo é a incarnação védica e mística da nossa Raça" (Mascarenhas, Telo de, "Rabindranath Tagore", in Índia Nova, n. 1 (7 de Maio de 1928), p. 3). Tagore seria uma das três personalidades que mereceram figurar na rubrica "Grandes figuras", para além dos já citados Shivaji e Sarojini Naidu.

${ }^{61}$ A instituição, que tinha alguma inspiração teosófica, era dedicada aos princípios da Educação Progressiva. O pedagogo português Álvaro Viana de Lemos, que participara do Congresso em Locarno, distinguiria as comunicações do pedagogo e cientista Jagadis Chandra Bose, dedicadas ao tema da unidade da vida, e do pedagogo M. B. Thaker, sobre a Liberdade e o domínio de si mesmo, para concluir: "A contribuição indiana ao congresso de Locarno mostra-nos só que a grande e enorme pátria de Tagore e Gandhi não pára na senda do progresso, nem larga das mãos o facho espiritual que sempre tem empunhado através dos séculos. Facho bem luminoso mas que nem todas as nações têm tido olhos para ver nem tão-pouco compreender, aproveitar e seguir" (Lemos, Álvaro Viana de, "O espírito indiano no Congresso de Locarno", in Índia Nova, n. 1 (7 de Junho de 1928), p. 7).

62 Os proprietários da região tinham visto as terras confiscadas por rejeitarem um aumento dos impostos e recusavam-se agora a abandoná-las. A luta duraria entre 1925 e 1928, com o recuo final das autoridades inglesas. "[Bardoli] está a escrever uma página brilhante na epopeia de dor e de sacrifício que é a moderna história da Índia. (...) A luta iniciada é ao mesmo tempo uma epopeia e uma lição: epopeia inédita pela resplandecente novidade dos seus processos (...) Lição para os que crêem dogmaticamente que o único meio de defender as reivindicações proletárias é a violência sanguinária erigida em deusa" (Barreto, Adeodato, “A epopeia de Bardoli", in Índia Nova, n. 4 (15 de Setembro de 1928), p.4). 
nizavam o encontro das civilizações e a promoção de uma nova ordem internacional. O facto de Rabindranath Tagore ser a personalidade indiana mais referenciada no jornal, só encontrando um rival em Gandhi, devia-se em parte à sua qualidade de poeta ${ }^{63}$ e como poeta, mas devia-se também, e talvez sobretudo, ao seu ideário universalista ${ }^{64}$ que suportava o trabalho desenvolvido em prol do diálogo civilizacional tanto através de conferências que proferia um pouco por todo o mundo, como do ashram de Visva-bharati onde ocorriam académicos asiáticos, europeus e americanos ${ }^{65}$.

\section{0 advento duma Nova Era. Da civilização indiana e europeia à civilização universal}

Seria essa Nova Era que Adeodato Barreto anunciaria no primeiro número do jornal em "A missão da Ásia", considerando que o seu impulso adviria do moderno Renascimento Hindu e da sua divulgação universal:

Mas é sobretudo o desvendamento paulatino dos velhos ideais hindus, abafados durante dois séculos pela servidão política, mas expandindo-se agora livremente com as asas duma nova vida, que constitui um marco milenário fulgurante na História Contemporânea, assentando o início auspicioso duma Era de Harmonia e Paz (...). ${ }^{66}$

O diagnóstico dum mundo em estado de tensão e crise provocado por uma Europa imperialista, cuja dinâmica capitalista assentava na exploração dos povos africanos e asiáticos e na concorrência agressiva entre as potências dominantes, justificava a urgência duma revolução civilizacional.

63 “Os apóstolos da independência da Índia são também grandes poetas, porque só os poetas podem acarinhar com maior fervor o belo sonho que é hoje de todos os povos que habitam as plagas do Hindustão oprimido e tiranizado" (Mascarenhas, Telo de,"Sarojini Naidu”,in Índia Nova, n. 5 (31 de Outubro de 1928), p. 3).

64 "Em política Rabindranath Tagore é universalista; as nações para ele não contam; só o preocupa o bem-estar da Humanidade - e é este o espírito da velha filosofia hindu. (...) E o seu mot-d'ordre tem sido sempre, em todas as conferências, em todas as mensagens: A Índia livre; mas livre para servir e preencher o papel que lhe cabe na História da Humanidade" (Mascarenhas, Telo de, "Rabindranath Tagore", in Índia Nova, n. 1 (7 de Maio de 1928), p. 3).

65 "No meio dum bosque verde e umbroso de mangueiras ergue-se o ashram seráfico de Santiniketan, lar das duas culturas - a oriental e a ocidental - onde os estudantes indianos aprendem as ciências e as línguas europeias, e os europeus estudam as línguas, a música e a filosofia, a literatura e a arte indianas, laço espiritual que liga os dois mundos - a Europa e a Ásia - separados pelos preconceitos das raças e até certo ponto pelo despotismo dos povos europeus, para o prosseguimento dum ideal comum, o bem-estar da Humanidade" (Idem, ibidem).

${ }^{66}$ Barreto, Adeodato,"A missão da Ásia",in Índia Nova, n. 1 (7 de Maio de 1928), p. 2. 
O trauma dos horrores de 14-18 parecia augurar para o mundo do pós-guerra um novo modo de estar no relacionamento entre os povos ${ }^{67}$. A criação da Sociedade das Nações sob o impulso do Presidente norte-americano Woodrow Wilson surgira como a resposta à ânsia de paz mundial e uma nova esperança de libertação para os povos dominados ${ }^{68}$. Mas a verdade é que o Pacto de Paris subtilmente consagraria o status quo internacional ${ }^{69}$, e a Sociedade agravaria mesmo a situação dos povos oprimidos com a instituição dos mandatos, a nova fórmula para o colonialismo europeu ${ }^{70}$. Dominada pelas potências imperiais, a Sociedade vinha-se consagrando como a "Santa Aliança" do século $X X$, só que "bem mais perigosa, pois que os princípios que proclama e nos quais se inspirou estão em flagrante contradição com os resultados a que chega, inspirada pelos imperialismos encapotados que no seu seio se acobertam"71.

Neste contexto, perdia-se a esperança dos povos colonizados de a sua libertação decorrer do concerto das nações. O eclodir dos movimentos nacionalistas no pós-guerra, espalhando-se por um efeito de dominó um pouco por toda a Ásia ${ }^{72}$, traduzia uma restaurada autoconfiança dos povos dominados ${ }^{73}$, apoiava-se num sentimento

67 "Sobre o solo abrasado da Europa a guerra terminara. E os corações europeus, conflagrados pela hecatombe terrível, com as visões vermelhas toldando ainda os olhos e os espíritos, supunham, num desvario louco, que ela terminara para sempre. Um anseio enorme, um anseio ardente pela Paz, por uma paz duradoura e forte, congraçava os povos do mundo" (Barreto, Adeodato, "A Sociedade das Nações e os povos oprimidos", in Índia Nova, n. ${ }^{\circ} 2$ (12 de Junho de 1928), p. 7).

68 "Um certo ideal universalista parecia animar a Sociedade nos seus primórdios. O princípio do self-determination dos povos resplandecia dentre os 14 pontos de Wilson, como uma auréola luminosa coroando todo o projecto" (idem, ibidem).

69 "Os Membros da Liga convêm em respeitar e defender contra a agressão externa a integridade territorial e a independência política existente de todos os membros da Liga" (idem, ibidem).

70 "Que são os 'mandatos' afinal senão autênticas colónias de ocupação militar, ocultas sob um nome mentiroso graças às exigências hipócritas do 'progresso internacional' do século XX? (...) O mandato foi uma invenção genial. A Inglaterra e a França comeram profusamente nesse lauto banquete, e a liberalidade foi tão longe (em certas esferas) que a própria Austrália, um país tutelado, teve também o seu quinhão na longínqua Nova-Guiné!" (Barreto, Adeodato, “Onde a verdadeira paz?”, in Índia Nova, n. 3 (3 de Julho de 1928, p. 7).

71 Idem, ibidem.

72 "Os historiadores do presente período terão de considerar o despertar da Ásia como o acontecimento mais importante da época que se seguiu à Grande Guerra. Uma a uma, as nações asiáticas libertam-se do jugo da dominação estrangeira e, pelo seu próprio esforço, procuram adaptar-se às condições da civilização moderna" ("Ásia rediviva", art. transcrito do jornal Pracasha, dirigido por Menezes de Bragança, in India Nova, n. 4 (5 de Setembro de 1928), p. 7).

73 "E se a última guerra poucos ou quase nenhuns benefícios trouxe para a Europa, a par das assustadoras crises sociais e económicas, trouxe para a Ásia, não obstante o seu enorme sacrifício, vantagens de sumo valor moral, fazendo despertar na sua alma multimilenária a força construtiva, o sentimento da sua dig- 
de revolta pela desumanidade do capitalismo europeu ${ }^{74}$ e consolidava-se na convicção de que a liberdade teria de ser disputada aos desígnios imperiais. A par, começavam a conceber-se alianças regionais ${ }^{75}$, que consolidariam uma organização das relações internacionais marcada pela mundialização da dinâmica do confronto e pela hostilidade racial e civilizacional ${ }^{76}$.

A atenção que a política internacional mereceu no jornal deve muito ao entusiasmo suscitado pelo avanço destes movimentos de libertação que apontavam para um fim próximo do domínio europeu na Ásia, mas deve igualmente à preocupação, particularmente evidente em Adeodato Barreto ${ }^{77}$, pela dinâmica de conflito do mundo pós-guerra, largamente forçada pela manutenção da atitude expansionista europeia ${ }^{78}$.

No contexto destas preocupações, a inauguração duma "Era de Harmonia e de Paz" anunciada por Adeodato Barreto constituía uma via alternativa ao caminho que a Europa vinha trilhando e que afectava toda a humanidade. A vivência da harmonia e da paz seriam o ponto de partida e de chegada dos indivíduos e dos povos na moti-

nidade aviltada, a consciência nacional - o sentimento nacionalista" (Mascarenhas, Telo de, "A Liga Pan-Asiática e a Sociedade das Nações", in Índia Nova, n. 5 (31 de Outubro de 1928, p. 7).

74 "Os mais completos inquéritos ingleses sobre a crueldade dos industriais nos inícios da grande indústria são pálidas constatações ao lado do quadro aterrorizador dos processos do capitalismo europeu na China" (Nitti Francesco, "O Capitalismo europeu", extracto de "Bolchevismo, Fascismo e Democracia", in Índia Nova, n. 4 (5 de Setembro de 1928), p.7).

75 "Os recentes tratados assinados pelo rei Amamullah com a Turquia, a Pérsia e o Egipto indicam que estes estados sentem a necessidade duma Federação Islâmica para se protegerem contra os desígnios do Imperialismo Ocidental" ("Ásia rediviva", in India Nova, n. 4 (5 de Setembro de 1928), p. 7).

76 "O primeiro passo para o entendimento mútuo inter-populos orientais foi a fundação da Liga Pan-Asiática, cuja primeira conferência teve lugar em Nagasaki, em Agosto de 1926: e como o jornal The Japan Adviser fez salientar - $O$ sentimento anti-ocidental foi o único elo que uniu os membros da conferência - $O$ Japão, a China, a Índia, a Pérsia, as Filipinas, o Afeganistão, etc., - e na sua opinião essa Liga foi criada para se opor à Sociedade das Nações que os povos asiáticos consideram não só como um organismo puramente europeu, mas ainda como um instrumento de dominação europeia" (Mascarenhas, Telo de,"A Liga Pan-Asiática e a Sociedade das Nações" in Índia Nova, n.o 5 (31 de Outubro de 1928), p. 7).

77 “Ouve-se já distintamente falar duma Liga das Nações Asiáticas, a qual, incluindo a Rússia, a metade odiada e temida da velha Europa, viria abrir uma cisão irremediável no Velho Continente. Essa Liga não é ainda uma realidade. Mas o falar-se dela, com a insistência com que se fala, já é um indício alarmante dum estado muito sintomático de espíritos. E os orientais pensando desta maneira não deixam de ter razão..." (Barreto, Adeodato, "A Sociedade das Nações e os povos oprimidos", in Índia Nova, n. 2 (12 de Junho de 1928), p.7).

78 "De Marrocos à China, e logo desde o início da decantada pax europeia (...) rios de sangue humano sacrificado à liberdade ante as balas francesas e inglesas têm corrido incessantemente, sem que a Sociedade das Nações (...) contraísse um só músculo da sua grande face internacional! Será que a paz europeia seja a única verdadeira paz?" (Barreto, Adeodato, "Onde a verdadeira paz?," in Índia Nova, n.o 3 (3 de Julho de 1928), p. 7). 
vação das suas acções e no relacionamento com os outros. À Europa, afundada numa crise de valores da qual a instabilidade política e social era o espelho, a essa Europa "exaurida e gasta"79 cabia virar-se para Oriente e aí buscar inspiração num novo ideal, verdadeiramente revolucionário para o futuro do velho continente e da humanidade: "[A Europa] precisa dum novo bordão que a ampare, um "viático novo", que the restaure a fé nos destinos do mundo! E esse viático sagrado, trar-lho-á o Oriente, o velho médico da Europa. Como o Cristianismo para a Roma decadente, os Ideais Hindus serão, para a civilização europeia, o bordão amparador." 80

Esta visão messiânica duma Ásia, leia-se Índia, que renascia para regenerar a humanidade tinha os seus apóstolos nos dois líderes espirituais que maior influência exerciam no nacionalismo indiano, Vivekananda e Ghandi ${ }^{81}$. E a oriente e a ocidente apoiava-se numa plêiade de intelectuais que vinham defendendo um reencontro civilizacional com vista ao ideal de criação duma civilização universal, destacando-se nesta corrente as figuras de Tolstoi, do Conde Keyserling, de Romain Rolland na Europa e de Ram Mohan Roi ${ }^{82}$ e Rabindranath Tagore na Índia.

Este messianismo asiático equacionava-se como uma imagem invertida do messianismo europeu em que assentava o discurso colonial e vivia inclusivamente dos mesmos estereótipos sobre o carácter das civilizações europeia e oriental ${ }^{83}$, mas ao contrário daquele lia-as como aspectos complementares do homem integral ${ }^{84}$, se bem que crente de que na espiritualidade radicava a fonte dos ideais que conduziam a um progresso efectivo do ser humano. A nova Era de Harmonia era, pois, a da recuperação do homem integral, e a Paz uma consequência da substituição da lógica da concorrência e domínio pela lógica da cooperação entre os povos.

79 Romain Rolland cit. por Barreto, Adeodato, "A missão da Ásia”, in Índia Nova, n. 1 (7 de Maio de 1928), p. 2.

80 Barreto, Adeodato, idem, ibidem.

81 "Gandhi e Vivekananda serão o Pedro e Paulo da civilização futura" (idem, ibidem). Swami Vivekananda foi o primeiro líder espiritual hindu a divulgar, em finais do século XIX, o Yoga e a filosofia vedanta no Ocidente, tendo inspirado largamente o pensamento dos intelectuais e líderes políticos indianos do princípio do século XX.

82 Pioneiro, no início do século XIX, do Renascimento Hindu.

83 "Um produz a razão, a ciência, a consciência; o outro segrega a intuição, a religião, o subconsciente" (Barreto, Adeodato, idem, ibidem). Mais tarde, Adeodato Barreto, numa série de artigos publicados na Seara Nova e posteriormente reunidos em volume, corrigiria esta visão estereotipada atribuindo-a ao discurso dos orientalistas ao serviço do poder britânico (Barreto, Adeodato, Civilização Hindu seguido de o Livro da Vida..., Lisboa, Hugin, 2000, p. 107).

84 "É que essas duas culturas são como dois 'lóbulos do cérebro humano"' (idem, ibidem). 
A leitura deste pequeno jornal académico demonstra a importância da imprensa periódica, em particular das revistas e jornais que se apresentavam como órgãos de movimentos culturais e políticos, como fonte para a história das ideias e a história intelectual e dos intelectuais no século XX.

No caso concreto, enquanto órgão dos estudantes universitários goeses, o jornal anunciava-se como projecto duma geração, destinando à jovem intelectualidade goesa o papel de questionar o status quo local - espelhasse ele o papel do poder metropolitano na configuração da condição goesa, ou significasse o modo de estar dominante das suas próprias elites - e de provocar os conterrâneos à acção pelo abrir dos seus horizontes políticos e culturais. Sendo evidente no jornal a abertura à circulação de ideias e saberes entre intelectuais de gerações e origens diversas, unidos por aspirações comuns ou simplesmente por uma postura intelectual partilhada, tal defesa, mais que uma particular vontade de ruptura geracional, traduzia a noção de que para a iniciativa duma acção colectiva as gerações anteriores estavam perdidas, radicando na energia e criatividade juvenil a esperança de transformação da realidade goesa.

O descerrar, nas páginas do Índia Nova, duma parte da Biblioteca do Instituto Indiano e da forma da sua constituição, o universo de referências intelectuais (bibliográficas, biográficas, conceptuais) presentes nas notas e nas reflexões dos directores e restantes colaboradores, e os ecos da receptividade de periódicos e individualidades nacionais e estrangeiras às iniciativas do Instituto e do jornal permitem-nos edificar uma imagem da formação intelectual informal desta geração. Complementarmente, possibilitam a apreensão de como a construção duma rede local e internacional de difusão de ideias e conhecimentos se alimentava tanto da potenciação dos contactos pessoais ${ }^{85}$ como da abordagem de periódicos, instituições e organizações de referência.

${ }^{85}$ Referimo-nos não só à doação de bibliografia, mas ao próprio acesso a personalidades de renome internacional. $\mathrm{O}$ caso de Rabindranath Tagore pode ser apresentado como exemplo. Mariano Saldanha (Ucassaim, 1878-1975), recentemente nomeado professor de Sânscrito na Faculdade de Letras, transportaria na sua viagem de Goa para a Metrópole uma mensagem do poeta à intelectualidade portuguesa (cf. Índia Nova, n.o 1 (7 de Maio de 1928), p. 1).É plausível que esta mensagem surgisse na sequência dos esforços dos jovens estudantes para darem a conhecer o seu trabalho a Tagore e que o canal tenha sido aberto por Francisco Bragança Cunha (Cuelim, 1887-Paris, 1954), professor na Sorbonne, que acompanhara Tagore como seu tradutor num périplo europeu em 1923, e que o elo de ligação fosse o seu irmão Tristão Bragança Cunha (1891-1958), que recentemente regressara da Europa para iniciar um Comité do Congresso Indiano em Goa (cf.Costa, Aleixo Manuel da, op.cit., v. 1, pp. 123-124; Cunha, T.B., Goa's Freedom Struggle:Selected Writings. Bombay:T.B.Cunha Memorial Committee, 1961). O mesmo Francisco Bragança 
Um dos aspectos mais marcantes deste periódico e que nos suscita algumas reflexões prende-se precisamente com a mencionada influência na formação do pensamento dos seus mentores duma corrente ecléctica de intelectuais que vinha advogando a urgência dum diálogo e intercâmbio civilizacional em busca de um novo humanismo. $\mathrm{O}$ que nos surge particularmente interessante sublinhar é como na formação desta corrente confluíam intelectuais a oriente e a ocidente, os quais, alimentando-se conjuntamente das diversas fontes culturais para construir uma nova mundividência, mutuamente se influenciavam na construção do seu pensamento.

A valorização do contributo das civilizações orientais para a construção do conceito de civilização universal constituía, em si, um momento de resistência ao discurso hegemónico na Europa. Ao Orientalismo oficial mas também ao discurso antiocidental que enformava a ideologia de algumas correntes anticoloniais, contrapunham a descoberta da alteridade como passo fundamental para a compreensão e aproximação entre povos. Este estado de espírito presidia, nomeadamente, a uma política diferenciada dos novos estudos orientais, levando a que a sua construção se fizesse não a partir do escrutínio ocidental, mas da busca de compreensão dos pontos de vista e da coerência interna dessas culturas. Essa diferença marcava-se, igualmente, no facto de muitas vezes esses estudos assentarem em projectos que envolviam académicos dos dois lados do mundo.

O Orientalismo construído a partir dessa perspectiva, se em muitos aspectos não escapava a visões estereotipadas das civilizações orientais, constituía-se como contradiscurso à ideologia imperial e renovava a imagem do Oriente nos círculos intelectuais ocidentais. No ambiente cultural europeu, esta imagem convergia com a influência da vaga orientalista na construção do movimento modernista, enquanto fonte de inspiração artística e mesmo de diálogo intercultural ${ }^{86}$. E convergia, igualmente, com o interesse demonstrado nesses círculos pelas novas correntes filosóficas espiritualistas que bebiam largamente das fontes hindus e budistas. Entre elas, destacava-se a corrente teosófica, fundada por Helena Blavatsky em finais do século XIX, que teria profunda influência nos círculos intelectuais ocidentais e na própria Índia; destaca-

Cunha era amigo de Sylvain Lévi, na altura a dirigir a Maison Franco-Japonaise em Tóquio e empenhado num projecto com o académico Junjirõ Takakusu de criação dum dicionário sobre o budismo - o qual, como já referimos, escreveria palavras de incentivo aos jovens estudantes.

${ }^{86}$ Cf. Boehmer, Elleke, op. cit., em particular pp. 22-23, 169-214; Said, Edward, op. cit., p. 292 e ss.; Qian, Zhaoming, Orientalism and Modernism: The Legacy of China in Pound and Williams, Durham, Duke University Press, 1995. 
va-se também o trabalho desenvolvido pelo Conde Keyserling, fundador, em 1920, da Escola da Sabedoria, em prol da construção duma cultura planetária. Assiste-se, assim, entre finais do século XIX e as primeiras décadas do século XX, a um virar do olhar para oriente, traduzido no interesse pelo legado das suas civilizações milenares e na atenção à expressão moderna da sua criatividade e do seu pensamento filosófico e político. Relativamente à Índia, este interesse chegaria ao ponto da "indianização" de diversos intelectuais europeus e americanos que, fascinados pelos contornos do movimento independentista indiano, se envolveriam activamente na sua promoção.

Para estes intelectuais, o eurocentrismo perdia sentido face à descoberta da relatividade cultural e do direito de os povos se autodeterminarem. A percepção das violentas consequências do imperialismo europeu para os povos dominados, em contradição evidente com os ideais e valores da modernidade, levava-os a questionar a validade do modelo civilizacional europeu e da sua hegemonia mundial, forçada pela aliança entre a espada e a pena. Por outro lado, a ruptura moral representada pela Primeira Guerra Mundial, bem como as próprias contradições sociais e políticas que assolavam a Europa, constituíam outras fontes importantes de uma crise de consciência que os impulsionaria a reflectir sobre a identidade europeia ${ }^{87}$ e a considerar que uma nova atitude teria de informar o modo de estar europeu no mundo. Neste contexto, a simpatia com que encaravam o emergir dos nacionalismos nos territórios coloniais aliava os sentimentos solidários à urgência sentida na necessidade dum reposicionamento da Europa no concerto das nações. Os movimentos anticoloniais surgiam como passos importantes para pôr em causa a ordem internacional imposta pela Europa e como respostas alternativas à reflexão sobre a acção política coeva. Neste caso, o exemplo indiano surgia edificante e merecedor de especial atenção, pela forma como Gandhi se propunha assentar a luta contra o poder inglês num ideário pacifista.

No que respeitava às elites coloniais, o ambiente filosófico, artístico e político em torno da nova corrente orientalista ajudava à consolidação do seu orgulho identitário e ajudava a perspectivar as lutas nacionais no âmbito mais vasto dos ideais universalistas reequacionados na óptica do movimento que temos descrito. Aos olhos destes intelectuais, a Europa não se fixava numa imagem uniforme cristalizada na ideologia e na acção do poder imperial; ela era também vista como o berço de uma plêiade de intelectuais reformadores, com os quais estabeleciam relações de troca intelectual e

87 Um exemplo do esforço de reflexão motivado por estas aporias encontra-se na criação por Romain Rolland, em 1923, da revista Europe. Seria aí que Rolland publicaria, primeiro, o seu ensaio sobre Gandhi. 
com os quais se sentiam irmanados numa luta comum. A resistência ao poder instituído e à ideologia hegemónica constituía a base para uma reflexão intercivilizacional sobre a condição e o destino humanos.

Através do jornal Índia Nova, o grupo de estudantes goeses promotores da iniciativa e os seus colaboradores goeses e metropolitanos, efectuando o percurso da particularidade goesa para a reflexão sobre os destinos da humanidade, integravam, por essa via, a corrente que a ocidente e oriente se batia por um novo humanismo, assentando a universalidade na harmonização da diversidade e tornando todos os indivíduos e povos coniventes na construção do futuro da humanidade. Seria para assumirem esse sentido de responsabilidade que os jovens desafiariam os conterrâneos a tomarem em mãos o seu destino.

O seu fundador, Adeodato Barreto, nunca regressaria a Goa, mas continuaria em Portugal a lutar pela divulgação deste ideário e integraria o movimento de resistência intelectual ao Estado Novo. Telo de Mascarenhas acabaria por regressar à Índia e tornar-se um freedom fighter. Sobre José Teles, o pouco que sabemos é que voltou à Índia e se dispôs, um dia, a evocar a figura do dinamizador da sua geração no Cine-Teatro Nacional de Goa ${ }^{88}$.

Se a iniciativa destes estudantes não teve a capacidade de despoletar um movimento nacionalista goês com significado político, tal como pouco êxito teriam os esforços de outros intelectuais goeses que em Goa ou na diáspora se batiam e bateriam para o mesmo fim, mesmo assim a sua acção tornou-se um símbolo de resistência para as futuras gerações goesas. A reflexão que efectuaram sobre a identidade goesa, bem como as marcas da sua formação intelectual nas páginas do Índia Nova, constituem elementos importantes para o estudo do pensamento dos intelectuais goeses da primeira metade do século $\mathrm{XX}$, o qual foi marcado por uma diversidade ideológica que ecoava os confrontos do século.

${ }^{88}$ Cf. supra, nota 24. A conferência, proferida em Agosto de 1941 pelo antigo director do Índia Nova, devia-se à iniciativa dum grupo de jovens, do qual o meu pai, Jorge Ataíde Lobo, fazia parte, que tinha criado um curso liceal alternativo ao ensino oficial, precisamente dedicado a Adeodato Barreto. 


\title{
Edição electrónica e estudo de revistas: o contributo do Seminário Livre de História das Ideias
}

\author{
Pedro Lisboa*
}

A edição electrónica de revistas vive actualmente um momento de experiências e avanços. A principal e mais palpável consequência deste facto é que a pesquisa electrónica permite, na esmagadora maioria dos casos, o manuseamento do texto em formato digital, permitindo assim também, através da pesquisa livre, a verificação automática das ocorrências do termo pesquisado. Como a sua designação indica, este tipo de busca não implica qualquer pressuposto teórico organizativo: a interacção entre o leitor e o texto não tem qualquer tipo de mediação. Esta atitude perante a informação é estruturada pelo princípio geral do acesso directo às fontes, que, sem ser redutível à questão da pesquisa, direcciona em grande parte a discussão e os desenvolvimentos na área.

A este respeito, pode dizer-se que existem hoje duas grandes correntes de edição electrónica de revistas: uma, que resume o seu serviço à pesquisa livre directa nos textos '; outra, que acrescenta a opção de pesquisa direccionada, com palavras-chave, assuntos, etc. ${ }^{2}$. O elemento comum às duas é, assim, a pesquisa livre, tornada omnipresente e indispensável no quotidiano da investigação científica (e mesmo no quotidiano, sem mais!) por motores de busca de Internet como o Google. A grande diferença objectiva entre o acesso à informação em papel ou em suporte electrónico encontra-se na utilização do computador como meio de integração da pesquisa e da leitura - separando o modelo geralmente seguido na indexação e classificação biblioteconómicas clássicas, em utilização nas bibliotecas físicas, do da publicação electrónica.

A principal desvantagem do uso exclusivo da pesquisa livre passa por, como refere Jeffrey Garrett, ficarmos dependentes de uma "contagem cega de palavras-chave

Seminário Livre de História das Ideias do Centro de História da Cultura da Faculdade de Ciências Sociais e Humanas da Universidade Nova de Lisboa.

1 Cf., por exemplo, a JSTOR (http://www.jstor.org) ou a Highwire Press da Stanford University (http:// highwire.stanford.edu).

2 Cf., por exemplo, a SciELO (http://www.scielo.org) ou o Project Euclid (http://projecteuclid.org). 
colhidas de forma mecânica" - e, poderíamos acrescentar, automática. Perante este cenário, e ainda segundo o mesmo autor, a pesquisa por termos analíticos funciona como "o dique que erigimos contra a enchente de informação que a progressiva digitalização de todos os textos está a criar. Ou antes, com mais precisão, é a torneira que colocámos nesse dique ${ }^{\prime \prime 3}$.

Sem nunca excluir a via da pesquisa livre, proveitosa em algumas situações, o Seminário Livre de História das Ideias (SLHI) pretende oferecer um acesso direccionado à informação, partindo dos princípios de representação descritiva da biblioteconomia e inovando e adaptando-os, de forma a reunir o melhor de dois mundos. Assim, o presente artigo procurará descrever o trabalho do Seminário sobre a edição electrónica de revistas, bem como discutir algumas das vantagens, desvantagens e implicações de um modelo híbrido de edição e estudo face às tendências actuais e aos objectivos propostos.

As revistas trabalhadas pelo SLHI inserem-se, maioritariamente, num plano concebido para representar as grandes correntes ideológicas dos movimentos intelectuais portugueses do princípio do século XX. Assim, são privilegiados os títulos proeminentes do republicanismo e da Renascença Portuguesa (A Águia, Vida Portuguesa, Pela Grei, etc.), do Integralismo Lusitano (Nação Portuguesa, Integralismo Lusitano, Alma Portuguesa), do pensamento católico (Estudos, Estudos Sociais), do anarquismo (Suplemento Literário e llustrado de A Batalha, Renovação, A Sementeira, Germinal) e do pensamento feminino (Alma Feminina, Educação Feminina). A par destes, juntam-se também algumas publicações que, fugindo ao critério geral de inclusão, foram escoIhidas pela sua relevância contextual ou temática (O Tempo e o Modo, Revista de Educação Geral e Técnica, Revista da Índia, Índia Nova). Desde logo, ficam delimitadas as fontes: revistas portuguesas emblemáticas de ideias e cultura, maioritariamente do começo do século passado. As particularidades deste corpus não são alheias à construção da metodologia, que se quer adaptada ao objecto de trabalho.

O processo de trabalho inicia-se com a recolha de dados biográficos gerais acerca da publicação. $O$ investigador (ou investigadores) responsável reúne toda a informação pertinente sobre a vida editorial da revista, como o seu período e local de publicação, os seus colaboradores mais destacados e o seu corpo redactorial. Pretende-se que, antes de mais, seja traçada uma primeira história do percurso do periódico, mesmo 
sendo passível de posteriores correcções e acrescentos decorrentes do curso do trabalho, que permita formar alicerces factuais. A par deste esforço, são feitas leituras complementares, quer de outras fontes quer de estudos, conferindo ao investigador uma contextualização plena.

Segue-se uma leitura exaustiva da revista na sua totalidade. Este passo é de uma evidente relevância para a apreensão do significado e do conteúdo da publicação no seu conjunto, interpretando os vários artigos, números e partes e articulando-os num todo. Do ponto de vista prático, é acompanhado da recolha sistemática de dados concretos relativos a cada artigo, que permitirão posteriormente construir as bases de dados de termos analíticos para a revista.

Quais são, então, os dados que importa recolher? Em primeiro lugar, toda a informação identificativa do artigo: título, autor e localização na revista (número, secção e páginas). Em seguida, as referências feitas pelo articulista ao longo do texto: todas as menções a nomes, títulos (de livros, outros periódicos, etc.), instituições ou entidades colectivas, acontecimentos e locais geográficos. Noutro plano, são também identificados os termos empregues pelo autor para expor as suas ideias e conceitos, fundamentais como base de construção do ideário apresentado.

Esta informação é inserida na base de dados, agrupada por fichas, onde cada ficha representa um artigo distinto. Por outras palavras, a unidade elementar da base, que contém todo o universo referencial da revista em questão, é o artigo, aqui entendido não apenas como texto de opinião, mas também englobando notícias, poemas, contos, peças gráficas, publicidade, etc. Veja-se a figura da página seguinte, que descreve de forma esquemática os vários tipos de entrada numa ficha. Em itálico, encontram-se os dados que não são meramente textuais, ou seja, que requerem o contributo crítico do investigador.

Dado que, em quase todos os casos, o texto das fontes não se encontra disponível em formato digital, o que seria demasiado dispendioso e demorado obter, a automatização de processos encontra-se limitada à organização e agilização da recolha de dados analíticos. A utilização de técnicas como o text mining, ou outras relacionadas com a computação semântica, é, assim, dificultada ${ }^{4}$. No entanto, e dado que se recorre a um conjunto de bases de dados integradas e uniformizadas, a pesquisa e a visualização de resultados de analíticos são inteiramente automatizadas.

4 Esta via, caso existissem as fontes com as características necessárias, teria o potencial de produzir resultados ricos e proveitosos, desde que se respeitassem os princípios metodológicos relevantes. 
Figura 1: Composição de ficha

Ficha Individual: representa um artigo na revista

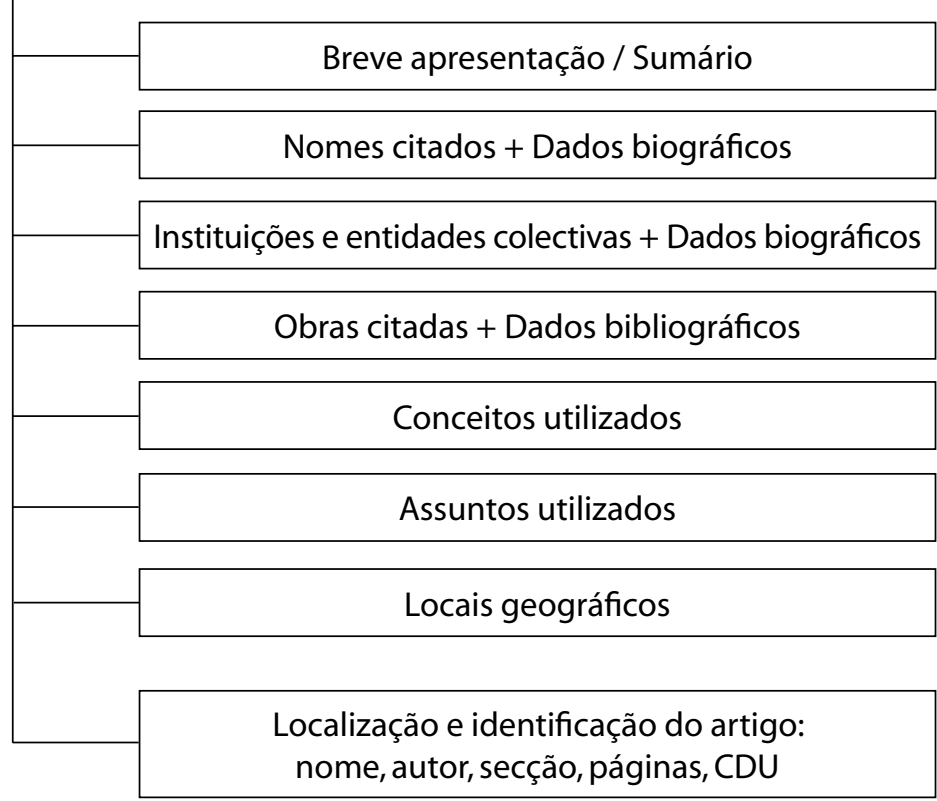

Note-se que é feita uma distinção entre "conceito" e "assunto": ao passo que o primeiro pressupõe uma maior profundidade conceptual ${ }^{5}$, o segundo pretende-se eminentemente descritivo e factual. Em ambos os casos, não basta atentar na referência textual explícita, ou seja, podem ser indexados conceitos e assuntos cujo sentido seja identificado pelo investigador, sem nunca serem referidos directamente no artigo.

A base é depois sujeita a uma série de revisões tanto sucessivas como exaustivas, procurando não apenas corrigir gralhas e erros, mas também uniformizar as entradas, de forma a garantir a sua coesão formal e a finalizar o processo prévio à sua publicação.

A par do trabalho do Seminário, é feita, por instituições em parceria, a digitalização das páginas da revista que, finalmente, acompanharão a base de dados. Durante esta

5 O SLHI elaborou, como instrumento de trabalho, um thesaurus de conceitos, discutido e revisto periodicamente, que serve como referência para a escolha de termos. 
fase, são feitas as ligações informáticas entre base e imagens digitalizadas, podendo optar-se pelo reconhecimento de caracteres e consequente possibilidade adicional de pesquisa livre 6 . O formato final da edição depende da revista e dos destinatários, perspectivando-se a sua disponibilização na Internet ou em suporte ROM.

Desta descrição facilmente se depreende o grau de detalhe que se procura atingir. $\mathrm{A}$ maioria dos esforços de indexação e classificação bibliográfica serve-se sobretudo de palavras-chave para facilitar o acesso à informação do leitor/investigador (deixando de parte a pesquisa livre que, como já vimos, representa uma estratégia de acesso à informação distinta). Nesta abordagem, para além dos dados formais bibliográficos (autor, título, local, data, idioma, etc.), são atribuídos descritores aos artigos que permitem buscas genericamente definíveis como buscas por assunto. Aqui cabem também temas, autores e obras, mas sempre a um nível muito simplificado e geral, apontando somente no sentido da relevância mais alta ${ }^{7}$. O seu único objectivo é descrever os principais assuntos tratados no texto, ignorando todas as demais referências e assumindo que o leitor, caso assim o deseje, a devido tempo se dedicará a estudá-las quando aceder directamente ao texto. Este princípio de simplificação, até certo ponto inevitável ao tratar de grandes acervos documentais, hierarquiza linearmente os assuntos, disponibilizando, na prática, apenas aqueles que ultrapassam determinado valor numa escala imaginária de pertinência. Dir-se-ia que apenas a extrema relevância permite a inclusão. Este esforço cumpre o tradicional e importante papel da organização como meio de gestão: classifica de forma sintética, eliminando toda a informação que possa ser secundária ou provocar ruído, contrastando em absoluto com o paradigma da pesquisa livre.

O SLHI procura uma abordagem algo distinta ao trabalho de indexação e classificação, sendo que se podem referir duas grandes diferenças teóricas em comparação com o princípio previamente referido no que toca à metodologia: exaustividade e interpretação crítica.

Apesar de ser sempre necessária alguma medida de síntese (para que, in extremis, a indexação não seja feita com o texto integra!!), pretende-se que o investigador tenha à sua disposição todo o corpo de referências utilizado pelo articulista. Assim, e por exemplo, não são recolhidos apenas os autores tratados em maior profundidade, mas

6 Como foi o caso da revista Alma Nacional. Cf. Alma Nacional, CD-ROM, Colecção de Revistas de Ideias e Cultura, n. 1 1, Lisboa, Fundação Mário Soares, 2004.

7 Veja-se, por exemplo, a SciELO. O mesmo se verifica na representação descritiva das bibliotecas nacionais. 
sim todos, exaustivamente. O mesmo se aplica a todos os outros critérios de pesquisa, como títulos de obras, locais, etc. Isto permite saber precisamente quantas vezes e onde surge determinada referência, e para cada ocorrência permite ainda cruzá-la com as demais referências do mesmo artigo. Pode dizer-se que, neste aspecto, oferece ao investigador um mapa de conteúdos da publicação, antes ou sem que seja necessária a sua consulta directa. Esta forma de metadados define-se, juntamente com a representação descritiva clássica, como "informação estruturada que descreve, explica, localiza ou, de alguma forma, facilita o acesso, uso ou gestão de um recurso de informação"8 - simplesmente, pretende que a rede referencial à disposição do leitor seja o mais completa possível e não sintética.

A isto junta-se a informação biobibliográfica complementar: todos os nomes são acompanhados das datas de nascimento e morte e das ocupações pelas quais foram conhecidos à época da publicação do texto, tanto quanto for possível apurá-las. São feitas pesquisas em todos os principais repositórios de dados biográficos, como catálogos de bibliotecas nacionais, enciclopédias e, caso seja necessário, dicionários especializados, para garantir que a informação não só está correcta, como é o mais abrangente possível. A Internet, para além de permitir aceder rapidamente a estes dados, representa também um recurso indispensável para chegar a referências mais obscuras e omitidas de todos os instrumentos clássicos ${ }^{9}$. Apesar de os nomes constituírem o objecto principal desta preocupação de documentação, ela estende-se também, ainda que em menor grau de aprofundamento, aos restantes tipos de entradas: datas e locais de congressos, cerimónias, publicações, etc. É sobre este trabalho que incide grande parte das revisões finais. É essencial, para o sucesso da utilização da base, garantir a sua homogeneidade e uniformidade, eliminando erros de recolha e mesmo de citação na própria revista, onde por vezes, por descuido ou por gralha, são feitas citações da mesma referência de forma díspar. Deve ainda dizer-se que o trabalho de revisão, considerando não apenas as incorrecções descritas mas também outros factores de dissonância (e.g., uma grafia arcaica), dota o modelo de uma considerável vantagem sobre a pesquisa livre, dada a vulnerabilidade desta ao erro humano ${ }^{10}$.

8 National Information Standards Organization, Understanding Metadata, NISO Press, 2004, p. 1.

9 Mantém-se aqui algum equilíbrio entre relevância do nome e esforço necessário para recolher as informações pertinentes. Exceptuando alguns casos extremos, como nomes de familiares ou autores de uma obra apenas, pode dizer-se que a taxa de sucesso é muito elevada.

10 Jeffrey Garrett, op. cit. 
A outra particularidade do trabalho do SLHI prende-se com a intenção de ir além da simples disponibilização de informação: as bases de dados contêm termos não só de indexação, mas também de classificação dos conceitos utilizados. O conteúdo das revistas e seus artigos é, assim, sujeito a um olhar interpretativo crítico - daí a designação. $O$ investigador não se limita a retirar algumas palavras e expressões do texto, ipsis verbis, como marcadores de indexação. Munido dos seus conhecimentos acerca dos assuntos tratados e do contexto histórico das revistas, dá um sentido focalizado aos conteúdos. Pretende-se que o seu contributo não seja meramente mecânico: as referências nas revistas não devem ser apenas identificadas e recolhidas, mas também interpretadas, articuladas e documentadas - alguns dos passos fundamentais de qualquer estudo historiográfico. Estes conceitos não coincidem, em definição, com os termos de indexação. Ao contrário destes últimos, é possível que a palavra que traduz o conceito nem sequer se encontre no texto - é responsabilidade do SLHI encontrar o conceito essencial que se encontra detrás da expressão textual de uma ideia.

Podemos, deste modo, resumir os principais objectivos do trabalho de edição de revistas em três pontos: permitir o acesso à informação; criar um aparato crítico que possibilite a sua análise detalhada; propor um estudo dos dados com base na experiência e nos instrumentos forjados. Se os princípios metodológicos apresentam, como acabámos de ver, acrescentos relativamente à indexação e classificação tradicionais ou mesmo à indexação e classificação electrónica emergentes, é inevitável que o horizonte dos objectivos também possa ser alargado. Aproveitando essa abertura, isto significa que, para além da acessibilidade, que se perspectiva em todos os casos, passa também a existir um instrumento de trabalho, não apenas de pesquisa. O resultado final da edição vai para além da criação de um meio de acesso à informação, concretiza-se na disponibilização de um instrumento de estudo ${ }^{11}$. A monografia ou o texto historiográfico que surge da mão do investigador após a finalização da base representa o culminar do processo, expressão do seu desenlace expectável e desejado: aproveitar o aparato crítico que se disponibiliza aos leitores para efectuar a sua primeira utilização especializada.

Pode-se, aliás, colocar inversamente a questão: a base de dados e a sua indexação e classificação são o trabalho necessário para, seguindo critérios metodológicos particulares e exaustivos, estudar determinada revista; uma vez que esse trabalho se

1 Veja-se, como exemplo, António Nóvoa e Filomena Bandeira (coord.), A Educação Portuguesa: Corpus documental (séculos XIX-XX), CD-ROM, Porto, Edições Asa, 2005. O CD reúne informação proveniente de diversas bases de dados bibliográficas relativas à área da educação, e a sua metodologia contém uma aproximação simplificada aos objectivos do SLHI. 
encontre completo, e visto que se mantém válido e - julgamos - útil para futuros investigadores, será proveitosa a sua partilha.

Em jeito de comparação, podem ser destacadas algumas iniciativas de índole semeIhante, apesar das diferenças metodológicas, como o trabalho levado a cabo para a revista Colóquio/Letras ${ }^{12}$, ou, a nível internacional, a edição em DVD da revista Esprit ${ }^{13}$. Deve notar-se que, nestes casos, é tratada apenas uma publicação, o que possibilita uma moldagem precisa de métodos e aparato crítico às suas características individuais. No entanto, o âmbito do SLHI é todo um universo de revistas, composto de constelações ideológicas coerentes, pelo que a sua estrutura metodológica deverá suportar variações particulares, sem condicionamento na sua aplicabilidade.

Se até aqui tem sido feita uma análise das sobreposições e especificidades do Seminário com os métodos de indexação e classificação geralmente utilizados, deve ser ainda mencionado um outro aspecto que, não sendo tão relevante nessa comparação, é fulcral para a caracterização em curso: o trabalho do SLHI é feito sobre revistas a partir de uma perspectiva da história das ideias, onde a noção de totalidade da revista é fundamental. Cada publicação encerra um conjunto de ideias, definidas e organizadas internamente de modos particulares. Identificar estes universos, articulá-los com os demais e situá-los no devido contexto histórico é um desígnio transversal do trabalho dos investigadores; ou seja, apesar de se tratar de revistas, dos seus impulsionadores e de todos os dados históricos que com eles se relacionam, as ideias que defendem e difundem estão sempre presentes como fio condutor e objecto final.

Retirando a componente analítica e historiográfica do trabalho, e cingindo-nos aos aspectos de indexação e classificação, é pertinente questionarmo-nos acerca das virtudes ou defeitos do modelo do Seminário relativamente aos restantes. Neste capítulo, pode dizer-se que a sua grande desvantagem é a considerável quantidade de trabalho - e portanto de tempo - que construir e finalizar uma base de dados deste tipo pressupõe. De forma a garantir a homogeneidade e correcção da base, são necessárias múltiplas revisões, técnicas e científicas, para além do trabalho volumoso que significa a própria recolha. Como seria de esperar, a extensão da revista em si, a quantidade de números, o tamanho dos mesmos, etc., determinam em grande parte o investimento que deve ser feito para a sua conclusão. Não obstante as eventuais complexidades particulares no ideário, o volume, e portanto o trabalho prático, de,

\footnotetext{
12 Cf. http://coloquio.gulbenkian.pt.

${ }^{13}$ Cf. La Collection intégrale d'Esprit, 1932-2006, DVD-ROM, Revue Esprit, 2008.
} 
por exemplo, Orpheu não é comparável ao da Seara Nova. Ainda assim, tratar uma qualquer revista com estes critérios, mesmo que tenham sido dela publicados apenas alguns números curtos, implica sempre um maior esforço do que o utilizado para a representação descritiva do mesmo título com fins de biblioteconomia.

Apesar de menos evidente, deve também ser mencionada a dificuldade do modelo em determinar hierarquias internas de relevância referencial. A unidade privilegiada de estudo do SLHI é, assumidamente, a revista na sua totalidade, ou seja, o conjunto de textos que a compõem. Assim, é fácil verificar quantitativamente a ocorrência de referências ao longo da publicação: a pesquisa por um nome ou por um conceito informa o leitor não só dos sítios onde se encontram, mas também do número total de entradas. No caso de O Tempo e o Modo ${ }^{14}$, o conceito "Fé" surge 33 vezes, ao passo que o conceito "Jogo" é utilizado apenas três vezes, indicando uma clara primazia do primeiro sobre o segundo em termos de importância no ideário da publicação. Aferir a mesma informação para apenas um artigo é, no entanto, mais problemático, já que, a partir da base, não existem dados que permitam fazê-lo imediatamente, sem a leitura do próprio texto. Os descritores biblioteconómicos também não resolvem esta insuficiência, mas, como geralmente procuram a síntese qualitativa de conteúdos, a sua natureza conduz o leitor aos temas mais importantes do texto, apesar de o fazer com o sacrifício de todos os outros. Neste aspecto e à primeira vista, o modelo do SLHI não parece ser tão assinalável a lidar com artigos individuais como com o conjunto da publicação. No entanto, esta dificuldade é facilmente ultrapassada fazendo o cruzamento com os restantes dados contidos na ficha - contextualizando o resultado automático da busca, depressa se determina o peso relativo no artigo. Mais uma vez, o principal motivo para isto suceder é o objecto globalmente mais importante de trabalho de um e outro modelos: texto/artigo/livro vs. revista/totalidade de uma publicação, e as consequências daí resultantes.

Nenhuma destas aparentes limitações resulta de falhas metodológicas estruturais. Decorrem das opções e dos objectivos do modelo analítico escolhido e são, nesse quadro, inevitáveis. Como, no âmbito do trabalho do Seminário, a indexação e a classificação não representam um fim, mas antes um meio - ao contrário do trabalho de representação descritiva das bibliotecas ou das iniciativas de edição electrónica de periódicos -, a sua operacionalização acarreta consequências particulares, tanto posi-

${ }^{14}$ O Tempo e o Modo - 1. ${ }^{a}$ série, DVD-ROM, Colecção de Revistas de Ideias e Cultura, n. ${ }^{\circ} 2$, Lisboa, Fundação Mário Soares, 2006. 
tivas como negativas. Por este motivo, a comparação nunca pode ser feita de forma totalmente directa: os instrumentos de indexação e classificação partilham linguagens semelhantes e coincidem em alguns pontos, mas os objectivos assumidos num e noutro caso determinam, de facto, aplicações práticas distintas.

A actualidade da edição electrónica de periódicos caminha, a par do desenvolvimento e difusão de meios informáticos cada vez mais eficazes, na direcção da acessibilidade alargada à informação. O SLHI propõe uma utilização especializada e aprofundada desses instrumentos, para a construção de uma nova metodologia de edição electrónica analítica. Neste sentido, apresenta uma abordagem própria, moldada pelas suas raízes na História e na Filosofia, aos princípios de uma das mais interessantes fronteiras tecnológicas da actualidade, a da computação semântica, aplicada à edição electrónica. Edição e estudo deixam de constituir etapas inteiramente distintas no processo de tratamento de uma revista - histórica ou não, apesar de, no caso do Seminário, esta característica ser fundamental -, para passarem a formar, desde o primeiro momento e de forma integrada, um só objectivo simbiótico. 


\title{
Da língua à cultura científica: \\ a Revista Internacional de Língua Portuguesa
}

\author{
Cristina Montalvão Sarmento*
}

Publicada desde o início da fundação da Associação das Universidades de Língua Portuguesa (AULP) em 1986, a Revista Internacional de Língua Portuguesa (RILP) tem sido o veículo da expressão da comunidade que se expressa em português, impulsionada pelo movimento associativo universitário dos anos oitenta e noventa do século $X X$.

Dirigida, primeiro, por Maria Helena Mira Mateus, numa série inicial composta por dezassete números, e, depois, coordenada por José-Augusto França, numa segunda série com três exemplares, perfaz hoje vinte e um títulos, o último dos quais abre a terceira série em curso, de cariz institucional e temático. A sua pretensão de divulgação da língua portuguesa, a longevidade e a expressão intercontinental fazem desta revista um caso nacional único de internacionalização do centro linguístico original para o universo multilateral das culturas associadas, em torno do vector comum da língua, alheia às vicissitudes políticas que o tempo impôs e os poderes engendraram.

Implícita está a consciência do grau de reconhecimento e influência internacional que as políticas de língua promovem para determinadas línguas ou podem promover para a língua portuguesa. Esta questão traz ainda inerente a actual tese da crescente importância de uma língua como instrumento gerador de poderes, quer ao nível simbólico na construção das identidades, quer ao nível funcional no impacte económico das línguas.

Saber em que medida uma política de língua activa e consciente poderá alcançar esse nível de poderes, administrá-los e ampliá-los, terá sido o objectivo dos participantes na vida da revista. A análise do conteúdo favorece a compreensão e a configuração da evolução da rede desses poderes.

Centro de História da Cultura da Faculdade de Ciências Sociais e Humanas da Universidade Nova de Lisboa. 


\section{Série - Pragmatismo e intenções iniciais}

A Associação das Universidades de Língua Portuguesa, AULP, reúne pela primeira vez em Lisboa em 1988 sob o tema "Os problemas da língua e o conhecimento das culturas", história que a RILP regista, anunciando-se no primeiro número como o resultado natural e pragmático dos dois primeiros anos do esforço associativo da AULP em criar um instrumento de cooperação académica, publicando na RILP todas as comunicações entregues pelos participantes desse encontro.

Nascida no seio do Conselho de Reitores das Universidades Portuguesas, na Cidade da Praia em Cabo Verde, a AULP tem no seu primeiro presidente, António Simões Lopes, à data presidente daquele Conselho e Reitor da Universidade Técnica de Lisboa' ${ }^{1}$, um convicto defensor da"generosidade do motivo que era, tão-só, o da cooperação e solidariedade, isto é, o da interacção e interajuda, extremamente interessadas em serem 'desinteressadas', total e completamente", como afirma na abertura do I Encontro da AULP, texto que abre simultaneamente a RILP em Julho de 1989, criada no Conselho de Administração de Março de 1988, como instrumento pragmático de intercâmbio cultural, científico e de cooperação universitária.

Já no editorial do seu primeiro número, a directora, Helena Mira Mateus, afirmava: "A RILP surgiu como manifestação do desejo de interconhecimento e de intercâmbio de todos os que na América, na Europa e na África falam português no seu quotidiano e se preocupam com a sua utilização e o seu ensino. Surgiu ainda a revista como um modo de aproximar as culturas que na língua portuguesa encontram expressão, ou a moldam para se exprimirem. E, se este é o destino do Português, não é mais do que a continuação da sua própria história em que esse destino - como todos os destinos já estava contido."

É este percurso de internacionalização do português, em que a história da língua acompanha certos pontos de referência da história mundial que directamente se invocam, lembrando como a língua portuguesa foi estendida através da África a partir do século XV, aporta à América no limiar do século XVI, em finais desse século, e durante o século XVII, era utilizada como língua geral do litoral africano e como língua

\footnotetext{
António Simões Lopes teve um papel determinante na emergência da AULP, assim como na sua manutenção. Assume a presidência entre 1986 e 1989, enquanto Reitor da Universidade Técnica de Lisboa, e posteriormente, após uma presidência proposta mas não concretizada da Universidade Federal do Maranhão durante apenas três meses, reassumirá os destinos da AULP de novo em nome da Universidade Técnica de Lisboa, no seu segundo consulado, no mandato 1993-1996, o que conferirá a estabilidade inicial à AULP.
} 
franca (indo-português e malaio-português) nos portos da Índia e do Sudoeste da Ásia. Como europeus e asiáticos comunicavam em português em extensas regiões da Índia, na ilha de Samatra e Java e na ilha de Timor. E ainda, como no Japão, na Tailândia e na China, serviu nas relações políticas, comerciais e religiosas.

Mas é sobretudo, e em particular, pela circunstância de o português ser a língua veicular e oficial de Angola, Moçambique, São Tomé e Príncipe, Guiné e Cabo Verde que a RILP se autojustifica.É por ser através da língua portuguesa que se veiculam conhecimentos, na escola e fora dela, no campo da ciência e da cultura, que a revista constitui um corpo de questões de complexa e delicada solução, numa rede de relações que o português estabelece com outras línguas, que será primeiramente o objecto do interesse de muitos dos que escrevem na RILP.

Uma terceira dimensão, a que a RILP atende, é o facto de as diferentes literaturas nacionais terem expressão escrita em língua portuguesa, com consequências maiores na deriva da própria língua, no seu enriquecimento e adequação a novas realidades. Como afirma a sua directora, “Esta é a única perspectiva que nos permite aproximar e diferenciar, em português, culturas não portuguesas, e através do português compreender a importância da especificidade dessas culturas. Neste magnífico movimento dialógico, a língua portuguesa diversifica-se e preserva-se, mantendo um destino plurímodo que confirma a sua própria história", diálogo fundacional da RILP.

Nestes termos emerge o espaço de troca cultural que toda a revista contém, unindo espíritos que comungam as mesmas inquietações. $O$ primeiro número abordará, em três partes distintas, os problemas da língua e do seu ensino, os conhecimentos das culturas associadas à literatura e à sua dimensão histórico-antropológica; finalmente, assume-se como instrumento público das actividades da AULP.

Com um conselho editorial intercontinental, ainda que sem representante nomeado por Angola, tem representantes no Brasil (Rosa Virgínia Mattos Silva e Atibila T. de Castilho), em Cabo Verde (Alice Gomes Fernandes de Matos), na Guiné-Bissau (Jorge Ampa Cumerlerbo), em Moçambique (Perpétua Gonçalves), em São Tomé e Príncipe (João Hermínio da Silva Pontífice) e, finalmente, em Portugal (Manuel Ferreira e Maria de Lurdes Crispim). Com eles estão lançadas as bases de um fórum de discussão científica, apoiado numa complexa estrutura orgânica.

Percorrer a revista implica compreender como foi solidamente ancorada na dinâmica da sua directora, Maria Helena Mira Mateus, que preside aos destinos dos dezassete primeiros números, regulares e consecutivos entre 1989 e 1997, oito anos durante os quais não se abstém de, na sua maioria, escrever o editorial, justificando, antecipando 
ou dando a conhecer ao leitor a ideia que presidiu ao número, as dificuldades que surgiram, a razão de ser ou, tão-só, os motivos das escolhas.

Estes editoriais não surgem, todavia, como um exclusivo seu e serão entregues aos diferentes organizadores que se sucedem, numa clara expressão de flexibilidade cooperativa, em que a manutenção de uma estrutura estável e a disposição de conteúdos Ihe darão unidade de sentido e continuidade estrutural.

Numa primeira fase, que se poderia grosseiramente reconduzir aos primeiros quatro números, a RILP emerge como uma revista sobre a língua e a análise dos vários problemas conexos. Assente num foco, denominação dada ao tema principal, formatação que se irá manter até 1997, contém acessoriamente uma zona de recensões e de notícias, local em que é aberto espaço, por um lado, para a divulgação da bibliografia associada e, por outro lado, para dar a conhecer ou registar as iniciativas académicas relativas aos temas articulados com a actividade da AULP.

Assim se segue um segundo número, publicado em Dezembro de 1989, com editorial assinado por Maria de Lurdes Crispim², que salienta como a RILP deve ser "o espaço vocacionado de diálogo intercontinental de Língua Portuguesa, sobre a Língua Portuguesa e as culturas que nela se expressam." O foco é dedicado à "Língua vista - Língua ouvida", o mote da responsabilidade do conselho editorial português; tratam-se alguns aspectos da relação oral/escrito, dos problemas de ensino/aprendizagem de ambos os códigos e da riqueza do seu uso como meio de expressão estética e cultural. São sobretudo as dificuldades de alfabetização que portugueses e brasileiros expressam, neste foco de ouvir e falar. Mas os artigos de Melo e Castro, “O português, língua de experimentar poesia”, ou de Nuno Júdice, “Poesia e invenção linguística", com que este segundo número da RILP abre, dão-lhe o carácter universal da "Alta Cultura" que a caracterizará. Ao assinalar, nas notícias, a realização do I Congresso de Escritores de Língua Portuguesa realizado nos dias 1,2 e 3 de Março desse ano em Lisboa e ao anunciar o IX Congresso da ALFAL (Associação de Linguística e Filologia da América Latina), a RILP prossegue na senda de se tornar o veículo informativo dos acontecimentos nacionais e internacionais relativos à língua portuguesa.

Aparentemente, o número três da RILP assume a polémica questão de abordar o "Português como língua estrangeira". Como explica Fernando Cristóvão no seu texto de abertura de Julho de 1990, é necessário assumir que "a nossa língua tenha futuro".

\footnotetext{
2 Maria de Lurdes Crispim assumirá a subdirecção da revista a partir do número quinze. Uma figura nova de coordenação emerge a partir do número doze, e será da responsabilidade de Margarida Correia que vem substituir a redacção de Isabel Fraústo que se manteve desde o início até ao número onze.
} 
Emergem as questões relacionadas com a criação de uma política de língua para a língua portuguesa. Timidamente ainda, assinala-se que, por "muitos descobrirem que não éramos só portadores de um património histórico e literário riquíssimo pouco comum em pequenos países, mas também porque a curva demográfica lusófona, francamente ascensional, nos vaticina um futuro promissor", importa que a língua tenha porvir. Ainda que não directamente focada numa política de língua específica, a matéria do português como língua estrangeira será bem ancorada em dois artigos, do conselho editorial português, de Maria de Lurdes Crispim e Manuel Ferreira. Estes artigos que abrem a RILP legam-nos exemplos práticos múltiplos da experiência do ensino do português como língua estrangeira, seja em Lisboa, no Brasil ou na Galiza, em Estrasburgo ou na Hungria, em Salzburgo ou em Utreque, ou finalmente em Perugia. É na pluralidade dos casos práticos ilustrados que as experiências individuais revelam a dimensão da problemática. Finaliza este foco o relatório do "ensino do português no estrangeiro" realizado pelo grupo de trabalho da CRSE ${ }^{3}$.

No final, uma breve notícia refere-se ao II Encontro da AULP, que decorrera em Abril de 1990, na Reitoria da Universidade de Évora, sob o tema "O papel da ciência e da tecnologia nos processos de desenvolvimento", modesta referência a que não é certamente alheio o afastamento do tema relativamente à questão da própria língua, mas também o facto de se ter iniciado com este Encontro a publicação autónoma das Actas Científicas, ainda que, neste caso, em versão meramente policopiada.

Este II Encontro da AULP marca o início do esforço de permanência e continuidade estruturada dos temas que a Associação promoverá nos anos subsequentes, nos seus III, IV e V Encontros. Em 1992 (Estoril), a "Ciência e tecnologia no desenvolvimento: os recursos e as infra-estruturas"; dois anos depois, em 1994, também no Estoril, o mesmo tema abrigará "O turismo e o seu papel no desenvolvimento dos países", para em 1995, em Recife, no Brasil, inflectir ligeiramente para "O sistema de ensino no processo de desenvolvimento", temas publicados em colecção autónoma, onde muitos dos responsáveis dos países envolvidos expressam posições e intenções, o que permite acompanhar o esforço cooperativo da Associação.

3 Comissão da Reforma do Sistema Educativo. Em 1988, fora criado um grupo de trabalho constituído pelos Professores Aníbal Pinto de Castro, Fernando Alves Cristóvão, João Malaca Casteleiro, Jorge Morais Barbosa, Helena Mira Mateus, Maria Helena Valente Rosa, Mário Quintela Vilela, Vasco Graça Moura e Vítor Manuel de Aguiar e Silva (coordenador) que apresentou à Comissão de Reforma do Sistema Educativo um relatório de que são publicados extractos e que dará a dimensão concreta sobre política de língua que a revista, neste número três, já contém. 
Doravante claramente autonomizada, a RILP manterá o foco em especial nos problemas técnicos da língua. O número quatro será dedicado à "Linguística e ensino das línguas". Como o texto inicial de Helena Silva Duarte permite entrever, o que está em causa é a procura de novos modelos técnicos e científicos com o objectivo de levar os falantes da língua a dominarem os processos de leitura e escrita, pois "não há ciência nem teoria científica que, por si só, forneça pré-preparados os ingredientes para a sua elaboração". Indício da dinâmica da revista é a criação, neste número, de uma nova secção - Ideias. Aqui se espelhará a criatividade múltipla de artigos sobre literatura lusófona.

Já a partir do seu único número duplo (cinco/seis) publicado em Dezembro de 1991, o âmbito emergirá alargado, como se a percepção do contacto cultural ganhasse existência. E concretiza um novo campo. O título do foco é sugestivo: "Viagens no português". Ora são as influências árabes na língua portuguesa, e o japonês ou o chinês quando em contacto com o português; ora são considerações sociolínguisticas sobre o português falado em Moçambique, ou os vocábulos de origem africana no espaço da língua portuguesa, ou ainda os empréstimos lexicais do português no tsonga ou os quimbundismos no português literário. A ambiguidade do título leva Helena Mira Mateus a intervir no editorial, justificando-o. "O título do FOCO no presente número da RILP tem um duplo objectivo. Apresentar aspectos da influência do português noutras línguas com que esteve/está em contacto e apresentar aspectos da influência dessas línguas sobre o português." É a dimensão da interculturalidade que se manifesta. É possível detectar no português europeu restos da presença árabe, como se encontram no português falado em África os íntimos contactos com as línguas africanas ou como se desvendam no português do Brasil os apertados laços com as línguas ameríndias. As línguas, como os seres humanos, não crescem em isolamento.

Este número fecha com uma homenagem póstuma ao Professor Luís Filipe Lindley Cintra, cujo percurso académico partiu da literatura, numa altura em que, em Portugal, dele não se tinha autonomizado ainda o estudo da língua. Quando começou a ensinar na Faculdade de Letras de Lisboa, não se falava de linguística mas sim de filologia; o estudo da língua portuguesa e a sua aplicação literária eram tão íntimos e inseparáveis que havia só um curso, onde moravam as outras línguas parentes: o curso de Românicas. Como aí afirma Helena Mira Mateus, não se tratou apenas de uma homenagem a quem a linguística tanto deve, mas ao seu conceito de universidade, que "não se compadecia com a existência de uma escola monolítica, orquestral, uniformizada. A escola que nos ensinou a viver, em respeito pela liberdade individual, é 
criadora e tem múltiplos caminhos, vivas discussões, encontros e desencontros, e um querer de comum consciência. A progressiva apropriação científica do nosso falar, da língua que usamos como uma construção do nosso ser-com-os-outros, de nosso ser em liberdade". Daí que talvez Lindley Cintra falasse de uma "língua românica da terceira geração", quando na sua síntese da História da Língua Portuguesa este filólogo assim classificou o crioulo de Cabo Verde.

Antecipava-se aqui uma concretização de conteúdo que se manterá nos três números seguintes (sete-oito-nove), em que a intervenção do Brasil também é mais manifesta. Agora o foco incidirá, claramente, nas políticas de língua. Rosa Virgínia Mattos e Silva, de S. Salvador da Bahia, do Brasil, assina o editorial do número sete, quando corria já o ano de 1992, e afirma:"Entra no seu quarto ano de vida a RILP, e este aniversário coincide com o ano em que se comemora ou contesta a descoberta ou invasão da América pela Europa. Entre essas formas antagónicas que retratam formas opostas de avaliar o evento histórico, nenhum melhor foco do que o escolhido para o n. 7 : Política da língua e políticas culturais. Não é afinal esse o foco intrínseco, subjacente ao nascimento e à vida da RILP?"

Aí não se abstêm de se pronunciar aqueles que, desde o início, o tinham compreendido. Artigos individuais, mas de representação institucional, sucedem-se: José Augusto Seabra, embaixador de Portugal na UNESCO; Eduardo Prado Coelho, à data conselheiro cultural junto da Embaixada de Portugal em França; António Simões Lopes. Este último, enquanto primeiro Presidente da AULP, assina o artigo com o título inequívoco:"Em Defesa de uma Política de Língua". Pede-se ainda a palavra às instituições:a Associação Portuguesa de Linguística e o Centro de Linguística da Universidade de Lisboa pronunciam-se. Entidades tão distintas quanto a Biblioteca Nacional, pela escrita da sua directora, Maria Leonor Machado de Sousa, ou a Lusa expressam-se e traduzem posições oficiais. Será José Augusto Seabra que melhor sintetiza:"a consciência crescente, mesmo se ainda difusa e propícia a alguma retórica fácil, de que uma política internacional de língua portuguesa deve ser hoje a prioridade das prioridades da nossa política cultural externa, começa enfim a dar frutos."

Em Março de 1993, o número oito era dado a público com o foco dirigido à "Língua, Línguas.Como falam os escritores."Maria Lúcia Lepecki, que substituíra Manuel Ferreira no conselho editorial português desde o número anterior, vem alertar no texto de abertura para o que já se manifestara. Sem perder de vista os problemas da língua portuguesa, das questões da linguística, da didáctica ou da sua pedagogia, tratava-se agora de o fazer de forma interdisciplinar. No caso,"entre linguística e literatura. Como 
falam os escritores, eis a questão".É a abordagem às utilizações estéticas, ideológicas e de narrativa que a língua regista.

Uma nota informativa no final deste oitavo número lamenta o falecimento do colaborador da Guiné-Bissau, Jorge Ampa, professor de português e responsável por muitas actividades de animação cultural, elemento essencial para a divulgação da língua portuguesa num país em que, sendo embora língua oficial, o seu ensino enfrenta dificuldades específicas devido ao crioulo e às várias línguas étnicas. Será João António de Sá que assegurará a continuidade do conselho editorial na Guiné-Bissau, numa altura em que a situação de guerra ainda não tinha permitido conquistar um membro angolano para o conselho editorial.

Um último número desta segunda fase, o número nove, será dedicado à "Literatura oral e popular" e encerra o ciclo dedicado mais directamente à Literatura. Maria del Rosário Albán, em Julho de 1993, no editorial, lembra que, quando se fala de literatura, a oralidade não pode ser esquecida. Será inevitável a referência à acção do Professor Dr. Manuel Viegas Guerreiro que, à frente da linha de acção número quatro do Centro de Estudos Geográficos de Lisboa, conseguiu fazer reconhecer os méritos da produção anónima e colectiva expressa pela voz popular,e cujos estudos encontraram ressonância no Brasil. Quando o Professor Viegas Guerreiro fez a sua primeira viagem à Universidade Federal da Bahia, em 1984, deixou aí alimento para um profícuo desenvolvimento do reconhecimento das tradições populares, portuguesas e brasileiras, expressas nos registos de aproximação luso-brasileira no âmbito da literatura oral e popular que nesta RILP transparecem e ficam apresentados.

Pela sua especificidade, dois números consecutivos inovam a rota da RILP, num justificado tema da responsabilidade de Isabel Hub Faria, "A criança e a linguagem", respectivamente em Dezembro de 1993 e em Julho de 1994. Diríamos que estes números, dez e onze, são a expressão da profundidade a que se chegara. Não bastava mais falar sobre o português, mas o seu ensino implicava reconhecer e dar o valor real a cada contexto e situação em que se adquire, aprende, amadurece ou rotiniza o conhecimento de uma língua materna. Afirma-se: "Parece imprescindível saber distinguir, neste final de século e de milénio, o que é necessariamente comum e o que é obrigatoriamente específico em cada sujeito tornado falante do português, monolingue, bilingue, multilingue, criado em família, em grupo, na rua, na escola, no interior ou na fronteira, a norte ou a sul do Equador."

E é a par desta consciência que o foco do número doze, em Dezembro de 1994, não surpreende. "Norma e variação da língua portuguesa" é agora a percepção do diversifi- 
cado complexo cultural que o mundo da lusofonia representa."São muitas raízes que se encontram e entrecruzam e onde a língua portuguesa se espraia como um denominador comum não uniforme, nem monocórdico, mas reflectindo a pluralidade e a multifacetação," palavras de Suzana Alice Marcelino Cardoso no editorial que abre a revista.

A Política da Língua será doravante mais abertamente assumida. Embora já abordada no número sete, é o número treze que lhe consagra o foco. Segundo Maria Helena Mira Mateus, "numa época em que alguns sectores da 'intelligentsia' mundial deixaram de olhar as relações económicas como o único, ou pelo menos o mais importante, motor da história, numa época em que o estudo das mentalidades voltou a constituir uma forma preferencial de iluminar o percurso do homem, a intervenção explícita no conhecimento e difusão de uma língua tornou-se indubitavelmente uma obrigação política pela qual, no futuro, todos seremos responsáveis." São em particular as colaborações de Moçambique, pelo contexto de utilização do português em contacto com as línguas nacionais, e as experiências relatadas pela colaboração brasileira neste número e que se referem às línguas indígenas do Brasil que mostram a dimensão universal dos problemas respeitantes a este domínio. E que dizer do artigo, fruto da colaboração alemã, que permite compreender como condições políticas determinadas, alemãs e africanas, estiveram na base do desenvolvimento de uma área científica particular, a Afrolusitanística, num país não-lusófono e não-africano.

Atravessávamos ainda o ano de 1995 e já um número especial vinha a caminho, o número catorze, dado a público em Dezembro. O foco é "O português no mundo", mas já não são mais as viagens do português pelo mundo, antes o registo concreto do seu ensino: a aventura crioula, os crioulos do Oriente, Macau no período de transição, Timor, o português que se aprende na Tailândia, no Senegal, na Rússia, na Argentina ou no Reino Unido, entre outros.

A particularidade deste número radica no facto de se inserir nas comemorações dos dez anos da Associação das Universidades de Língua Portuguesa (1986-1996). António Simões Lopes, na sua qualidade de Presidente da AULP, vem referir que a RILP colhe "contributos de praticamente todos os espaços geográficos da lusofonia, contributos que, deliberadamente ou não, permitem um balanço do desenvolvimento da língua portuguesa".

É certo que o tema se justificava no ano em que se constituía a Comunidade dos Países de Língua Portuguesa (CPLP) e na mesma data em que os acordos do Mercosul eram assinados. No entanto, mais dez anos serão ainda precisos para que a AULP se venha a constituir como Observador Consultivo privilegiado da CPLP. 
Finalmente, uma fase final, como que de relacionamento externo que anuncia o futuro, marca o ano de 1996, com os números quinze (Julho) e dezasseis (Dezembro). O primeiro traz a marca da pretensão de expansão maior, quando a representante da União Latina em Portugal, Renée Gomes, assina o editorial, numa revista cujo foco serão "As linguagens científicas e técnicas." Procura-se realçar o papel que desempenham as linguagens de especialidade, e em particular as terminologias, na fixação da língua e na sua adequação à modernidade, entendendo a língua como factor predominante de manutenção e transmissão da cultura. O segundo será dedicado ao "Português nos meios de comunicação", expressão já dessa abertura ao exterior, reconhecendo-se as inúmeras questões que se põem ao uso da língua na rádio, na televisão e na imprensa.

Um último número, dezassete, já em Julho de 1997, será especialmente dedicado à literatura infanto-juvenil. No editorial, Maria Augusta Seabra Diniz lembra que a educação das crianças é um dos elementos fundamentais de qualquer processo cultural, e a dedicação de um número da RILP a este foco significa, antes de mais, o reconhecimento da existência de uma literatura de qualidade lusófona especificamente destinada a crianças e jovens. Está em causa o encontro da fantasia do adulto com as experiências e fantasias da criança, dinamizando o encontro do ser humano imaturo com a experiência vivida pelos mais velhos e com a estrutura cultural que organizaram para dar expressão comunicável e partilhável a essa experiência.

Será também este número que marca a saída da última RILP, pela mão de Helena Mira Mateus, que, iniciadora do projecto, o vai adoptando, filiando e finalmente visando a sua autonomia, prosseguindo na senda de a registar formalmente em seu nome e das suas colaboradoras, numa fase em que as exigências sobre a edição já se faziam sentir e impunham novas obrigações.

Adversidades marcam a saída de Helena Mateus. Em desacordo com a manutenção da revista como propriedade da AULP, esta reage e em acção judicial ${ }^{4}$ contesta o registo nominativo de Helena Mira Mateus, ganhando o reconhecimento da propriedade formal sobre a RILP.

4 Em acta do Conselho de Administração de 15 de Julho de 1999, dá-se conta desta ocorrência. Uma acção judicial proposta pela AULP, intentada pelo gabinete jurídico de Pena, Machete \& Associados, recuperará a propriedade formal da RILP. Na pendência da decisão judicial, decide o Conselho de Administração, na mesma reunião, que o próximo número da RILP deveria ser publicado no Brasil e o director da revista deveria ser, por inerência, o presidente da AULP. 
Anos idos, desgostos passados, aqui fica o reconhecimento. Sem o trabalho, a sabedoria e o empenho de Maria Helena Mira Mateus, muito não se teria feito pela língua portuguesa, da qual fica o registo em dezassete números exemplarmente consecutivos, numa gestão cooperativa, cuja forma e conteúdo falam por si, malgrado as dissidências na despedida.

\section{Série - A maturidade cultural e os incidentes de percurso}

A intenção institucional de manter a RILP levou a AULP a solicitar ao embaixador José Augusto Seabra, à data representando Portugal na Roménia, que dela se ocupasse.Este, ao aceitar o encargo, fá-lo na qualidade de coordenador, trazendo a público um primeiro número, em Dezembro de 2000, impresso no Brasil.

Assumindo que de uma segunda série se tratava (vol.1, n. ${ }^{\circ} 1$ ), numa altura em que a Presidência da AULP era moçambicana, a Universidade Eduardo Mondlane, na sequência do primeiro mandato brasileiro efectivo, pela mão do Reitor Ruy Pauletti da Universidade de Caxias do Sul (1996-1999), será adoptada uma clara posição institucional para a RILP, e o editorial de Inguelore Scheunemann de Souza, Reitora da Universidade Federal de Pelotas, Vice-Presidente brasileira, igualmente o esclarece.

Este número será publicado no Brasil e realizado na gráfica da Universidade Federal de Pelotas, marcando assim um esforço de internacionalização do próprio local de edição, consequência de novos tempos associativos e das dificuldades jurídico-legais do momento. Certamente em resultado dos embaraços de transporte transatlântico, a sua distribuição em Portugal foi restrita e existem apenas alguns exemplares na sede da AULP. As mudanças gráficas realizadas actualizaram-na, e à nova figuração e imagem corresponde um conteúdo mais livre e culturalmente amadurecido.

A dignidade do número um desta nova série espraia-se no seu objectivo. Porque em 2000 o Brasil festejava quinhentos anos, Inguelore de Souza vem, no editorial, afirmar que o Brasil,"com 165 milhões de habitantes, sabe de suas altas responsabilidade na preservação da língua comum, pois esta pertence a todos os usuários." Pois será “Em nome de uma identidade comum e por ocasião do relançamento da RILP, editada pela AULP, que as Universidades do Brasil, Portugal, Angola, Moçambique, Cabo Verde, Guiné-Bissau, São Tomé e Príncipe,Timor-Leste e Macau reforçam o génio mais íntimo de cada povo, sua alma profunda, está presente, sobretudo, em sua língua".

O texto de José Augusto Seabra, na qualidade de coordenador, vem reforçar a afirmação: 
A Revista Internacional de Língua Portuguesa dedica este seu número especial, sob o signo do Quinto Centenário da Descoberta do Brasil, à evocação de domínios e momentos relevantes da vida de um povo que é hoje uma das nações mais importantes da América Latina e do mundo inteiro. No quadro das comemorações oficiais e institucionais dessa efeméride de alcance histórico e civilizacional, não apenas para os dois países irmãos e os da Comunidade linguística a que pertencem, mas para toda a humanidade, pelo seu significado universalista, as Universidades assinalando o acontecimento e mostrando a necessidade de um estudo rigoroso das grandes questões que interessam à prospecção do passado, do presente e do futuro do povo brasileiro, nas suas relações com os outros povos e antes demais com aqueles com quem partilha o idioma comum.

Para o efeito, foram convidados muitos autores. Maria Helena da Rocha Pereira, Antonio Paim ou António Braz Teixeira, Miguel Real, Maria Beatriz Nizza da Silva ou o próprio José Augusto Seabra constituem um elenco admirável na expressão escrita que concedem ao diálogo luso-brasileiro.

Simultaneamente, a AULP já tinha festejado dez anos de existência; se o VI Encontro (1996) em Lisboa terá ficado marcado pela comemoração e pelo alento da constituição da estrutura política federativa que a CPLP, dez anos depois de ser criada, representava, também a realização do segundo encontro realizado no Brasil, no Rio de Janeiro ${ }^{5}$ (o VII), e o primeiro encontro realizado em Macau, o VIII em 1998, marcava o período de efectiva internacionalização da associação, potenciada pela plena participação da franja asiática. Esta última integração fora significativamente apoiada pelo Governador da Região Administrativa de Macau, General Vasco Rocha Vieira, e pelo seu Secretário adjunto para a Administração, Educação e Juventude, Jorge Rangel, apoio com expressão financeira que possibilitou a reforma física e a efectiva instalação e equipamento da sede própria da AULP em 1999, em edifício arrendado por valor simbólico pela Câmara Municipal de Lisboa.

No entanto, na AULP vinha-se então sentindo a necessidade de maior vigor de actuação, para além do convívio interuniversitário que os encontros proporcionavam, de direcção de objectivos e de recuperação da participação de associados, ausentes na sequência de um longo debate interno, iniciado em 1999, com a chamada do Ensino Superior Politécnico à participação associativa, pela mão do secretário-geral, Dr. Manuel Coelho da Silva. Este tema viria trazer alguma intranquilidade à vida associa- 
tiva, particularmente sentida no XI Encontro em Viseu, então atenuada pela intervenção e acção do Presidente da AULP, Brazão Mazula (1999-2002).

As perturbações sentidas germinaram a convicção da necessidade de mudanças funcionais e, nessa sequência, foram aprovadas, em 2001, alterações significativas aos Estatutos, à luz dos quais foi eleita, em 2002, uma nova direcção, presidida pelo Reitor da Universidade Agostinho Neto de Angola, João Sebastião Teta (2002-2005).

Do ponto de vista institucional, desde 2001 que a AULP sofria as mutações que levariam à recomposição do seu Secretariado, uma vez que o Dr. Manuel Joaquim Coelho da Silva, que ocupara funções entre 1986 e 2002, durante dezasseis anos consecutivos, num sistema de eleição pessoal, saía, após a alteração estatutária que democratizava a eleição do Secretariado, abandonando funções em desacordo de orientação com sucessivas presidências. Sem prejuízo da sua intensa e longa dedicação, a que a AULP deve vida, a sua saída acarretará consequências que transformarão decisivamente o funcionamento da Associação.

Nesta fase deliberativa da AULP, a RILP manteve a tónica cultural. Aberta que fora uma segunda série da revista, um segundo número (Vol.1, n. 2) sairá em Abril de 2002. Justificada será a sua dedicação à Africa Lusófona. Tal como o número anterior fora consagrado à evocação dos cinco séculos de irradiação histórica do idioma comum no vasto território geocultural do Brasil, caberá agora a África a atenção de um número especial, que se autolegitima também na sequência da realização do XII Encontro da AULP, nesse ano de 2002, em Luanda.

Será das línguas, mas também de poesia, romance e escrita africanos que esta RILP se ocupará. Uma breve antologia dos poetas africanos de língua portuguesa e o encerramento do número com uma tradução de Manuel Viegas Guerreiro do Conto maconde de tema universal compõem este número, tornando-o um dos mais atraentes da colecção.

Simultaneamente, tomará o lugar de secretário-geral Alarcão Troni (2002-2005), que acompanhará a Presidência angolana, mas a sua disponibilidade será interrompida no final desse mandato, pela nomeação subsequente para Presidente do INATEL - hoje Fundação INATEL, prestadora de serviços sociais nas áreas do turismo social e sénior, do termalismo social, da organização dos tempos livres, da cultura e do desporto populares, com profundas preocupações de humanismo e de qualidade, herdeira histórica da antiga Fundação Nacional para a Alegria no Trabalho (FNAT) fundada em 1935.

Os encontros da AULP emergiam então à luz dos seus associados como fóruns e arenas de discussão em que a centralidade do tema lançado em 2002, no X Encontro 
em Ponta Delgada, "O ensino superior na sociedade do século XXI", continha a promessa e acalentava a possibilidade de instituir um espaço lusófono do Ensino Superior. Aliás, esta temática fora já anunciada em Maputo, quando o primeiro encontro realizado do lado do Índico, em 1999, o IX, se desenvolvera em torno do sugestivo tema "A Universidade em mudança".Tal ocorrerra durante a presidência da AULP pela Universidade Eduardo Mondlane, cujo Reitor, Brazão Mazula, foi um impulsionador activo da presença de Moçambique na Associação das Universidades de Língua Portuguesa e cujo consulado foi marcado pela presença conciliatória e serena de intelectual consagrado às matérias pedagógicas e ao ensino universitário.

De facto, desde 2000 que as reuniões dos dirigentes das Universidades participantes se concentraram na constituição de instrumentos capazes de criar estruturas visando a uniformidade das Instituições de Ensino Superior e Investigação Científica do espaço lusófono com vista à mobilidade crescente de natureza intercontinental.

Os temas dos encontros reflectem-no e concretizam-se. O XIII, realizado em Macau,em 2003, será dedicado ao“Espaço lusófono de investigação do ensino superior e investigação"; no ano seguinte em São Paulo, em 2004, a temática do XIV Encontro será "Em busca de uma cooperação académica efectiva entre os países da CPLP", para em 2005, no XV Encontro em Lisboa, se concretizar nos "Novos desafios no espaço do ensino e da investigação dos países de língua portuguesa".Estas reuniões são sede de importantes reflexões sobre os caminhos a percorrer para instituir um espaço académico lusófono e são acompanhadas da questão transversal da Universidade Virtual de Língua Portuguesa.

Mas são, sobretudo, o eco e o reflexo da atenção que as autoridades políticas dão a estas propostas, em particular a recepção dos ministros da Comunidade dos Países de Língua Portuguesa, que nas suas reuniões assinam a decisão de criar o Espaço Lusófono do Ensino Superior (em Fortaleza, em 2004), constituindo um grupo de trabalho no qual foi incluído um representante da AULP, destinado a preparar a respectiva implementação.

As dificuldades de concretização dos objectivos da vida associativa da AULP eram patentes na constituição deste espaço de Ensino Superior, quanto à investigação.Como afirma José Lopes da Silva, “Embora tenha sido avançada em reunião de Ministros da Ciência da Comunidade dos Países de Língua Portuguesa a ideia de criação do espaço de investigação, a sua concretização vai requerer algum tempo. Convém notar que, neste ponto, também não foram plenamente dados, no seio da AULP, todos os passos necessários para uma intervenção efectiva da Associação". 
O funcionamento corrente era também dificultado pela sucessão de dois mandatos exercidos a partir de presidências longínquas da sede internacional, sediada estatutariamente em Portugal.Todavia, devido ao falecimento súbito de José Augusto Seabra, esta série da revista será prematuramente interrompida.

O terceiro e último número (Vol. 1, n. ${ }^{\circ}$ 3) estava pronto e viria a público in memoriam do seu coordenador em Setembro de 2004. Será a José Lopes da Silva, Reitor da Universidade Técnica e Vice-Presidente português da AULP (2002-2005), que caberá, na sua nota de abertura, ligar de novo de forma intrínseca AULP e RILP.

Este número é o corolário lógico dos dois primeiros. Na sua aparente anarquia cultural, a ordem é fornecida pelo intuito de representação equilibrada e pelo valor equitativo dados aos diferentes universos culturais em presença. Cabia agora ao Oriente, a Macau, onde se realizara em 2003, o XIII Encontro, esse espaço onde, conforme as palavras de José Augusto Seabra, "essa diáspora linguística asiática foi, desde as descobertas até hoje, um elemento precioso de diálogo entre as civilizações orientais e ocidentais, que através de vicissitudes históricas abria caminho à mundialização em curso".

São poemas orientais, sequências goesas, é o Japão íntimo de Armindo Martins Janeira, ou as variações sobre uma ideia de Oriente, escritos de autores onde a paixão pelo Oriente se impõe e onde não faltam textos sobre as famosas "Afinidades com o Oriente" pensadas por Agostinho da Silva.

Do empenho e da coordenação de José Augusto Seabra fica-nos um legado marcante, transmutado em três volumes da RILP: um dedicado ao Brasil, outro a África e este último ao Oriente.

Desde então órfã de coordenação e atenção, a RILP ficará abandonada à sorte institucional e à inexistência de coordenação na sede ou de conselhos editoriais repartidos pelos vários continentes, onde países e culturas diferentes concorrem pela expressão em português. Apenas três números $(2000,2002,2004)$ em oito anos autenticam o esforço realizado pela manutenção da RILP, mas também a quebra da estrutura antes consolidada.

As vicissitudes da RILP, ao longo da segunda série, são certamente intrínsecas, mas são também reflexo de um período de forte debate interno na AULP, de rearranjo de forças e energias, num mundo em mutação que também na AULP se reflectiu e a vida associativa espelhou.

No final do mandato da Universidade Agostinho Neto, de Angola, em 2005, a presidência da AULP será entregue a Portugal, à Universidade do Algarve (2005-2008), 
que pela mão do seu Reitor, Adriano Pimpão, se irá ocupar da crise institucional que então assolava o ambiente universitário português, em que Universidades e Institutos Superiores Politécnicos se desencontravam na procura do respectivo lugar no seio do mundo académico português. Esta controvérsia reproduzia-se no seio da AULP, e os outros sistemas de Ensino Superior demonstravam estranheza.

A esta escolha da Presidência por Portugal não será alheio o facto de a Universidade do Algarve ser a única instituição nacional onde convivem aqueles dois tipos de ensino superior, certamente não sem dificuldades, mas com que os seus responsáveis estão familiarizados e são contrafeitos a bem gerir.

Assim, em Janeiro de 2006, para Portugal, a questão prioritária da AULP será a recomposição do Conselho de Administração, o que será levado a bom porto pelas conversações do seu Presidente, Adriano Pimpão, com o Presidente do Conselho Coordenador dos Institutos Superiores Politécnicos Portugueses, Luciano de Almeida, hábeis negociadores que permitiram alcançar a estabilidade, não sem sequelas no âmbito associativo, que muitos associados, nomeadamente do Brasil, não tinham sustentado.

Todavia, a característica de a Presidência ser de foro institucional não permitiu maiores desenvolvimentos até Março de 2006, data de substituição electiva dos responsáveis da Universidade do Algarve. Controvertida era a questão do lugar de secretário-geral, que continuava por preencher, suscitando-se dúvidas sobre a necessidade de profissionalização ou não do cargo, tendo o Conselho de Administração decidido que o funcionamento corrente seria assumido pela equipa de colaboradores composta por Gabriel Feio, Analídia Perdigão e Rogério Rei, com a promessa, registada em acta de Janeiro de 2006, de que se tentaria estabelecer contactos com vista ao preenchimento do lugar dentro dos condicionalismos financeiros da Associação.

Em Junho de 2006, realizava-se em Macau o XVI Encontro da AULP, o último dedicado à "Organização do espaço de ensino superior e investigação dos países de língua portuguesa",que demarca quase uma década de esforço cooperativo particularmente dirigido, mas também de arrastamento de uma questão, que ganhava intenção política formal cada vez mais significativa; no entanto, adquiria também distância real da prática efectiva, face à pressão sobre o sistema de ensino superior e de investigação portuguesa provocada pela profunda reforma europeia que, entretanto, condicionava a dinâmica e a autonomia institucionais.

Às alterações no espaço nacional português correspondem também dinâmicas internacionais, de integração regional, de crescimento individual ou regressão dos outros espaços de língua portuguesa. 
Se em 2006 nascia a primeira Universidade Pública em Cabo Verde, já em 2008 era suspensa a única participada em $50 \%$ pelo Governo da Guiné-Bissau. Se em São Tomé e Príncipe a abertura ao crescimento cooperativo se mantém necessária ao pequeno espaço equatorial, em Timor a cooperação acentua-se sob forma bilateral, a única sustentável face às dificuldades do longínquo novo Estado falante de língua portuguesa. A par, registam-se fortes impulsos governamentais sobre o ensino superior em Angola, cujo impacte certamente se fará sentir nas próximas décadas e que ainda não pode ser mensurado, ao ser descentralizado o ensino superior de Luanda para regiões académico-administrativas com vista à expansão nacional do ensino superior público, que concorre com o manifesto incremento das instituições privadas recém-criadas. Se em Moçambique o crescimento do Ensino Superior Público e Privado aparentemente se alheia, por vezes, da unidade linguística, já no Brasil a Presidência Lula veio incentivar fortes dinâmicas autónomas no ensino superior e na investigação, em particular com acentuada motivação na direcção sul-sul e incentivando a participação em organizações sul-americanas.

Neste quadro diferenciado e dinâmico que se estabelece e vai emergindo, a AULP prossegue a sua actuação. A segunda metade do ano de 2006 foi o ano da estabilização do Secretariado ${ }^{6}$, por proposta da recém-reassumida Presidência da Universidade do Algarve, pelo Reitor João Guerreiro, e aprovada na Assembleia-Geral de Macau. Em 2007 a AULP acorrerá a Cabo Verde, onde realiza o seu XVII Encontro, para acolher no seu seio a recém-criada Universidade Estatal, sob os auspícios da "Universidade em Rede", única formulação que parece corresponder aos novos tempos e define também uma instituição criada a partir de uma rede polimórfica anterior de Institutos de Ensino Superior acolhidos sob uma mesma autoridade académica.

Assumida a necessidade científica de ser a Universidade anfitriã a propor o tema sob o qual se reúnem as Universidades e Instituições de Ensino Superior e Investigação Científica de Língua Portuguesa, será à luz deste princípio de democraticidade que, doravante, pugnará a actuação da AULP.

A interrupção da publicação das actas dos Encontros Científicos da AULP em 2004 concentrará, na fase inicial, os esforços do Secretariado em disponibilizar os materiais de que entretanto dispunha ou recolhia: XIV Encontro em São Paulo, Brasil (2004); XV

6 A opção será a de nomeação de uma académica sem exclusividade de funções. Será contratado um jovem cabo-verdiano, Suzano Costa, que entrará aquando da saída por reforma de Ana Lídia Perdigão e da indisponibilidade entretanto manifestada por Gabriel Feio, que exercia as funções de secretário-geral interino desde a saída de Alarcão Troni. 
Encontro em Lisboa, Portugal (2005); XVI Encontro em Macau, China (2006); e, já sob o título de Universidade em Rede, XVII Encontro da Cidade da Praia em Cabo Verde, todos vindos a público entre Novembro de 2007 e Fevereiro de 2008, num esforço de recuperação que estabilizou estas edições e garantiu o acesso da comunidade aos debates neles realizados.

Estreia-se ainda o interesse em disponibilizar edições úteis e capazes de homenagear as Universidades anfitriãs dos Encontros Científicos da AULP, os que nelas se dedicam à investigação, ou se lhes devotaram ou nelas se investiram de corpo e alma de investigadores e humanistas. Assim em Cabo Verde, com a reedição de Santiago, a llha e os Homens, de llídio do Amaral; assim em Brasília, com a colaboração com a Universidade Católica Portuguesa que permitiu levar ao XVIII Encontro, em 2008, Ano Vieirino, novas fixações de textos, belamente ilustrados, de três Sermões do Padre António Vieira, embaixador das relações luso-brasileiras; assim em Angola, no ano de 2009, no XIX Encontro em Luanda, em que foi possível renovar o acesso ao público académico às obras de José Redinha (Etnias e Culturas de Angola) e de José Grandvaux Barbosa (Carta Fitogeográfica de Angola), ambas as obras desaparecidas, com reedições agora realizadas pela AULP, fruto do empenho conjunto de várias instituições académicas e científicas.

Entre 2006 e 2008, com a actualização do logótipo, marca da Associação onde se registam os vinte anos agora decorridos, com a actualização de recursos pelo reinvestimento na página electrónica da AULP, para que a Universidade de Macau concorrera, e conseguidas a estabilidade financeira e a dignificação externa do edifício da sede, estavam criadas as condições de continuidade saudável da vida institucional da AULP.

A partir da reunião do Conselho de Ministros da CPLP, realizada em Bissau em Julho de 2006, a AULP adquire formalmente o Estatuto de Observador Consultivo da Comunidade dos Países de Língua Portuguesa, conquistando o direito de assistir às reuniões de carácter técnico que se afigurem de interesse para os objectivos que a AULP prossegue; no entanto, neste contexto, funções formalizadas cruzam-se e desencontram-se com as burocracias institucionais.

Em 2008, a necessidade de adiar de Maio para Setembro a realização do XVIII Encontro em Brasília, consequência de dificuldades internas vividas pela Universidade anfitriã e da participação efectiva de várias instituições, embaraçou a operacionalidade dos meios do Secretariado, porquanto obrigou à duplicação de meios postos à disposição da organização do Encontro que se viria a realizar sob o lema proposto de 
"Ciência, tecnologia e desenvolvimento", conforme as Actas publicadas em Fevereiro de 2009 documentam.

Nesse período foram reabertas as relações exteriores da AULP, nomeadamente com a União Latina e com a AUF (Associação das Universidades Francesas), e acentuou-se o esforço para reconstituir um Conselho Editorial que permitisse dar continuidade à RILP, mas contactos infrutíferos em Cabo Verde, Angola ou Moçambique não o permitiram. A intenção é clara, os meios são restritos e a actividade publicista da Associação é intensa. No entanto, em 2008, a Revista Internacional de Língua Portuguesa foi dada à estampa.

\section{Série - Um veículo para a ciência e o esforço pela continuidade}

Podemos afirmar que, fruto desta viragem e organização, foi pela consciência colectiva que envolveu os órgãos da Administração e do Secretariado e pela iniciativa do seu Presidente que a RILP renasceu.

Assim, em Maio de 2008, o Presidente da AULP à data, João Guerreiro, Reitor da Universidade do Algarve, anuncia, nas palavras de abertura: "A Revista Internacional de Língua Portuguesa, órgão da Associação das Universidades de Língua Portuguesa, inicia com este número a sua III Série. Esta nova série representa uma alteração no rumo editorial da revista. $O$ carácter genérico das séries anteriores é abandonado em benefício da procura de temas que suscitem o interesse da comunidade universitária da CPLP e para os quais se detectam fortes expectativas de criação de redes de investigação ou de pós-graduação, ou do lançamento de programas de mobilidade que abranjam membros da nossa comunidade."

Não se tratará mais de uma revista sobre a língua portuguesa mas em língua portuguesa, em que os diferentes estágios da ciência e os desenvolvimentos científicos dos países das comunidades que por ela e através dela comunicam possam interagir em vários domínios científicos.

A primeira escolha temática recai sobre as ciências agrárias e será resultado do empenho e da competência de um grupo de trabalho liderado por Fernando de Oliveira Baptista do Instituto Superior de Agronomia da Universidade Técnica de Lisboa, em colaboração com Izabel Cristina Takitane, da Universidade Estadual Paulista, do Campus de Botucatu, Brasil, surgindo a público com o título Agricultura e Desenvolvimento Rural.

Aí se afirma:"O interesse deste número temático, dedicado às ciências agrárias e aos espaços rurais nos países da CPLP, reside no facto de se poder antever, através da refle- 
xão que os diversos autores fazem sobre essas mesmas realidades, qual o 'estado da arte' das preocupações académicas e das pesquisas científicas com incidência naqueles domínios científicos."

Este primeiro número da terceira série retomará a numeração inicial, pelo que se apresentará sob o número vinte e um, esforço de diferenciação na continuidade, rendendo-se dessa forma homenagem à longevidade de mais de vinte anos da RILP.

Nas palavras de abertura, prospecta-se ainda o futuro:"As colaborações solicitadas terão sempre a preocupação de oferecer um leque tão alargado quanto possível das inquietações que, em cada momento, permitem reflectir as problemáticas dos países da CPLP, garantindo que cada número temático possa cumprir o seu papel de catalisador no processo de elaboração científica que decorre da inconformidade universitária."

Focada a atenção na agricultura, será tratada a problemática do desenvolvimento rural nos períodos colonial e pós-independência em Angola e Moçambique e os modelos de desenvolvimento aplicados; mas são também tratadas as especificidades de Cabo Verde, as questões relativas ao agronegócio e à produção do biodiesel ou os aspectos relativos à sanidade animal no Brasil; aborda-se ainda a procura dos novos caminhos portugueses para o desenvolvimento rural que conciliem as unidades do espaço agroflorestal, com uma gestão multifuncional e adequado quadro institucional, bem como a experiência de rearticulação do ensino superior das Ciências Agrárias em Timor-leste. "É uma diversidade que, cremos, pode permitir enriquecer o diálogo e o debate na academia entre os países de língua portuguesa", como refere a nota introdutória dos seus editores.

Tempos diferentes impuseram novos rigores. A RILP é agora preparada editorialmente no Secretariado para registo e referenciada no catálogo internacional LATINDEX, sistema internacional de informação internacional de revistas científicas, cujas exigências impuseram a sua anualidade, um conselho de acompanhamento científico e um processo de revisão de conteúdos que a transformou numa adequada revista científica tendente à circulação internacional.

Reassumida a importância deste veículo de transmissão e criação de cultura científica em português, assim se perspectivará no Conselho de Administração de Janeiro de 2009, por proposta do agora vice-presidente português da AULP, João Guerreiro, Reitor da Universidade do Algarve, repto aceite pela recém-eleita Presidência brasileira, da Universidade Federal de Minas Gerais (2009-2011), com a Reitoria a cargo de Ronaldo Tadêu Pena e ainda a colaboração aceite pela Universidade Agostinho 
Neto, de Angola. Mais um número da RILP se anuncia a partir de uma estrutura com responsabilidade tripartida. A proposta inicial de a consagrar aos Recursos Hídricos Costeiros. Necessidades de Cooperação Científica, Educação e Perspectivas Futuras, com vários tópicos, evoluiu para a centralidade do tema Água, cuja formulação final virá a resultar da compilação dos artigos da responsabilidade dos seus editores científicos designados pelas Universidades referidas.

Estamos em crer que a importância do tema, mas também da RILP como meio de comunicação científica, determinarão a conclusão da mesma e assegurarão à revista a continuidade da sua publicação. Queremos, para concluir, retomar a tese que justificou estas incursões no domínio da Revista Internacional de Língua Portuguesa.

Como antes afirmámos, a cultura, como recurso político e económico, tem ganho legitimidade e é hoje o eixo de uma nova estrutura assolada por uma racionalidade económica, de tal forma que a conservação, o acesso, a distribuição e o investimento em "cultura" e nos seus resultados se tornam prioritários e politicamente relevantes. A cultura é no presente percebida como algo em que se deve investir, distribuída nas mais diversas formas, utilizada como atracção para o desenvolvimento económico e turístico, como mola de indústrias culturais e como uma fonte inesgotável para novas indústrias que dependem da propriedade intelectual.

A alta cultura tornou-se um recurso para o desenvolvimento urbano. As indústrias da cultura de massas, em especial as indústrias do entretenimento que integram a música, o filme, o vídeo, a televisão, as revistas, a difusão por satélite e por cabo, constituem importantes contributos para os Produtos Internos Brutos. Vendendo cidades, regiões ou inventada na tradição, a cultura como ideia e conceito ganha novos contornos analíticos.

As noções convencionais de cultura esvaziaram-se e o papel da cultura expandiu-se como nunca para as esferas política e económica. Se tomarmos aqui como pressuposto que a cultura não precisa de ser apreendida como a consideração particular de certos atributos (normas, valores, costumes ou crenças) que seriam as características de um qualquer grupo particular da sociedade, ou seja, como a sua intrínseca identidade, ela pode ser considerada como um sistema simbólico que permite que as pessoas partilhem significados e, por consequência, poderemos assumir que as transformações sociais e políticas estão culturalmente ancoradas. Com as indústrias culturais, o capitalismo tornou-se cultural. Este capitalismo, que conduz as mudanças de comportamento em todas as áreas culturais, terá na versão política a sua consagração na expressão soft power de Joseph Nye. 
A língua enquanto código de cultura partilhado é fonte de soft power. Este tipo de poder está presente tanto na dimensão política, quanto na económica e na da cultura por via da língua, e mostra que o tipo de poder que a "cultura" veicula tem certamente graus de imaterialidade mas dá corpo a tipos de exercício do poder em formatos benévolos que nos comprazemos a preferir em sociedades pacificamente organizadas.

Cultura e poder são forças interligadas que se podem utilizar como um instrumento em benefício estrutural. Importa assegurar que as comunidades de língua portuguesa o saibam conservar, potenciar e transmitir, no ano de 2009 que a Europa dedica à criatividade e inovação no âmbito da Agenda Cultural Europeia. 
Recensões críticas 



\title{
SOUTO, Maria Helena, História do Design em Portugal I, Prefácio de José- -Augusto França, Lisboa: Edições IADE, 2009, 94 pp. + [50] il.
}

\author{
Leonor Ferrão
}

Importa, antes de mais, saudar uma publicação que se inscreve num registo disciplinar no qual escasseiam os contributos, embora o título prometa o que não cumpre. $O$ número romano aposto ao título História do Design em Portugal sugere o arranque de uma série subordinada à mesma temática, mas acaba por induzir em erro, ao fazer prever uma obra com outra extensão e coesão interna. Dispersos, subsídios ou contributos para a História do Design em Portugal seriam algumas das possibilidades para designar esta colectânea de ensaios historiográficos de curta dimensão, redigidos seguramente em momentos diferentes, embora essa informação não seja disponibilizada ao leitor: falta-Ihes um fio condutor, para além do que é sugerido pelo contexto disciplinar indicado no título, apesar de alguns textos se posicionarem em territórios de fronteira ou para além da fronteira do campo disciplinar do design. Falta, também, um texto que explicite os critérios que presidiram à selecção e ao alinhamento propostos (a "nótula" não cumpre essa função). O único propósito anunciado no pequeno texto introdutório é o de "dar aos estudantes de design uma ferramenta a partir da qual possam iniciar o seu conhecimento e as suas pesquisas sobre a história da disciplina no caso português" (p. 18). A complexidade dos textos e os espaços que deixam por preencher, se olharmos de novo para o título da colectânea, onde se anuncia uma narrativa estruturada sequencialmente, não parecem estar ao alcance da maioria dos estudantes de Design. Celebrar os quarenta anos do IADE, cumpridos em 2009 - propósito anunciado pelo coordenador das edições do IADE -, teria sido razão bastante para justificar esta publicação, embora, insista-se, continue a não justificar o título escolhido e, menos ainda, o desenvolvimento do ensaio final (pp.83-88): mais útil fora elaborar um texto sobre os fundamentos do IADE, sem ignorar o contexto e sem perder o foco no essencial, mostrando que a importância da instituição não ficou só a dever-se à sua circunstância. Se outras razões não houvesse, a efeméride justificaria, plenamente, que se desse a conhecer a sua história. Esperava-se, por isso, muito mais do que um alinhamento de imagens que não são tecidas com o texto e muito mais do que a enumeração de disciplinas e de professores, embora a autora procure articular 
estes dados com considerações mais ou menos avulsas sobre outros protagonistas (ou sobre o que é o Design). Acrescente-se que Helena Souto é professora do IADE e tem currículo científico e pedagógico muito relevante, pelo que dispensa condescendência na apreciação do seu trabalho. Dito isto, os textos mais interessantes são o ensaio "Desenvolvimento das estruturas metálicas" (pp. 41-50) e algumas páginas sobre Rafael Bordalo Pinheiro (pp. 57-71). A propósito deste último ensaio, discordamos da aplicação do conceito "design de exposições" (porque, no contexto, soa a anacronismo) - e constata-se, de novo, o desajuste entre o título e o desenvolvimento. Por exemplo, a autora não esclarece qual é a relação entre a obra de Bordalo Pinheiro (1846-1905) e a de Leal da Câmara (1876-1948), para além de um denominador que foi comum a outras personalidades artísticas, i.e., a suposta "influência geométrica", próxima do Modern Style e da Wiener Secession (conceitos que coincidem no tempo, mas que diferem em muitíssimos aspectos). Pelo meio, fala de raspão de Raul Lino (1879-1974), mas a formação, as notas de personalidade e os pressupostos estéticos e ideológicos de Bordalo e de Lino são dissemelhantes. A preocupação de Bordalo com a necessidade de requalificação estética e funcional da produção industrial parece-nos bem exposta, mas não é possível ignorar que parte significativa da sua produção para a fábrica das Caldas da Rainha assentou em peças únicas e que uma das suas linhas de inspiração, talvez a mais importante, não teve nada de vernacular, nem de "portuguesa": referimo-nos à influência da cerâmica de Bernard Palissy (c. 1510-c. 1590), pese embora que parte da temática acabou sendo "aportuguesada". Sumariando razões, ficou por traçar a genealogia formal e simbólica da cerâmica de Bordalo e por problematizar por que razão Bordalo Pinheiro cultivou várias linguagens. Dito de outro modo, ficamos sem saber se Bordalo foi um ecléctico por opção ou por imposição de alguns encomendadores. No ensaio "O debate entre engenheiros e arquitectos" (pp. 26-39) verifica-se de novo o desajuste entre o título e o desenvolvimento. De facto, não houve debate nenhum, pelo menos durante o século XVIII;e, mesmo durante o século XIX, tudo não terá passado de desabafos sem eco, como os de Joaquim Possidónio Narciso da Silva (1806-1896): a desproporção entre os hipotéticos opositores, em número e em notoriedade social, não autoriza o termo "debate". A equidade entre arquitectos e engenheiros, pelo menos no acesso a concursos públicos para provimento de vagas para técnicos de 1. a classe, só aconteceu nos anos 30 do século XX, por iniciativa do engenheiro Duarte Pacheco (1899-1943). Assim, o reconhecimento que faltou aos arquitectos, até ao consulado de Duarte Pacheco, manteve-se muito para além do razoável, se admitirmos que a razão primeira para esta realidade 
poderia justificar-se pela fraca qualidade do ensino de arquitectura ministrado nas escolas de Belas-Artes portuguesas. No entanto, os arquitectos portugueses diplomados nas Beaux-Arts de Paris também não lograram obter qualquer reconhecimento extra pela excelência artística e técnica da formação recebida, em muitos casos com bolsas de estudo do mesmo Estado que Ihes negava os lugares cimeiros na Administração Pública. Sobre estas questões, valeria a pena considerar os estudos de Maria Helena Lisboa, de mestrado (1996) e de doutoramento (2007) - o primeiro é citado (p.45), mas apenas a propósito do texto dedicado às estruturas metálicas. Em Portugal, ao contrário de outras nações europeias, a figura socioprofissional do engenheiro cresceu em importância desde que surgiu formação específica para este grupo profissional, também por causa das fragilidades (já apontadas) no ensino de arquitectura e, talvez, por omissão dos arquitectos, mas não terá sido apenas por estes motivos: a difícil conjuntura político-militar posterior ao golpe palaciano de 1 de Dezembro de 1640 e a carência de técnicos qualificados nas colónias ultramarinas foram favoráveis aos engenheiros, tal como o quadro da reconstrução da cidade de Lisboa, em contexto cultural do lluminismo (que valorizou a cultura técnica em detrimento da cultura artística). Poderíamos, ainda, se mais não houvesse, invocar a ausência de produção teórica em arquitectura e a falta de profissionais com a envergadura intelectual do mesmo nível de Luís Serrão Pimentel (1613-1679) e de Manuel Azevedo Fortes (1660-1749), engenheiros que se bateram pela dignificação do estatuto socioprofissional dos seus pares nas várias tribunas a que tiveram acesso. Neste momento, $\mathrm{e}$ reportando aos séculos XVII e (parte do?) XVIII, não é possível saber quais foram as razões para o silêncio dos arquitectos relativamente à sua condição de subalternos perante os engenheiros, pelo menos até Possidónio da Silva, embora haja os protestos do arquitecto José Manuel de Carvalho e Negreiros (1752-1815) nas suas Jornadas pelo Tejo (1792) e no Aditamento (1797) - todavia, Negreiros disparou em diversas direcções, inclusive sobre os arquitectos, nomeadamente sobre os diletantes (e não o eram todos?). Assim, tanto Negreiros como Possidónio terão sido atípicos, porque se formaram fora de Portugal e porque protestaram. O que pensariam os outros, que eram a maioria? Ao contrário dos seus colegas franceses, nomeadamente os que estavam sob a asa protectora da Academia Real de Arquitectura, os arquitectos portugueses, com formação na Aula de Arquitectura Civil do Paço da Ribeira, eram muito poucos (comparativamente com o número de engenheiros formados na Aula de Fortificação), e a maioria não passou do estatuto de "criado para todo o serviço" na Casa das Obras e Paços Reais. A própria encomenda arquitectónica privada não pri- 
mou pela exigência, pelo que as razões para a posição de desfavor dos arquitectos relativamente aos engenheiros não podem comparar-se, por exemplo, com a situação francesa, nomeadamente após a abertura da École Nationale des Ponts et Chaussées (1747). E, porque a recensão vai longa, termina-se com o que nos parece ser o melhor deste livro, o prefácio de José-Augusto França.Trata-se de um texto curto, que se lê de uma assentada e com imenso prazer. No lapso de uma respiração, França traça o essencial sobre o pouco que se conhece de história do design em Portugal, campo disciplinar que não é a sua "zona de conforto".É, por isso, de elementar justiça reconhecer o mérito de Helena Souto, em primeiro lugar, pela escolha do prefaciador e, em segundo lugar, por ter conseguido publicar os seus ensaios, o que não é fácil no actual panorama editorial; por fim, por ter sabido vencer o silêncio que costuma pairar sobre a maior parte da produção científica em Portugal nas áreas da história da arte (e do design). Espera-se, por isso, para breve uma História do Design em Portugal II, para não quebrar a linha de continuidade, com um subtítulo que possa enquadrar os conteúdos, sem prometer nem mais nem menos do que pode oferecer. 


\title{
GUIBAL, Francis, Le Courage de la raison - La philosophie pratique d'Eric Weil.Paris: Editions du Félin, 2009, 391 pp.
}

\author{
Luís Manuel A. V. Bernardo
}

Vítima, quer do contexto, quer da sua recepção, a obra de Eric Weil (1904-1977), editada entre os anos 50 e 70 do século passado, não tem obtido o devido acolhimento pela comunidade filosófica. Se as interpretações magistrais de Kant (Problèmes kantiens. Paris:Vrin, 1970) e de Hegel (Hegel et l'état. Paris; Vrin, 1950) constituem referências cada vez mais frequentes nos trabalhos da especialidade (os quais persistem, contudo, em ignorar os importantes artigos sobre a filosofia dos dois autores germânicos publicados em Essais et conférences. Paris: Vrin, 1991 e Philosophie et réalité. Paris: Beauchesne, 1982), já os livros que encerram o seu pensamento original pouco são mencionados, fora de um círculo restrito de académicos cujo contributo investigatório se encontra ainda parcialmente compilado na página recente da "Association des amis d'Eric Weil", sediada no Centre Eric Weil da Universidade Charles de Gaulle, em Lille, onde leccionou durante quase duas décadas. Não fosse a indiscutível qualidade filosófica desses trabalhos, bem como a respectiva intenção de actualidade, esse relativo desinteresse seria facilmente compreensível. Com efeito, num tempo em que se impunha desconstruir as versões sistemáticas e metafísicas da História, tidas por matriz teórica dos horrores cometidos durante a II Guerra Mundial, a obra-prima de Eric Weil, Logique de la philosophie (Paris:Vrin, 1950), no seu esforço de síntese categorial em prol de uma compreensão das possibilidades enunciativas do discurso filosófico para conferir sentido à pluralidade de atitudes e de linguagens do mundo, aparecia, tal como a designou Jacques d'Hondt, como uma espécie de nova Fenomenologia do Espírito, ensaio revivalista portanto de uma prática filosófica que convinha, a todo o custo, exorcizar. Dessa reflexão fundamental resultava a exigência de uma Filosofia da Acção, na dupla vertente moral e política, de que deram conta duas obras: Philosophie politique (Paris:Vrin, 1956) e Philosophie morale (Paris:Vrin, 1961). Ao reproduzirem idêntico gesto ordenador, sobre ambas recaía a mesma suspeita de formalismo anacrónico e de intencionalidade totalizadora, aparentemente confirmada pela centralidade que, na primeira, se atribuía ao Estado, quando, em contrapartida, se impunha o quesito de desmontar a lógica do poder, e por um regresso, na segunda, a 
noções como a de vida moral, numa suposta ignorância do niilismo axiológico que afectava inexoravelmente a contemporaneidade. Essa versão de um Weil inconsequentemente conservador tem vindo progressivamente a alterar-se, por um lado, fruto de um tipo de interpretação mais atento ao sentido dos textos, por outro, não menos importante, como efeito colateral de haver muitos outros que, entretanto, têm seguido percursos então delineados, como sejam a retoma crítica do paradigma antigo ou a tentativa de produzir concepções positivas da moral e da política. Na realidade, a proposta de Eric Weil revela toda a sua oportunidade na medida em que, ao procurar um equilíbrio entre crítica e sentido, enuncia a questão filosófica de um modo que, depois de todos os intentos de fragmentação e de dissensão com os quais se visou obstar aos escolhos totalitários, se aproxima do coevo. Essa situação tornou perceptível que o que ficara muitas vezes por entender fora a intencionalidade primeira que assistia à constante apologia da razão por parte do autor:face aos excessos de violência, os quais, na leitura do filósofo, atingiram os limites da insensatez, deixando-nos a tarefa complexa de reconstruir a partir de um sentimento vivo de finitude um mundo onde o sentido se revelasse de novo possível, a opção pela razão, reconduzida por via de uma tal negatividade à expressão modesta da razoabilidade, deverse-ia assumir como um acto de coragem. Porquanto a Logique de la philosophie foi merecendo uma atenção mais consistente, nomeadamente em estudos de doutoramento, de entre os quais constitui menção obrigatória o do maior intérprete weiliano, Gilbert Kirscher (publicado como La philosophie d'Eric Weil.Paris:PUF, 1989), de uma tal revisão saíram, sobretudo, beneficiadas a Philosophie politique, em particular nas leituras de Patrice Canivez (La politique et sa logique dans l'oeuvre d'Eric Weil. Paris: Kimé, 1993), e a Philosophie morale que, após alguns artigos esclarecedores, nomeadamente os escritos por Émilienne Naert, encontra na obra em apreço um destaque apropriado, bem como a devida articulação com a política. Reunindo, em dez capítulos, nove artigos publicados ao longo da última década, actualizados e enquadrados por dois momentos - um, introdutório, no qual se contextualiza em termos de actualidade o problema de esteio; outro, conclusivo, em que surgem valorizadas as pontes com outros autores, de entre os quais avultam Paul Ricoeur e Emmanuel Lévinas, aos quais foi acrescentado um inédito, obedecendo a idêntico esquema -, saiu assim um trabaIho, cujo título, como decorre do exposto, não poderia ser mais adequado, destinado a ficar como um marco nos estudos weilianos. Se, no que respeita à filosofia moral, à qual dedica um terço do volume, não substitui uma análise sistemática da obra (mormente por se centrar predominantemente nos dispositivos previstos de efectuação 
da moralidade) e, quanto à filosofia política, deixa por aprofundar alguns dos assuntos de cariz mais político, preferindo-Ihes entradas mais amplas, como a das relações entre moral e política ou a da educação do cidadão (de que trata precisamente o capítulo VIII, escrito para esta publicação), no fim da leitura não restam dúvidas sobre a correcção e a consistência das análises, o elevado grau de esclarecimento que uma hermenêutica vocacionada para interrogar filosoficamente as concepções de Weil proporciona, ou a pertinência do tema do discernimento, capital nesta interpretação, para restituir a coerência do exigente percurso dialéctico que as duas obras procuram delinear. Dessa feita, Guibal acaba por bater a maioria das questões canónicas (evitando, não ignorando, uma ou outra polémica, como a discussão sobre as relações entre o discurso da filosofia moral e as categorias lógicas da "Consciência" e da "Acção"), nas quais introduz algumas perspectivas que poderão figurar como menos usuais: a relevância da terceira Crítica de Kant, que Eric Weil designava como a Judiciária, para um entendimento adequado do lugar do sentido na filosofia weiliana, em particular do lugar que aí detém esse tipo peculiar de juízo que é o"reflexionante"; a dominância da prudência, enquanto expressão da sabedoria prática, no conjunto das virtudes; a importância da consciência da finitude para o trânsito de uma razão formal para uma razoabilidade concreta; a pertinência de insistir no papel resolutivo do regresso a Aristóteles, em virtude de, que não a despeito, um reconhecimento agudo dos paradoxos da Modernidade, nomeadamente dos legados pelas tradições kantiana e hegeliana; a fecundidade hermenêutica da introdução de uma pluralidade de vozes, aquelas com as quais se foi estabelecendo, explícita ou implicitamente, um diálogo (Jürgen Habermas, Martin Heidegger ou Jacques Derrida, por exemplo, ou o menos referido Marcel Conche, ao lado de outras mais recentes), com as quais Guibal recria hipotéticos nexos de interlocução (François Galichet, Étienne Balibar ou Jean-Luc Nancy, uma vez mais a título exemplificativo). Em conformidade, o capítulo conclusivo intitula-se, sugestivamente, "E. Weil e nós." Como é natural, são também estes pontos de vista que definem os limites substanciais desta leitura, já que os formais se reduzem praticamente à escassíssima referência a publicações fora do universo editorial francófono, o que surpreende, tanto mais quanto Francis Guibal editou, em espanhol, uma introdução à concepção de Weil (Historia, Razón, Libertad - Una introducción al pensamiento político y filosófico de Eric Weil. Lima: Fondo Editorial de la PUCP, 2002). O acento posto na recepção de Kant e Aristóteles cumpre uma dupla função cuja relevância não basta para afastar algumas ambiguidades: por um lado, se a ligação a Hegel fica minorada, senão por vezes mesmo elidida, o que permite evitar os excessos da primeira geração 
de intérpretes, essa reconfiguração acarreta a perda de alguns elos do discurso weiliano como, por exemplo, o papel mediador da moral da cidadania responsável como expressão do universal concreto, entre o formalismo do dever subjectivo e a invenção de uma vida moral, ou o intento de reordenar as diferentes figuras da política, recuperadas em grande parte da filosofia hegeliana, segundo uma matriz dialéctica inclusiva, que não de superação, de modo que é o próprio significado do regresso a Kant e/ou a Aristóteles para lá de Hegel que fica menos perceptível; por outro, se a insistência nas "questões kantianas" torna o filósofo nosso contemporâneo, em particular no que diz respeito a temas que estão na ordem do dia, como a crise do Estado-Nação, o cosmopolitismo, o valor da educação para a cidadania, a consciência da historicidade, o papel do sujeito singular, o sentido da política face à ascensão da violência, o que acaba escamoteado é o permanente esforço de Weil para ultrapassar igualmente o formalismo da razão kantiana, porquanto o acesso ao filósofo germânico era preconizado a partir da passagem atenta pela interpretação crítica de Hegel; por fim, ao sugerir a existência de uma espécie de neo-aristotelicismo no pensamento moral e político de Weil, Guibal relança-o uma vez mais no vórtice das problemáticas mais recentes em torno da sabedoria prudencial, como antídoto para todos os positivismos, incluindo o da própria razão, e da necessidade de repensar os modelos de organização social e política, eventualmente, por uma revalidação de configurações de índole mais orgânica, local e agregadora, para o que a versão da politeia antiga poderá cumprir uma função exemplar; mas, para o efeito, deixa por equacionar deliberadamente dois aspectos fulcrais, a saber, que é a magnanimidade que constitui a última virtude para Weil (e não a prudência, à qual cabe um papel de mediação num mundo em que universalidade e particularidade ainda se opõem) e que, como Naert assentou, porque o retorno ao filósofo antigo se faz a partir de um horizonte inexoravelmente moderno, o sentido de cada termo, de cada expressão, de cada tese do Estagirita sofre uma profunda alteração, o que implica a impossibilidade de a orientação aristotélica se constituir como estância definitiva. São, aliás, ao que cremos, estes jogos de apropriação e de distanciação (diferentes de uma filiação convencional, aristotélica, kantiana ou hegeliana) que conferem à filosofia de Weil essa abertura plástica para levar o intérprete a conseguir estabelecer a ligação com perspectivas tão contrastadas como, por exemplo, a de Alexandre Kojève e a de Léo Strauss (cap. VIII), aproximação que, não obstante, se reveste do maior interesse. Todavia, a limitação que se nos afigura mais drástica decorre do modo como a associação entre discernimento, prudência e sabedoria acaba por circunscrever o problema do sentido à racionalidade prática, dei- 
xando assim por reflectir aquele que será, estamos convictos, o traço mais original da filosofia de Weil: a indecisão ponderada sobre o interesse de uma sabedoria substantiva face à pertinência inequívoca do sentido de uma lógica dos sentidos, em todos os regimes discursivos."Conflito de interpretações", parafraseando o título de uma conhecida obra de Paul Ricoeur, há que reconhecê-lo, decisivo para quem estuda a obra de Eric Weil, insuficiente para abalar o rigor, a amplitude e a eloquência da leitura que Francis Guibal, actualmente professor emérito da Universidade Marc Bloch de Estrasburgo, nos propõe. Por fim, estamos perante um exemplo da proficuidade de construir um percurso consequente por via da publicação em revistas tão diferentes como as francesas Cités, Archives de Philosophie, Cahiers Philosophiques, Annales Littéraires de L'Université de Besançon, Revue des sciences religieuses, a belga Revue Philosophique de Louvain ou a peruana Arétè. 



\title{
ROSAS, João Cardoso (org.), Manual de Filosofia Política, Lisboa, Almedina, 2008, 299 pp.
}

\author{
Maria João Cabrita
}

Ao longo da história, a relação entre a filosofia e a política tem-se revelado espinhosa, denunciando a dificuldade em se conceptualizar sobre o que é por natureza antagónico à cristalização, porque particular e pluralista. Na esfera da opinião, o filósofo deve restringir-se a analisar, criticar, rever e aperfeiçoar os valores políticos coevos, a explicar aos seus conterrâneos o universo de acepções sociais partilhadas, consciente de que a sua concepção fundamenta uma via entre as muitas possíveis e assim como a distinção entre "artefactos filosóficos" e "questões de facto". Consequentemente, o estudo da filosofia política contemporânea deve incidir quer sobre os paradigmas teóricos predominantes, quer sobre os problemas mais preocupantes e iminentes. $\mathrm{O}$ Manual de Filosofia Política cumpre escrupulosamente este desígnio.

Organizada por João Cardoso Rosas, esta obra cresce sobretudo no solo da filosofia analítica, de uma tradição revigorada para a "razão prática" pela publicação e discussão em redor de $A$ Theory of Justice (1971) de John Rawls e que, nas últimas décadas, tem estimulado como nenhuma outra a reflexão sobre a política. Reunindo onze artigos assinados por especialistas deste domínio, Manual de Filosofia Política expõe e clarifica o aparato conceptual inerente a uma demanda que espelha a dialéctica entre ideias e factos, teoria e realidade social. Na senda dos seus trabalhos anteriores - entre os quais se destacam Ideias e Políticas para o Nosso Tempo (2004) e, em parceria com João Carlos Espada, Pensamento Político Contemporâneo (2004) -, João Cardoso Rosas oferece-nos, assim, um compêndio imprescindível a quem se debruça sobre estas matérias, seja por preciosismo, seja por mera curiosidade.

A encetar "Paradigmas", primeira parte desta colectânea, Pedro Galvão discorre sobre o "utilitarismo", alumiando as suas peculiaridades - consequencialismo, welfarismo e agregacionismo - e as distintas concepções de bem-estar das vertentes "clássica","preferencial" e das "teorias de lista objectiva". Paladina da "maximização do bem-estar", esta teoria é extremamente influente na esfera pública, mesmo não sendo estruturante de uma política única. Na generalidade, advogando políticas de redistribuição de riqueza que, em simultâneo, protegem as liberdades individuais, justifica o Estado-Providência 
das democracias liberais europeias, mas também nela se encontra uma justificação para o Estado mínimo - como evidencia o debate entre Robert Goodin e David Schmidtz, em Social Welfare and Individual Responsibility: For and Against (1998).

A análise de "utilitarismo" estende-se às argumentações directas de Mill (século XIX), Hare e Harsanyi (século XX), assim como às críticas que lhes são dirigidas por outras perspectivas teóricas. Particularmente, incide na objecção rawlsiana à sua concepção de justiça distributiva - sumariamente, mostra-nos como a aplicação do princípio da escolha racional do sujeito à sociedade denota o esbatimento da distinção entre os indivíduos. Fruto da oposição à hegemonia utilitarista na moral, política e economia, a teoria da justiça de John Rawls constitui o núcleo do liberalismo igualitário, paradigma teórico analisado por João Cardoso Rosas.

Como sublinhado na introdução, "ao contrário do utilitarismo, o liberalismo igualitário é uma teoria politicamente bem definida e que vinca sempre a prevalência da justiça e das liberdades individuais" (p. 8). Sucintamente, conjuga a justiça civil e política com a justiça social e económica, reconhecendo a prioridade daquela, das liberdades básicas, sobre esta. A análise de "Liberalismo igualitário" alastra-se da justiça como equidade rawlsiana - focalizando, sobretudo, as noções nucleares e vias de justificação - ao tributo de outros pensadores liberais igualitários - Ronald Dworkin e Amartya Sen - e à aplicação da visão neo-rawlsiana às questões da justiça global Charles Beitz e Thomas Pogge. Alumia, deste modo, a discussão sobre a natureza e o alcance da igualdade liberal e evidencia como o requisito rawlsiano de igualdade se constrói "a partir da cultura pública das democracias liberais" (p. 65).

O liberalismo igualitário rawlsiano não fundamenta o Estado-Providência, tal como faz o utilitarismo. Diferentemente, considera como as melhores hipóteses de realização dos princípios de justiça da estrutura básica da sociedade - princípio das liberdades, igualdade equitativa de oportunidades e princípio da diferença - a democracia de proprietários e o socialismo liberal, sendo que aquele constitui, na perspectiva rawlsiana, o melhor sistema.

Na senda destas reflexões, seguem-se os ensaios de Rui Fonseca sobre o "libertarismo" e de Carlos Amaral sobre o "comunitarismo", duas doutrinas que conquistaram o seu lugar no horizonte dos grandes paradigmas teóricos contemporâneos em grande medida pelas objecções que colocaram à teoria rawlsiana, crescendo no seio do liberalismo.

O libertarismo enfatiza o respeito pela liberdade do indivíduo como "ausência de coerção" (liberdade negativa), opondo-se "ao controlo político dos estilos de vida dos 
indivíduos e às soluções públicas para as externalidades do mercado" (p. 67). Neste sentido, advoga ou o Estado mínimo (Robert Nozick) ou a privatização total da esfera pública (Murray Rothbard e David Friedman). Se no domínio das implicações políticas reina um certo consenso no seio do libertarismo, o mesmo não acontece ao nível da sua fundamentação teórica. Consequentemente, a análise de Rui Fonseca desenvolve-se nos meandros da distinção entre "liberalismo instrumental" (Friedrich von Hayek e Friedman) - paladino da instrumentalização da liberdade em prol da maior eficácia económica - e "liberalismo fundamental" (Nozick, Rothbard e Eric Mack, entre outros) - segundo o qual "o respeito pela liberdade individual constitui um imperativo moral de natureza deontológica" (p. 68). Estende-se, ainda, às objecções de Nozick ao liberalismo igualitário rawlsiano e à distinção entre libertarismos de direita e de esquerda.

No trilho de uma ética teleológica, da concepção de homem como condição histórica e da ideia de "indivíduo situado", o comunitarismo, como nos mostra Carlos Amaral, procura revitalizar os valores da comunidade, compreendida como um bem humano fundamental, e fomenta uma maior participação dos indivíduos na comunidade política. Sob este desígnio, colide com o individualismo liberal, acusando-o de amputar os vínculos naturais do homem pela exacerbação dos valores individuais. Na sua feição política propõe-se, sobretudo, como correctivo da subversão liberal apelando a valores do ideário republicano, à solidariedade, civismo e benevolência, a uma moralidade enraizada nas práticas sociais e políticas, procura reencantar a actividade política.

A completar a primeira parte, Roberto Merril e Vincent Bourdeau dissertam sobre o republicanismo, e Acílio Rocha sobre a democracia deliberativa. Com origem na "Escola de Cambridge", o republicanismo contemporâneo constitui uma corrente da filosofia política que coloca a ênfase nos valores da igualdade e da participação política e que se fragmenta nas vertentes cívica (Hannah Arendt), política (Philip Pettit) e crítica (John Maynor e Célice Laborde). Para além de ilustrarem a especificidade de cada uma delas, os autores explicitam as concepções de "perfeccionismo" e de "liberdade como não dominação", nucleares a este paradigma teórico.

Essencialmente habermasiana, a democracia deliberativa revela o tributo maior do pensamento europeu na filosofia política contemporânea: uma concepção que enfatiza a cidadania participativa através do diálogo, do debate e da argumentação. Distinto dos liberalismos, republicanismos e comunitarismos, este paradigma acaba por contribuir para a sua discussão num plano metateórico. Ao longo da sua análise, Acílio Rocha dilucida as noções habermasianas de "agir comunicacional" e de "racio- 
nalidade" e mostra como este modelo de democracia constitui uma espécie de terceira via entre os modelos liberal e republicano.

Os cinco artigos que perfazem a segunda parte de Manual de Filosofia Política, "Problemas", incidem sobre as dificuldades maiores que se colocam àqueles paradigmas teóricos, espelhando a inquietação dos filósofos políticos ante o "estado do mundo." Diana Chaves escreve sobre a pobreza absoluta, lembrando as propostas de resolução deste flagelo quer do utilitarismo (Peter Singer), quer do liberalismo igualitário (Charles Beitz e Thomas Pogge); Juan Carlos Velasco apresenta uma análise sobre as migrações internacionais - questão entrelaçada com as da pobreza e da multiculturalidade -, urdida no contraste entre a corrente de pensamento que reconhece significado moral às fronteiras e advoga o seu encerramento parcial (o comunitarismo de Michael Walzer) e a perspectiva apologética da sua abertura (o liberalismo de Carens); e Conceição Moreira versa sobre a multiculturalidade e o multiculturalismo, lembrando as fundamentações das políticas multiculturais quer de feição comunitarista, como é o caso de Charles Taylor (política do reconhecimento) e de Iris Marion Young (política da diferença), quer liberal igualitária, como é o caso da abordagem de Will Kymlicka sobre os direitos multiculturais.

A completar "Problemas", Fátima Costa analisa a questão da guerra e do terrorismo, centrando-se no utilitarismo e na teoria da guerra justa de Michael Walzer, teoria que dilucida a injustiça do terrorismo, quer seja de Estado ou de guerra; e Viriato Soromenho-Marques versa sobre a política do ambiente. Protagonista do debate sobre o ambiente, este filósofo mostra-nos o que verdadeiramente está em causa na crise ambiental:"o reinventar radical do relacionamento humano com e na natureza" (p. 275). A sua globalização evidencia a urgência em construir instituições que permitam melhorar a administração da política ambiental por todos os cantos do mundo. 


\title{
MENDES, Manuel da Silva, Socialismo Libertário ou Anarchismo, Prefácio de João Freire. Lisboa, Livraria Letra Livre, edição fac-símile, 2006, 369 pp.
}

\author{
Maria João Cabrita
}

Publicada no ano de 1896, num contexto político adverso à propaganda anarquista - considerada como um crime pela Lei de 13 de Fevereiro desse mesmo ano -, esta obra revela os contornos doutrinários e históricos do anarquismo, sobretudo da feição dominante na militância anarquista em Portugal, o "anarquismo social".Como assinala João Freire em "Revistas anarquistas portuguesas: entre a política e a cultura" (in Revistas, Ideias e Doutrinas, 2003), "o anarquismo social era certamente um socialismo, todavia mais ambicioso e radical que a maioria das outras variantes, em particular o marxismo" (p. 155). E isso é, sem dúvida, acentuado ao longo de Socialismo Libertário ou Anarchismo, obra de referência que, conquanto esquecida pelos libertários coevos, revela a imensa qualidade intelectual do seu jovem autor, que não destoa ao lado de obras como Histoire de l'anarchie (1949), de Claude Harmel, ou mesmo da mais recente Histoire de l'anarchisme (1993), de Jean Préposiet.

Silva Mendes (1876-1931) tem sido lembrado ao longo das últimas décadas, não tanto pelo seu contributo para a propaganda anarquista quanto pela sua paixão pela filosofia e arte orientais - nesse âmbito, escreveu Lao Tse e a Sua Doutrina segundo o Tao-te-Ching (1908) e Excertos de Filosofia Taoísta (1930). Oriundo de São Miguel das Aves, Santo Tirso, tirou o bacharelato em Direito, na Universidade de Coimbra, com apenas 19 anos. Em 1894 foi preso em Braga por propaganda anarquista e, dois anos depois, trouxe a lume Socialismo Libertário ou Anarchismo. Em 1901 partiu para Macau, onde viveu durante três décadas, desfrutando dos prazeres da cultura oriental, tal como Wenceslau de Moraes e Camilo Pessanha, seus contemporâneos. Foi professor e reitor do liceu, juiz e procurador da República e, ainda, Administrador do Concelho e Presidente do Leal Senado. Colaborou nos jornais A Vida Nova, Jornal de Macau e Pátria e nas revistas O Oriente e Revista de Macau, escrevendo crónicas sobre a cidade - como nos dá conta a antologia Macau. Impressões e Recordações (1979). Nesta obra biográfica torna-se evidente que o jovem anarquista cedera o lugar ao republicano e liberal, avesso à disciplina partidária. 
Em Socialismo Libertário ou Anarchismo, Silva Mendes começa por apresentar uma longa síntese sobre os precursores das ideias socialistas, escavando o subsolo dos filósofos da revolução do século XVIII - Morelly, Mably, Diderot, Rousseau, Helvétius, Sieyès, Brissot de Warville, Linguet, etc. - pelo recurso a Flor O'Squarr, para quem Santan seria o primeiro dos anarquistas, e a Félix Dubois, que ancora a sua origem no renascentista francês François Rabelais. Comparando os sistemas sociais imaginados por Platão, Thomas Morus, Campanella, Rabelais, Fourier, etc., a encenações teatrais, lembra que o nascimento do anarquismo não se deveu a esse artificialismo, mas antes às "condições económicas e políticas, e do sentir e do pensar dos trabalhadores e d'aquelles que entenderam ser um dever da humanidade e de justiça propugnar pela implantação de um regimen de sociedade em que todos possam mover-se livremente na coexistência social" (p. 7). Todavia, com o intuito de seguir o encadeamento lógico das ideias, e não apenas o dos factos, debruça-se, no capítulo de abertura, sobre os filósofos da revolução acima mencionados, ainda que sejam precursores indirectos do anarquismo, e estende a abordagem aos seus maiores teóricos: William Godwin, Tompson, Saint-Simon, Fourier, Robert Owen, Max Stirner e, por último, a Pierre-Joseph Proudhon e Karl Marx.

Segue-se-lhe uma análise sobre as principais questões e querelas suscitadas, no âmbito político, entre o socialismo e o libertarismo, que percorre os capítulos II ("Karl Marx e a Associação Internacional dos Trabalhadores") e III ("Bakounine e o Movimento Anarquista até 1876"). O autor explora aqui, quer o abismo ideológico entre o sábio Marx e o apóstolo Bakounine, quer a sua adversidade congénita:"Karl Marx mais frio, mais calculista, mais nebuloso, mais autoritário; Bakounine, mais expansivo, mais franco, mais revolucionário, mais libertário" (p. 67). A morte deste último, em 1876, constituiu o marco de uma nova fase doutrinal do anarquismo, também ela alumiada por dois grandes teóricos, Kropotkine e Elisée Reclus - como mostra no quarto capítulo, através de um exame crítico que cobre as duas últimas décadas do movimento teórico anarquista. As resoluções do Congresso de Berna, de Outubro de 1876, evidenciam o triunfo do anarquismo no seio da Internacional, na sequência da disputa com o colectivismo marxista, desde o Congresso de Haia, em 1872.

A estes dois teóricos, sobre os quais o autor apresenta os seus itinerários biobibliográficos, acresce a referência a publicistas e sociólogos de renome - Tolstoi, M. Guyau, Novicow, Spencer, Gumplowicz, Carlo Malato, Sébastien Faure, Hamon, Descaves, entre outros -, assim como a poetas socialistas libertários - entre os quais, Paul Paillette e 
Brunel. Assinala, ainda, a efemeridade da maior parte das revistas e jornais anarquistas, publicados nos quatro cantos do mundo - o que se fica a dever quer à falta de recursos, quer ao "horror que a palavra anarchia causa á maior parte dos indivíduos, como também o receio de serem acoimados de sectários" (p. 151). Não obstante, e como faz questão de sublinhar, as publicações circulam de mão em mão - gesto que amplia em muito o seu universo de leitores.

A concluir a análise tecida na articulação entre ideias e factos, o quinto capítulo coloca a ênfase na propaganda pelo facto, mostrando o impacte deste movimento no contexto nacional, numa moldura que engloba o estado da questão em Inglaterra, Alemanha, França, Bélgica, Suíça, Itália, Espanha e toda a América.Tal como na restante Europa, e distintamente do que se passa na América, em Portugal o anarquismo individualista mutualista cedeu o lugar ao anarquismo colectivista; ou seja, a tendência essencialmente proudhoniana foi suplantada pela de Bakunine. Retenhamo-nos nas palavras de Silva Mendes: "Em Portugal, o movimento anarchista não tem acompanhado o de outros paizes. $\mathrm{O}$ socialismo, organisado primeiramente pelos estatutos da Alliança de Bakunine, tem-se desenvolvido com tendências diversas; hoje, porem, mercê da influencia educadora de alguns operários hespanhoes que têm vivido e vivem no meio dos revolucionários portuguezes, o socialismo propende geralmente para a forma anarchista. O operariado de Lisboa, Porto, Coimbra e outros centros industriaes vae pouco a pouco abandonando as tendências marxistas para se lançar no anarchismo. Convencido da improficuidade da táctica parlamentar, repugna-lhe aceitar o socialismo autoritário. Bastantes grupos, mais ou menos secretos, existem nos principaes centros, uns professando a propaganda pelo facto sem restricções, outros subordinando-a a certas regras. Os seus jornaes são hoje clandestinos por via da lei de Fevereiro d'este anno, provocada pelo attentado de Lisboa. Pelo mesmo motivo, é secreta a organisação actual dos grupos" (p. 169).

Nos últimos seis capítulos, o autor esclarece a derivação e sequência lógica das ideias, demorando-se em questões a que aludira vagamente nos capítulos precedentes.Versa, então, sobre a evolução teórica do anarquismo, a teoria histórica socialista, a evolução económica, a sociedade comunista, a evolução política e a sociedade comunista anarquista, evidenciando o seu conhecimento sociológico, sobretudo da obra de Helbert Spencer, de onde "é fácil deduzir conclusões anarquistas" (p. 333). Na sua perspectiva, a noção spenceriana de evolução social - entendida como a passagem da sociedade de um estado de homogeneidade indefinida a um estado de heterogeneidade definida e coerente, através de uma dissipação do movimento que sofre uma 
metamorfose análoga - é conforme ao anarquismo comunista, dado que este prevê na sociedade futura "um regímen de completa egualdade pela adaptação solidária de todos ás condições sociaes e aceitando os hábitos moraes como base de conducta individual nas relações com a sociedade" (p. 186).

A manutenção do princípio da soberania individual, de Max Stirner para Bakounine, a substituição do dissocionismo daquele pelo federalismo proudhoniano e bakouninista e a cedência do individualismo económico stirneriano ao mutalismo proudhoniano e deste ao colectivismo de Marx e Bakounine reflectem a evolução do anarquismo até 1876. Nesse ano reconhecer-se-ia que o sistema colectivista, assente na ideia de repartição integral do produto do trabalho, pressupõe inevitavelmente a aceitação de um sistema de regulamentação autoritária, o reconhecimento do Estado, da "besta negra", na terminologia bakouninista. Contradição que encaminhou os libertários no anarquismo comunista - "systema que reconhece o communismo livre e espontâneo na produção e no consummo como a única base sólida da sociedade, a federação livre dos grupos productores e consummidores, o principio da autonomia individual, a abolição do Estado sob todas as suas formas substituido pela organização livre e espontanea que os grupos autónomos ou federados se derem, a liberdade de pensamento e das suas manifestações, etc." (p. 214). Ou seja, na defesa da igualdade pela abolição da propriedade individual e da liberdade pela abolição dos governos.

A encerrar Socialismo Libertário ou Anarchismo, Silva Mendes salienta que a sociedade tende a evoluir nos contornos dessa perspectiva; como escreve, "será (...) livre pela associação federativa e espontânea dos homens para a vida, sobre a base da communidade da terra e de todos os instrumentos de trabalho" (p.359). Hoje, à distância de mais de um século, podemos lamentar que assim não tenha sido. Mas também podemos, com outra liberdade, deleitar-nos na leitura desta obra. 


\section{Autores}

Luís Andrade é professor auxiliar do Departamento de Filosofia da FCSH, coordenador do Seminário Livre de História das Ideias e investigador do Centro de História da Cultura. A sua investigação decorre no âmbito da história cultural e política do século XX, domínio em que é autor de vários estudos.

Lucia Maria Paschoal Guimarães é doutora em História Social pela Universidade de São Paulo, professora titular de Historiografia do Departamento de História da Universidade do Estado do Rio de Janeiro, pesquisadora do Programa Prociência da UERJ, pesquisadora do CNPq, do Programa Cientista do Nosso Estado e do PRONEX CNPq/FAPERJ "Dimensões da Cidadania nos Oitocentos", coordenado pelo Dr. José Murilo de Carvalho.É ainda sócia honorária do Instituto Histórico e Geográfico Brasileiro.

Zília Osório de Castro é professora catedrática jubilada de História das Ideias da FCSH. Coordenou o mestrado de História Cultural e Política da Universidade Nova de Lisboa.Constituiu e dirigiu várias equipas de investigação, com destaque para o Seminário Livre de História das Ideias, o Grupo de Investigação em Ciência Política e Relações Internacionais e Estudos sobre a Mulher, que publica a revista Faces de Eva. Tem extensa obra publicada, de que se destacam: Cultura e Política. Borges Carneiro e o vintismo (Lisboa, INIC, 1990), Portugal e os Caminhos do Mar (dir.) (Lisboa, Ed. Inapa, 1998), Dicionário do Primeiro Vintismo e do Cartismo (dir.) (Lisboa, Assembleia da República e Edições Afrontamento, 2002) e Dicionário do Feminino (dir.) (Lisboa, Livros Horizonte, 2005).

Adelino Cardoso é investigador auxiliar do Centro de História da Cultura da Faculdade de Ciências Sociais e Humanas da Universidade Nova de Lisboa. Doutorou-se pela Universidade de Lisboa com uma tese sobre O Trabalho da Mediação no Pensamento Leibniziano (2003), publicada em 2006. Coordena o projecto Filosofia, Medicina e Sociedade. É autor, nomeadamente, de Leibniz Segundo a Expressão (1992), Fulgurações do Eu. Indivíduo e singularidade no pensamento do Renascimento (2002) e de Vida e Percepção de Si. Figuras da subjectividade no século XVII (2008). Traduziu, entre outras obras, Discurso de Metafísica e Novos Ensaios de Leibniz. 
Teresa Salvador é professora auxiliar na Secção de Filosofia da Universidade de Évora e investigadora integrada no CIDEHUS da mesma instituição. Colabora no Cesnova (FCSH/UNL) como coordenadora de Faces de Eva. Em 2008 publicou: "A Educação - Tomada de posição do jovem Antero", in Dias, J.M. de Barros e Sebastião, Luís (org.), Da Filosofia, da Pedagogia, da Escola, Évora, Universidade de Évora, 2008, pp. 245-262; “Memória das ruas. Toponímia educativa eborense", in Nico, Bravo, Aprendizagens do Interior: Reflexões e fragmentos (org.), Mangualde, Edições Pedago, 2008, pp. 179-219; Entre o Defeito e o Excesso: Da demissão dos pais ao seu protagonismo na escola, Funchal, 2008; "Três metáforas auto-apresentativas:uma maneira peculiar de interpretar a existência,"in Reflexões em Torno de María Zambrano, Lisboa, Câmara Municipal de Lisboa, 2008, pp. 9-16; "Hélène, a irmã de Simone de Beauvoir. De passagem por Portugal”, in Faces de Eva. Estudos sobre a Mulher, Lisboa, 20 (Dezembro) 2008, pp.157-162; “Luísa Freire. O Japão no Feminino Haiku", in Faces de Eva. Estudos sobre a Mulher, Lisboa, 20 (Dezembro) 2008, pp. 210-212 (co-dir.); Educação. Temas e Problemas - Educação e diálogo intercultural, Lisboa, Ano 3, n. 5, 2008 (co-dir.); Educação. Temas e Problemas - O planeta Terra e a educação, Lisboa, Ano 3, n. 6, 2008.

Maria João Cabrita, doutorada em História e Teoria das Ideias, na especialidade de História das Ideias Políticas, pela FCSH/UNL, desenvolve trabalhos de investigação no âmbito do pensamento político contemporâneo. É membro do Seminário Livre de História das Ideias e do Centro de História da Cultura da FCSH/UNL. Integra o Projecto Edição de Revistas e Cultura, dedicando-se ao estudo das revistas anarquistas, em especial de A Batalha:Suplemento Semanal Ilustrado (1923-1927).

José Manuel Cordeiro é doutorando no ramo de Filosofia, especialidade Filosofia Moral e Política, na FCSH/UNL; mestre em História Cultural e Política; e licenciado em Filosofia (variante História das Ideias) pela mesma Universidade. Leccionou Filosofia das Ciências no Instituto Superior de Informática de Gestão e é membro da equipa de investigação do Seminário Livre de História das Ideias/Centro de História da Cultura da FCSH/UNL no Projecto "Revistas: Ideias e Cultura". Encontra-se a preparar uma tese de doutoramento intitulada "Integralismo Lusitano: filosofia e política de acção".

Paulo Dias Oliveira tem como formação inicial a Filosofia (UCP - 1989), tendo enveredado, uns anos depois, pela História das Ideias. Nessa área, concluiu o mestrado em História Cultural e Política (FCSH/UNL - 1997). Ingressou, de seguida, na Universidade do Algarve, onde não abandonou o seu gosto pela história das ideias, tendo vindo a doutorar-se na área de História Contemporânea (UALG - 2007). É, neste momento, professor auxiliar do Departamento de História, Arqueologia e Património na Faculdade de Ciências Humanas e Sociais, onde é docente do curso de Património Cultural e dos mestrados de História do Algarve e de História da Arte. 
Além do estudo do movimento krausiano em Portugal, que foi objecto das dissertações de mestrado e doutoramento, tem investigado o fenómeno do Integralismo Lusitano.

Pedro Silva é professor de História no Ensino Básico e Secundário, investigador do Seminário Livre de História das Ideias, nos domínios do estudo e da edição electrónica das revistas católicas portuguesas do século XX, e doutorando em História e Teoria das Ideias, na especialidade de Pensamento, Cultura e Política.

Adelaide Maria Muralha Vieira Machado é licenciada em História, mestre em História Cultural e Política e doutoranda em História e Teoria das Ideias, especialidade Pensamento, Cultura e Política. A sua pesquisa como investigadora do Seminário Livre de História das Ideias e bolseira de investigação do Centro de História da Cultura tem-se dirigido para a História das Ideias Políticas Contemporâneas.

Sandra Ataíde Lobo é bolseira de doutoramento desde 2006 (FCT), na área de História Social das Ideias (FCSH/UNL); é ainda mestre em História Cultural e Política (2001) (FCHS/UNL) e licenciada em História (1987) (FL/UL).

Tem-se interessado pela História da Imprensa Periódica portuguesa nos séculos XIX e XX. Desde 1994 integra, a convite da Prof. ${ }^{a}$ Dra. Zília Osório de Castro, o Seminário Livre de História das Ideias, tendo participado, desde essa data, nos seus diversos projectos de investigação. Actualmente prepara o doutoramento sobre a "Intelectualidade goesa entre finais do século XIX e as primeiras décadas do século XX", visando estudar a formação dessa elite intelectual e a sua reflexão crítica sobre o colonialismo português em Goa e sobre a identidade goesa.

Pedro Lisboa é licenciado em História pela FLUL e mestre em História Cultural e Política pela FCSH/UNL. As suas principais áreas de interesse são a história do jogo e dos jogos, a história do livro e da leitura e os sistemas de informação aplicados às ciências sociais. Desempenha, desde 2005, funções de bolseiro de investigação no Projecto Revistas: Ideias e Cultura, tendo participado na preparação e edição electrónica de revistas como O Tempo e o Modo - 1. a série e Nova série, Raiz \& Utopia, A Águia, entre outras.

Cristina Montalvão Sarmento é licenciada em Direito pela Universidade Católica (1985) e em História pela Faculdade de Letras da Universidade de Lisboa (1997). Foi bolseira da Fundação Calouste Gulbenkian no Institut Européen des Hautes Études Internationales em Nice, França, onde concluiu o $2^{\text {éme }}$ Cycle em Relações Internacionais (1987). É pós-graduada em Ciência Política pelo Instituto de Ciências Sociais e Políticas da Universidade Técnica de Lisboa (1994) e em Filosofia pela Faculdade de Letras da Universidade de Lisboa (1999), doutora em Ciência 
Política (Teoria Política) pela Universidade Nova de Lisboa (2004). Assistente na Universidade dos Açores (1986-1991) e na Universidade do Algarve (1991-1998), é actualmente professora auxiliar da FCSH/UNL (desde 2004), da qual foi subdirectora-adjunta para a área da Investigação (2007-2009). Secretária-geral da Associação das Universidades de Língua Portuguesa (desde 2006), é investigadora e subdirectora do Centro de História da Cultura da UNL (desde 2004), onde coordenou a edição da revista Cultura - Revista de História e Teoria das Ideias (20042008), sendo ainda responsável por várias publicações na área da Ciência Política e Relações Internacionais, domínios no âmbito dos quais tem orientado vários trabalhos académicos. 


\section{Resumos e palavras-chave}

\section{Pensamento e actualidade. As revistas no século XX}

Luís Andrade

Face ao papel central que as revistas desempenharam nas transformações culturais e na criação de movimentos doutrinários e cívicos, entre o final do século XIX e o final do século XX, procura-se caracterizar esta modalidade de imprensa a partir dos traços distintivos que lhe permitiram unir, segundo diferentes propósitos e modalidades, pensamento e actualidade.

Palavras-chave: revista, intelectual, cultura, cosmopolitismo, movimentos doutrinários.

\section{A luso-brasilidade e o projecto da revista Atlântida}

Lucia Maria Paschoal Guimarães

O artigo examina os primeiros números da revista Atlântida, o mais expressivo veículo de divulgação de um projeto político-cultural, intentado no início do século passado, em defesa da formação de uma comunidade luso-brasileira. Dirigida no Rio de Janeiro por Paulo Barreto, o popular João do Rio,e em Lisboa por João de Barros, a Atlântida circulou mensalmente entre 1915 e 1920. Ao lado da permanente reflexão doutrinária acerca da conveniência do estreitamento das relações entre Brasil e Portugal, o periódico ocupava-se de questões literárias, históricas e artísticas contemporâneas, o que Ihe conferia um alcance político e, ao mesmo tempo, cultural.

Palavras-chave: luso-brasilidade, revistas culturais, relações luso-brasileiras.

\section{"Uma nova e grande Lusitânia"}

\section{Zília Osório de Castro}

Pela pena de homens de letras de Portugal e do Brasil, a aproximação cultural entre os dois países tornou-se um ideal pelo qual valia a pena lutar e que encontrou espaço adequado nas recentes sociedades republicanas de aquém e além-Atlântico. João de Barros e Olavo Bilac foram os arautos deste projecto que, exaltando os laços de uma comum identidade história, tradição, cultura, raça - e neles se fundamentando, salvaguardadas as respectivas independências, pretendia criar, em conjunto com Angola, uma unidade política de domínio do 
Atlântico Sul e de interlocutora forte na cena internacional. Neste sentido, deram corpo a uma verdadeira militância que iria encontrar na criação da revista Atlântida, patrocinada por altas entidades da política externa dos dois governos, a sua expressão de maior significado.

Palavras-chave: relações luso-brasileiras, Atlântico Sul, republicanismo, patriotismo, identidade cultural.

\section{Uma nova revista de Filosofia?}

\section{Adelino Cardoso}

O autor desenvolve uma narrativa que combina a descrição com a sua experiência enquanto leitor e sobretudo enquanto membro envolvido no lançamento e dinamização de revistas de Filosofia. O artigo destaca o percurso solitário da Revista Portuguesa de Filosofia, ao longo de décadas, e a sua capacidade de renovação evidenciada na última década; assume que o lançamento da revista Filosofia e Epistemologia significou a pedrada no charco que rompeu com hábitos paralisantes, afirmando um estilo que influenciou projectos futuros, nomeadamente a Análise, cujo carácter adveio, em larga medida, da sua articulação com um programa de investigação coerente e pluridisciplinar. Por último, o artigo interroga-se sobre o papel das revistas de Filosofia no incremento da incipiente comunidade filosófica portuguesa.

Palavras-chave: revista de filosofia, renovação, comunidade filosófica, debate de ideias, público.

\section{Em torno dos periódicos femininos}

Teresa Salvador

O texto é campo de confluência de algumas preocupações: uma, a necessidade de dissociar a imprensa periódica feminina da conotação negativa decorrente da sua classificação em petite presse; outra, a de esclarecer a natureza dos periódicos femininos e acertar uma designação ou distinguir as possíveis designações; outra ainda, a de afirmar o poder e os limites desta imprensa, independentemente de reproduzir estereótipos tradicionais ou propor novos papéis para as mulheres em regime de igualdade de oportunidades. Nesta abordagem geral inclui-se uma listagem de periódicos que vai de 1807 a 1974.

Palavras-chave: periódicos femininos, imprensa, estudos sobre as mulheres. 


\section{No rasto da passagem de Ferreira de Castro pelos suplemento e revista de A Batalha (1919-1927)}

Maria João Cabrita

Neste artigo pretende-se elucidar os contornos libertários do pensamento do escritor Ferreira de Castro, através de uma análise dos seus artigos publicados em A Batalha - Suplemento Literário e llustrado e na Renovação. Na esteira de uma breve apreciação biobibliográfica, em que se assinala o percurso jornalístico do escritor, sonda-se a sua demora em temáticas como a arte social e a injustiça social.

Palavras-chave: libertarismo, liberdade, arte social, justiça social.

\section{Nação Portuguesa (1914-1916). Que Integralismo Lusitano? \\ José Manuel Cordeiro}

Através deste artigo, pretende-se uma revisitação ao Integralismo Lusitano pela via da revista Nação Portuguesa (1914-1916). Este excurso adensa potencialidades de estudo para o conhecimento do que foi o Integralismo Lusitano nas suas primeiras expressões, as suas ligações ideológicas à Alma Portuguesa, a sua postura anti-republicana, a sua cruzada contra a democracia e o parlamentarismo. Conclui-se que o municipalismo, o nacionalismo, o maurrasianismo, o parlamentarismo, o constitucionalismo, a monarquia tradicionalista, a monarquia integral e a monarquia orgânica são conceitos a exigirem depuração e estabilização para se empreender o estabelecimento coerente de um corpo teórico do integralismo lusitano.

Palavras-chave: Integralismo Lusitano, república, tradicionalismo, maurrasianismo, municipalismo, nacionalismo, monarquia orgânica, antiparlamentarismo, anticonstitucionalismo.

\section{Da Filosofia Política à Cultura Nacionalista. A segunda série da Nação Portuguesa (1922-1923)}

Paulo Dias Oliveira

Nestes artigos da Nação Portuguesa é perceptível um pendor mais prático que surge com maior clareza no princípio da série seguinte, na qual o periódico é seccionado em duas partes distintas, já claramente perceptíveis nesta segunda leva: a primeira, onde se inserem os estudos de momentânea curiosidade, feitos de crónica, transcrições, referências à revista, etc.; a subsequente, onde se podem encontrar os ensaios de crítica, filosofia, história e ciência,"em que os altos problemas do espírito vão sendo discutidos". Por esse motivo, foi desta última secção 
que nos ocupámos, tentando traçar as linhas gerais dos textos de António Sardinha, Pequito Rebelo, Rolão Preto, Afonso Lucas, Francisco Veloso, Rodrigues Cavalheiro e Avelino Soares.

Palavras-chave: Nação Portuguesa, Integralismo Lusitano, monarquia, nacionalismo, tradição, política, história, filosofia, economia, religião, reaportuguesamento, ordem nova.

\section{Estudos Sociais: percursos temáticos de um ímpeto reformista (1905-1911) Pedro Silva}

Publicada entre 1905 e 1911, a revista Estudos Sociais nasceu no âmbito da acção desenvolvida pelo Centro Académico de Democracia Cristã de Coimbra e tinha como finalidades contribuir para a difusão do catolicismo social e para a implantação da democracia cristã em Portugal.Ao longo do período de sete anos em que foi editada, muitos foram os momentos em que se lançou um apelo à Igreja Católica para que ocupasse o lugar que lhe pertencia na civilização actual, reafirmando-se, sistematicamente, que só através da concepção cristã de democracia e do movimento social católico o Cristianismo responderia aos desafios sociais e o Clero desempenharia um papel de vanguarda na resolução dos problemas sociais do povo. Desta forma, muitos foram os textos, práticos e teóricos, nacionais e internacionais, que abordaram questões como a da verdadeira democracia, a do catolicismo/cristianismo social, a da urgente reforma do Clero e da Igreja ou a do modernismo. O principal objectivo do presente artigo é esboçar os itinerários temáticos presentes na revista ao longo dos sete anos em que foi publicada.

Palavras-chave: catolicismo social, democracia cristã, modernismo, ciência, religião, laicismo, dogma, socialismo, fé, razão.

\section{Os cavaleiros da espada de pau e os arcanjos da espada dum trovão: a Renascença Portuguesa e a cultura democrática}

\section{Adelaide Maria Muralha Vieira Machado}

A partir da implantação da República, surgiu um movimento de intelectuais que procurou congregar e dinamizar num esforço comum os pensadores de várias áreas do conhecimento, através da revista A Águia, tendo em vista uma nova ordem moral e cívica dentro do ideal democrático. Procurámos dar a conhecer as linhas principais que consubstanciaram o espaço aberto pela revista, as influências recebidas e os debates que a animaram.

Palavras-chave: Renascença Portuguesa, saudosismo, república, democracia, liberdade, identidade nacional, cultura portuguesa. 


\title{
Índia Nova: nacionalismo e cosmopolitismo num jornal académico
}

\author{
Sandra Ataíde Lobo
}

Integrar o estudo de um jornal como o Índia Nova:jornal de expansão da cultura indiana numa publicação dedicada a estudos sobre revistas justifica-se por estarmos perante um projecto cultural, com inevitáveis ressonâncias políticas. Órgão dos estudantes goeses nas Universidades portuguesas, a sua criação deveu-se à iniciativa de um grupo de jovens intelectuais goeses, criados sob os auspícios da República, que, sob o signo da ruptura, vinham chamar a si a responsabilidade de intervenção na cidade. A publicação, se buscava atingir o público europeu metropolitano, sensibilizando-o para a magnitude da civilização indiana, visava essencialmente os goeses na Metrópole e em Goa, assumindo o objectivo de recuperar uma identidade goesa formatada na tradição civilizacional indiana e de promover uma actividade cultural e científica centrada em temas e referências indianos. Através desta proposta, associava-se ao movimento político-cultural nacionalista que atingia a "Grande Índia" e, mais globalmente, aos diversos nacionalismos que despontavam por todo o continente asiático nas primeiras décadas do século XX. Finalmente, o grupo de estudantes goeses e os seus colaboradores goeses e metropolitanos, efectuando o percurso da particularidade goesa para a reflexão sobre os destinos da humanidade, integravam, por essa via, a corrente que a Ocidente e Oriente se batia por um novo humanismo, assentando a universalidade na harmonização da diversidade e tornando todos os indivíduos e povos coniventes na construção do futuro da humanidade.

Palavras-chave: intelectuais goeses, intelectuais europeus, imprensa académica, império português na Índia, resistência cultural, identidade cultural, história, imperialismo, colonialismo, civilização indiana, civilização ocidental, orientalismo, diálogo civilizacional, humanismo.

\section{Edição electrónica e estudo de revistas: o contributo do Seminário Livre de História das Ideias}

Pedro Lisboa

O mundo da edição electrónica de periódicos encontra-se em permanente evolução, a par dos avanços tecnológicos e da crescente utilização de meios informáticos que facilitem o acesso à informação.

A maioria das iniciativas que utilizam a edição electrónica de revistas tem como principal objectivo permitir aos investigadores um acesso fácil e centralizado à informação, alargando desta forma a potencial difusão das publicações consultadas.

Partilhando alguns elementos deste princípio funcional, o Seminário Livre de História das Ideias (SLHI) propõe-se editar e estudar revistas históricas, preocupando-se não apenas com 
a acessibilidade da informação mas também, e sobretudo, com a construção de um aparato analítico que permita uma leitura crítica das fontes. Discutir o seu trabalho e a sua experiência pode ser, pois, um passo importante para superar obstáculos e definir rumos para a edição electrónica de revistas.

Palavras-chave: edição electrónica, edição analítica, revistas, classificação e indexação bibliográficas.

\section{Da língua à cultura científica: a Revista Internacional de Língua Portuguesa}

\section{Cristina Montalvão Sarmento}

A Revista Internacional de Língua Portuguesa (RILP) tem sido o veículo da expressão da comunidade que se expressa em português, impulsionada pelo movimento associativo universitário dos anos oitenta e noventa do século XX. Dirigida, primeiro, por Maria Helena Mira Mateus, numa série inicial composta por dezassete números, e, depois, coordenada por José-Augusto França, numa segunda série com três exemplares, perfaz hoje vinte e um títulos, o último dos quais abre a terceira série em curso, de cariz institucional e temático. A sua pretensão de divulgação da língua portuguesa, a longevidade e a expressão intercontinental fazem desta revista um caso nacional único de internacionalização, do centro linguístico original para o universo multilateral das culturas associadas, em torno do vector comum da língua, alheia às vicissitudes políticas que o tempo impôs e os poderes engendraram. Neste artigo são revisitadas as várias séries.

Palavras-chave: Revista Internacional de Língua Portuguesa, Associação das Universidades de Língua Portuguesa, língua portuguesa, Angola, Brasil, Cabo Verde, Guiné-Bissau, Macau, Moçambique, Portugal, São Tomé e Príncipe, Timor-Leste. 


\section{Abstratcs and keywords}

\section{Thought and actuality. The magazines of the $20^{\text {th }}$ century} Luís Andrade

Considering the central role played by magazines in the cultural transformations and the creation of doctrinarian and civic movements, between the late $19^{\text {th }}$ century and the late $20^{\text {th }}$ century, we attempt to characterize this type of press, from the distinctive features which enabled it to gather, following different purposes and modalities, both thought and actuality.

Keywords: magazine, intellectual, culture, cosmopolitanism, doctrinarian movements

\section{Portuguese-Brazilianhood and the Atlântida magazine project Lucia Maria Paschoal Guimarães}

The article examines the first issues of the magazine Atlântida, the most expressive diffusion medium of a cultural and political project, put forward in the early $20^{\text {th }}$ century, defending the constitution of a Portuguese-Brazilian community. Atlântida, directed in Rio de Janeiro by Paulo Barreto, the wellknown João do Rio, and in Lisbon by João de Barros, was published monthly between 1915 and 1920. Together with the permanent doctrinarian reflection on the need to narrow the relationship between Brazil and Portugal, the periodical was also devoted to contemporary literary, historical and artistic questions, making its reach both political and cultural.

Keywords: Portuguese-Brazilianhood, cultural magazines, Portuguese-Brazilian relations.

\section{"A new and great Lusitânia"}

\section{Zília Osório de Castro}

Through the writings of Portuguese and Brazilian intellectuals the cultural proximity of both countries became an ideal worth fighting for and found its appropriate place among the recent republican societies on both sides of the Atlantic. João de Barros and Olavo Bilac were the heralds of this project which, by exalting the bonds of a shared identity - history, tradition, culture, race - and by using them as its fundaments, all the while safeguarding national independences, intended to create a political unit, together with Angola, which projected a 
strong international voice and guaranteed the domination of the South Atlantic. In this sense, they embodied the true militancy which had its most significant expression in the creation of the Atlântida magazine, sponsored by the top entities of both governments' foreign policy.

Keywords: Portuguese-Brazilian relations, South Atlantic, republicanism, patriotism, cultural identity.

\section{A new magazine of Philosophy?}

\section{Adelino Cardoso}

The author develops a narrative that conjugates the description with his experience as reader, and mainly as a fellow engaged in the launch and in the creation of Philosophical Journals.

This article stresses the solitary path of Revista Portuguesa de Filosofia, throughout several decades, and its power of renovation showed during the last decade; it assumes that the launch of Filosofia e Epistemologia meant the turning-point against paralyzing habits, creating a work's style which influenced further projects, namely Análise, whose character resulted in large measure from its articulation with a coherent and interdisciplinary program of research. Lastly, the author inquires about the role of the Philosophical Journals in the increase of the incipient Portuguese philosophical community.

Key words: journal of Philosophy, updating, philosophical community, debate of ideas, audience.

\section{On women's periodicals}

\section{Teresa Salvador}

This article contributes to a more in-depth understanding of portuguese feminist journals. Some concerns are supposed: one, to get free feminist periodical press from negative connotation like 'petit press'; another, to classify feminist journals according to their objectives and expectations; another one, to know the limits and the power of this kind of press. This work has not been reached by far, so we are trying to enlarge the academic debate. In this article a periodical listing from 1807 to 1974 is included.

Keywords: feminist journals, press, women studies. 


\section{On the track of Ferreira de Castro's passage by the supplement and the magazine of $A$ Batalha (1919-1927)}

Maria João Cabrita

In this paper we intend to elucidate the contours of the libertarian thinking of the writer Ferreira de Castro, through an analysis of his articles published in A Batalha - Suplemento Literário e llustrado and Renovação. Following a brief bio-bibliographical appreciation, where the journalistic course of the writer is detailed, we discuss his interest and work in subjects like social art and social injustice.

Keywords: libertarianism, liberty, social art, social justice.

\section{Nação Portuguesa (1914-1916) - Which Integralismo Lusitano? José Manuel Cordeiro}

With this article, we intend to revisit the Integralismo Lusitano through the Nação Portuguesa magazine (1914-1916). This text will hopefully broaden the potential for studying what were the first expressions of the Integralismo Lusitano, its ideological connections to the Alma Portuguesa magazine, its anti-republican posture, its crusade against democracy and parliamentarism. We come to the conclusion that municipalism, nationalism, maurrasianism, parliamentarism, constitutionalism, and the traditionalist, integral and organic monarchies are all concepts which demand further analysis and stabilization to achieve a coherent establishment of the Integralismo Lusitano's theoretical corpus.

Keywords: political philosophy, nationalist culture, Integralismo Lusitano, traditionalism, anti-republicanism, traditional monarchy, organic monarchy, municipalism, constitutionalism, democracy.

\section{From Political Philosophy to Nationalist Culture. The second series of Nação Portuguesa (1922-1923) Paul Dias Oliveira}

In these Nação Portuguesa articles, and throughout the second series, a more practical slant can be identified in the partitioning of the periodical in two separate sections. The first, where we can find the studies of flitting curiosity, made of chronicles, transcriptions, references to the magazine, etc.; the second, with its critic, philosophy, history and science essays, "in which higher problems of the spirit are discussed". As such, we have focused on this last part, and attempted 
to draw the general guidelines of the texts authored by António Sardinha, Pequito Rebelo, Rolão Preto, Afonso Lucas, Francisco Veloso, Rodrigues Cavalheiro and Avelino Soares.

Keywords: Nação Portuguesa, Integralismo Lusitano, monarchy, nationalism, tradition, politics, history, philosophy, economy, religion, reaportuguesamento, ordem nova.

\section{Estudos Sociais: thematic paths of a reformist impetus (1905-1911) Pedro Silva}

The Estudos Sociais magazine, published between 1905 and 1911, was an element in the action carried out by the Centro Académico de Democracia Cristã of Coimbra and its purpose was to contribute to the spread of social Catholicism and to the rooting of Christian Democracy in Portugal. Throughout the seven-year period in which it was published, many calls were made to the Catholic Church to occupy its rightful place in the current civilization, with repeated reaffirmations that only through a Christian conception of democracy and the social Catholic movement could Christianity respond to social challenges and the clergy would play a vanguard role in the solution of the people's social problems. Consequently, it contained several texts, practical and theoretical, national and international, which approached questions such as that of true democracy, of social Catholicism/Christianity, of the urgent reform of clergy and Church or that of modernism. The main goal of this article is to trace the thematic itineraries present in the magazine, along the seven years in which it was published.

Keywords: social catholicism, christian democracy, modernism, science, religion, laicism, dogma, socialism, faith, reason.

\section{The knights of the wooden sword and the archangels of the thunder sword: the Renascença Portuguesa and the democratic culture}

Adelaide Maria Muralha Vieira Machado

After the republican revolution arose an intellectual movement that tried to congregate thinkers of several areas of thought, trough the publication of the magazine AÁguia, in order to established a new civic moral within the democratic ideal. We tried to show the main lines that gave substance to the space open by the magazine, the influences received and the debates it promoted.

Keywords: Renascença Portuguesa, saudosismo, republicanism, democracy, liberty, National identity, Portuguese culture. 


\title{
Índia Nova: nationalism and cosmopolitanism in an academic journal
}

\author{
Sandra Ataíde Lobo
}

To insert a newspaper like Índia Nova: jornal de expansão da cultura indiana, in a volume dedicated to studies about magazines, is justified by the fact that we are dealing with the product of a cultural project, with inevitable political implications. Organ of the Goan students in the Portuguese Universities, its creation was promoted by a young group of Goan intellectuals, grown under the auspices of the Republic, which under the sign of rupture, assumed the responsibility of intervening in the city. If the publication aimed to touch the European metropolitan public with the magnitude of Indian civilization, it was essentially directed to the Goans in the metropolis and in Goa, assuming the intention of recovering a Goan identity inspired by the Indian civilizational tradition and of promoting a cultural and scientific activity centered on Indian themes and references. Through this proposal, it associated itself to the nationalist cultural and political movement in "Great India", and more globally to the different nationalist movements, that were emerging in the Asiatic continent on the first decades of the Twentieth Century. Finally, the group of Goan students, and their Goan and metropolitan collaborators, crossing the path from Goan particularity to the reflection about the destiny of humanity, inscribed themselves in the current, that at Orient and at Occident, battled for a new humanism. This current settled the idea of universality in the harmonization of diversity and convened all individuals and peoples in the construction of the future of humanity.

Keywords: Goan intellectuals, European intellectuals, academic press, Portuguese Empire in India, cultural resistance, cultural identity, history, imperialism, colonialism, Indian civilization, Western civilization, orientalism, dialog between civilizations, humanism.

\section{Electronic publishing of magazines: tendencies, limitations and the contribution of the SLHI}

Pedro Lisboa

The world of electronic publishing of periodicals is in constant evolution, keeping up with technological advances and the increase in use of digital means to facilitate access to information.

The majority of initiatives which incorporate the electronic publishing of magazines has the primary goal of offering researchers an easy and centralized access to data, thereby broadening the potential diffusion of the consulted publications.

Sharing some elements of this functional principle, the Seminário Livre de História das Ideias (SLHI) intends to publish and study historical magazines, focusing not only on the accessibility 
of information but also, and foremost, on the construction of an analytical apparatus which allows a critical reading of sources. Discussing its work and its experience can therefore represent a significant step towards overcoming obstacles and defining a course for the future of the electronic publishing of magazines.

Keywords: electronic publishing, analytical edition, magazines, bibliographic classification and indexation.

\section{From scientific language to scientific culture: the Revista Internacional de Língua Portuguesa}

Cristina Montalvão Sarmento

The Revista Internacional de Língua Portuguesa (RILP), in print since the foundation of the Associação das Universidades de Língua Portuguesa (AULP) in 1986, has served as the means of expression for the Portuguese-speaking community, driven by the university association movement of the 1980s and 1990s. The magazine was first directed by Maria Helena Mira Mateus, in an initial series of seventeen issues, and later coordinated by José-Augusto França, in a second series of three issues. The current twenty-first issue marks the beginning of the ongoing third series, dedicated to institutional and other selected themes. RILP's intention of increasing the visibility of the Portuguese language, in addition to its longevity and intercontinental expression, makes the magazine a unique national case of internationalization, from the original linguistic centre to the multilateral universe of associated cultures, all based on the common ground of language, ignoring the political vicissitudes imposed by time and devised by different powers. This article revisits all three series.

Keywords: Revista Internacional de Língua Portuguesa, Associação das Universidades de Língua Portuguesa, Portuguese language, Angola, Brazil, Cape Verde, Guinea-Bissau, Macau, Mozambique, Portugal, São Tomé and Príncipe, East Timor. 


\title{
Cultura Revista de História e Teoria das ideias
}

\begin{abstract}
Assinaturas
Junto envio cheque n. ${ }^{\circ}$ do Banco passado à ordem de FCSH, UNL, com a quantia de para assinatura da revista Cultura.
\end{abstract}

Data:___ _ _ _ Assinatura

(Enviar para CHC UNL, Av. de Berna, 26 C - 1069-061 Lisboa)

Dados do assinante:

Nome

Morada

Telef. E-mail:

Assinatura para dois números:
Normal - 26 euros
Estudante - 17 euros
UE - 40 euros
Resto do mundo - 50 euros 


\section{Recomendações aos Autores}

\section{Envio}

- Pelo correio, um exemplar em papel acompanhado de uma disquete (formato Word) para:

Cultura. Revista de História e Teoria das Ideias

Centro de História da Cultura

Faculdade de Ciências Sociais e Humanas

Av. de Berna, n. ${ }^{\circ} 26-\mathrm{C}$

1069-061 Lisboa

- Por correio electrónico para:

chc@fcsh.uni.pt

\section{Forma e dimensão}

\section{Artigos}

- Preferencialmente, até cerca de 70000 caracteres, seja 20 páginas com 3450 caracteres por página, Times New Roman, 12 (formatação a um espaço e meio).

- Referências bibliográficas inseridas nas notas de rodapé de página (tendo bibliografia no final, não pode exceder uma página).

- Apresentação das referências segundo o modelo seguinte: apelido, nome, título da obra (itálico), local, editora, ano; ou, para artigos, apelido, nome, "título do artigo", revista (itálico), n. o de volume, data, páginas.

- Artigos longos deverão ter subtítulos.

- Ilustrações, gráficos e quadros: a preto e branco, com legenda, fonte e numeração.

\section{Recensões}

- Até cerca de 10000 caracteres, seja 3 páginas, Times New Roman, 10 (formatação a um espaço).

\section{Resumo e Biografia}

- Resumo de cerca de 750 caracteres, acompanhado de uma tradução em inglês de idêntica dimensão.

- Biografia do autor que refira o estatuto profissional, principais publicações, domínios de investigação e morada.

\section{Procedimento}

- Será acusada a recepção ao autor no dia de chegada do texto.

- Avaliação do artigo sob orientação da comissão científica.

- A decisão de publicação será comunicada nos 90 dias seguintes à data da recepção. 


\author{
O valor das ideias \\ Luís Andrade \\ As minhas revistas \\ Mário Soares \\ Pensamento e actualidade. As revistas no século XX \\ Luís Andrade \\ A luso-brasilidade e o projeto da revista Atlântida \\ Lucia Maria Paschoal Guimarães \\ "Uma nova e grande Lusitânia" \\ Zília Osório de Castro \\ Uma nova revista de Filosofia? \\ Adelino Cardoso \\ Em torno dos periódicos femininos \\ Teresa Salvador
}

No rasto da passagem de Ferreira de Castro pelos suplemento e revista de A Batalha (1919-1927)

Maria João Cabrita

Nação Portuguesa (1914-1916) - Que Integralismo Lusitano?

José Manuel Cordeiro

Da Filosofia Política à Cultura Nacionalista. A segunda série da Nação Portuguesa (1922-1923)

Paulo Dias Oliveira

Estudos Sociais: percursos temáticos de um ímpeto reformista (1905-1911)

Pedro Silva

Os cavaleiros da espada de pau e os arcanjos da espada dum trovão:

a Renascença Portuguesa e a cultura democrática

Adelaide Maria Muralha Vieira Machado

Índia Nova: nacionalismo e cosmopolitismo num jornal académico

Sandra Ataíde Lobo

Edição electrónica e estudo de revistas: o contributo do Seminário Livre de História das Ideias Pedro Lisboa

Da língua à cultura científica: a Revista Internacional de Língua Portuguesa

Cristina Montalvão Sarmento

RECENSÕES CRÍTICAS

Souto, Maria Helena, História do Design em Portugall

Leonor Ferrão

Guibal, Francis, Le Courage de la raison - La philosophie pratique d'Eric Weil

Luís Manuel A. V. Bernardo

Rosas, João Cardoso (org.), Manual de Filosofia Política

Maria João Cabrita

Mendes, Manuel da Silva, Socialismo Libertário ou Anarchismo

Maria João Cabrita 